Closure Report for Corrective Action Unit 481: Area 12 T-Tunnel Conditional Release Storage Yard, Nevada Test Site, Nevada

Revision: 0

November 2008

Prepared by National Security Technologies, LLC for the U.S. Defense Threat Reduction Agency

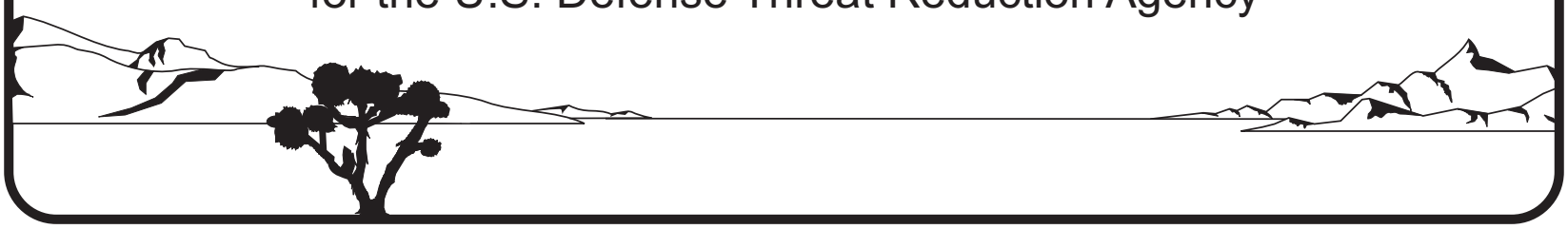


THIS PAGE INTENTIONALLY LEFT BLANK 


\title{
CLOSURE REPORT FOR CORRECTIVE ACTION UNIT 481: AREA 12 T-TUNNEL CONDITIONAL RELEASE STORAGE YARD, NEVADA TEST SITE, NEVADA
}

\author{
Prepared by \\ National Security Technologies, LLC
}

Controlled Copy No.

Revision: 0

November 2008 
THIS PAGE INTENTIONALLY LEFT BLANK 


\section{CLOSURE REPORT FOR CORRECTIVE ACTION UNIT 481: AREA 12 T-TUNNEL CONDITIONAL RELEASE STORAGE YARD, NEVADA TEST SITE, NEVADA}

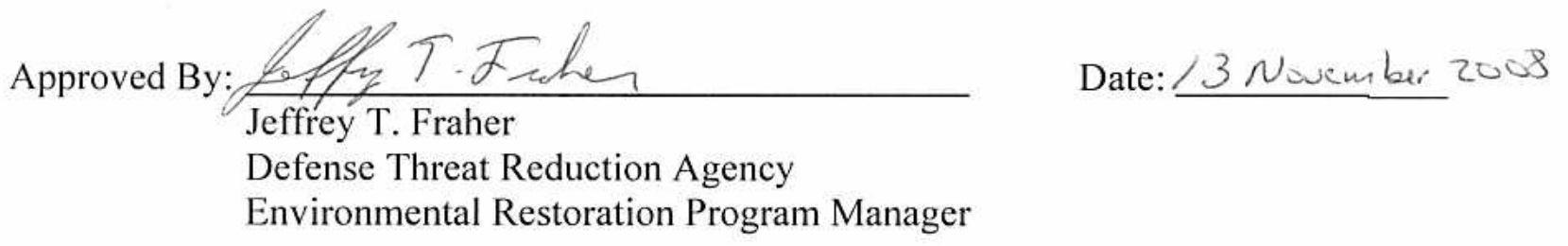


THIS PAGE INTENTIONALLY LEFT BLANK 


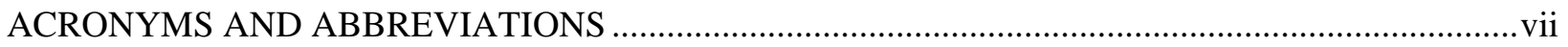

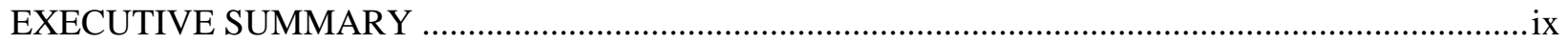

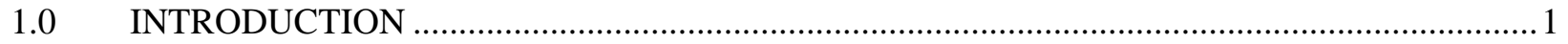

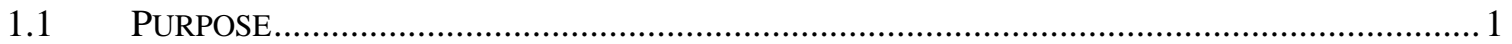

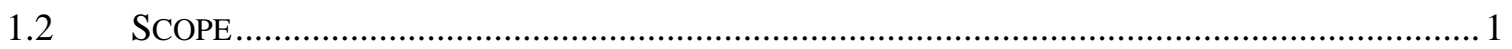

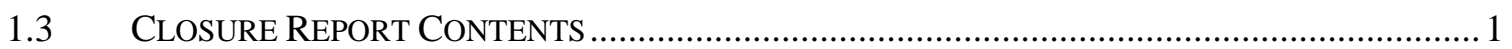

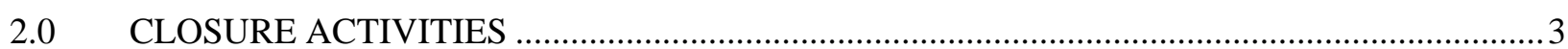

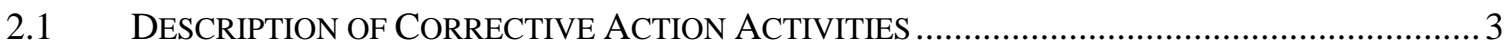

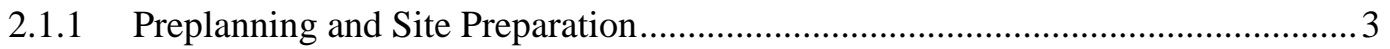

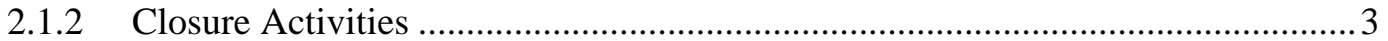

2.2 DEVIATIONS FROM THE CORRECTIVE ACTION PLAN AS APPROVED ................................. 4

2.3 CORRECTIVE ACTION SCHEDULE AS COMPLETED........................................................ 4

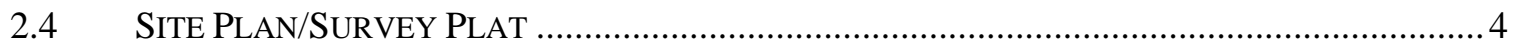

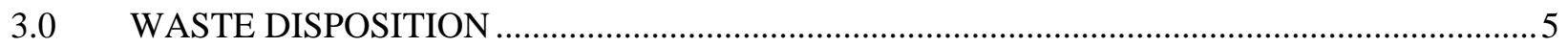

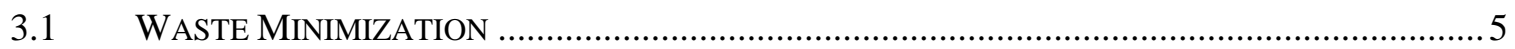

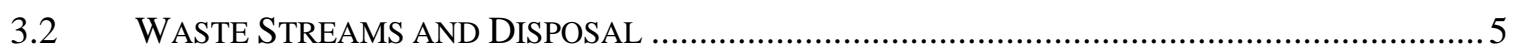

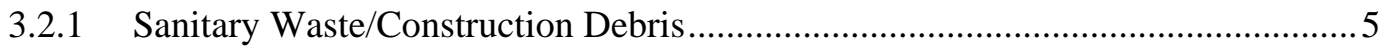

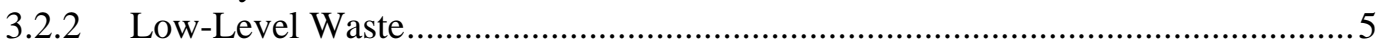

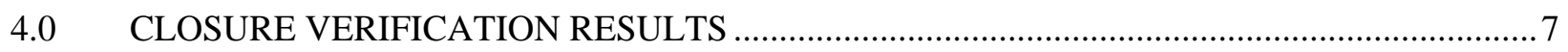

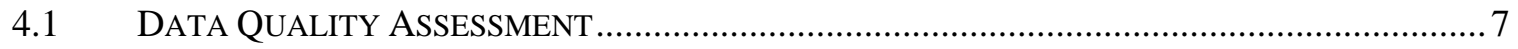

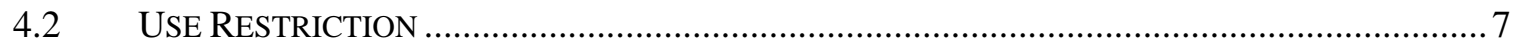

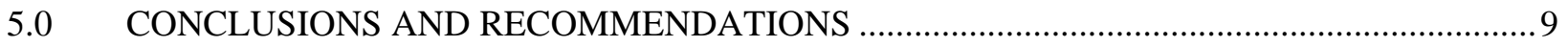

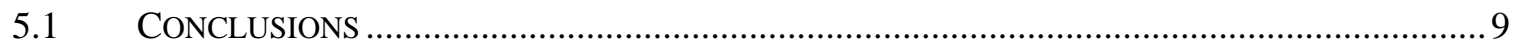

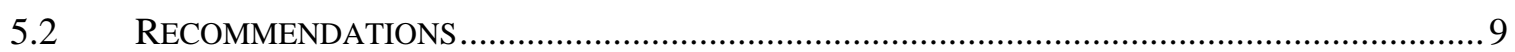

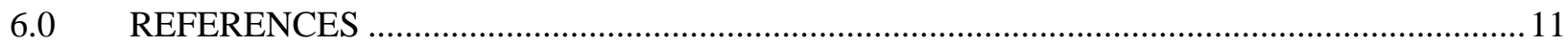

LIBRARY DISTRIBUTION LIST

\section{LIST OF FIGURES}

Figure 1. Corrective Action Unit 481 Site Location MaP............................................... 2

\section{APPENDICES}

ApPEndix A. PhOtOGRAPHS

APPENDIX B. WASTE DisPOSITION DOCUMENTATION

Appendix C. SEctored Housekeeping Site Closure Verification Form

APPENDIX D. SPILL REPORT NUMBER 070813-01

APPENDIX E. ANALYTICAL RESULTS

ApPEndix F. NEVAdA Division of ENVIRONMENTAL PROTECTION COMMENT RESPONSE Form 
CAU 481 Closure Report

Section: Table of Contents

Revision: 0

Date: November 2008

THIS PAGE INTENTIONALLY LEFT BLANK 


\section{ACRONYMS AND ABBREVIATIONS}

ACM

CAS

CAU

CR

DTRA

FFACO

LLW

LOS

NNSA/NSO

NTS

RMA

RWMS

SCWP asbestos-containing material

Corrective Action Site

Corrective Action Unit

Closure Report

Defense Threat Reduction Agency

Federal Facility Agreement and Consent Order

low-level waste

line-of-site

U.S. Department of Energy, National Nuclear Security Administration Nevada Site Office

Nevada Test Site

Radioactive Material Area

Radioactive Waste Management Site

Sectored Clean-up Work Plan 
CAU 481 Closure Report

Section: Acronyms and Abbr.

Revision: 0

Date: November 2008

THIS PAGE INTENTIONALLY LEFT BLANK 
Corrective Action Unit (CAU) 481 is identified in the Federal Facility Agreement and Consent Order (FFACO, 1996; as amended February 2008) as Area 12 T-Tunnel Conditional Release Storage Yard. CAU 481 is located in Area 12 of the Nevada Test Site, which is approximately 65 miles northwest of Las Vegas, Nevada. This CAU consists of one Corrective Action Site (CAS), CAS 12-42-05, Housekeeping Waste. CAU 481 closure activities were conducted by the Defense Threat Reduction Agency from August 2007 through July 2008 according to the FFACO and Revision 3 of the Sectored Clean-up Work Plan for Housekeeping Category Waste Sites (U.S. Department of Energy, National Nuclear Security Administration Nevada Site Office [NNSA/NSO], 2003).

Closure activities included removal and disposal of construction debris and low-level waste (LLW). Drained fluids, steel, and lead was recycled as appropriate. Waste generated during closure activities was appropriately managed and disposed, as follows:

\section{Area 9 U10c Sanitary Landfill}

- 1,464 tons of construction debris were transported to the Area 9 U10c Sanitary Landfill for disposal after being screened for radiological contamination according to the $N V / Y M P$ Radiological Control Manual (NNSA/NSO, 2004).

o Construction debris included rail cars; generators; compressors; hoists; winches; test chambers; metal, stainless steel, and fiberglass piping; vent lines; vent fans; metal couplers, joints, bolts, brackets, containers, and vessels; empty tanks; steel sheeting, plates, framework, mesh, and I-beams; curved steel sets; rails; fencing material; valves; wire spools; wallboard; flanges; brush; and other aluminum, fiberglass, metal, and wood debris.

o Prior to disposal, all equipment (e.g., generators, compressors, hoists, and winches) was drained of fluid.

\section{Recycle/Re-use}

- 259 tons of debris, which consisted of unused curved steel sets, were shipped off site to be recycled.

- Approximately 400 gallons of fluid drained from equipment were recycled on site.

- 8 lead sheets were transported to the Area 6 Storage Yard for re-use.

\section{Area 5 Radioactive Waste Management Site}

- 50 tons of LLW were transported to and disposed of at the Area 5 Radioactive Waste Management Site.

o LLW included one mining drill rig, mining rail cars, flat cars, a trailer, air pumps, motors, bellows, blower units, drilling rods, hoses, cables, I-beams, mufflers, vent lines, metal piping, line-of-sight piping, air handlers, steel framework, filter boxes, filter housing, and other metal and wood debris. 
The Sectored Housekeeping Site Closure Verification Form for CAS 12-42-05 is included as Appendix $\mathrm{C}$ of this report. This form includes before and after photographs of the site, descriptions of waste, and waste disposal information. 
This Closure Report (CR) documents closure activities conducted by the Defense Threat Reduction Agency (DTRA) for Corrective Action Unit (CAU) 481, Area 12 T-Tunnel Conditional Release Storage Yard, according to the Federal Facility Agreement and Consent Order (FFACO, 1996; as amended February 2008) and Revision 3 of the Sectored Clean-up Work Plan (SCWP) for Housekeeping Category Waste Sites (U.S. Department of Energy, National Nuclear Security Administration Nevada Site Office [NNSA/NSO], 2003). CAU 481 is located in Area 12 of the Nevada Test Site (NTS) (Figure 1) and consists of one Corrective Action Site (CAS), CAS 12-42-05, Housekeeping Waste.

\subsection{Purpose}

CAU 481, Area 12 T-Tunnel Conditional Release Storage Yard, was closed by removing and recycling reusable materials and by characterizing and disposing of waste. The purpose of this $\mathrm{CR}$ is to summarize the completed closure activities, document appropriate waste disposal, and confirm that the closure standards were met.

\subsection{SCOPE}

Closure activities included removal and recycling or disposal of all materials from the Area 12 T-Tunnel Conditional Release Storage Yard, which is more commonly known as the T-Tunnel Lower Laydown Yard.

\subsection{Closure Report Contents}

This CR includes the following sections:

- Section 1.0 - Introduction

- $\quad$ Section 2.0 - Closure Activities

- Section 3.0 - Waste Disposition

- Section 4.0 - Closure Verification Results

- Section 5.0 - Conclusions and Recommendations

- Section 6.0 - References

- Appendix A - Photographs

- Appendix B - Waste Disposition Documentation

- Appendix C - Sectored Housekeeping Site Closure Verification Form

- Appendix D - Spill Report Number 070813-01

- Appendix E - Analytical Results

- Appendix F - Nevada Division of Environmental Protection Comment Response Form

- Library Distribution List 


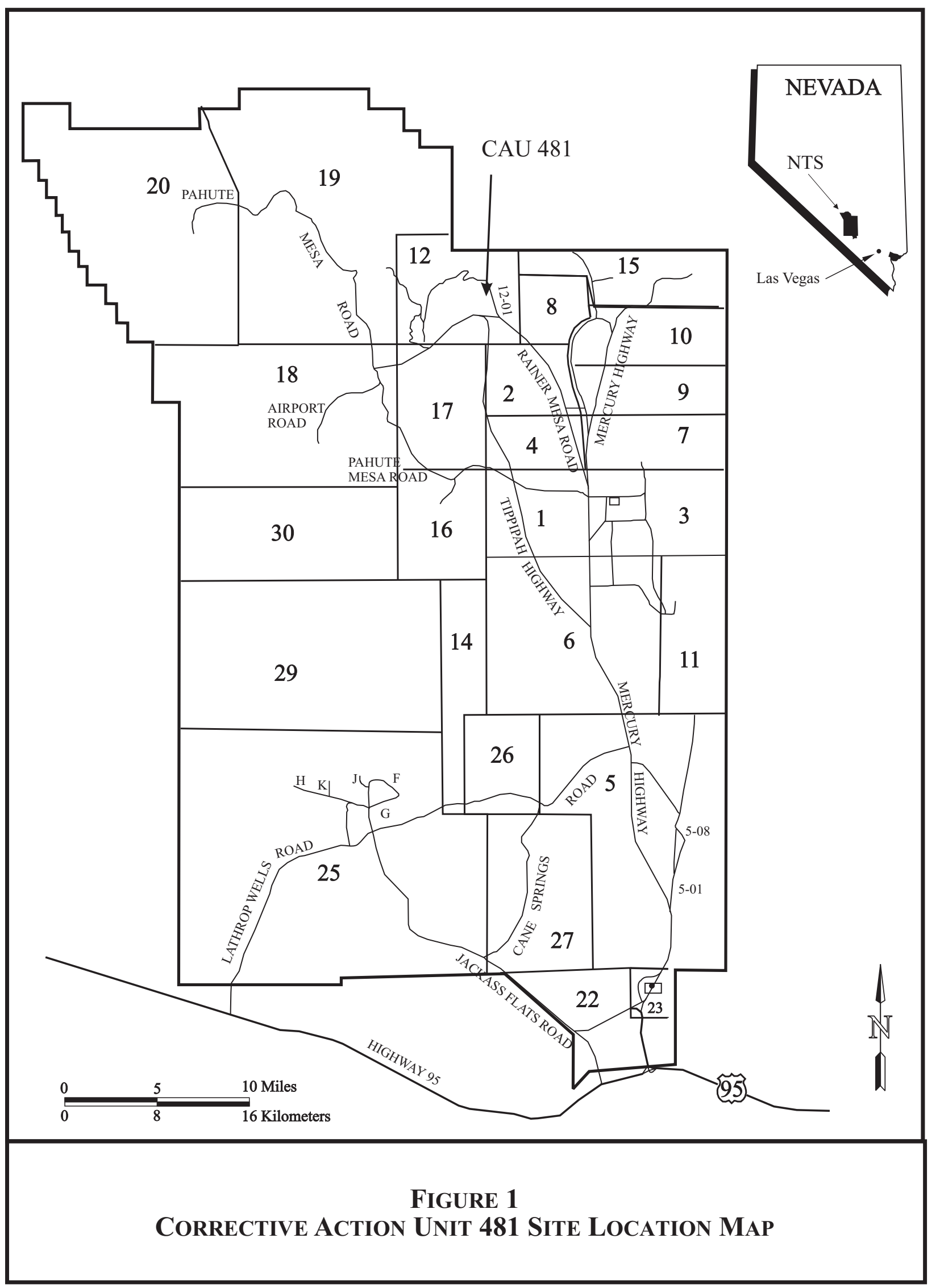




\subsection{CLOSURE ACTIVITIES}

This section details the specific activities completed during the closure of CAU 481. The Sectored Housekeeping Site Closure Verification Form is included as Appendix C of this report. This form includes before and after photographs of the site, descriptions of waste, and waste disposal information.

\subsection{Description of Corrective Action Activities}

Closure activities for CAU 481 were completed by DTRA according to the SCWP (NNSA/NSO, 2003). The following sections detail the closure activities as completed.

\subsubsection{Preplanning and Site Preparation}

Prior to closure activities, the following documents were prepared:

- National Environmental Policy Act Checklist

- Site-Specific Health and Safety Plan

- Field Management Plan

- NNSA/NSO Real Estate/Operations Permit

- Work control packages

\subsubsection{Closure Activities}

CAS 12-42-05, Housekeeping Waste, consisted of equipment, materials, and debris located at the Area 12 T-Tunnel Lower Laydown Yard. One portion of the yard was posted as a Radioactive Material Area (RMA). Photographs of the waste and recyclable materials are provided in Appendix A of this report.

The equipment and debris were systematically screened for radiological contamination according to the NV/YMP Radiological Control Manual (NNSA/NSO, 2004), waste was segregated accordingly, and the equipment and debris were either recycled or disposed of appropriately, as follows:

- 1,464 tons of equipment and debris were transported to the Area 9 U10c Sanitary Landfill for disposal as sanitary waste.

- 259 tons of debris, which consisted of unused curved steel sets, were shipped off site to be recycled.

- Approximately 400 gallons of fluid were recycled on site.

- 8 lead sheets were transported to the Area 6 Storage Yard for re-use.

- 50 tons of LLW were transported to and disposed of at the Area 5 Radioactive Waste Management Site (RWMS). LLW was packaged in a transportainer and B-25 boxes or was transported as bulk waste if the item was too large to fit in a container. 
After removal of all equipment and debris, the area was radiologically surveyed, and the Radioactive Material Area signs were removed. The area no longer requires radiological postings per the NV/YMP Radiological Control Manual (NNSA/NSO, 2004).

During closure activities, an estimated 40 to 60 gallons of mineral oil spilled onto the soil from an electrical breaker box that had tipped over. A spill report was submitted to the Nevada Division of Environmental Protection under spill report number 070813-01, as required by the Nevada Administrative Code 445A.347 and the Resource Conservation and Recovery Act. The spill report is included as Appendix D of this CR. The impacted soil was excavated, and samples confirmed that the soil did not contain polychlorinated biphenyls above the laboratory's minimum detection limits. The soil was disposed at the Area 9 U10c Sanitary Landfill. Analytical results for the soil are included in Appendix E of this CR.

\subsection{Deviations from the Corrective Action Plan as Approved}

This section is not applicable to CAU 481.

\subsection{Corrective ACtion Schedule As COMPLETED}

Closure activities were conducted from August 2007 through July 2008.

\subsection{Site Plan/Survey Plat}

This section is not applicable to CAU 481. 
This section describes the waste streams generated during closure activities and their final disposition. Waste streams included sanitary waste/construction debris and LLW. Waste disposition documentation is included as Appendix B of this report.

\subsection{WASTE Minimization}

Industry standard waste minimization practices were applied throughout the course of closure activities. These practices included the following:

- Perform radiological surveys of debris, equipment, and other waste from an existing RMA to identify materials that meet the criteria for disposal at the Area 9 U10c Sanitary Landfill.

- Drain, capture, and recycle fluids from equipment. Approximately 300 gallons of used oil and 100 gallons of anti-freeze were recycled on site.

- Recycle metal debris. 259 tons of debris, which consisted of unused curved steel sets, were shipped off site to be recycled.

- Relocate lead sheets to the Area 6 Storage Yard for re-use elsewhere on the NTS.

- Size-reduce debris to minimize the volume of landfill waste.

\subsection{WASTE STREAMS AND Disposal}

\subsubsection{Sanitary Waste/Construction Debris}

A total of approximately 1,464 tons of sanitary waste was generated during closure activities. Construction debris was determined to be sanitary waste based on process knowledge and radiological survey results. The sanitary waste was transported in end-dump trucks to the Area 9 U10c Sanitary Landfill for disposal.

\subsubsection{Low-Level Waste}

A total of approximately 50 tons of LLW was generated during closure activities. LLW was transported to the Area 5 RWMS for disposal. 
CAU 481 Closure Report

Section: Waste Disposition

Revision: 0

Date: November 2008

THIS PAGE INTENTIONALLY LEFT BLANK 


\subsection{CLOSURE VERIFICATION RESULTS}

Verification sampling was not required for CAU 481. Closure verification consisted of visual inspections to verify that waste is no longer present and photographic documentation of the final site conditions. The Sectored Housekeeping Site Closure Verification Form for CAS 12-42-05 is included as Appendix C. This form includes before and after photographs of the site, descriptions of the waste, and waste disposal information.

\subsection{Data Quality Assessment}

This section is not applicable to CAU 481.

\subsection{USE RESTRICTION}

Use restrictions were not implemented for CAU 481, and the future land use of any land related to CAU 481 is not restricted from any activity. 
CAU 481 Closure Report

Section: Closure Verification

Revision: 0

Date: November 2008

THIS PAGE INTENTIONALLY LEFT BLANK 


\subsection{CONCLUSIONS AND RECOMMENDATIONS}

\subsection{CONCLUSIONS}

Closure activities at CAU 481 consisted of recycling fluids and metal; removing and disposing debris, parts, equipment, and other sanitary waste; and removing and disposing of LLW. It was verified and documented that the waste originally identified at the site is no longer present. The Sectored Housekeeping Site Closure Verification Form was completed and is included as Appendix $\mathrm{C}$ of this report.

\subsection{RECOMMENDATIONS}

Since closure activities for CAU 481 have been completed following Revision 3 of the SCWP (NNSA/NSO, 2003) as documented in this report, DTRA requests the following:

1. A Notice of Completion be provided by the Nevada Division of Environmental Protection to DTRA for the closure of CAU 481

2. The transfer of CAU 481 from Appendix III to Appendix IV, Closed Corrective Action Units, of the FFACO 
CAU 481 Closure Report

Section: Conclusions \& Recom.

Revision: 0

Date: November 2008

THIS PAGE INTENTIONALLY LEFT BLANK 


\subsection{REFERENCES}

Federal Facility Agreement and Consent Order, 1996 (as amended February 2008). Agreed to by the State of Nevada; the U.S. Department of Energy, Environmental Management; the U.S. Department of Defense; and the U.S. Department of Energy, Legacy Management.

FFACO, see Federal Facility Agreement and Consent Order.

NNSA/NSO, see U.S. Department of Energy, National Nuclear Security Administration Nevada Site Office

U.S. Department of Energy, National Nuclear Security Administration Nevada Site Office, 2003. Sectored Clean-up Work Plan for Housekeeping Category Waste Sites. DOE/NV--579-REV-3. Las Vegas, NV.

U.S. Department of Energy, Nevada Operations Office, 2004. NV/YMP Radiological Control Manual. DOE/NV/11718--079-REV 5. Las Vegas, NV. 
CAU 481 Closure Report

Section: References

Revision: 0

Date: November 2008

THIS PAGE INTENTIONALLY LEFT BLANK 
CAU 481 Closure Report

Section: Appendix A

Revision: 0

Date: November 2008

APPENDIX A

PhOTOGRAPHS 
CAU 481 Closure Report

Section: Appendix A

Revision: 0

Date: November 2008

THIS PAGE INTENTIONALLY LEFT BLANK 
PHOTOGRAPH LOG

\begin{tabular}{|c|c|c|}
\hline $\begin{array}{c}\text { Photo } \\
\text { Number }\end{array}$ & Date & Description \\
\hline 1 & $10 / 25 / 2007$ & Beams \\
\hline 2 & $10 / 30 / 2007$ & Bellows \\
\hline 3 & 07/30/2007 & Blowers \\
\hline 4 & 07/30/2007 & Blower, marked to drain \\
\hline 5 & $10 / 04 / 2007$ & Bolts and pipe \\
\hline 6 & $10 / 16 / 2007$ & Compressor \\
\hline 7 & $10 / 30 / 2007$ & Conveyor \\
\hline 8 & $10 / 30 / 2007$ & Countertop-type material \\
\hline 9 & $11 / 15 / 2005$ & Couplers \\
\hline 10 & $10 / 08 / 2007$ & Couplers \\
\hline 11 & $10 / 09 / 2007$ & Couplers \\
\hline 12 & 07/30/2007 & Debris \\
\hline 13 & 08/13/2007 & Debris \\
\hline 14 & $10 / 01 / 2007$ & Debris \\
\hline 15 & $10 / 16 / 2007$ & Debris \\
\hline 16 & $10 / 30 / 2007$ & Drill \\
\hline 17 & $10 / 30 / 2007$ & Drill parts \\
\hline 18 & 09/07/2007 & Fence \\
\hline 19 & 07/10/2007 & Filter boxes \\
\hline 20 & $10 / 30 / 2007$ & Filter housing \\
\hline 21 & 07/30/2007 & Generator \\
\hline 22 & 07/30/2007 & Generators \\
\hline 23 & $10 / 30 / 2007$ & Hoses \\
\hline 24 & $11 / 15 / 2005$ & Metal \\
\hline 25 & $11 / 15 / 2005$ & Metal frames \\
\hline 26 & $10 / 30 / 2007$ & Ore car with panel box \\
\hline 27 & 09/07/2007 & Other metal waste \\
\hline 28 & 08/28/2007 & Other metal waste \\
\hline 29 & $11 / 15 / 2005$ & Parts \\
\hline 30 & 09/07/2007 & Parts \\
\hline 31 & 07/18/2007 & Pipe \\
\hline 32 & $10 / 04 / 2007$ & Pipe \\
\hline 33 & $10 / 04 / 2007$ & Pipe \\
\hline
\end{tabular}


PHOTOGRAPH LOG

\begin{tabular}{|c|c|c|}
\hline $\begin{array}{l}\text { Photo } \\
\text { Number }\end{array}$ & Date & Description \\
\hline 34 & $10 / 04 / 2007$ & Pipe \\
\hline 35 & 07/30/2007 & Pipe \\
\hline 36 & $07 / 30 / 2007$ & Pipe, line-of-sight (LOS) \\
\hline 37 & $08 / 02 / 2007$ & Pipe, LOS \\
\hline 38 & $08 / 02 / 2007$ & Pipe, LOS \\
\hline 39 & $09 / 25 / 2007$ & Pipe \\
\hline 40 & $11 / 15 / 2005$ & Rail cars \\
\hline 41 & 08/07/2007 & Rail car turntable \\
\hline 42 & $11 / 15 / 2005$ & Skids \\
\hline 43 & 09/07/2007 & Steel mesh \\
\hline 44 & $11 / 15 / 2005$ & Steel plate \\
\hline 45 & $11 / 15 / 2005$ & Steel plate \\
\hline 46 & 07/30/2007 & Steel sets \\
\hline 47 & 07/30/2007 & Steel sets \\
\hline 48 & 09/07/2007 & Steel sets \\
\hline 49 & $07 / 30 / 2007$ & Steel supports \\
\hline 50 & $10 / 03 / 2007$ & Structural supports \\
\hline 51 & 08/06/2007 & Structural support \\
\hline 52 & $05 / 15 / 2005$ & Empty tank \\
\hline 53 & $05 / 15 / 2005$ & Test chamber \\
\hline 54 & $08 / 02 / 2007$ & Test chamber \\
\hline 55 & 08/29/2007 & Test chamber \\
\hline 56 & 08/28/2007 & Test chamber \\
\hline 57 & 09/25/2007 & Valves \\
\hline 58 & 09/27/2007 & Valves \\
\hline 59 & $10 / 30 / 2007$ & Vent fans \\
\hline 60 & $07 / 30 / 2007$ & Vent line pipe, fiberglass \\
\hline 61 & 07/30/2007 & Vent line pipe, fiberglass \\
\hline 62 & $10 / 30 / 2007$ & Vent line pipe, metal \\
\hline 63 & $10 / 04 / 2007$ & Vent line pipe, metal \\
\hline 64 & $08 / 22 / 2007$ & Wallboard \\
\hline 65 & $07 / 30 / 2007$ & Winches \\
\hline 66 & $11 / 15 / 2005$ & Wire spools and drum rack \\
\hline
\end{tabular}




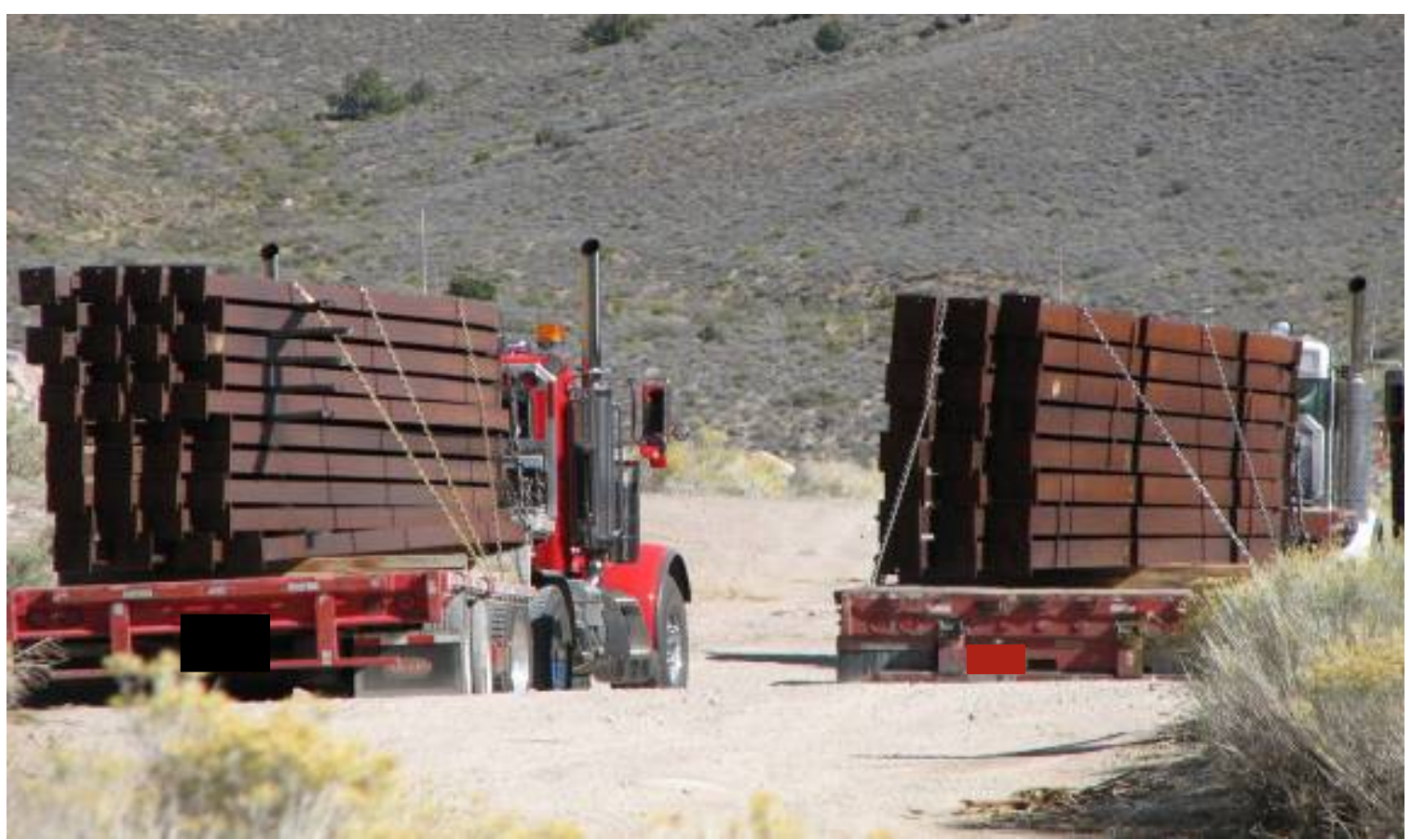

Photograph 1. Beams (10/25/2007)

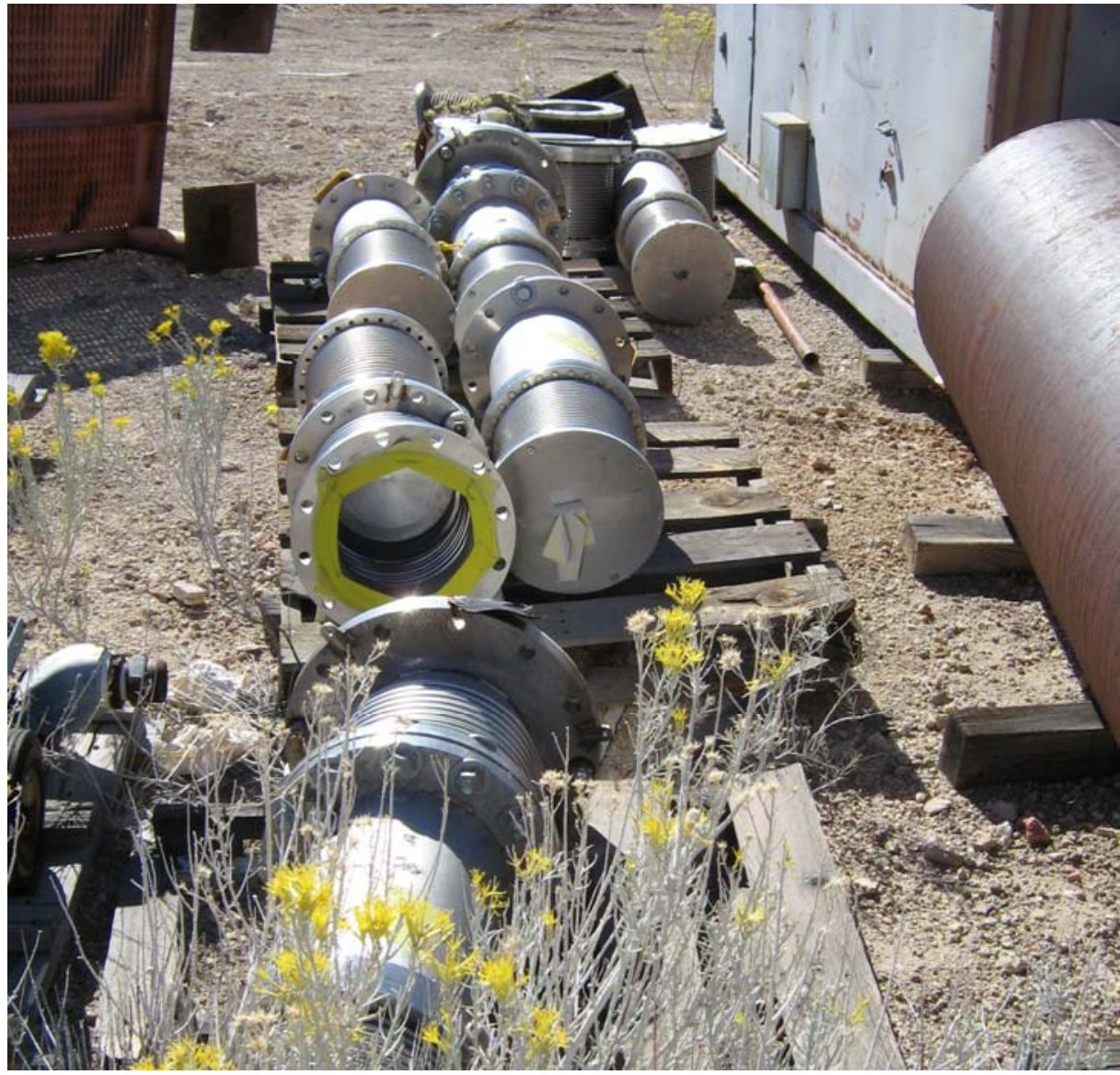

Photograph 2. Bellows (10/30/2007) 


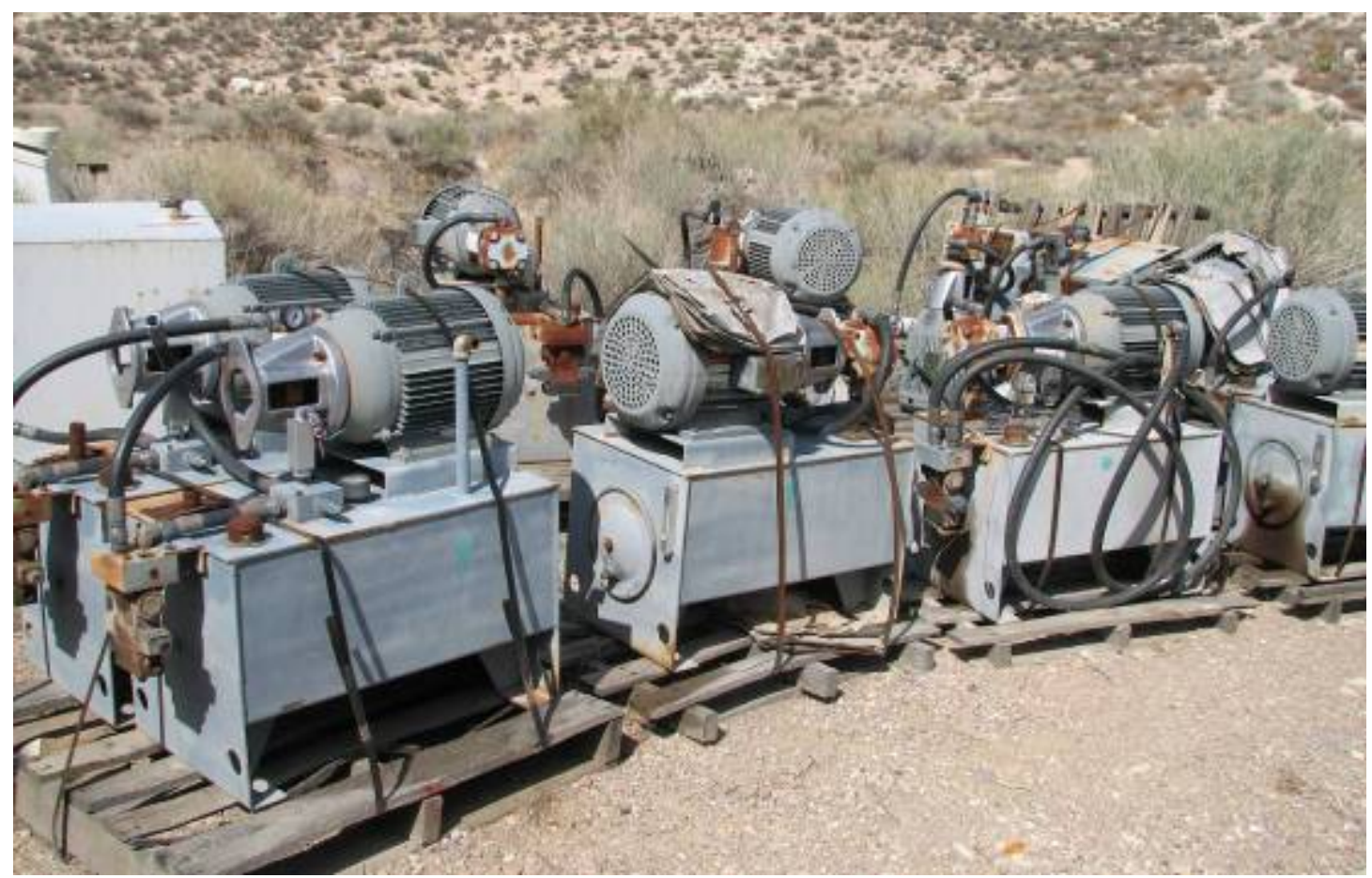

Photograph 3. Blowers (07/30/2007)

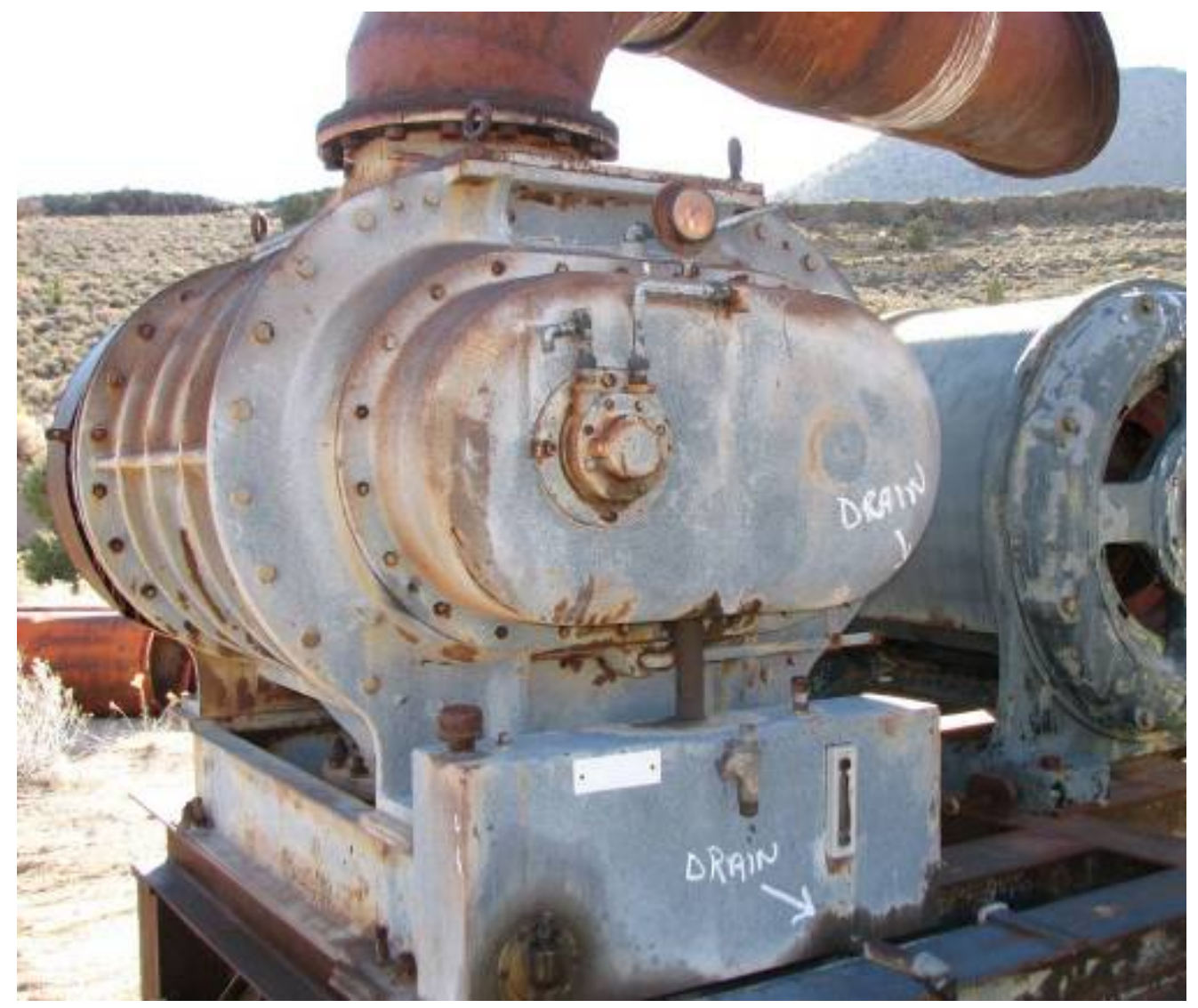

Photograph 4. Blower, marked to drain (07/30/2007) 


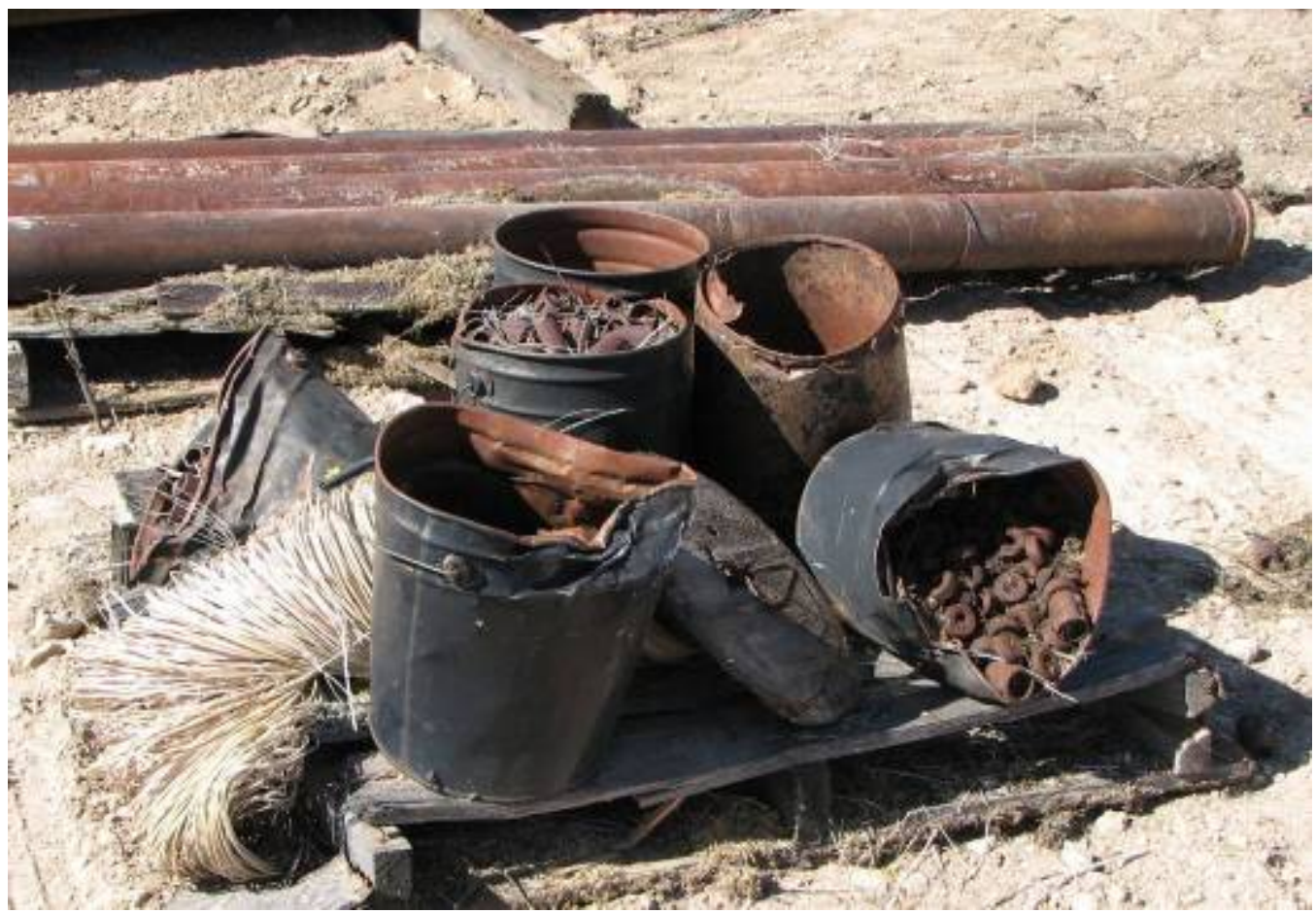

Photograph 5. Bolts and pipe (10/04/2007)

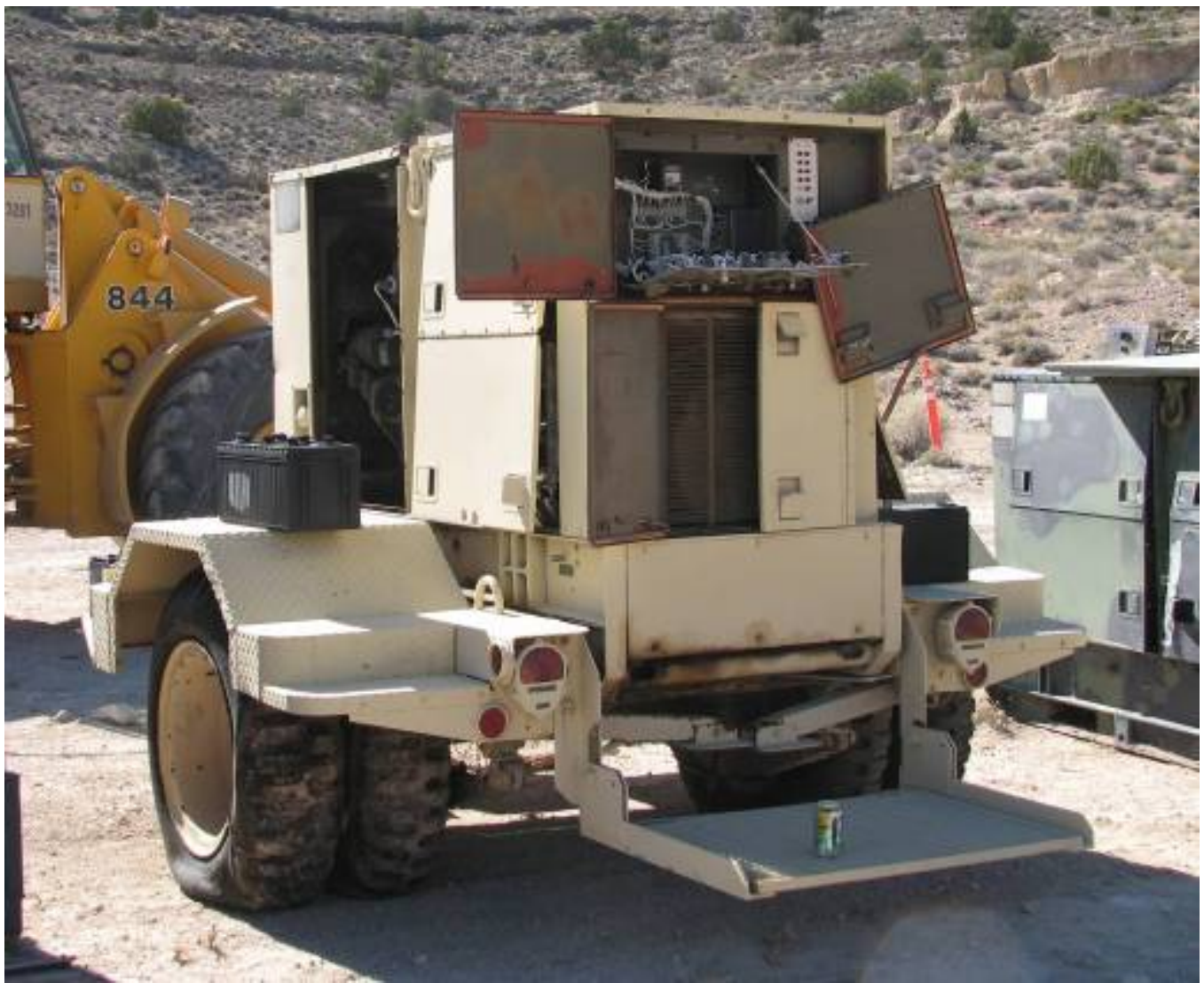

Photograph 6. Compressor (10/16/2007) 


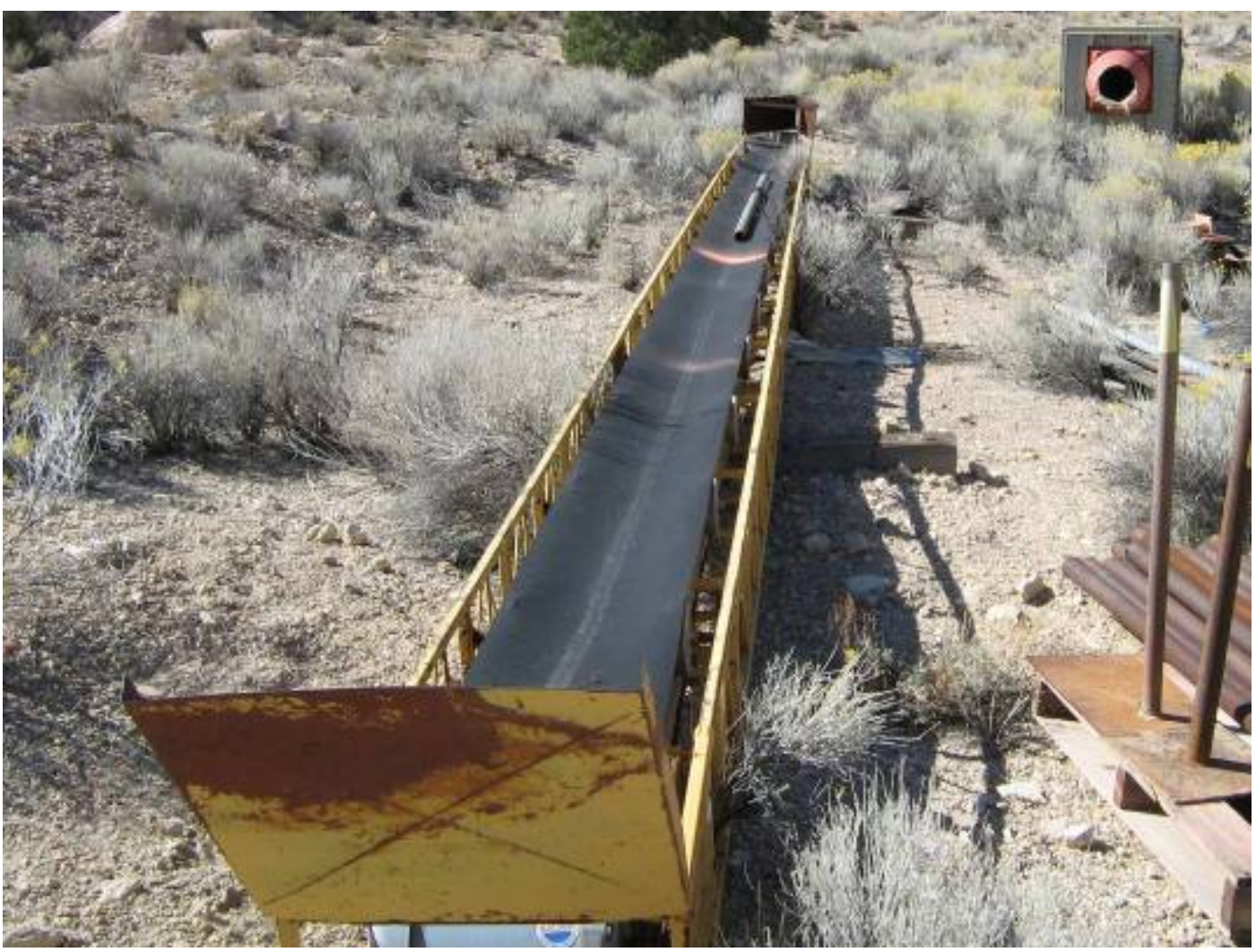

Photograph 7. Conveyor (10/30/2007)

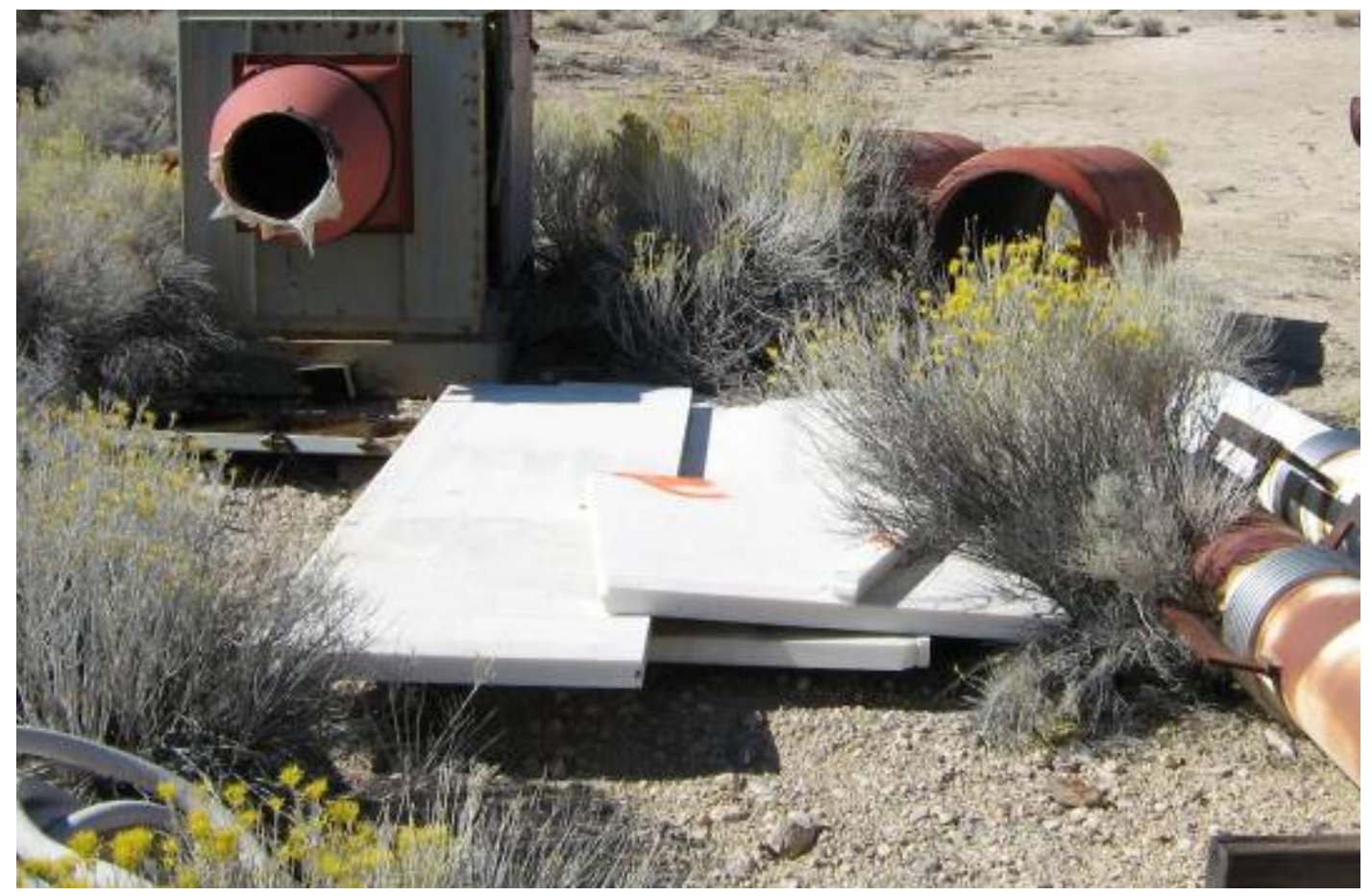

Photograph 8. Countertop-type Material (10/30/2007) 


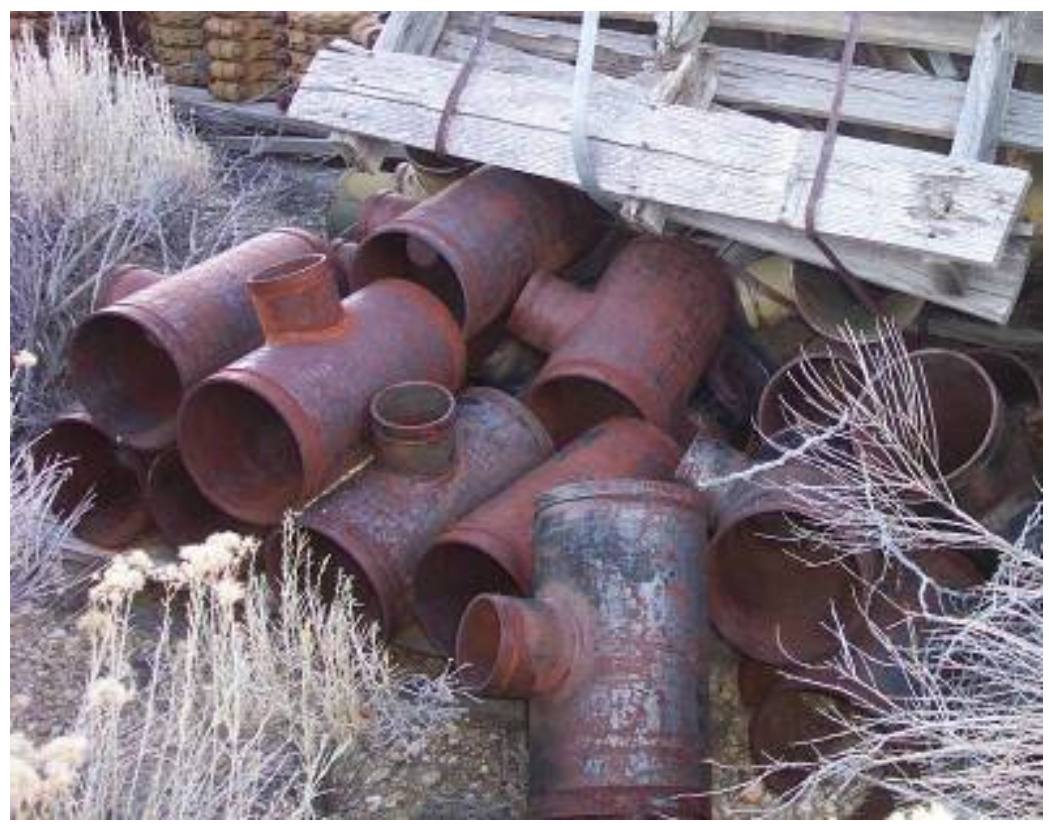

Photograph 9. Couplers (11/15/2005)

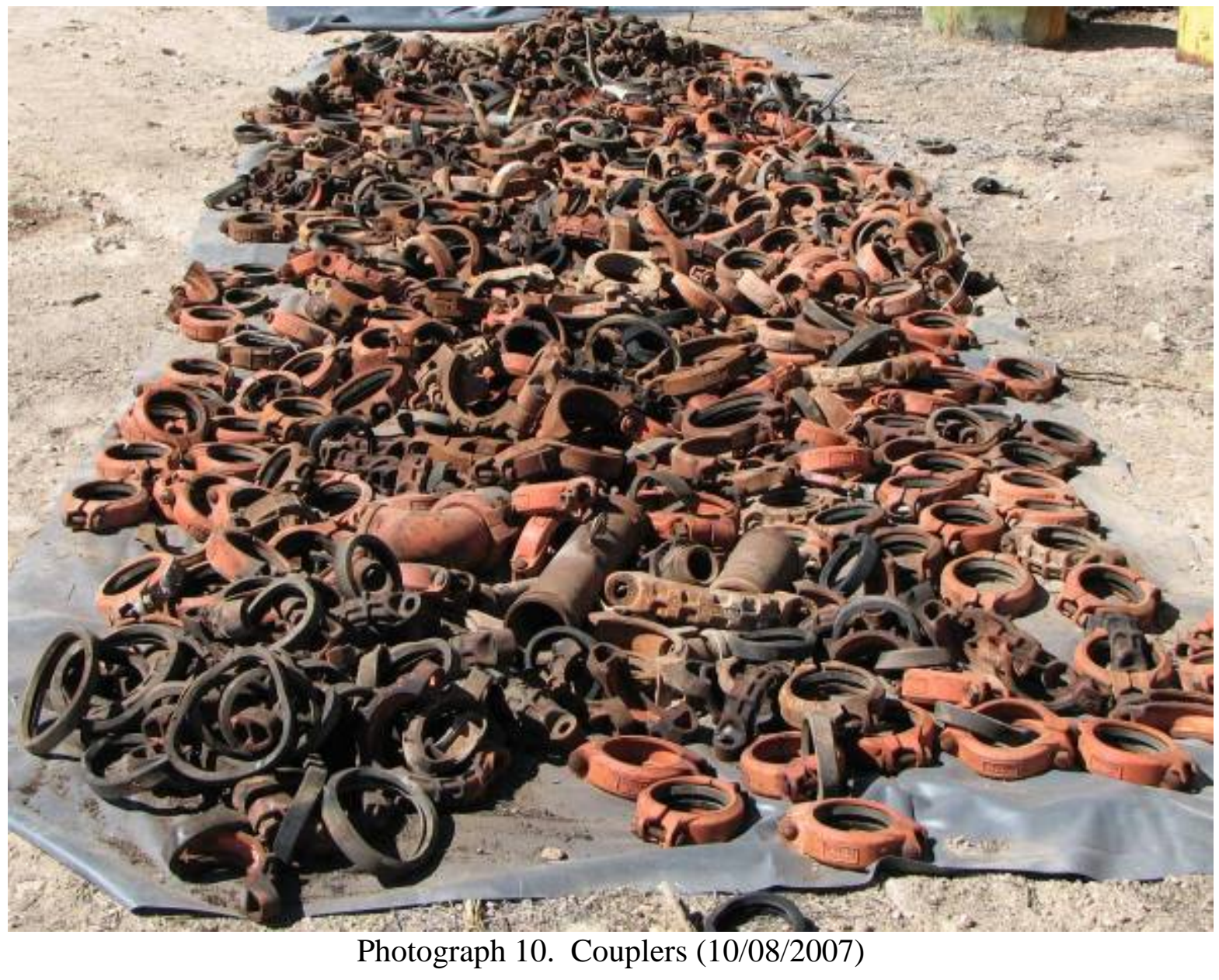




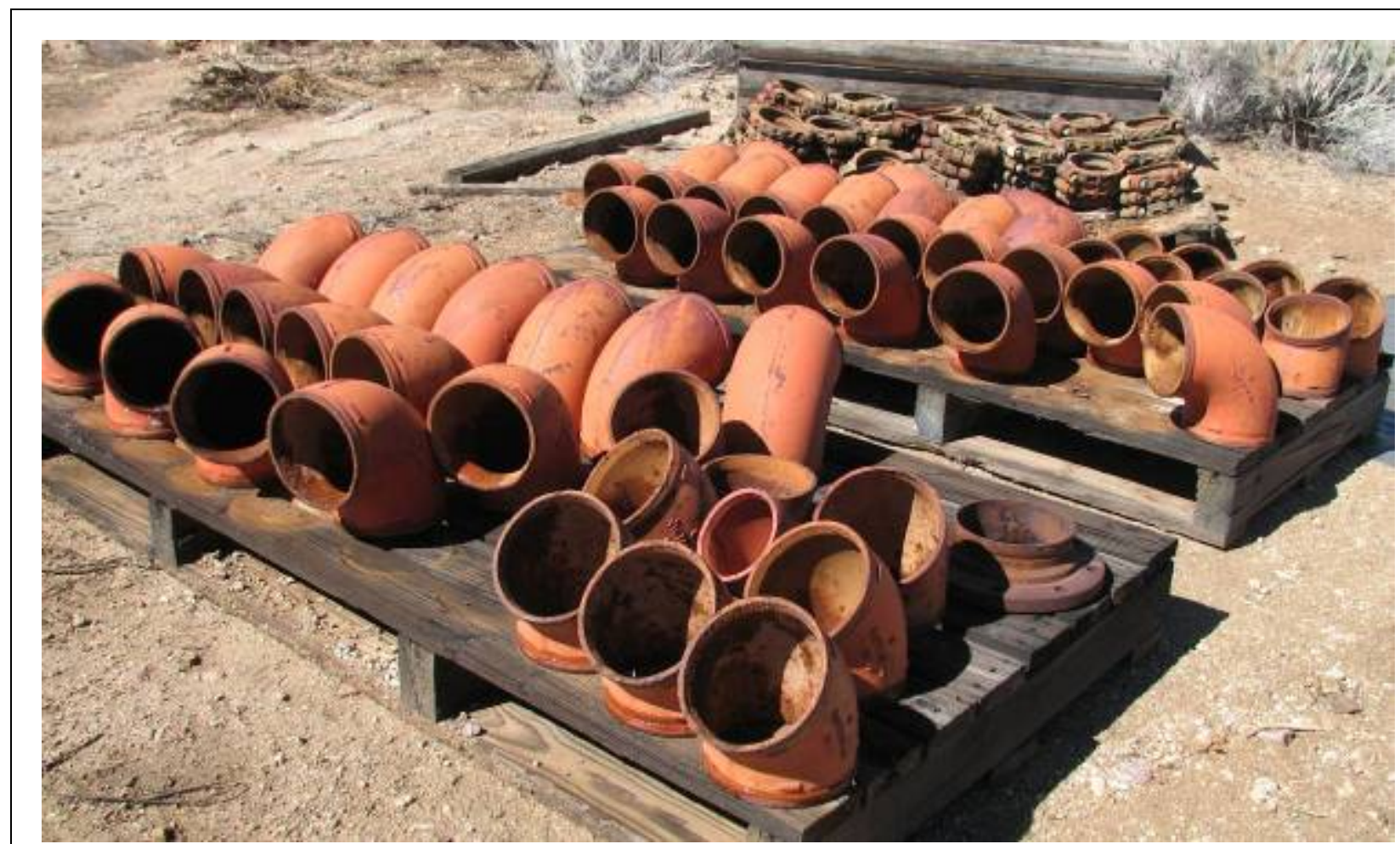

Photograph 11. Couplers (10/09/2007)

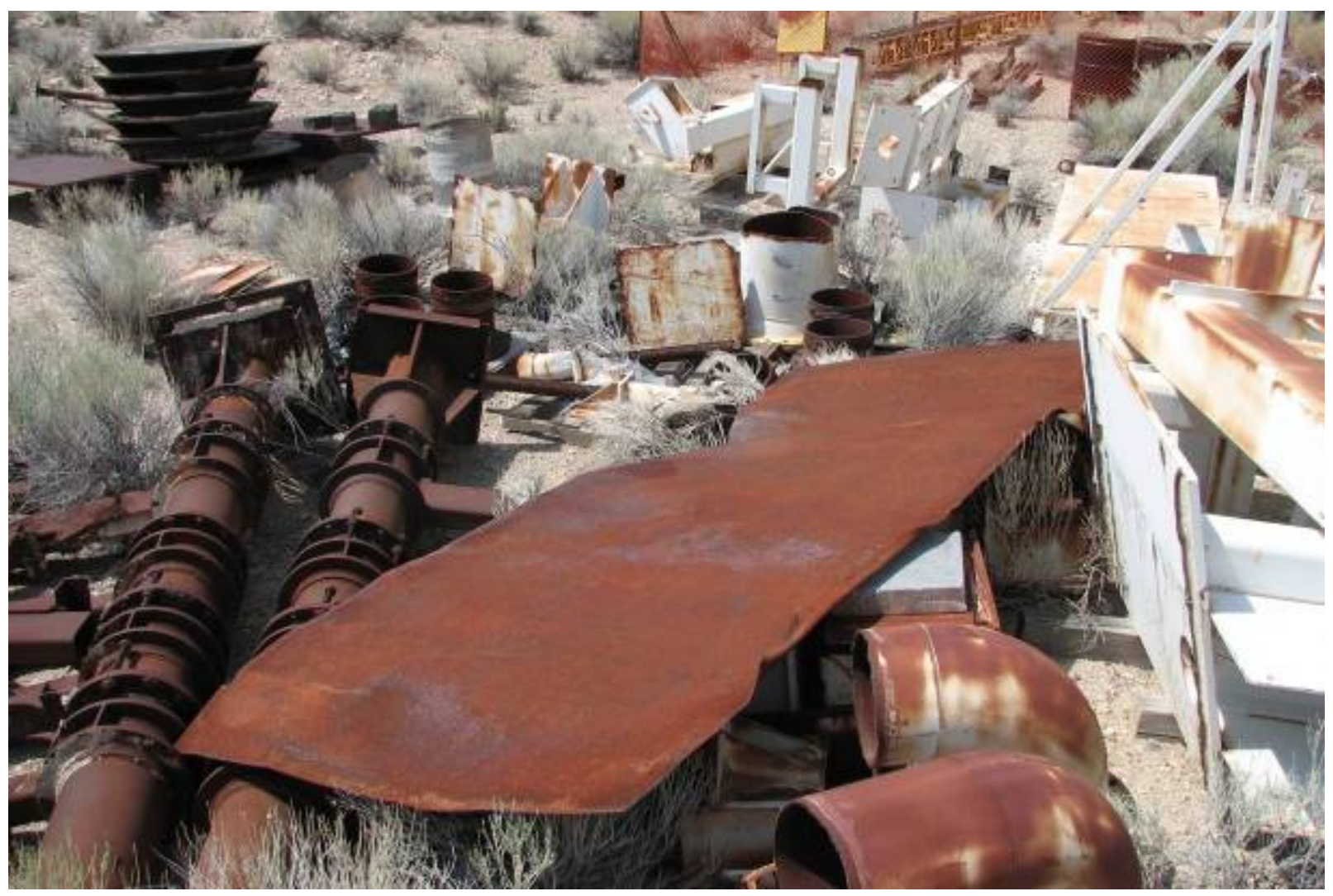

Photograph 12. Debris (07/30/2007) 


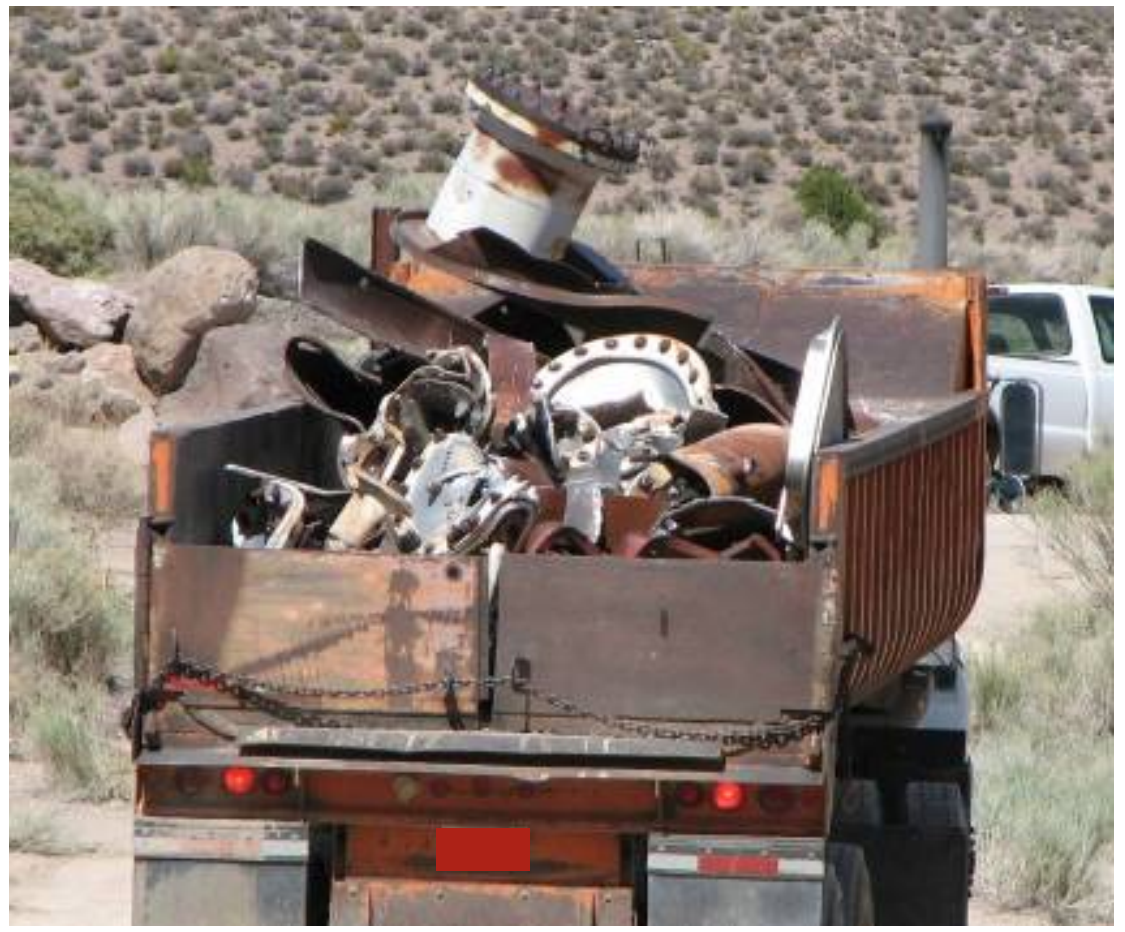

Photograph 13. Debris (08/13/2007)

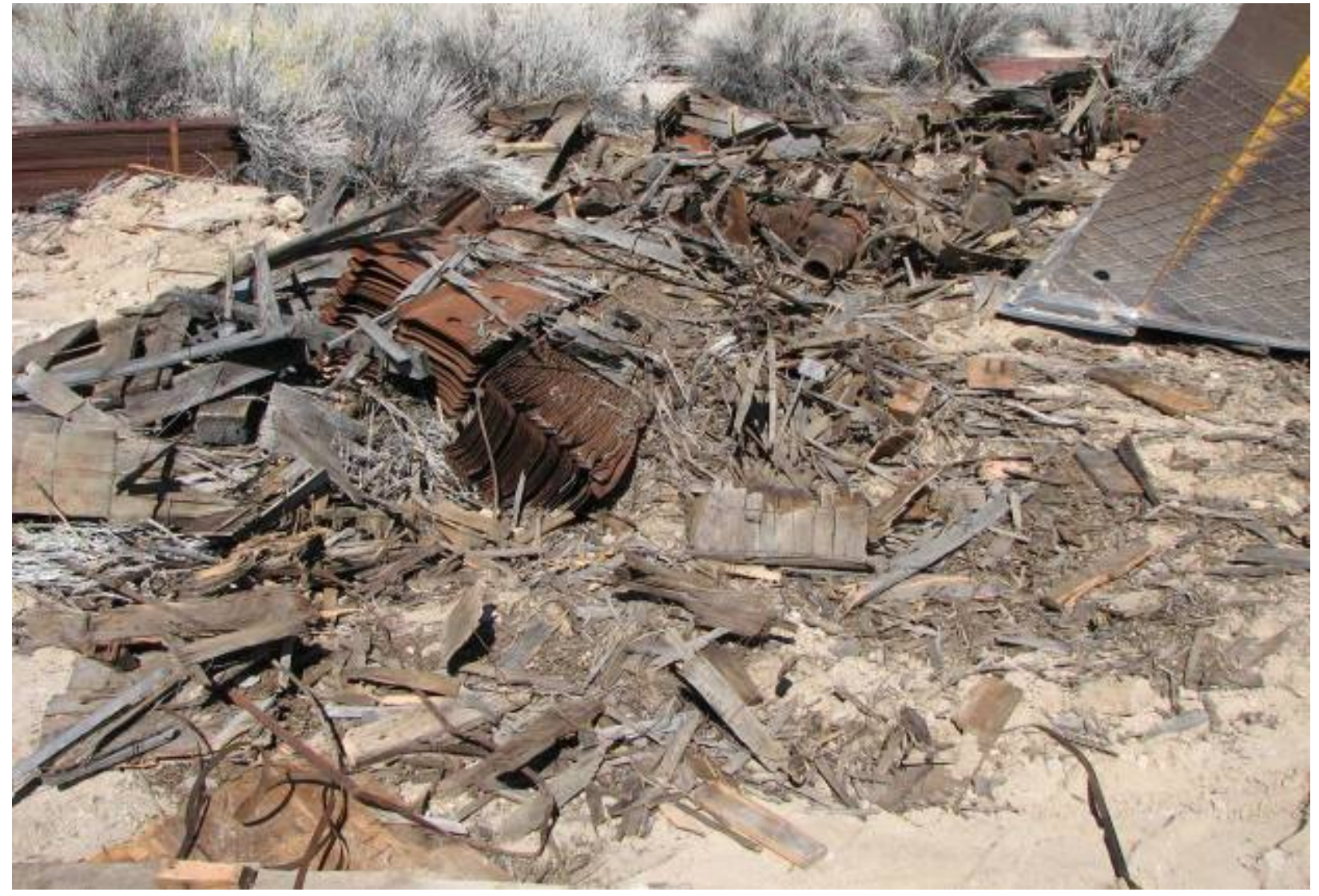

Photograph 14. Debris (10/01/2007) 


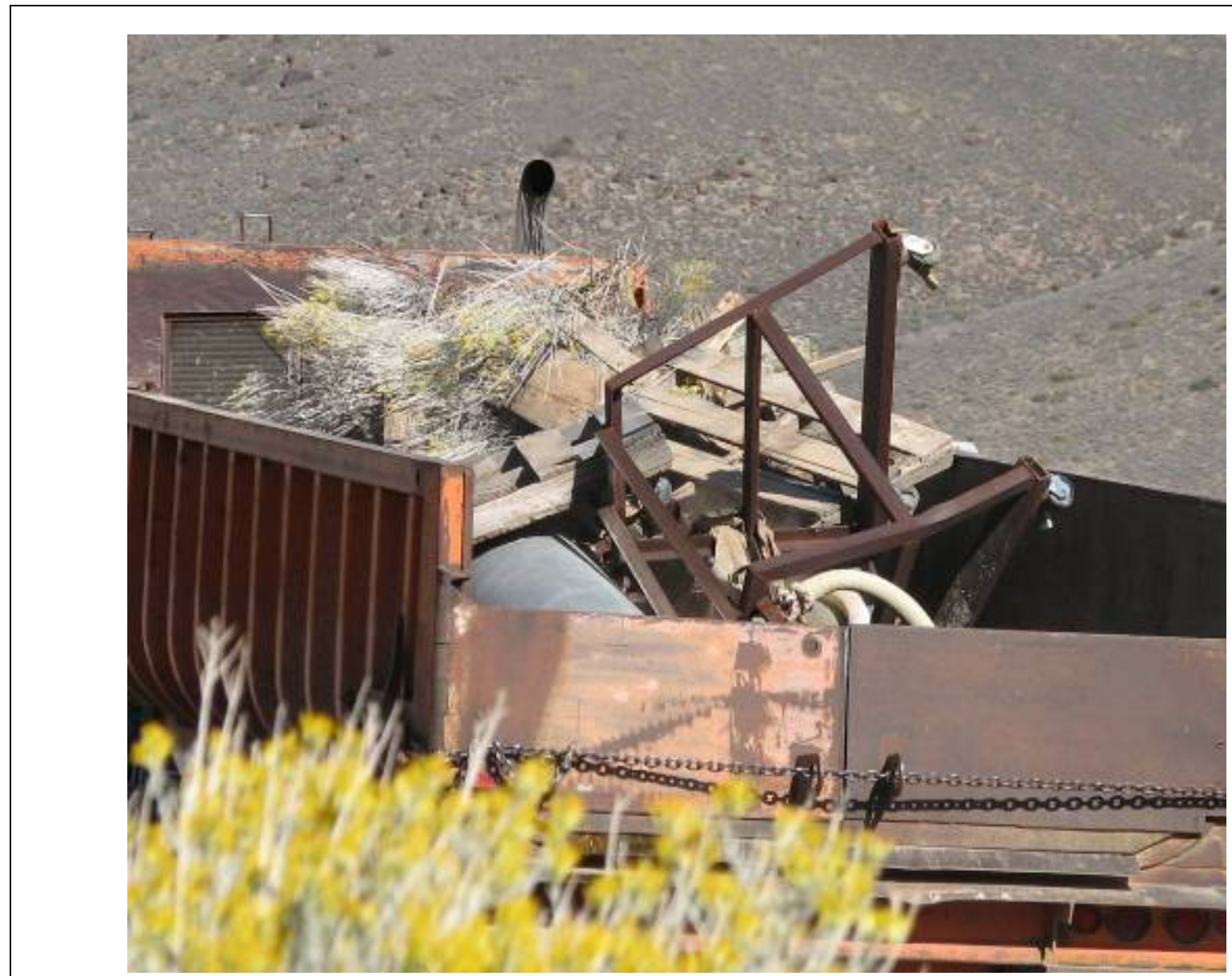

Photograph 15. Debris (10/16/2007)

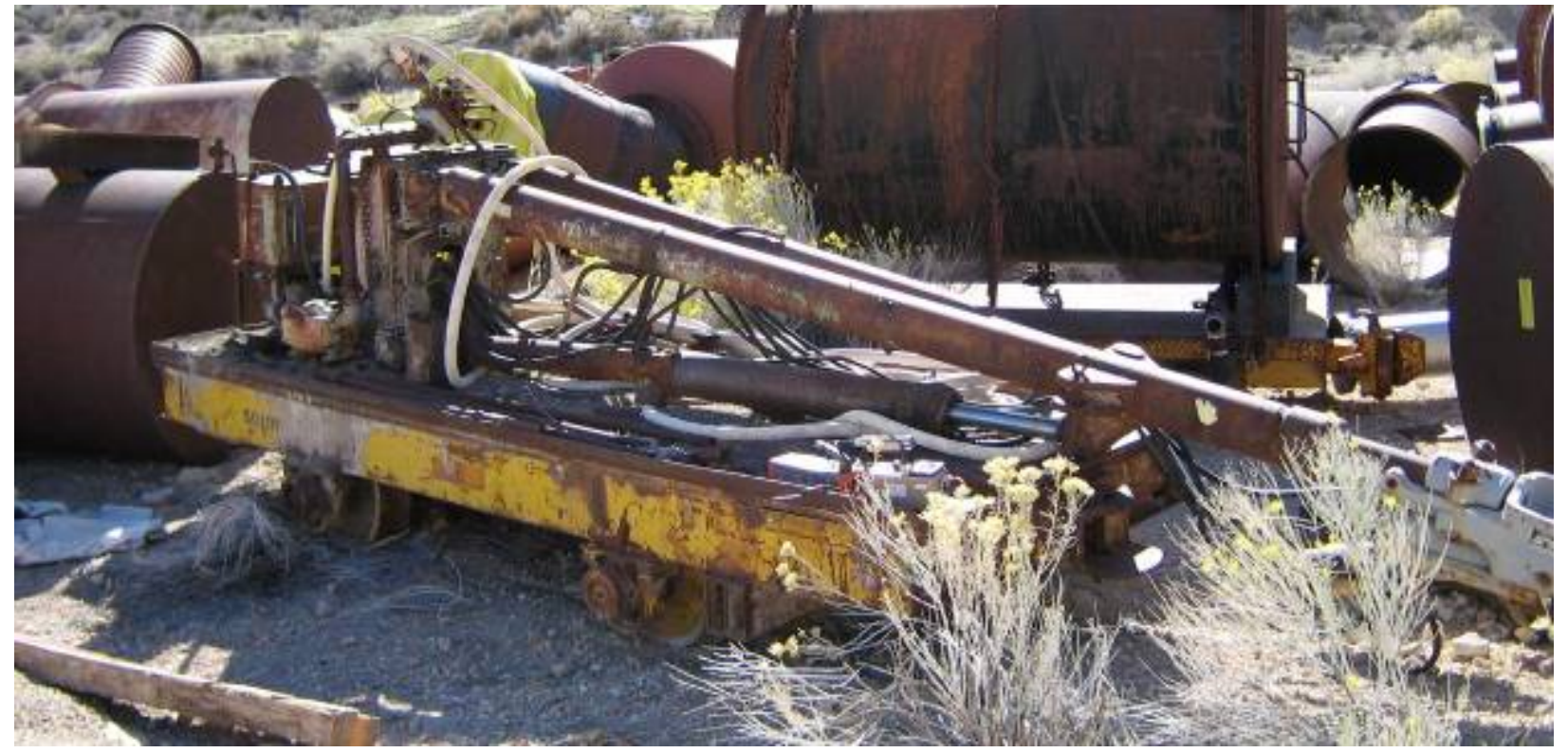

Photograph 16. Drill (10/30/2007) 


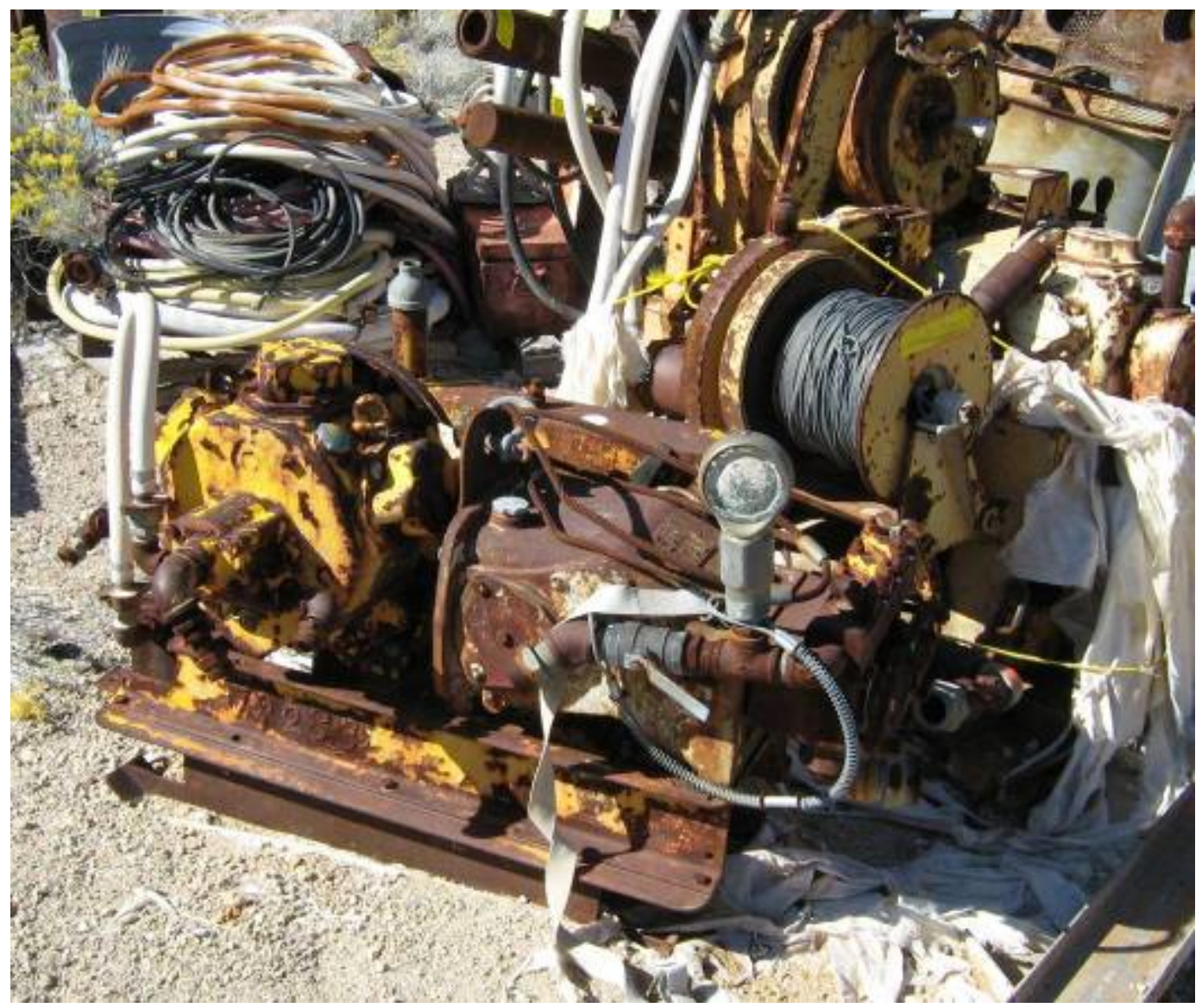

Photograph 17. Drill parts (10/30/2007)

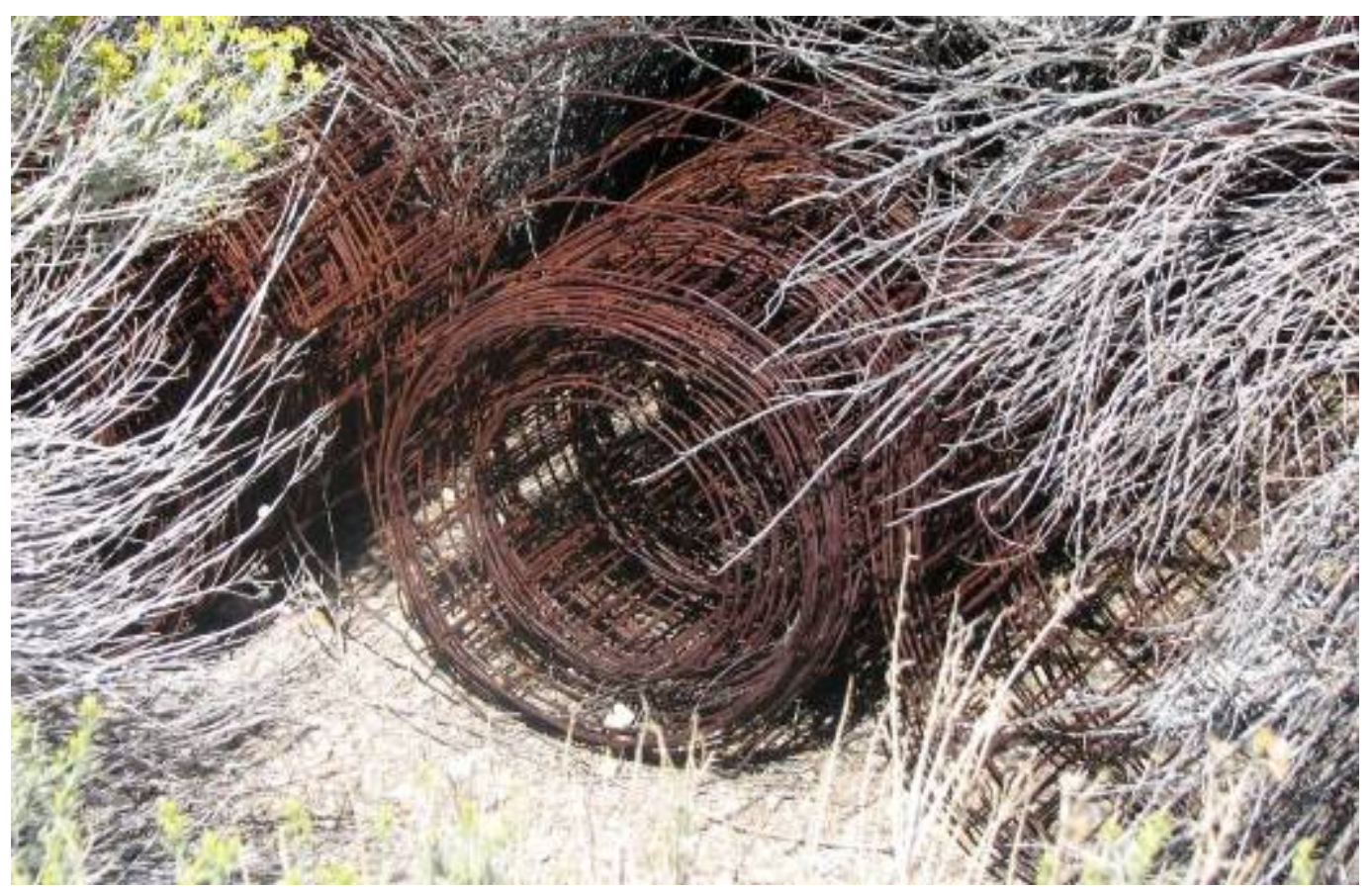

Photograph 18. Fence (09/07/2007) 


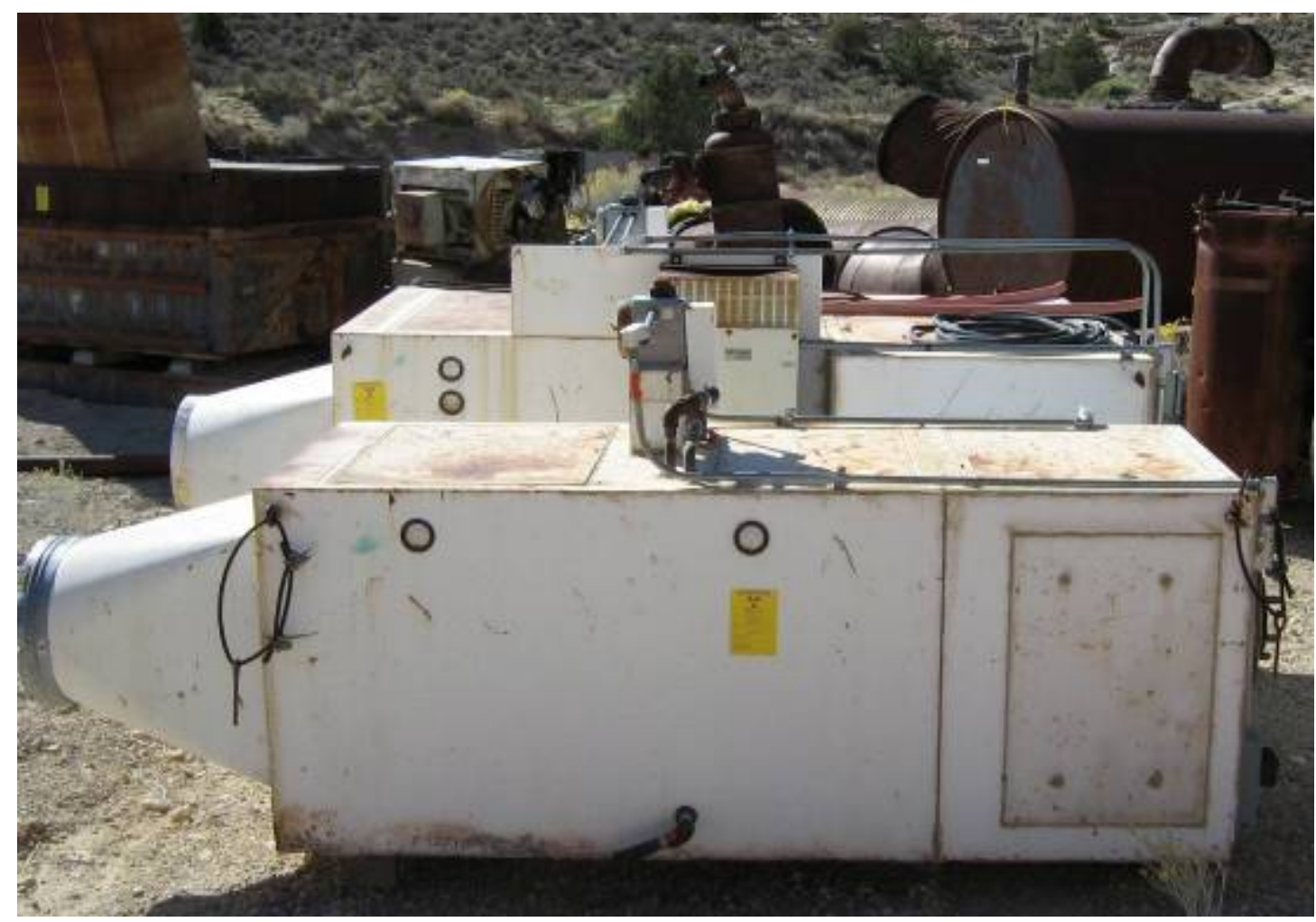

Photograph 19. Filter Boxes (07/10/2007)

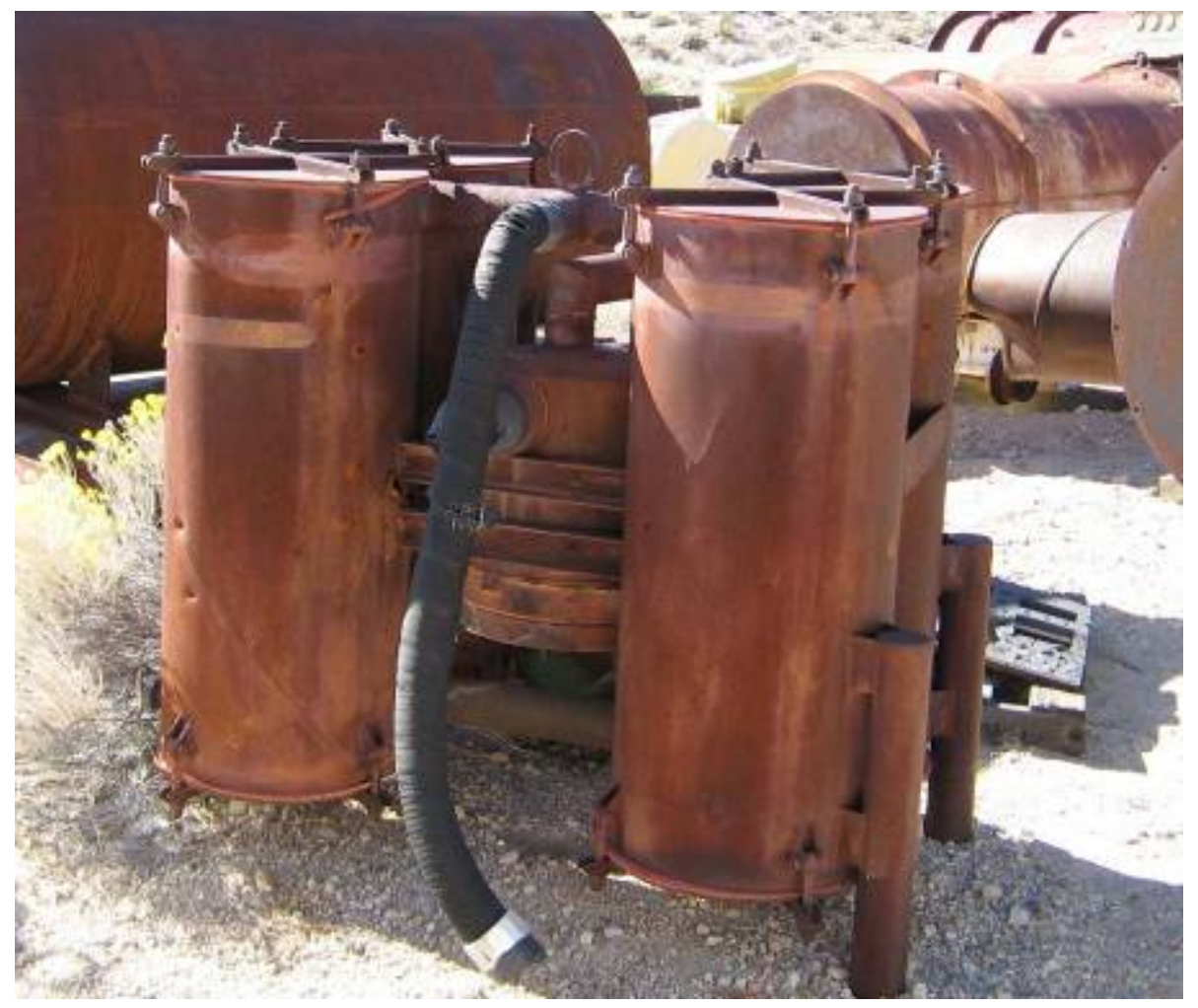

Photograph 20. Filter housing (10/30/2007) 


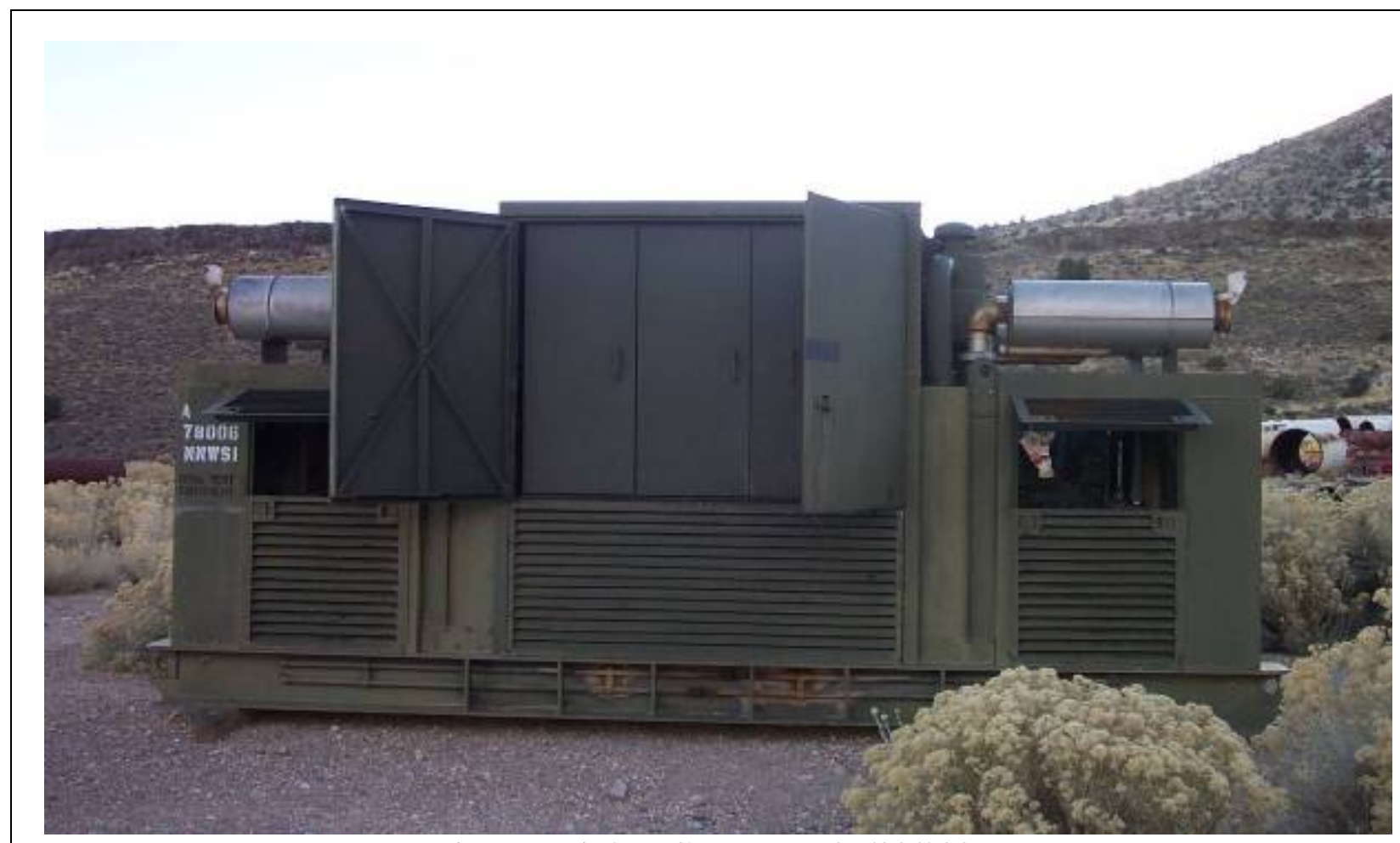

Photograph 21. Generator (07/30/2007)

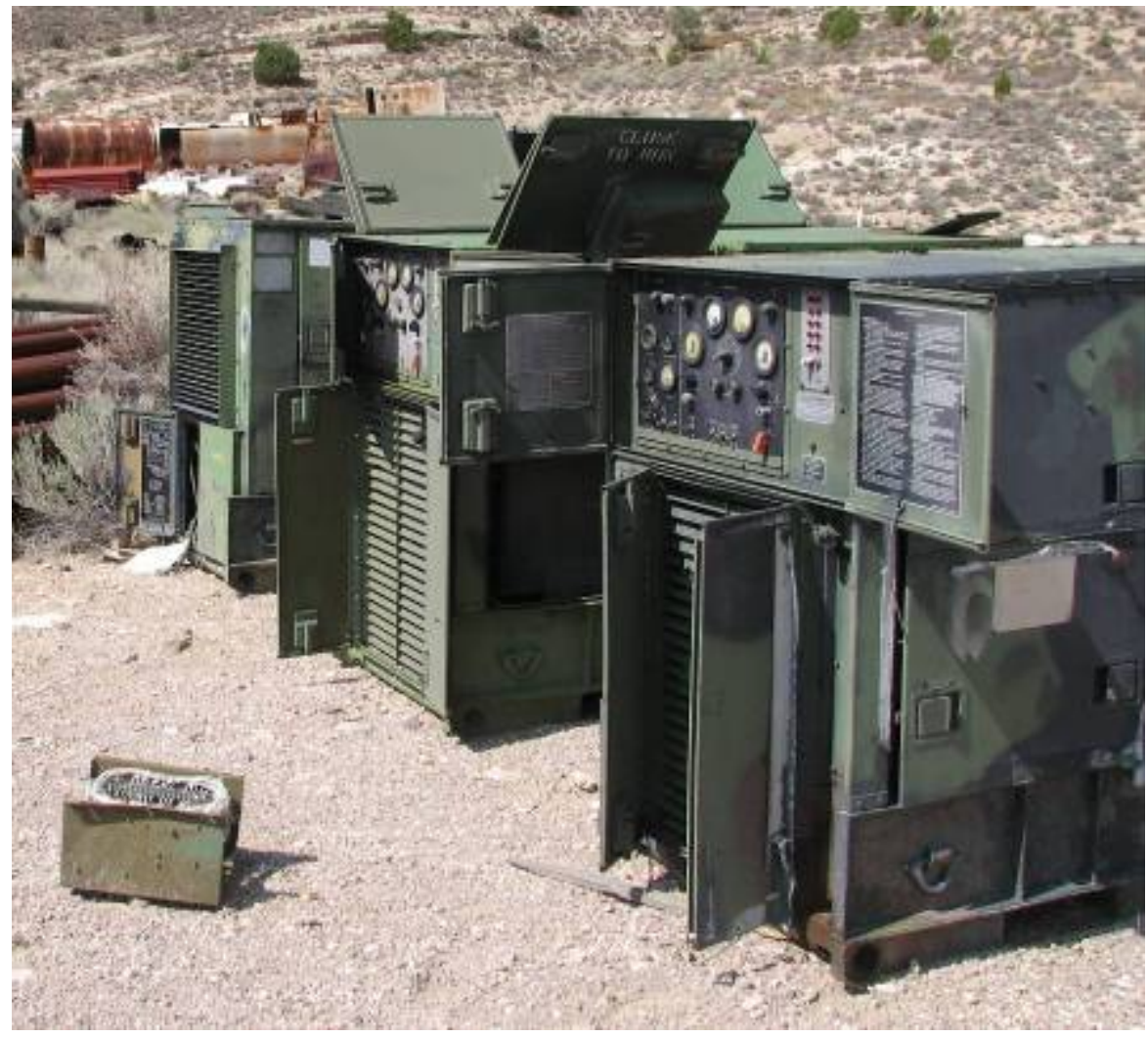

Photograph 22. Generators (07/30/2007) 


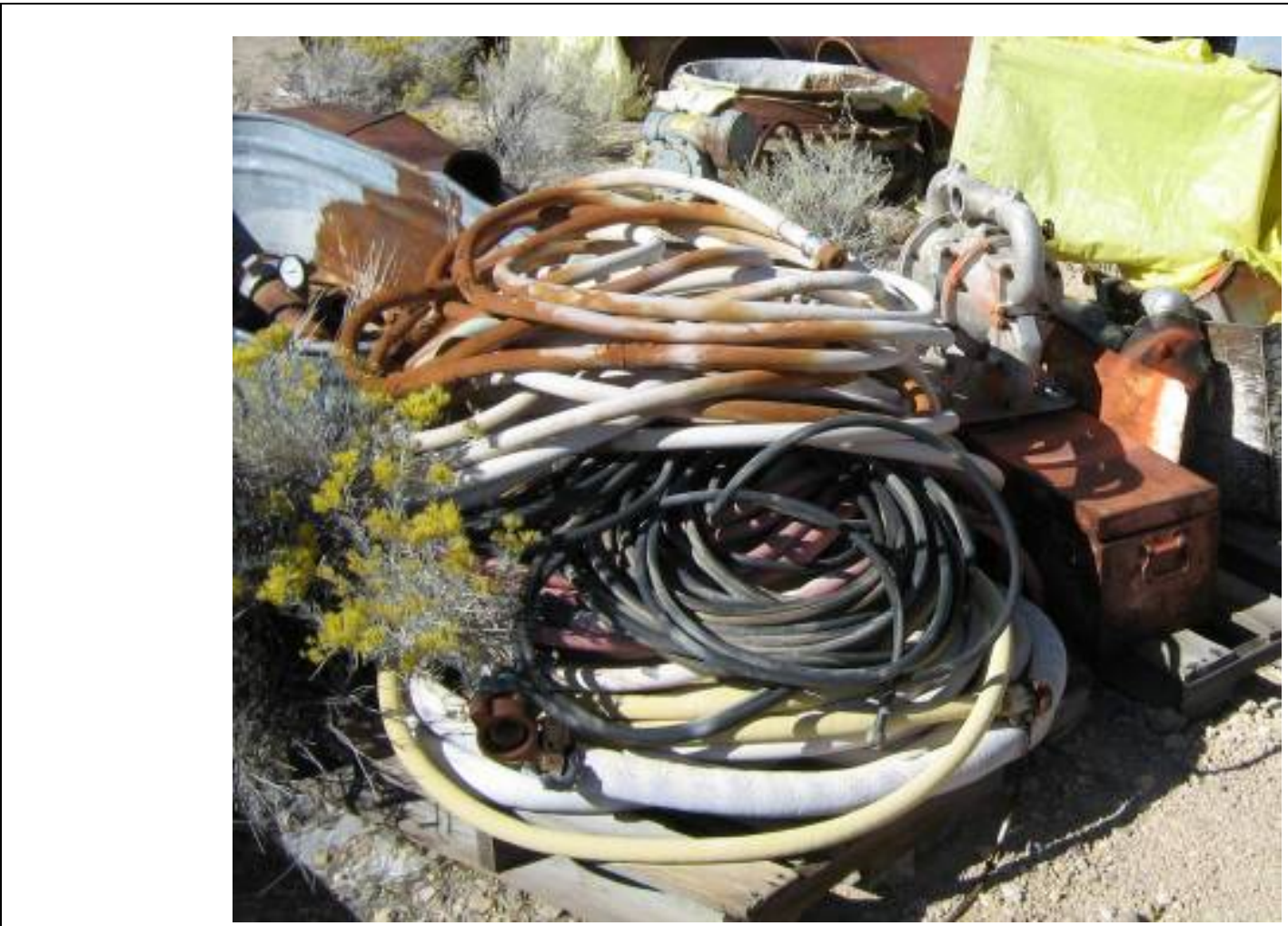

Photograph 23. Hoses (10/30/2007)

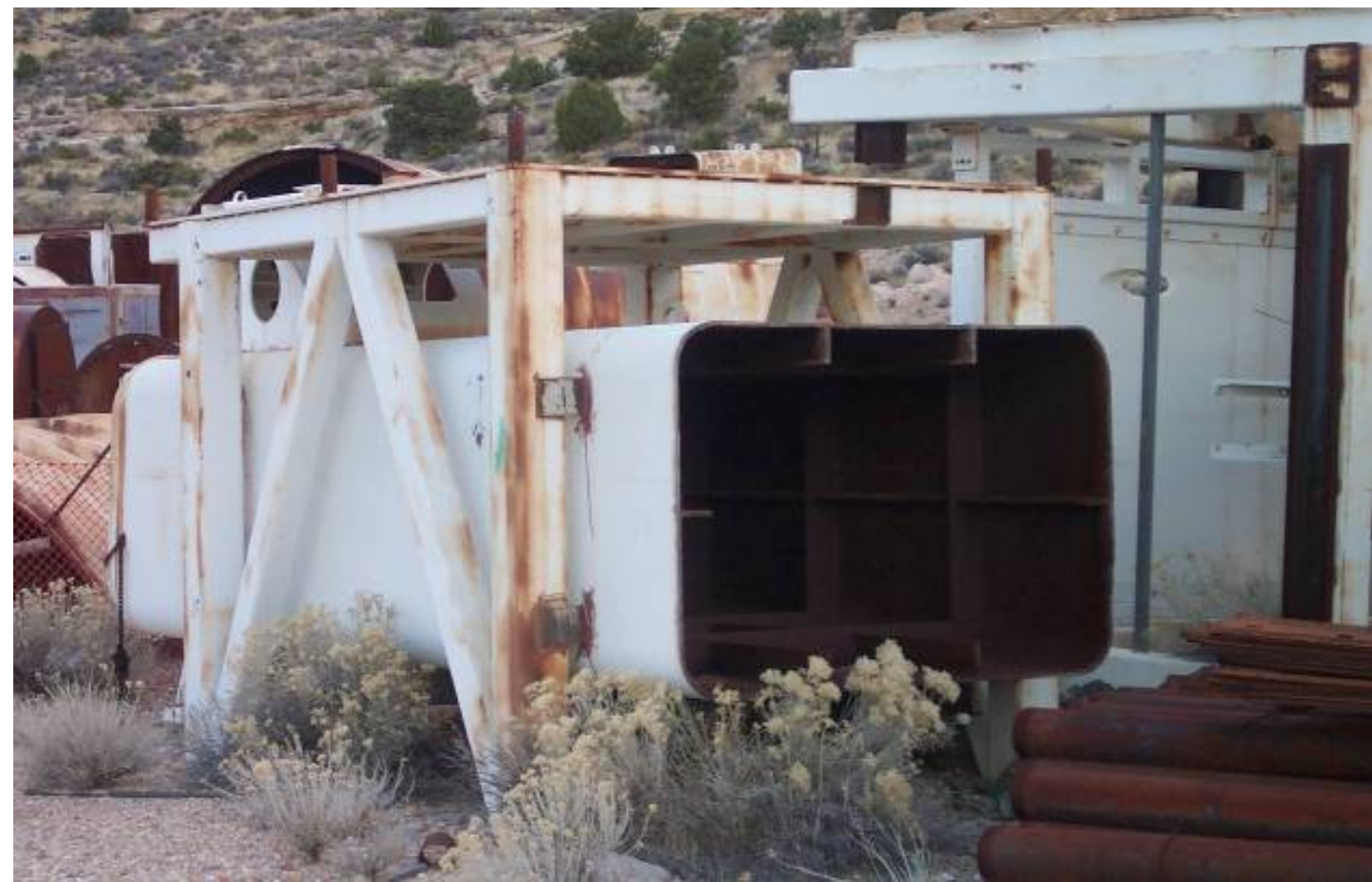

Photograph 24. Metal (11/15/2005) 


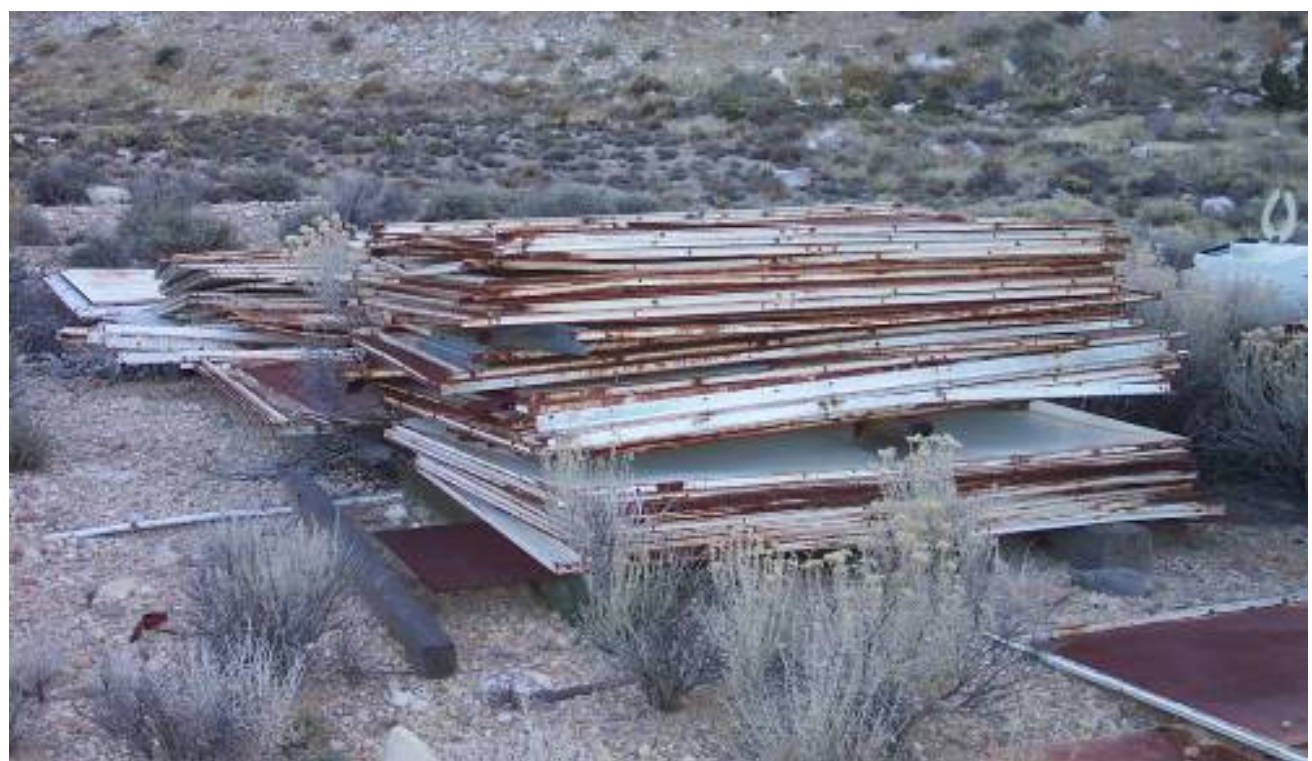

Photograph 25. Metal frames (11/15/2005)

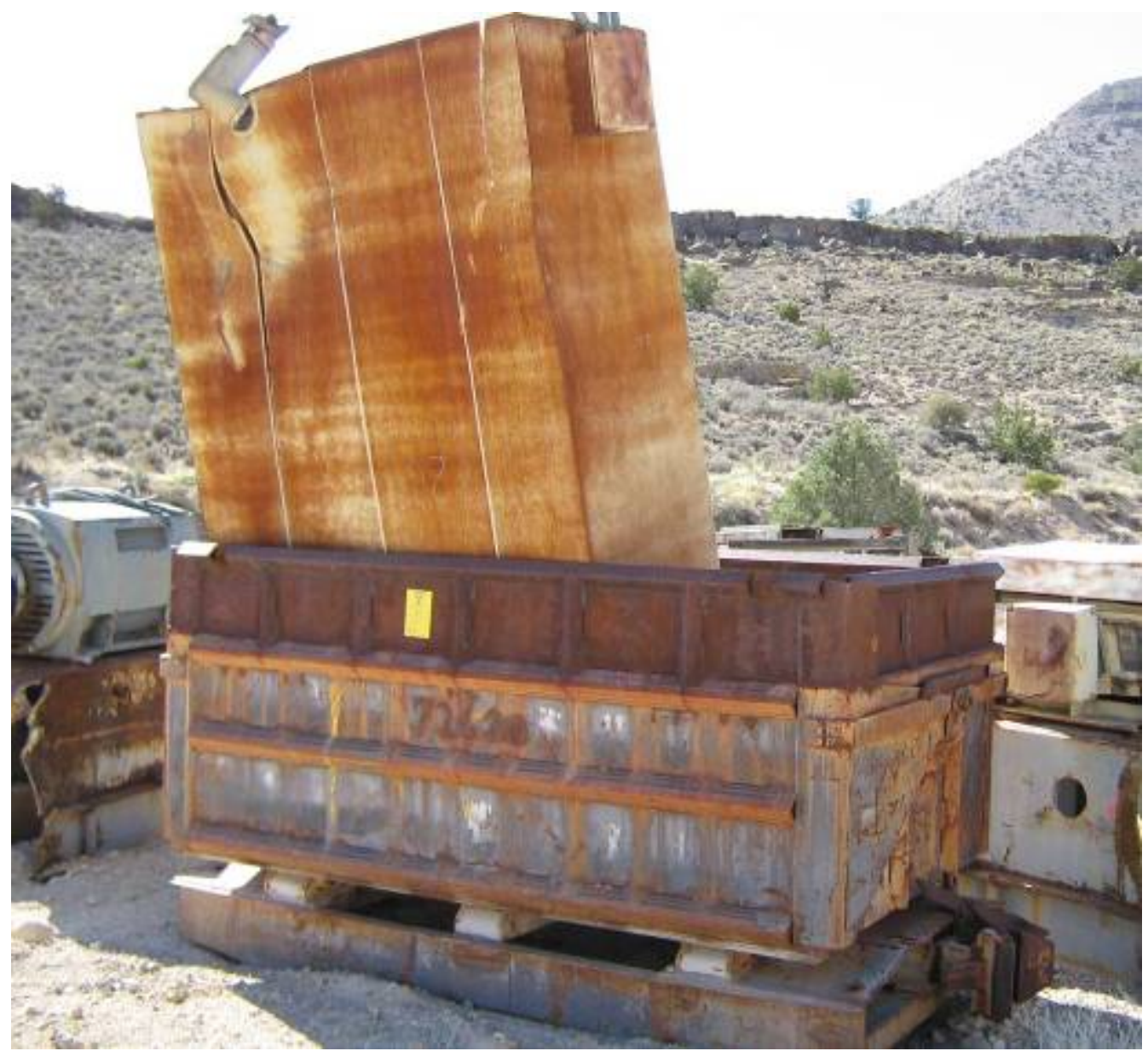

Photograph 26. Ore car with panel box (10/30/2007) 


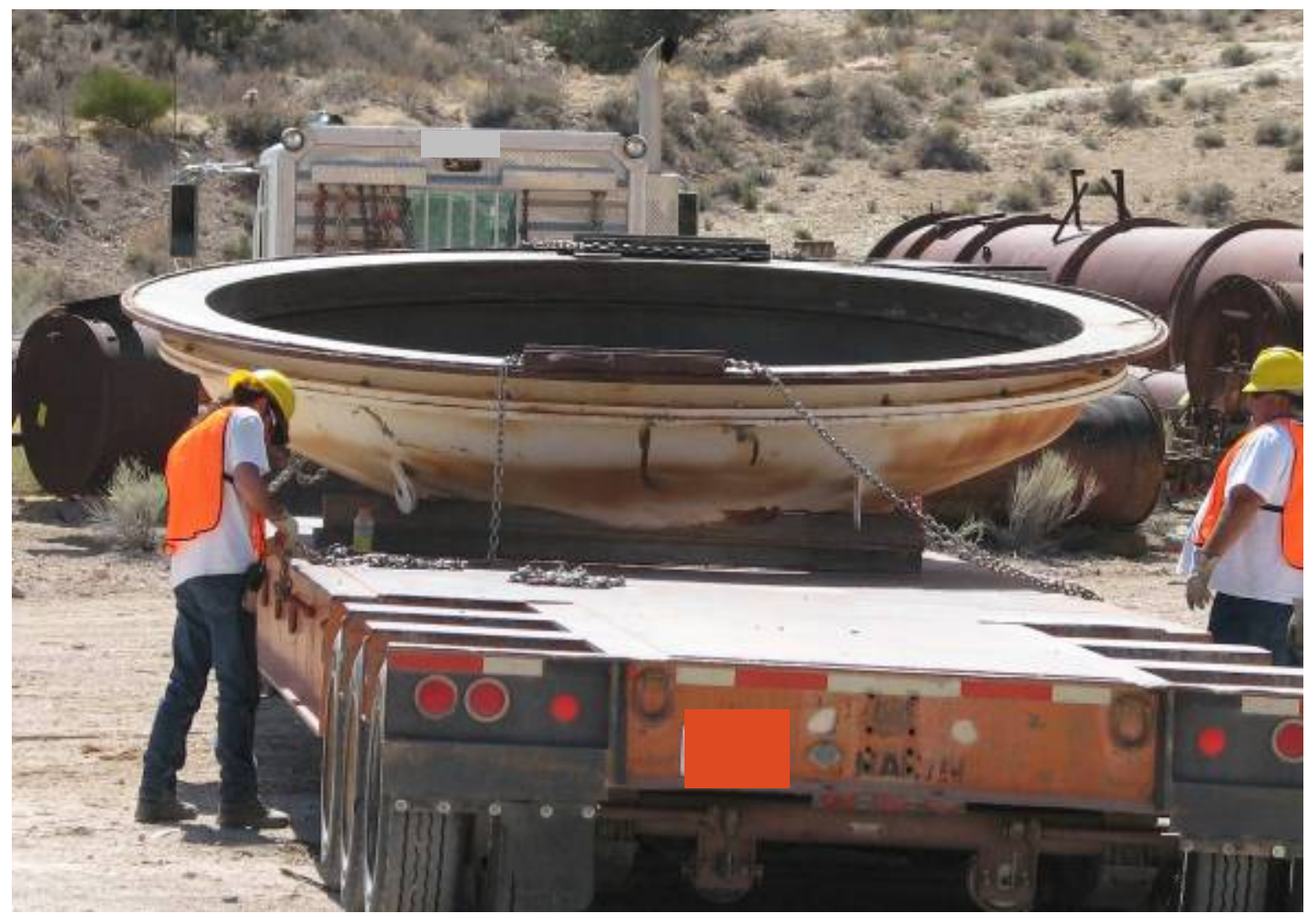

Photograph 27. Other metal waste (09/07/2007)

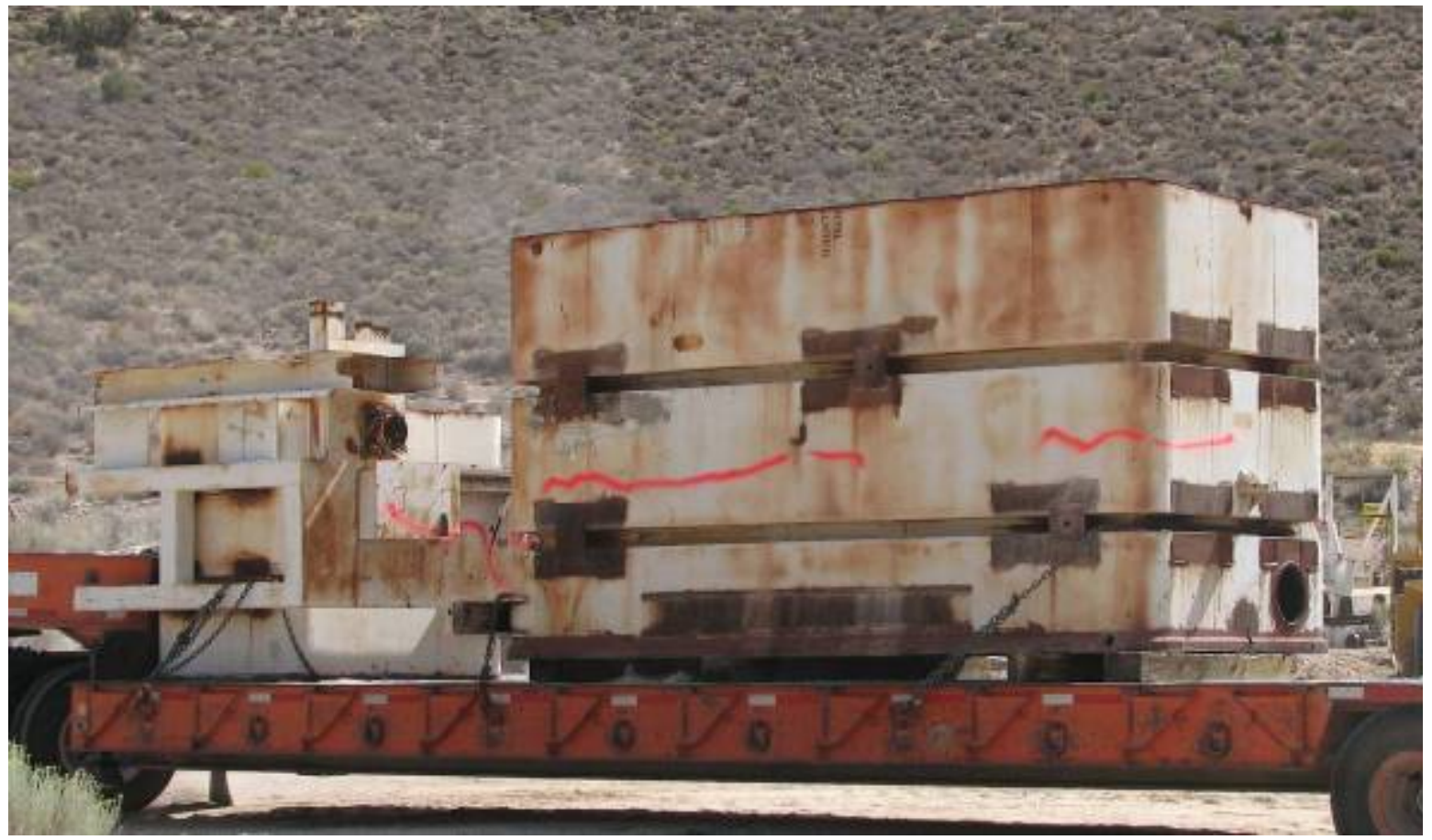

Photograph 28. Other metal waste (08/28/2007) 


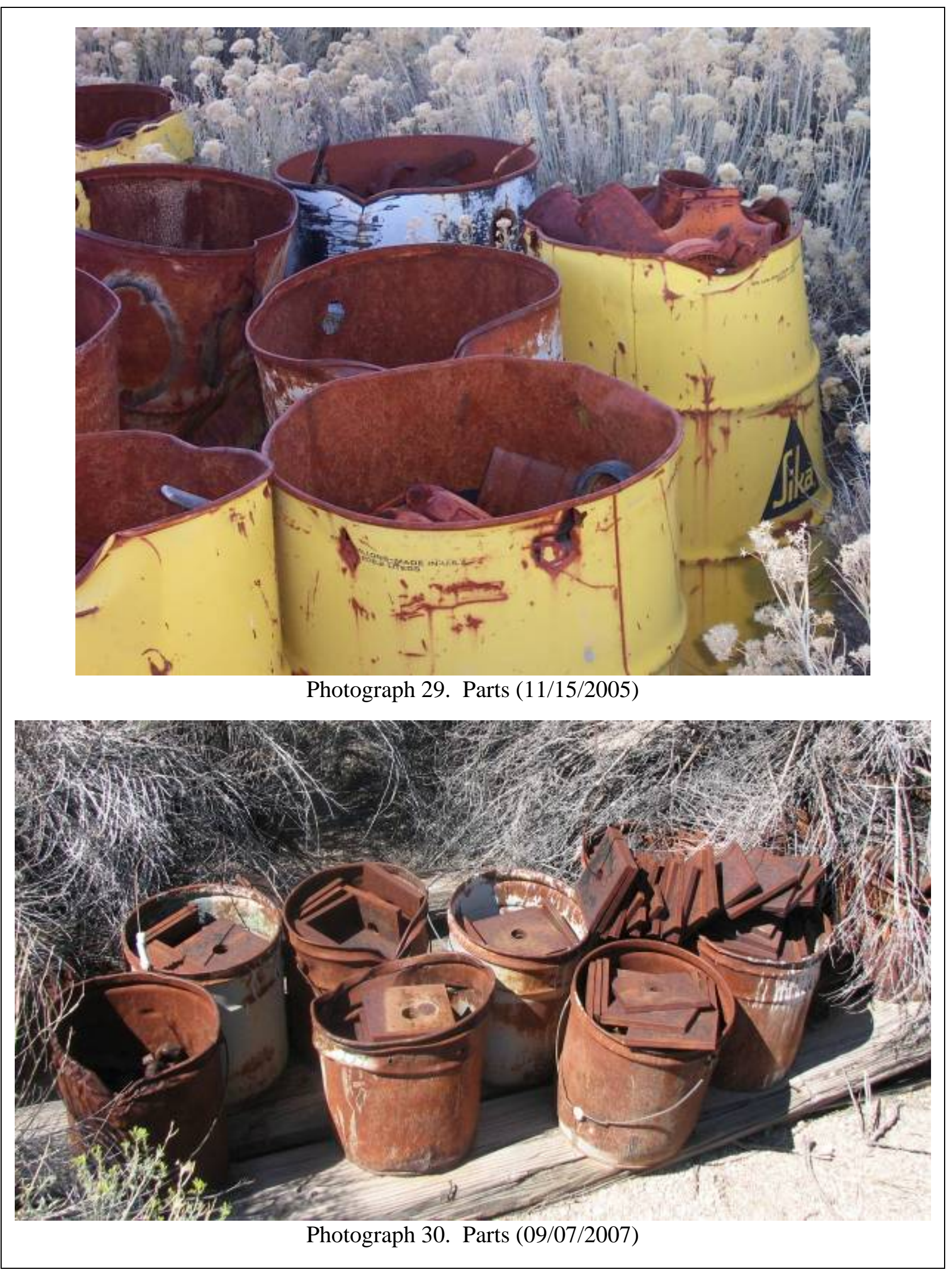




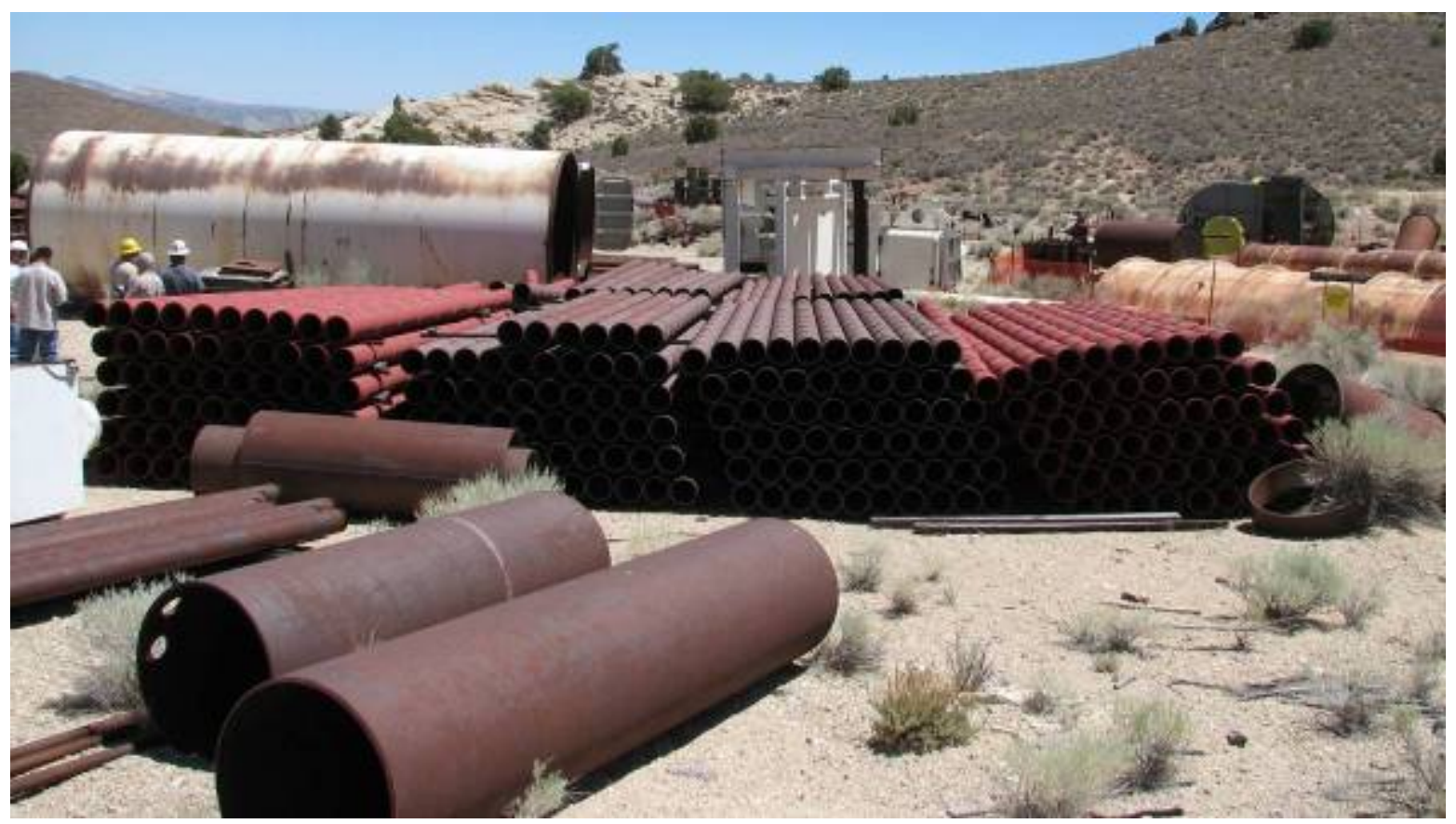

Photograph 31. Pipe (07/18/2007)

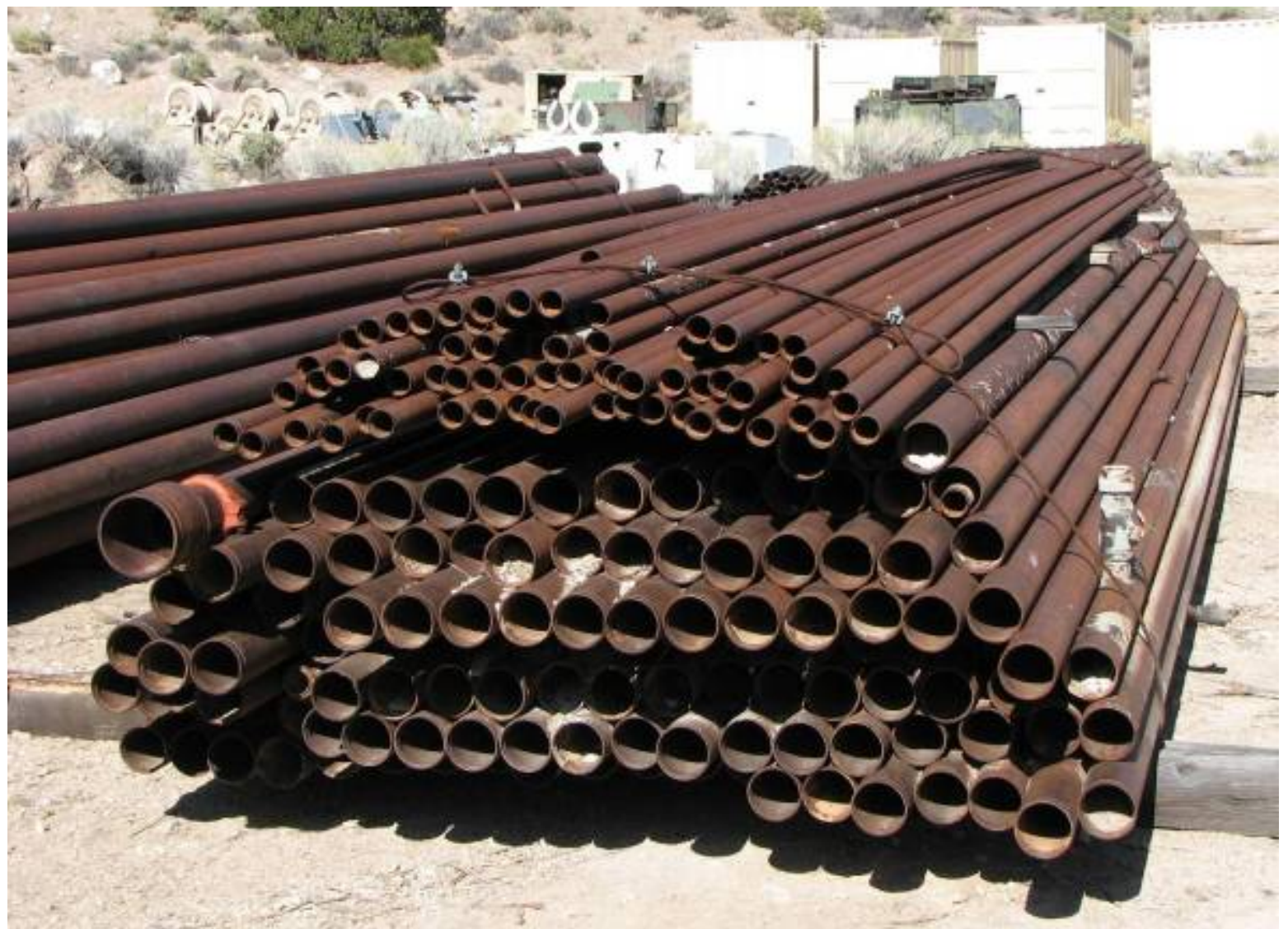

Photograph 32. Pipe (10/04/2007) 


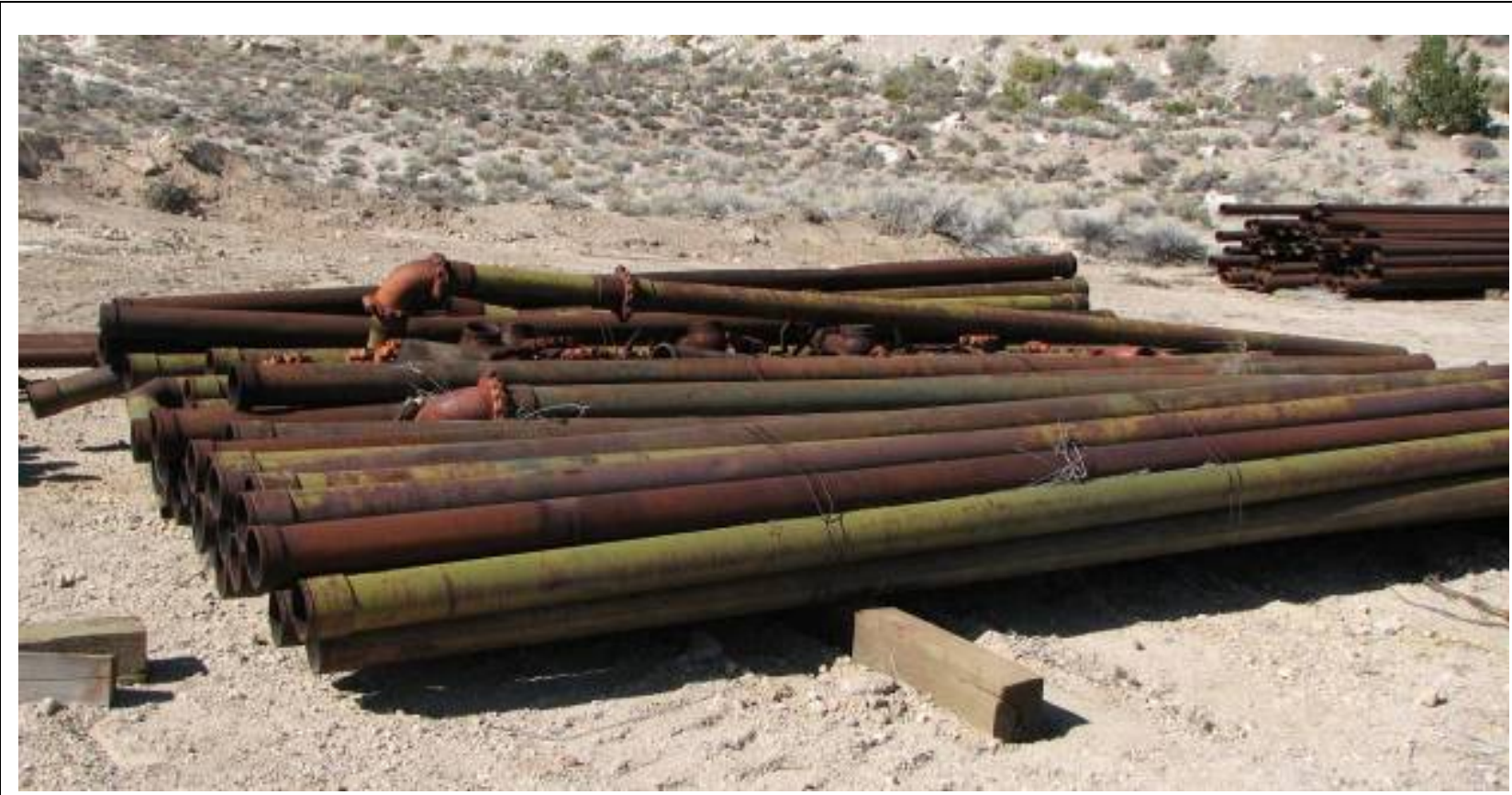

Photograph 33. Pipe (10/04/2007)

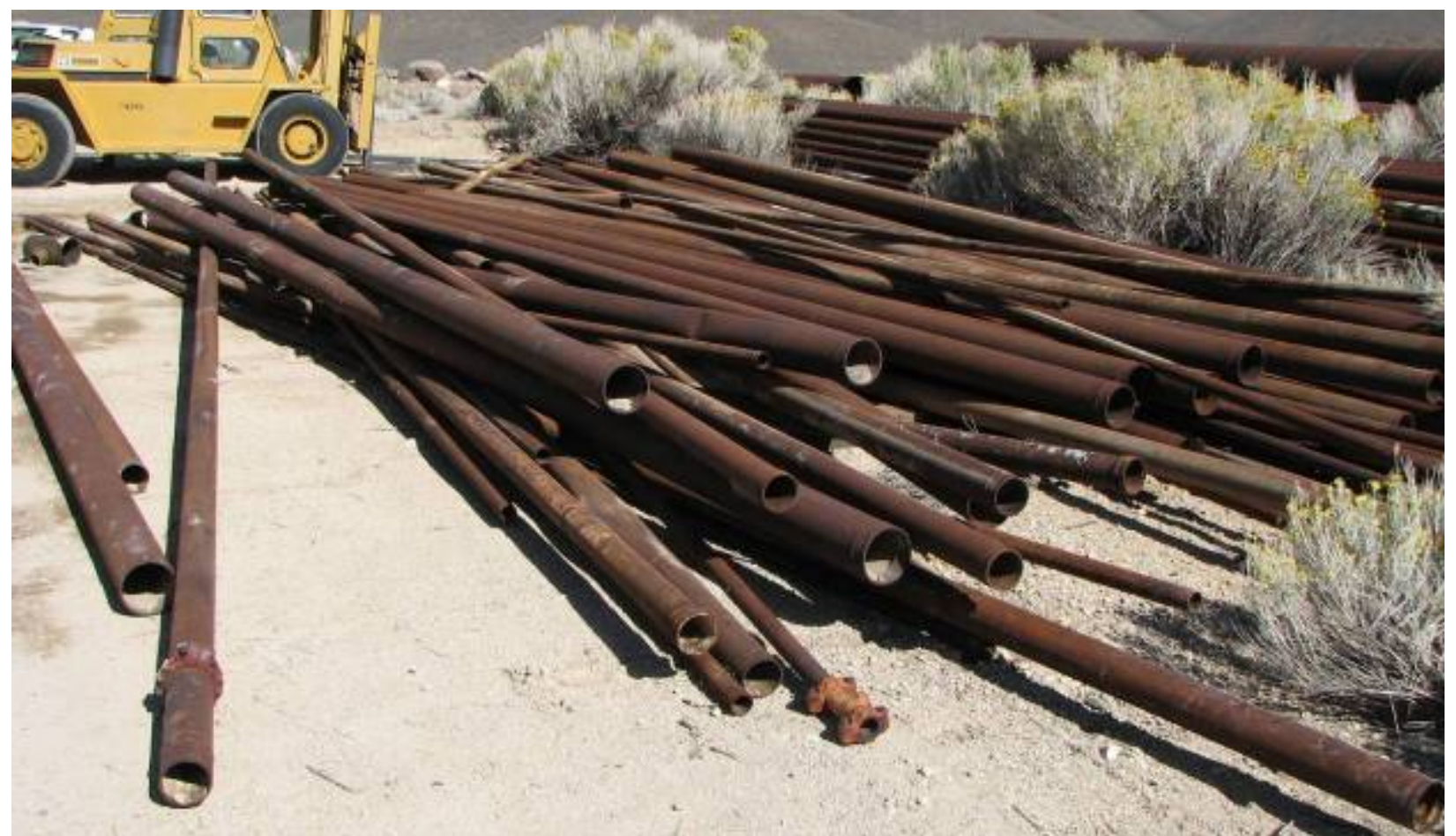

Photograph 34. Pipe (10/04/2007) 


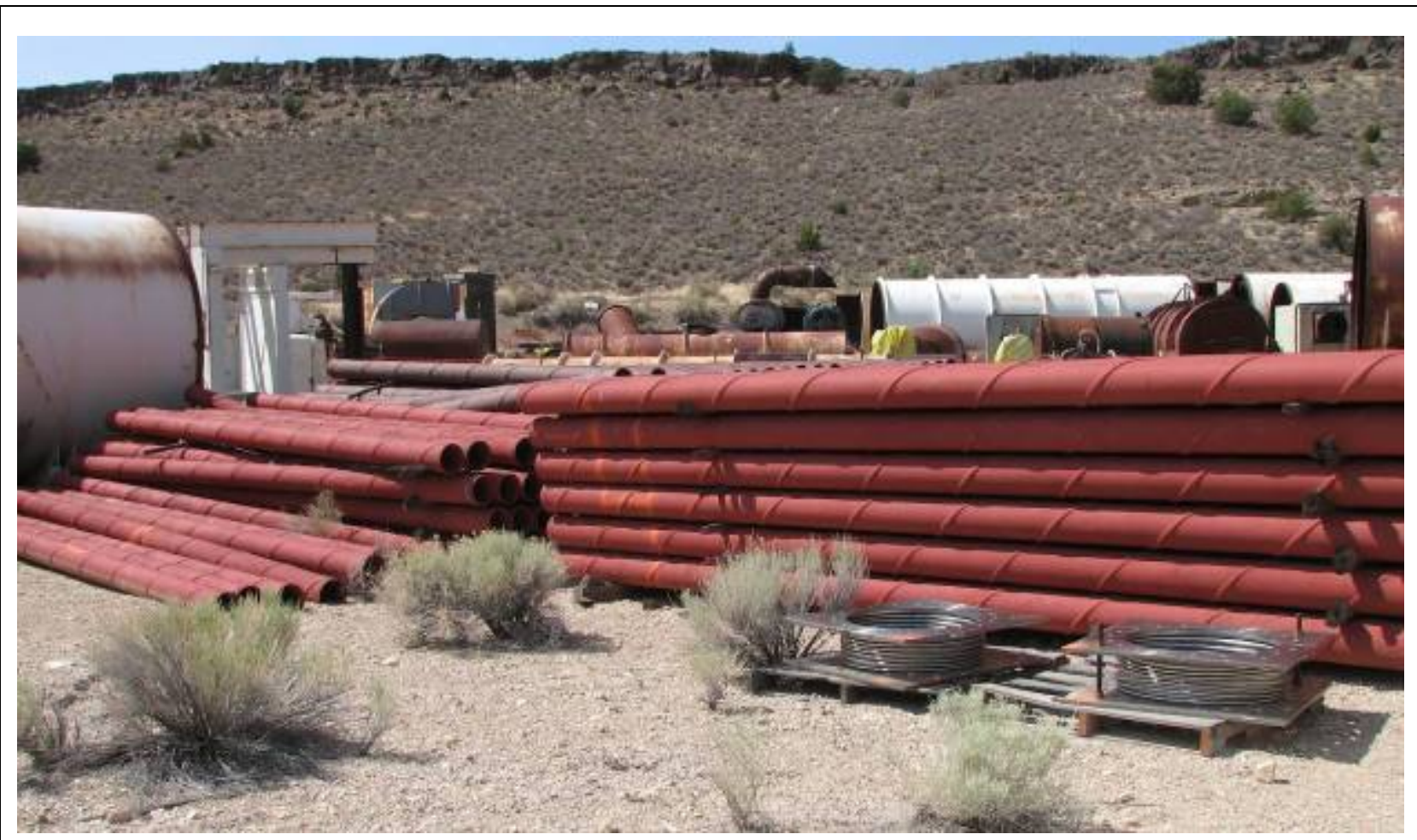

Photograph 35. Pipe (07/30/2007)

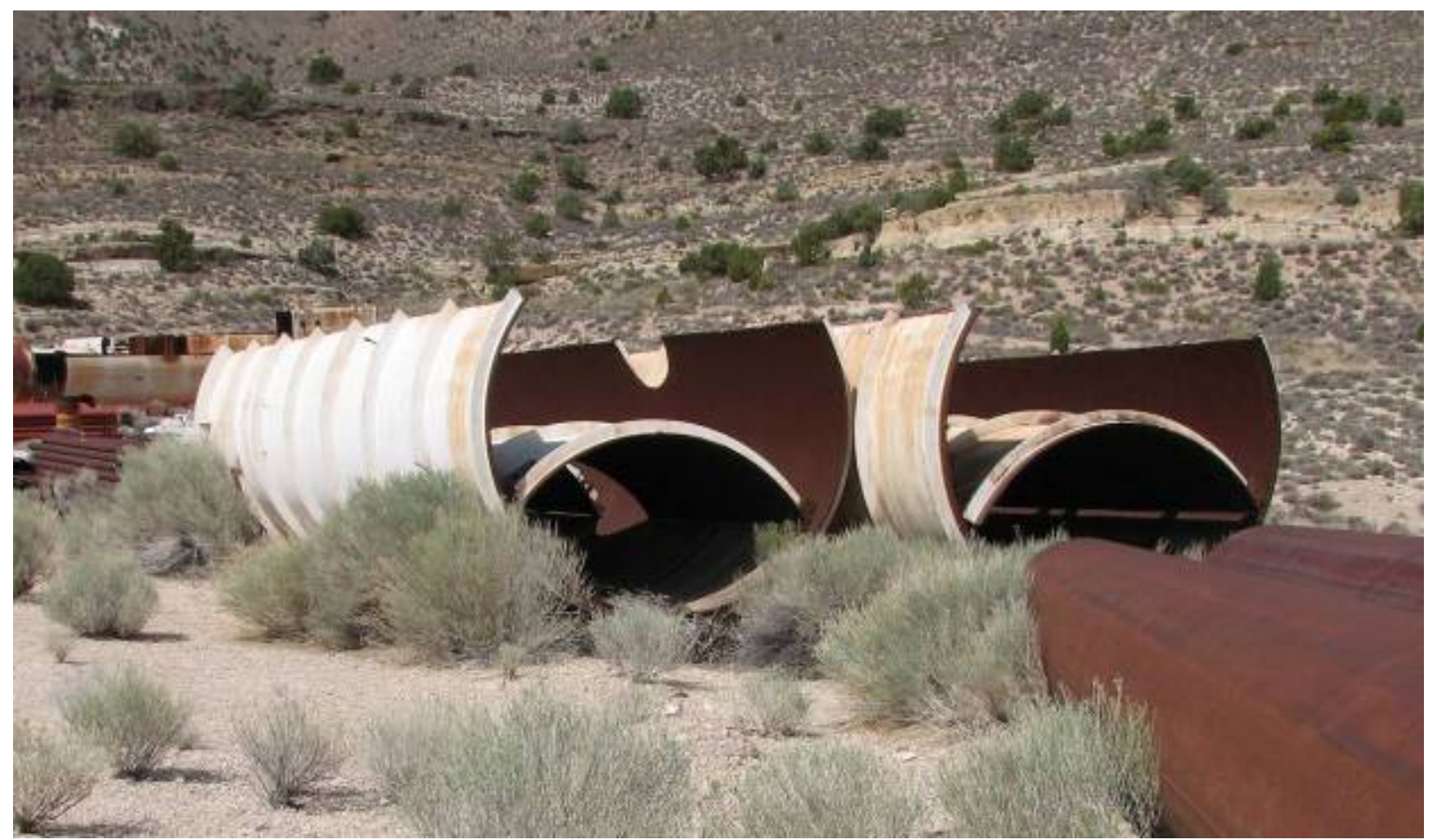

Photograph 36. Pipe, line-of-sight (LOS) (07/30/2007) 
CAU 481 Closure Report

Section: Appendix A

Revision: 0

Date: November 2008

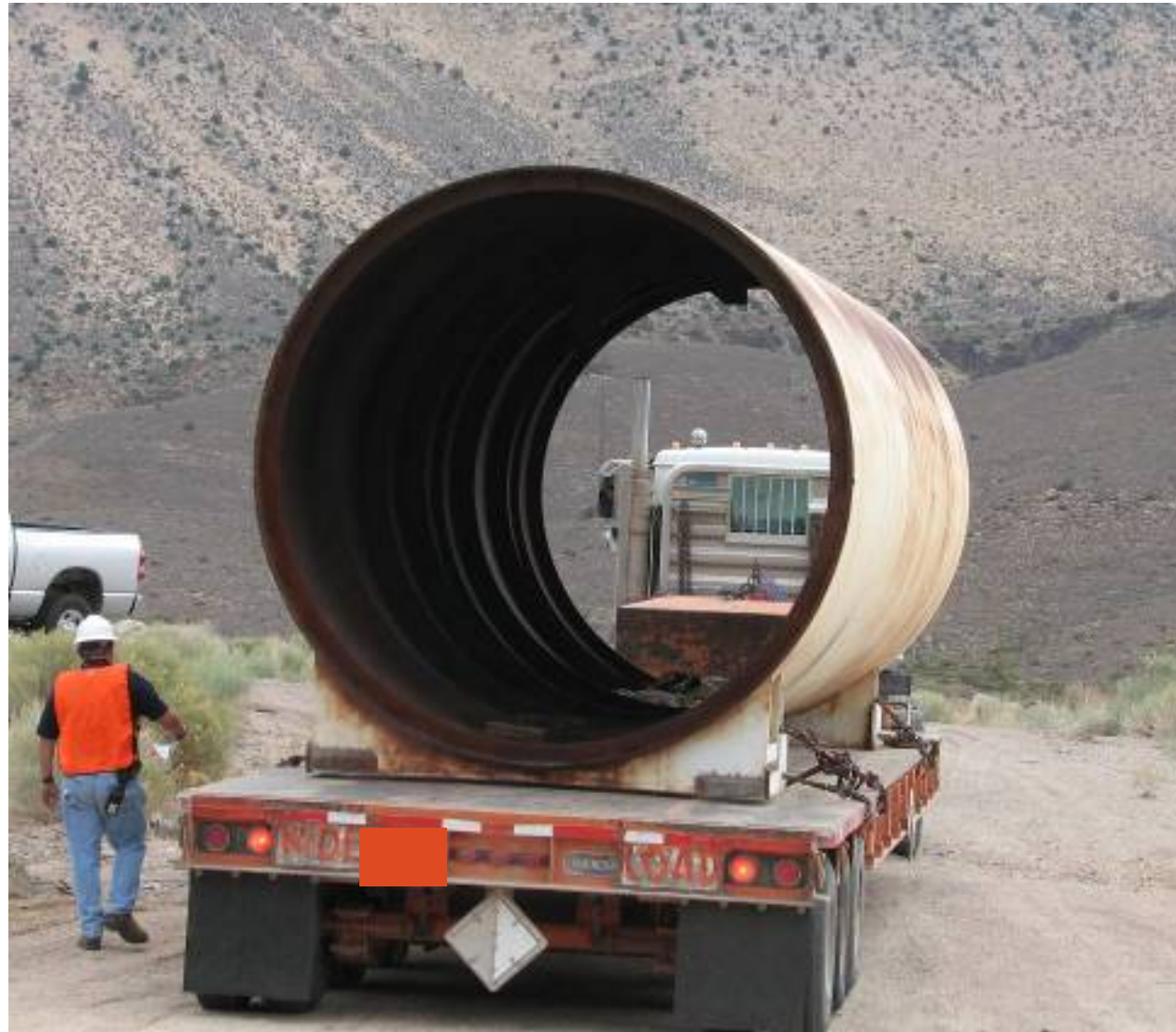

Photograph 37. Pipe, LOS (08/02/2007)

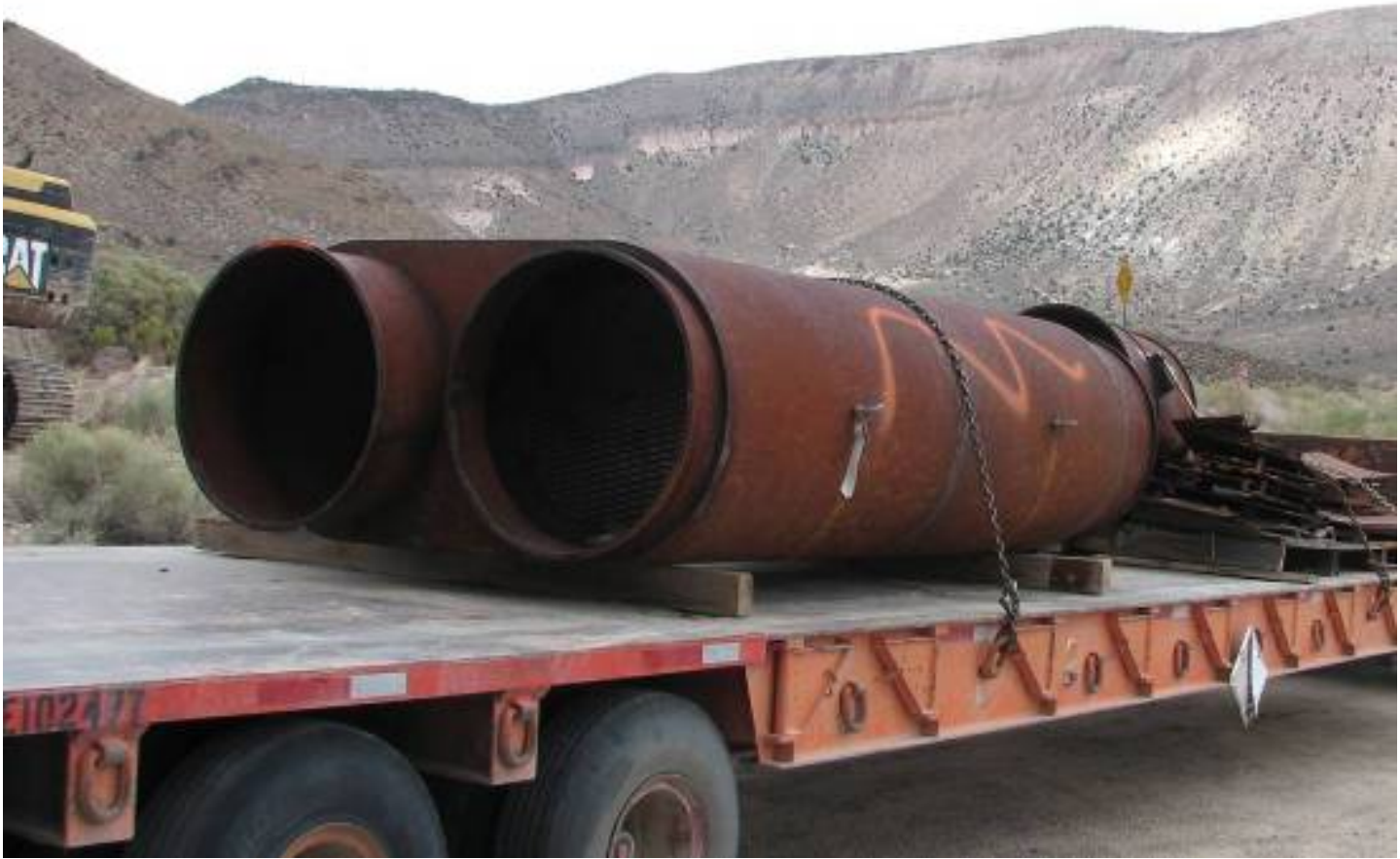

Photograph 38. Pipe, LOS (08/02/2007) 


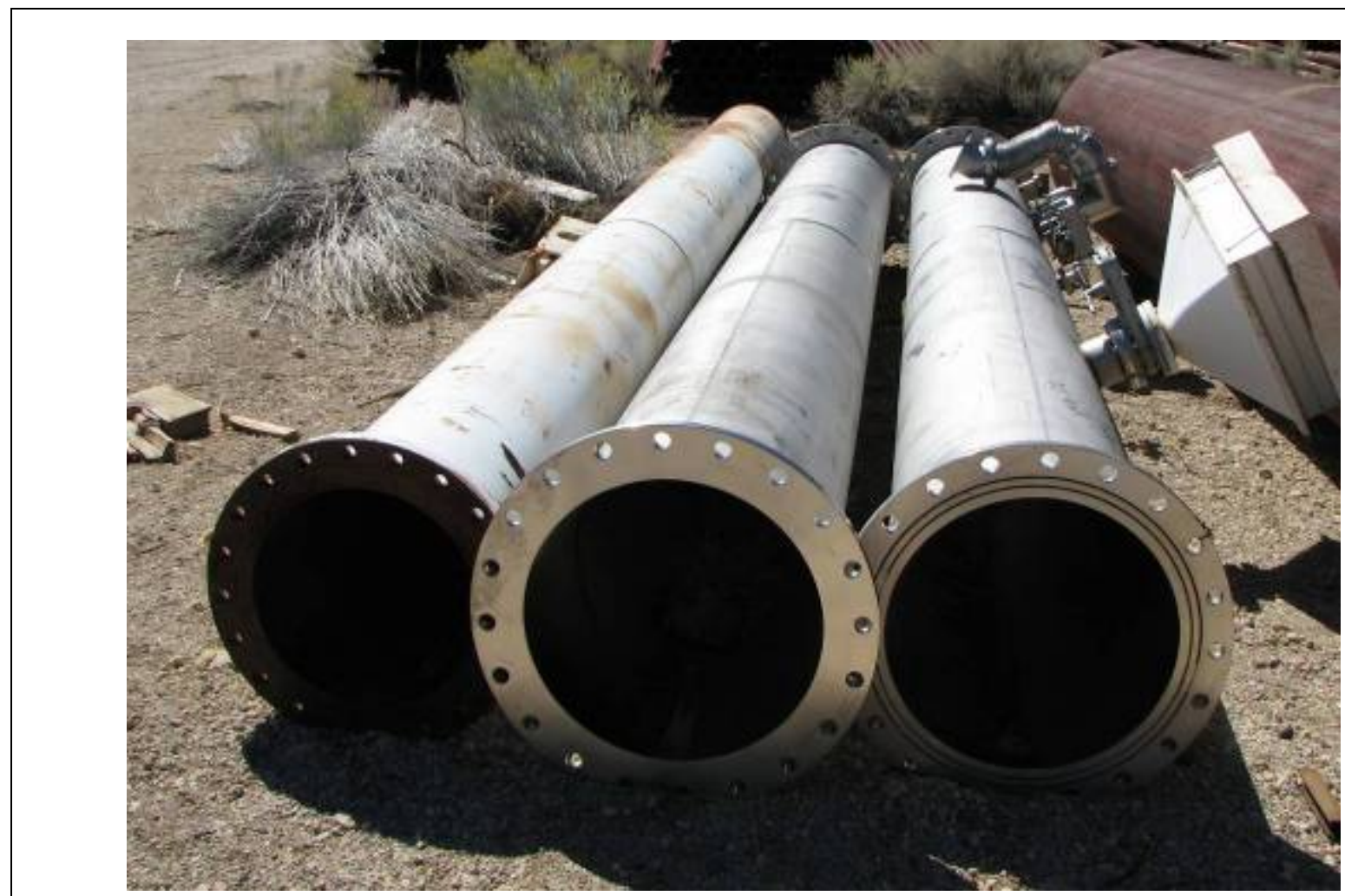

Photograph 39. Pipe (09/25/2007)

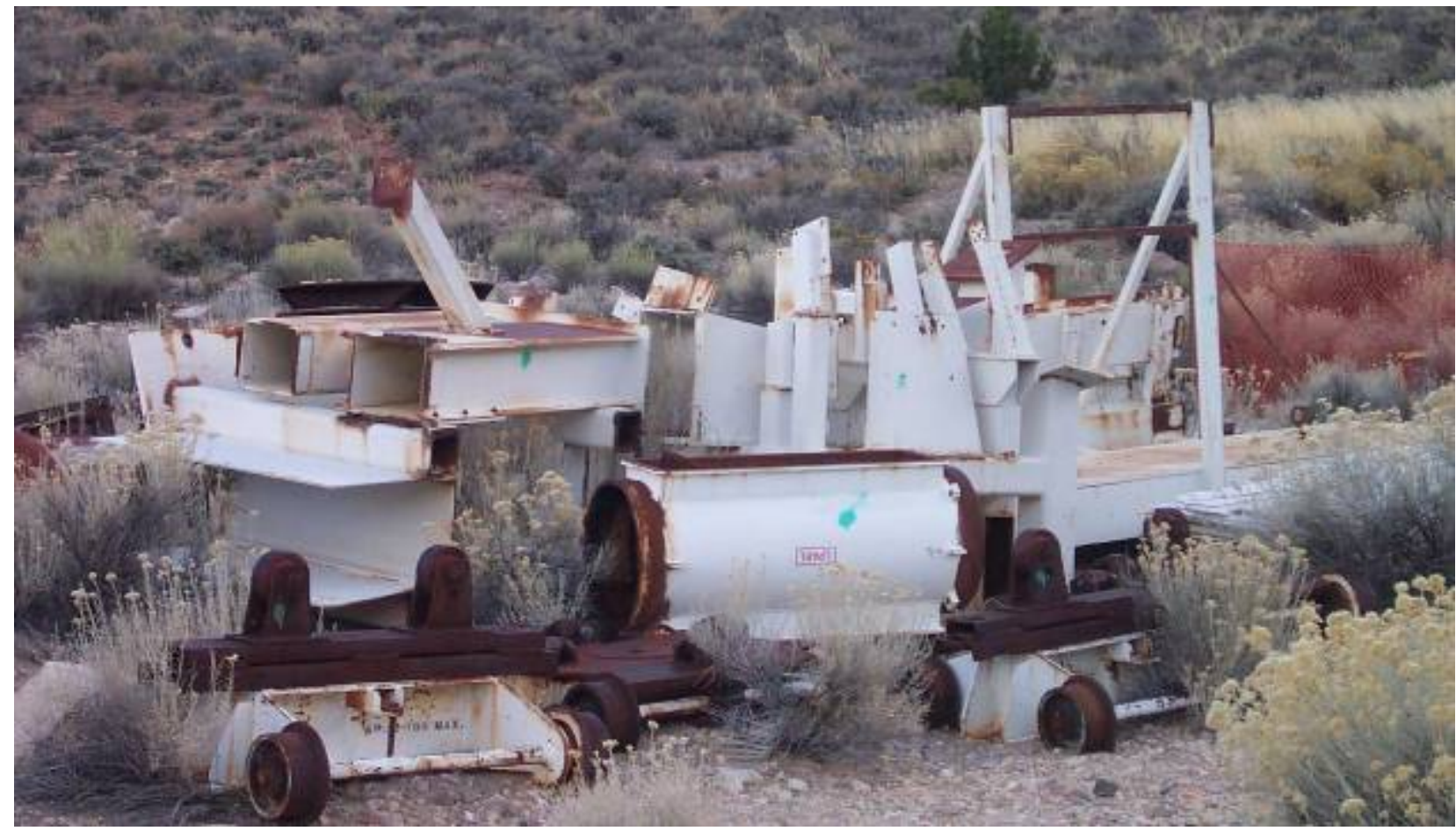

Photograph 40. Rail cars (11/15/2005) 


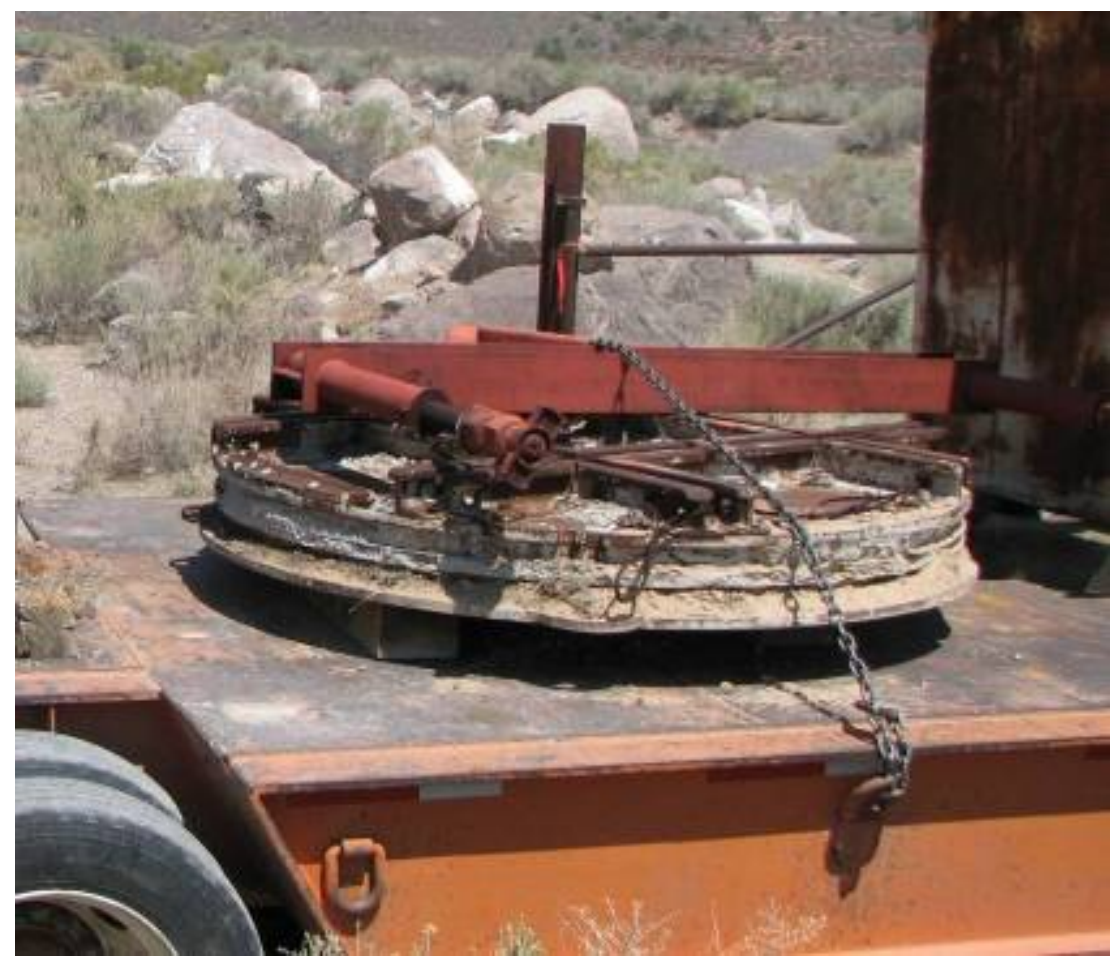

Photograph 41. Rail car turntable (08/07/2007)

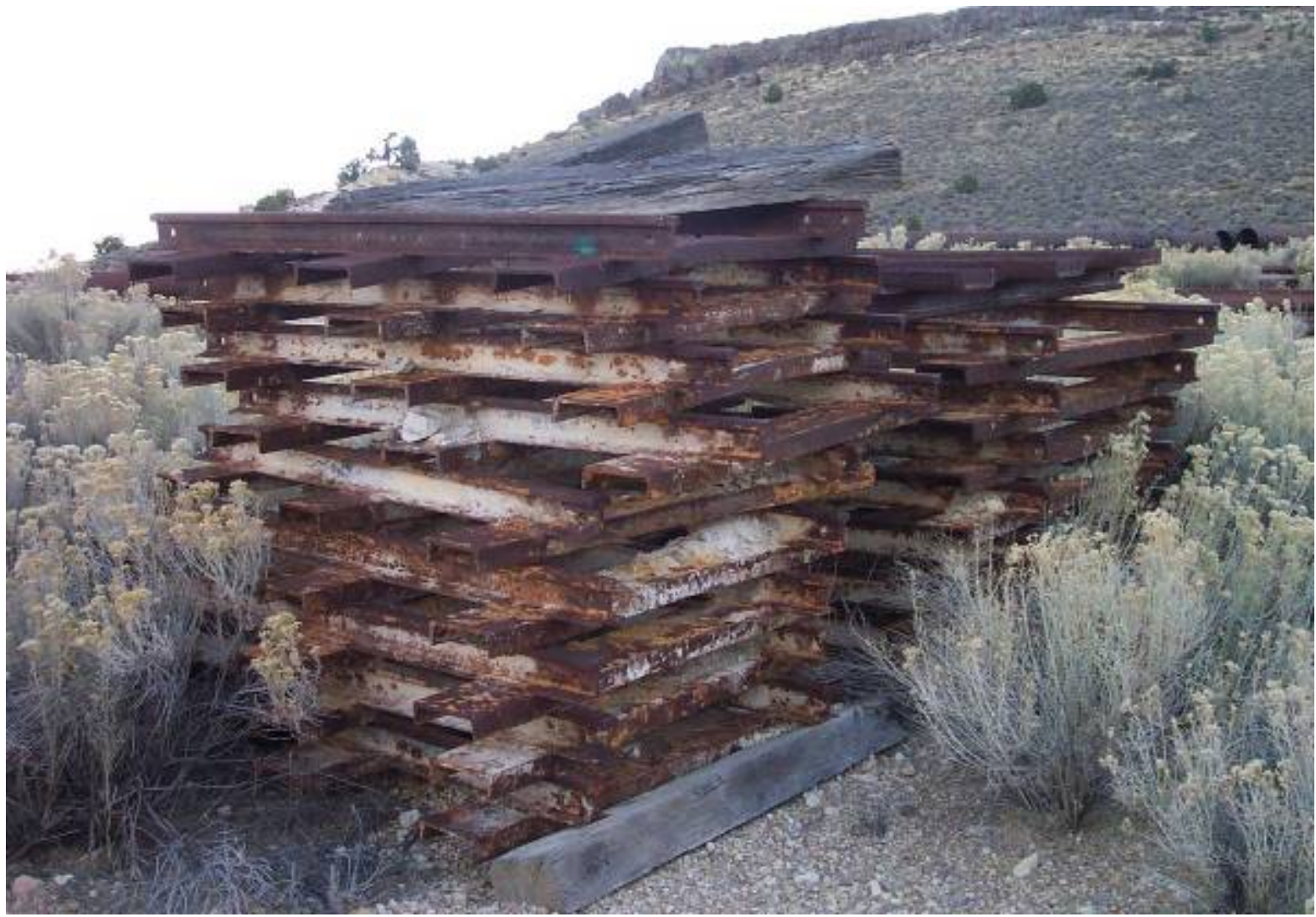

Photograph 42. Skids (11/15/2005) 


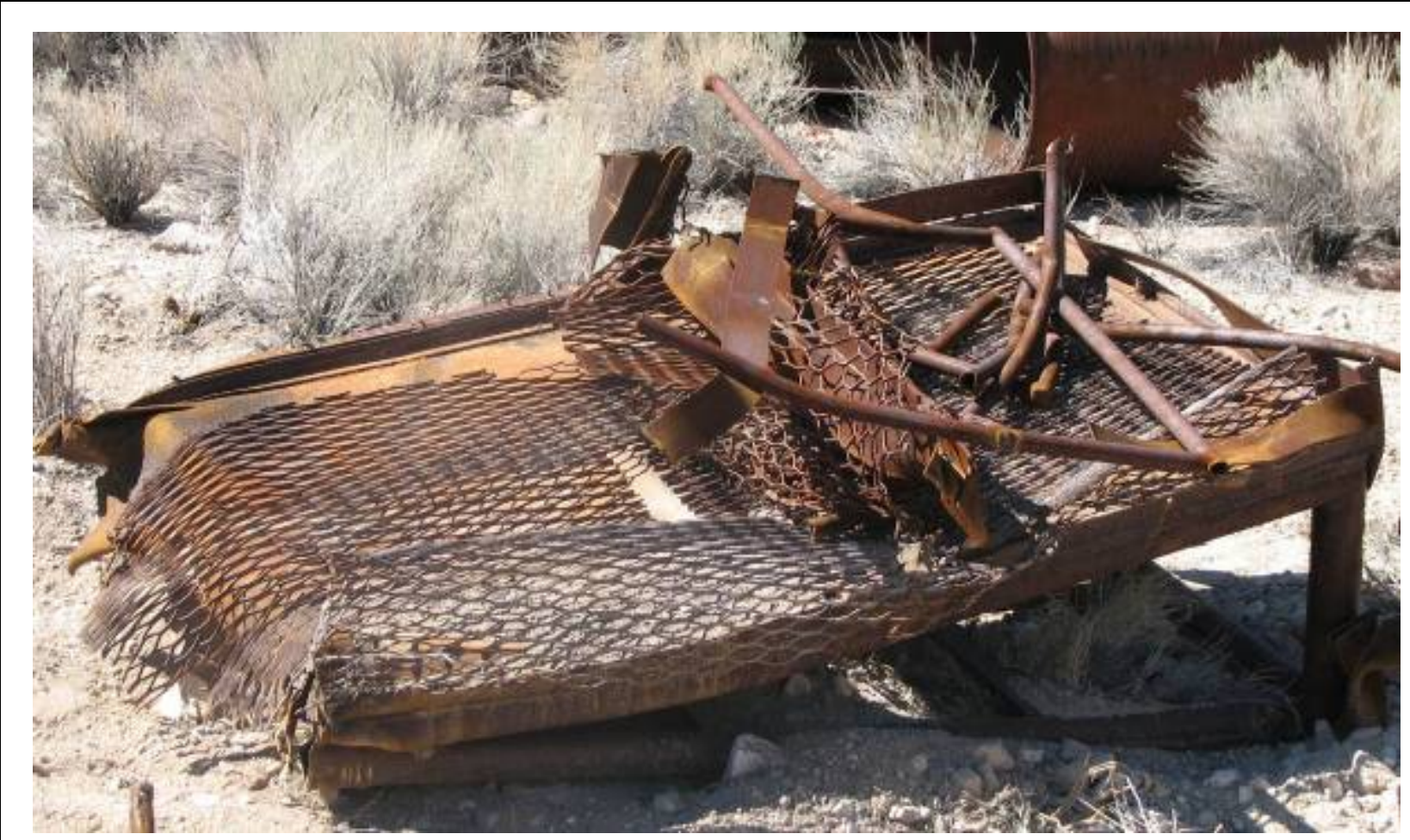

Photograph 43. Steel mesh (09/07/2007)

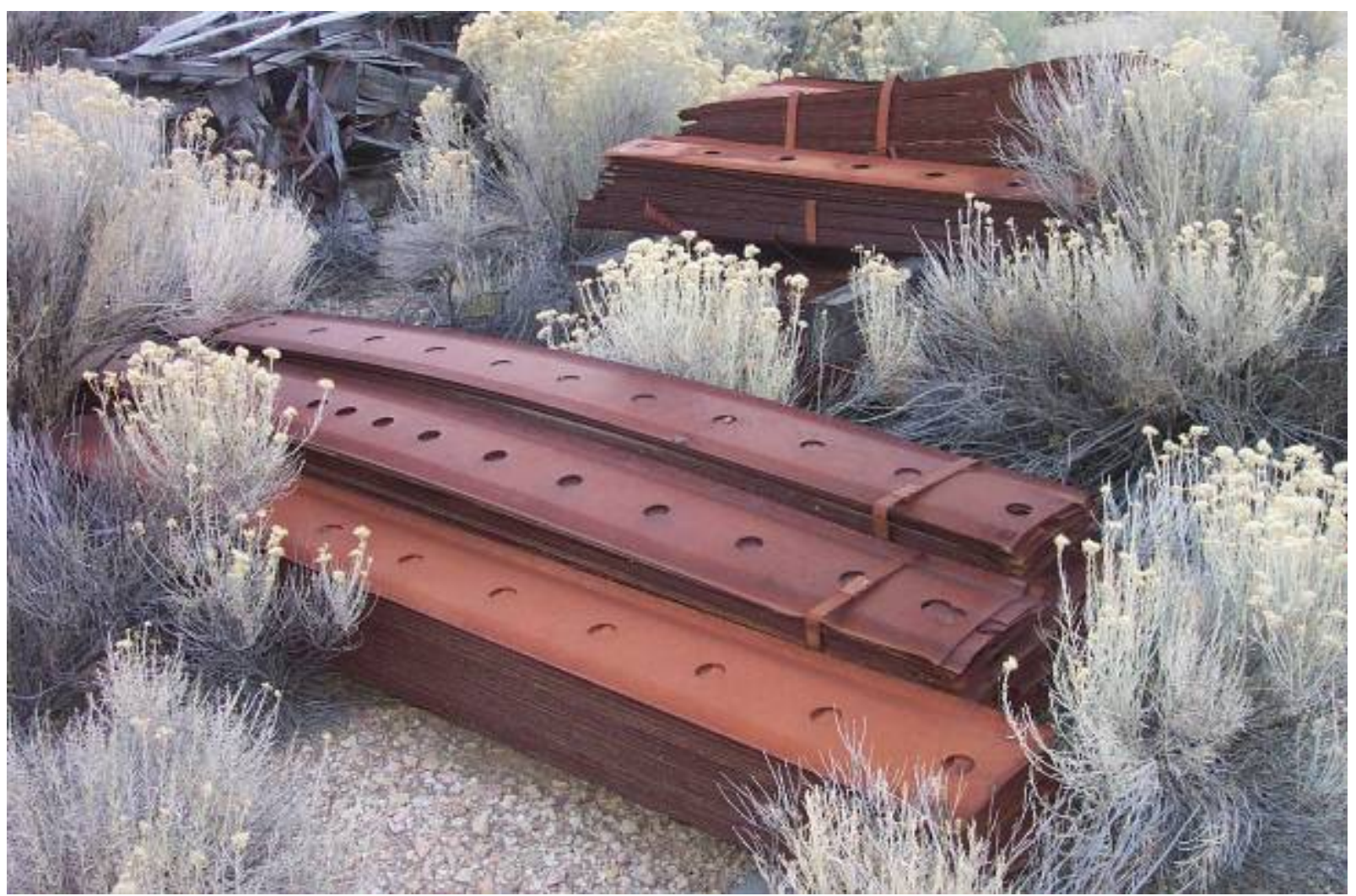

Photograph 44. Steel plate (11/15/2005) 


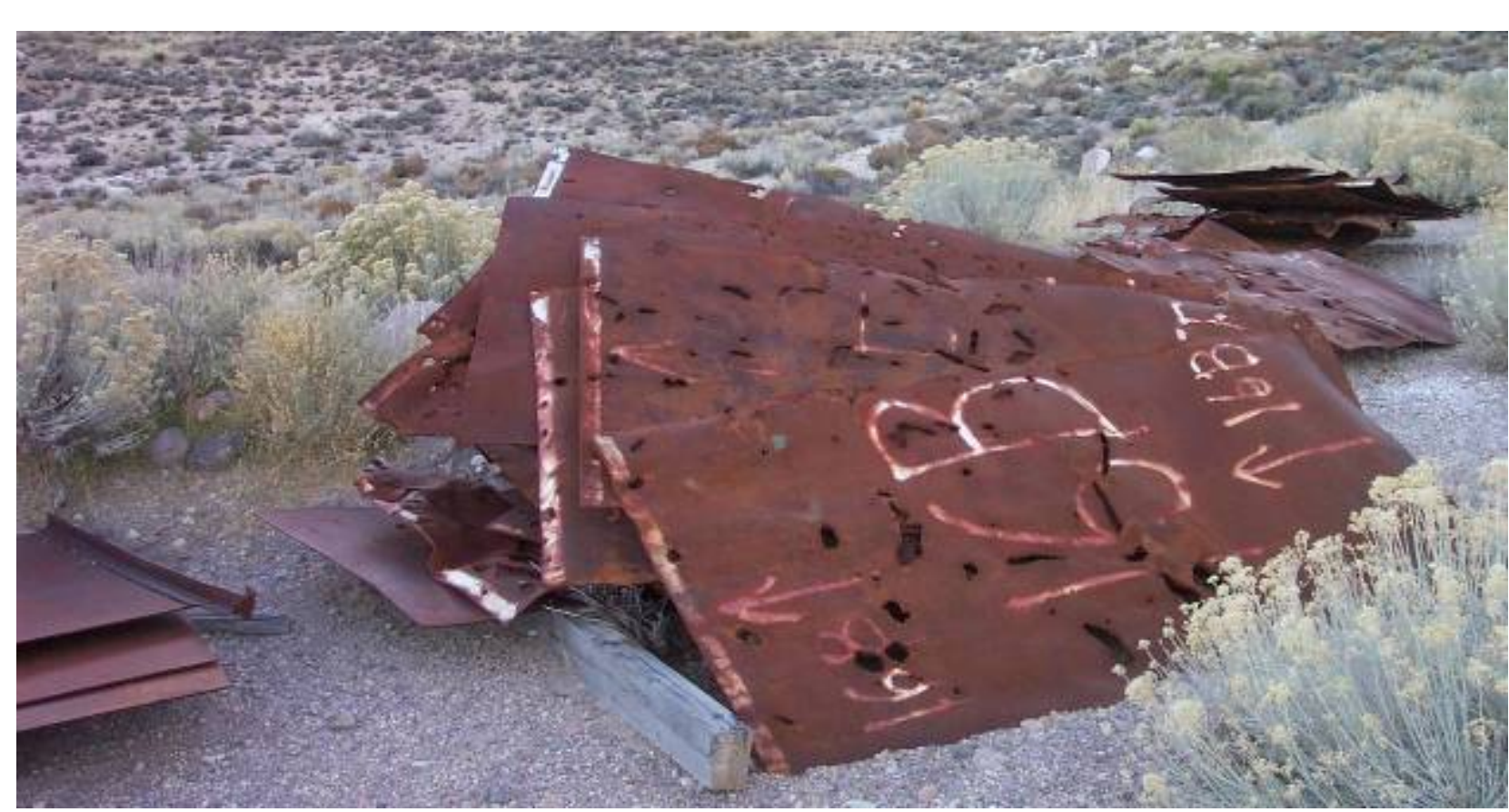

Photograph 45. Steel plate (11/15/2005)

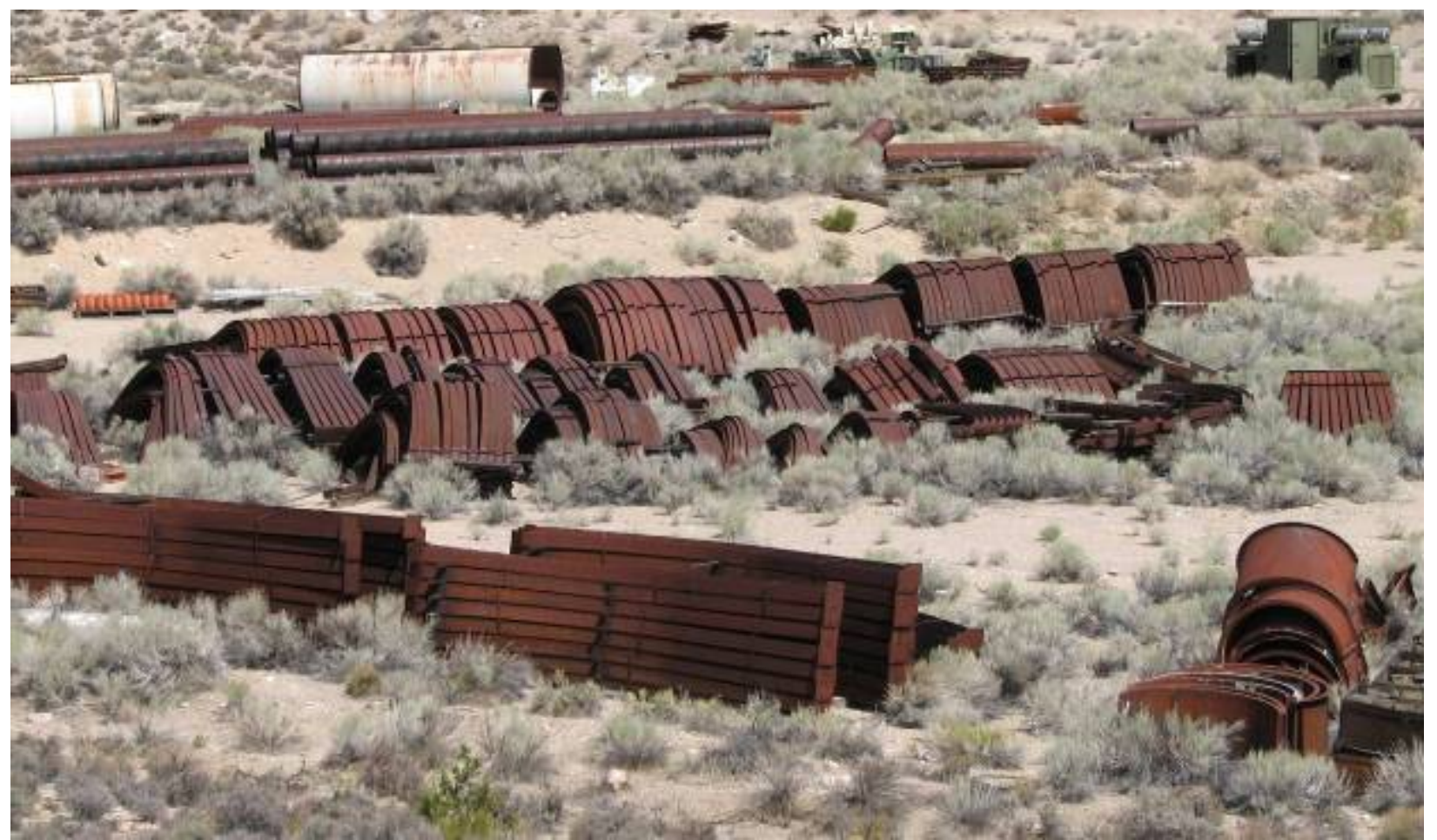

Photograph 46. Steel sets (07/30/2007) 


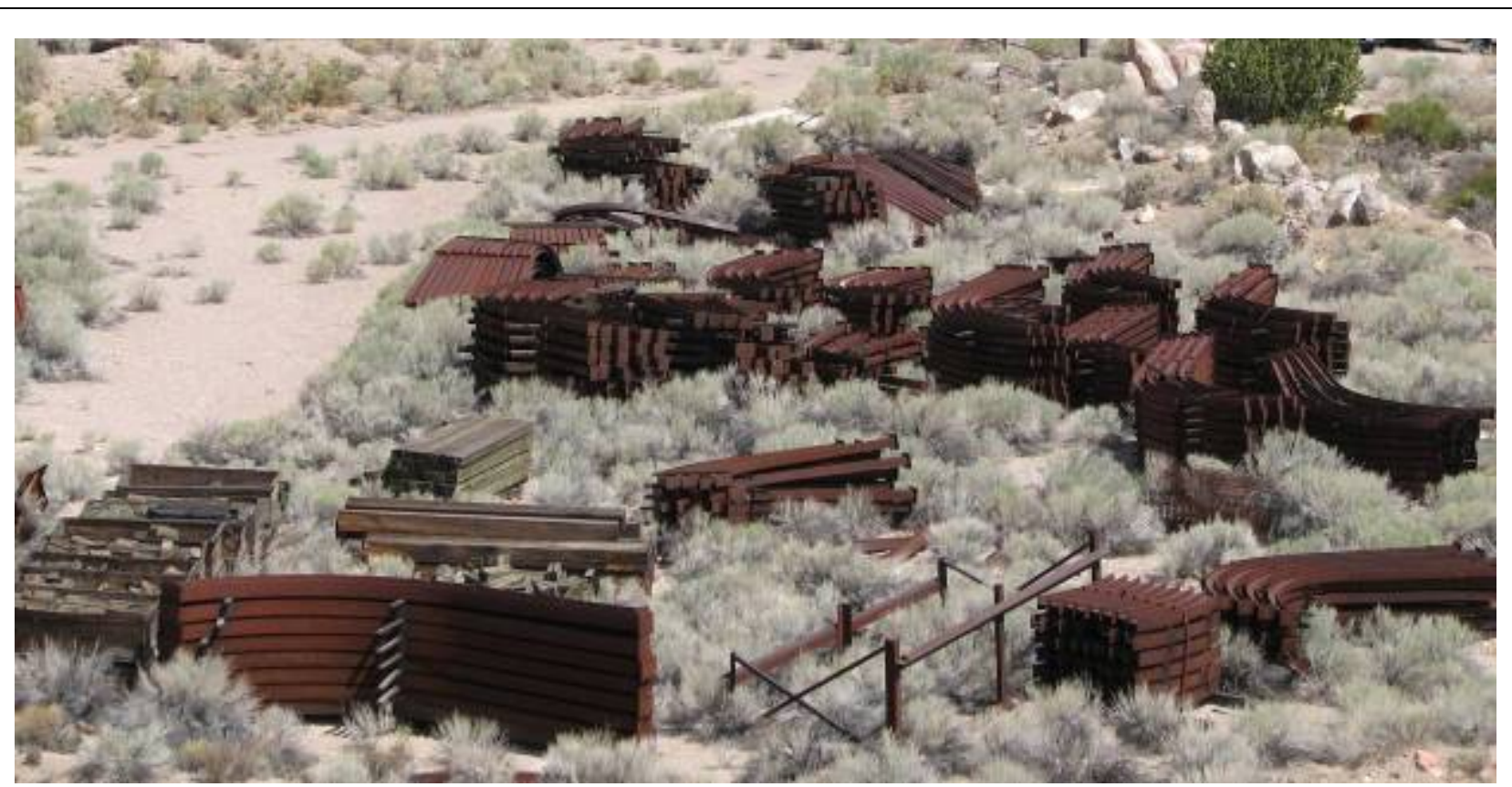

Photograph 47. Steel sets (07/30/2007)

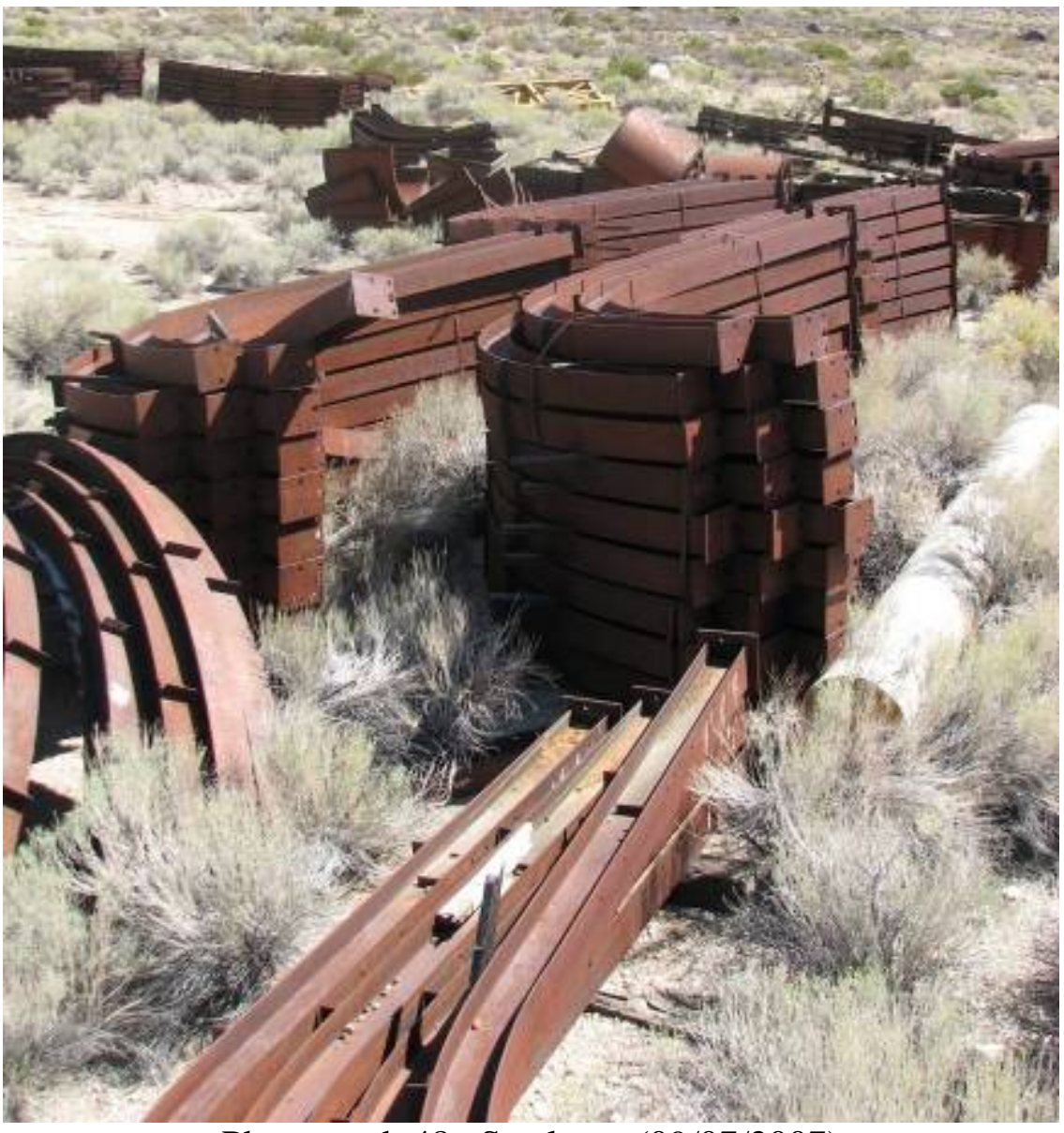

Photograph 48. Steel sets (09/07/2007) 


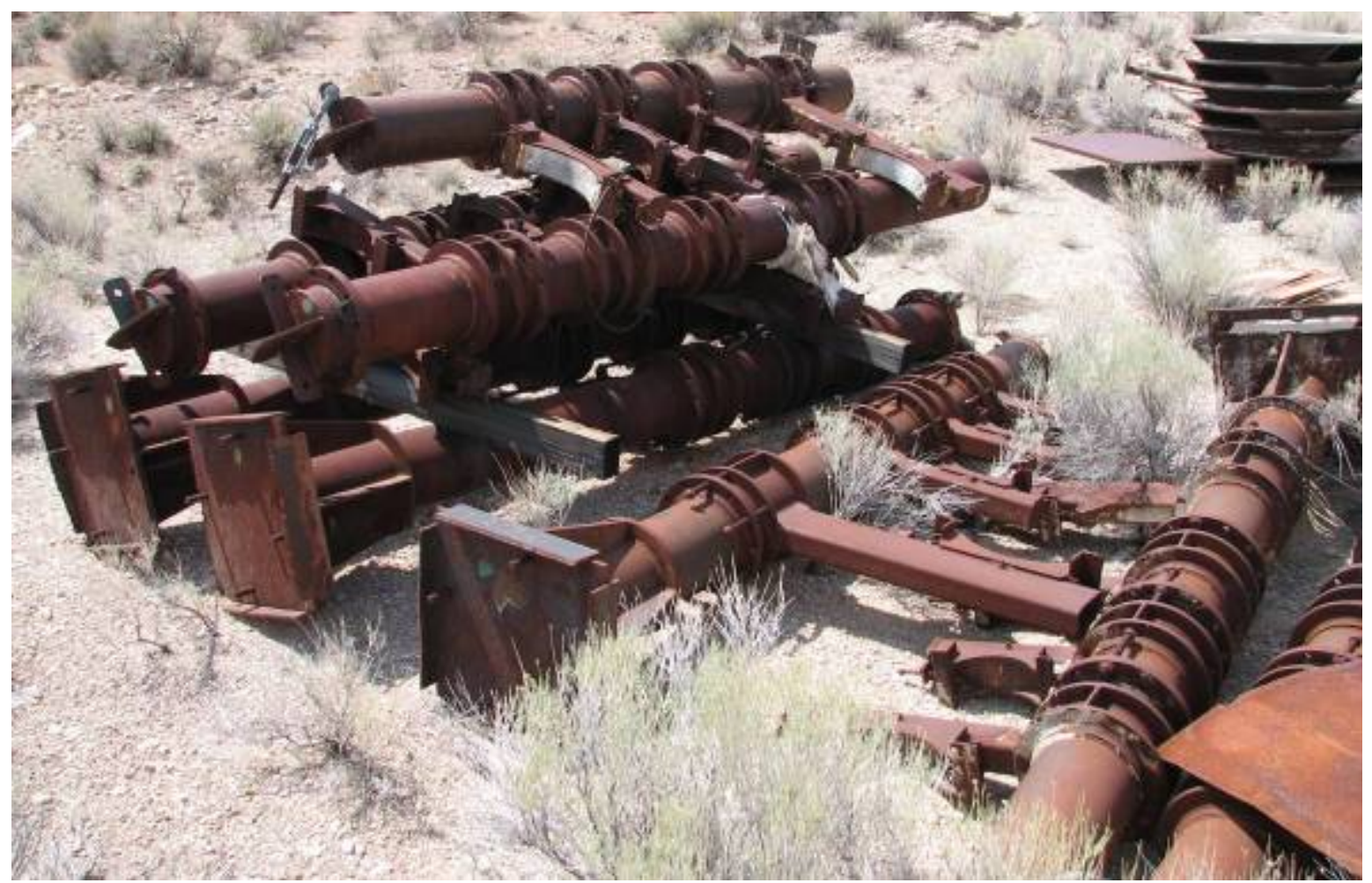

Photograph 49. Steel supports (07/30/2007)

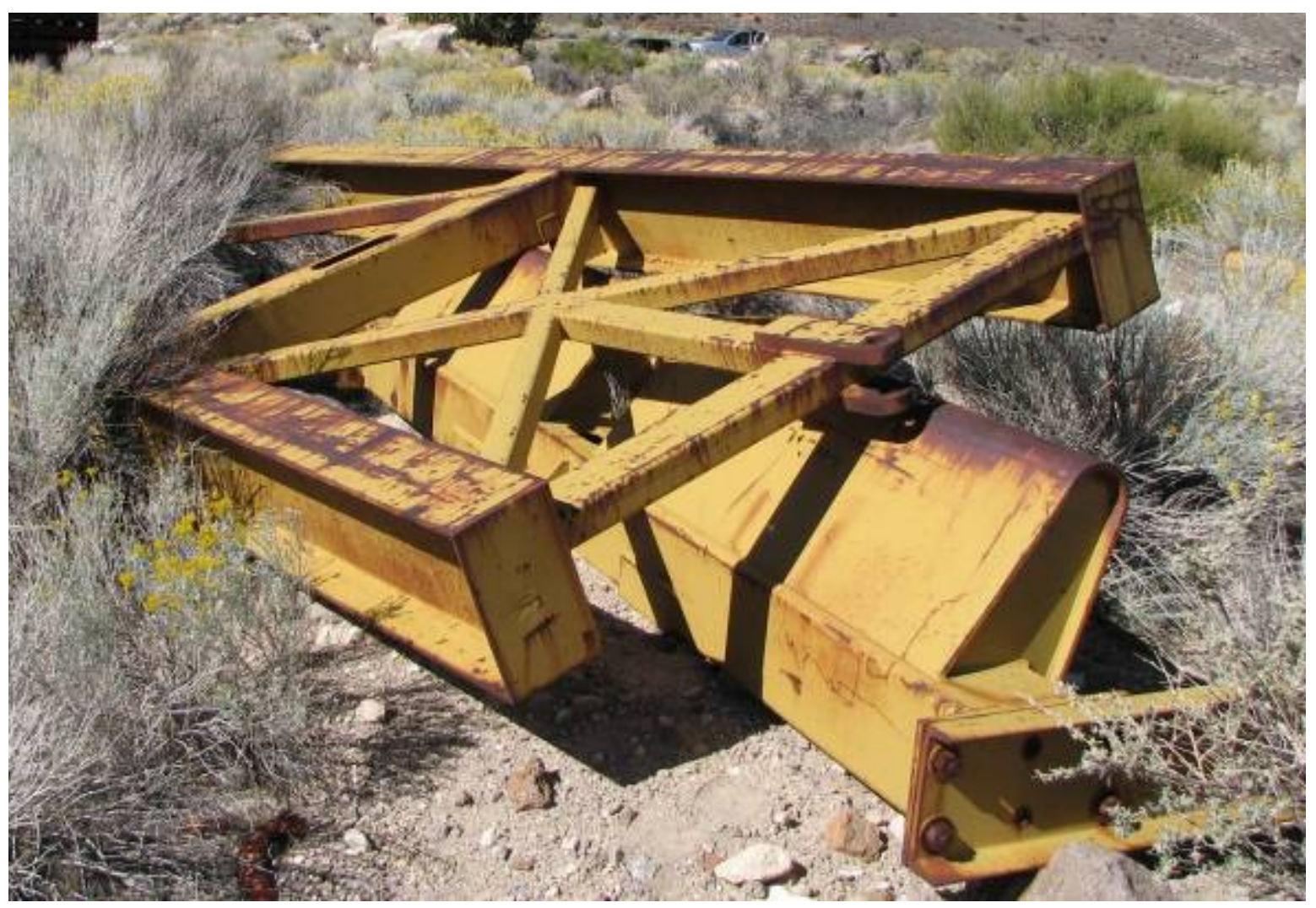

Photograph 50. Structural supports (10/03/2007) 


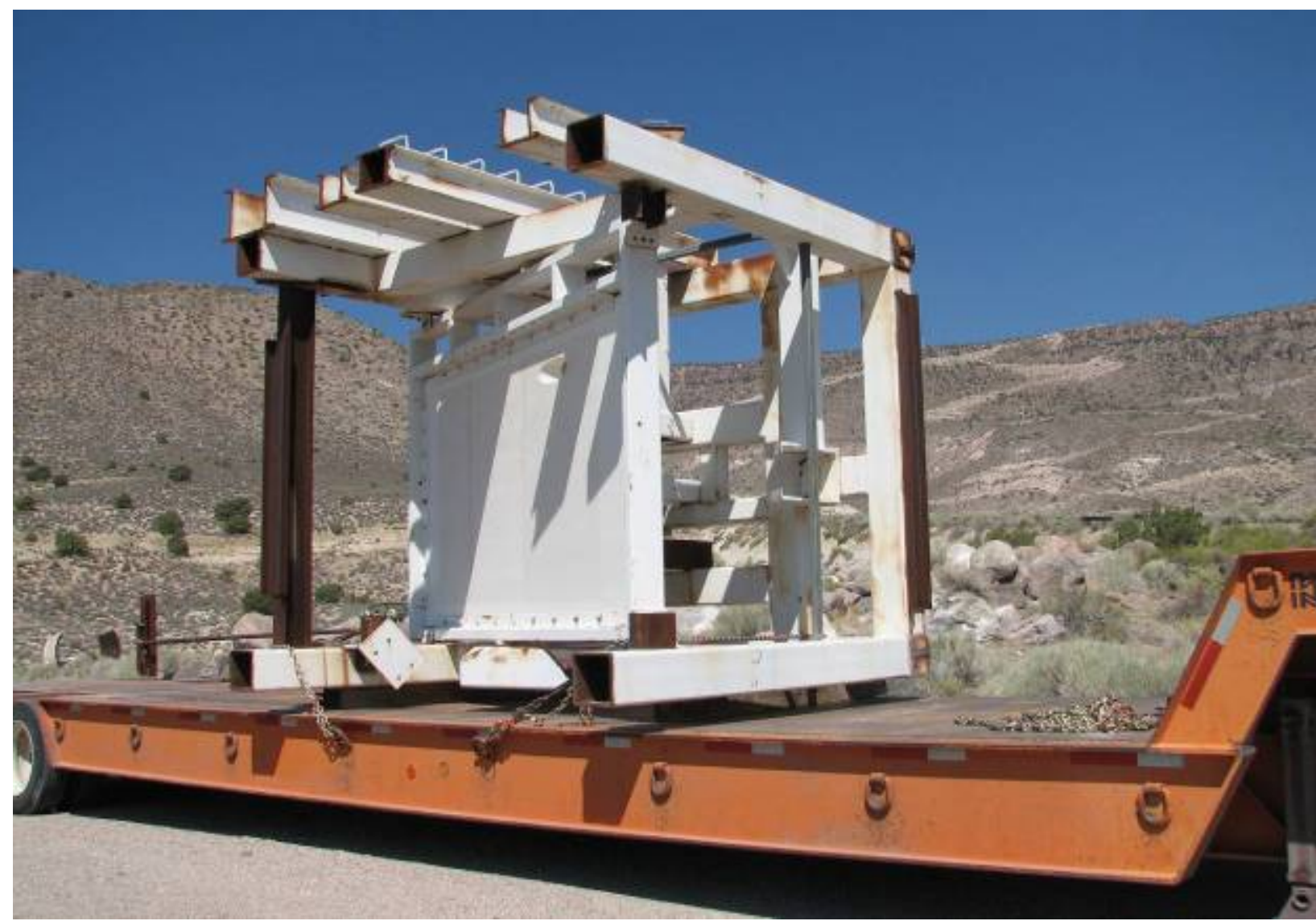

Photograph 51. Structural support (08/06/2007)

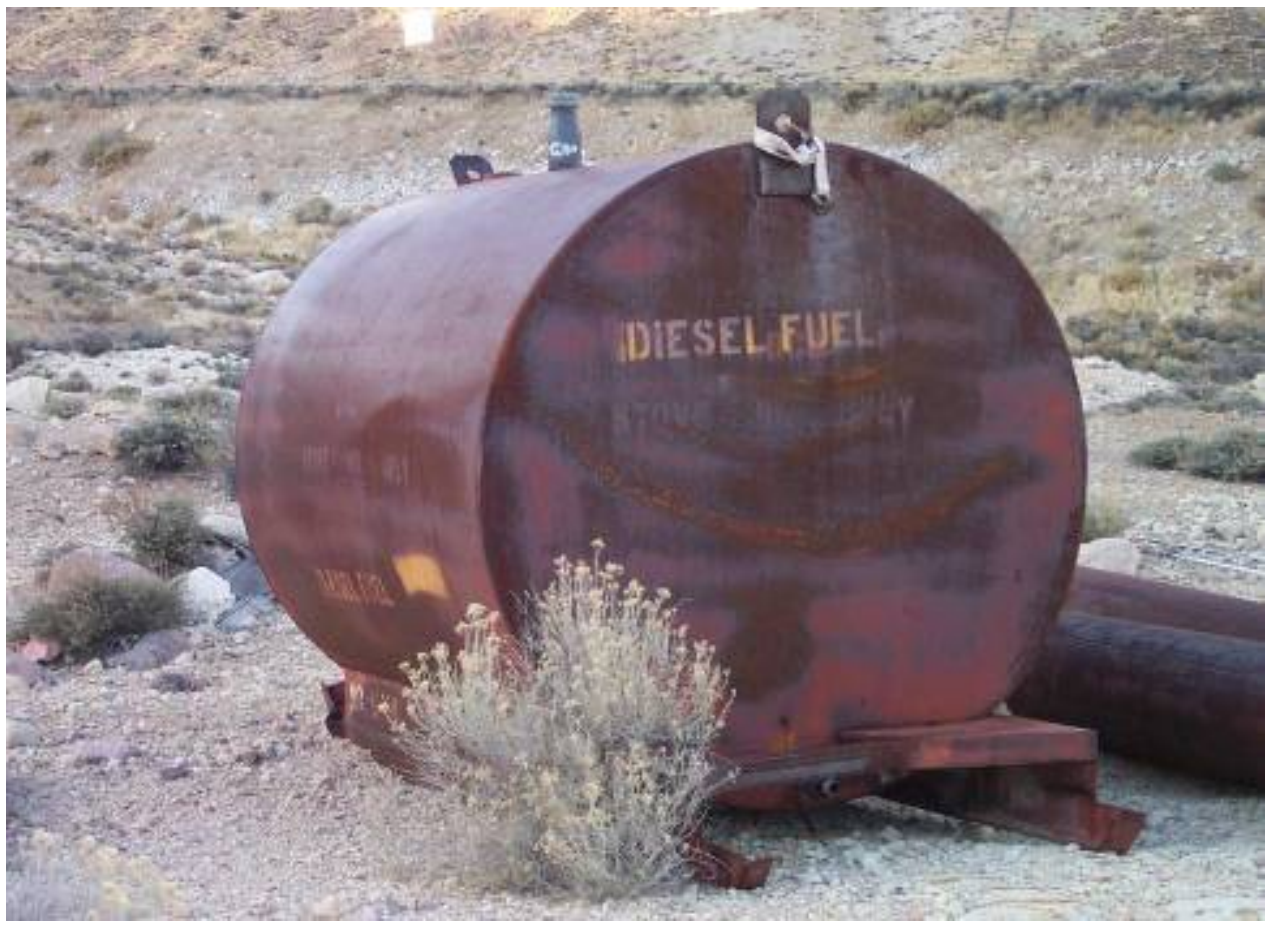

Photograph 52. Empty tank (05/15/2005) 


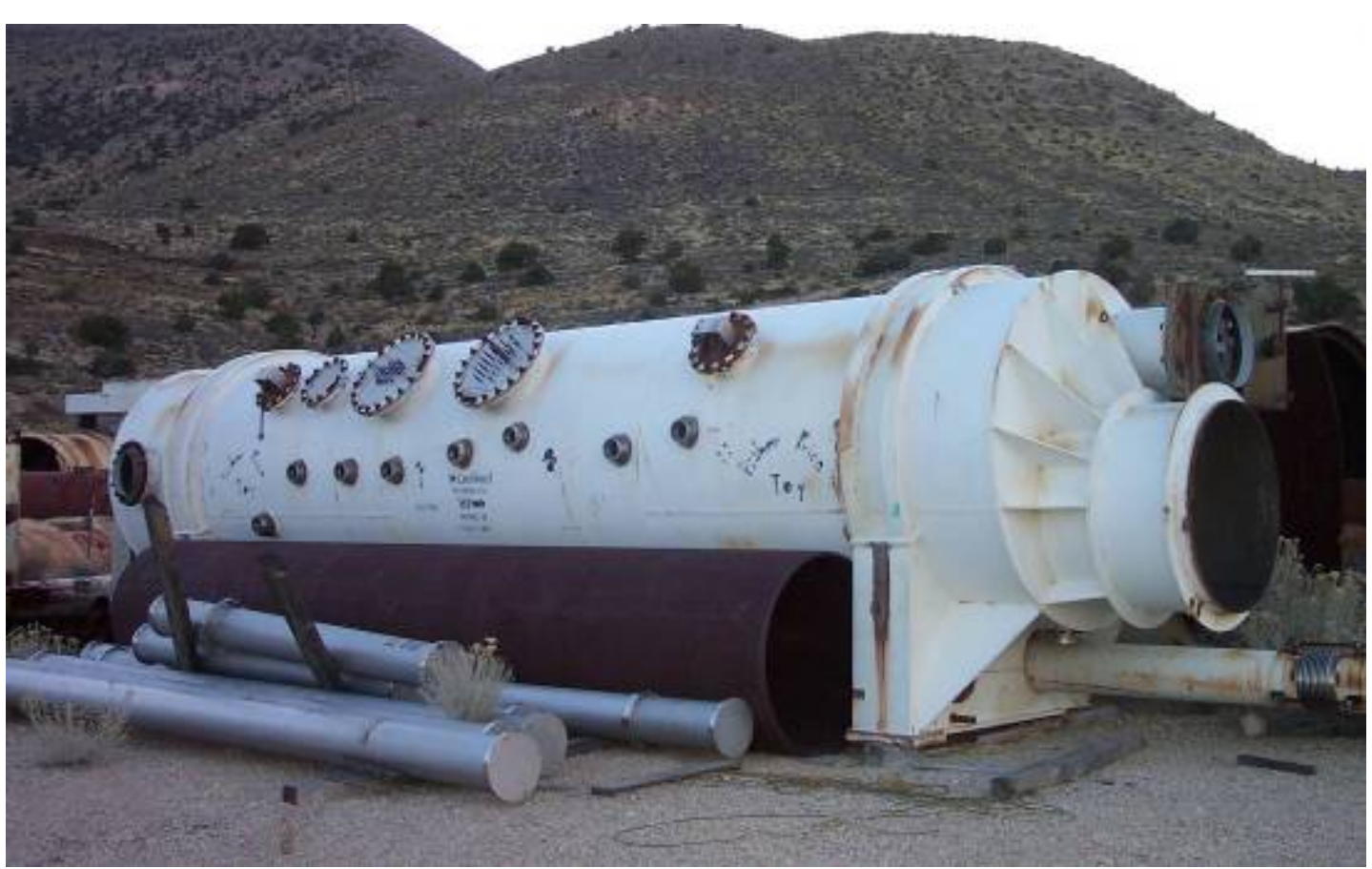

Photograph 53. Test chamber (05/15/2005)

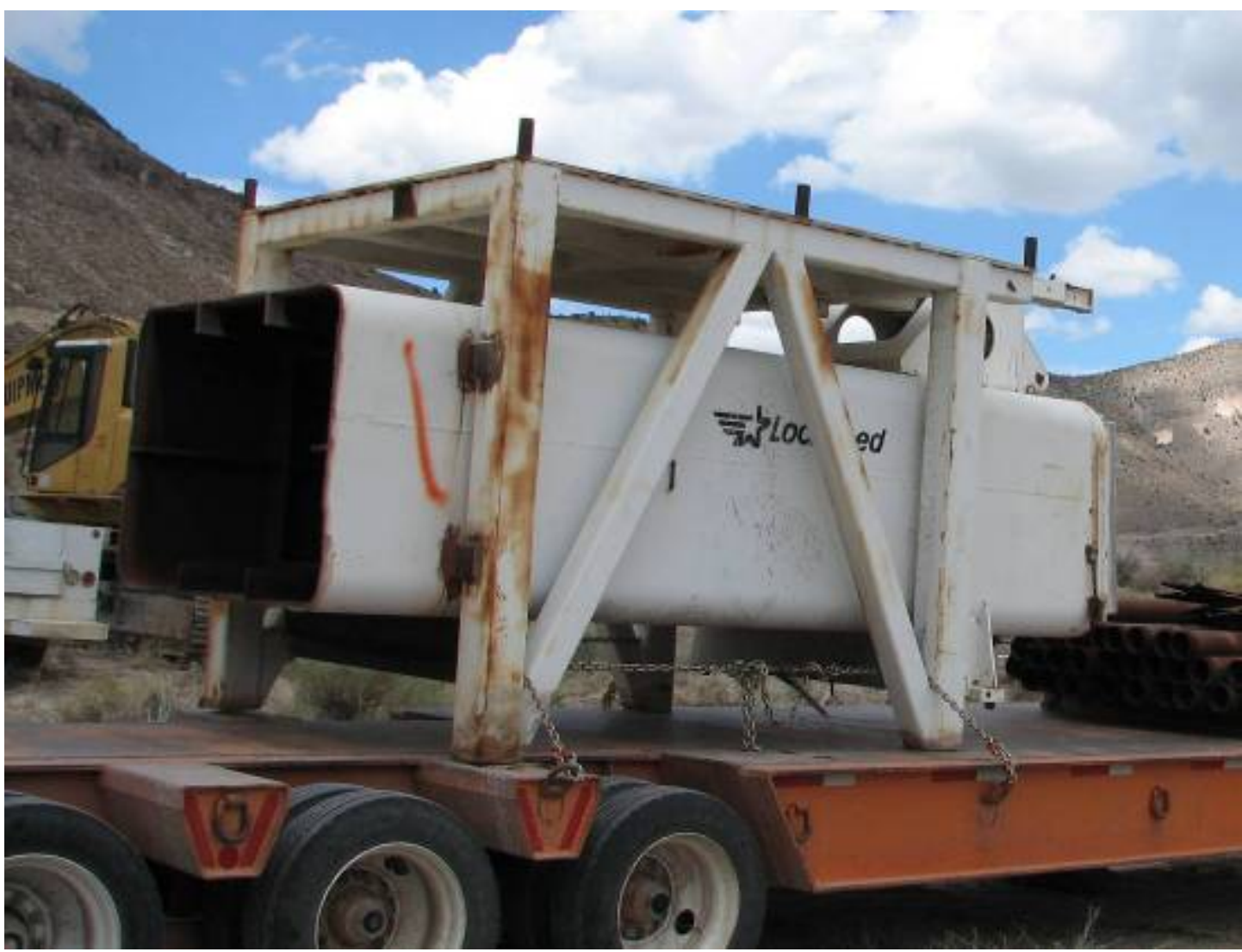

Photograph 54. Test chamber (08/02/2007) 
CAU 481 Closure Report

Section: Appendix A

Revision: 0

Date: November 2008

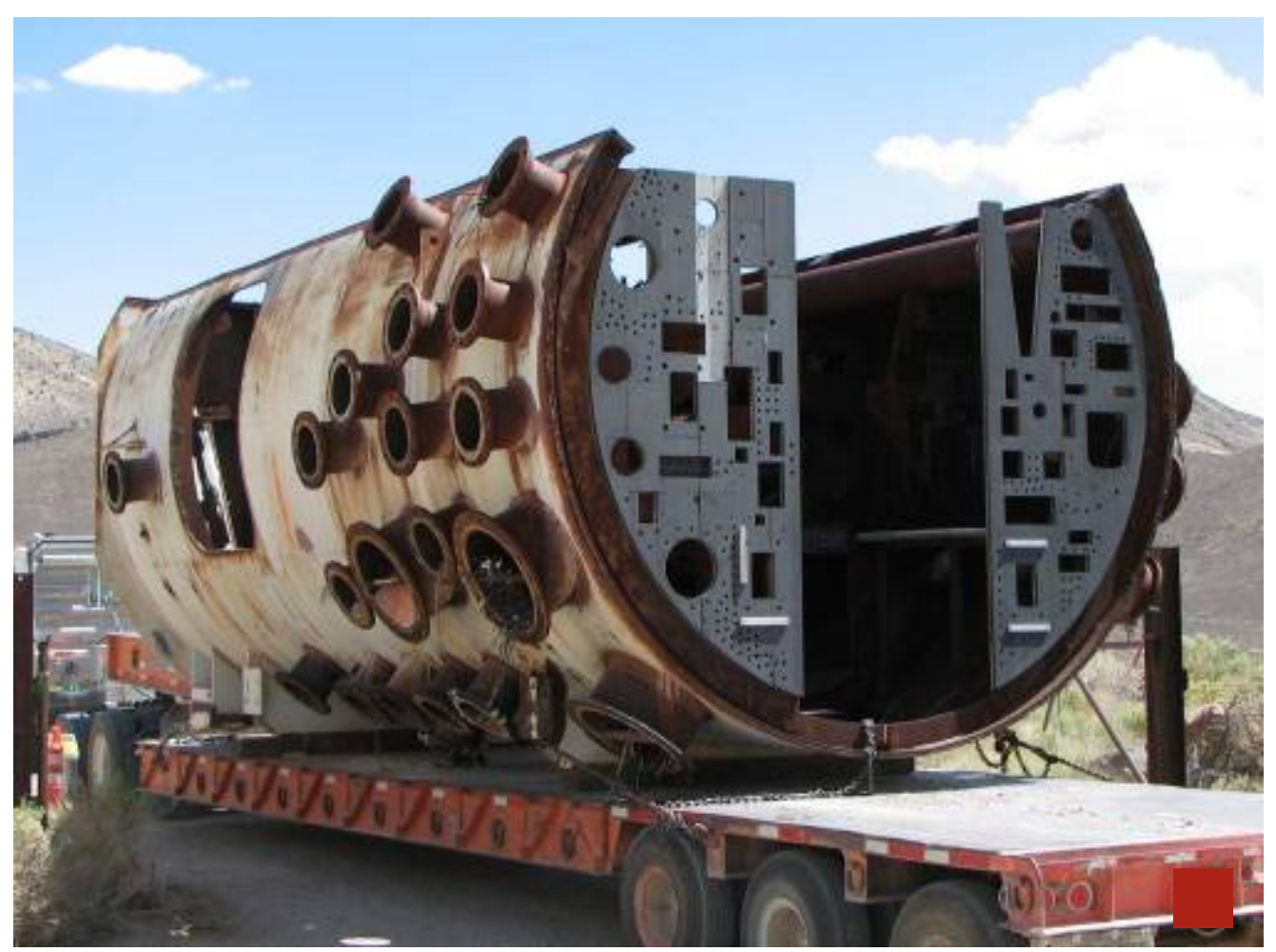

Photograph 55. Test chamber (08/29/2007)

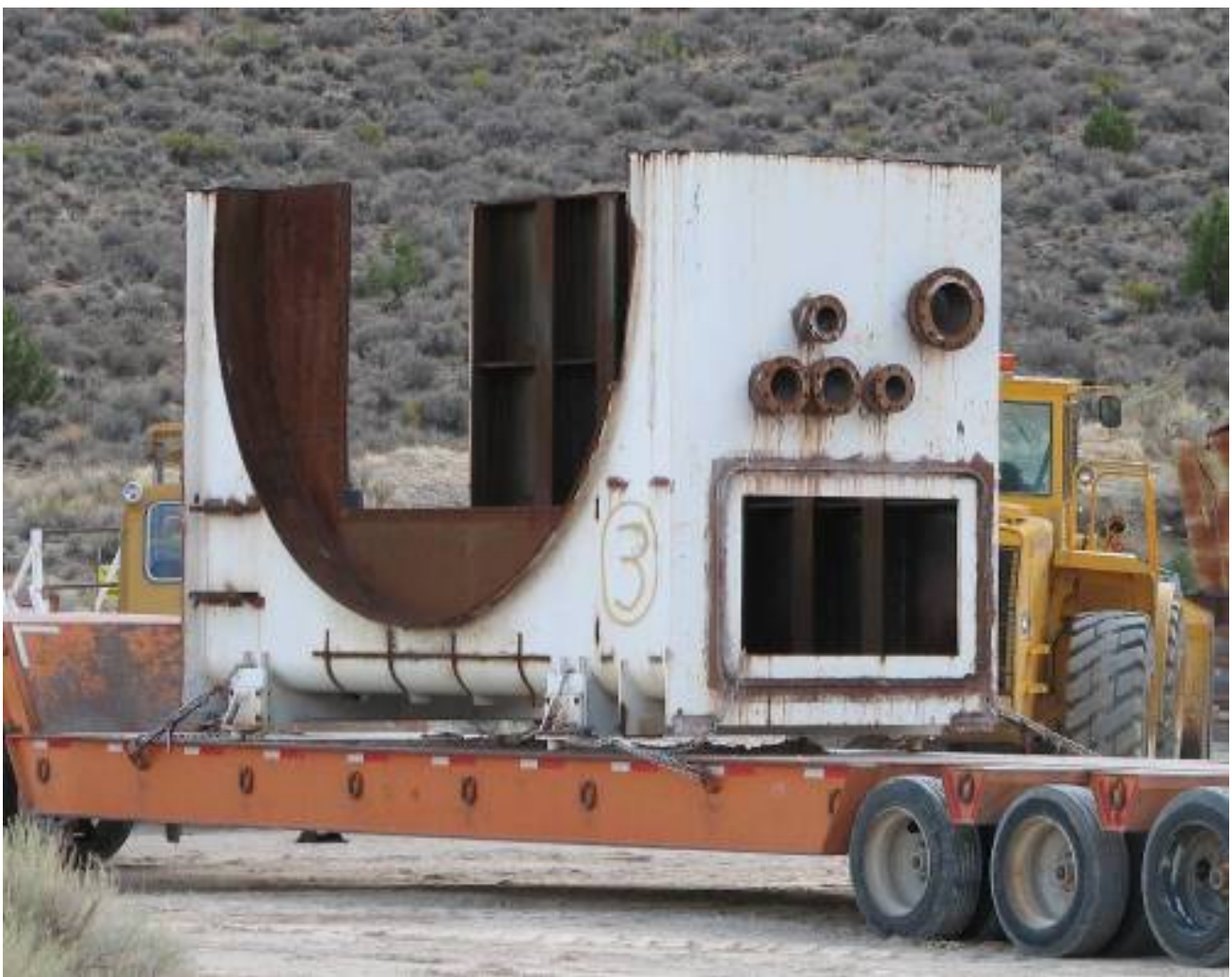

Photograph 56. Test chamber (08/28/2007) 


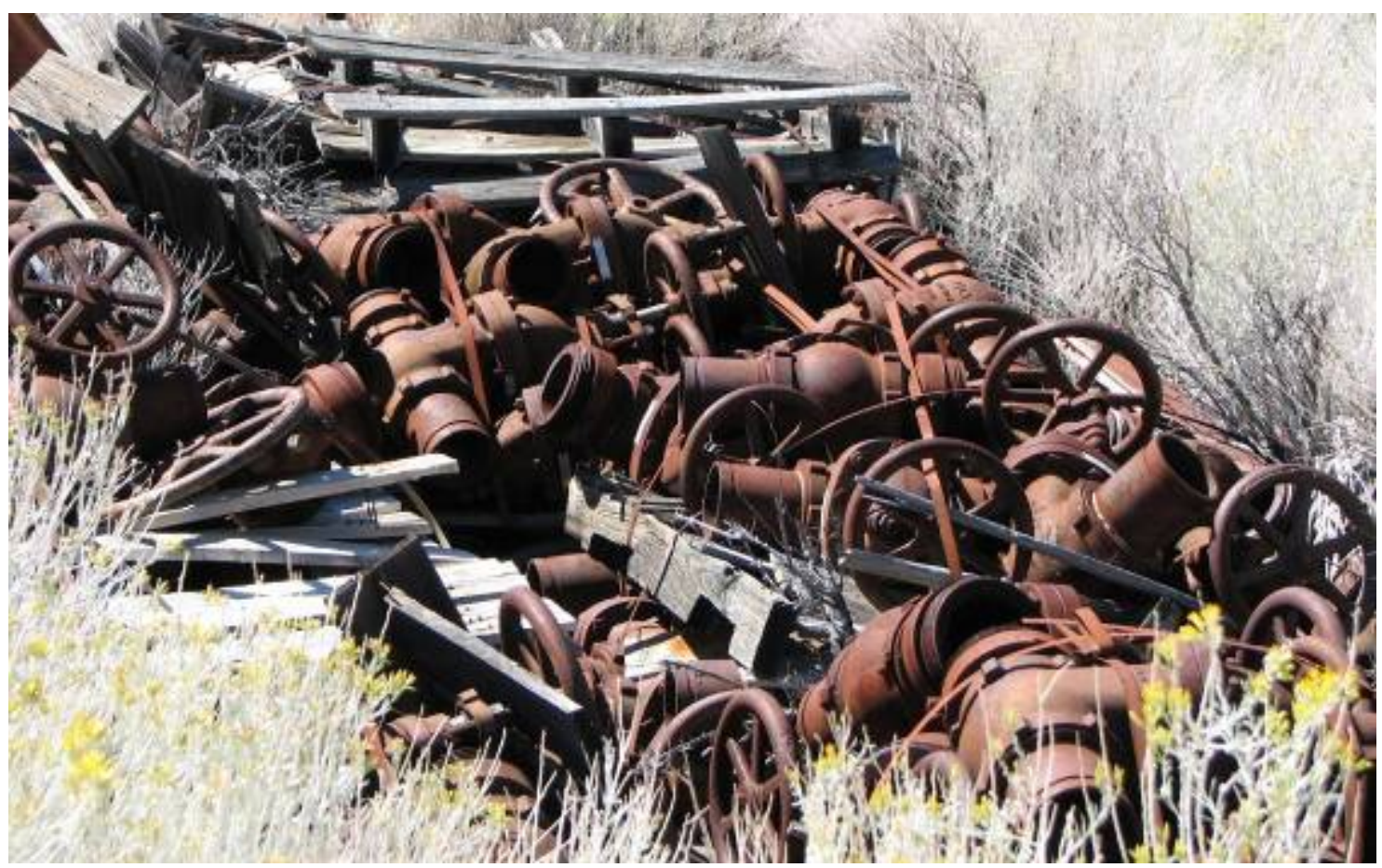

Photograph 57. Valves (09/25/2007)

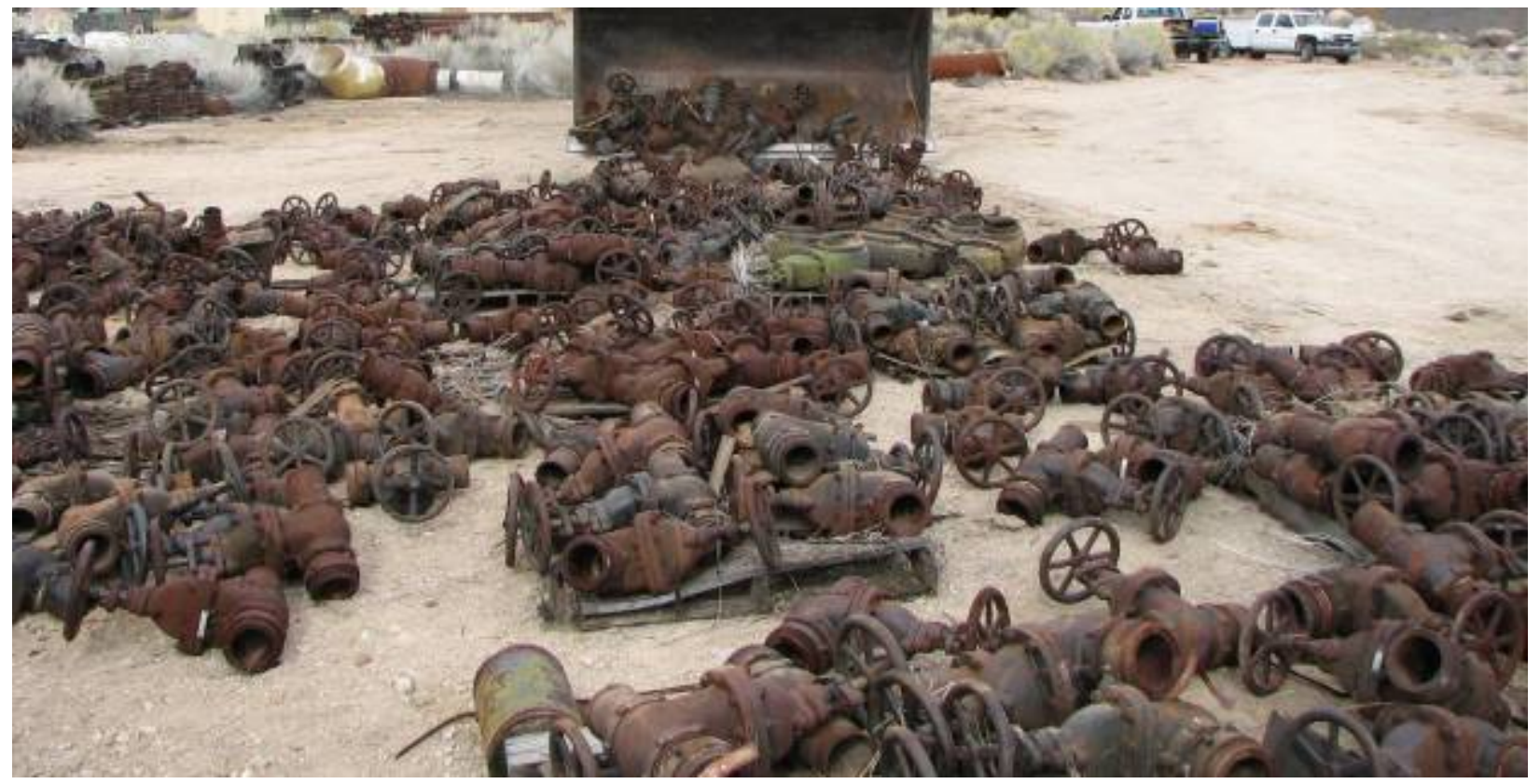

Photograph 58. Valves (09/27/2007) 


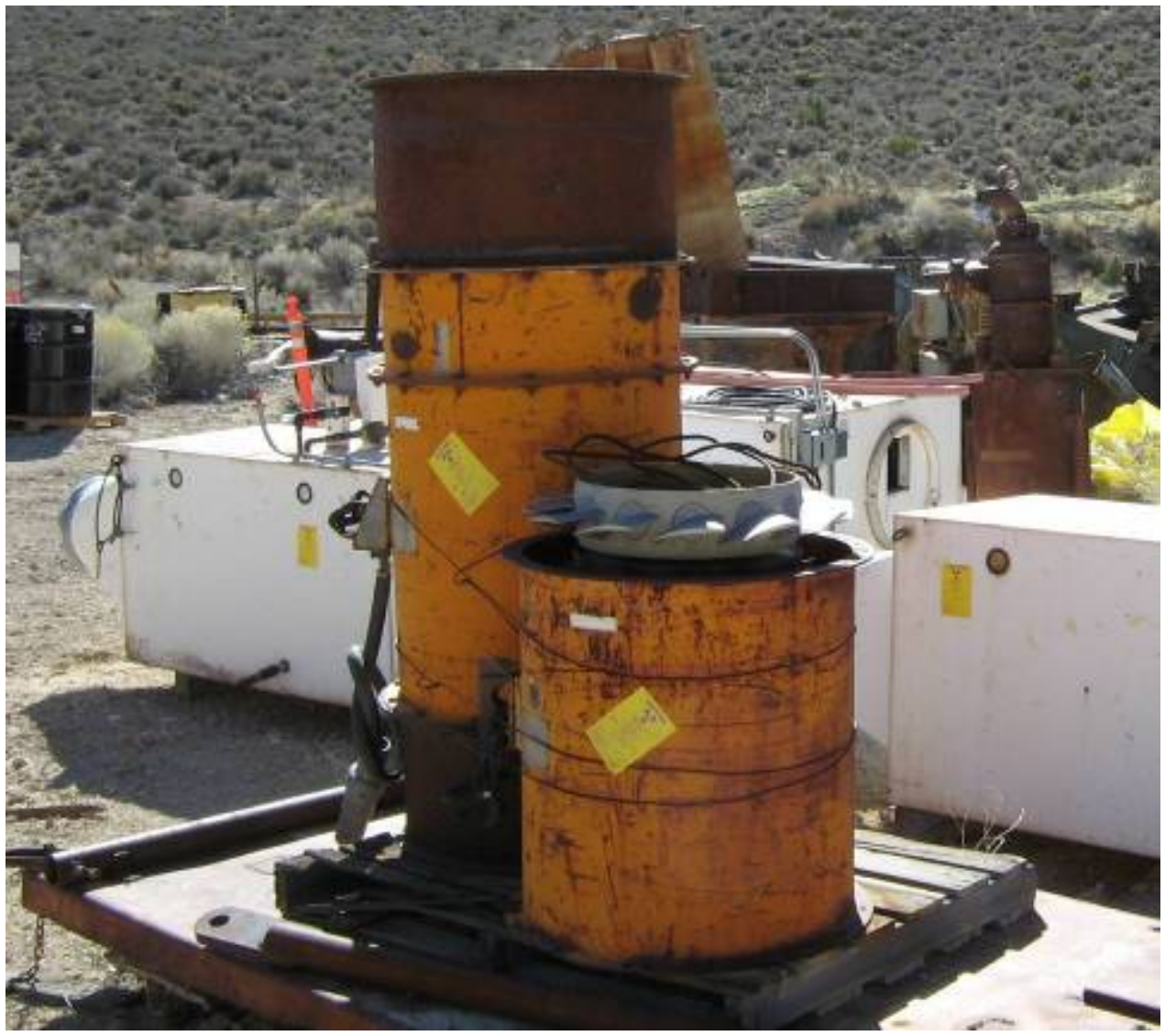

Photograph 59. Vent fans (10/30/2007)

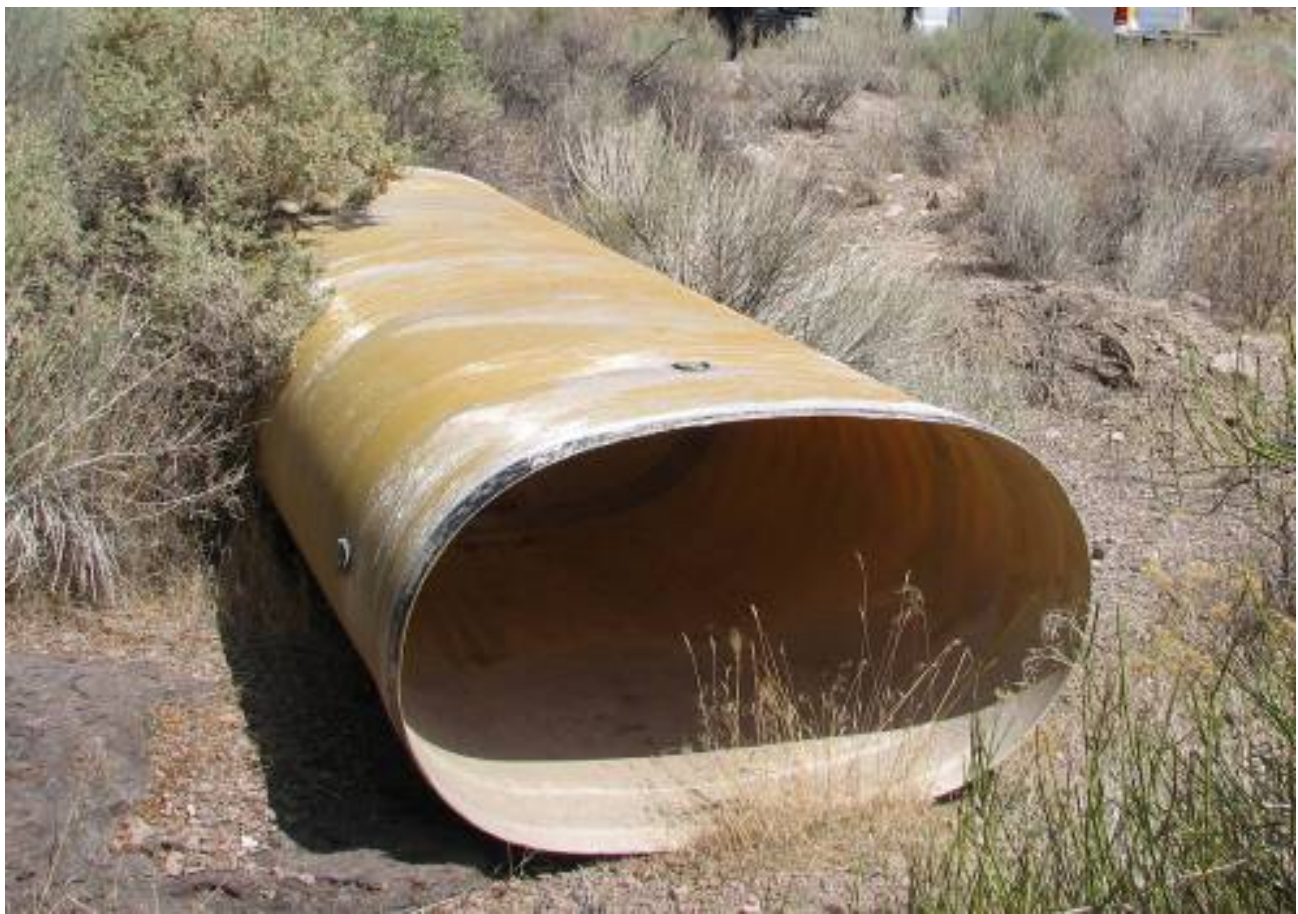

Photograph 60. Vent line pipe, fiberglass (07/30/2007) 


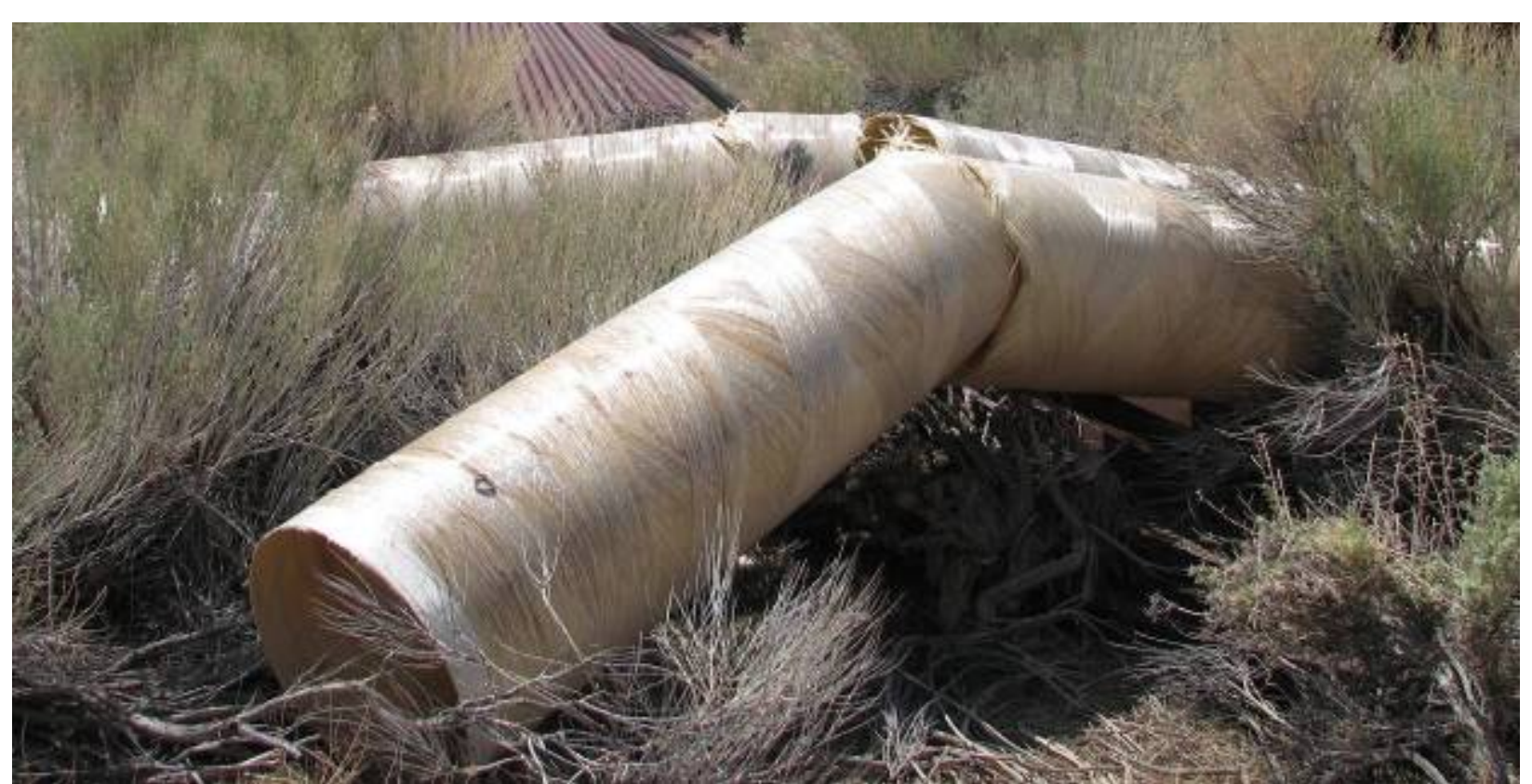

Photograph 61. Vent line pipe, fiberglass (07/30/2007)

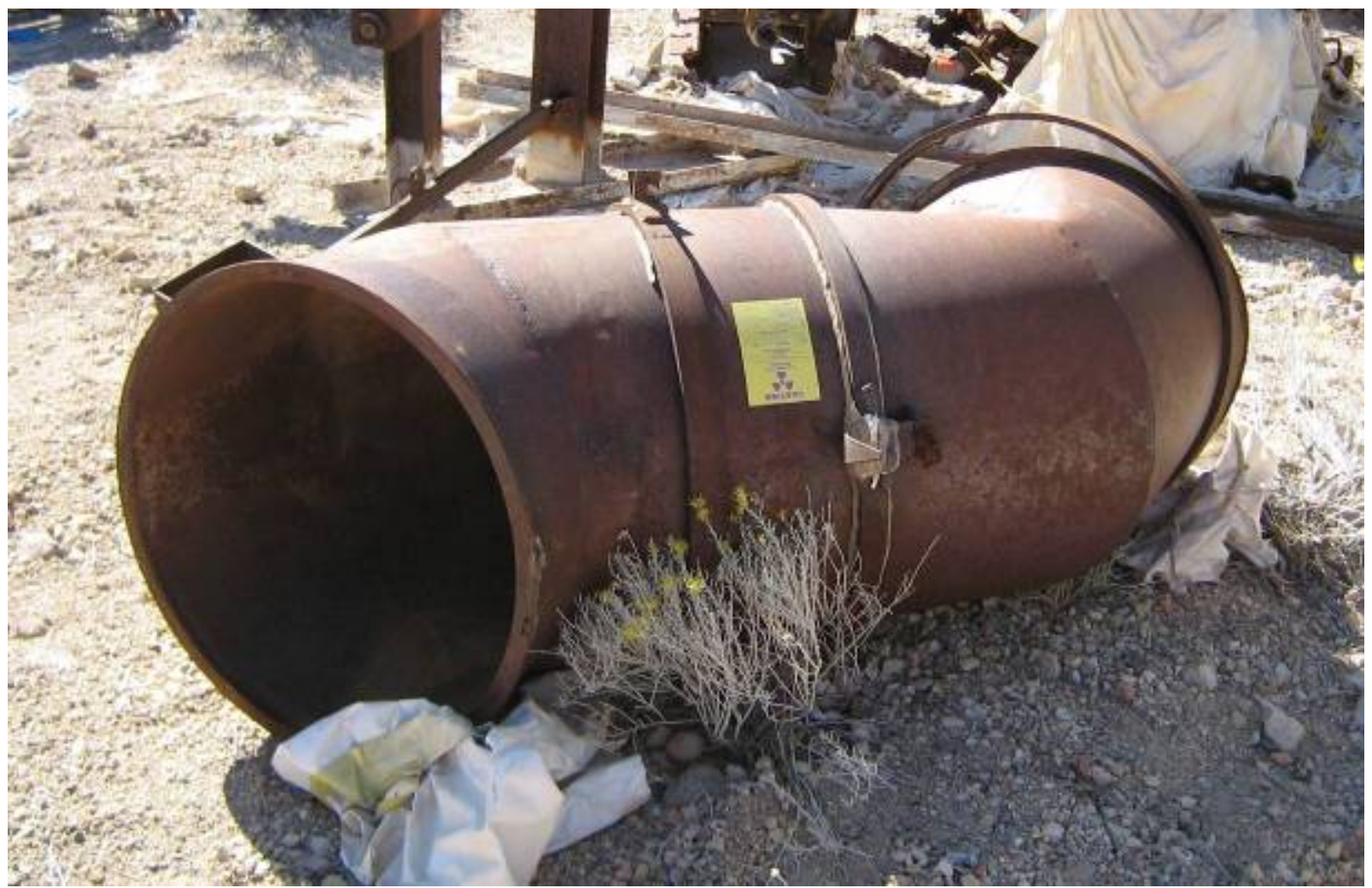

Photograph 62. Vent line pipe, metal (10/30/2007) 


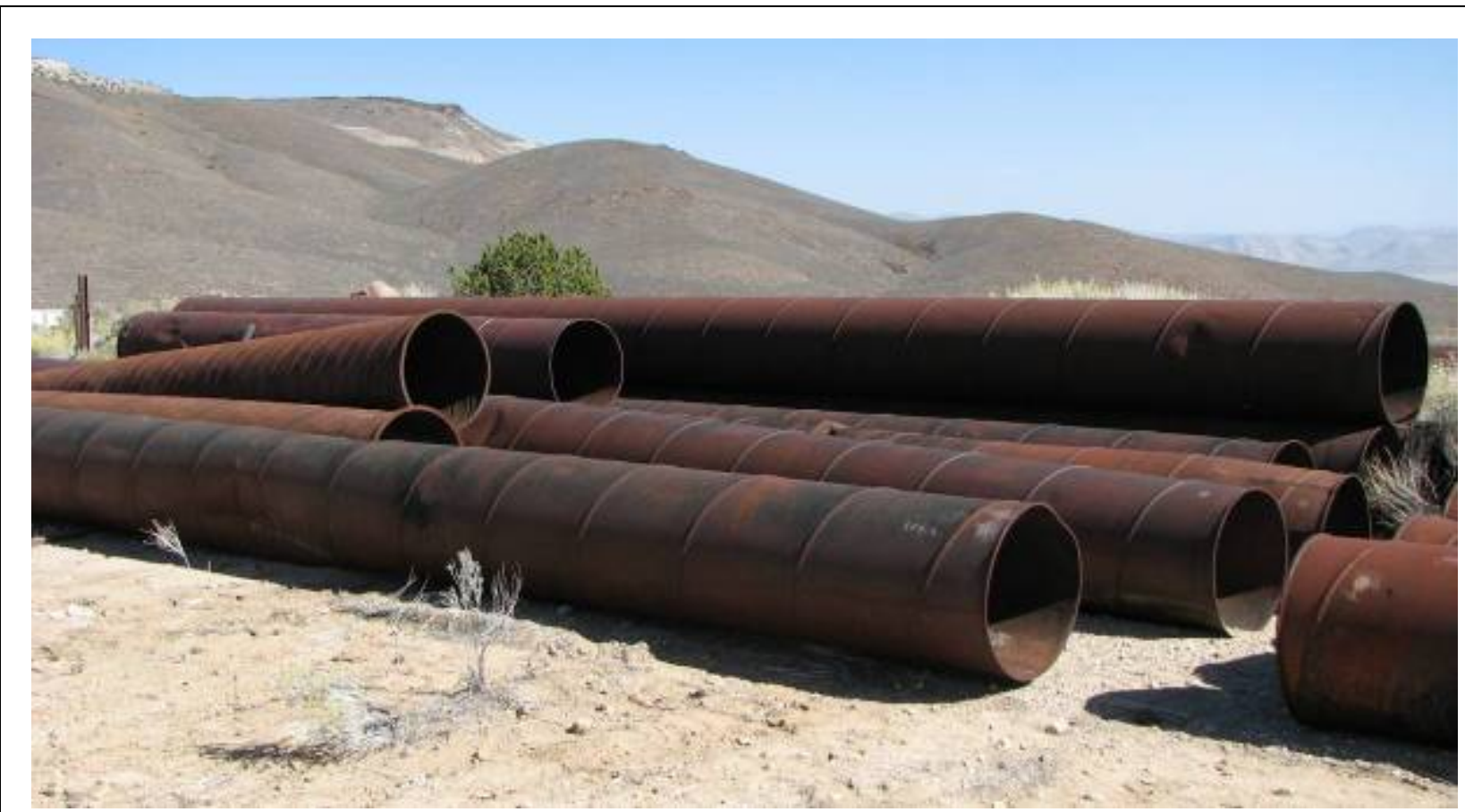

Photograph 63. Vent line pipe, metal (10/04/2007)

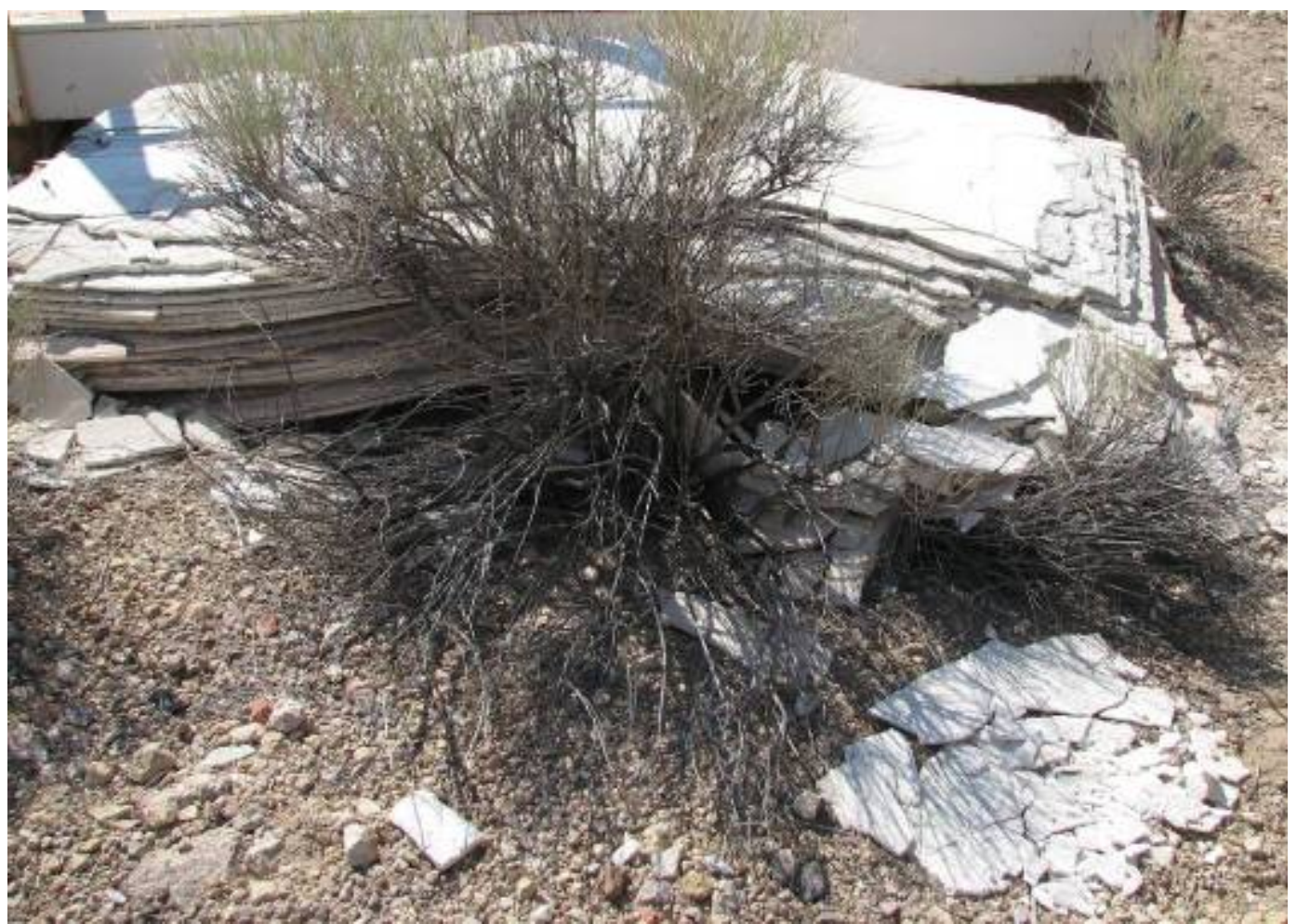

Photograph 64. Wallboard (08/22/2007) 


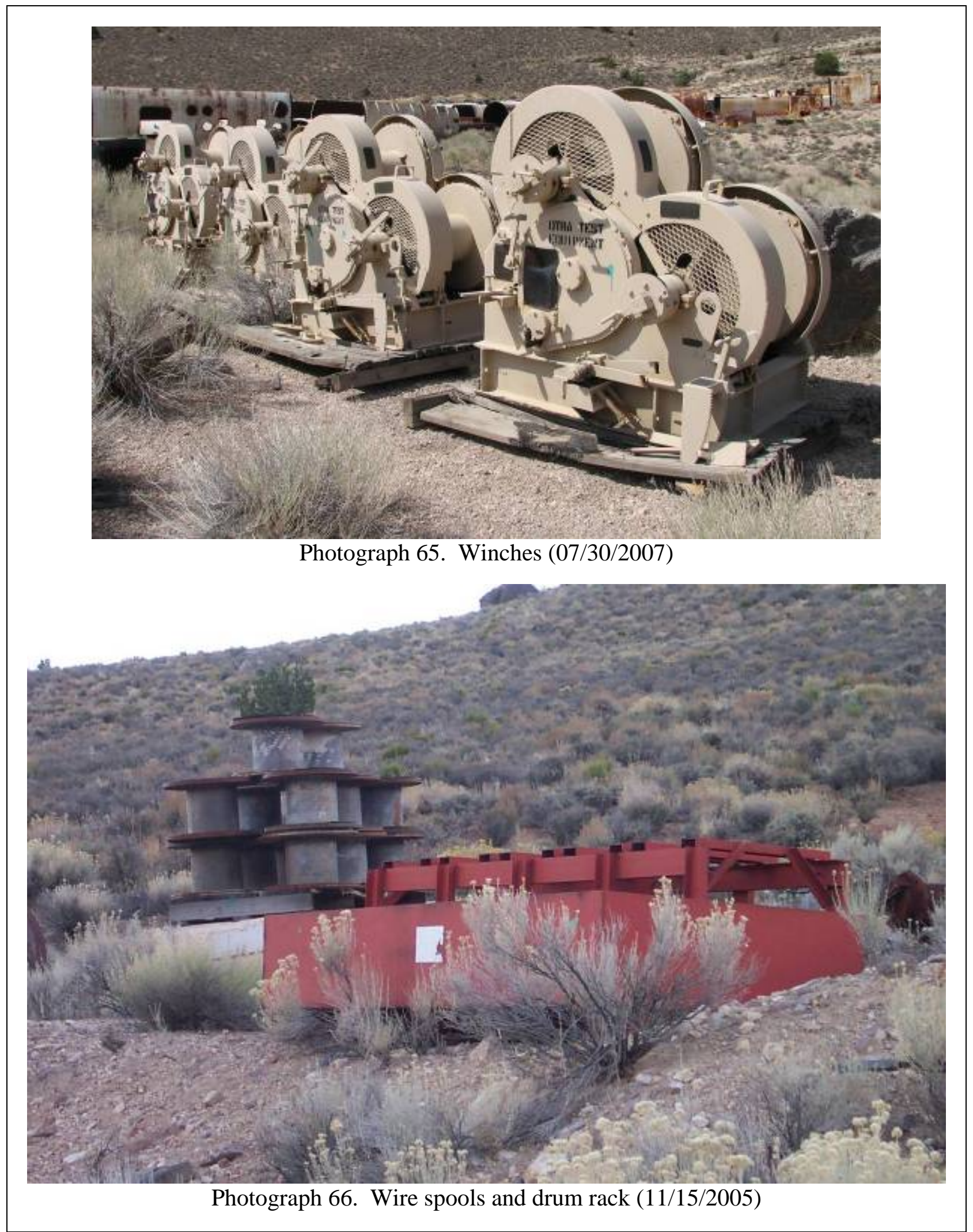


CAU 481 Closure Report

Section: Appendix A

Revision: 0

Date: November 2008

THIS PAGE INTENTIONALLY LEFT BLANK 


\title{
APPENDIX B WASTE DISPOSITION DOCUMENTATION
}

\author{
AREA 9 U10C SANITARY LANDFILL \\ LOW-LEVEL WASTE \\ OFF-SITE RECYCLING
}


CAU 481 Closure Report

Section: Appendix B

Revision: 0

Date: November 2008

THIS PAGE INTENTIONALLY LEFT BLANK 
CAU 481 Closure Report

Section: Appendix B

Revision: 0

Date: November 2008

AREA 9 U10C SANITARY LANDFILL 
CAU 481 Closure Report

Section: Appendix B

Revision: 0

Date: November 2008

THIS PAGE INTENTIONALLY LEFT BLANK 


\section{$\begin{array}{llllll}\text { SWO USE (Select One) } & \text { AREA } & \square 23 & \square 6 & \square 9 & \square \text { LANDFILL }\end{array}$}

For waste characterization, approval, and/or assistance, contact Solid Waste Operation (SWO) at 5-7898.

\section{REQUIRED: WASTE GERERATOR INFORMATION}

(This form is for rolloffs, dump trucks, and other onsite disposal of materials.)

Waste Generator: Dan Tobiason

Phone Number: 295-6169

Location / Origin: T-Tunnel Lower Laydown Yard A/Z

Waste Category: (check one)

Waste Type: $\triangle$ NTS

(check one) $\square$ Non-Putrescible $\square$ Asbestos Containing Material

Pollution Prevention Category: (check one) $\square$ Environmental management

Pollution Prevention Category: (check one) $\triangle$ Clean-Up

Method of Characterization: (check one)

$\square$ Sampling \& Analysis

$\square$ Commercial $\quad$ Industrial $0586-07$

QFFACO-OnSIte $\square$ WAC Exception

Prohibited Waste at all three Radioactive waste; RCRA waste; Hazardous waste; Free liquids, P.CBs above TSCA regulatory NTS landfills:

Additional Prohibited Waste

at the Area 9 U10C Landfill:

levels, and Medical wastes (needles, sharps, bloody clothing).

Sewage Sludge, Animal carcasses, Wet garbage (food waste); and Friable asbestos

\section{REQUIRED: WASTE CONTENTS ALLOWABLE WASTES}

Check all allowable wastes that are contained within this load:

NOTE: Waste disposal at the Area 6 Hydrocarbon Landfill must have come into contact with petroleum hydrocarbons or coolants, such as: gasoline (no benzene, lead); jet fuel; diesel fuel; lubricants and hydraulics; kerosene; asphaltic petroleum hydrocarbon; and ethylene glycol.

Acceptable waste at any NTS landfill: $\triangle$ Paper $\square$ Rocks/unaltered geologic materials

$\bigotimes$ Asphalt $\quad$ Metal $\quad$ Wood $\quad$ Soil $\quad$ Rubber (excluding tires)

$\triangle$ Plastic $\quad$ Wire $\quad$ Cable $\quad$ Cloth $\quad$ Insulation (non-Asbestosform)

$\bigotimes$ Manufactured items: (swamp coolers, furniture, rugs, carpet, electronic components, PPE, etc.)

Additional waste accepted at the Area 23 Mercury Landfill: $\square$ Office Waste $\square$ Food Waste $\square$ Animal Carcasses
$\square$ Asbestos
Friable
Non-Friable (contact SWO if regulated load)
Quantity:

\section{Additional waste accepted at the Area 9 U10c Landfill:}

$\begin{array}{ll}\square \text { Non-friable asbestos } & \square \text { Drained automobiles and military vehicles } \\ \square \text { Light ballasts (contact SWO) } & \square \text { Drained fuel filters (gas \& diesel) } \\ \square \text { Hydrocarbons (contact SWO) } & \text { \ Other Drained generators/equipment }\end{array}$

$\square$ Solid fractions from sand/oil/water

$\triangle$ Deconned Underground and Above

Ground Tanks

\section{Additional waste accepted at the Area 6 Hydrocarbon Landfill:}
$\square$ Septic sludge
$\square$ Rags
Plants
$\square$ Soil
$\square$ Drained fuel filters (gas \& diesel)
$\square$ Sludge from sand/oil/water separators
REQUIRED: WASTE GENERATOR SIGNATURE

Initials: (if initialed, no radiological clearance is necessary.)

The above mentioned waste was generated outside of a Controlled Waste Management Area (CWMA) and to the best of my knowledge, does not contain radiological materials.

To the best of my knowledge, the waste described above contains only those materials that are allowed for disposal at this site. I have verified this through the waste characterization method identified above and a review of the above-mentioned prohibited and allowable waste items. I have contacted Property Manas

is approved for disposal in the landfill.

Print Name: Dan Tobiasson

Signature:

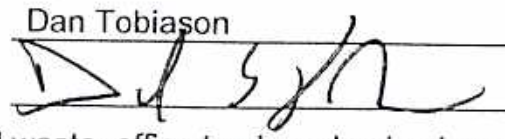

Radiation Survey Release for Waste Disposal RCT Initials

RChis container/load is free of external radioactive Date:

Note: "Food waste, office trash and animal carcasses do not require a re must have signed removal certification statement with Load Verific

SWO USE ONLY

Load Weight (net from scale or estimate) 34,000 $8-2-07$ Signature o verumer: 
NSTec

Form

FRM-0918

NTS LANDFILL LOAD VERIFICATION

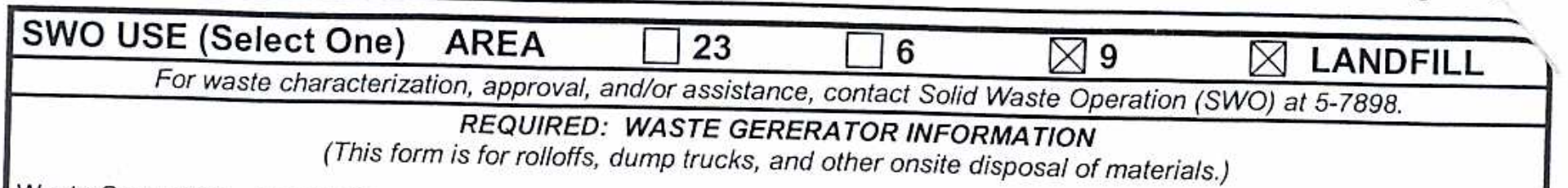

Waste Generator: Dan Tobiason

Location / Origin: T-Tunnel Lower Laydown Yard $A / 2$

Phone Number: 295-6169

Waste Category: (check one)

Waste Type: $\triangle$ NTS

(check one)

$\square$ Non-Putrescible

Pollution Prevention Category: (check one)

Pollution Prevention Category: (check one)

Method of Characterization: (check one)

Prohibited Waste at all three

NTS landfills:

Additional Prohibited Waste

at the Area 9 U10C Landfill: Radioactive waste; RCRA waste; Hazardous waste; Free liquids, PCBs above TSCA regulatory
levels, and Medical wastes (needles, sharps, bloody clothing).

Sewage Sludge, Animal carcasses, Wet garbage (food waste); and Friable asbestos

\section{REQUIRED: WASTE CONTENTS ALLOWABLE WASTES}

Check all allowable wastes that are contained within this load:

NOTE: Waste disposal at the Area 6 Hydrocarbon Landfill must have come into contact with petroleum hydrocarbons or coolants, such as: gasoline (no benzene, lead); jet fuel; diesel fuel; lubricants and hydraulics; kerosene; asphaltic petroleum hydrocarbon; and ethylene glycol.

Acceptable waste at any NTS landfill: $\square$ Paper

$\triangle$ Asphalt $\square$ Metal $\square$ Wood $\square$ Soil

$\bigotimes$ Plastic

$\triangle$ Wire

$\bigotimes$ Cable

Cloth
$\square$ Rocks / unaltered geologic materials
$\triangle$ Rubber (excluding tires)
$\bigotimes$ Insulation (non-Asbestosform)

$\triangle$ Industrial Q8s $8-6-\sigma 7$

$\square$ WAC Exception

$\square$ Historic DOE/NV

$\square$ YMP

Defense Projects

YMP

$\triangle$ Manufactured items: (swamp coolers, furniture, rugs, carpet, electronic components, PPE, etc.)

Additional waste accepted at the Area 23 Mercury Landfill: $\square$ Office Waste

$\square$ Asbestos

Friable

Non-Friable (contact SWO if regulated load)

Food Waste

Quantity:

Additional waste accepted at the Area 9 U10c Landfill:

$\square$ Non-friable asbestos

$\square$ Light ballasts (contact SWO)

$\square$ Hydrocarbons (contact SWO)

$\square$ Drained automobiles and military vehicles

$\square$ Drained fuel filters (gas \& diesel)

$\bigotimes$ Other Drained generators/equipment
Solid fractions from sand/oil/water

$\bigotimes$ Deconned Underground and Above Ground Tanks

Additional waste accepted at the Area 6 Hydrocarbon Landfill:

$\begin{array}{lll}\square \text { Septic sludge } & \square \text { Rags } \\ \square \text { Plants } & \square \text { Soil } & \square \text { Drained fuel filters (gas \& diesel) } \\ \end{array}$ REQUIRED: WASTE GENERATOR SIGNATURE

Crushed non-teme plated oil filters PCBs below 50 parts per million

Initials: (if initialed, no radiological clearance is necessary.) The above mentioned waste was generated outside of a Controlled Waste Management Area (CWMA) and to the best of my
knowledge, does not contain radiological materials.

To the best of my knowledge, the waste described above contains only those materials that are allowed for disposal at this site. I have verified this through the waste characterization method identified prohibited and allowable waste items. I have contacted Property Management is approved for disposal in the landfill.

Print Name: Dan Tobiason

Signature:
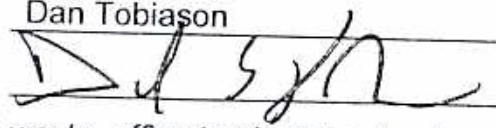

Note: "Food waste, office trash and animal carcasses do not require a radiologi must have signed removal certification statement with Load Verification." SWO USE ONLY

Load Weight (net from scale or estimate): i) $078,2-07$ Signature of Certifier:
Radiation Survey Release for Waste Disposal RCT Initials

17 This container/load is free of external radioactive - Tontamination.

This container/load is exempt ffom survey due to process knowledge anog grigin.

Q This cantainerlload is f f e of fadioactive

SIGNATURE:

ntamination based on readjogalysis
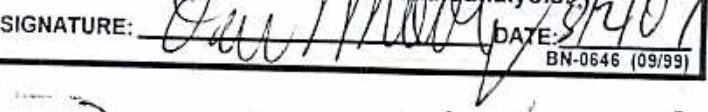

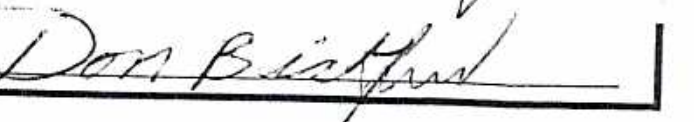




\section{NSTec \\ Form

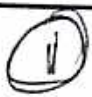 \\ FRM-0918 \\ NTS LANDFILL LOAD VERIFICATION}

SWO USE (Select One) AREA

23

$\begin{array}{llllll}\text { For waste characterization, approval, and/or assistance, contact Solid Wasto } & \text { Op } & \square \text { LANDFIL }\end{array}$

For waste characterization, approval, and/or assistance, contact solid wasto $99 \quad \square$ LANDFIL

Pac

REQUIRED: WASTE GERERATOR INFORMATION Operation (SWO) at 5-7898.

(This form is for rolloffs, dumP ITE GERERATOR INFORMATION

Waste Generator: Dan Tobiason

Location / Origin: T-Tunnel Lower Laydown Yard $A / Z$

Phone Number: $295-6169$

Waste Category: (check one)

Waste Type: $\square$ Commercial

\NTS $\square$ Putrescrible

$\triangle$ FFACO-OIStE

$\triangle$ Industrial ogs olith

$\square$ Non-Putrescible $\quad \square$ Asbestos Containing Material

Pollution Prevention Category: (check one)

Pollution Prevention Category: (check one)

Method of Characterization: (check one)

$\square$ Elean-Up

Prohibited Waste at all three

NTS landfills:

Sampling \& Analysis

$\square$ FFACO-offsite

WAC Exception

$\triangle$ Defense Projects

Historic DOE/NV

Additional Prohibited Waste

at the Area 9 U10C Landfill:

levels, and Medical waste waste; Hazardous waste; Free liquids, PCBs above TSCA regulatory

$\square$ Routine

$\triangle$ Process Knowledge $\square$ Contents

levels, and Medical wastes (needles, sharps, bloody clothing).

Sewage Sludge, Animal carcasses, Wet garbage (food waste); and Friable asbestos

\section{REQUIRED: WASTE CONTENTS ALLOWABLE WASTES}

NOTE: Waste disposal at the Areck all allowable wastes that are contained within this load:

coolants, such as: gasoline (no benzene, Landfill must have come into contact with petroleum hydrocarbons or petroleum hydrocarbon; and ethylene glycol.

Acceptable waste at any NTS landfill:
$\bigotimes$ Asphalt
Мetal
$\triangle$ Wood
$\bigotimes$ Paper
$\otimes$ Soil
$\triangle$ Cable
$\triangle$ Cloth
$\square$ Rocks / unaltered geologic materials
Q Rubber (excluding tires)
$\triangle$ Plastic
$\triangle$ Wire
$\triangle$ Insulation (non-Asbestosform)

$\triangle$ Manufactured items: (swamp coolers, furniture, rugs, carpet, electronic components, PPE, etc.)

Additional waste accepted at the Area 23 Mercury Landfill: $\square$ Office Waste
$\square$ Asbestos $\quad \square$ Friable $\square$ Non-Friable (contact Swo if

Non-Friable (contact SWO if regulated load)

Food Waste

Quantity:

Additional waste accepted at the Area 9 U10c Landfill:

$\square$ Non-friable asbestos

$\square$ Light ballasts (contact SWO)

Hydrocarbons (contact SwO)

$\square$ Drained automobiles and military vehicles

$\square$ Drained fuel filters (gas \& diesel)

Other Drained generators/equipment

Additional waste accepted at the Area 6 Hydrocarbon Landfill:

$\begin{array}{ll}\square \text { Septic sludge } & \square \text { Rags } \\ \square \text { Plants } & \square \text { Soil }\end{array}$

Initials: (if initialed, no radiological clearance is necessary.)

The above mentioned waste was generated outside of a Controlled Waste Management Area (CWMA) and to the best of my
knowledge, does not contain radiological materials.

To the best of my knowledge, the waste described above contains only those materials that are allowed for disnncal at thic

prohibited and allowab through the waste characterization method identified a

is approved for disposal in the landfill.

is ape landfill.

Print Name: Dan Tobiason

Signature:
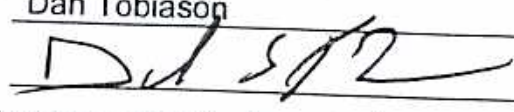

$\square$ Drained fuel filters (gas \& diesel)

$\square$ Sludge from sand/oil/water separators

Solid fractions from sand/oil/water

$\triangle$ Deconned Underground and Above Ground Tanks

Note: "Food waste, office trash and animal carcasses do not require a radiologic must have signed removal certification statement with Load Verification."

\section{SWO USE ONLY}

Load Weight (net from scale or estimate):

8.6 .07

Signature of Certifier:
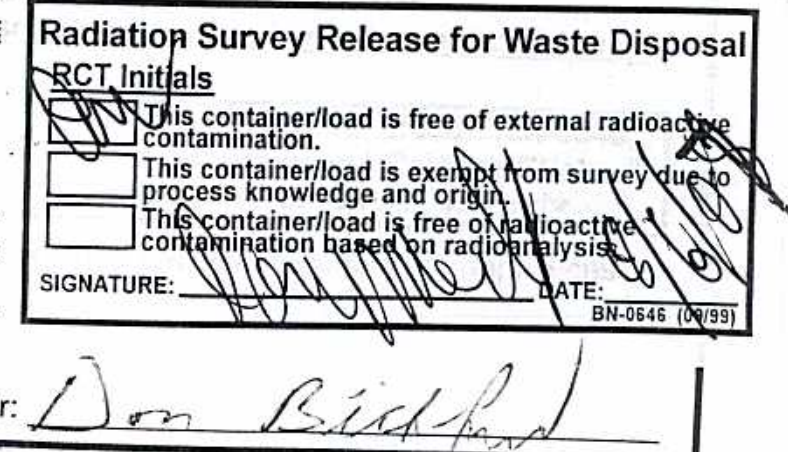


\section{$\begin{array}{llllll}\text { SWO USE (Select One) } & \text { AREA } & \square 23 & \square 6 & \square 9 & \square \text { LANDFILL }\end{array}$}

For waste characterization, approval, and/or assistance, contact Solid Waste Operation (SWO) at 5-7898.

REQUIRED: WASTE GERERATOR INFORMATION

(This form is for rolloffs, dump trucks, and other onsite disposal of materials.)

Waste Generator: Dan Tobiason

Phone Number: 295-6169

Location / Origin: T-Tunnel Lower Laydown Yard

\begin{tabular}{|c|c|c|c|}
\hline Waste Category: (check one) & $\square$ Commercial & $\otimes$ Industrial & 17107 \\
\hline Waste Type: & $\square$ Putrescrible & $\triangle F F A G \theta-\theta$ site & $\square$ WAC Exception \\
\hline$\square$ Non-Putrescible & $\square$ Asbestos Containing Material & $\square$ FFACO-offsite & $\square$ Historic DOE/NV \\
\hline Pollution Prevention Category: (check one) & $\square$ Environmental management & $\triangle$ Defense Projects & $\square$ YMP \\
\hline Pollution Prevention Category: (check one) & $\triangle$ Clean-Up & $\square$ Routine & \\
\hline Method of Characterization: (check one) & $\square$ Sampling \& Analysis & $\triangle$ Process Know & Contents \\
\hline
\end{tabular}

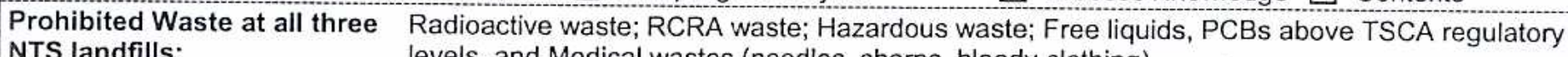
NTS landfills:

Additional Prohibited Waste at the Area 9 U10C Landfill: levels, and Medical wastes (needles, sharps, bloody clothing).

Sewage Sludge, Animal carcasses, Wet garbage (food waste); and Friable asbestos

\section{REQUIRED: WASTE CONTENTS ALLOWABLE WASTES}

Check all allowable wastes that are contained within this load:

NOTE: Waste disposal at the Area 6 Hydrocarbon Landfill must have come into contact with petroleum hydrocarbons or coolants, such as: gasoline (no benzene, lead); jet fuel; diesel fuel; lubricants and hydraulics; kerosene; asphaltic petroleum hydrocarbon; and ethylene glycol.
Acceptable waste at any NTS landfill:
Asphalt $\bigotimes$ Metal
Wood
$\triangle$ Paper
区 Soil
$\triangle$ Cable

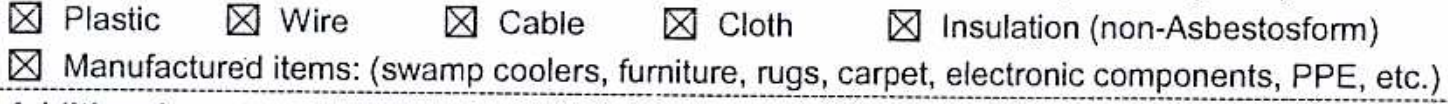
Rocks / unaltered geologic materials
$\triangle$ Rubber (excluding tires)
$\bigotimes$ Plastic $\triangle$ Wire $\triangle$ Cable $\square$ Cloth $\square$ Insulation (non-Asbestosform)
$\square$ Manufactured items: (swamp coolers, furniture, rugs, carpet, electronic components, PPE, etc.)
$\triangle$ Empty containers
$\triangle$ Demolition debris
Additional waste accepted at the Area 23 Mercury Landfill: $\square$ Office Waste
$\square$ Asbestos
$\square$ Friable
Non-Friable (contact SWO if regulated load)
Food Waste
$\otimes$ Cement \& concrete
Quantity:
Animal Carcasses

Additional waste accepted at the Area 9 U10c Landfill:

$\square$ Non-friable asbestos $\quad \square$ Drained automobiles and military vehicles
$\square$ Light ballasts (contact SWO) $\quad \square$ Drained fuel filters (gas \& diesel)
$\square$ Hydrocarbons (contact SWO) $\quad$ O Other Drained generators/equipment

Additional waste accepted at the Area 6 Hydrocarbon Landfill:
$\square$ Septic sludge
$\square$ Rags
$\square$ Drained fuel filters (gas \& diesel)
$\square$ Sludge from sand/oil/water separators
REQUIRED: WASTE GENERATOR SIGNATURE
Crushed non-teme plated oil filters
Plants
Soil

Solid fractions from sand/oil/water

$\triangle$ Deconned Underground and Above Ground Tanks

Initials: (if initialed, no radiological clearance is necessary.)

The above mentioned waste was generated outside of a Controlled Waste Management Area (CWMA) and to the best of my knowledge, does not contain radiological materials.

To the best of my knowledge, the waste described above contains only those materials that are allowed for disposal at this site. I have verified this through the waste characterization method identified above and a review of the above-mentioned prohibited and allowable waste items. I have contacted Property Management and have verified that this material/equipment is approved for disposal in the landfill.

Print Name: Dan Tobiason

Signature:
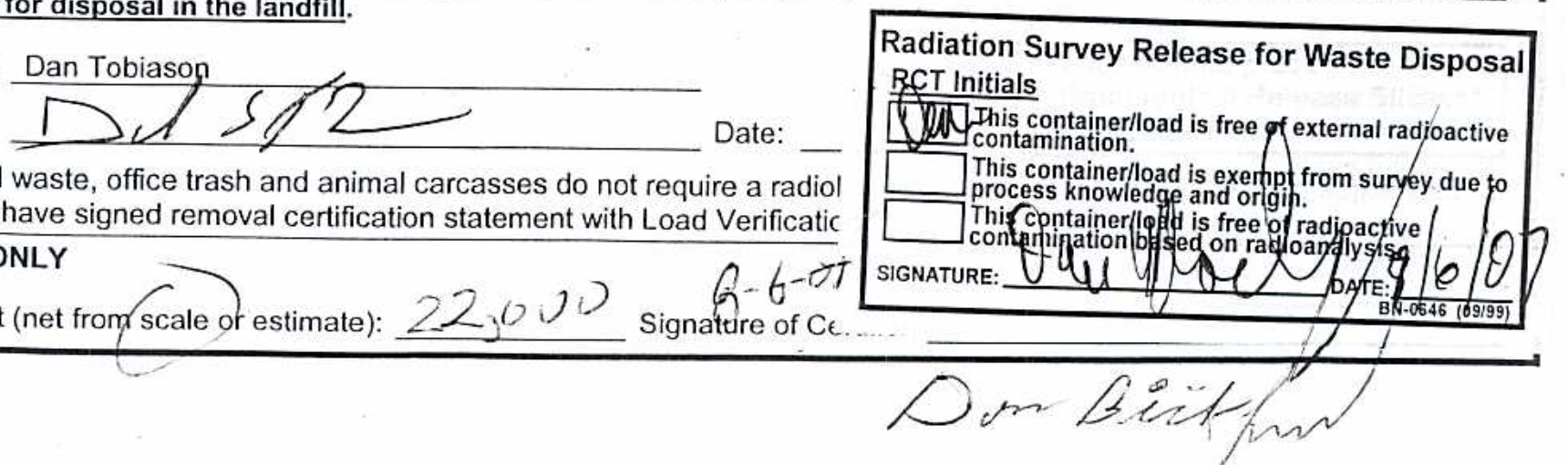

Note: "Food waste, office trash and animal carcasses do not require a radiol must have signed removal certification statement with Load Verificatic

\section{SWO USE ONLY}

Load Weight (net from scale or estimate):
Q. $6-\nabla j$ Signature of $\mathrm{C} \epsilon$
Radiation Survey Release for Waste Disposal RCT Initials

This container/load is free of external radioactive This container process knowledae and org from suryey due to This container/lo SIGNATURE: 3010 


\begin{tabular}{|llllll}
\hline SWO USE (Select One) & AREA & $\square 23$ & $\square 6$ & (S) & LANDFILL
\end{tabular}

For waste characterization, approval, and/or assistance, contact Solid Waste Operation (SWO) at 5-7898.

REQUIRED: WASTE GERERATOR INFORMATION

(This form is for rolloffs, dump trucks, and other onsite disposal of materials.)

Waste Generator: Dan Tobiason

Phone Number: 295-6169

Location / Origin: T-Tunnel Lower Laydown Yard

Waste Category: (check one)

Waste Type: $\square$ NTS

(check one)

$\square$ Non-Putrescible

$\square$ Commercial

$\square$ Putrescrible $\triangle$ Industrial egs of 17107

A-FFAGO-Angite की $\square$ WAC Exception

Pollution Prevention Category: (check one)

$\square$ Asbestos Containing Material

$\square$ FFACO-offsite

$\square$ Historic DOE/NV

Pollution Prevention Category: (check one)

$\square$ Environmental management

$\triangle$ Defense Projects

YMP

Method of Characterization: (check one)

$\triangle$ Clean-Up

Routine

Prohibited Waste at all three Radioactive waste; RCRA waste; Hazardous waste; Free liquids, PCBs above TSCA regulatory NTS landfills:

levels, and Medical wastes (needles, sharps, bloody clothing).

Additional Prohibited Waste

at the Area 9 U10C Landfill:

Sewage Sludge, Animal carcasses, Wet garbage (food waste); and Friable asbestos

\section{REQUIRED: WASTE CONTENTS ALLOWABLE WASTES}

Check all allowable wastes that are contained within this load:

NOTE: Waste disposal at the Area 6 Hydrocarbon Landfill must have come into contact with petroleum hydrocarbons or coolants, such as: gasoline (no benzene, lead); jet fuel; diesel fuel; lubricants and hydraulics; kerosene; asphaltic petroleum hydrocarbon; and ethylene glycol.
Acceptable waste at any NTS landfill:
$\triangle$ Paper
$\square$ Rocks / unaltered geologic materials
$\bigotimes$ Empty containers
冈 Asphalt
Metal
$\triangle$ Wood
$\otimes$ Soil
$\triangle$ Rubber (excluding tires)
$\otimes$ Demoiition debris
$\triangle$ Plastic $\otimes$ Wire
冈 Cable
$\triangle$ Cloth
$\triangle$ Insulation (non-Asbestosform)
$凶$ Cement \& concrete
$\triangle$ Manufactured items: (swamp coolers, furniture, rugs, carpet, electronic components, PPE, etc.)
Additional waste accepted at the Area 23 Mercury Landfill: $\square$ Office Waste
Food Waste
Animal Carcasses
$\square$ Asbestos
Friable
Non-Friable (contact SWO if regulated load)
Quantity:

Additional waste accepted at the Area 9 U10c Landfill:
Non-friable asbestos
Drained automobiles and military vehicles
Light ballasts (contact SWO)
Drained fuel filters (gas \& diesel)
Hydrocarbons (contact SWO)
Other Drained generators/equipment

Solid fractions from sand/oil/water

$\triangle$ Deconned Underground and Above Ground Tanks

Additional waste accepted at the Area 6 Hydrocarbon Landfill:
$\square$ Septic sludge
$\square$ Rags
$\square$ Drained fuel filters (gas \& diesel)
Crushed non-teme plated oil filters
Plants
Soil
$\square$ Sludge from sand/oil/water separators
$\square$ PCBs below 50 parts per million

\section{REQUIRED: WASTE GENERATOR SIGNATURE}

Initials: (if initialed, no radiological clearance is necessary.)

The above mentioned waste was generated outside of a Controlled Waste Management Area (CWMA) and to the best of my knowledge, does not contain radiological materials.

To the best of my knowledge, the waste described above contains only those materials that are allowed for disposal at this site. I have verified this through the waste characterization method identified above and a review of the above-mentioned prohibited and allowable waste items. I have contacted Property Managen is approved for disposal in the landfill.

Print Name: Dan Tobiason

Signature:
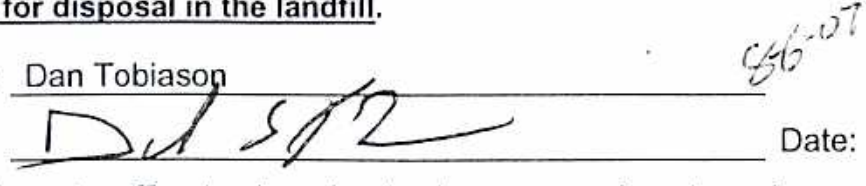

Date:

Note: "Food waste, office trash and animal carcasses do not require a radi must have signed removal certification statement with Load Verificat

SWO USE ONLY

Load Weight (net from scale or estimate): 4 osc
8.6- 17 Signature of Certifier:

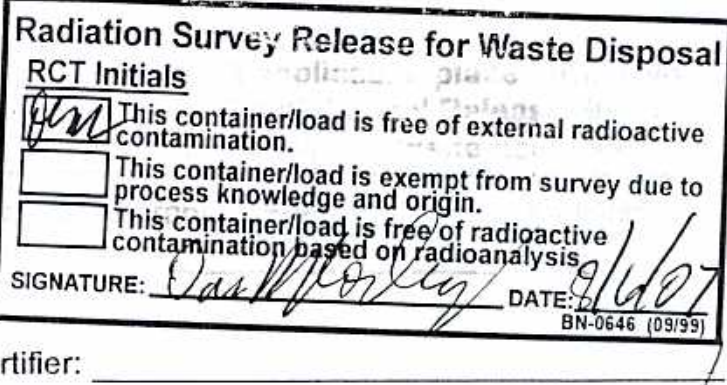


For waste characterization, approval, and/or assistance, contact Solid Waste Operation (SWO) at 5-7898.

REQUIRED: WASTE GERERATOR INFORMATION

(This form is for rolloffs, dump trucks, and other onsite disposal of materials.)

Waste Generator: Dan Tobiason

Phone Number: 295-6169

Location / Origin: T-Tunnel Lower Laydown Yard

Waste Category: (check one)

Waste Type: $₫$ NTS

(check one) $\quad \square$ Non-Putrescible $\square$ Asbestos Containing Material

(check one) $\square$ Non-Putrescible $\square$ Asbestos Containing Material

$\square$ Commercial

$\square$ Putrescrible

$\triangle$ Industrial cgs $8 / 7 / 07$

Pollution Prevention Category: (check one)

Pollution Prevention Category: (check one)

$\square$ Environmental management

$\triangle$ Clean-Up

Method of Characterization: (check one)

Sampling \& Analysis

$\triangle$ FFACO-Onsite

$\square$ FFACO-offsite

WAC Exception

$\triangle$ Defense Projects

$\square$ Historic DOE/NV

Prohibited Waste at all three

NTS landfills:

Additional Prohibited Waste

at the Area 9 U10C Landfill:

Radioactive waste; RCRA waste; Hazardous waste; Free liquids, PCBs above TSCA regulatory levels, and Medical wastes (needles, sharps, bloody clothing).

Sewage Sludge, Animal carcasses, Wet garbage (food waste); and Friable asbestos

\section{REQUIRED: WASTE CONTENTS ALLOWABLE WASTES}

Check all allowable wastes that are contained within this load:

NOTE: Waste disposal at the Area 6 Hydrocarbon Landfill must have come into contact with petroleum hydrocarbons or coolants, such as: gasoline (no benzene, lead); jet fuel; diesel fuel; lubricants and hydraulics; kerosene; asphaltic petroleum hydrocarbon; and ethylene glycol.

Acceptable waste at any NTS landfill: $\triangle$ Paper
$\triangle$ Asphalt
$凶$ Metal
$\bigotimes$ Wood
¿ Soil
$\square$ Rocks / unaltered geologic materials
$\triangle$ Rubber (excluding tires)
$\triangle$ Plastic $\otimes$ Wire
Q Cable
$\triangle$ Cloth
\Insulation (non-Asbestosform)

$\triangle$ Empty containers

$\triangle$ Demolition debris

$\triangle$ Manufactured items: (swamp coolers, furniture, rugs, carpet, electronic components, PPE, etc.)
Additional was
$\square$ Friable
Area 23 Mercury Landfill:
Office Waste
Food Waste
Animal Carcasses
Quantity:

Additional waste accepted at the Area 9 U10c Landfill:
$\square$ Non-friable asbestos
$\square$ Light ballasts (contact SWO)
$\square$ Drained automobiles and military vehicles
$\square$ Drained fuel filters (gas \& diesel)
Hydrocarbons (contact SWO)
Other
Drained generators/equipment

$凶$ Cement \& concrete

Additional waste accepted at the Area 6 Hydrocarbon Landfill:

$\square$ Septic sludge $\square$ Rags $\quad \square$ Drained fuel filters (gas \& diesel)

Plants

Soil

$\square$ Sludge from sand/oil/water separators REQUIRED: WASTE GENERATOR SIGNATURE

Solid fractions from sand/oil/water

$\triangle$ Deconned Underground and Above Ground Tanks

Initials: (if initialed, no radiological clearance is necessary.)

The above mentioned waste was generated outside of a Controlled Waste Management Area (CWMA) and to the best of my
knowledge, does not contain radiological materials.

To the best of my knowledge, the waste described above contains only those materials that are allowed for disposal at this site. I have verified this through the waste characterization method identified above and a review of the above-mentioned prohibited and allowable waste items. I have contacted Property Managem is approved for disposal in the landfill.

Print Name: Dan Tobiason

Signature:
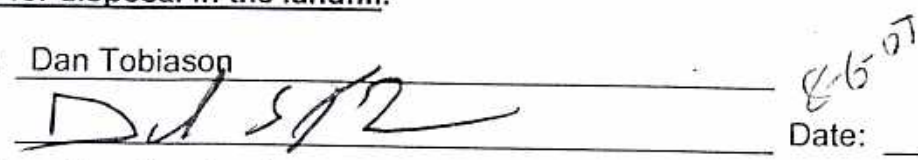

Note: "Food waste, office trash and animal carcasses do not require a radiol must have signed removal certification statement with Load Verificatic

\section{SWO USE ONLY}

Load Weight (net from scale or)estimate): $34 \mathrm{E}$ : s
4.6.07

Signature of $\mathrm{Ce}$ เ uı
Radiation Survey Release for Waste Disposal

RCT Initials

1U1 This container/load is free of external radioactive contamination.

This container/load is exempt from survey due to process knowledge and origin.

This Egntainer//oad is/free of radioactive

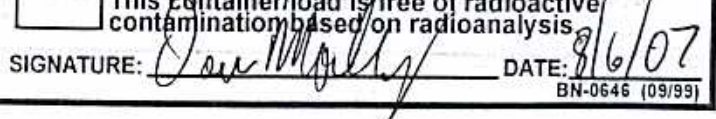




\section{SWO USE (Select One) AREA 23 $\square 6$ 凶9 \\ $\triangle$ LANDFILL \\ For waste characterization, approval, and/or assistance, contact Solid Waste Operation (SWO) at 5-7898.}

\section{REQUIRED: WASTE GERERATOR INFORMATION}

(This form is for rolloffs, dump trucks, and other onsite disposal of materials.)

Waste Generator: Dan Tobiason

Phone Number: 295-6169

Location / Origin: T-Tunnel Lower Laydown Yard

Waste Category: (check one)

Waste Type: $\triangle$ NTS

(check one)

$\square$ Non-Putrescible

$\square$ Commercial
$\square$ Putrescrible
$\square$ Asbestos Containing Material
$\square$ Environmental management
$\square$ Clean-Up
$\square$ Sampling \& Analysis

$\triangle$ Industrial ofs $8 / 8 / 07$

$\triangle$-FFAGO-Onsite.

WAC Exception

FFACO-offsite

$\triangle$ Defense Projects

$\square$ Historic DOE/NV

$\square$ Routine

$\triangle$ Process Knowledge $\square$ Contents

Method of Characteriz

Prohibited Waste at all three

NTS landfills:

Additional Prohibited Waste

at the Area 9 U10C Landfill:

levels, and Medical wastes (needles, sharps, bloody clothing).

Sewage Sludge, Animal carcasses, Wet garbage (food waste); and Friable asbestos

\section{REQUIRED: WASTE CONTENTS ALLOWABLE WASTES}

Check all allowable wastes that are contained within this load:

NOTE: Waste disposal at the Area 6 Hydrocarbon Landfill must have come into contact with petroleum hydrocarbons or coolants, such as: gasoline (no benzene, lead); jet fuel; diesel fuel; lubricants and hydraulics; kerosene; asphaltic petroleum hydrocarbon; and ethylene glycol.

Acceptable waste at any NTS landfill: $\bigotimes$ Paper
$凶$ Asphalt
$\bigotimes$ Metal
区 Wood
区 Soil
$\square$ Rocks / unaltered geologic materials
$\triangle$ Rubber (excluding tires)
$\bigotimes$ Insulation (non-Asbestosform)
$\triangle$ Plastic $\quad \square$ Vire

$\triangle$ Cable $\square$ Cloth

$\triangle$ Cable $\square$ Cloth

$\bigotimes$ Empty containers

$\triangle$ Demolition debris

arpet, electronic components, PPE, etc
Additional waste accepted at the Area 23 Mercury Landfill:
$\square$ Asbestos
Friable
Non-Friable (contact SWO if regulated load)
Food Waste
Quantity:

Additional waste accepted at the Area 9 U10c Landfill:

$\square$ Non-friable asbestos

$\square$ Light ballasts (contact SWO)

$\square$ Drained automobiles and military vehicles

$\square$ Drained fuel filters (gas \& diesel)

Hydrocarbons (contact SWO)

$凶$ Other

Drained generators/equipment
Solid fractions from sand/oil/water

$\bigotimes$ Deconned Underground and Above Ground Tanks

Additional waste accepted at the Area 6 Hydrocarbon Landfill:

$\square$ Septic sludge $\square$ Rags $\square$ Drained fuel filters (gas \& diesel)

Plants

Soil

$\square$ Sludge from sand/oil/water separators REQUIRED: WASTE GENERATOR SIGNATURE

Crushed non-teme plated oil filters PCBs below 50 parts per million

Initials: (if initialed, no radiological clearance is necessary.)

The above mentioned waste was generated outside of a Controlled Waste Management Area (CWMA) and to the best of my
knowledge, does not contain radiological materials.

To the best of my knowledge, the waste described above contains only those mater site. I have verified this through the waste characterization method identified above prohibited and allowable waste items. I have contacted Property Management and I is approved for disposal in the landfill.

Print Name: Dan Tobiason

Signature:

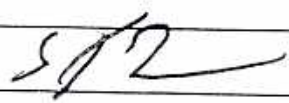

Date: $\dot{8}, 7-0 \eta$

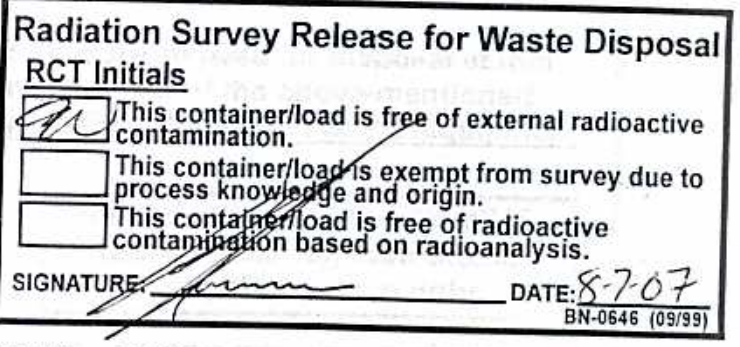

Note: "Food waste, office trash and animal carcasses do not require a radiological cl must have signed removal certifisation statement with Load Verification."

SWO USE ONLY

8.7.07 Signature of Certifier:

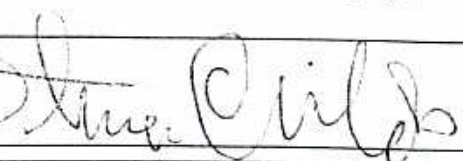




\section{$\begin{array}{llllll}\text { SWO USE (Select One) } & \text { AREA } & \square 23 & \square 6 & \square 9 & \square \text { LANDFILL }\end{array}$}

For waste characterization, approval, and/or assistance, contact Solid Waste Operation (SWO) at 5-7898.

\section{REQUIRED: WASTE GERERATOR INFORMATION}

(This form is for rolloffs, dump trucks, and other onsite disposal of materials.)

Waste Generator: Dan Tobiason

Phone Number: 295-6169

Location / Origin: T-Tunnel Lower Laydown Yard

Waste Category: (check one)

Waste Type: $₫$ NTS

(check one)

$\square$ Non-Putrescible

$\square$ Commercial

$\triangle$ Industrial egs $8 / 8 / 07$

$\square$ Putrescrible

AfFACO-onsite

$\square$ WAC Exception

$\square$ FFACO-offsite

$\square$ Historic DOE/NV

Pollution Prevention Category: (check one)

$\square$ Asbestos Containing Material

$\triangle$ Defense Projects

YMP

Method of Characterization: (check one)

$\triangle$ Clean-Up

Prohibited Waste at all three

NTS landfills:

Additional Prohibited Waste

at the Area 9 U10C Landfill:

Radioactive waste; RCRA waste; Hazardous waste; Free liquids, PCBs above TSCA regulatory levels, and Medical wastes (needles, sharps, bloody clothing).

Sewage Sludge, Animal carcasses, Wet garbage (food waste); and Friable asbestos

\section{REQUIRED: WASTE CONTENTS ALLOWABLE WASTES}

Check all allowable wastes that are contained within this load:

NOTE: Waste disposal at the Area 6 Hydrocarbon Landfill must have come into contact with petroleum hydrocarbons or coolants, such as: gasoline (no benzene, lead); jet fuel; diesel fuel; lubricants and hydraulics; kerosene; asphaltic petroleum hydrocarbon; and ethylene glycol.
Acceptable waste at any NTS landfill:
Q Asphalt
Metal
Q Wood
$\triangle$ Paper
Q Soil
$\triangle$ Cloth
$\square$ Rocks / unaltered geologic materials
$\triangle$ Rubber (excluding tires)
$凶$ Insulation (non-Asbestosform)
$\triangle$ Empty containers
$\triangle$ Demolition debris
$\triangle$ Plastic $\quad$ Wire $\quad \square$ Cable
$\triangle$ Manufactured items: (swamp coolers, furniture, rugs, carpet, electronic components, PPE, etc.)
Additional waste accepted at the Area 23 Mercury Landfill: $\square$ Office Waste
Asbestos
$\square$ Friable
$\square$ Non-Friable (contact SWO if reguiated load)
Food Waste
$\triangle$ Cement \& concrete Quantity:

Additional waste accepted at the Area 9 U10c Landfill:

$\square$ Non-friable asbestos

Light ballasts (contact SWO)

Hydrocarbons (contact SWO) $\square$ Drained automobiles and military vehicles

$\square$ Drained fuel filters (gas \& diesel)

Other Drained generators/equipment Ground Tanks

\section{Additional waste accepted at the Area 6 Hydrocarbon Landfill:}
Septic sludge
$\square$ Rags
$\square$ Drained fuel filters (gas \& diesel)
Plants
Soil
$\square$ Sludge from sand/oil/water separators

\section{REQUIRED: WASTE GENERATOR SIGNATURE}
Crushed non-teme plated oil filters PCBs below 50 parts per million

Initials: (if initialed, no radiological clearance is necessary.)

The above mentioned waste was generated outside of a Controlled Waste Man knowledge, does not contain radiological materials.

To the best of my knowledge, the waste described above contains only those $r$ site. I have verified this through the waste characterization method identified : prohibited and allowable waste items. I have contacted Property Management is approved for disposal in the landfill.

Print Name: Dan Tobiason

Signature:
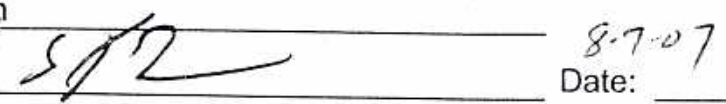

Solid fractions from sand/oil/water

$\triangle$ Deconned Underground and Above

Note: "Food waste, office trash and animal carcasses do not require a radiological clearance. Freon-containing appliances must have signed removal certification statement with Load Verification."

SWO USE ONLY

Load Weight (net from scale or estimate): 5000
$8-7 \cdot 07$

Signature of Certifier:
Radiological Survey Release for Waste Disposal RCT Initials

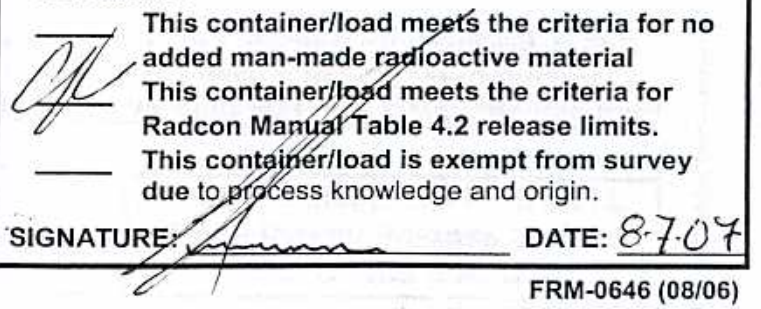
FRM-0646 (08/06) 


\section{$\begin{array}{llllll}\text { SWO USE (Select One) } & \text { AREA } & \square 23 & \square 6 & \square 9 & \square \text { LANDFILL }\end{array}$}

For waste characterization, approval, and/or assistance, contact Solid Waste Operation (SWO) at 5-7898.

REQUIRED: WASTE GERERATOR INFORMATION

(This form is for rolloffs, dump trucks, and other onsite disposal of materials.)

Waste Generator: Dan Tobiason

Phone Number: 295-6169

Location / Origin: T-Tunnel Lower Laydown Yard

Waste Category: (check one)

Waste Type: $\triangle$ NTS

Commercial

(check one)

$\square$ Non-Putrescible

$\square$ Putrescrible

$\triangle$ Industrial os $8 / 8 / 07$

$\triangle$ IFACO-Onsite $\square$

$\square$ Asbestos Containing Material

$\square$ FFACO-offsite

Pollution Prevention Category: (check one) $\square$ Environmental management

Pollution Prevention Category: (check one) $\triangle$ Clean-Up

Method of Characterization: (check one)

Sampling \& Analysis

$\triangle$ Defense Projects

Prohibited Waste at all three

NTS landfills:

Additional Prohibited Waste

at the Area 9 U10C Landfill:

Radioactive waste; RCRA waste; Hazardous waste; Free liquids, PCBs above TSCA regulatory
levels, and Medical wastes (needles, levels, and Medical wastes (needles, sharps, bloody clothing).

$\square$ Routine

$\mathrm{Q}$ Process
ste; Free liquids

Sewage Sludge, Animal carcasses, Wet garbage (food waste); and Friable asbestos

\section{REQUIRED: WASTE CONTENTS ALLOWABLE WASTES}

Check all allowable wastes that are contained within this load:

NOTE: Waste disposal at the Area 6 Hydrocarbon Landfill must have come into contact with petroleum hydrocarbons or coolants, such as: gasoline (no benzene, lead); jet fuel; diesel fuel; lubricants and hydraulics; kerosene; asphaltic petroleum hydrocarbon; and ethylene glycol.

Acceptable waste at any NTS landfill:
冈 Asphalt
Мetal
Whood
$\triangle$ Paper
$\triangle$ Soil
$\square$ Rocks / unaltered geologic materials
$\triangle$ Rubber (excluding tires)
$凶$ Plastic
$\triangle$ Wire
$\triangle$ Cable
Cloth
$\bigotimes$ Insulation (non-Asbestosform)

$\triangle$ Empty containers

$\bigotimes$ Demolition debris

$\bigotimes$ Cement \& concrete

$\triangle$ Manufactured items: (swamp coolers, furniture, rugs, carpet, electronic components, PPE, etc.)
Additional was
$\square$ Friable
Area 23 Mercury Landfill:
Office Waste
$\square$ Food Waste
Animal Carcasses
Quantity:

Additional waste accepted at the Area 9 U10c Landfill:

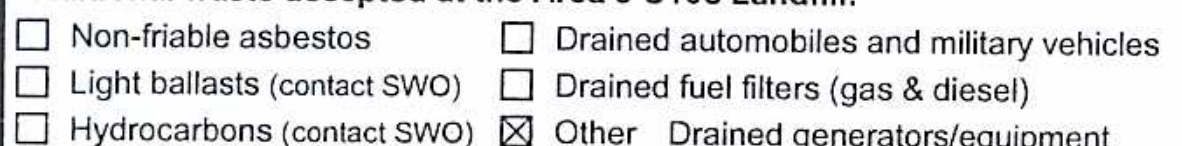

$\otimes$ Other Drained generators/equipment

\section{Additional waste accepted at the Area 6 Hydrocarbon Landfill:}

$\begin{array}{ll}\square \text { Septic sludge } \quad \square \text { Rags } \\ \square \text { Plants } & \square \text { Soil }\end{array}$

Initials: (if initialed, no radiological clearance is necessary.) $\square$ Drained fuel filters (gas \& diesel)

$\square$ Sludge from sand/oil/water separators REQUIRED: WASTE GENERATOR SIGNATURE
Solid fractions from sand/oil/water

$\triangle$ Deconned Underground and Above Ground Tanks

The above mentioned waste was generated outside of a Controlled Waste Management Area (CWMA) and to the best of mv
knowledge, does not contain radiological materials.

To the best of my knowledge, the waste described above contains only those matel site. I have verified this through the waste characterization method identified abovi prohibited and allowable waste items. I have contacted Property Management and is approved for disposal in the landfill.

Print Name: Dan Tobiason

Signature:
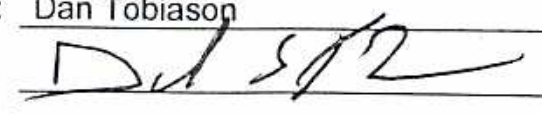
Date: $8.7 \cdot 67$ Radiological Survey Release for Waste Disposal RCT Initials

This container/load meets the criteria for no

M $\sim$ added man-made radioactive material This container/load meets the criteria for Radcon Manual Table 4.2 release limits. This containeerload is exempt from survey due to prgetess knowledge and origin.

Note: "Food waste, office trash and animal carcasses do not require a radiological cl must have signed removal certification statement with Load Verification."

\section{SWO USE ONLY}

Load Weight (net from scale of estimate): $\mathrm{A}, \mathrm{CO}$,

$8-7-07$ Signature of Certifier: 


\section{$\begin{array}{llllll}\text { SWO USE (Select One) } & \text { AREA } & \square 23 & \square 6 & \square 9 & \square \text { LANDFILL }\end{array}$}

For waste characterization, approval, and/or assistance, contact Solid Waste Operation (SWO) at 5-7898.

REQUIRED: WASTE GERERATOR INFORMATION

(This form is for rolloffs, dump trucks, and other onsite disposal of materials.)

Waste Generator: Dan Tobiason

Phone Number: 295-6169

Location / Origin: T-Tunnel Lower Laydown Yard

\begin{tabular}{|c|c|c|c|c|}
\hline \multicolumn{2}{|c|}{ Waste Category: (check one) } & \multirow{2}{*}{$\begin{array}{l}\square \text { Commercial } \\
\square \text { Putrescrible }\end{array}$} & \multicolumn{2}{|c|}{$\Delta$ Industrial cos 8/8/0? } \\
\hline Waste Type: & $\triangle N T S$ & & $\triangle$ FFACO-OAsite & $\square$ WAC Exception \\
\hline check one) & $\square$ Non-Putrescible & $\square$ Asbestos Containing Material & $\square$ FFACO-offsite & $\square$ Histori \\
\hline \multicolumn{2}{|c|}{ Pollution Prevention Category: (check one) } & $\square$ Environmental management & $\triangle$ Defense Projects & $\square$ YMP \\
\hline \multicolumn{2}{|c|}{ Pollution Prevention Category: (check one) } & $\triangle$ Clean-Up & $\square$ Routine & \\
\hline \multicolumn{2}{|c|}{ Method of Characterization: (check one) } & $\square$ Sampling \& Analysis & $\triangle$ Process Knowledge & $\square$ Contents \\
\hline
\end{tabular}

Additional Prohibited Waste at the Area 9 U10C Landfill:

Sewage Sludge, Animal carcasses, Wet garbage (food waste); and Friable asbestos

\section{REQUIRED: WASTE CONTENTS ALLOWABLE WASTES}

Check all allowable wastes that are contained within this load:

NOTE: Waste disposal at the Area 6 Hydrocarbon Landfill must have come into contact with petroleum hydrocarbons or coolants, such as: gasoline (no benzene, lead); jet fuel; diesel fuel; lubricants and hydraulics; kerosene; asphaltic petroleum hydrocarbon; and ethylene glycol.
Acceptable waste at any NTS landfill: $\bigotimes$ Paper
$\square$ Rocks / unaltered geologic materials
$\triangle$ Empty containers
Asphal
Metal
Wood
Q Soil
Q Rubber (excluding tires)
冈 Plastic
$凶$ Wire
$\triangle$ Cable
$\otimes$ Cloth
冈 Insulation (non-Asbestosform)
$\triangle$ Demolition debris
$\bigotimes$ Cement \& concrete

$\triangle$ Manufactured items: (swamp coolers, furniture, rugs, carpet, electronic components, PPE, etc.)
Additional waste accepted at the Area 23 Mercury Landfill: $\square$ Office Waste
$\square$ Asbestos
Friable
Non-Friable (contact SWO if regulated load)
$\square$ Food Waste
Animal Carcasses
Quantity:

Additional waste accepted at the Area 9 U10c Landfill:

$\square$ Non-friable asbestos

Drained automobiles and military vehicles

$\square$ Light ballasts (contact SwO)

Drained fuel filters (gas \& diesel)

Solid fractions from sand/oil/water

Hydrocarbons (contact SWO)

Other Drained generators/equipment

$\bigotimes$ Deconned Underground and Above Ground Tanks

\section{Additional waste accepted at the Area 6 Hydrocarbon Landfill:}

$\begin{array}{ll}\square \text { Septic sludge } & \square \text { Rags } \\ \square \text { Plants } & \square \text { Soil }\end{array}$

$\square$ Drained fuel filters (gas \& diesel)

$\square$ Sludge from sand/oil/water separators

Crushed non-teme plated oil filters REQUIRED: WASTE GENERATOR SIGNATURE

Initials: (if initialed, no radiological clearance is necessary.)

The above mentioned waste was generated outside of a Controlled Waste Management Area (CWMA) and to the best of my knowledge, does not contain radiological materials.

To the best of my knowledge, the waste described above contains only those ma site. I have verified this through the waste characterization method identified abi prohibited and allowable waste items. I have contacted Property Management an is approved for disposal in the landfill.

Print Name: Dan Tobiason

Signature:

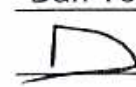

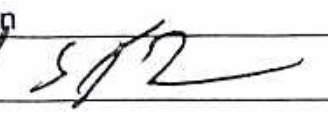

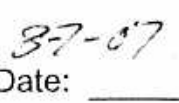

Date:
Radiological Survey Release for Waste Disposal RCT Initials

This container/load meets the criteria for no added man-made radioactive material This container/load meets the criteria for Radcon ManualJable 4.2 release limits. This contaifer Hoad is exempt from survey due to pross knowledge and origin.

SIGNATURE L DATE: 8.707

Note: "Food waste, office trash and animal carcasses do not require a radiological must have signed removal certification statement with Load Verification."

\section{SWO USE ONLY}

Load Weight (net from scale or estimate):

$8-n-0.7$ Signature of Certifier: 
NSTec

Form

FRM-0918

(1)

NTS LANDFILL LOAD VERIFICATION

\begin{tabular}{llllll}
\hline SWO USE (Select One) & AREA & $\square 23$ & $\square 6$ & Q 39 & $\square$ LANDFIL
\end{tabular}

For waste characterization, approval, and/or assistance, contact Solid Waste Operation (SWO) at 5-7898.

REQUIRED: WASTE GERERATOR INFORMATION

(This form is for rolloffs, dump trucks, and other onsite disposal of materials.)

Waste Generator: Dan Tobiason

Phone Number: 295-6169

Location / Origin: T-Tunnel Lower Laydown Yard

Waste Category: (check one)

$\square$ Commercial

$\triangle$ Industrial

Waste Type: $\triangle$ NTS

$\square$ Putrescrible

$\triangle$ FFACO-onsite

(check one)

Non-Putrescible

$\square$ Asbestos Containing Material

$\square$ FFACO-offsite

WAC Exception

Pollution Prevention Category: (check one)

Pollution Prevention Category: (check one)

$\square$ Environmental management

$\triangle$ Defense Projects

$\triangle$ Clean-Up

Method of Characterization: (check one)

$\square$ Sampling \& Analysis

$\square$ Routine

Prohibited Waste at all three Radioactive waste; RCRA waste; Hazardous waste; Free liquids, PCBs above TSCA regulatory NTS landfills:

levels, and Medical wastes (needles, sharps, bloody clothing).

Additional Prohibited Waste

at the Area 9 U10C Landfill:

Sewage Sludge, Animal carcasses, Wet garbage (food waste); and Friable asbestos

\section{REQUIRED: WASTE CONTENTS ALLOWABLE WASTES}

Check all allowable wastes that are contained within this load:

NOTE: Waste disposal at the Area 6 Hydrocarbon Landfill must have come into contact with petroleum hydrocarbons or coolants, such as: gasoline (no benzene, lead); jet fuel; diesel fuel; lubricants and hydraulics; kerosene; asphaltic petroleum hydrocarbon; and ethylene glycol.

Acceptable waste at any NTS landfill: $\triangle$ Paper $\square$ Rocks / unaltered geologic materials

Asphalt $\bigotimes$ Metal $\bigotimes$ Wood $\bigotimes$ Soil

Plastic $\quad$ Wire $\quad$ Cable $\quad$ Cloth

$\triangle$ Rubber (excluding tires)

$\triangle$ Insulation (non-Asbestosform)

$\triangle$ Empty containers

$\triangle$ Demolition debris

$\triangle$ Manufactured items: (swamp coolers, furniture, rugs, carpet, electronic components, PPE, etc.)

Additional waste accepted at the Area 23 Mercury Landfill: $\square$ Office Waste $\square$ Food Waste $\square$ Animal Carcasses
$\square$ Asbestos
Friable
Non-Friable (contact SWO if regulated load)
Quantity:

\section{Additional waste accepted at the Area $9 \mathrm{U} 10 \mathrm{c}$ Landfill:}

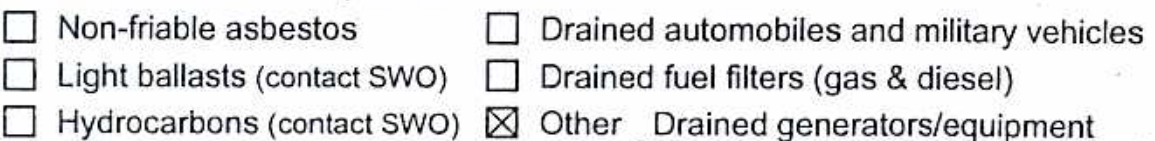

Additional waste accepted at the Area 6 Hydrocarbon Landfill:
$\square$ Septic sludge
$\square$ Rags
$\square$ Drained fuel filters (gas \& diesel)
Plants
Soil
$\square$ Sludge from sand/oil/water separators

\section{REQUIRED: WASTE GENERATOR SIGNATURE}
Crushed non-teme plated oil filters
PCBs below 50 parts per million

Solid fractions from sand/oil/water

$\otimes$ Deconned Underground and Above

Ground Tanks

Initials: ___ (if initialed, no radiological clearance is necessary.)

The above mentioned waste was generated outside of a Controlled Waste Management Area (CWMA) and to the best of my knowledge, does not contain radiological materials.

To the best of my knowledge, the waste described above contains only those I site. I have verified this through the waste characterization method identified : prohibited and allowable waste items. I have contacted Property Management is approved for disposal in the landfill.

Print Name: Dan Tobiason

Signature:
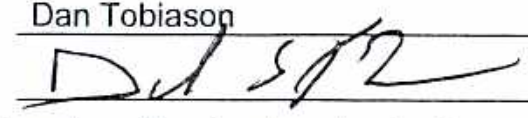

Note: "Food waste, office trash and animal carcasses do not require a radiologi must have signed removal certification statement with Load Verification."

Radiological Survey Release for Waste Disposal RCT Initials

This container/load meets the criteria for no added man-made radioactive material This container/load meets the criteria for Radcon Manual Table 4.2 release limits. This containery bad is exempt from survey due to process knowledge and origin.
SWO USE ONLY

Load Weight (net from scale or estimate):
$6.8-077$

Signature of Certifier:
DATE: 8.707

FRM-0646 (08/06) 


\begin{tabular}{|c|c|c|c|c|}
\hline SWO USE (Select One) & AREA & 23 & $\otimes 9$ & $\triangle$ LANDFI \\
\hline
\end{tabular}

Waste Generator: Dan Tobiason Phone Number: 295-6169

Location / Origin: T-Tunnel Lower Laydown Yard

Waste Category: (check one)

Waste Type: $\triangle$ NTS

$\square$ Commercial

$\triangle$ Industrial

(check one)

$\square$ Non-Putrescible

$\square$ Putrescrible

$\triangle$ FFACO-onsite

Pollution Prevention Category: (check one)

Pollution Prevention Category: (check one)

Method of Characterization: (check one)

$\square$ Asbestos Containing Material

$\square$ FFACO-offsite

$\square$ Environmental management

$\triangle$ Clean-Up

Prohibited Waste at all three

NTS landfills:

$\square$ Sampling \& Analysis

$\triangle$ Defense Projects

$\square$ Routine

Additional Prohibited Waste

at the Area 9 U10C Landfill:

levels, and Medical wastes (needles, sharps, bloody clothing).

Sewage Sludge, Animal carcasses, Wet garbage (food waste); and Friable asbestos

\section{REQUIRED: WASTE CONTENTS ALLOWABLE WASTES}

Check all allowable wastes that are contained within this load:

NOTE: Waste disposal at the Area 6 Hydrocarbon Landfill must have come into contact with petroleum hydrocarbons or coolants, such as: gasoline (no benzene, lead); jet fuel; diesel fuel; lubricants and hydraulics; kerosene; asphaltic petroleum hydrocarbon; and ethylene glycol.

Acceptable waste at any NTS landfill: $\triangle$ Paper $\square$ Rocks / unaltered geologic materials

Asphalt $\bigotimes$ Metal $\bigotimes$ Wood $\bigotimes$ Soil

$\triangle$ Plastic $\quad$ Wire $\quad$ Cable $\quad$ Cloth

$\triangle$ Rubber (excluding tires)

$\triangle$ Insulation (non-Asbestosform)

$\triangle$ Empty containers

$\triangle$ Demolition debris

$\bigotimes$ Manufactured items: (swamp coolers, furniture, rugs, carpet, electronic components, PPE, etc.)
Additional was
$\square$ Asbestos
Friable
Area 23 Mercury Landfill:
Office Waste
$\square$ Food Waste
Animal Carcasses

$凶$ Cement \& concrete

Additional waste accepted at the Area 9 U10c Landfill:
$\square$ Non-friable asbestos
Drained automobiles and military vehicles
$\square$ Light ballasts (contact SWO)
$\square$ Drained fuel filters (gas \& diesel)
$\square$ Hydrocarbons (contact SWO)
$\triangle$ Other
Drained generators/equipment

Quantity:

Additional waste accepted at the Area 6 Hydrocarbon Landfill:
$\square$ Septic sludge
$\square$ Rags
$\square$ Drained fuel filters (gas \& diesel)
Plants
Soil
$\square$ Sludge from sand/oil/water separators
Crushed non-teme plated oil filters
REQUIRED: WASTE GENERATOR SIGNATURE
$\square$ Solid fractions from sand/oil/water
$\triangle$ Deconned Underground and Above
Ground Tanks

Initials: (if initialed, no radiological clearance is necessary.)

The above mentioned waste was generated outside of a Controlled Waste Management Area (CWMA) and to the best of mv knowledge, does not contain radiological materials.

To the best of my knowledge, the waste described above contains only those mate! site. I have verified this through the waste characterization method identified abovi prohibited and allowable waste items. I have contacted Property Management and is approved for disposal in the landfill.

Print Name: Dan Tobiason

Signature:
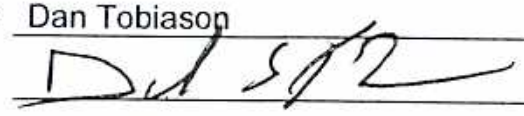

$8 \cdot 8 \cdot 0 \%$

Note: "Food waste, office trash and animal carcasses do not require a radiological cl Radiological Survey Release for Waste Disposal RCT Initials

This container/load méts the criteria for nc

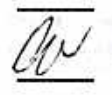
added man-made radioactive material This container $/ 16$ ad meets the criteria for Radcon Manua Table 4.2 release limits. This contanerlload is exempt from survey due to profess knowledge and origin. must have signed removal certification statement with Load Verification."

\section{SWO USE ONLY}

Load Weight (net from scale or estimate):

$8-8-07$ Signature of Certifier:

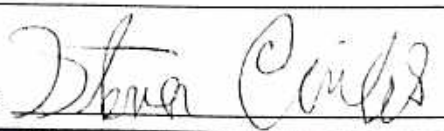




\begin{tabular}{llllll}
\hline SWO USE (Select One) & AREA & $\square 23$ & $\square 6$ & $\square 9$ & $\square$ LANDFILL
\end{tabular}

For waste characterization, approval, and/or assistance, contact Solid Waste Operation (SWO) at 5-7898.

REQUIRED: WASTE GERERATOR INFORMATION

(This form is for rolloffs, dump trucks, and other onsite disposal of materials.)

Waste Generator: Dan Tobiason

Phone Number: 295-6169

Location / Origin: T-Tunnel Lower Laydown Yard

\begin{tabular}{|c|c|c|c|c|}
\hline \multicolumn{2}{|c|}{ Waste Category: (check one) } & $\square$ Commercial & \multicolumn{2}{|l|}{$\bigotimes$ Industrial } \\
\hline Waste Type: & $\triangle \mathrm{NTS}$ & $\square$ Putrescrible & $\triangle$ FFACO-onsite & $\square$ WAC Exception \\
\hline (check one) & $\square$ Non-Putrescible & $\square$ Asbestos Containing Material & $\square$ FFACO-offsite & $\square$ Historic DOE/NV \\
\hline \multicolumn{2}{|c|}{ Pollution Prevention Category: (check one) } & $\square$ Environmental management & $\triangle$ Defense Projects & $\square$ YMP \\
\hline \multicolumn{2}{|c|}{ Pollution Prevention Category: (check one) } & $\triangle$ Clean-Up & $\square$ Routine & \\
\hline \multicolumn{2}{|c|}{ Method of Characterization: (check one) } & $\square$ Sampling \& Analysis & Q Process Knowledge & $\square$ Contents \\
\hline
\end{tabular}

Additional Prohibited Waste at the Area 9 U10C Landfill:

Sewage Sludge, Animal carcasses, Wet garbage (food waste); and Friable asbestos

REQUIRED: WASTE CONTENTS ALLOWABLE WASTES

Check all allowable wastes that are contained within this load:

NOTE: Waste disposal at the Area 6 Hydrocarbon Landfill must have come into contact with petroleum hydrocarbons or coolants, such as: gasoline (no benzene, lead); jet fuel; diesel fuel; lubricants and hydraulics; kerosene; asphaltic petroleum hydrocarbon; and ethylene glycol.

Acceptable waste at any NTS landfill:

$\triangle$ Paper $\square$ Rocks / unaltered geologic materials

$\triangle$ Asphalt

$\bigotimes$ Metal

$\triangle$ Wood

$\bigotimes$ Soil

$\triangle$ Rubber (excluding tires)

$凶$ Plastic

Wire

$凶$ Cable

$凶$ Cloth

$\bigotimes$ Insulation (non-Asbestosform)

$\bigotimes$ Empty containers

$\bigotimes$ Demolition debris

$\bigotimes$ Manufactured items: (swamp coolers, furniture, rugs, carpet, electronic components, PPE, etc.)
Additional waste accepted at the Area 23 Mercury Landfill:
$\square$ Office Waste
$\square$ Food Waste
Animal Carcasses
$\square$ Asbestos
$\square$ Friable
Non-Friable (contact SWO if regulated load)
Quantity:

Additional waste accepted at the Area 9 U10c Landfill:

$\square$ Non-friable asbestos

Light ballasts (contact SWO)

Hydrocarbons (contact SWO
Drained automobiles and military vehicles

$\square$ Drained fuel filters (gas \& diesel)

Other Drained generators/equipment
Solid fractions from sand/oil/water

$\bigotimes$ Deconned Underground and Above Ground Tanks

Additional waste accepted at the Area 6 Hydrocarbon Landfill:

$\square$ Septic sludge $\square$ Rags

$\square$ Drained fuel filters (gas \& diesel)

Crushed non-teme plated oil filters

Plants

Soil

$\square$ Sludge from sand/oil/water separators REQUIRED: WASTE GENERATOR SIGNATURE

Initials: (if initialed, no radiological clearance is necessary.)

The above mentioned waste was generated outside of a Controlled Waste Management Area (CWMA) and to the best of my knowledge, does not contain radiological materials.

To the best of my knowledge, the waste described above contains only those site. I have verified this through the waste characterization method identified prohibited and allowable waste items. I have contacted Property Management is approved for disposal in the landfill.

Print Name:

Signature:
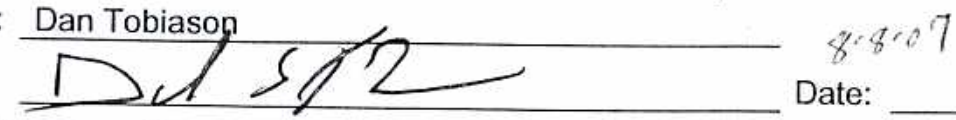

Note: "Food waste, office trash and animal carcasses do not require a radiolog

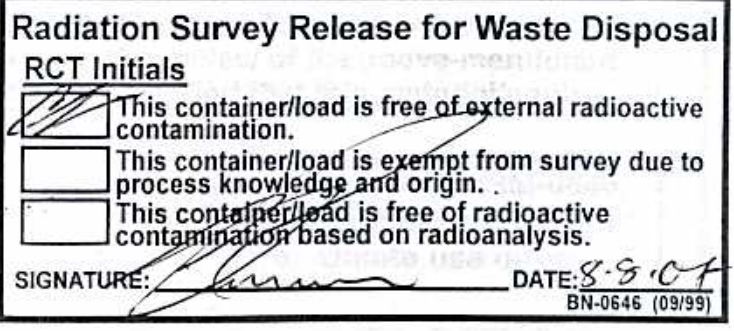
must have signed removal certification statement with Load Verification.'

SWO USE ONLY

Load Weight (net from scale or estimate):

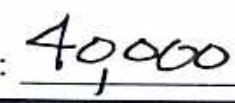

$8-8-07$

Signature of Certifier: 


\section{$\begin{array}{llllll}\text { SWO USE (Select One) } & \text { AREA } & \square 23 & \square 6 & \square 9 & \square \text { LANDFILL }\end{array}$}

For waste characterization, approval, and/or assistance, contact Solid Waste Operation (SWO) at 5-7898.

\section{REQUIRED: WASTE GERERATOR INFORMATION}

(This form is for rolloffs, dump trucks, and other onsite disposal of materials.)

Waste Generator: Dan Tobiason

Phone Number: 295-6169

Location / Origin: T-Tunnel Lower Laydown Yard

Waste Category: (check one)

Waste Type: $\triangle$ NTS

(check one)

$\square$ Non-Putrescible

Pollution Prevention Category: (check one)

Pollution Prevention Category: (check one)

Method of Characterization: (check one)

$\square$ Commercial

$\square$ Putrescrible

$\square$ Asbestos Containing Material

Environmental management

$\triangle$ Clean-Up

Prohibited Waste at all three

NTS landfills:

Additional Prohibited Waste at the Area 9 U10C Landfill:

Radioactive waste; RCRA waste; Hazardous waste; Free liquids, PCBs above TSCA regulatory levels, and Medical wastes (needles, sharps, bloody clothing).

Sewage Sludge, Animal carcasses, Wet garbage (food waste); and Friable asbestos

\section{REQUIRED: WASTE CONTENTS ALLOWABLE WASTES}

Check all allowable wastes that are contained within this load:

NOTE: Waste disposa! at the Area 6 Hydrocarbon Landfill must have come into contact with petroleum hydrocarbons or coolants, such as: gasoline (no benzene, lead); jet fuel; diesel fuel; lubricants and hydraulics; kerosene; asphaltic petroleum hydrocarbon; and ethylene glycol.

Acceptable waste at any NTS landfill: $\triangle$ Paper $\square$ Rocks / unaltered geologic materials

$\triangle$ Asphalt

$\triangle$ Metal

$\bigotimes$ Wood

$\otimes$ Soil

$\triangle$ Rubber (excluding tires)

¿ Flastic

$\triangle$ Wire

$\triangle$ Cajle

$\otimes$ Cloth

$\bigotimes$ Insulation (non-Asbestosform)

$\triangle$ Empty containers

$\triangle$ Demolition debris

$\triangle$ Manufactured items: (swamp coolers, furniture, rugs, carpet, electronic components, PPE, etc.)

Additional waste accepted at the Area 23 Mercury Landfill: $\square$ Office Waste

$\square$ Asbestos

Friable

Non-Friable (contact SWO if regulated load)

Food Waste

Animal Carcasses

\section{Additional waste accepted at the Area 9 U10c Landfill:}

Non-friable asbestos

Light ballasts (contact SwO)

Hydrocarbons (contact SWO)

Drained automobiles and military vehicles

Drained fuel filters (gas \& diesel)

Other Drained generators/equipment

Quantity:

\section{Additional waste accepted at the Area 6 Hydrocarbon Landfill:}
Septic sludge
$\square$ Rags
$\square$ Drained fuel filters (gas \& diesel)
Plants
Soil
$\square$ Sludge from sand/oil/water separators
REQUIRED: WASTE GENERATOR SIGNATURE
Crushed non-teme plated oil filters
PCBs below 50 parts per million

Solid fractions from sand/oil/water

$\triangle$ Deconned Underground and Above Ground Tanks

Initials: (if initialed, no radiological clearance is necessary.)

The above mentioned waste was generated outside of a Controlled Waste Management Area (CWMA) and to the best of rmv knowledge, does not contain radiological materials.

To the best of my knowledge, the waste described above contains only those site. I have verified this through the waste characterization method identifiec prohibited and allowable waste items. I have contacted Property Managemer is approved for disposal in the landfill.

Print Name: Dan Tobiason

Signature:
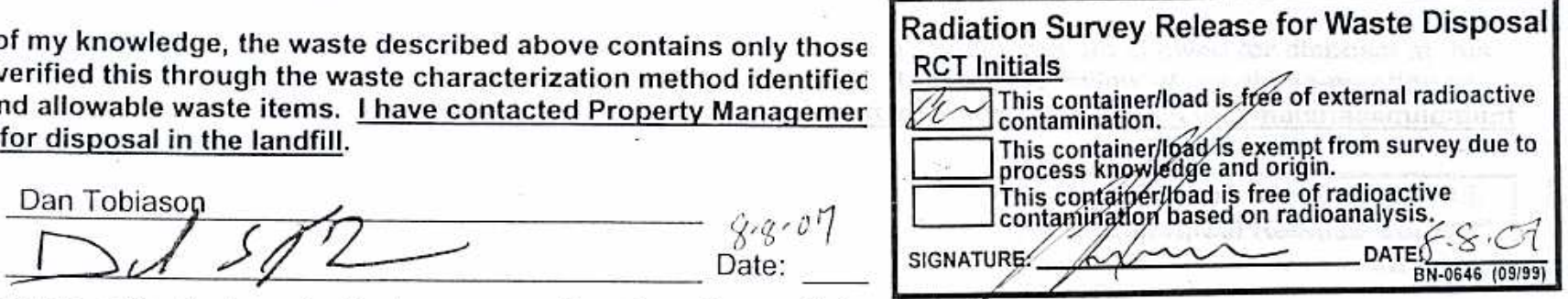

Note: "Food waste, office trash and animal carcasses do not require a radiolos must have signed removal certification statement with Load Verification."

\section{SWO USE ONLY}

Load Weight (net from scale or estimate):

$750018-07$

Signature of Certifier:

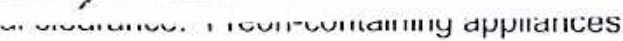




\section{$\begin{array}{lllllll}\text { SWO USE (Select One) } & \text { AREA } & \square 23 & \square 6 & \text { \9 } & \text { \ LANDFILL }\end{array}$}

For waste characterization, approval, and/or assistance, contact Solid Waste Operation (SWO) at 5-7898.

REQUIRED: WASTE GERERATOR INFORMATION

(This form is for rolloffs, dump trucks, and other onsite disposal of materials.)

Waste Generator: Dan Tobiason

Phone Number: 295-6169

Location / Origin: T-Tunnel Lower Laydown Yard

Waste Category: (check one)

Waste Type: $\triangle$ NTS

(check one) $\quad \square$ Non-Putrescible

Pollution Prevention Category: (check one)

Pollution Prevention Category: (check one)

Method of Characterization: (check one)

Prohibited Waste at all three

NTS landfills:

Additional Prohibited Waste

at the Area 9 U10C Landfili:

Sampling \& Analysis $\square$ Commercial

$\square$ Putrescrible

$\square$ Asbestos Containing Material

$\square$ Environmental management

$\triangle$ Clean-Up

Radioactive waste; RCRA waste; Hazardous waste; Free liquids, PCBs above TSCA regulatory levels, and Medical wastes (needles, sharps, bloody clothing).

Sewage Sludge, Animal carcasses, Wet garbage (food waste); and Friable asbestos

\section{REQUIRED: WASTE CONTENTS ALLOWABLE WASTES}

NOTE: Waste dispeck all allowable wastes that are contained within this load:

coolants, petroleum hydrocarbon; and ethylene glycol.

Acceptable waste at any NTS landfill: $\triangle$ Paper
$\triangle$ Asphalt
$\triangle$ Metal
Wood
$\bigotimes$ Soil
$\triangle$ Plastic
$\triangle$ Wire
¿ Cable
$\triangle$ Cloth
$\square$ Rocks / unaltered geologic materials
$\bigotimes$ Rubber (excluding tires)
$\triangle$ Insulation (non-Asbestosform)

$\triangle$ Manufactured items: (swamp coolers, furniture, rugs, carpet, electronic components, PPE, etc.)

Additional waste accepted at the Area 23 Mercury Landfill: $\square$ Office Waste
$\square$ Asbestos $\square$ Friable $\square$ Non-Friable (contact SWO if regulated load)

Non-Friable (contact SWO if regulated load)

$\square$ Food Waste

Quantity:

Additional waste accepted at the Area 9 U10c Landfill:

$\square$ Non-friable asbestos

Light ballasts (contact SWO)

Hydrocarbons (contact SWO)

Drained automobiles and military vehicles

$\square$ Drained fuel filters (gas \& diesel)

$\bigotimes$ Other Drained generators/equipment

Additional waste accepted at the Area 6 Hydrocarbon Landfill:

$\begin{array}{ll}\square \text { Septic sludge } & \square \text { Rags } \\ \square \text { Plants } & \square \text { Soil }\end{array}$

$\square$ Drained fuel filters (gas \& diesel)
$\square$ Sludge from sand/oil/water separators

REQUIRED: WASTE GENERATOR SIGNATURE

Initials: (if initialed, no radiological clearance is necessary.)

The above mentioned waste was generated outside of a Controlled Waste Management Area (CWMA) and to the best of my
knowledge, does not contain radiological materials.

To the best of my knowledge, the waste described above contains only those mi site. I have verified this through the waste characterization method identified at is approved for dispobale waste items. I have contacted Property Management a is approved for disposal in the landfill.

Print Name: Dan Tobiason

Signature:
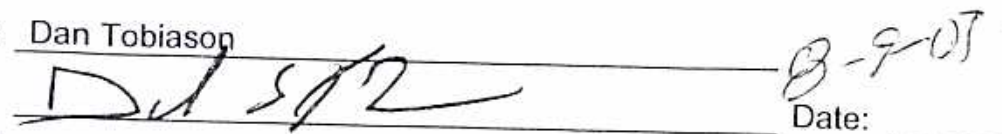

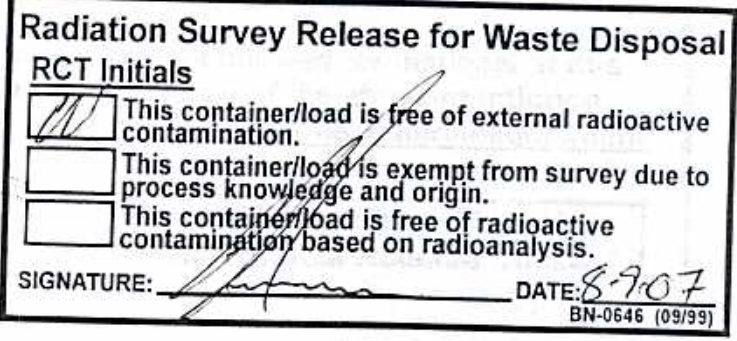

BN-0646 (09/99)

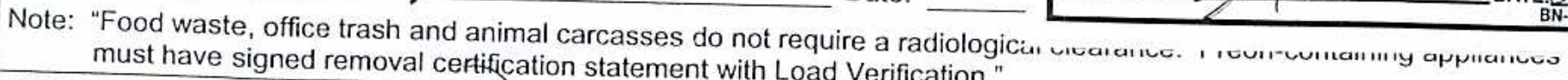

SWO USE ONLY 
SWO USE (Select One) AREA

23

凶9

$\bigotimes$ LANDFILL

For waste characterization, approval, and/or assistance, contact Solid Waste Operation (SWO) at 5-7898.

REQUIRED: WASTE GERERATOR INFORMATION

(This form is for rolloffs, dump trucks, and other onsite disposal of materials.)

Waste Generator: Dan Tobiason

Phone Number: 295-6169

Location / Origin: T-Tunnel Lower Laydown Yard

\begin{tabular}{|c|c|c|c|c|}
\hline Waste Categ & (check one) & $\square$ Commercial & $\otimes$ Industrial cgs \& & 1.7 \\
\hline Waste Type: & $\triangle \mathrm{NTS}$ & $\square$ Putrescrible & $\triangle$ FFAGQ-OAsite & $\square$ WAC Exception \\
\hline (check one) & $\square$ Non-Putrescible & $\square$ Asbestos Containing Material & $\square$ FFACO-offsite & $\square$ Historic DOE/NV \\
\hline Pollution Pre & tion Category: (check one) & $\square$ Environmental management & $\triangle$ Defense Projects & $\square$ YMP \\
\hline Pollution Pre & tion Category: (check one) & $\triangle$ Clean-Up & $\square$ Routine & \\
\hline Method of $\mathrm{Cr}$ & terization: (check & $\square$ Sampling \& Analysis & Q Process Knowledge & $\square$ Contents \\
\hline
\end{tabular}

Prohibited Waste at all three Radioactive waste; RCRA waste; Hazardous waste; Free iquids, PCBs above TSCA regulatory NTS landfills:

levels, and Medical wastes (needles, sharps, bloody clothing).

Additional Prohibited Waste

at the Area 9 U10C Landfill:

Sewage Sludge, Animal carcasses, Wet garbage (food waste); and Friable asbestos

\section{REQUIRED: WASTE CONTENTS ALLOWABLE WASTES}

Check all allowable wastes that are contained within this load:

NOTE: Waste disposal at the Area 6 Hydrocarbon Landfill must have come into contact with petroleum hydrocarbons or coolants, such as: gasoline (no benzene, lead); jet fuel; diesel fuel; lubricants and hydraulics; kerosene; asphaltic petroleum hydrocarbon; and ethylene glycol.

Acceptable waste at any NTS landfill:
$\triangle$ Asphalt
$凶$ Metal
$\triangle$ Wood
$凶$ Soil
$\triangle$ Plastic $\quad \square$ Wire
凶 Cable
$\otimes$ Cloth
$\bigotimes$ Rubber (excluding tires)
$\bigotimes$ Insulation (non-Asbestosform)

$\square$ Rocks / unaltered geologic materials

Empty containers

$\bigotimes$ Demolition debris

$\bigotimes$ Cement \& concrete

$\triangle$ Manufactured items: (swamp coolers, furniture, rugs, carpet, electronic components, PPE, etc.)
Additional waste accepted at the Area 23 Mercury Landfill:
$\square$ Office Waste
$\square$ Asbestos
$\square$ Friable
$\square$ Non-Friable (contact SWO if regulated load)
Quantity:

$\square$ Food Waste

Animal Carcasses

Additional waste accepted at the Area 9 U10c Landfill:

$\square$ Non-friable asbestos

Light ballasts (contact SWO)

Hydrocarbons (contact SWO)

$\square$ Drained automobiles and military vehicles

$\square$ Drained fuel filters (gas \& diesel)

$凶$ Other Drained generators/equipment
Solid fractions from sand/oil/water

$\bigotimes$ Deconned Underground and Above Ground Tanks

Additional waste accepted at the Area 6 Hydrocarbon Landfill:
$\square$ Septic sludge
$\square$ Rags
$\square$ Drained fuel filters (gas \& diesel)
Crushed non-teme plated oil filters
Plants
Soil
$\square$ Sludge from sand/oil/water separators
$\square$ PCBs below 50 parts per million
REQUIRED: WASTE GENERATOR SIGNATURE

Initials: (if initialed, no radiological clearance is necessary.)

The above mentioned waste was generated outside of a Controlled Waste Manas knowledge, does not contain radiological materials.

To the best of my knowledge, the waste described above contains only those m: site. I have verified this through the waste characterization method identified ab prohibited and allowable waste items. I have contacted Property Management al is approved for disposal in the landfill.

Print Name: Dan Tobiason
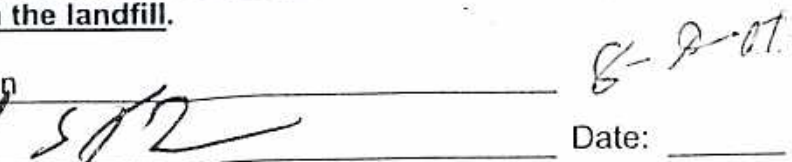

Signature:

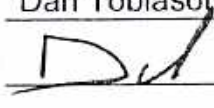

Date:

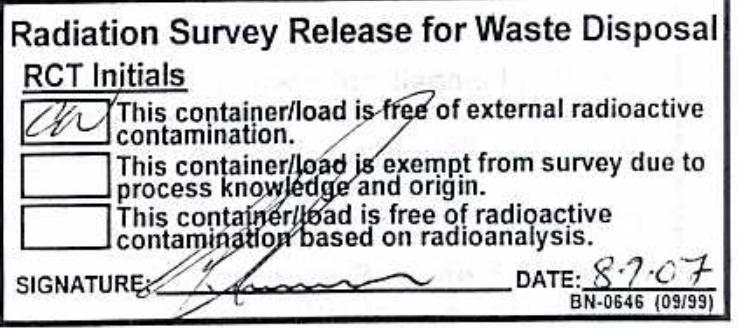

Note: "Food waste, office trash and animal carcasses do not require a radiological clearance. Freon-containing appliances must have signed removal certification statement with Load Verification." 
NSTec

Form

FRM-0918

NTS LANDFILL LOAD VERIFICATION

Page 1

SWO USE (Select One) AREA

23

6

凶9

$\triangle$ LANDFILL

For waste characterization, approval, and/or assistance, contact Solid Waste Operation (SWO) at 5-7898.

REQUIRED: WASTE GERERATOR INFORMATION

(This form is for rolloffs, dump trucks, and other onsite disposal of materials.)

Waste Generator: Dan Tobiason

Phone Number: 295-6169

Location / Origin: T-Tunnel Lower Laydown Yard

Waste Category: (check one)

$\square$ Commercial

$\triangle$ Industrial cos.s/13/07

Waste Type: $\square$ NTS

$\square$ Putrescrible

¿ FFACO-OAsite

WAC Exception

(check one)

$\square$ Asbestos Containing Material

$\square$ FFACO-offsite

$\square$ Historic DOE/NV

Pollution Prevention Category: (check one) $\square$ Environmental management

Pollution Prevention Category: (check one) $\triangle$ Clean-Up

Method of Characterization: (check one)

Sampling \& Analysis

$\triangle$ Defense Projects

YMP

Prohibited Waste at all three

NTS landfills:

Additional Prohibited Waste

at the Area 9 U10C Landfill:

Radioactive waste; RCRA waste; Hazardous waste; Free liquids
levels, and Medical wastes (needles, sharps, bloody clothing)

Sewage Sludge, Animal carcasses, Wet garbage (food waste); and Friable asbestos

\section{REQUIRED: WASTE CONTENTS ALLOWABLE WASTES}

Check all allowable wastes that are contained within this load:

NOTE: Waste disposal at the Area 6 Hydrocarbon Landfill must have come into contact with petroleum hydrocarbons or coolants, such as: gasoline (no benzene, lead); jet fuel; diesel fuel; lubricants and hydraulics; kerosene; asphaltic petroleum hydrocarbon; and ethylene glycol.

Acceptable waste at any NTS landfill: $\bigotimes$ Paper

$\bigotimes$ Asphalt $\square$ Metal $\bigotimes$ Wood $\bigotimes$ Soil

$\triangle$ Plastic $\square$ Wire

¿ Cable

$\otimes$ Cloth

$\square$ Rocks / unaltered geologic materials

Empty containers

$\bigotimes$ Rubber (excluding tires)

$\triangle$ Manufactured items: (swamp coolers, furniture, rugs, carpet, electronic components, PPE, etc.)

Additional waste accepted at the Area 23 Mercury Landfill: $\square$ Office Waste $\square$ Food Wast

$\square$ Asbestos $\quad \square$ Friable $\quad \square$ Non-Friable (contact SWO if regulated load) Quantity:

Additional waste accepted at the Area 9 U10c Landfill:
$\square$ Non-friable asbestos
Drained automobiles and military vehicles
$\square$ Light ballasts (contact SWO)
$\square$ Drained fuel filters (gas \& diesel)
Hydrocarbons (contact SWO
Other Drained generators/equipment

$\bigotimes$ Demolition debris

$凶$ Cement \& concrete

Additional waste accepted at the Area 6 Hydrocarbon Landfill:
$\square$ Septic sludge
$\square$ Rags
$\square$ Drained fuel filters (gas \& diesel)
Crushed non-teme plated oil filters
Plants
Soil
$\square$ Sludge from sand/oil/water separators
PCBs below 50 parts per million
REQUIRED: WASTE GENERATOR SIGNATURE

Initials: (if initialed, no radiological clearance is necessary.)

The above mentioned waste was generated outside of a Controlled Waste Management Area (CWMAl and to the hest of mv knowledge, does not contain radiological materials.

To the best of my knowledge, the waste described above contains only those m: site. I have verified this through the waste characterization method identified at prohibited and allowable waste items. I have contacted Property Management a is approved for disposal in the landfill.

Print Name: Dan Tobiason
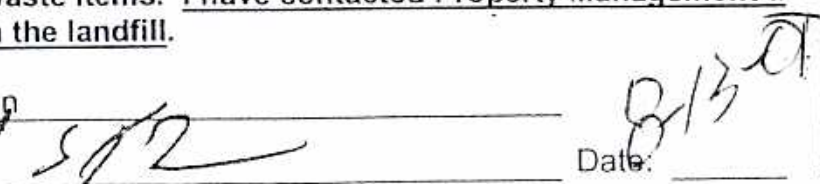

Radiological Survey Release for Waste Disposal RCT Initials

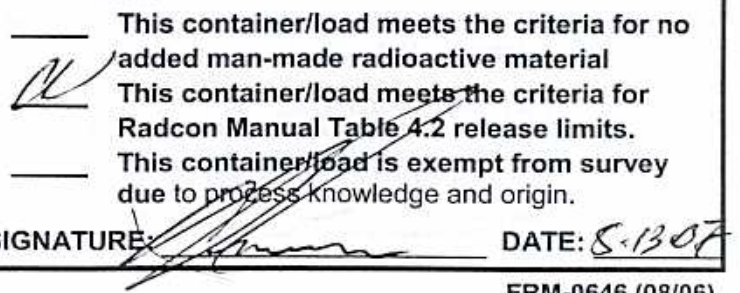

Signature:
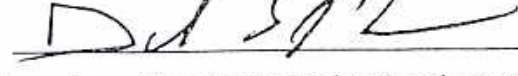

Date

FRM-0646 (08/06)

Note: "Food waste, office trash and animal carcasses do not require a radiologici must have signed removal certification statement with Load Verification." 
SWO USE (Select One) AREA

AREA $\square 23$

23

6

\9

$\bigotimes$ LANDFILL

For waste characterization, approval, and/or assistance, contact Solid Waste Operation (SWO) at 5-7898.

\section{REQUIRED: WASTE GERERATOR INFORMATION}

(This form is for rolloffs, dump trucks, and other onsite disposal of materials.)

Waste Generator: Dan Tobiason

Phone Number: 295-6169

Location / Origin: T-Tunnel Lower Laydown Yard

Waste Category: (check one)

Waste Type: $\triangle$ NTS

$\square$ Commercial

$\triangle$ Industrial cgs $8 / 13 / 07$

(check one)

Non-Putrescible

$\square$ Putrescrible

QFFAGQ Onsite

WAC Exception

Pollution Prevention Category: (check one)

$\square$ Asbestos Containing Material

[] FFACO-offsite

Pollution Prevention Category: (check one)

$\square$ Environmental management

$\triangle$ Deiense Projects

$\square$ Historic DOE/NV

Method of Characterization: (check one)

$\triangle$ Clean-Up

Prohibited Waste at all three

NTS landfills:

Additional Prohibited Waste

at the Area 9 U10C Landfill:

Radioactive waste; RCRA waste; Hazardous waste; Free liquids, PCBs above TSCA regulatory levels, and Medical wastes (needles, sharps, bloody clothing).

Sewage Sludge, Animal carcasses, Wet garbage (food waste); and Friable asbestos

\section{REQUIRED: WASTE CONTENTS ALLOWABLE WASTES}

Check all allowable wastes that are contained within this load:

NOTE: Waste disposal at the Area 6 Hydrocarbon Landfill must have come into contact with petroleum hydrocarbons or coolants, such as: gasoline (no benzene, lead); jet fuel; diesel fuel; lubricants and hydraulics; kerosene; asphaltic petroleum hydrocarbon; and ethylene glycol.

Acceptabie waste at any NTS landfill: $\bigotimes$ Paper

$\bigotimes$ Asphialt $\triangle$ Metal $\square$ Wood $\bigotimes$ Soil

Q Plastic $\triangle$ Wire $\triangle$ Cable $\otimes$ Cloth

$\square$ Rocks / unaltered geologic materials

$\triangle$ Rubber (excluding tires)

$\triangle$ insulation (non-Ásbestosformi)

$\bigotimes$ Empty containers

$\bigotimes$ Demolition debris

¿ Cement \& concrete

$\triangle$ Manufactured items: (swamp coolers, furniture, rugs, carpet, electronic components, PPE, etc.)

Additional waste accepted at the Area 23 Mercury Landfill: $\square$ Office Waste

$\square$ Asbestos $\square$ Friabie $\quad \square$ Non-Friable (contact SWO if regulated load)

$\square$ Food Waste

Animal Carcasses

Additional waste accepted at the Area 9 U10c Landfill:

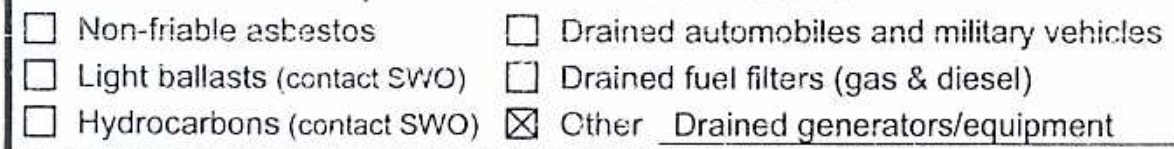

Quantity:

Additional waste accepted at the Area 6 Hydrocarbon Landfill:
$\square$ Septic sludge
$\square$ Rags
$\square$ Drained fuel filters (gas \& diesel)
Plants
Soil
$\square$ Sludge from sand/oil/water separators

\section{REQUIRED: WASTE GENERATOR SIGNATURE}
Crushed non-teme plated oil filters PCBs below 50 parts per million

Solid fractions from sand/oil/water

Q Deconned Underground and Above

Ground Tanks

Initials: (if initialed, no radiological clearance is necessary.)

The above mentioned waste was generated outside of a Controlled Waste Manaciement Area (CWMA) and to the hest of mv knowledge, does not contain radiological materials.

To the best of my knowledge, the waste described above contains only those $\mathrm{m}_{\mathrm{i}}$ site. I have verified this through the waste characterization method identified at. prohibited and allowable waste items. I have contacted Property Management a is approved for disposal in the landfill.

Print Name: Dan Tobiason

Signature:
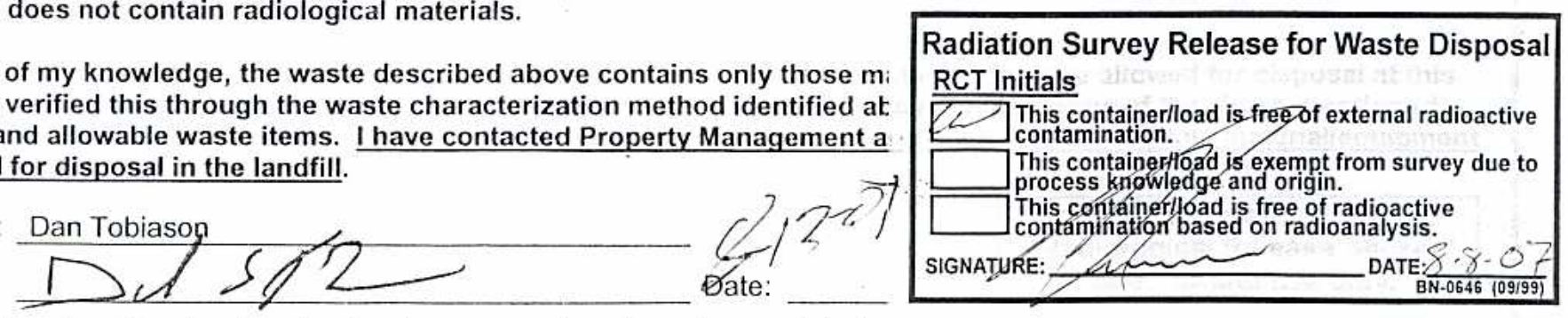

Note: "Food waste, office trash and animal carcasses do not require a radiologicaı ciearance. rreun-contannng appuances must have signed removal certification statement with Load Verification."

\section{SWO USE ONLY}

Load Weight (net from scale or estimate): $27,000 \begin{aligned} & 8-13-07 \\ & \text { Signature of Certifier: }\end{aligned}$ 


\begin{tabular}{llllll}
\hline SWO USE (Select One) & AREA & $\square 23$ & $\square 6$ & $\square 9$ & $\square$ LANDFILL
\end{tabular}

For waste characterization, approval, and/or assistance, contact Solid Waste Operation (SWO) at 5-7898.

\section{REQUIRED: WASTE GERERATOR INFORMATION}

(This form is for rolloffs, dump trucks, and other onsite disposal of materials.)

Waste Generator: Dan Tobiason

Phone Number: $295-6169$

Location / Origin: T-Tunnel Lower Laydown Yard

\begin{tabular}{|c|c|c|c|c|c|}
\hline \multicolumn{2}{|c|}{ Waste Category: (check one) } & & Commercial & \multicolumn{2}{|c|}{$\triangle$ Industrial $c / s \quad 8-14-07$} \\
\hline Waste Type: & $\triangle$ NTS & $\square$ & Putrescrible & $\triangle F F A C Q$ Onsite & $\square$ WA \\
\hline (check one) & $\square$ Non-Putrescible & 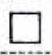 & Asbestos Containing Materia! & FFACO-offsite & $\square$ Histor \\
\hline \multicolumn{2}{|c|}{ Pollution Prevention Category: (check one) } & 5 & Environmental management & Q Deíense Projects & $\square$ YMP \\
\hline \multicolumn{2}{|c|}{ Pollution Prevention Category: (check one) } & $凶$ & Clean-Up & $\square$ Ro & \\
\hline \multicolumn{2}{|c|}{ Method of Characterization: (check one) } & & Sampling \& Analysis & $\triangle$ Process Knowledg & \\
\hline
\end{tabular}

Prohibited Waste at all three Radioactive waste; RCRA waste; Hazardous waste; Free liquids, PCBs above TSCA regulatory NTS landfills:

levels, and Medical wastes (needles, sharps, bloody clothing).

Additional Prohibited Waste Sewage Sludge, Animal carcasses, Wet garbage (food waste); and Friable asbestos
at the Area 9 U10C Landfill:

\section{REQUIRED: WASTE CONTENTS ALLOWABLE WASTES}

Check all allowable wastes that are contained within this load:

NOTE: Waste disposal at the Area 6 Hydrocarbon Landfill must have come into contact with petroleum hydrocarbons or coolants, such as: gasoline (no benzene, lead); jet fuel; diesel fuel; lubricants and hydraulics; kerosene; asphaltic petroleum hydrocarbon; and ethylene glycol.

Acceptable waste at any NTS landfill: $\square$ Pape
$\triangle$ Asprialt
$\bigotimes$ Metal
$\triangle$ Wood
$\bigotimes$ Soil
$\triangle$ Plastic $\square$ Wire
$\triangle$ Cable
$凶$ Cloth
$\bigotimes$ Rubber (excluding tires)
$\bigotimes$ Insulation (non-Asbestosform)

$\square$ Rocks/ unaltered geologic materials

$\bigotimes$ Empty containers

$\bigotimes$ Demolition debris

$\triangle$ Manufactured items: (swamp coolers, furniture, rugs, carpet, electronic components, PPE, etc.)
Additional waste accepted at the Area 23 Mercury Landfill:
Office Waste
Food Waste
Animal Carcasses
$\square$ Asbestos
[] Friable
$\square$ Non-Friable (contact SWO if regulated load)
Quantity:

Additional waste accepted at the Area 9 U10c Landfill:

$\begin{array}{ll}\square \text { Non-friable astestos } & \square \text { Drained automobiles and military vehicles } \\ \square \text { Light ballasts (contact swo) } \square \text { Drained fuel filters (gas \& diesel) } \\ \square \text { Hydrocarbons (contact SwO) } \square \text { Other Drained generators/equipment }\end{array}$

Solid fractions from sand/oil/water

$\bigotimes$ Deconned Underground and Above

Ground Tanks

Additional waste accepted at the Area 6 Hydrocarbon Landfill:
$\square$ Septic sludge
$\square$ Rags
$\square$ Drained fuel filters (gas \& diesel)
Crushed non-teme plated oil filters
Plants
Soil
$\square$ Sludge from sand/oil/water separators PCBs below 50 parts per million

Initials: REQUIRED: WASTE GENERATOR SIGNATURE

The above mentioned waste was generated outside of a Controlled Waste Management Area (CWMA) and to the hest of mv knowledge, does not contain radiological materials.

To the best of my knowledge, the waste described above contains only those $\mathrm{m}$; site. I have verified this through the waste characterization method identified at prohibited and allowable waste items. I have contacted Property Management a is approved for disposal in the landfill.

Print Name: Dan Tobiason

Signature:
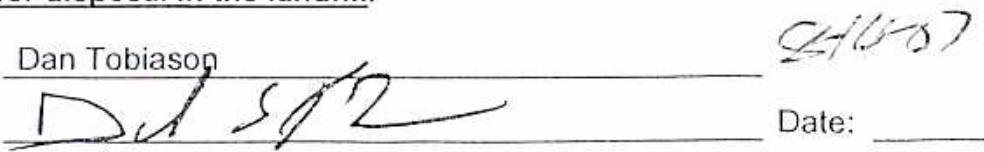

Radiological Survey Release for Waste Disposal RCT Initials

Note: "Food waste, office trash and animal carcasses do not require a radiologica This container/load meets the criteria for no
added man-made radioactive material
This container/load meets the criteria for
Radcon Manual Torle 4.2 release limits.
This container/16ad is exempt from survey
due to orgegos knowledge and origin.
DATE: $8 / 4$ C must have signed removal certification statement with Load Verification." SWO USE ONLY

Load Weight (net from scale or estimate): 


\section{Form}

\section{$\begin{array}{llllll}\text { SWO USE (Select One) } & \text { AREA } & \square 23 & \square 6 & \square 9 & \text { L LANDFILL }\end{array}$}

For waste characterization, approval, and/or assistance, contact Solid Waste Operation (SWO) at 5-7898.

\section{REQUIRED: WASTE GERERATOR INFORMATION}

(This form is for rolloffs, dump trucks, and other onsite disposal of materials.)

Waste Generator: Dan Tobiason

Phone Number: 295-6169

Location / Origin: T-Tunnel Lower Laydown Yard

Waste Category: (check one)

Waste Type: $\triangle$ NTS

(check one) $\quad \square$ Non-Putrescible

$\square$ Commercial

$\square$ Asbestos Containing Material

Pollution Prevention Category: (check one)

Pollution Prevention Category: (check one)

Method of Characterization: (check one)

$\square$ Environmental management

$\triangle$ Clean-Up

$\square$ Sampling \& Analysis $\triangle$ Industrial c2s $8-14-7$

$\triangle$ FFACOAite $\square$ WAC Exception

$\square$ FFACO-offsite $\square$ Historic DOE/NV

Q Defense Projects $\square$ YMP

[] Routine

$\triangle$ Process Knowledge $\square$ Contents

Prohibited Waste at all three Radioactive waste; RCRA waste; Hazardous waste; Free liquids, PCBs above TSCA regulatory NTS landfills:

Additional Prohibited Waste

at the Area 9 U10C Landfill: levels, and Medical wastes (needles, sharps, bloody clothing).

Sewage Sludge, Animal carcasses, Wet garbage (food waste); and Friable asbestos

\section{REQUIRED: WASTE CONTENTS ALLOWABLE WASTES}

Check all allowable wastes that are contained within this load:

NOTE: Waste disposal at the Area 6 Hydrocarbon Landfill must have come into contact with petroleum hydrocarbons or coolants, such as: gasoline (no benzene, lead); jet fuel; diesel fuel; lubricants and hydraulics; kerosene; asphaltic petroleum hydrocarbon; and ethylene glycol.
Acceptable waste at any NTS landfill:
$\otimes$ Paper
$\triangle$ Wood
$凶$ Soil
$\triangle$ Cable
Cloth
$\square$ Rocks / unaltered geologic materials
$\triangle$ Rubber (excluding tires)
$\triangle$ Plastic $\quad$ Wire
$\triangle$ Manufactured items: (swamp coolers, furniture, rugs, carpet, electronic components, PPE, etc.)
$\bigotimes$ Insulation (non-Asbestosform)
$\triangle$ Empty containers
$\bigotimes$ Demolition debris
Additional was
$\square$ Asbestos
[ F Friable
Office Waste
Food Waste
Animal Carcasses
Quantity:

Additional waste accepted at the Area 9 U10c Landfill:

Non-friable astestos

Light ballasts (contact swo)

Hydrocarbons (contact SWO)
Drained automobiles and military vehicles

$\square$ Drained fuel filters (gas \& diesel)

$\triangle$ Other

Drained generators/equipment

Additional waste accepted at the Area 6 Hydrocarbon Landfill:
Septic sludge
$\square$ Rags
$\square$ Drained fuel filters (gas \& diesel)
Plants
Soil
$\square$ Sludge from sand/oil/water separators
REQUIRED: WASTE GENERATOR SIGNATURE

Solid fractions from sand/oil/water

$\bigotimes$ Deconned Underground and Above Ground Tanks

Initials: (if initialed, no radiological clearance is necessary.)

The above mentioned waste was generated outside of a Controlled Waste Manaciement Aron inin.....

knowledge, does not contain radiological materials.

To the best of my knowledge, the waste described above contains only those site. I have verified this through the waste characterization method identified prohibited and allowable waste items. I have contacted Property Management is approved for disposal in the landfill.

Print Name: Dan Tobiason,

Signature:
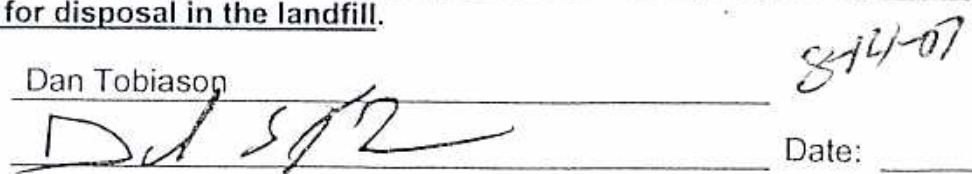

Note: "Food waste, office trash and animal carcasses do not require a radiologican wearance. rreun-contanung appuances must have signed removal certification statement with Load Verification."

This container/load meets the criteria for no added man-made radioactive material This container/load meets the criteria for Radcon Manual Table 4.2 release limits. This container/load is exempt from survey due to protess knowledge and origin. DATE: $8-1467$ FRM-0646 (08/06) 
SWO USE (Select One) AREA

23

$\square 6$

$\triangle 9$

$\triangle$ LANDFILL

For waste characterization, approval, and/or assistance, contact Solid Waste Operation (SWO) at 5-7898.

REQUIRED: WASTE GERERATOR INFORMATION

(This form is for rolloffs, dump trucks, and other onsite disposal of materials.)

Waste Generator: Dan Tobiason

Phone Number: 295-6169

Location / Origin: T-Tunnel Lower Laydown Yard

Waste Category: (check one)

Waste Type: $\square$ NTS

(check one)

$\square$ Non-Putrescible

$\square$ Commercial

$\square$ Putrescrible

$\square$ Asbestos Containing Material

Pollution Prevention Category: (check one)

Pollution Prevention Category: (check one)

Method of Characterization: (check one)

$\square$ Environmental management

$\otimes$ Clean-Up

Prohibited Waste at all three

NTS landfills:

Additional Prohibited Waste

at the Area 9 U10C Landfill:

Radioactive waste; RCRA waste; Hazardous waste; Free liquids, PCBs above TSCA regulatory levels, and Medical wastes (needles, sharps, bloody clothing).

Sewage Sludge, Animal carcasses, Wet garbage (food waste); and Friable asbestos

\section{REQUIRED: WASTE CONTENTS ALLOWABLE WASTES}

Check all allowable wastes that are contained within this load:

NOTE: Waste disposal at the Area 6 Hydrocarbon Landfill must have come into contact with petroleum hydrocarbons or coolants, such as: gasoline (no benzene, lead); jet fuel; diesel fuel; lubricants and hydraulics; kerosene; asphaltic petroleum hydrocarbon; and ethylene glycol.
Acceptable waste at any NTS landfill:
$\triangle$ Paper
$\bigotimes$ Soil
$\triangle$ Asprialt
$凶$ Metal
$\triangle$ Wood
$\triangle$ Cloth
$\square$ Rocks / unaltered geologic materials
$\triangle$ Rubber (excluding tires)
$\bigotimes$ Insulation (non-Asbestosform)
Empty containers
$\triangle$ Plastic $\square$ Wire
$\triangle$ Cable
$凶$ Cloth
carpet, electronic components, PPE, etc.)
Additional waste accepted at the Area 23 Mercury Landfill: $\square$ Office Waste
$\square$ Asbestos $\square]$ Friable
Non-Friable (contact SWO if regulated load)
$\square$ Food Waste
Quantity:

\section{Additional waste accepted at the Area 9 U10c Landfill:}
$\square$ Non-friable astestos
Drained automobiles and military vehicles
$\square$ Light ballasts (contact SWO)
$\square$ Drained fuel filters (gas \& diesel)
Hydrocarbons (contact SWO)

$\triangle$ Other

Drained generators/equipment

Solid fractions from sand/oil/water

$\bigotimes$ Deconned Underground and Above Ground Tanks

Additional waste accepted at the Area 6 Hydrocarbon Landfill:
$\square$ Septic sludge
$\square$ Rags
$\square$ Drained fuel filters (gas \& diesel)
Plants
Soil
$\square$ Sludge from sand/oil/water separators
Crushed non-teme plated oil filters PCBs below 50 parts per million

\section{REQUIRED: WASTE GENERATOR SIGNATURE}

Initials: (if initialed, no radiological clearance is necessary.)

The above mentioned waste was generated outside of a Controlled Waste Manaciement Area (CWMA) and to the best of mv knowledge, does not contain radiological materials.

To the best of my knowledge, the waste described above contains only those $\pi$ site. I have verified this through the waste characterization method identified a prohibited and allowable waste items. I have contacted Property Management : is approved for disposal in the landfill.

Print Name: Dan Tobiason

Signature:
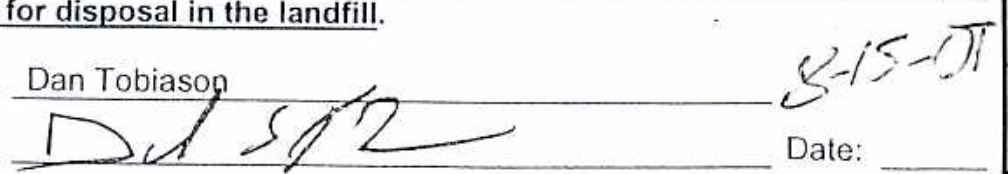

Note: "Food waste, office trash and animal carcasses do not require a radiologic "must have signed removal certification statement with Load Verification."
Radiological Survey Release for Waste Disposal RCT Initials

This container/load meets the criteria for no added man-made radioactive material This container/load meets the criteria for Radcon Manual Table 4.2 release limits. This container/load is exempt from survey due toprocess knowledge and origin.

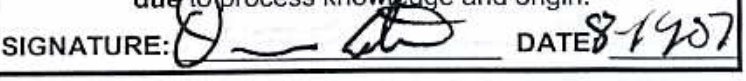

FRM-0646 (08/06) 


\section{$\begin{array}{llllll}\text { SWO USE (Select One) } & \text { AREA } & \square 23 & \square 6 & \text { Q } 99 & \square \text { LANDFILL }\end{array}$}

For waste characterization, approval, and/or assistance, contact Solid Waste Operation (SWO). at 5-7898.

REQUIRED: WASTE GERERATOR INFORMATION

(This form is for rolloffs, dump trucks, and other onsite disposal of materials.)

Waste Generator: Dan Tobiason

Phone Number: 295-6169

Location / Origin: T-Tunnel Lower Laydown Yard

Waste Category: (check one)

Waste Type: $\triangle$ NTS

(check one) $\square$ Non-Putrescible $\square$ Asbestos Containing Material

Pollution Prevention Category: (check one) $\square$ Environmental management

Pollution Prevention Category: (check one) $\otimes$ Clean-Up

Method of Characterization: (check one)

$\square$ Commercial
$\square$ Putrescrible
$\square$ Asbestos Containing Material
$\square$ Environmental management
$\otimes$ Clean-Up
$\square$ Sampling \& Analysis

$\triangle$ Industrial egs $8 / 16 / 07$

$\triangle$ FFACO-onsite $\square$ WAC Exception

$\square$ FFACO-offsite $\square$ Historic DOE/NV

$\triangle$ Déense Projects

YMP

Prohibited Waste at all three

NTS landfills:

Additional Prohibited Waste

at the Area 9 U10C Landfill:

Radioactive waste; RCRA waste; Hazardous waste; Free liquids, PCBs above TSCA regulatory levels, and Medical wastes (needles, sharps, bloody clothing).

Sewage Sludge, Animal carcasses, Wet garbage (food waste); and Friable asbestos

\section{REQUIRED: WASTE CONTENTS ALLOWABLE WASTES}

Check all allowable wastes that are contained within this load:

NOTE: Waste disposal at the Area 6 Hydrocarbon Landfill must have come into contact with petroleum hydrocarbons or coolants, such as: gasoline (no benzene, lead); jet fuel; diesel fuel; lubricants and hydraulics; kerosene; asphaltic petroleum hydrocarbon; and ethylene glycol.

Acceptable waste at any NTS landfill:

$\otimes$ Asphalt $\quad$ Metal $\quad$ Wood $\square$ Soil

$\triangle$ Plastic $\quad$ Wire $\quad$ Cable $\quad$ Cloth

$\square$ Rocks / unaltered geologic materials

$\triangle$ Rubber (excluding tires)

$\triangle$ Insulation (non-Asbestosform)

$\triangle$ Manufactured items: (swamp coolers, furniture, rugs, carpet, electronic components, PPE, etc.)

Additional waste accepted at the Area 23 Mercury Landfill: $\square$ Office Waste

$\square$ Asbestos

[ $]$ Friable

$\square$ Non-Friable (contact SWO if regulated load)

Food Waste

$\triangle$ Empty containers

$\triangle$ Demolition debris

$\triangle$ Cement \& concrete

\section{Additional waste accepted at the Area 9 U10c Landfill:}

$\square$ Non-friable asbestos

Light ballasts (contact SwO)

Drained automobiles and military vehicles

$\square$ Drained fuel filters (gas \& diesel)

Hydrocarbons (contact SwO)

Other Drained generators/equipment

Quantity:

Animal Carcasses

\section{Additional waste accepted at the Area 6 Hydrocarbon Landfill:}
$\square$ Septic sludge
$\square$ Rags
$\square$ Drained fuel filters (gas \& diesel)
Plants
Soil
$\square$ Sludge from sand/oil/water separators
REQUIRED: WASTE GENERATOR SIGNATURE
Crushed non-teme plated oil filters PCBs below 50 parts per million

Initials: (if initialed, no radiological clearance is necessary.)

The above mentioned waste was generated outside of a Controlled Waste Manag knowledge, does not contain radiological materials.

To the best of my knowledge, the waste described above contains only those $\mathrm{m}$ : site. I have verified this through the waste characterization method identified at: prohibited and allowable waste items. I have contacted Property Management a is approved for disposal in the landfill.

Print Name: Dan Tobiason

Signature:
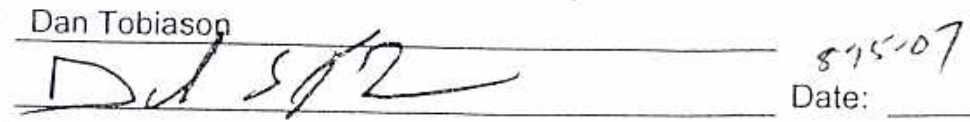

Solid fractions from sand/oil/water

$\bigotimes$ Deconned Underground and Above Ground Tanks

\section{Note: "Food waste, office trash and animal} must have signed removal certification statement with Load Verification."

Radiological Survey Release for Waste Disposa RCT Initials

This container/load meets the criteria for no added man-made radioactive material This container/load meets the criteria for Radcon Manual Table 4.2 release limits. This container/load is exempt from surve duete process knowledige and origin. SIgNATURE: $(-)$

DATE: 2 \% FRM-0646 (08/06)
reun-contanng appuaimes FRM-0646 (08/06)
reun-contanning appuaiko 
NSTec

Form

FRM-0918

NTS LANDFILL LOAD VERIFICATION

Rev.

SWO USE (Select One) AREA

23

$\square 6$

凶9

$\triangle$ LANDFILL

For waste characterization, approval, and/or assistance, contact Solid Waste Operation (SWO) at 5-7898.

REQUIRED: WASTE GERERATOR INFORMATION

(This form is for rolloffs, dump trucks, and other onsite disposal of materials.)

Waste Generator: Dan Tobiason

Phone Number: 295-6169

Location / Origin: T-Tunnel Lower Laydown Yard

Waste Category: (check one)

Waste Type:

$凶$ NTS

(check one)

$\square$ Non-Putrescible

$\square$ Commercial
$\square$ Putrescrible

$\triangle$ Industrial \&s $8 / 16 / 17$

$\square$ Asbestos Containing Material

\#-FFACO-onsite

$\square$ WAC Exception

Pollution Prevention Category: (check one) $\square$ Environmental management

Pollution Prevention Category: (check one) $\triangle$ Clean-Up

Method of Characterization: (check one)

Sampling \& Analysis

FFACO-offsite

$\square$ Historic DOE/NV

Prohibited Waste at all three

NTS landfills:

Additional Prohibited Waste

at the Area 9 U10C Landfill:

Radioactive waste; RCRA waste; Hazardous waste; Free liquids, PCBs above TSCA regulatory levels, and Medical wastes (needles, sharps, bloody clothing).

Sewage Sludge, Animal carcasses, Wet garbage (food waste); and Friable asbestos

\section{REQUIRED: WASTE CONTENTS ALLOWABLE WASTES}

Check all allowable wastes that are contained within this load:

NOTE: Waste disposal at the Area 6 Hydrocarbon Landfill must have come into contact with petroleum hydrocarbons or coolants, such as: gasoline (no benzene, lead); jet fuel; diesel fuel; lubricants and hydraulics; kerosene; asphaltic petroleum hydrocarbon; and ethylene glycol.

Acceptable waste at any NTS landfill: $\square$ Paper

$\triangle$ Asphait $\quad$ Metal $\quad$ Wood $\quad \square$ Soil

$\triangle$ Plastic $\quad \square$ Wire $\quad \square$ Cable $\quad \square$ Cloth

$\square$ Rocks / unaltered geologic materials

$\triangle$ Rubber (excluding tires)

$\bigotimes$ Insulation (non-Asbestosform)

$\bigotimes$ Empty containers

$\bigotimes$ Demolition debris

$\triangle$ Manufactured items: (swamp coolers, furniture, rugs, carpet, electronic components, PPE, etc.)

Additicnal waste accepted at the Area 23 Mercury Landfill: $\square$ Office Waste

Asbestos

Friable

$\square$ Non-Friable (contact SWO if regulated load)

$\square$ Food Waste

$\bigotimes$ Cement \& concrete

Additional waste accepted at the Area 9 U10c Landfill:

$\square$ Non-friable asbestos

$\square$ Drained automobiles and military vehicles

Light ballasts (contact SWO)

Drained fuel filters (gas \& diesel)

Hydrocarbons (contact SWO)

$\otimes$ Other Dra

Drained generators/equipment

Quantity:

Animal Carcasses

Additional waste accepted at the Area 6 Hydrocarbon Landfill:
$\square$ Septic sludge
$\square$ Rags
$\square$ Drained fuel filters (gas \& diesel)
Plants
Soil
$\square$ Sludge from sand/oil/water separators
REQUIRED: WASTE GENERATOR SIGNATURE
Crushed non-teme plated oil filters PCBs below 50 parts per million

Initials: (if initialed, no radiological clearance is necessary.)

The above mentioned waste was generated outside of a Controlled Waste Management Area (CWMA) and to the best of my knowledge, does not contain radiological materials.

To the best of my knowledge, the waste described above contains only those matel site. I have verified this through the waste characterization method identified abovi prohibited and allowable waste items. I have contacted Property Management and is approved for disposal in the landfill.

Print Name: Dan Tobiason

Signature:
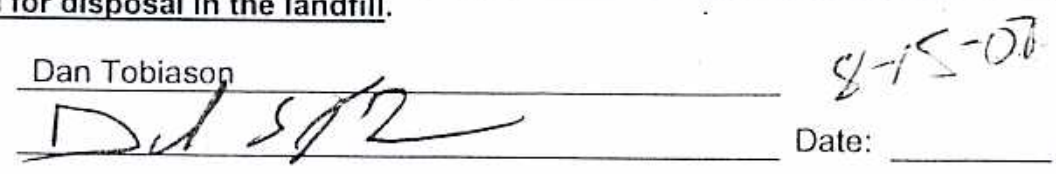

Note: "Food waste, office trash and animal carcasses do not require a radiological c must have signed removal certification statement with Load Verification."

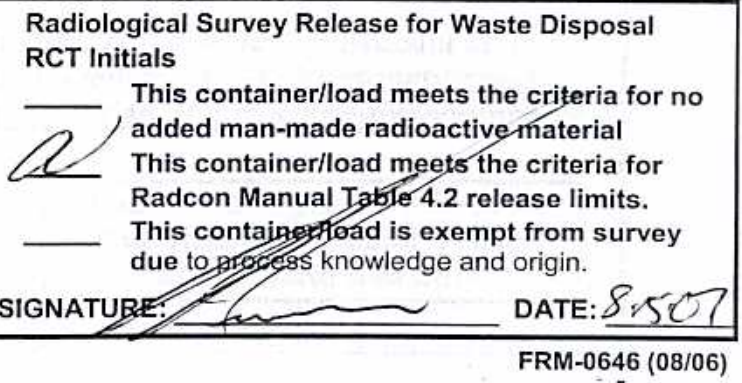

SWO USE ONLY

Load Weight (net from scale or estimate): $7,0 \Omega$

$8-15-0.7$ Signature of Certifie

Solid fractions from sand/oil/water

$\triangle$ Deconned Underground and Above Ground Tanks 
NSTec

Form

FRM-0918

NTS LANDFILL LOAD VERIFICATION

Rev.

Page 1 of 2

\begin{tabular}{|llllll}
\hline SWO USE (Select One) & AREA & $\square 23$ & $\square 6$ & Q 39 & $\square$ LANDFILL
\end{tabular}

For waste characterization, approval, and/or assistance, contact Solid Waste Operation (SWO) at 5-7898.

REQUIRED: WASTE GERERATOR INFORMATION

(This form is for rolloffs, dump trucks, and other onsite disposal of materials.)

Waste Generator: Dan Tobiason

Phone Number: 295-6169

Location / Origin: T-Tunnel Lower Laydown Yard

Waste Category: (check one)

$\square$ Commercial

$\triangle$ Industrial ogs $8 / 16 / 07$

Waste Type: \ NTS

$\square$ Putrescrible

A-FFACO=onsite

$\square$ WAC Exception

(check one)

Non-Putrescible

$\square$ Asbestos Containing Material

$\square$ FFACO-offsite

$\square$ Historic DOE/NV

Pollution Prevention Category: (check one) $\square$ Environmental management

Pollution Prevention Category: (check one) $₫$ Clean-Up

Method of Characterization: (check one) $\square$ Sampling \& Analysis

$\triangle$ Defense Projects $\square$ YMP

Prohibited Waste at all three

NTS landfills:

Additional Prohibited Waste

at the Area 9 U10C Landfill:

\begin{abstract}
Radioactive waste; RCRA waste; Hazardous waste; Free liquids, PCBs above TSCA regulatory
\end{abstract} levels, and Medical wastes (needles, sharps, bloody clothing).

Sewage Sludge, Animal carcasses, Wet garbage (food waste); and Friable asbestos

\title{
REQUIRED: WASTE CONTENTS ALLOWABLE WASTES
}

Check all allowable wastes that are contained within this load:

NOTE: Waste disposal at the Area 6 Hydrocarbon Landfill must have come into contact with petroleum hydrocarbons or coolants, such as: gasoline (no benzene, lead); jet fuel; diesel fuel; lubricants and hydraulics; kerosene; asphaltic petroleum hydrocarbon; and ethylene glycol.
Acceptable waste at any NTS landfill:
$\triangle$ Paper
$\triangle$ Soil
$\square$ Rocks / unaltered geologic materials
$\bigotimes$ Asphalt
$凶$ Metal
$凶$ Wood
$\triangle$ Cloth
$\triangle$ Rubber (excluding tires)
$\bigotimes$ Insulation (non-Asbestosform)
Plastic
$\bigotimes$ Cable

$凶$ Empty containers

$\square$ Manufactured items: (swamp coolers, furniture, rugs, carpet, electronic components. PPE, etc.)
Additional waste accepted at the Area 23 Mercury Landfill: $\square$ Office Waste $\square$ Food Was

$\bigotimes$ Demolition debris

Additional waste accepted at the Area 23 Mercury Landfill: $\quad \square$ Office Waste

$\square$ Asbestos $\square$ Friable

$\square$ Non-Friable (contact SWO if regulated load)

Quantity:

Additional waste accepted at the Area 9 U10c Landfill:

$\begin{array}{ll}\square \text { Non-friable asbestos } & \square \text { Drained automobiles and military vehicles } \\ \square \text { Light ballasts (contact SwO) } \\ \square \text { Drained fuel filters (gas \& diesel) } \\ \square \text { Hydrocarbons (contact SwO) } & \square \text { Other Drained generators/equipment }\end{array}$

Solid fractions from sand/oil/water

$\bigotimes$ Deconned Underground and Above Ground Tanks

Additional waste accepted at the Area 6 Hydrocarbon Landfill:
$\square$ Septic sludge
$\square$ Rags
$\square$ Drained fuel filters (gas \& diesel)
Plants
Soil
$\square$ Sludge from sand/oil/water separators
$\square$ Crushed non-teme plated oil filters REQUIRED: WASTE GENERATOR SIGNATURE PCBs below 50 parts per million

Initials: (if initialed, no radiological clearance is necessary.)

The above mentioned waste was generated outside of a Controlled Waste Management Area (CWMA) and to the best of my knowledge, does not contain radiological materials.

To the best of my knowledge, the waste described above contains only those $\mathrm{m}$ site. I have verified this through the waste characterization method identified al prohibited and allowable waste items. I have contacted Property Management a is approved for disposal in the landfill.

Print Name: Dan Tobiason

Signature:
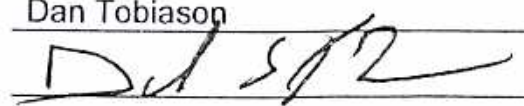
$3-15=0.7$ Date:

-

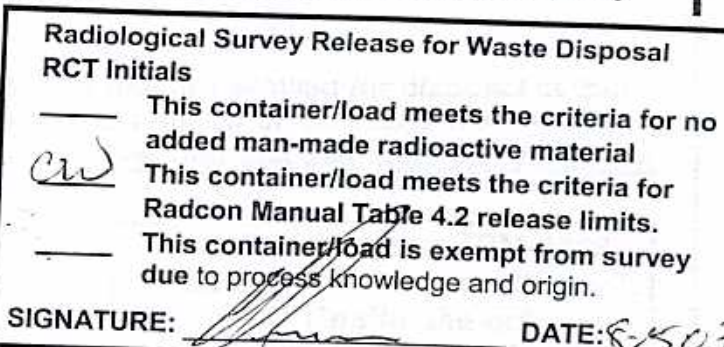

Note: "Food waste, office trash and animal carcasses do not require a radiologic must have signed removal certification statement with Load Verification." 


\begin{tabular}{llllll}
\hline SWO USE (Select One) & AREA & $\square 23$ & $\square 6$ & $\square 9$ & $\square$ LANDFILL
\end{tabular}

For waste characterization, approval, and/or assistance, contact Solid Waste Operation (SWO) at 5-7898.

REQUIRED: WASTE GERERATOR INFORMATION

(This form is for rolloffs, dump trucks, and other onsite disposal of materials.)

Waste Generator: Dan Tobiason

Phone Number: 295-6169

Location / Origin: T-Tunnel Lower Laydown Yard

Waste Category: (check one)

Waste Type: \NTS

(check one)

$\square$ Non-Putrescible

$\square$ Commercial

$\otimes$ Industrial $\varnothing 58 / 16 / 17$

$\square$ Putrescrible

$\triangle$-FFACO-OHSite

$\square$ WAC Exception

Pollution Prevention Category: (check one)

$\square$ Asbestos Containing Material

$\square$ FFACO-offsite

$\square$ Historic DOE/NV

Pollution Prevention Category: (check one) $\$ Clean-Up

Method of Characterization: (check one)

Sampling \& Analysis

$\triangle$ Defense Projects

YMP

Prohibited Waste at all three

NTS landfills:

Additional Prohibited Waste at the Area 9 U10C Landfill:

\section{Radioactive waste; RCRA waste; Hazardous waste; Free liquids, PCBs above TSCA regulatory} levels, and Medical wastes (needles, sharps, bloody clothing).

Sewage Sludge, Animal carcasses, Wet garbage (food waste); and Friable asbestos

\section{REQUIRED: WASTE CONTENTS ALLOWABLE WASTES}

Check all allowable wastes that are contained within this load:

NOTE: Waste disposal at the Area 6 Hydrocarbon Landfill must have come into contact with petroleum hydrocarbons or coolants, such as: gasoline (no benzene, lead); jet fuel; diesel fuel; lubricants and hydraulics; kerosene; asphaltic petroleum hydrocarbon; and ethylene glycol.
Acceptable waste at any NTS landfill:
$\triangle$ Paper
$\square$ Rocks / unaltered geologic materials
Empty containers
$\bigotimes$ Asphalt
$凶$ Wood
$凶$ Soil
$\bigotimes$ Rubber (excluding tires)
$\triangle$ Plastic $\triangle$ Wire
$\bigotimes$ Cable
$\bigotimes$ Cloth
$\bigotimes$ Insulation (non-Asbestosform)
$\bigotimes$ Demolition debris
$凶$ Cement \& concrete

$\bigotimes$ Manufactured items: (swamp coolers, furniture, rugs, carpet, electronic components, PPE, etc.)

Additional waste accepted at the Area 23 Mercury Landfill: $\square$ Office Waste

$\square$ Asbestos

Friable

$\square$ Non-Friable (contact SWO if regulated load)

$\square$ Food Waste

Additional waste accepted at the Area 9 U10c Landfill:

$\square$ Drained automobiles and military vehicles

Quantity:

$\square$ Drained fuel filters (gas \& diesel)

Solid fractions from sand/oil/water

$\square$ Light ballasts (contact SWO)

$\bigotimes$ Other Drained generators/equipment

$\bigotimes$ Deconned Underground and Above Ground Tanks

Additional waste accepted at the Area 6 Hydrocarbon Landfill:

$\square$ Ser

$\begin{array}{ll}\text { Septic sludge } & \square \text { Rags } \\ \text { Plants } & \square \text { Soil }\end{array}$

$\square$ Drained fuel filters (gas \& diesel)

Crushed non-teme plated oil filters

Soil

Sludge from sand/oil/water separators

REQUIRED: WASTE GENERATOR SIGNATURE

Initials: (if initialed, no radiological clearance is necessary.)

The above mentioned waste was generated outside of a Controlled Waste Management Area (CWMA) and to the best of my knowledge, does not contain radiological materials.

To the best of my knowledge, the waste described above contains only those materi site. I have verified this through the waste characterization method identified above prohibited and allowable waste items. I have contacted Property Management and I is approved for disposal in the landfill.

Print Name: Dan Tobiason

Signature:
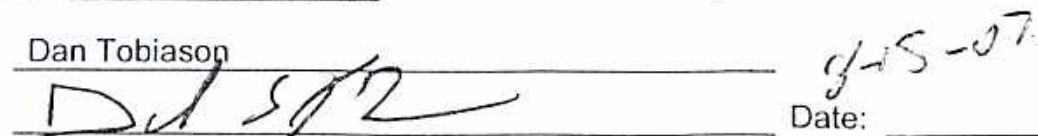

Note: "Food waste, office trash and animal carcasses do not require a radiological c must have signed removal certification statement with Load Verification."

\section{SWO USE ONLY}

Load Weight (net from scale or estimate)
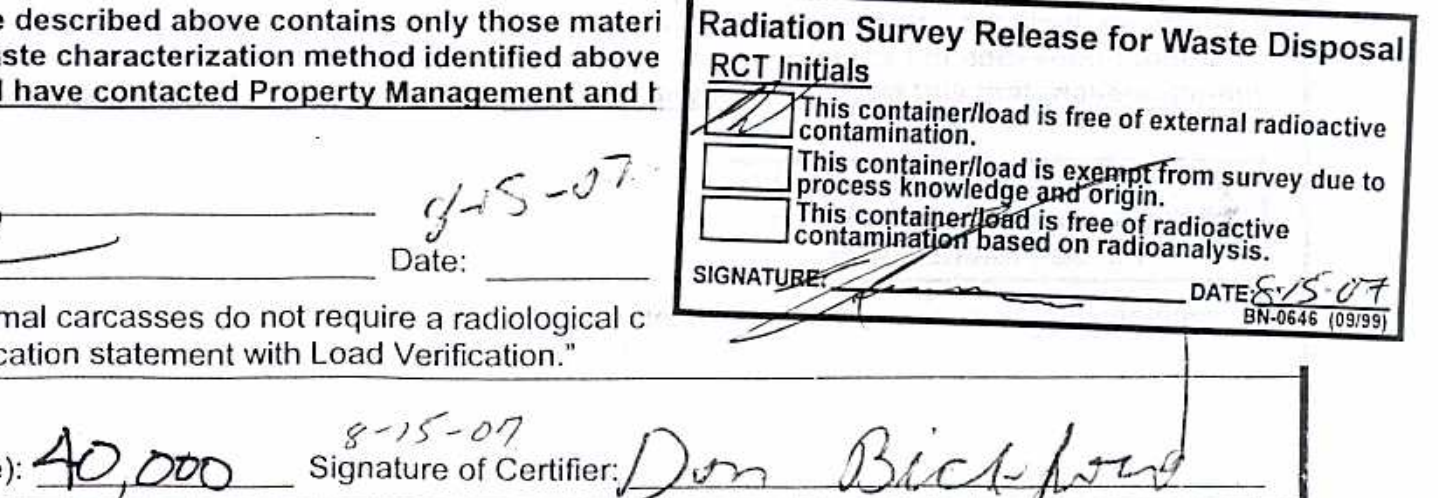


\begin{tabular}{|llllll}
\hline SWO USE (Select One) & AREA & $\square 23$ & $\square 6$ & AR & LANDFILL
\end{tabular}

For waste characterization, approval, and/or assistance, contact Solid Waste Operation (SWO) at 5-7898.

REQUIRED: WASTE GERERATOR INFORMATION

(This form is for rolloffs, dump trucks, and other onsite disposal of materials.)

Waste Generator: Dan Tobiason

Phone Number: 295-6169

Location / Origin: T-Tunnel Lower Laydown Yard

\begin{tabular}{|c|c|c|c|c|}
\hline \multicolumn{2}{|c|}{ Waste Category: (check one) } & \multirow{2}{*}{$\begin{array}{l}\square \text { Commercial } \\
\square \text { Putrescrible }\end{array}$} & \multicolumn{2}{|c|}{$\triangle$ Industrial $\quad$ cgs $8 / 21 / 07$} \\
\hline Waste Type: & $\triangle N T S$ & & DFFAGG-OAsite & $\square$ WAC \\
\hline e) & $\square$ Non & $\square$ Asbestos Containing Material & $\square$ FFA & $\square \mathrm{H}$ \\
\hline \multicolumn{2}{|c|}{ Pollution Prevention Category: (check one) } & al management & $Q$ Defense Projects & $\square$ YMP \\
\hline \multicolumn{2}{|c|}{ Pollution Prevention Category: (check one) } & $\triangle$ Clean-Up & $\square$ RoI & \\
\hline \multicolumn{2}{|c|}{ Method of Characterization: (check one) } & $\square$ Sampling \& Analysis & $\triangle$ Process Knowledge & $\square$ Contents \\
\hline
\end{tabular}

Prohibited Waste at all three Radioactive waste; RCRA waste; Hazardous waste; Free liquids, PCBs above TSCA regulatory NTS landfills:

Additional Prohibited Waste

at the Area 9 U10C Landfill:

levels, and Medical wastes (needles, sharps, bloody clothing).

Sewage Sludge, Animal carcasses, Wet garbage (food waste); and Friable asbestos

\section{REQUIRED: WASTE CONTENTS ALLOWABLE WASTES}

Check all allowable wastes that are contained within this load:

NOTE: Waste disposal at the Area 6 Hydrocarbon Landfill must have come into contact with petroleum hydrocarbons or coolants, such as: gasoline (no benzene, lead); jet fuel; diesel fuel; lubricants and hydraulics; kerosene; asphaltic petroleum hydrocarbon; and ethylene glycol.

Acceptable waste at any NTS landfill: $\triangle$ Paper

$\bigotimes$ Asphalt $\bigotimes$ Metal $\bigotimes$ V Vood

S Soil

$\square$ Rocks / unaltered geologic materials

$凶$ Empty containers

$\triangle$ Plastic $\bigotimes$ Wire

$\triangle$ Cable

$\triangle$ Cloth

$\triangle$ Rubber (excluding tires)

$\bigotimes$ Insulation (non-Asbestosform)

$\bigotimes$ Demolition debris

$\triangle$ Manufactured items: (swamp coolers, furniture, rugs, carpet, electronic components, PPE, etc.)

Additional waste accepted at the Area 23 Mercury Landfill: $\square$ Office Waste $\square$ Food Waste $\square$ Animal Carcasses

$\square$ Asbestos

$\square$ Friable

$\square$ Non-Friable (contact SWO if regulated load)

Quantity:

Additional waste accepted at the Area 9 U10c Landfill:

$\begin{array}{ll}\square \text { Non-friable asbestos } & \square \text { Drained automobiles and military vehicles } \\ \square \text { Light ballasts (contact SWO) } & \square \text { Drained fuel filters (gas \& diesel) } \\ \square \text { Hydrocarbons (contact SWO) } & \square \text { Other Drained generators/equipment }\end{array}$

$\square$ Solid fractions from sand/oil/water

$\otimes$ Deconned Underground and Above

Ground Tanks

\section{Additional waste accepted at the Area 6 Hydrocarbon Landfill: \\ $\begin{array}{llll}\square \text { Septic sludge } & \square \text { Rags } & \square \text { Drained fuel filters (gas \& diesel) } & \square \text { Crushed non-teme plated oil filters } \\ \square \text { Plants } & \square \text { Soil } & \square \text { Sludge from sand/oil/water separators } & \square \text { PCBs below 50 parts per million }\end{array}$ REQUIRED: WASTE GENERATOR SIGNATURE}

Initials: (if initialed, no radiological clearance is necessary.)

The above mentioned waste was generated outside of a Controlled Waste Management Area (CWMA) and to the best of my knowledge, does not contain radiological materials.

To the best of my knowledge, the waste described above contains only those mate। site. I have verified this through the waste characterization method identified abov prohibited and allowable waste items. I have contacted Property Management and is approved for disposal in the landfill.

Print Name: Dan Tobiason

Signature:
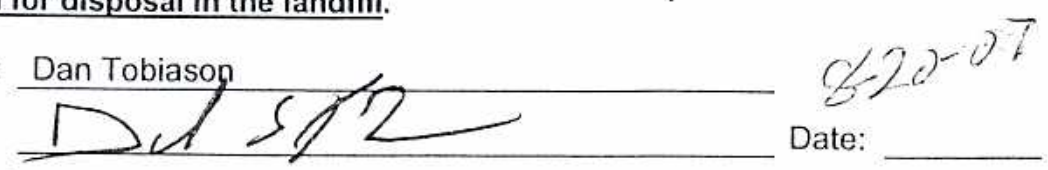

Note: "Food waste, office trash and animal carcasses do not require a radiological c must have signed removal certification statement with Load Verification."

\section{SWO USE ONLY}

Load Weight (net from scale or estimate):
$8-20-07$

Signature of Certifier:
Radiological Survey Release for Waste Disposal RCT Initials

This container/load meets the criteria for no added man-made radioactive material This container/load meets the criteria for Radcon Manual Tabte 4.2 release limits. This containenlload is exempt from survey due to prgeses Knowledge and origin.

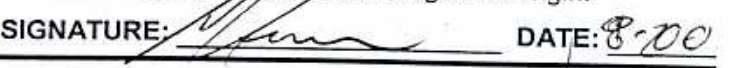
FRM-0646 (08/0€ 
NSTec

Form

FRM-0918

NTS LANDFILL LOAD VERIFICATION

Page 1 of

\begin{tabular}{|llllll}
\hline SWO USE (Select One) & AREA & $\square 23$ & $\square 6$ & $\square 9$ & $\square$ LANDFILL
\end{tabular}

For waste characterization, approval, and/or assistance, contact Solid Waste Operation (SWO) at 5-7898.

REQUIRED: WASTE GERERATOR INFORMATION

(This form is for rolloffs, dump trucks, and other onsite disposal of materials.)

Waste Generator: Dan Tobiason

Phone Number: 295-6169

Location / Origin: T-Tunnel Lower Laydown Yard

Waste Category: (check one)

Waste Type: $\otimes$ NTS

$\square$ Commercial

(check one) $\quad \square$ Non-Putrescible

$\square$ Putrescrible

$\triangle$ Industrial

$\square$ Asbestos Containing Material

$\triangle$-FFACO-OAsite

Q $58 / 21 / 07$

Pollution Prevention Category: (check one)

Pollution Prevention Category: (check one)

Method of Characterization: (check one)

$\square$ Environmental management

FFACO-offsite

WAC Exception

Prohibited Waste at all three Radioactive waste; RCRA waste; Hazardous waste; Free liquids, PCBs above TSCA regulatory NTS landfills:

Additional Prohibited Waste

at the Area 9 U10C Landfill:

levels, and Medical wastes (needles, sharps, bloody clothing).

Sewage Sludge, Animal carcasses, Wet garbage (food waste); and Friable asbestos

REQUIRED: WASTE CONTENTS ALLOWABLE WASTES

Check all allowable wastes that are contained within this load:

NOTE: Waste disposal at the Area 6 Hydrocarbon Landfill must have come into contact with petroleum hydrocarbons or coolants, such as: gasoline (no benzene, lead); jet fuel; diesel fuel; lubricants and hydraulics; kerosene; asphaltic petroleum hydrocarbon; and ethylene glycol.

Acceptable waste at any NTS landfill: $\quad \square$ Paper $\square$ Rocks/unaltered geologic materials $\triangle$ Empty containers

$\bigotimes$ Asphalt $\quad$ Metal $\quad$ Wood $\quad$ Soil $\quad$ Rubber (excluding tires) $\quad$ Demolition debris

$\triangle$ Plastic $\quad$ Wire $\quad$ Cable $\quad$ Cloth $\quad$ Insulation (non-Asbestosform)

$\bigotimes$ Cement \& concrete

$\triangle$ Manufactured items: (swamp coolers, furniture, rugs, carpet, electronic components, PPE, etc.)

Additional waste accepted at the Area 23 Mercury Landfill: $\square$ Office Waste $\square$ Food Waste $\square$ Animal Carcasses
$\square$ Asbestos
Friable
Non-Friable (contact SWO if regulated load)
Quantity:

Additional waste accepted at the Area 9 U10c Landfill:

$\square$ Non-friable asbestos

Light ballasts (contact SWO)

Hydrocarbons (contact SWO)

$\square$

Drained automobiles and military vehicles

Drained fuel filters (gas \& diesel)

Other Drained generators/equipment
Solid fractions from sand/oil/water

$\bigotimes$ Deconned Underground and Above Ground Tanks

Additional waste accepted at the Area 6 Hydrocarbon Landfill:
Septic sludge
$\square$ Rags
$\square$ Drained fuel filters (gas \& diesel)
Crushed non-teme plated oil filters
Plants
Soil
$\square$ Sludge from sand/oil/water separators
REQUIRED: WASTE GENERATOR SIGNATURE
PCBs below 50 parts per million

Initials: (if initialed, no radiological clearance is necessary.)

The above mentioned waste was generated outside of a Controlled Waste Management Area (CWMA) and to the best of my knowledge, does not contain radiological materials.

To the best of my knowledge, the waste described above contains only those materi site. I have verified this through the waste characterization method identified above prohibited and allowable waste items. I have contacted Property Management and $h$ is approved for disposal in the landfill.

Print Name: Dan Tobiason

Signature:
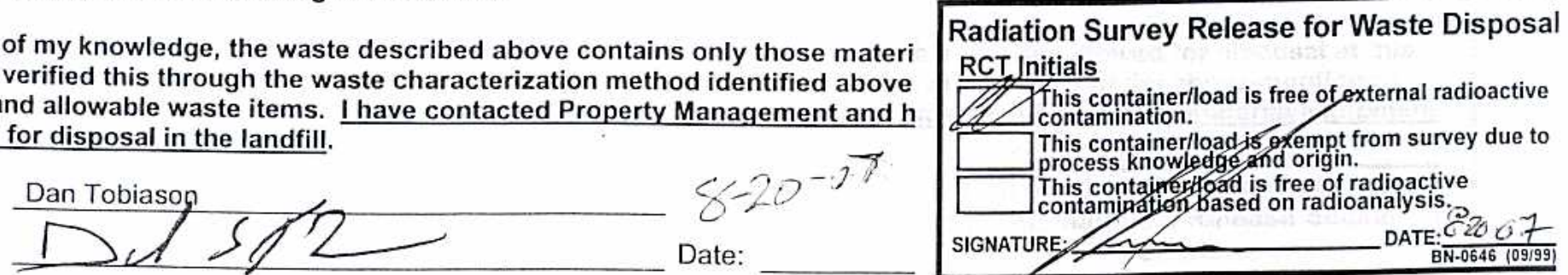

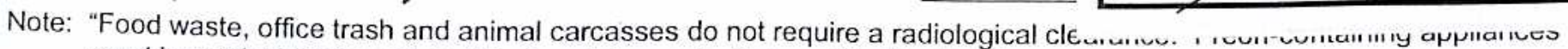
must have signed removal certification statement with Load Verification."

SWO USE ONLY

Load Weight (net from scale or estimate): $11,280 \quad \begin{array}{cc}8-20-07 \\ \text { Signature of Certifiec }\end{array}$ 


$\begin{array}{llllll}\text { SWO USE (Select One) } & \text { AREA } & \square 23 & \square 6 & \square 9 & \square \text { LANDFILL }\end{array}$

For waste characterization, approval, and/or assistance, contact Solid Waste Operation (SWO) at 5-7898.

REQUIRED: WASTE GERERATOR INFORMATION

(This form is for rolloffs, dump trucks, and other onsite disposal of materials.)

Waste Generator: Dan Tobiason

Phone Number: 295-6169

Location / Origin: T-Tunnel Lower Laydown Yard

Waste Category: (check one)

Waste Type: $\triangle$ NTS

$\square$ Commercial

$\triangle$ Industrial

coss $8 / 21 / 07$

(check one)

$\square$ Non-Putrescible

$\square$ Putrescrible

$\triangle$ FFACO-OISite

$\square$ WAC Exception

Pollution Prevention Category: (check one)

$\square$ Asbestos Containing Material

$\square$ FFACO-offsite

$\square$ Historic DOE/NV

Pollution Prevention Category: (check one)

Method of Characterization: (check one)

$\square$ Environmental management

$\triangle$ Defense Projects

YMP

Prohibited Waste at all three

NTS landfills:

Additional Prohibited Waste

at the Area 9 U10C Landfill:

Radioactive waste; RCRA waste; Hazardous waste; Free liquids, PCBs above TSCA regulatory levels, and Medical wastes (needles, sharps, bloody clothing).

\section{at the Area 9 Uioc Landfill:}

Sewage Sludge, Animal carcasses, Wet garbage (food waste); and Friable asbestos

\section{REQUIRED: WASTE CONTENTS ALLOWABLE WASTES}

Check all allowable wastes that are contained within this load:

NOTE: Waste disposal at the Area 6 Hydrocarbon Landfill must have come into contact with petroleum hydrocarbons or coolants, such as: gasoline (no benzene, lead); jet fuel; diesel fuel; lubricants and hydraulics; kerosene; asphaltic petroleum hydrocarbon; and ethylene glycol.
Acceptable waste at any NTS landfill:
$\triangle$ Paper
$\triangle$ Wood
$\bigotimes$ Soil
$\square$ Rocks/unaltered geologic materials
$\bigotimes$ Empty containers
$\triangle$ Asphalt $\otimes$ Metal
$凶$ Cable
$\triangle$ Cloth
$\triangle$ Rubber (excluding tires)
$\bigotimes$ Insulation (non-Asbestosform)
$\otimes$ Demolition debris
$\triangle$ Plastic $\quad$ Wire
$\triangle$ Cement \& concrete

$\bigotimes$ Manufactured items: (swamp coolers, furniture, rugs, carpet, electronic components, PPE, etc.)

$\triangle$ Manufactured items: (swamp coolers, furniture, rugs, carpet, electronic components, PPE, etc.)
Additional waste accepted at the Area 23 Mercury Landfill: $\square$ Office Waste
$\square$ Asbestos $\square$ Friable $\quad \square$ Non-Friable (contact SWO if regulated load)
$\square$ Food Waste
Quantity:

Non-Friable (contact

Additional waste accepted at the Area 9 U10c Landfill:

$\square$ Non-friable asbestos

Light ballasts (contact SWO)

$\square$ Drained automobiles and military vehicles

Hydrocarbons (contact SWO) $\bigotimes$ Other Drained generators/equipment
$\square$ Solid fractions from sand/oil/water
$\otimes$ Deconned Underground and Above

Ground Tanks

Additional waste accepted at the Area 6 Hydrocarbon Landfill:
$\square$ Septic sludge
$\square$ Rags
$\square$ Drained fuel filters (gas \& diesel)
$\square$ Sludge from sand/oil/water separators
REQUIRED: WASTE GENERATOR SIGNATURE
Crushed non-teme plated oil filters
Plants
Soil

Initials: (if initialed, no radiological clearance is necessary.)

The above mentioned waste was generated outside of a Controlled Waste Management Area (CWMA) and to the best of my knowledge, does not contain radiological materials.

To the best of my knowledge, the waste described above contains only those 1 site. I have verified this through the waste characterization method identified : prohibited and allowable waste items. I have contacted Property Management is approved for disposal in the landfill.

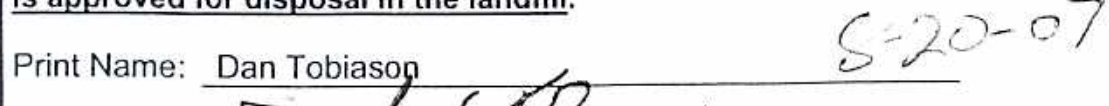

Signature:

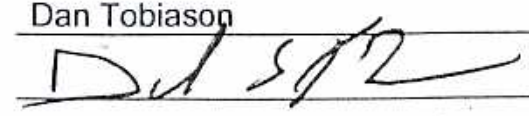

Date:

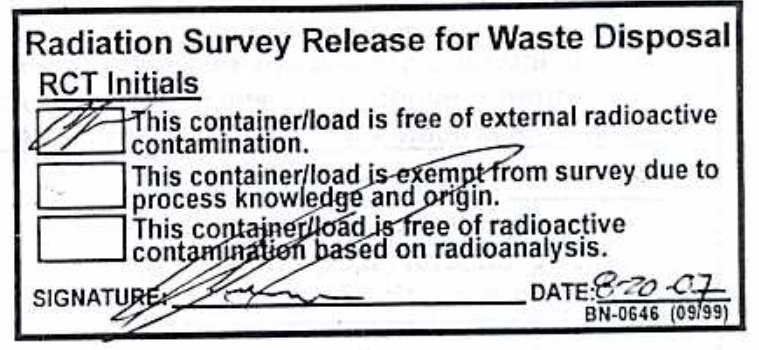

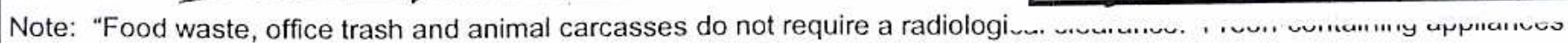
must have signed removal certification statement with Load Verification." 
NSTec

Form

FRM-0918

SWO USE (Select One) AREA

AREA $\square 23$

$23 \square 6$

$6 \quad$ 邓9

Page 1 of

For waste characterization, approval, and/or assistance, contact Solid Waste Operation (SWO) at 5-7898.

REQUIRED: WASTE GERERATOR INFORMATION

(This form is for rolloffs, dump trucks, and other onsite disposal of materials.)

Waste Generator: Dan Tobiason

Phone Number: 295-6169

Location / Origin: T-Tunnel Lower Laydown Yard

Waste Category: (check one)

Waste Type: $\bigotimes$ NTS

(check one) $\square$ Non-Putrescible $\square$ Asbestos Containing Material

(check one) $\square$ Non-Putrescible $\square$ Asbestos Containing Material

$\square$ Commercial

$\triangle$ Industrial cgs $8 / 21 / 07$

$\triangle$ FFACO-Onsite

WAC Exception

Pollution Prevention Category: (check one)

$\square$ Environmental management

Pollution Prevention Category: (check one)

$凶$ Clean-Up

Method of Characterization: (check one)

Sampling \& Analysis

$\square$ FFACO-offsite

$\square$ Historic DOE/NV

Prohibited Waste at all three

NTS landfills:

$\triangle$ Defense Projects

YMP

$\square$ Routine

Additional Prohibited Waste

at the Area 9 U10C Landfill:

Radioactive waste; RCRA waste; Hazardous waste; Free liquids, PCBs above TSCA regulatory levels, and Medical wastes (needles, sharps, bloody clothing).

Sewage Sludge, Animal carcasses, Wet garbage (food waste); and Friable asbestos

\section{REQUIRED: WASTE CONTENTS ALLOWABLE WASTES}

Check all allowable wastes that are contained within this load:

NOTE: Waste disposal at the Area 6 Hydrocarbon Landfill must have come into contact with petroleum hydrocarbons or coolants, such as: gasoline (no benzene, lead); jet fuel; diesel fuel; lubricants and hydraulics; kerosene; asphaltic petroleum hydrocarbon; and ethylene glycol.

Acceptable waste at any NTS landfill:

$\triangle$ Asphalt $\square$ Metal $\square$ Wood $\square$ Soil

$\triangle$ Plastic $\quad$ Wire $\quad$ Cable $\quad$ Cloth

$\square$ Rocks / unaltered geologic materials

Empty containers

$\triangle$ Manufactured items: (swamp coolers, furniture, rugs, carpet, electronic components, PPE, etc.)

Additional waste accepted at the Area 23 Mercury Landfill: $\square$ Office Waste

Asbestos $\square$ Friable

$\square$ Non-Friable (contact SWO if regulated load)

$\square$ Food Waste

Animal Carcasses

Additional waste accepted at the Area 9 U10c Landfill:

$\square$ Non-friable asbestos

$\square$ Light ballasts (contact SWO)

Hydrocarbons (contact SWO)
Drained automobiles and military vehicles

Drained fuel filters (gas \& diesel)

Other Drained generators/equipment

Quantity:

$\bigotimes$ Demolition debris

$\bigotimes$ Cement \& concrete

Additional waste accepted at the Area 6 Hydrocarbon Landfill:
$\square$ Septic sludge
$\square$ Rags
$\square$ Drained fuel filters (gas \& diesel)
Plants
Soil
$\square$ Sludge from sand/oil/water separators
REQUIRED: WASTE GENERATOR SIGNATURE

Solid fractions from sand/oil/water

$\bigotimes$ Deconned Underground and Above Ground Tanks

Initials: (if initialed, no radiological clearance is necessary.)

The above mentioned waste was generated outside of a Controlled Waste Managemant Area ICWMAI and to the host of mu knowledge, does not contain radiological materials.

To the best of my knowledge, the waste described above contains only those ma site. I have verified this through the waste characterization method identified ab، prohibited and allowable waste items. I have contacted Property Management an is approved for disposal in the landfill.

Print Name: Dan Tobiason

Signature:
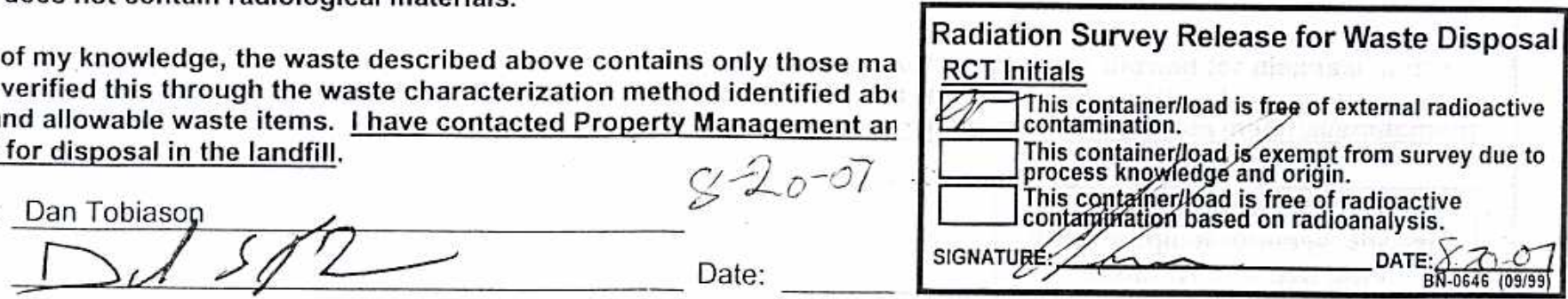

Note: "Food waste, office trash and animal carcasses do not require a radiological clearance. rreon-contaınıng appliances must have signed removal certification statement with Load Verification." 


$\begin{array}{llllll}\text { SWO USE (Select One) } & \text { AREA } & \square 23 & \square 6 & \square 9 & \text { Q LANDFILL }\end{array}$

For waste characterization, approval, and/or assistance, contact Solid Waste Operation (SWO) at 5-7898.

REQUIRED: WASTE GERERATOR INFORMATION

(This form is for rolloffs, dump trucks, and other onsite disposal of materials.)

Waste Generator: Dan Tobiason

Phone Number: 295-6169

Location / Origin: T-Tunnel Lower Laydown Yard

\begin{tabular}{|c|c|c|c|}
\hline Waste Category: (check one) & $\square$ Commercial & Q Industrial cys & $122 / 07$ \\
\hline Waste Type: & $\square$ Putrescrible & 区TFACO-onsite & $\square$ WAC Exception \\
\hline$\square$ Non-Putrescible & $\square$ Asbestos Containing Material & $\square$ FFACO-offsite & $\square$ Historic DOE/NV \\
\hline Pollution Prevention Category: (check one) & $\square$ Environmental management & $\triangle$ Defense Projects & $\square$ YMP \\
\hline Pollution Prevention Category: (check one) & Q Clean-Up & $\square$ Routine & \\
\hline Method of Characterization: (check one) & $\square$ Sampling \& Analysis & $\triangle$ Process & its \\
\hline
\end{tabular}

Prohibited Waste at all three Radioactive waste; RCRA waste; Hazardous waste; Free liquids, PCBs above TSCA regulatory NTS landfills:

Additional Prohibited Waste at the Area 9 U10C Landfill: levels, and Medical wastes (needles, sharps, bloody clothing).

Sewage Sludge, Animal carcasses, Wet garbage (food waste); and Friable asbestos

\section{REQUIRED: WASTE CONTENTS ALLOWABLE WASTES}

Check all allowable wastes that are contained within this load:

NOTE: Waste disposal at the Area 6 Hydrocarbon Landfill must have come into contact with petroleum hydrocarbons or coolants, such as: gasoline (no benzene, lead); jet fuel; diesel fuel; lubricants and hydraulics; kerosene; asphaltic petroleum hydrocarbon; and ethylene glycol.
Acceptable waste at any NTS landfill:
$\triangle$ Paper
$\square$ Rocks / unaltered geologic materials
$\bigotimes$ Empty containers
$\bigotimes$ Asphalt $\quad$ Metal $\quad$ Wood
$\bigotimes$ Soil
$\bigotimes$ Rubber (excluding tires)
$\triangle$ Demolition debris
$\triangle$ Plastic $\otimes$ Wire
$凶$ Cable
Cloth
\Insulation (non-Asbestosform)
$\otimes$ Cement \& concrete

$\triangle$ Manufactured items: (swamp coolers, furniture, rugs, carpet, electronic components, PPE, etc.)
Additional waste accepted at the Area 23 Mercury Landfill: $\square$ Office Waste
Food Waste
Animal Carcasses

$\square$ Asbestos

Friable

Non-Friable (contact SWO if regulated load)

Additional waste accepted at the Area 9 U10c Landfill:
Non-friable asbestos
$\square$ Drained automobiles and military vehicles
Light ballasts (contact SWO)
Drained fuel filters (gas \& diesel)
Hydrocarbons (contact SWO)
Other
Drained generators/equipment

Quantity:

\section{Additional waste accepted at the Area 6 Hydrocarbon Landfill:}
$\square$ Septic sludge
$\square$ Rags
Plants
Soil
$\square$ Drained fuel filters (gas \& diesel)
Crushed non-teme plated oil filters
$\square$ Sludge from sand/oil/water separators

\section{REQUIRED: WASTE GENERATOR SIGNATURE}

\section{$\triangle$ Deconned Underground and Above}

Solid fractions from sand/oil/water Ground Tanks

Initials:

(if initialed, no radiological clearance is necessary.)

The above mentioned waste was generated outside of a Controlled Waste Management Area (CWMA) and to the best of my knowledge, does not contain radiological materials.

To the best of my knowledge, the waste described above contains only those $n$ site. I have verified this through the waste characterization method identified a prohibited and allowable waste items. I have contacted Property Management : is approved for disposal in the landfill.

Print Name:

Signature:
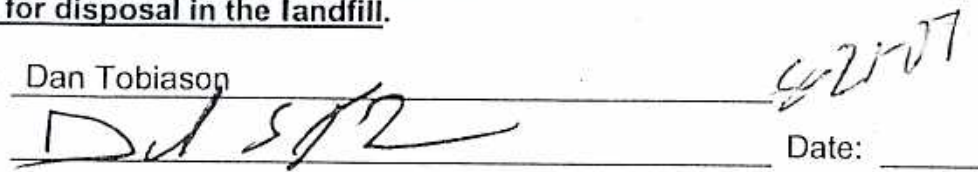

Date:

Note: "Food waste, office trash and animal carcasses do not require a radiologic must have signed removal certification statement with Load Verification."
Radiation Survey Release for Waste Disposal RCT Initials

This containeriload is free of external radioactive contamination.

This container/load is exempt from survey due to process knowledge and origin.

This containe foad is free of radioactive contaminguron based on radioanalysis.

\section{SWO USE ONLY}

Load Weight (net from(scale or) estimate)
$8.21-67$

Signature of Certifier 


\begin{tabular}{|llllll}
\hline SWO USE (Select One) & AREA & $\square 23$ & $\square 6$ & $\square 9$ & $\square$ LANDFILL
\end{tabular}

For waste characterization, approval, and/or assistance, contact Solid Waste Operation (SWO) at 5-7898.

REQUIRED: WASTE GERERATOR INFORMATION

(This form is for rolloffs, dump trucks, and other onsite disposal of materials.)

Waste Generator: Dan Tobiason

Phone Number: 295-6169

Location / Origin: T-Tunnel Lower Laydown Yard

Waste Category: (check one)

Commercial

$\triangle$ Industrial egs $s / 22 / 07$

Waste Type:

$\triangle$ NTS

$\square$ Putrescrible

Q-FFACO-Onsite

$\square$ WAC Exception

(check one)

$\square$ Non-Putrescible

$\square$ Asbestos Containing Material

$\square$ FFACO-offsite

$\square$ Historic DOE/NV

Pollution Prevention Category: (check one) $\square$ Environmental management

Pollution Prevention Category: (check one) $\bigotimes$ Clean-Up

Method of Characterization: (check one)

7 Sampling \& Analysis

$\triangle$ Defense Projects

YMP

Prohibited Waste at all three

NTS landfills:

Additional Prohibited Waste

at the Area 9 U10C Landfill:

Radioactive waste; RCRA waste; Hazardous waste; Free liquids, PCBs above TSCA regulatory levels, and Medical wastes (needles, sharps, bloody clothing).

Sewage Sludge, Animal carcasses, Wet garbage (food waste); and Friable asbestos

\section{REQUIRED: WASTE CONTENTS ALLOWABLE WASTES}

Check all allowable wastes that are contained within this load:

NOTE: Waste disposal at the Area 6 Hydrocarbon Landfill must have come into contact with petroleum hydrocarbons or coolants, such as: gasoline (no benzene, lead); jet fuel; diesel fuel; lubricants and hydraulics; kerosene; asphaltic petroleum hydrocarbon; and ethylene glycol.

Acceptable waste at any NTS landfill: $\triangle$ Paper
$\bigotimes$ Asphalt
$\otimes$ Metal
$\otimes$ Wood
$\otimes$ Soil
$\square$ Rocks / unaltered geologic materials
$\bigotimes$ Rubber (excluding tires)
$\bigotimes$ Plastic
Wire
$\triangle$ Cable
$\otimes$ Cloth
$\bigotimes$ Insulation (non-Asbestosform)

$\triangle$ Empty containers

Demolition debris

$\triangle$ Manufactured items: (swamp coolers, furniture, rugs, carpet, electronic components, PPE, etc.)

\section{Additional waste accepted at the Area 23 Mercury Landfill: $\square$ Office Waste \\ Food Waste}

Asbestos

$\square$ Friable

$\square$ Non-Friable (contact SWO if regulated load)

$\otimes$ Cement \& concrete

\section{Additional waste accepted at the Area $9 \mathrm{U} 10 \mathrm{c}$ Landfill:}
$\square$ Non-friable asbestos
Light ballasts (contact SWO)
Drained automobiles and military vehicles
$\square$ Drained fuel filters (gas \& diesel)

Solid fractions from sand/oil/water

Hydrocarbons (contact SWO)

$\bigotimes$ Other Drained generators/equipment

$\bigotimes$ Deconned Underground and Above Ground Tanks

\section{Additional waste accepted at the Area 6 Hydrocarbon Landfill:}
$\square$ Septic sludge
$\square$ Rags
$\square$ Drained fuel filters (gas \& diesel)
Plants
Soil
$\square$ Sludge from sand/oil/water separators
REQUIRED: WASTE GENERATOR SIGNATURE
Crushed non-teme plated oil filters
$\square$ PCBs below 50 parts per million

Initials: (if initialed, no radiological clearance is necessary.)

The above mentioned waste was generated outside of a Controlled Waste Management Area (CWMA) and to the best of my knowledge, does not contain radiological materials.

To the best of my knowledge, the waste described above contains only those ma site. I have verified this through the waste characterization method identified abı prohibited and allowable waste items. I have contacted Property Management an is approved for disposal in the landfill.

Print Name: Dan Tobiason

Signature:
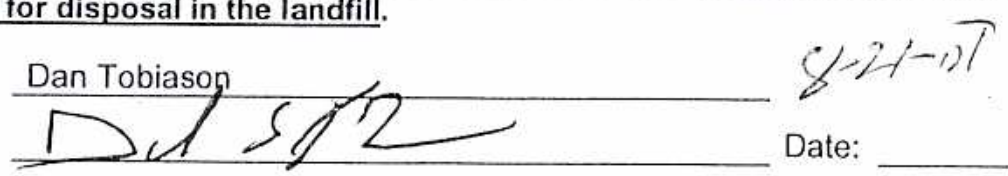

Note: "Food waste, office trash and animal carcasses do not require a radiological must have signed removal certification statement with Load Verification."
Radiation Survey Release for Waste Disposal RCT Initials

This containerlload is free of external radioactive Ch This container. This container/load is exempt from survey due to

process knowledge and origin. This container/load is free of radioanalysis. SIGNATURE. DATE: $\frac{O-60 \% 0}{\mathrm{~N} .0646(09 / 99)}$ B 


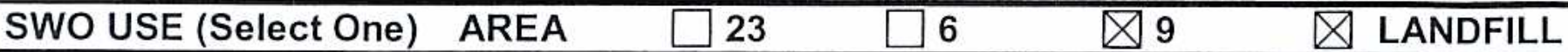

For waste characterization, approval, and/or assistance, contact Solid Waste Operation (SWO) at 5-7898.

REQUIRED: WASTE GERERATOR INFORMATION

(This form is for rolloffs, dump trucks, and other onsite disposal of materials.)

Waste Generator: Dan Tobiason

Phone Number: 295-6169

Location / Origin: T-Tunnel Lower Laydown Yard

Waste Category: (check one)

Waste Type: $\square$ NTS

(check one)

\section{$\square$ Commercial}

$\square$ Putrescrible

$\square$ Asbestos Containing Material
Q Industrial ofs $8 / 22 / 07$

X-FFAEO-Ongite

$\square$ FFACO-offsite

$\triangle$ Defense Projects

$\square$ Routine

$\triangle$ Process Knowledge $\square$ Contents

Method of Characterization: (check one) $\square$ Sampling \& Analysis

$\square$ WAC Exception

Prohibited Waste at all three

NTS landfills:

Additional Prohibited Waste

at the Area 9 U10C Landfill:

levels, and Medical wastes (needles, sharps, bloody clothing).

Sewage Sludge, Animal carcasses, Wet garbage (food waste); and Friable asbestos

\section{REQUIRED: WASTE CONTENTS ALLOWABLE WASTES}

Check all allowable wastes that are contained within this load:

NOTE: Waste disposal at the Area 6 Hydrocarbon Landfill must have come into contact with petroleum hydrocarbons or coolants, such as: gasoline (no benzene, lead); jet fuel; diesel fuel; lubricants and hydraulics; kerosene; asphaltic petroleum hydrocarbon; and ethylene glycol.

\section{Acceptable waste at any NTS landfill: $\square$ Paper}

$\triangle$ Asphalt $\bigotimes$ Metal $\bigotimes$ Wood

$\triangle$ Soil

Rocks / unaltered geologic materials

\.astic

Wire

$凶$ Cable

$\otimes$ Cloth

Rubber (excluding tires)

$\bigotimes$ Insulation (non-Asbestosform)

$\bigotimes$ Empty containers

$\bigotimes$ Demolition debris

$\bigotimes$ Manufactured items: (swamp coolers, furniture, rugs, carpet, electronic components, PPE, etc.)
Additional waste accepted at the Area 23 Mercury Landfill:
$\square$ Office Waste
$\square$ Food Waste
Animal Carcasses

$\square$ Asbestos

Friable

$\square$ Non-Friable (contact SWO if regulated load)

Quantity:

Additional waste accepted at the Area 9 U10c Landfill:

$\square$ Non-friable asbestos

Light ballasts (contact SWO)

Hydrocarbons (contact SWO)

Drained automobiles and military vehicles

Drained fuel filters (gas \& diesel)

Other

Drained generators/equipment
Solid fractions from sand/oil/water

$\bigotimes$ Deconned Underground and Above Ground Tanks

Additional waste accepted at the Area 6 Hydrocarbon Landfill:
$\square$ Septic sludge
$\square$ Rags
$\square$ Drained fuel filters (gas \& diesel)
Crushed non-teme plated oil filters
Plants
Soil
Sludge from sand/oil/water separators
PCBs below 50 parts per million

\section{REQUIRED: WASTE GENERATOR SIGNATURE}

Initials: (if initialed, no radiological clearance is necessary.)

The above mentioned waste was generated outside of a Controlled Waste Management Area (CWMA) and to the best of my knowledge, does not contain radiological materials.

To the best of my knowledge, the waste described above contains only those materials site. I have verified this through the waste characterization method identified above ar prohibited and allowable waste items. I have contacted Property Management and hav is approved for disposal in the landfill.

Print Name: Dan Tobiason

Signature:
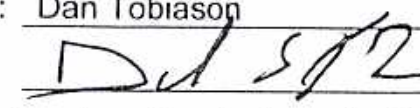

Date:

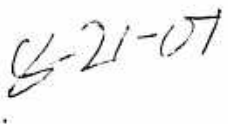

Note: "Food waste, office trash and animal carcasses do not require a radiological clea must have signed removal certification statement with Load Verification."
Radiological Survey Release for Waste Disposal RCT Initials

This container/load meets the criteria for no added man-made radioactive material This container/load mets the criteria for Radcon Manua/Table 4.2 release limits. This containerilgad is exempt from survey due to grocess knowledge and origin.

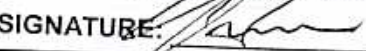
DATE: $8: 21.08$ FRM-0646 (08/06)

\section{SWO USE ONLY}

Load Weight (net from scale or estimate):
$8-21-07$

Signature of Certifier: 


$\begin{array}{llllll}\text { SWO USE (Select One) } & \text { AREA } & \square 23 & \square 6 & \square 9 & \square \text { LANDFILL }\end{array}$

For waste characterization, approval, and/or assistance, contact Solid Waste Operation (SWO) at 5-7898.

REQUIRED: WASTE GERERATOR INFORMATION

(This form is for rolloffs, dump trucks, and other onsite disposal of materials.)

Waste Generator: Dan Tobiason

Phone Number: 295-6169

Location / Origin: T-Tunnel Lower Laydown Yard

Waste Category: (check one)

Waste Type: $\triangle$ NTS

(check one) $\square$ Non-Putrescible

Pollution Prevention Category: (check one)

Pollution Prevention Category: (check one)

Method of Characterization: (check one)

Prohibited Waste at all three

NTS landfills:

Additional Prohibited Waste

at the Area 9 U10C Landfill:
Radioactive waste; RCRA waste; Hazardous waste; Free liquids, PCBs above TSCA regulatory levels, and Medical wastes (needles, sharps, bloody clothing).

Sewage Sludge, Animal carcasses, Wet garbage (food waste); and Friable asbestos

\section{REQUIRED: WASTE CONTENTS ALLOWABLE WASTES}

Check all allowable wastes that are contained within this load:

NOTE: Waste disposal at the Area 6 Hydrocarbon Landfill must have come into contact with petroleum hydrocarbons or coolants, such as: gasoline (no benzene, lead); jet fuel; diesel fuel; lubricants and hydraulics; kerosene; asphaltic petroleurn hydrocarbon; and ethylene glycol.

Acceptable waste at any NTS landfill: $\triangle$ Paper $\square$ Rocks/ unaltered geologic materials

Asphalt

$\bigotimes$ Metal

$\triangle$ Wood

$凶$ Soil

$\bigotimes$ Plastic

Wire

$\triangle$ Cabie

Cloth

\ Rubber (excluding tires)

$\bigotimes$ Insulation (non-Asbestosform)

$\bigotimes$ Empty containers

$\bigotimes$ Demolition debris

$\triangle$ Manufactured items: (swamp coolers, furniture, rugs, carpet, electronic components, PPE, etc.)

Additional waste accepted at the Area 23 Mercury Landfill: $\square$ Office Waste

Asbestos

Friable

$\square$ Non-Friable (contact SWO if regulated load)

$\square$ Food Waste

$\otimes$ Cement \& concrete

Additional waste accepted at the Area 9 U10c Landfill:

[. Non-friable asbestos

Light ballasts (contact SWO)

Hydrocarbons (contact SWO)

$\square$ Drained automobiles and military vehicles

$\square$ Drained fuel filters (gas \& diesel)

$\bigotimes$ Other Drained generators/equipment

Quantity:

Additional waste accepted at the Area 6 Hydrocarbon Landfill:
Septic sludge
$\square$ Rags
$\square$ Drained fuel filters (gas \& diesel)
Crushed non-teme plated oil filters
Plants
Soil
Sludge from sand/oil/water separators
REQUIRED: WASTE GENERATOR SIGNATURE

Initials: (if initialed, no radiological clearance is necessary.)

The above mentioned waste was generated outside of a Controlled Waste Manag knowledge, does not contain radiological materials.

To the best of my knowledge, the waste described above contains only those ma site. I have verified this through the waste characterization method identified ab prohibited and allowable waste items. I have contacted Property Management ar is approved for disposal in the landfill.

Print Name: Dan Tobiason

Signature:
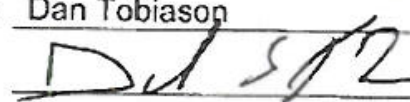
$6-2,-07$

Date:
Solid fractions from sand/oil/water

$\bigotimes$ Deconned Underground and Above Ground Tanks

Note: "Food waste, office trash and animal carcasses do not require a radiological clearance. Freon-containing appliances must have signed removal certification statement with Load Verification." 


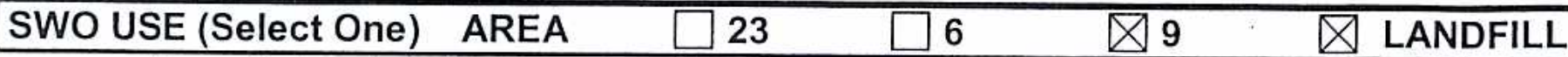

For waste characterization, approval, and/or assistance, contact Solid Waste Operation (SWO) at 5-7898.

REQUIRED: WASTE GERERATOR INFORMATION

(This form is for rolloffs, dump trucks, and other onsite disposal of materials.)

Waste Generator: Dan Tobiason

Phone Number: 295-6169

Location / Origin: T-Tunnel Lower Laydown Yard

Waste Category: (check one)

Waste Type: $\square$ NTS

(check one)

$\square$ Non-Putrescible

Pollution Prevention Category: (check one)

Pollution Prevention Category: (check one)

Method of Characterization: (check one)

$\square$ Commercial

$\square$ Putrescrible

$\square$ Asbestos Containing Material

$\triangle$ Industrial egs 8/22/07

D_EEAGO-onsite

$\square$ WAC Exception

$\square$ Environmental management

$\triangle$ Clean-Up

$\square$ Sampling \& Analysis

$\square$ FFACO-offsite

$\square$ Historic DOE/NV

$\triangle$ Defense Projects $\square$ YMP

$\square$ Routine

$\triangle$ Process Knowledge $\square$ Contents

Prohibited Waste at all three Radioactive waste; RCRA waste; Hazardous waste; Free liquids, PCBs above TSCA regulator NTS landfills:

Additional Prohibited Waste at the Area 9 U10C Landfill:

Sewage Sludge, Animal carcasses, Wet garbage (food waste); and Friable asbestos

\section{REQUIRED: WASTE CONTENTS ALLOWABLE WASTES}

Check all allowable wastes that are contained within this load:

NOTE: Waste disposal at the Area 6 Hydrocarbon Landfill must have come into contact with petroleum hydrocarbons or coolants, such as: gasoline (no benzene, lead); jet fuel; diesel fuel; lubricants and hydraulics; kerosene; asphaltic petroleum hydrocarbon; and ethylene glycol.
Acceptable waste at any NTS landfill:
$\triangle$ Paper
$\square$ Rocks / unaltered geologic materials
Empty containers
$\triangle$ Asphalt
$\triangle$ Metal
$\triangle$ Wood
$\triangle$ Soil
$\bigotimes$ Rubber (excluding tires)
$\triangle$ Plastic $\square$ Wire
$凶$ Cable
$\bigotimes$ Cloth
$\bigotimes$ Insulation (non-Asbestosform)
$\bigotimes$ Demolition debris
$\bigotimes$ Cement \& concrete

$\triangle$ Manufactured items: (swamp coolers, furniture, rugs, carpet, electronic components, PPE, etc.)
Additional waste accepted at the Area 23 Mercury Landfill:
$\square$ Food Waste
Animal Carcasses

Asbestos

Friable

$\square$ Non-Friable (contact SWO if regulated load)

Additional waste accepted at the Area 9 U10c Landfill:

$\square$ Non-friable asbestos

Light ballasts (contact SWO)

Hydrocarbons (contact SWO)

Drained automobiles and military vehicles

Drained fuel filters (gas \& diesel)

Other Drained generators/equipment
Quantity:

Additional waste accepted at the Area 6 Hydrocarbon Landfill:
Septic sludge
$\square$ Rags
$\square$ Drained fuel filters (gas \& diesel)
Crushed non-teme plated oil filters
Plants
Soil
$\square$ Sludge from sand/oil/water separators
$\square$ PCBs below 50 parts per million
REQUIRED: WASTE GENERATOR SIGNATURE

Initials: (if initialed, no radiological clearance is necessary.)

The above mentioned waste was generated outside of a Controlled Waste Manar knowledge, does not contain radiological materials.

To the best of my knowledge, the waste described above contains only those $\mathrm{m}$ : site. I have verified this through the waste characterization method identified ab prohibited and allowable waste items. I have contacted Property Management ai is approved for disposal in the landfill.

Print Name: Dan Tobiason

Signature:
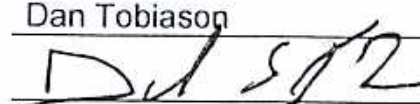

$$
\text { c) }-21-07
$$

Date:
Solid fractions from sand/oil/water

$\bigotimes$ Deconned Underground and Above Ground Tanks

Note: "Food waste, office trash and animal carcasses do not require a radiological clearance. Freon-containing appliances must have signed removal certification statement with Load Verification."

Radiological Survey Release for Waste Disposal RCT Initials

This container/load meets the criteria for no added man-made radioactive material This container/load meets the criteria for Radcon Manual Table 4.2 release limits. This contaireriload is exempt from survey due to process knowledge and origin. SIGNATURE: Lum DATE? Z1 OT FRM-0646 (08/06) 


\begin{tabular}{llllll}
\hline SWO USE (Select One) & AREA & $\square 23$ & $\square 6$ & $\square 9$ & $\square$ LANDFILL
\end{tabular}

For waste characterization, approval, and/or assistance, contact Solid Waste Operation (SWO) at 5-7898.

REQUIRED: WASTE GERERATOR INFORMATION

(This form is for rolloffs, dump trucks, and other onsite disposal of materials.)

Waste Generator: Dan Tobiason Phone Number: 295-6169

Location / Origin: T-Tunnel Lower Laydown Yard

Waste Category: (check one)

Waste Type: $\square$ NTS

(check one)

$\square$ Non-Putrescible

Pollution Prevention Category: (check one)

Pollution Prevention Category: (check one)

Method of Characterization: (check one)

$\square$ Commercial
$\square$ Putrescrible
$\square$ Asbestos Containing Material
$\square$ Environmental management
$\square$ Clean-Up
$\square$ Sampling \& Analysis

$\triangle$ Industrial egs 8/22/07

$\triangle$-FFAGQ-OAgite

$\square$ WAC Exception

$\square$ FFACO-offsite

$\triangle$ Defense Projects

$\square$ Historic DOE/NV

$\square$ Routine

$\triangle$ Process Knowledge

YMP

Prohibited Waste at all three

NTS landfills:

Additional Prohibited Waste at the Area 9 U10C Landfill: levels, and Medical wastes (needles, sharps, bloody clothing).

Sewage Sludge, Animal carcasses, Wet garbage (food waste); and Friable asbestos

\section{REQUIRED: WASTE CONTENTS ALLOWABLE WASTES}

Check all allowable wastes that are contained within this load:

NOTE: Waste disposal at the Area 6 Hydrocarbon Landfill must have come into contact with petroleum hydrocarbons or coolants, such as: gasoline (no benzene, lead); jet fuel; diesel fuel; lubricants and hydraulics; kerosene; asphaltic petroleum hydrocarbon; and ethylene glycol.

Acceptable waste at any NTS landfill: $\triangle$ Pape

$\triangle$ Asphalt

$\bigotimes$ Metal

$\triangle$ Wood

$\otimes$ Soil

$\square$ Rocks / unaltered geologic materials

$\bigotimes$ Plastic

$\triangle$ Wire

$\triangle$ Cable

$\bigotimes$ Cloth

Rubber (excluding tires)

$\bigotimes$ Insulation (non-Asbestosform)

$\triangle$ Empty containers

$\bigotimes$ Demolition debris

$\bigotimes$ Cement \& concrete

$\triangle$ Manufactured items: (swamp coolers, furniture, rugs, carpet, electronic components, PPE, etc.)

Additional waste accepted at the Area 23 Mercury Landfill: $\square$ Office Waste $\square$ Food Waste
$\square$ Asbestos
Friable
$\square$ Non-Friable (contact SWO if regulated load)
Quantity:

Additional waste accepted at the Area 9 U10c Landfill:

$\square$ Non-friable asbestos

Light ballasts (contact SWO)

Hydrocarbons (contact SWO)

$\square$ Drained automobiles and military vehicles

$\square$ Drained fuel filters (gas \& diesel)

$\bigotimes$ Other

Drained generators/equipment
Solid fractions from sand/oil/water

$\bigotimes$ Deconned Underground and Above Ground Tanks

Additional waste accepted at the Area 6 Hydrocarbon Landfill:
$\square$ Septic sludge
$\square$ Rags
$\square$ Drained fuel filters (gas \& diesel)
Plants
$\square$ Soil
$\square$ Sludge from sand/oil/water separators
Crushed non-teme plated oil filters REQUIRED: WASTE GENERATOR SIGNATURE

Initials: (if initialed, no radiological clearance is necessary.)

The above mentioned waste was generated outside of a Controlled Waste Manag knowledge, does not contain radiological materials.

To the best of my knowledge, the waste described above contains only those ma site. I have verified this through the waste characterization method identified ab. prohibited and allowable waste items. I have contacted Property Management ar is approved for disposal in the landfill.

Print Name: Dan Tobiason

Signature:
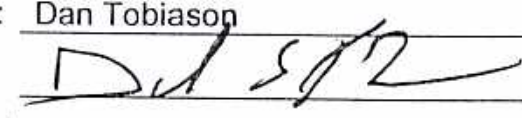

Radiological Survey Release for Waste Disposal RCT Initials

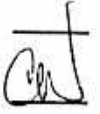

This container/load meets the criteria for no adied man-made radioactive material This containerlibad meets the criteria for Radcon Manual Table 4.2 release limits. This container/load is exempt from survey due top process knowledge and origin.

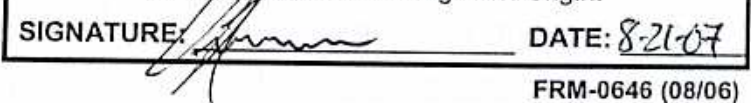

Note: "Food waste, office trash and animal carcasses do not require a radiological clearance. Freon-containing appliances must have signed removal certification statement with Load Verification."

\section{SWO USE ONLY}

Load Weight (net from scale or estimate):
32,000
$8 / 21 / 07$ Signature of Certifier: $\angle$

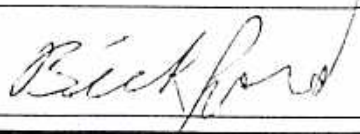




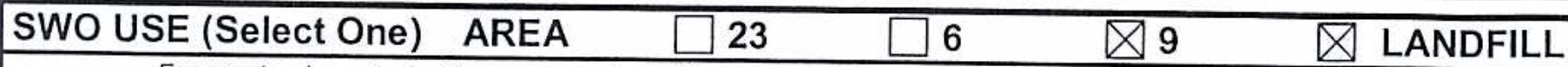

For waste characterization, approval, and/or assistance, contact Solid Waste Operation (SWO) at 5-7898.

REQUIRED: WASTE GERERATOR INFORMATION

(This form is for rolloffs, dump trucks, and other onsite disposal of materials.)

Waste Generator: Dan Tobiason

Phone Number: 295-6169

Location / Origin: T-Tunnel Lower Laydown Yard

Waste Category: (check one)

Waste Type: $\triangle$ NTS

(check one)

Non-Putrescible

Pollution Prevention Category: (check one)

Pollution Prevention Category: (check one)

Method of Characterization: (check one)

$\square$ Commercial

$\square$ Putrescrible

$\square$ Asbestos Containing Material

Environmental management

$\triangle$ Clean-Up

$\square$ Sampling \& Analysis

Prohibited Waste at all three

NTS landfills:

Additional Prohibited Waste

at the Area 9 U10C Landfill:

Radioactive waste; RCRA waste; Hazardous waste; Free liquids, PCBs above TSCA regulatory levels, and Medical wastes (needles, sharps, bloody clothing)

Sewage Sludge, Animal carcasses, Wet garbage (food waste); and Friable asbestos

\section{REQUIRED: WASTE CONTENTS ALLOWABLE WASTES}

Check all allowable wastes that are contained within this load:

NOTE: Waste disposal at the Area 6 Hydrocarbon Landfill must have come into contact with petroleum hydrocarbons or coolants, such as: gasoline (no benzene, lead); jet fuel; diesel fuel; lubricants and hydraulics; kerosene; asphaltic petroleum hydrocarbon; and ethylene glycol.
Acceptable waste at any NTS Iandfill:
$\triangle$ Paper
$\triangle$ Asphalt
$\triangle$ Metal
$\triangle$ Wood
$\triangle$ Soil
$\square$ Rocks / unaltered geologic materials
$\triangle$ Empty containers
$\bigotimes$ Plastic $\quad$ Wire
$\triangle$ Cable
$凶$ Cloth
$\triangle$ Rubber (excluding tires)
$\triangle$ Insulation (non-Asbestosform)
$\bigotimes$ Demolition debris

$\bigotimes$ Manufactured items: (swamp coolers, furniture, rugs, carpet, electronic components, PPE, etc.)

\section{Additional waste accepted at the Area 23 Mercury Landfill: $\square$ Office Waste}

$\square$ Asbestos

Friable

Non-Friable (contact SWO if regulated load)

$\square$ Food Waste

Animal Carcasses

Additional waste accepted at the Area 9 U10c Landfill:

$\square$ Non-friable asbestos

Light ballasts (contact SWO)

Hydrocarbons (contact SWO)
Drained automobiles and military vehicles

Drained fuel filters (gas \& diesel)

Other Drained generators/equipment
Quantity:

Additional waste accepted at the Area 6 Hydrocarbon Landfill:
$\square$ Septic sludge
$\square$ Rags
Plants
Soil
$\square$ Drained fuel filters (gas \& diesel)
$\square$ Sludge from sand/oil/water separators
REQUIRED: WASTE GENERATOR SIGNATURE
Crushed non-teme plated oil filters PCBs below 50 parts per million

Initials: (if initialed, no radiological clearance is necessary.)

The above mentioned waste was generated outside of a Controlled Waste Manag knowledge, does not contain radiological materials.

To the best of my knowledge, the waste described above contains only those mat site. I have verified this through the waste characterization method identified abc prohibited and allowable waste items. I have contacted Property Management an is approved for disposal in the landfill.

Print Name: Dan Tobiason

Signature:
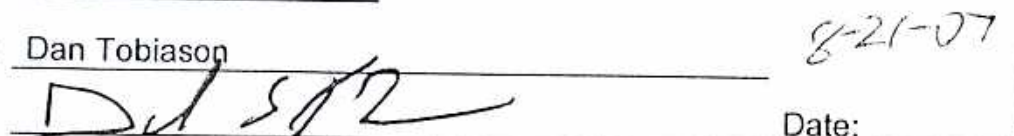

Date:

Solid fractions from sand/oil/water

$\bigotimes$ Deconned Underground and Above Ground Tanks

Note: "Food waste, office trash and animal carcasses do not require a radiological clearance. Freon-containing applian FRM-0646 (08/06) must have signed removal certification statement with Load Verification."

\section{SWO USE ONLY}

Load Weight (net from scale gr estimate): 5,900 $8 / 21 / 07$ Signature of Certifier: $\triangle$ 


\section{\begin{tabular}{llllll}
\hline SWO USE (Select One) & AREA & $\square 23$ & $\square 6$ & \9 & Q LANDFILL
\end{tabular}}

For waste characterization, approval, and/or assistance, contact Solid Waste Operation (SWO) at 5-7898.

REQUIRED: WASTE GERERATOR INFORMATION

(This form is for rolloffs, dump trucks, and other onsite disposal of materials.)

Waste Generator: Dan Tobiason

Phone Number: 295-6169

Location / Origin: T-Tunnel Lower Laydown Yard

Waste Category: (check one)

Waste Type: $\square$ NTS

(check one)

$\square$ Non-Putrescible

$\square$ Commercial

$\square$ Putrescrible

$\triangle$ Industrial cgs $8 / 23 / 07$

Pollution Prevention Category: (check one) $\square$ Environmental management

Pollution Prevention Category: (check one) $₫$ Clean-Up

Method of Characterization: (check one) $\square$ Sampling \& Analysis

$\square$ FFACO-offsite

$\square$ WAC Exception

$\bigotimes$ Defense Projects

$\square$ Historic DOE/NV

\section{Prohibited Waste at all three}

NTS landfills:

Additional Prohibited Waste

at the Area 9 U10C Landfill:
Radioactive

$\square$ Routine

$\triangle$ Process Knowledge $\square$ Contents

levels, and Medical wastes (needles, sharps, bloody clothing).

Sewage Sludge, Animal carcasses, Wet garbage (food waste); and Friable asbestos

REQUIRED: WASTE CONTENTS ALLOWABLE WASTES

Check all allowable wastes that are contained within this load:

NOTE: Waste disposal at the Area 6 Hydrocarbon Landfill must have come into contact with petroleum hydrocarbons or coolants, such as: gasoline (no benzene, lead); jet fuel; diesel fuel; lubricants and hydraulics; kerosene; asphaltic petroleum hydrocarbon; and ethylene glycol.
Acceptable waste at any NTS landfill:
$凶$ Paper
$\square$ Rocks / unaltered geologic materials
Empty containers
$\bigotimes$ Asphalt
$\triangle$ Metal
$\triangle$ Wood
\Soil
$\bigotimes$ Rubber (excluding tires)
$\triangle$ Plastic $\square$ Wire
$凶$ Cable
$凶$ Cloth
$\triangle$ Insulation (non-Asbestosform)
$\bigotimes$ Demolition debris

$\triangle$ Manufactured items: (swamp coolers, furniture, rugs, carpet, electronic components, PPE, etc.)
Additional waste accepted at the Area 23 Mercury Landfill: $\quad \square$ Office Waste
$\square$ Food Waste
Animal Carcasses
$\square$ Asbestos
Friable
Non-Friable (contact SWO if regulated load)
Quantity:

\section{Additional waste accepted at the Area 9 U10c Landfill:}

Non-friable asbestos

Light ballasts (contact SwO)

$\square$

Hydrocarbons (contact SWO)

Drained fuel filters (gas \& diesel)

Other Drained generators/equipment
Solid fractions from sand/oil/water

$\bigotimes$ Deconned Underground and Above Ground Tanks

Additional waste accepted at the Area 6 Hydrocarbon Landfill:
$\square$ Septic sludge
$\square$ Rags
$\square$ Drained fuel filters (gas \& diesel)
Plants
Soil
$\square$ Sludge from sand/oil/water separators
$\square$ Crushed non-teme plated oil filters
$\square$ PCBs below 50 parts per million REQUIRED: WASTE GENERATOR SIGNATURE

Initials: (if initialed, no radiological clearance is necessary.)

The above mentioned waste was generated outside of a Controlled Waste Management Area (CWMA) and to the best of my knowledge, does not contain radiological materials.

To the best of my knowledge, the waste described above contains only thc site. I have verified this through the waste characterization method identifi prohibited and allowable waste items. I have contacted Property Managem is approved for disposal in the landfill.

Print Name: Dan Tobiason Signature:
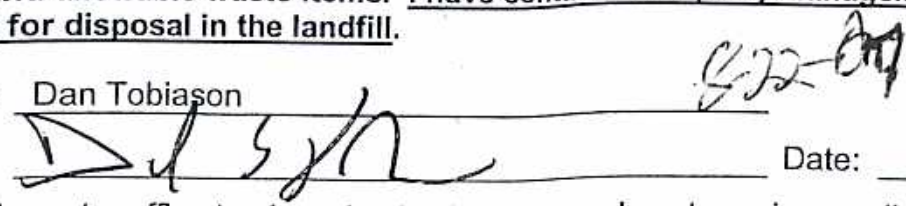

Note: "Food waste, office trash and animal carcasses do not require a radiol must have signed removal certification statement with Load Verification.

Radiological Survey Release for Waste Disposal RCT Initials

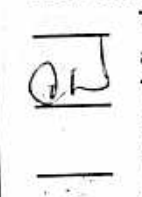

This container/load meets the criteria for no added man-made radioactive material This container/load meets the criteria for Radcon Manual Jable 4.2 release limits. This containefyoad is exempt from survey due to $5006 \mathrm{~s}$ knowledge and origin.

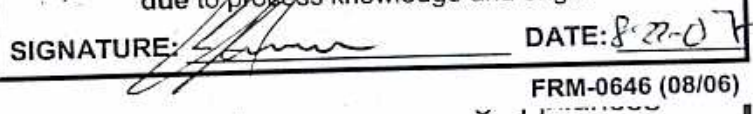

\section{SWO USE ONLY}

Load Weight (net from scale or estimate): 6,000 $8-z z-c 7$ Signature of Certifier: 
For waste characterization, approval, and/or assistance, contact Solid Waste Operation (SWO) at 5-7898.

REQUIRED: WASTE GERERATOR INFORMATION

(This form is for rolloffs, dump trucks, and other onsite disposal of materials.)

Waste Generator: Dan Tobiason

Phone Number: 295-6169

Location / Origin: T-Tunnel Lower Laydown Yard

Waste Category: (check one)

Waste Type: $\square$ NTS

(check one) $\quad \square$ Non-Putrescible

$\square$ Commercial

$\square$ Putrescrible

$\triangle$ Industrial cqs $8 / 23 / 07$

$\square$ Asbestos Containing Material

\-FFAGQ-onsite

$\square$ WAC Exception

Pollution Prevention Category: (check one)

Pollution Prevention Category: (check one)

Method of Characterization: (check one)

$\square$ Environmental management

$\triangle$ Clean-Up

$\square$ FFACO-offsite
$\square$ Defense Projects
$\square$ Routine

$\square$ Historic DOE/NV

Prohibited Waste at all three

NTS landfills:

Additional Prohibited Waste

at the Area 9 U10C Landfill:

\section{levels, and Medical wastes (needles, sharps, bloody clothing).}

Sewage Sludge, Animal carcasses, Wet garbage (food waste); and Friable asbestos

\section{REQUIRED: WASTE CONTENTS ALLOWABLE WASTES}

Check all allowable wastes that are contained within this load:

NOTE: Waste disposal at the Area 6 Hydrocarbon Landfill must have come into contact with petroleum hydrocarbons or coolants, such as: gasoline (no benzene, lead); jet fuel; diesel fuel; lubricants and hydraulics; kerosene; asphaltic petroleum hydrocarbon; and ethylene glycol.
Acceptable waste at any NTS landfill:
$\triangle$ Asphalt
$\bigotimes$ Metal
$\bigotimes$ Wood
$\triangle$ Paper
$凶$ Soil
$\triangle$ Cable
$\otimes$ Cloth
$\square$ Rocks / unaltered geologic materials
$\triangle$ Rubber (excluding tires)
$\triangle$ Insulation (non-Asbestosform)
$\bigotimes$ Empty containers
$\triangle$ Plastic $\triangle$ Wire
$\bigotimes$ Demolition debris
$\bigotimes$ Cement \& concrete

wamp coolers,

,urniture, rugs

carpet, electronic components, PPE, etc.)

Additional waste accepted at the Area 23 Mercury Landfill: $\square$ Office Waste

$\square$ Asbestos

Friable

$\square$ Non-Friable (contact SWO if regulated load)

$\square$ Food Waste

Additional waste accepted at the Area $9 \mathrm{U10}$ c Landfill:

$\square$ Non-friable asbestos

$\square$ Light ballasts (contact SWO)

$\square$ Hydrocarbons (contact SWO)

$\square$ Drained automobiles and military vehicles

$\square$ Drained fuel filters (gas \& diesel)

$\triangle$ Other

Drained generators/equipment
Quantity:

\section{Additional waste accepted at the Area 6 Hydrocarbon Landfill:}

$\square$ Septic sludge $\square$ Rags

Plants

$\square$ Soil

$\square$ Drained fuel filters (gas \& diesel)

$\square$ Sludge from sand/oil/water separators

REQUIRED: WASTE GENERATOR SIGNATURE

Solid fractions from sand/oil/water

$凶$ Deconned Underground and Above Ground Tanks

Initials: (if initialed, no radiological clearance is necessary.)

The above mentioned waste was generated outside of a Controlled Waste Ma knowledge, does not contain radiological materials.

To the best of my knowledge, the waste described above contains only those site. I have verified this through the waste characterization method identified prohibited and allowable waste items. I have contacted Property Management is approved for disposal in the landfill.

Print Name: Dan Tobiason

Signature:
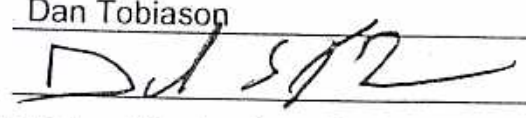

Date:

Crushed non-teme plated oil filters PCBs below 50 parts per million Note: "Food waste, office trash and animal carcasses do not require a radiological clearance. Freon-containing appliances (08/06) must have signed removal certification statement with Load Verification."

LWO USE ONLY

Lad Weight (net from scale of estimate): $6,3 \mathrm{c}$

Signature of Certifier: 2

Radiological Survey Release for Waste Disposal RCT Initials

- This container/load meets the criteria for no added man-made radioactive material This container/load meets the criteria for Radcon Manual fable 4.2 release limits. This containg Moad is exempt from survey due to promess knowledge and origin.

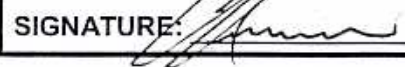
DATE: $21-07$ Freon-containing appliances 
Form

For waste characterization, approval, and/or assistance, contact Solid Waste Operation (SWO) at 5-7898.

REQUIRED: WASTE GERERATOR INFORMATION

(This form is for rolloffs, dump trucks, and other onsite disposal of materials.)

Waste Generator: Dan Tobiason

Phone Number: 295-6169

Location / Origin: T-Tunnel Lower Laydown Yard

Waste Category: (check one)

Waste Type: $\square$ NTS

Commercial

(check one)

$\square$ Non-Putrescible

$\square$ Putrescrible

$\triangle$ Industrial

$\triangle$ IFACO-OASite

$8 / 25107$

$\square$ Asbestos Containing Material

$\square$ FFACO-offsite

Pollution Prevention Category: (check one)

Pollution Prevention Category: (check one)

$\square$ Environmental management

$\triangle$ Defense Projects

$\square$ WAC Exception

Method of Characterization: (check one)

$\triangle$ Clean-Up

Prohibited Waste at all three

NTS landfills:

Additional Prohibited Waste at the Area 9 U10C Landfill:

Radioactive waste; RCRA waste; Hazardous waste; Free liquids, PCBs above TSCA regulatory levels, and Medical wastes (needles, sharps, bloody clothing).

Sewage Sludge, Animal carcasses, Wet garbage (food waste); and Friable asbestos

\section{REQUIRED: WASTE CONTENTS ALLOWABLE WASTES}

Check all allowable wastes that are contained within this load:

NOTE: Waste disposal at the Area 6 Hydrocarbon Landfill must have come into contact with petroleum hydrocarbons or coolants, such as: gasoline (no benzene, lead); jet fuel; diesel fuel; lubricants and hydraulics; kerosene; asphaltic petroleum hydrocarbon; and ethylene glycol.

Acceptable waste at any NTS landfill: $\square$ Paper

$\triangle$ Asphalt $\quad$ Metal $\quad$ Wood $\quad$ Soil

$\triangle$ Plastic $\quad$ Wire $\quad \square$ Cable $\quad$ Cloth

$\square$ Rocks / unaltered geologic materials

$\bigotimes$ Rubber (excluding tires)

$\bigotimes$ Insulation (non-Asbestosform) $\triangle$ Empty containers

$\triangle$ Demolition debris

$\bigotimes$ Cement \& concrete

$\bigotimes$ Manufactured items: (swamp coolers, furniture, rugs, carpet, electronic components, PPE, etc.)

Additional waste accepted at the Area 23 Mercury Landfill: $\square$ Office Waste $\square$ Food Waste $\square$ Animal Carcasses

$\square$ Asbestos $\quad \square$ Friable $\quad \square$ Non-Friable (contact SWO if regulated load) Quantity:

Additional waste accepted at the Area 9 U10c Landfill:

$\square$ Non-friable asbestos

$\square$ Light ballasts (contact SWO)

$\square$ Drained automobiles and military vehicles

Drained fuel filters (gas \& diesel)

Hydrocarbons (contact SWO)

$凶$ Other

Drained generators/equipment

$\square$ Solid fractions from sand/oil/water

$\bigotimes$ Deconned Underground and Above Ground Tanks

Additional waste accepted at the Area 6 Hydrocarbon Landfill:

$\begin{array}{llll}\square \text { Septic sludge } & \square \text { Rags } & \square \text { Drained fuel filters (gas \& diesel) } & \square \text { Crushed non-teme plated oil filters } \\ \square \text { Plants } & \square \text { Soil } & \square \text { Sludge from sand/oil/water separators } \square \text { PCBs below } 50 \text { parts per million }\end{array}$

Initials: (if initialed, no radiological clearance is necessary.)

The above mentioned waste was generated outside of a Controlled Waste Management Area (CWMA) and to the best of my knowledge, does not contain radiological materials.

To the best of my knowledge, the waste described above contains only those site. I have verified this through the waste characterization method identified prohibited and allowable waste items. I have contacted Property Managemen is approved for disposal in the landfill.

Print Name: Dan Tobiason

Signature:
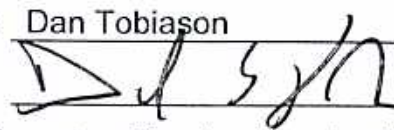

$8-22-1)$

Date:

Radiological Survey Release for Waste Disposal RCT Initials

This container/load meets the criteria for no

added man-made radioactive material

(d) This container/load meets the criteria for Radcon Manuakffable 4.2 release limits. This containe flload is exempt from survey due to ptocess knowledge and origin.

SIGNATURE: DATE: $\{-2-C 7$ FRM-0646 (08/06)

Note: "Food waste, office trash and animal carcasses do not require a radiolog must have signed remaval certification statement with Load Verification."

SWO USE ONLY

Load Weight (net from scale or estimate): 6,100
$8-22-07$

Signature of Certifier: $\mathrm{On}$ 
NSTec

Form

FRM-0918

NTS LANDFILL LOAD VERIFICATION

\section{$\begin{array}{llllll}\text { SWO USE (Select One) } & \text { AREA } & \square 23 & \square 6 & \text { AR } & \text { Q LANDFILL }\end{array}$}

For waste characterization, approval, and/or assistance, contact Solid Waste Operation (SWO) at 5-7898.

REQUIRED: WASTE GERERATOR INFORMATION

(This form is for rolloffs, dump trucks, and other onsite disposal of materials.)

Waste Generator: Dan Tobiason

Phone Number: 295-6169

Location / Origin: T-Tunnel Lower Laydown Yard

Waste Category: (check one)

Waste Type: $\triangle$ NTS

Pollution Prevention Category: (check one)

Pollution Prevention Category: (check one)

Method of Characterization: (check one)

$\square$ Commercial

$\square$ Putrescrible

Industrial ofs $8 / 23 / 07$

$\square$ Asbestos Containing Material

$\triangle F F A G \theta-O n B i t e$

$\square$ WAC Exception

Environmental management

$\triangle$ Clean-Up

$\square$ Sampling \& Analysis

$\square$ FFACO-offsite

$\triangle$ Defense Projects

$\square$ Historic DOE/NV

Prohibited Waste at all three

NTS landfills:

Additional Prohibited Waste

at the Area 9 U10C Landfill:

levels, and Medical wastes (needles, sharps, bloody clothing)

Sewage Sludge, Animal carcasses, Wet garbage (food waste); and Friable asbestos

\section{REQUIRED: WASTE CONTENTS ALLOWABLE WASTES}

Check all allowable wastes that are contained within this load:

NOTE: Waste disposal at the Area 6 Hydrocarbon Landfill must have come into contact with petroleum hydrocarbons or coolants, such as: gasoline (no benzene, lead); jet fuel; diesel fuel; lubricants and hydraulics; kerosene; asphaltic petroleum hydrocarbon; and ethylene glycol.

Acceptable waste at any NTS landfill:

$\triangle$ Asphalt $\quad$ Metal $\otimes$ Wood $\otimes$ Soil

$\triangle$ Plastic $\square$ Wire $\quad$ Cable $\quad$ Cloth

$\square$ Rocks / unaltered geologic materials

$\triangle$ Rubber (excluding tires)

\Insulation (non-Asbestosform)

$\bigotimes$ Empty containers

$\triangle$ Demolition debris

$\triangle$ Manufactured items: (swamp coolers, furniture, rugs, carpet, electronic components, PPE, etc.)

Additional waste accepted at the Area 23 Mercury Landfill: $\square$ Office Waste

$\square$ Asbestos $\square$ Friable $\quad \square$ Non-Friable (contact SWO if regulated load)

$\square$ Food Waste

$\bigotimes$ Cement \& concrete

Additional waste accepted at the Area 9 U10c Landfill:

$\square$ Non-friable asbestos

$\square$ Light ballasts (contact SWO)

Hydrocarbons (contact SWO)

$\square$ Drained automobiles and military vehicles

$\square$ Drained fuel filters (gas \& diesel)

$\bigotimes$ Other Drained generators/equipment

Quantity:

Animal Carcasses

Additional waste accepted at the Area 6 Hydrocarbon Landfill:
$\square$ Septic sludge
Plants
$\square$ Rags
Soil
$\square$ Drained fuel filters (gas \& diesel)
$\square$ Sludge from sand/oil/water separators
Crushed non-teme plated oil filters
PCBs below 50 parts per million

REQUIRED: WASTE GENERATOR SIGNATURE

Initials: (if initialed, no radiological clearance is necessary.)

The above mentioned waste was generated outside of a Controlled Waste Mananement Area (C.WMA) and to the hest of mv knowledge, does not contain radiological materials.

To the best of my knowledge, the waste described above contains only thos site. I have verified this through the waste characterization method identifit prohibited and allowable waste items. I have contacted Property Managem! is approved for disposal in the landfill.

Print Name:

Signature:
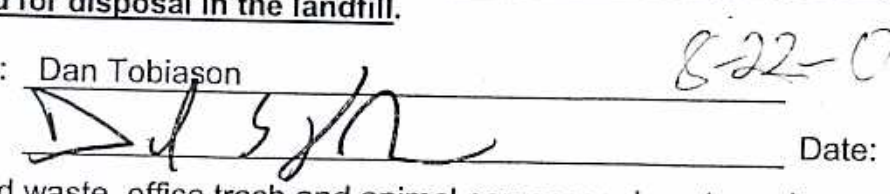

Radiological Survey Release for Waste Disposal RCT Initials

This container/load meets the criteria for no added man-made radioactive material This container/load meets the criteria for Radcon Manual Table 4.2 release limits. This container/load is exempt from survey due to process knowledge and origin.

Note: "Food waste, office trash and animal carcasses do not require a radioluy must have signed removal certification statement with Load Verification."

SWO USE ONLY

Load Weight (net from scale on $8-22-07$ Signature of Certifier 


\section{NSTec \\ Form \\ FRM-0918 \\ NTS LANDFILL LOAD VERIFICATION}

Page

SWO USE (Select One) AREA

$\square \square$

69

$\triangle 9$ Q

For waste characterization, approval, and/or assistance, contact Solid Waste Operation (SWO) at 5-7898.

REQUIRED: WASTE GERERATOR INFORMATION

(This form is for rolloffs, dump trucks, and other onsite disposal of materials.)

Waste Generator: Dan Tobiason

Phone Number: 295-6169

Location / Origin: T-Tunnel Lower Laydown Yard

Waste Category: (check one)

Waste Type: $\triangle$ NTS

(check one)

$\square$ Non-Putrescible

$\square$ Commercial
$\square$ Putrescrible

Pollution Prevention Category: (check one)

Pollution Prevention Category: (check one)

Method of Characterization: (check one)

$\square$ Asbestos Containing Material

$\triangle$ Industrial gfs s/27/07

$\triangle F F A C O-O A S i t e$

WAC Exception

$\square$ Environmental management

$\triangle$ Clean-Up

Prohibited Waste at all thr: (check one)

Sampling \& Analysis

FFACO-offsite

$\square$ Historic DOE/NV

NTS landfills:

Additional Prohibited Waste

at the Area 9 U10C Landfill:

levels, and Medical wastes (needles, sharps, bloody clothing).

Sewage Sludge, Animal carcasses, Wet garbage (food waste); and Friable asbestos

\section{REQUIRED: WASTE CONTENTS ALLOWABLE WASTES}

Check all allowable wastes that are contained within this load:

NOTE: Waste disposal at the Area 6 Hydrocarbon Landfill must have come into contact with petroleum hydrocarbons or coolants, such as: gasoline (no benzene, lead); jet fuel; diesel fuel; lubricants and hydraulics; kerosene; asphaltic petroleum hydrocarbon; and ethylene glycol.

Acceptable waste at any NTS landfill: $\square$ Pape

$\triangle$ Asphalt $\square$ Metal $\square$ Wood $\square$ Soil

$\triangle$ Plastic $\quad$ Wire

$\bigotimes$ Cable

Cloth

$\square$ Rocks / unaltered geologic materials

$\triangle$ Rubber (excluding tires)

$\triangle$ Insulation (non-Asbestosform)

Empty containers

$\bigotimes$ Demolition debris

$\triangle$ Manufactured items: (swamp coolers, furniture, rugs, carpet, electronic components, PPE, etc.)

Additional waste accepted at the Area 23 Mercury Landfill: $\square$ Office Waste

$\square$ Asbestos

Friable

Non-Friable (contact SWO if regulated load)

$\square$ Food Waste

Quantity:

Additional waste accepted at the Area 9 U10c Landfill:

Non-friable asbestos

Light ballasts (contact SWO)

Hydrocarbons (contact Swo

$\square$ Drained automobiles and military vehicles

$\square$ Drained fuel filters (gas \& diesel)

$\bigotimes$ Other Drained generators/equipment
Solid fractions from sand/oil/water

$\bigotimes$ Deconned Underground and Above Ground Tanks

Additional waste accepted at the Area 6 Hydrocarbon Landfill:
Septic sludge
$\square$ Rags
$\square$ Drained fuel filters (gas \& diesel)
Plants
$\square$ Soil
$\square$ Sludge from sand/oil/water separators
REQUIRED: WASTE GENERATOR SIGNATURE
Crushed non-teme plated oil filters
PCBs below 50 parts per million

Initials: (if initialed, no radiological clearance is necessary.) The above mentioned waste was generated outside of a Controlled Waste Management Area (CWMA) and to the best of my
knowledge, does not contain radiological materials.

To the best of my knowledge, the waste described above contains only those $n$ site. I have verified this through the waste characterization method identified a prohibited and allowable waste items. I have contacted Property Management is approved for disposal in the landfill.

Print Name: Dan Tobiason

Signature:
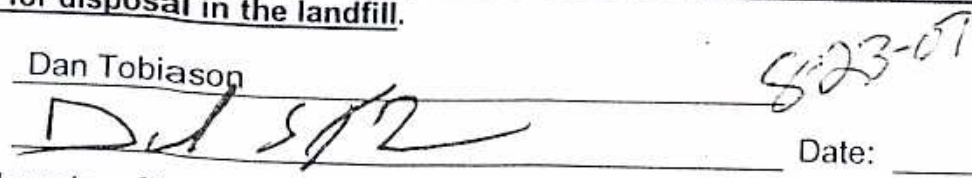

Date:

Note: "Food waste, office trash and animal carcasses do not require a radiolog must have signed removal certification statement with Lead Verification.

SWO USE ONLY

Load Weight (net from scale on estimate) 32,000

$8-23-07$ Signature of Certifier:
Radiological Survey Release for Waste Disposal RCT Initials

This container/load meets the criteria for no added man-made radioactive material This container/load meets the criteria for Radcon Manyải Table 4.2 release limits. due to proess knowlon is exempt from survey SIGNATURE: DATES: 20107 FRM-0646 (08/D6) 


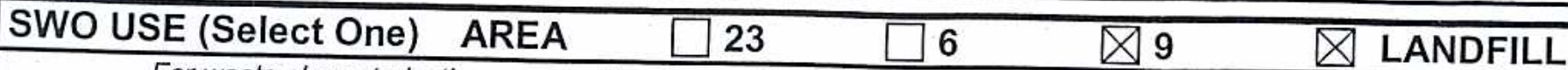

For waste characterization, approval, and/or assistance, contact Solid Waste Operation (SWO) at 5-7898.

\section{REQUIRED: WASTE GERERATOR INFORMATION}

(This form is for rolloffs, dump trucks, and other onsite disposal of materials.)

Waste Generator: Dan Tobiason

Phone Number: 295-6169

Location / Origin: T-Tunnel Lower Laydown Yard

Waste Category: (check one)

Waste Type: $\triangle$ NTS

(check one)

$\square$ Non-Putrescible

$\square$ Commercial

$\square$ Putrescrible

$\triangle$ Industrial cf5 8/27/07

$\square$ Asbestos Containing Material

Category: (check one)

Pollution Prevention Category: (check one)

$\square$ Environmental management

Method of Characterization: (check one)

$\triangle$ Clean-Up

$\square$ Sampling \& Analysis

$\triangle F F A G Q$-ansite

$\square$ WAC Exception

$\square$ FFACO-offsite

$\square$ Historic DOE/NV

Prohibited Wast

Additional Prohibited Waste

at the Area 9 U10C Landfill:

levels, and waste; RCRA waste; Hazardous waste; Free liquids, PCBs above TSCA regulatory levels, and Medical wastes (needles, sharps, bloody clothing).

Sewage Sludge, Animal carcasses, Wet garbage (food waste); and Friable asbestos

\section{REQUIRED: WASTE CONTENTS ALLOWABLE WASTES}

Check all allowable wastes that are contained within this load:

NOTE: Waste disposal at the Area 6 Hydrocarbon Landfill must have come into contact with petroleum hydrocarbons or coolants, such as: gasoline (no benzene, lead); jet fuel; diesel fuel; lubricants and hydraulics; kerosene; asphaltic petroleum hydrocarbon; and ethylene glycol.
Acceptable waste at any NTS landfill:
$\triangle$ Asphalt
Metal
$\bigotimes$ Wood
$\triangle$ Paper
$\triangle$ Soil
$\square$ Rocks / unaltered geologic materials
$\triangle$ Plastic
$\triangle$ Wire
$凶$ Cable
$\otimes$ Cloth
$\bigotimes$ Rubber (excluding tires)
Insulation (non-Asbestosform)

$\bigotimes$ Empty containers
$\bigotimes$ Demolition debris
$\bigotimes$ Cement \& concrete

$\triangle$ Manufactured items: (swamp coolers, furniture, rugs, carpet, electronic components, PPE, etc.)
Additional waste accepted at the Area 23 Mercury Landfill:
Asbestos
Friable
$\square$ Food Waste

Non-Friable (contact SWO if regulated load)

Animal Carcasses

Additional waste accepted at the Area 9 U10c Landfill:
$\square$ Non-friable asbestos
Light ballasts (contact SWO)
Hydrocarbons (contact SWO)
Drained automobiles and military vehicles
Drained fuel filters (gas \& diesel)

Other

Drained generators/equipment

Quantity:

Additional waste accepted at the Area 6 Hydrocarbon Landfill:

$\begin{array}{ll}\square \text { Septic sludge } & \square \text { Rags } \\ \square \text { Plants } & \square \text { Soil }\end{array}$

Soil

$\square$ Drained fuel filters (gas \& diesel)

$\square$ Sludge from sand/oil/water separators

REQUIRED: WASTE GENERATOR SIGNATURE

Solid fractions from sand/oil/water

$\triangle$ Deconned Underground and Above Ground Tanks

Initials: (if initialed, no radiological clearance is necessary.)

The above mentioned waste was generated outside of a Controlled Waste Management Area (CWMA) and to the best of my knowledge, does not contain radiological materials.

To the best of my knowledge, the waste described above contains only thos site. I have verified this through the waste characterization method identifie prohibited and allowable waste items. I have contacted Property Manageme is approved for disposal in the landfill.

Print Name: Dan Tobiason

Signature:
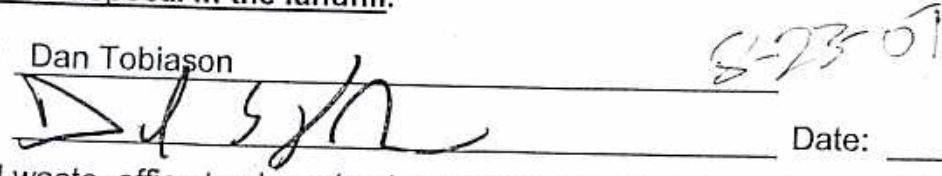

Radiological Survey Release for Waste Disposal RCT Initials

This container/load meets the criteria for no

added man-made radioactive material

This container/load meets the criteria for Radcon Manual Tabte 4.2 release limits. This container/load is exempt from survey due to process hrowledge and origin.

Note: "Food waste, office trash and animal carcasses do not require a radiolo must have signed removal certification statement with Load Verification."

\section{SWO USE ONLY}

Load Weight (net from scale or estimate): 40000
$8-23-07$ Signature of Certifier: DATE: $\underline{8-73.07}$ FRM-0646 (08/06) 
Form

\section{$\begin{array}{llllll}\text { SWO USE (Select One) } & \text { AREA } & \square 23 & \square 6 & \text { Q } 9 & \text { LANDFILL }\end{array}$}

For waste characterization, approval, and/or assistance, contact Solid Waste Operation (SWO) at 5-7898.

REQUIRED: WASTE GERERATOR INFORMATION

(This form is for rolloffs, dump trucks, and other onsite disposal of materials.)

Waste Generator: Dan Tobiason

Phone Number: 295-6169

Location / Origin: T-Tunnel Lower Laydown Yard

Waste Category: (check one)

Waste Type: $\triangle$ NTS

(check one)

$\square$ Non-Putrescible

$\square$ Commercial

$\square$ Putrescrible

$\triangle$ Industrial cgs $8 / 27 / 07$

Pollution Prevention Category: (check one)

Pollution Prevention Category: (check one)

Method of Characterization: (check one)

$\square$ Asbestos Containing Material

$\square$ Environmental management

$\triangle$ Clean-Up

\FFAGQ-onsite $\square$ WAC Exception

$\square$ FFACO-offsite

$\triangle$ Defense Projects

$\square$ Historic DOE/NV

Prohibited Waste at all three
NTS landfills:

Additional Prohibited Waste

at the Area 9 U10C Landfill:

Radioactive waste; RCRA waste; Hazardous waste; Free liquids, PCBs above TSCA regulatory
levels, and Medical wastes (needles,

levels, and Medical wastes (needles, sharps, bloody clothing).

Sewage Sludge, Animal carcasses, Wet garbage (food waste); and Friable asbestos

\section{REQUIRED: WASTE CONTENTS ALLOWABLE WASTES}

Check all allowable wastes that are contained within this load:
NOTE: Waste disposal at the Area 6 Hydrocarbon Landfill must have come into contact with petroleum hydrocarbons or coolants, such as: gasoline (no benzene, lead); jet fuel; diesel fuel; lubricants and hydraulics; kerosene; asphaltic petroleum hydrocarbon; and ethylene glycol.

Acceptable waste at any NTS landfill: $\square$ Paper $\square$ Rocks / unaltered geologic materials

$\triangle$ Asphalt $\triangle$ Metal $\square$ Wood

$\triangle$ Asphalt $\triangle$ Metal $\otimes$ Wood $\triangle$ Soil

Q Plastic

Q Wire

\ Cable

$\triangle$ Cloth

$\bigotimes$ Rubber (excluding tires)

Insulation (non-Asbestosform)

$\triangle$ Empty containers

$\bigotimes$ Demolition debris

$\bigotimes$ Cement \& concrete

$\triangle$ Manufactured items: (swamp coolers, furniture, rugs, carpet, electronic components, PPE, etc.)
Additional waste accepted at the Area 23 Mercury Landfill:
$\square$ Office Waste
$\square$ Food Waste
Animal Carcasses
$\square$ Asbestos
Friable
$\square$ Non-Friable (contact SWO if regulated load)
Quantity:

Additional waste accepted at the Area 9 U10c Landfill:

$\square$ Non-friable asbestos

$\square$ Light ballasts (contact SWO)

Hydrocarbons (contact SWO)

$\square$

Drained automobiles and military vehicles

$\square$ Drained fuel filters (gas \& diesel)

O Other

Drained generators/equipment

Additional waste accepted at the Area 6 Hydrocarbon Landfill:
Septic sludge
Plants
$\square$ Rags
Soil

$\square$ Drained fuel filters (gas \& diesel)
$\square$ Sludge from sand/oil/water separato

REQUIRED: WASTE GENERATOR SIGNAT
Solid fractions from sand/oil/water

$\triangle$ Deconned Underground and Above Ground Tanks

Initials: (if initialed, no radiological clearance is necessary.)

The above mentioned waste was generated outside of a Controlled Waste Management Area (CWMA) and to the best of my knowledge, does not contain radiological materials.

To the best of my knowledge, the waste described above contains only thos site. I have verified this through the waste characterization method identifie prohibited and allowable waste items. I have contacted Property Manageme is approved for disposal in the landfill.

Print Name: Dan Tobiason

Signature:

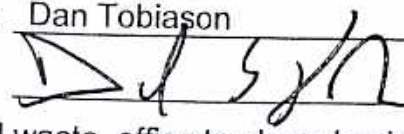

Date:

Note: "Food waste, office trash and animal carcasses do not require a radiol

Radiological Survey Release for Waste Disposal RCT Initials

( This container/load meets the criteria for no added man-made radíoactive material This container/loadmeets the criteria for Radcon Manual Table 4.2 release limits. This containerlload is exempt from survey due toprocess knowledge and origin.

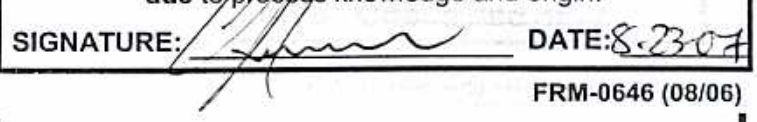

\section{SWO USE ONLY}

Load Weight (net from scale or estimate):
8. 23.07

Signature of Certifier: 
For waste characterization, approval andh REQUIRED: WASTE GERERATOR INFORMATION

(This form is for rolloffs, dump trucks, and other onsite disposal of materials.)

Waste Generator: Dan Tobiason

Phone Number: 295-6169

Location / Origin: T-Tunnel Lower Laydown Yard

Waste Category: (check one)

Waste Type: $\square$ NTS

(check one) $\square$ Non-Putrescible

$\square$ Commercial
$\square$ Putrescrible
$\square$ Asbestos Containing Material
$\square$ Environmental management
$\triangle$ Clean-Up
$\square$ Sampling \& Analysis

$\Delta$ Industrial cfS 8/28/07

QFFACO-Onsite

$\square$ WAC Exception

Pollution Prevention Category: (check one)

Pollution Prevention Category: (check one)

Method of Characterization: (check one)

Prohibited Waste at all three

NTS landfills:

Additional Prohibited Waste

at the Area 9 U10C Landfill:

Radioactive waste; RCRA waste; Hazardous waste; Free liquids, PCBs above TSCA regulatory
levels, and Medical wastes (needles, sharps, bloody clothing).

Sewage Sludge, Animal carcasses, Wet garbage (food waste); and Friable asbestos

\section{REQUIRED: WASTE CONTENTS ALLOWABLE WASTES}

Check all allowable wastes that are contained within this load:
NOTE: Waste disposal at the Area 6 Hydrocarbon Landfill must have come into contact with petroleum hydrocarbons or coolants, such as: gasoline (no benzene, lead); jet fuel; diesel fuel; lubricants and hydraulics; kerosene; asphaltic
petroleum hydrocarbon; and ethylene glycol.

Acceptable waste at any NTS landfill: $\square$ Paper

$\bigotimes$ Asphalt $\quad$ Metal $\quad$ Wood $\quad$ Soil

$\triangle$ Plastic $\quad$ Wire

$\triangle$ Cable

$\triangle$ Cloth
$\square$ Rocks / unaltered geologic materials
$\triangle$ Rubber (excluding tires)
$\triangle$ Insulation (non-Asbestosform)

$\bigotimes$ Empty containers
$\bigotimes$ Demolition debris
$\bigotimes$ Cement \& concrete

$\triangle$ Manufactured items: (swamp coolers, furniture, rugs, carpet, electronic components, PPE, etc.)
Additional waste accepted at the Area 23 Mercury Landfill:
$\square$ Asbestos
Friable
$\square$ Non-Friable (contact SWO if regulated load)
$\square$ Food Waste
Animal Carcasses
Quantity:

Additional waste accepted at the Area 9 U10c Landfill:
$\square$ Non-friable asbestos
$\square$ Light ballasts (contact Swo)
$\square$ Drained automobiles and military vehicles
$\square$ Drained fuel filters (gas \& diesel)
Hydrocarbons (contact SWO)
Other
Drained generators/equipment

Additional waste accepted at the Area 6 Hydrocarbon Landfill:
$\square$ Septic sludge
Plants

$\square$ Rags
$\square$ Soil

$\square$ Drained fuel filters (gas \& diesel)

$\square$ Sludge from sand/oil/water separators

REQUIRED: WASTE GENERATOR SIGNATURE

Solid fractions from sand/oil/water

$凶$ Deconned Underground and Above Ground Tanks

Initials: (if initialed, no radiological clearance is necessary.)

The above mentioned waste was generated outside of a Controlled Waste Management Area (CWMA) and to the best of my
knowledge, does not contain radiological materials.

To the best of my knowledge, the waste described above contains only those materials that are allowed for disposal at this site. I have verified this through the waste characterization method identified above and a review of the above-mentioned is approved for disposal in the landfill.

Print Name:

Signature:
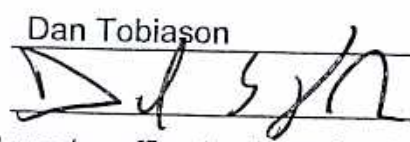

Note: "Foc

must wave, office trash and animal carcasses do not require a radio SWO USE ONLY

Load Weight (net from scale or estimate): $35, \mathrm{v} \Omega$

Date:
Radiological Survey Release for Waste Disposal RCT Initials

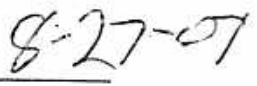

- This container/load meets the criteria for no

OC added man-made radioactive material

This container/load meets the criteria for Radcon Manual Table 4.2 release limits. This container/load is exempt from survey duo-to process knowledge and origin.

SIgnature: DATE:270] FRM-0646 (08/06)
$8 \cdot 27-0.7$ SIGN
Signature of Cerumer:
Crushed non-teme plated oil filters PCBs below 50 parts per million

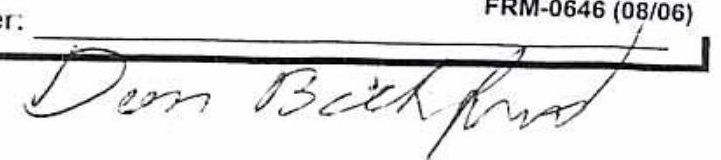




\section{SWO USE (Select One) AREA 23 \\ Х9 \\ $\triangle$ LANDFILL}

For waste characterization, approval, and/or assistance, contact Solid Waste Operation (SWO) at 5-7898.

REQUIRED: WASTE GERERATOR INFORMATION

(This form is for rolloffs, dump trucks, and other onsite disposal of materials.)

Waste Generator: Dan Tobiason

Phone Number: 295-6169

Location / Origin: T-Tunnel Lower Laydown Yard

Waste Category: (check one)

Waste Type: $\square$ NTS

(check one)

Non-Putrescible

Pollution Prevention Category: (check one)

Pollution Prevention Category: (check one)

Method of Characterization: (check one)

$\square$ Commercial
$\square$ Putrescrible
$\square$ Asbestos Containing Material

$\square$ Environmental management

$\triangle$ Clean-Up

Sampling \& Analysis

Radioactive waste; RCRA waste; Hazardous waste; Free liquids, PCBs above TSCA regulatory levels, and Medical wastes (needles, sharps, bloody clothing).

NTS landfills:

Additional Prohibited Waste

at the Area 9 U10C Landfill:

Sewage Sludge, Animal carcasses, Wet garbage (food waste); and Friable asbestos

REQUIRED: WASTE CONTENTS ALLOWABLE WASTES

Check all allowable wastes that are contained within this load:

NOTE: Waste disposal at the Area 6 Hydrocarbon Landfill must have come into contact with petroleum hydrocarbons or coolants, such as: gasoline (no benzene, lead); jet fuel; diesel fuel; lubricants and hydraulics; kerosene; asphaltic petroleum hydrocarbon; and ethylene glycol.
Acceptable waste at any NTS landfill:
$\triangle$ Paper
$\triangle$ Soil
$\square$ Rocks / unaltered geologic materials
$\bigotimes$ Rubber (excluding tires)
$\bigotimes$ Asphalt $\bigotimes$ Meta
$\triangle$ Wood
$\bigotimes$ Cloth
\Insulation (non-Asbestosform)
叉 Plastic
$\triangle$ Wire
$凶$ Cable

$\bigotimes$ Empty containers

$\bigotimes$ Demolition debris

arpet, electronic components, PPE, etc.)

Additional waste accepted at the Area 23 Mercury Landfill: $\square$ Office Waste

$\square$ Asbestos

Friable

$\square$ Non-Friable (contact SWO if regulated load)

$\square$ Food Waste

$\bigotimes$ Cement \& concrete

Additional waste accepted at the Area 9 U10c Landfill:

$\square$ Non-friable asbestos

Light ballasts (contact SWO)

$\square$ Drained automobiles and military vehicles

Quantity:
Solid fractions from sand/oil/water

$\bigotimes$ Deconned Underground and Above Ground Tanks

\section{Additional waste accepted at the Area 6 Hydrocarbon Landfill}
$\square$ Septic sludge
$\square$ Rags
$\square$ Drained fuel filters (gas \& diesel)
Crushed non-teme plated oil filters
Plants
Soil
$\square$ Sludge from sand/oil/water separators
$\square$ PCBs below 50 parts per million

\section{REQUIRED: WASTE GENERATOR SIGNATURE}

Initials: (if initialed, no radiological clearance is necessary.)

The above mentioned waste was generated outside of a Controlled Waste Management Area (CWMA) and to the best of my knowledge, does not contain radiological materials.

To the best of my knowledge, the waste described above contains only those materials that are allowed for disposal at this site. I have verified this through the waste characterization method identified above and a review of the above-mentioned prohibited and allowable waste items. I have contacted Property Management a is approved for disposal in the landfill.

Print Name: Dan Tobiason

Signature:
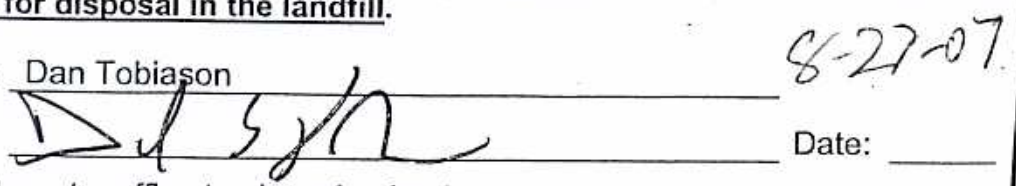

Date:

Note: "Food waste, office trash and animal carcasses do not require a radiologic must have signed removal certification statement with Load Verification."

SWO USE ONLY

Load Weight (net from scale or estimate)

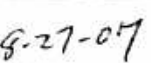

Signature of Certifier:
Radiological Survey Relat-1/natuinment RCT Initials

- This container/load meets the criteria for no OC added man-made radioactive material This container/load meets the criteria for Radcon Manual Table 4.2 release limits. This container/load is exempt from survey due to process knowledge and origin.

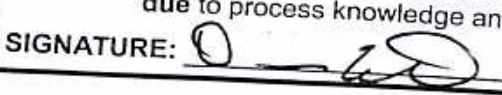

DATE: $\geq 270$ 


\section{$\begin{array}{llllll}\text { SWO USE (Select One) } & \text { AREA } & \square 23 & \square 6 & \text { X } 9 & \text { \ LANDFILL }\end{array}$}

For waste characterization, approval, and/or assistance, contact Solid Waste Operation (SWO) at 5-7898.

REQUIRED: WASTE GERERATOR INFORMATION

(This form is for rolloffs, dump trucks, and other onsite disposal of materials.)

Waste Generator: Dan Tobiason

Phone Number: 295-6169

Location / Origin: T-Tunnel Lower Laydown Yard

Waste Category: (check one)

Waste Type: $\bigotimes$ NTS

(check one) $\square$ Non-Putrescible $\square$ Asbestos Containing Material

(check one) $\square$ Non-Putrescible $\square$ Asbestos Containing Material

$\square$ Commercial

$\triangle$ Industrial cgs $8 / 28 / 07$

Pollution Prevention Category: (check one) $\square$ Environmental management

Pollution Prevention Category: (check one) $\$ Clean-Up

Method of Characterization: (check one) $\square$ Sampling \& Analysis

$\triangle F F A C O$ monsite $\square$ WAC Exception

Prohibited Waste at all three

NTS landfills:

Additional Prohibited Waste

at the Area 9 U10C Landfill:

Radioactive waste; RCRA waste; Hazardous waste; Free liquids, PCBs above TSCA regulatory
levels, and Medical wastes (needles, levels, and Medical wastes (needles, sharps, bloody clothing).

$\square$ FFACO-offsite $\square$ Historic DOE/NV

$\bigotimes$ Defense Projects $\square$ YMP

$\square$ Routine

Sewage Sludge, Animal carcasses, Wet garbage (food waste); and Friable asbestos

REQUIRED: WASTE CONTENTS ALLOWABLE WASTES

Check all allowable wastes that are contained within this load:

NOTE: Waste disposal at the Area 6 Hydrocarbon Landfill must have come into contact with petroleum hydrocarbons or coolants, such as: gasoline (no benzene, lead); jet fuel; diesel fuel; lubricants and hydraulics; kerosene; asphaltic petroleum hydrocarbon; and ethylene glycol.

Acceptable waste at any NTS landfill: $\triangle$ Paper
$\triangle$ Asphalt $\square$ Metal
$\triangle$ Wood
$\bigotimes$ Soil
$\square$ Rocks / unaltered geologic materials
$\bigotimes$ Rubber (excluding tires)
$\triangle$ Plastic $\quad$ Wire
$\triangle$ Cable
$凶$ Cloth
$\triangle$ Insulation (non-Asbestosform)

Empty containers

$\bigotimes$ Demolition debris

$\bigotimes$ Manufactured items: (swamp coolers, furniture, rugs, carpet, electronic components, PPE, etc.)
Additional waste accepted at the Area 23 Mercury Landfill:
$\square$ Office Waste
$\square$ Food Waste
$\square$ Asbestos
Friable
Non-Friable (contact SWO if regulated load)
Quantity:

$\bigotimes$ Cement \& concrete

Additional waste accepted at the Area 9 U10c Landfill:
$\square$ Non-friable asbestos
$\square$ Light ballasts (contact SWO)
$\square$ Drained automobiles and military vehicles
Drained fuel filters (gas \& diesel)
$\square$ Hydrocarbons (contact SWO)

Other

Drained generators/equipment

Solid fractions from sand/oil/water

$凶$ Deconned Underground and Above Ground Tanks

Additional waste accepted at the Area 6 Hydrocarbon Landfill:
$\square$ Septic sludge
$\square$ Rags
Plants
Soil

$\square$ Drained fuel filters (gas \& diesel)

$\square$ Sludge from sand/oil/water separators REQUIRED: WASTE GENERATOR SIGNATURE

Crushed non-teme plated oil filters PCBs below 50 parts per million

Initials: (if initialed, no radiological clearance is necessary.)

The above mentioned waste was generated outside of a Controlled Waste Management Area (CWMA) and to the best of my knowledge, does not contain radiological materials.

To the best of my knowledge, the waste described above contains only those materials that are allowed for disposal at this site. I have verified this through the waste characterization method identified above and a revipw of tho shnum mant:-.... prohibited and allowable waste items. I have contacted Property Managem is approved for disposal in the landfill.

Print Name:

Signature:
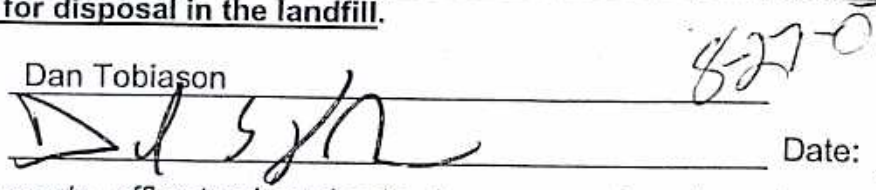

Date:

Note: "Food waste, office trash and animal carcasses do not require a radiol must have signed removal certification statement with Load Verificatio

SWO USE ONLY

$$
8.27-0.7
$$

Radiological Survey Release for Waste Disposal RCT Initials

This container/load meets the criteria for no added man-made radioactive material This container/load meets the criteria for Radcon Manual Table 4.2 release limits. This container/load is exempt from survey due to process knowledge and origin.

SIGNATURE: 
For waste characterization approval and/or assistance, co REQUIRED: WASTE GERERATOR INFORMATION

(This form is for rolloffs, dump trucks, and other onsite disposal of materials.)

Waste Generator: Dan Tobiason

Phone Number: 295-6169

\section{Location / Origin: T-Tunnel Lower Laydown Yard}

Waste Category: (check one)

Waste Type: $\triangle$ NTS

(check one)

$\square$ Non-Putrescible

Pollution Prevention Category: (check one)

Pollution Prevention Category: (check one)

Method of Characterization: (check one)

Prohibited Waste at all three

NTS landfills:

Additional Prohibited Waste

at the Area 9 U10C Landfill:
Radioactive waste; RCRA waste; Hazardous waste; Free liquids, PCBs above TSCA regulatory
levels, and Medical wastes (needles, sharps, bloody clothing).

Sewage Sludge, Animal carcasses, Wet garbage (food waste); and Friable asbestos

\section{REQUIRED: WASTE CONTENTS ALLOWABLE WASTES}

Check all allowable wastes that are contained within this load:

NOTE: Waste disposal at the Area 6 Hydrocarbon Landfill must have come into contact with petroleum hydrocarbons or coolants, such as: gasoline (no benzene, lead); jet fuel; diesel fuel; lubricants and hydraulics; kerosene; asphaltic petroleum hydrocarbon; and ethylene glycol.
Acceptable waste at any NTS landfill:
$\triangle$ Asphalt
$\triangle$ Wood $\triangle$ Soil
$\triangle$ Plastic $\otimes$ Wire
$凶$ Cable
$\triangle$ Cloth
$\square$ Rocks / unaltered geologic materials
$\triangle$ Rubber (excluding tires)
$\bigotimes$ Insulation (non-Asbestosform)
$\bigotimes$ Empty containers
$\bigotimes$ Demolition debris
$\bigotimes$ Cement \& concrete

$\bigotimes$ Manufactured items: (swamp coolers, furniture, rugs, carpet, electronic components, PPE, etc.)
Additional waste accepted at the Area 23 Mercury Landfill:
$\square$ Asbestos
Friable
$\square$ Non-Friable (contact SWO if regulated load)
$\square$ Food Waste
Quantity:

\section{Additional waste accepted at the Area 9 U10c Landfill:}

$\square$ Non-friable asbestos

$\square$ Light ballasts (contact SWO)

Hydrocarbons (contact SWO)

$\square$ Drained automobiles and military vehicles

$\square$ Drained fuel filters (gas \& diesel)

Other Drained generators/equipment
Solid fractions from sand/oil/water

$\otimes$ Deconned Underground and Above Ground Tanks

\section{Additional waste accepted at the Area 6 Hydrocarbon Landfill:}
Septic sludge
Plants

$\square$ Drained fuel filters (gas \& diesel)

$\square$ Sludge from sand/oil/water separators
Crushed non-teme plated oil filters PCBs below 50 parts per million

Initials: (if initialed, no radiological clearance is necessary.)

The above mentioned waste was generated outside of a Controlled Waste Management Area (CWMA) and to the best of my
knowledge, does not contain radiological materials.

To the best of my knowledge, the waste described above contains only those materials that are allowed for disposal at this site. I have verified this through the waste characterization method identified above and a review of the above-mentioned prohibited and allowable waste items. I have contacted Property Manageme is approved for disposal in the landfill.

Print Name: Dan Tobiason Signature:
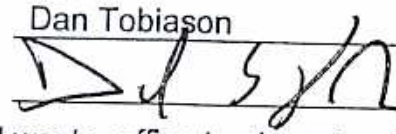

$$
\text { h }
$$<smiles>C1CCCC1</smiles>

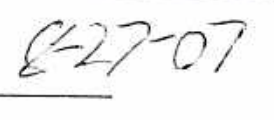

Note: "Food waste, office trash and animal carcasses do not require a radiol must have signed removal certification statement with Load Verificatio

\section{SWO USE ONLY}

Load Weight (net from scale or estimate) $; \leq 1,000$ Date:

Radiological Survey Release for Waste Disposal RCT Initials

$$
8.27-07
$$

Signature of Ce.
This container/load meets the criteria for no

$D C$ added man-made radioactive material Radcon Manual Table 4.2 release limits. This container/load is exempt from survey SIGNATURE: due to process knowledge and origin. FRM-0646 (ф8/06) 
NSTec

Form

FRM-0918

NTS LANDFILL LOAD VERIFICATION

Pas

\begin{tabular}{|llllll}
\hline SWO USE (Select One) & AREA & $\square 23$ & $\square 6$ & $\square 9$ & $\square$ LANDFILL
\end{tabular}

For waste characterization, approval, and/or assistance, contact Solid Waste Operation (SWO) at 5-7898.

REQUIRED: WASTE GERERATOR INFORMATION

(This form is for rolloffs, dump trucks, and other onsite disposal of materials.)

Waste Generator: Dan Tobiason

Phone Number: 295-6169

Location / Origin: T-Tunnel Lower Laydown Yard

Waste Category: (check one)

Waste Type: $\triangle$ NTS

$\square$ Commercial

(check one)

$\square$ Non-Putrescible

$\square$ Putrescrible

Q Industrial Q/s $8 / 29 / 07$

$\square$ Asbestos Containing Material

ZFFACO-onsite $\square$ WAC Exception

Pollution Prevention Category: (check one) $\square$ Environmental management

Pollution Prevention Category: (check one) $\triangle$ Clean-Up

Method of Characterization: (check one) $\square$ Sampling \& Analysis $\quad$ Process Knowledge $\square$ Contents

$\square$ FFACO-offsite

$\square$ Historic DOE/NV

NTS landfills:

Additional Prohibited Waste

at the Area 9 U10C Landfill:

levels, and Medical wastes (needles, sharps, bloody clothing).

Sewage Sludge, Animal carcasses, Wet garbage (food waste); and Friable asbestos

\section{REQUIRED: WASTE CONTENTS ALLOWABLE WASTES}

Check all allowable wastes that are contained within this load:

NOTE: Waste disposal at the Area 6 Hydrocarbon Landfill must have come into contact with petroleum hydrocarbons or coolants, such as: gasoline (no benzene, lead); jet fuel; diesel fuel; lubricants and hydraulics; kerosene; asphaltic petroleum hydrocarbon; and ethylene glycol.

Acceptable waste at any NTS landfill: $\triangle$ Paper

$\triangle$ Asphalt $\otimes$ Metal $\otimes$ Wood $\otimes$ Soil

$\triangle$ Plastic $\quad$ Wire $\quad$ Cable $\quad$ Cloth

$\square$ Rocks / unaltered geologic materials

$\bigotimes$ Rubber (excluding tires)

$\triangle$ Insulation (non-Asbestosform)

Empty containers

$\triangle$ Demolition debris

$\triangle$ Manufactured items: (swamp coolers, furniture, rugs, carpet, electronic components, PPE, etc.)
Additional waste accepted at the Area 23 Mercury Landfill:
$\square$ Office Waste
$\square$ Food Waste
Animal Carcasses
$\square$ Asbestos
Friable
Non-Friable (contact SWO if regulated load)
Quantity:

Additional waste accepted at the Area 9 U10c Landfill:
$\square$ Non-friable asbestos
$\square$ Drained automobiles and military vehicles
Light ballasts (contact SWO)
Drained fuel filters (gas \& diesel)
Hydrocarbons (contact SWO)
$\bigotimes$ Other
Drained generators/equipment

Solid fractions from sand/oil/water

$\triangle$ Deconned Underground and Above

Ground Tanks

Additional waste accepted at the Area 6 Hydrocarbon Landfill:
$\square$ Septic sludge
$\square$ Rags
$\square$ Drained fuel filters (gas \& diesel)
Plants
Soil
$\square$ Sludge from sand/oil/water separators
Crushed non-teme plated oil filters REQUIRED: WASTE GENERATOR SIGNATURE PCBs below 50 parts per million

Initials: (if initialed, no radiological clearance is necessary.)

The above mentioned waste was generated outside of a Controlled Waste Management Area (CWMA) and to the best of my knowledge, does not contain radiological materials.

To the best of my knowledge, the waste described above contains only those materials that are allowed for disposal at this site. I have verified this through the waste characterization method identified above and a review of the above-mentioned prohibited and allowable waste items. I have contacted Property Management an is approved for disposal in the landfill.

Print Name:

Signature:
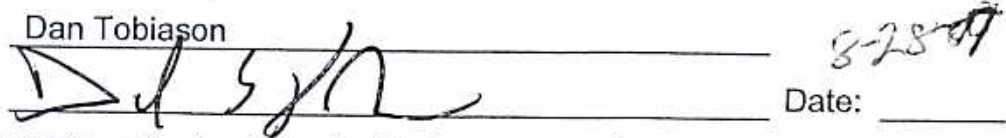

Note: "Food waste, office trash and animal carcasses do not require a radiologica must have signed removal certification statement with Load Verification."

SWO USE ONLY

Load Weight (net from scale or estimate):

$8-28-67$ (2) Signature of Certifier in material/eauinment

Radiological Survey Release for Waste Disposal RCT Initials

- This container/load meets the criteria for no added man-made radioactive material $\$$ L This container/load meets the criteria for Radcon Manual Table 4.2 release limits. This container/load is exempt from survey due toprocess knowledge and origin. SIGNATURE: DATE: 8.280 
NSTec

Form

FRM-0918

NTS LANDFILL LOAD VERIFICATION

Pac

\begin{tabular}{|llllll}
\hline SWO USE (Select One) & AREA & $\square 23$ & $\square 6$ & A & $\square$ LANDFILL
\end{tabular}

For waste characterization, approval, and/or assistance, contact Solid Waste Operation (SWO) at 5-7898.

REQUIRED: WASTE GERERATOR INFORMATION

(This form is for rolloffs, dump trucks, and other onsite disposal of materials.)

Waste Generator: Dan Tobiason

Phone Number: 295-6169

Location / Origin: T-Tunnel Lower Laydown Yard

Waste Category: (check one)

Waste Type: $\square$ NTS

(check one)

$\square$ Non-Putrescible

$\square$ Commercial

Q Industrial cgs 8/29/07

$\square$ Putrescrible

- $\triangle$ EFAGO-OAsite $\square$ WAC Exception

Pollution Prevention Category: (check one)

Pollution Prevention Category: (check one)

Method of Characterization: (check one) $\square$ Sampling \& Analysis

$\square$ Asbestos Containing Material

$\square$ FFACO-offsite

$\square$ Historic DOE/NV

$\bigotimes$ Defense Projects

YMP

Prohibited Waste at all three

NTS landfills:

Additional Prohibited Waste

at the Area 9 U10C Landfill:

Radioactive waste; RCRA waste; Hazardous waste; Free liquids, PCBs above TSCA regulatory levels, and Medical wastes (needles, sharps, bloody clothing).

Sewage Sludge, Animal carcasses, Wet garbage (food waste); and Friable asbestos

REQUIRED: WASTE CONTENTS ALLOWABLE WASTES

Check all allowable wastes that are contained within this load:

NOTE: Waste disposal at the Area 6 Hydrocarbon Landfill must have come into contact with petroleum hydrocarbons or coolants, such as: gasoline (no benzene, lead); jet fuel; diesel fuel; lubricants and hydraulics; kerosene; asphaltic petroleum hydrocarbon; and ethylene glycol

Acceptable waste at any NTS landfill: $\square$ Paper

$\bigotimes$ Asphalt $\square$ Metal $\square$ Wood $\square$ Soil

Plastic $\quad$ Wire $\quad \square$ Cable $\quad$ Cloth

$\square$ Rocks / unaltered geologic materials

$\square$ Rubber (excluding tires)

$\triangle$ Insulation (non-Asbestosform)

Empty containers

$\bigotimes$ Demolition debris

$\triangle$ Manufactured items: (swamp coolers, furniture, rugs, carpet, electronic components, PPE, etc.)

Additional waste accepted at the Area 23 Mercury Landfill: $\square$ Office Waste $\square$ Food Waste

$\bigotimes$ Cement \& concrete
$\square$ Asbestos
Friable
Non-Friable (contact SWO if regulated load)
Quantity:

Additional waste accepted at the Area 9 U10c Landfill:

$\square$ Non-friable asbestos

Light ballasts (contact SWO)

$\square$ Drained automobiles and military vehicles

Solid fractions from sand/oil/water

Hydrocarbons (contact SWO)

Drained fuel filters (gas \& diesel)

$\bigotimes$ Other Drained generators/equipment

$\bigotimes$ Deconned Underground and Above

Ground Tanks

Additional waste accepted at the Area 6 Hydrocarbon Landfill:

$\square$ Septic sludge $\square$ Rags $\square$ Drained fuel filters (gas \& diesel)

Plants

$\square$ Soil

$\square$ Sludge from sand/oil/water separators

Crushed non-teme plated oil filters REQUIRED: WASTE GENERATOR SIGNATURE PCBs below 50 parts per million

Initials: (if initialed, no radiological clearance is necessary.)

The above mentioned waste was generated outside of a Controlled Waste Management Area (CWMA) and to the best of my knowledge, does not contain radiological materials.

To the best of my knowledge, the waste described above contains only those materials that are allowed for disposal at this site. I have verified this through the waste characterization method identified above and a review of the above-mentioned prohibited and allowable waste items. I have contacted Property Management an is approved for disposal in the landfill.

Print Name:

Signature:
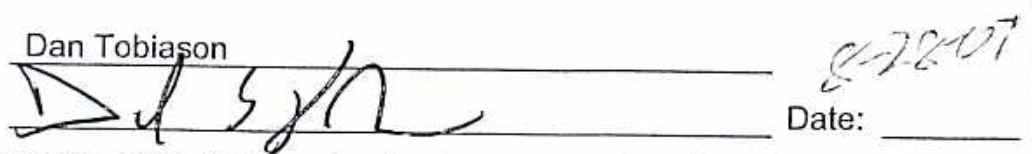

Note: "Food waste, office trash and animal carcasses do not require a radiological must have signed removal certification statement with Load Verification."

SWO USE ONLY

Load Weight (net from scale or estimate): 20,000

$8-28-07$

Signature of Certifier:
Radiological Survey Release for Waste Disposa RCT Initials

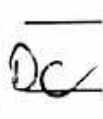

This container/load meets the criteria for no added man-made radioactive material This container/load meets the criteria for Radcon Manual Table 4.2 release limits. This container/load is exempt from survey due to process knowledge and origin.

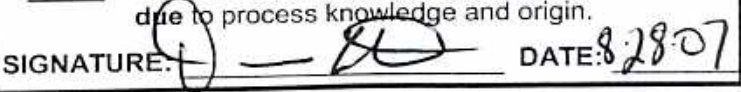
FRM-0646 (08/06) 
For waste characterization, approval, and/or assistance,

Waste Operation (SWO) at 5-7898.

(This form is for rolloffs, WUTP IIE GERERATOR INFORMATION

Waste Generator: Dan Tobiason

Location / Origin: T-Tunnel Lower Laydown Yard

Phone Number: 295-6169

Waste Category: (check one)

Waste Type: $\square$ NTS

(check one) $\quad \square$ Non-Putrescible

Pollution Prevention Category: (check one)

Pollution Prevention Category: (check one)

Method of Characterization: (check one)

$\square$ Commercial

$\square$ Putrescrible

$\square$ Asbestos Containing Material $\square$ FFACO-offsite

Q Industrial cgs $9 / 4 / 0 n$

Environmental management

$\triangle$ Clean-Up

Radioactive waste; RCRA waste; Hazardous waste; Free liquids, PCBs above TSCA regul

$\triangle$ Defense Projects

WAC Exception

Prohibited Waste at all three

NTS landfills:

Additional Prohibited Waste

at the Area 9 U10C Landfill: levels, and Medical wastes (needles, sharps,

Sewage Sludge, Animal carcasses, Wet garbage (food waste); and Friable asbestos

\section{REQUIRED: WASTE CONTENTS ALLOWABLE WASTES}

Check all allowable wastes that are contained within this load:

coolants, such as: gasoline (nodrocarbon Landfill must have come into contact with petroleum hydrocarbons or petroleum hydrocarbon; and ethylene glycol.

Acceptable waste at any NTS landfill:

$\triangle$ Paper

$\triangle$ Asphalt $\quad$ Metal $\quad$ Wood $\quad$ Soil

\Cable

$\triangle$ Cloth

Rocks / unaltered geologic materials

$\bigotimes$ Rubber (excluding tires)

$\bigotimes$ Insulation (non-Asbestosform)

$\triangle$ Manufactured items: (swamp coolers, furniture, rugs, carpet, electronic components, PPE, etc.)

Additional waste accepted at the Area 23 Mercury Landfill: $\square$ Office Waste

$\square$ Asbestos $\square$ Friable

$\square$ Non-Friable (contact SWO if regulated load)

$\square$ Food Waste

Quantity:

\section{Additional waste accepted at the Area $9 \mathrm{U10}$ c Landfill:}

Non-friable asbestos

Light ballasts (contact SwO)

Hydrocarbons (contact SwO)

Drained automobiles and military vehicles

Drained fuel filters (gas \& diesel)

Other Drained generators/equipment
Solid fractions from sand/oil/water

$\triangle$ Deconned Underground and Above Ground Tanks

Additional waste accepted at the Area 6 Hydrocarbon Landfill:
Septic sludge
Plants
$\square$ Rags
$\square$ Soil

$\square$ Drained fuel filters (gas \& diesel)

$\square$ Sludge from sand/oil/water separators

REQUIRED: WASTE GENERATOR SIGNATURE

Initials: (if initialed, no radiological clearance is necessary.)

The above mentioned waste was generated outside of a Controlled Waste Management Area (CWMA) and to the best of my
knowledge, does not contain radiological materials. To the best of my knowledge, the waste described above contains only those materials that are allowed for disposal at this
site. I have verified this through the waste characterization method identified above and a review of the above-mentioned
prohibited and allowable waste items. I have contacted Pronerty Managementand is approved for disposal in the landfill.

Print Name:

Signature:
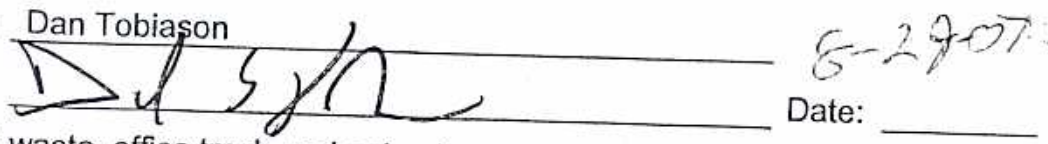

Note: "Fod

must have SWO USE ONLY

Load Weight (net from scale or estimate):
$8,2 y-0.7$

Signature of Certifier:

\section{...nesind that thie matarial/arutinment}

Radiological Survey Release for Waste Disposal

RCT Initials

- This container/load meets the criteria for no

RL added man-made radioactive material

This container/load meets the criteria for Radcon Manual Table 4.2 release limits. This container/load is exempt from survey due to process knowledge and origin. SIgNATURE: $(2)$ DATE: $\left.928^{2}\right]$ 
NSTec

Form

FRM-0918

NTS LANDFILL LOAD VERIFICATION

SWO USE (Select One) AREA

23

$\triangle 9$

Page 1 of

For Waste characterization, approval, and/or assistance, contact Solid Waste Operation (SWO) at 5-7898.

REQUIRED: WASTE GERERATOR INFORMATION

(This form is for rolloffs, dump trucks, and other onsite disposal of materials.)

Waste Generator: Dan Tobiason

Phone Number: 295-6169

Location / Origin: T-Tunnel Lower Laydown Yard

Waste Category: (check one)

Waste Type: $\triangle$ NTS

(check one)

$\square$ Non-Putrescible

$\square$ Commercial

$\square$ Putrescrible

$\triangle$ Industrial

$\triangle$ FFAGO-onste

$\square$ Asbestos Containing Material

$\square$ FFACO-offsite

Pollution Prevention Category: (check one)

Pollution Prevention Category: (check one)

Method of Characterization: (check one)

Environmental management

$\triangle$ Defense Projects

$\triangle$ Clean-Up

Prohibited Waste at all three

NTS landfills:

Sampling \& Analysis

$\square$ Routine

$\triangle$ Process Knowledge

$9 / 4 / 07$

$\square$ WAC Exception

$\square$ Historic DOE/NV

Additional Prohibited Waste

at the Area 9 U10C Landfill:

Radioactive waste; RCRA waste; Hazardous waste; Free liquids, PCBs above TSCA regulatory levels, and Medical wastes (needles, sharps, bloody clothing)

Sewage Sludge, Animal carcasses, Wet garbage (food waste); and Friable asbestos

\section{REQUIRED: WASTE CONTENTS ALLOWABLE WASTES}

Check all allowable wastes that are contained within this load:

NOTE: Waste disposal at the Area 6 Hydrocarbon Landfill must have come into contact with petroleum hydrocarbons or coolants, such as: gasoline (no benzene, lead); jet fuel; diesel fuel; lubricants and hydraulics; kerosene; asphaltic petroleum hydrocarbon; and ethylene glycol.

Acceptable waste at any NTS landfill:

$\triangle$ Asphalt $\quad$ Metal $\quad$ Wood $\quad$ Soil

$\triangle$ Plastic $\quad$ Wire $\quad$ Cable $\quad$ Cloth

$\square$ Rocks / unaltered geologic materials

$\triangle$ Rubber (excluding tires)

$\bigotimes$ Insulation (non-Asbestosform)

Empty containers

$\bigotimes$ Demolition debris

$\triangle$ Cement \& concrete

$\triangle$ Manufactured items: (swamp coolers, furniture, rugs, carpet, electronic components, PPE, etc.)

Additional waste accepted at the Area 23 Mercury Landfill: $\square$ Office Waste $\square$ Food Waste
Asbestos
Friable
Non-Friable (contact SWO if regulated load)
Quantity:

\section{Additional waste accepted at the Area 9 U10c Landfill:}

$\square$ Non-friable asbestos

$\square$ Light ballasts (contact SwO)

Hydrocarbons (contact SwO)

Drained automobiles and military vehicles

Drained fuel filters (gas \& diesel)

Other Drained generators/equipment

$\square$ Solid fractions from sand/oil/water

$\triangle$ Deconned Underground and Above Ground Tanks

Additional waste accepted at the Area 6 Hydrocarbon Landfill:
$\square$ Septic sludge
$\square$ Rags
Plants
Soil
$\square$ Drained fuel filters (gas \& diesel)
Crushed non-teme plated oil filters
$\square$ Sludge from sand/oil/water separators
REQUIRED: WASTE GENERATOR SIGNATURE

Initials: (if initialed, no radiological clearance is necessary.)

The above mentioned waste was generated outside of a Controlled Waste Management Area (CWMA) and to the best of my knowledge, does not contain radiological materials.

To the best of my knowledge, the waste described above contains only those materials that are allowed for disposal at this site. I have verified this through the waste characterization method identified above and a review of the above-mentioned is approve for antere contacted Property Management and have verified that this material/equipmen or disposal in the landfill.

Print Name:

Signature:
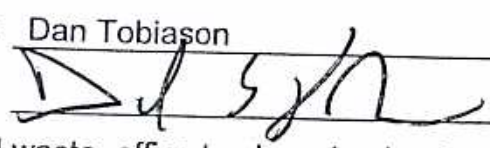

Note: "Food waste, office trash and animal carcasses do not require a radiolog must have signed removal certification statement with Load Verification.

\section{SWO USE ONLY}

Load Weight (net from scale or estimate) 35,02

$8-29-8.7$

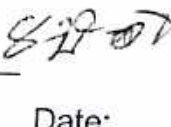

Radiological Survey Release for Waste Disposal RCT Initials

This container/load meets the criteria for no added man-made radioactive material This container/load meets the criteria for Radcon Manual Table 4.2 release limits. This container/load is exempt from survey due to process knowledge and origin Signature of Certit.
DATE 


\section{$\begin{array}{lllllll}\text { SWO USE (Select One) } & \text { AREA } & \square 23 & \square 6 & \square 9 & \text { \ LANDFILL }\end{array}$}

For waste characterization, approval, and/or assistance, contact Solid Waste Operation (SWO) at 5-7898.

REQUIRED: WASTE GERERATOR INFORMATION

(This form is for rolloffs, dump trucks, and other onsite disposal of materials.)

Waste Generator: Dan Tobiason

Phone Number: 295-6169

Location / Origin: T-Tunnel Lower Laydown Yard

\begin{tabular}{|c|c|c|c|}
\hline Waste Category: (check one) & $\square$ Commercial & QIndustrial gs & Hor \\
\hline Waste Type: & $\square$ Putrescrible & 区FFACO-Onsite & $\square$ WAC EXC \\
\hline$\square$ Non-Putrescible & $\square$ Asbestos Containing Material & $\square$ FFACO-offsite & $\square$ Historic DOE/NV \\
\hline Pollution Prevention Category: (check one) & $\square$ Environmental management & Defense Projects & $\square \mathrm{YMP}$ \\
\hline Pollution Prevention Category: (check one) & $\otimes$ Clean-Up & $\square$ Routine & \\
\hline Method of Characterization: (check one) & $\square$ Sampling \& Analysis & $\triangle$ Process Knowl & $\square$ Contents \\
\hline
\end{tabular}

Prohibited Waste at all three Radioactive waste: RCRA waste; Hazardous waste; Free NTS landfills:

Additional Prohibited Waste

at the Area 9 U10C Landfill:

levels, and Medical wastes (needles, sharps, bloody clothing)

Sewage Sludge, Animal carcasses, Wet garbage (food waste); and Friable asbestos

\section{REQUIRED: WASTE CONTENTS ALLOWABLE WASTES}

Check all allowable wastes that are contained within this load:

NOTE: Waste disposal at the Area 6 Hydrocarbon Landfill must have come into contact with petroleum hydrocarbons or coolants, such as: gasoline (no benzene, lead); jet fuel; diesel fuel; lubricants and hydraulics; kerosene; asphaltic petroleum hydrocarbon; and ethylene glycol.
Acceptable waste at any NTS landfill: $\triangle$ Paper
$\triangle$ Asphalt $\quad$ Metal $\quad$ Wood $\quad$ Soil
Q Plastic
$\triangle$ Wire
$凶$ Cable
Cloth
$\square$ Rocks / unaltered geologic materials
$\otimes$ Rubber (excluding tires)
$\bigotimes$ Insulation (non-Asbestosform)
Empty containers
$\bigotimes$ Demolition debris
$\bigotimes$ Cement \& concrete

$\triangle$ Manufactured items: (swamp coolers, furniture, rugs, carpet, electronic components, PPE, etc.)

Additional waste accepted at the Area 23 Mercury Landfill: $\square$ Office Waste

$\square$ Asbestos

$\square$ Friable

Non-Friable (contact SWO if regulated load)

$\square$ Food Waste

\section{Additional waste accepted at the Area 9 U10c Landfill:}
$\square$ Non-friable asbestos
Drained automobiles and military vehicles
Light ballasts (contact SWO)
Drained fuel filters (gas \& diesel)
Hydrocarbons (contact SWO)
$\otimes$ Other
Drained generators/equipment

\section{Additional waste accepted at the Area 6 Hydrocarbon Landfill:}
$\square$ Septic sludge
$\square$ Rags
$\square$ Drained fuel filters (gas \& diesel)
Plants
Soil
$\square$ Sludge from sand/oil/water separators

\section{REQUIRED: WASTE GENERATOR SIGNATURE}
Crushed non-teme plated oil filters
PCBs below 50 parts per million

Quantity:

Animal Carcasses

Initials: ___ (if initialed, no radiological clearance is necessary.)

The above mentioned waste was generated outside of a Controlled Waste Management Area (CWMA) and to the best of my knowledge, does not contain radiological materials.

To the best of my knowledge, the waste described above contains only those materials that are allowed for disposal at this

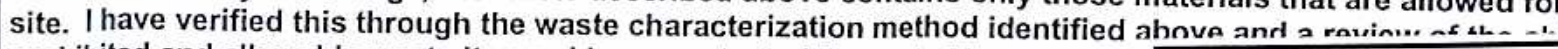

prohibited and allowable waste items. I have contacted Property Management is approved for disposal in the landfill.

Print Name: Dan Tobiason

Signature:
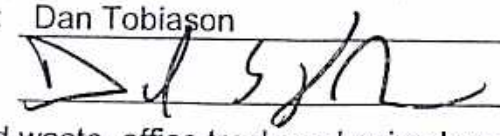

$(5-29-\overrightarrow{7}$
Date:

Note: "Food waste, office trash and animal carcasses do not require a radiologii must have signed removal certification statement with Load Verification."

SWO USE ONLY

$8 \cdot 29-07$ Radiological Survey Release for Waste Disposal RCT Initials

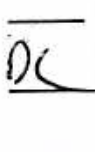

This container/load meets the criteria for no added man-made radioactive material This container/load meets the criteria for Radcon Manual Table 4.2 release limits. This container/load is exempt from survey due 1 process knowledge and origin.

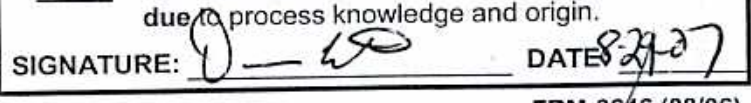

Load Weight (net from scale or estimates): $60,0 \Omega 0$ Signature of Certifier: FRM-06/46 (08/06) 


\section{SWO USE (Select One) AREA}

23

$\begin{array}{llllll}\text { Fer waste characterization, approval, and/or assistance } & \square 6 & \square 9 & \text { (Select One) }\end{array}$

$\begin{array}{llllll}\text { For waste characterization, approval, and/or assistance } & \square 6 & \square 9 & \text { (Select One) }\end{array}$

Page 1 of 2 REQUIRED: WASTE GERERATOR INFORMATION

(This form is for rolloffs, dump trucks, and other onsite disposal of materials.)

Waste Generator: Dan Tobiason

Location / Origin: T-Tunnel Lower Laydown Yard

Phone Number: 295-6169

Waste Category: (check one)

Waste Type: $₫$ NTS

(check one) $\square$ Non-Putrescible

Pollution Prevention Category: (check one)

Pollution Prevention Category: (check one)

Method of Characterization: (check one)

Prohibited Waste at all thre

$\square$ Commercial

$\square$ Putrescrible

$\triangle$ Industrial os $9 / 4 / 07$

$\square$ Asbestos Containing Material

QIFAGO-Onsite

WAC Exception

$\square$ Environmental management

$\square$ FFACO-offsite

$\triangle$ Defense Projects

$\square$ Historic DOE/NV

\section{$\triangle$ Clean-Up}

NTS landfills:

Additional Prohibited Waste

at the Area 9 U10C Landfill:

$$
\begin{aligned}
& \text { Radioactive waste; RCRA waste; Hazardous waste; Free liquids, PCBs above TSCA regulatory } \\
& \text { levels, and Medical wastes (needles, sharps, bloody clothing). }
\end{aligned}
$$

Sewage Sludge, Animal carcasses, Wet garbage (food waste); and Friable asbestos

\section{REQUIRED: WASTE CONTENTS ALLOWABLE WASTES}

Check all allowable wastes that are contained within this load: coolants, such as: gasoline (no benzene, lead); jet fuel; diesel fuel; lubricants and hydraulics; kerosene; asphaltic
petroleum hydrocarbon; and ethylene glycol.

Acceptable waste at any NTS landfill: $\triangle$ Paper

$\bigotimes$ Asphalt $\bigotimes$ Metal $\quad$ Wood $\bigotimes$ Soil

$\bigotimes$ Plastic

$\triangle$ Wire

Cable

$\otimes$ Cloth

$\square$ Rocks / unaltered geologic materials

$\bigotimes$ Rubber (excluding tires)

$\triangle$ Insulation (non-Asbestosform)

$\bigotimes$ Manufactured items: (swamp coolers, furniture, rugs, carpet, electronic components, PPE, etc.)

Additional waste accepted at the Area 23 Mercury Landfill: $\square$ Office Waste

$\square$ Asbestos

Friable

$\square$ Non-Friable (contact SWO if regulated load)

Food Waste

Quantity:

Additional waste accepted at the Area 9 U10c Landfill:

$\square$ Non-friable asbestos

$\square$ Light ballasts (contact SWO)

$\square$ Hydrocarbons (contact SWO)

$\square$ Drained automobiles and military vehicles

$\square$ Drained fuel filters (gas \& diesel)

$\triangle$ Other Drained generators/equipment

Additional waste accepted at the Area 6 Hydrocarbon Landfill:

$\begin{array}{ll}\square \text { Septic sludge } & \square \text { Rags } \\ \square \text { Plants } & \square \text { Soil }\end{array}$

$\square$ Drained fuel filters (gas \& diesel)

$\square$ Sludge from sand/oil/water separators REQUIRED: WASTE GENERATOR SIGNATURE

Solid fractions from sand/oil/water

$\triangle$ Deconned Underground and Above Ground Tanks PCBs below 50 parts per million

Initials: (if initialed, no radiological clearance is necessary.)

The above mentioned waste was generated outside of a Controlled Waste Management Area (CWMA) and to the best of my
knowledge, does not contain radiological materials.

To the best of my knowledge, the waste described above contains only those materials that are allowed for disposal at this site. I have verified this through the waste characterization method identifier prohibited and allowable waste items. I have contacted Property ManagemeI is approved for disposal in the landfill.

Print Name: Dan Tobiason

Signature:
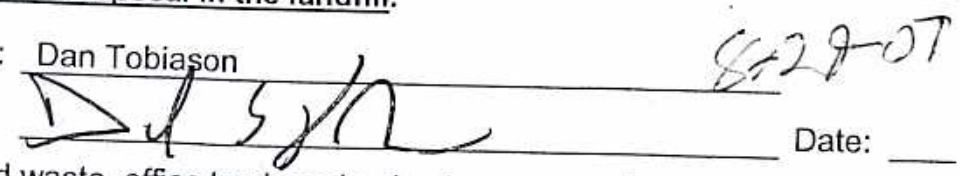

Note: "Food waste, Date: must have signed removal animal carcasses do not require a radiolo SWO USE ONLY

\section{$\bigotimes$ Empty containers \\ $\bigotimes$ Demolition debris \\ $\bigotimes$ Cement \& concrete} Animal Carcasses Radiological Survey Release for Waste Disposal RCT Initials

- This container/load meets the criteria for no added man-made radioactive material This container/load meets the criteria for Radcon Manual Table 4.2 release limits. This container/load is exempt from survey due to process knowledge and origin.

SIGNATURE: 1 __ DATE: $\$$-29-0) FRM-06,46 (08/06) 


\section{Form}

For waste characterization, approval, and/or assistance, contact Solid Waste Operation (SWO) at 5-7898.

\section{REQUIRED: WASTE GERERATOR INFORMATION}

(This form is for rolloffs, dump trucks, and other onsite disposal of materials.)

Waste Generator: Dan Tobiason

Phone Number: 295-6169

Location / Origin: T-Tunnel Lower Laydown Yard

Waste Category: (check one)

Waste Type: $\bigotimes$ NTS

(check one)

$\square$ Non-Putrescible

$\square$ Commercial

$\square$ Putrescrible

$\triangle$ Industrial ogs 9/5/07

Pollution Prevention Category: (check one)

Pollution Prevention Category: (check one)

Method of Characterization: (check one)

$\square$ Asbestos Containing Material

$\square$ Environmental management

$\triangle$ Clean-Up

Prohibited Waste at all three

NTS landfills:

Additional Prohibited Waste

at the Area 9 U10C Landfill:

Radioactive waste; RCRA waste; Hazardous waste; Free liquids, PCBs above TSCA regulatory
levels, and Medical wastes (needles, sharps, bloody clothing).

Sewage Sludge, Animal carcasses, Wet garbage (food waste); and Friable asbestos

\section{REQUIRED: WASTE CONTENTS ALLOWABLE WASTES}

NOTE: Waste disposal at the Check all allowable wastes that are contained within this load: coolants, such as: gasoline (no benzene Landfill must have come into contact with petroleum hydrocarbons or petroleum hydrocarbon; and ethylene glycol.

Acceptable waste at any NTS landfill: $\square$ Paper

$\triangle$ Asphalt

$\otimes$ Plastic

$\triangle$ Metal

$\triangle$ Wood

Q Soil

\Cable

$凶$ Cloth

$\square$ Rocks / unaltered geologic materials

$\triangle$ Rubber (excluding tires)

$\triangle$ Insulation (non-Asbestosform)

$\triangle$ Manufactured items: (swamp coolers, furniture, rugs, carpet, electronic components, PPE, etc.)

Additional waste accepted at the Area 23 Mercury Landfill: $\square$ Office Waste $\square$ Food Waste
$\square$ Asbestos
Friable
$\square$ Non-Friable (contact SWO if regulated load)
Quantity:

Additional waste accepted at the Area 9 U10c Landfill:

$\square$ Non-friable asbestos

Light ballasts (contact SWO)

Hydrocarbons (contact SWO)

$\square$

Drained automobiles and military vehicles

$\square$ Drained fuel filters (gas \& diesel)

$\triangle$ Other

Drained generators/equipment
Solid fractions from sand/oil/water

$\bigotimes$ Deconned Underground and Above Ground Tanks

Additional waste accepted at the Area 6 Hydrocarbon Landfill:

$\square$ Septic sludge $\square$ Rags

Plants $\square$ Drained fuel filters (gas \& diesel)

$\square$ Sludge from sand/oil/water separators
Crushed non-teme plated oil filters PCBs below 50 parts per million

Initials: ___ (if initialed, no radiological clearance is necessary.) REQUIRED: WASTE GENERATOR SIGNATURE

The above mentioned waste was generated outside of a Controlled Waste Ma knowledge, does not contain radiological materials.

To the best of my knowledge, the waste described above contains only those site. I have verified this through the waste characterization method identified prohibited and allowable waste items. I have contacted Property Managemen is approved for disposal in the landfill.

Print Name: Dan Tobiason Signature:
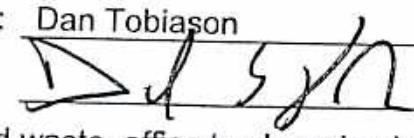

Note: "Food must have

SWO USE ONLY

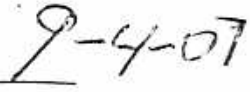

Date: Radiological Survey Release for Waste Disposal
RCT Initials

t This container/load megts the criteria for no

(N) added man-made radjoactive material This containeriload/meets the criteria for Radcon Manual Table 4.2 release limits. This contamerlload is exempt from survey due toporeess knowledge and origin.

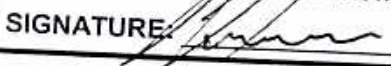

DATE: PRT

FRM-0646 (08/06)

Freon-containing appliances gic

$$
4-4-67
$$

Signature of Certifier: 
NSTec

Form

FRM-0918

NTS LANDFILL LOAD VERIFICATION

Page 1

\begin{tabular}{|llllll}
\hline SWO USE (Select One) & AREA & $\square 23$ & $\square 6$ & Q 39 & LANDFILL
\end{tabular}

For waste characterization, approval, and/or assistance, contact Solid Waste Operation (SWO) at 5-7898.

REQUIRED: WASTE GERERATOR INFORMATION

(This form is for rolloffs, dump trucks, and other onsite disposal of materials.)

Waste Generator: Dan Tobiason

Phone Number: 295-6169

Location / Origin: T-Tunnel Lower Laydown Yard

Waste Category: (check one)

Waste Type: $\triangle$ NTS

(check one) $\quad \square$ Non-Putrescible $\square$ Asbestos Containing Material

Pollution Prevention Category: (check one) $\square$ Environmental management

Pollution Prevention Category: (check one) $\otimes$ Clean-Up

Method of Characterization: (check one)

Sampling \& Analysis

$\square$ Commercial
$\square$ Putrescrible
$\square$ Asbestos Containing Material
$\square$ Environmental management
$\otimes$ Clean-Up
$\square$ Sampling \& Analysis

Q Industrial

AFFACO-Onste $9 / 5 / 07$

$\square$ FFACO-offsite

$\triangle$ Defense Projects

$\square$ Historic DOE/NV

Prohibited Waste at all three

NTS landfills:

Additional Prohibited Waste

at the Area 9 U10C Landfill:

Radioactive waste; RCRA waste; Hazardous waste; Free liquids, PCBs above TSCA regulatory levels, and Medical wastes (needles, sharps, bloody clothing).

Sewage Sludge, Animal carcasses, Wet garbage (food waste); and Friable asbestos

\section{REQUIRED: WASTE CONTENTS ALLOWABLE WASTES}

Check all allowable wastes that are contained within this load:

NOTE: Waste disposal at the Area 6 Hydrocarbon Landfill must have come into contact with petroleum hydrocarbons or coolants, such as: gasoline (no benzene, lead); jet fuel; diesel fuel; lubricants and hydraulics; kerosene; asphaltic petroleum hydrocarbon; and ethylene glycol.
Acceptable waste at any NTS landfill:
$\triangle$ Paper
Wood
$\triangle$ Soil
$\square$ Rocks / unaltered geologic materials
$\bigotimes$ Rubber (excluding tires)
$\bigotimes$ Asphalt
$凶$ Metal
Q Cable
$\triangle$ Cloth
$\bigotimes$ Insulation (non-Asbestosform)
Empty containers
$\otimes$ Demolition debris
$\bigotimes$ Cement \& concrete
$\triangle$ Manufactured items: (swamp coolers, furniture, rugs, carpet, electronic components, PPE, etc.)
Additional waste accepted at the Area 23 Mercury Landfill: $\square$ Office Waste $\square$ Food Waste
$\square$ Asbestos $\quad \square$ Friable $\square$ Non-Friable (contact SWO if regulated load) Quantity:

Additional waste accepted at the Area 9 U10c Landfill:

$\square$ Non-friable asbestos

Light ballasts (contact SWO)

Drained automobiles and military vehicles

Solid fractions from sand/oil/water

Hydrocarbons (contact SWO)

Drained fuel filters (gas \& diesel)

$\otimes$ Deconned Underground and Above

$\triangle$ Other Drained generators/equipment Ground Tanks

Additional waste accepted at the Area 6 Hydrocarbon Landfill:
$\square$ Septic sludge
$\square$ Rags
$\square$ Drained fuel filters (gas \& diesel)
$\square$ Sludge from sand/oil/water separators
REQUIRED: WASTE GENERATOR SIGNATURE
Crushed non-teme plated oil filters
Plants
Soil

(if initialed, no radiological clearance is necessary.)

Initials:

The above mentioned waste was generated outside of a Controlled Waste Management Area (CWMA) and to the best of mv knowledge, does not contain radiological materials.

To the best of my knowledge, the waste described above contains only those $n$ site. I have verified this through the waste characterization method identified a prohibited and allowable waste items. I have contacted Property Management is approved for disposal in the landfill.

Print Name: Dan Tobiason

Signature:
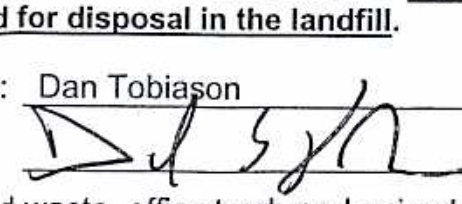

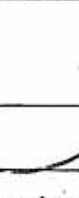

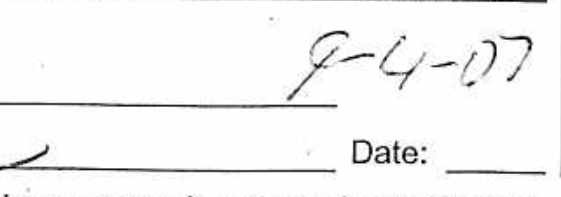

Note: "Food waste, office trash and animal carcasses do not require a radiologic must have signed removal certification statement with Load Verification."
SWO USE ONLY
Load Weight (net from scale or estimate): $4 / 0,000$ $\begin{gathered}9-4-07 \\ \text { Signature of Certifier: }\end{gathered}$
Radiological Survey Release for Waste Disposal RCT Initials

This container/load meets the criteria for no added man-made radioactive material This container/loat meets the criteria for Radcon Manuaf Table 4.2 release limits. This containgflload is exempt from survey; due to process knowledge and origin.
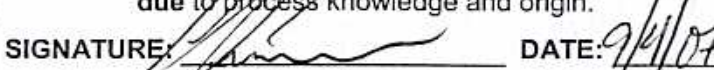
FRM-064d (08/06)

.

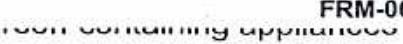
(1) 
NSTec

Form

FRM-0918

NTS LANDFILL LOAD VERIFICATION

Page

SWO USE (Select One) AREA

For waste characterization, approval, and/or assistance, contact Solid Waste Operation (SWO) at 5-7898.

REQUIRED: WASTE GERERATOR INFORMATION

(This form is for rolloffs, dump trucks, and other onsite disposal of materials.)

Waste Generator: Dan Tobiason

Phone Number: 295-6169

Lócation / Origin: T-Tunnel Lower Laydown Yard

Waste Category: (check one)

Waste Type: $\square$ NTS $\square$ Putrescrible

(check one)

$\square$ Non-Putrescible

$\square$ Asbestos Containing Material

$\triangle$ Industrial cgs 9/6/07

Pollution Prevention Category: (check one)

Pollution Prevention Category: (check one)

Environmental management

Method of Characterization: (check one

$\bigotimes$ Clean-Up

Prohibited Waste at all three

NTS landfills:

Additional Prohibited Waste

at the Area 9 U10C Landfill:

Radioactive waste; RCRA waste; Hazardous waste; Free liquids, PCBs above TSCA regulatory levels, and Medical wastes (needles, sharps, bloody clothing).

Sewage Sludge, Animal carcasses, Wet garbage (food waste); and Friable asbestos

\section{REQUIRED: WASTE CONTENTS ALLOWABLE WASTES}

Check all allowable wastes that are contained within this load:

NOTE: Waste disposal at the Area 6 Hydrocarbon Landfill must have come into contact with petroleum hydrocarbons or coolants, such as: gasoline (no benzene, lead); jet fuel; diesel fuel; lubricants and hydraulics; kerosene; asphaltic petroleum hydrocarbon; and ethylene glycol.

Acceptable waste at any NTS landfill:

Asphalt $\quad$ Metal $\quad$ Wood $\quad$ Soil

$\otimes$ Plastic $\quad$ Wire $\quad \square$ Cable $\quad$ Cloth

$\square$ Rocks / unaltered geologic materials

$\bigotimes$ Rubber (excluding tires)

\Insulation (non-Asbestosform)

$\bigotimes$ Empty containers

$\bigotimes$ Demolition debris

$\triangle$ Manufactured items: (swamp coolers, furniture, rugs, carpet, electronic components, PPE, etc.)

Additional waste accepted at the Area 23 Mercury Landfill: $\square$ Office Waste

Asbestos

$\square$ Friable

Non-Friable (contact SWO if regulated load)

$\square$ Food Waste

Quantity:

Additional waste accepted at the Area 9 U10c Landfill:

$\square$ Non-friable asbestos

Drained automobiles and military vehicles

Light ballasts (contact SWO)

Drained fuel filters (gas \& diesel)

Hydrocarbons (contact SWO)

$\triangle$ Other Drained generators/equipment

Solid fractions from sand/oil/water

$\triangle$ Deconned Underground and Above Ground Tanks

Additional waste accepted at the Area 6 Hydrocarbon Landfill:
$\square$ Septic sludge
$\square$ Rags
$\square$ Drained fuel filters (gas \& diesel)
Plants
Soil
$\square$ Sludge from sand/oil/water separators
REQUIRED: WASTE GENERATOR SIGNATURE
Crushed non-teme plated oil filters
PCBs below 50 parts per million

Initials: (if initialed, no radiological clearance is necessary.)

The above mentioned waste was generated outside of a Controlled Waste Management Area (CWMA) and to the best of my knowledge, does not contain radiological materials.

To the best of my knowledge, the waste described above contains only those $n$ site. I have verified this through the waste characterization method identified a prohibited and allowable waste items. I have contacted Property Management is approved for disposal in the landfill.

Print Name: Dan Tobiason

Signature:
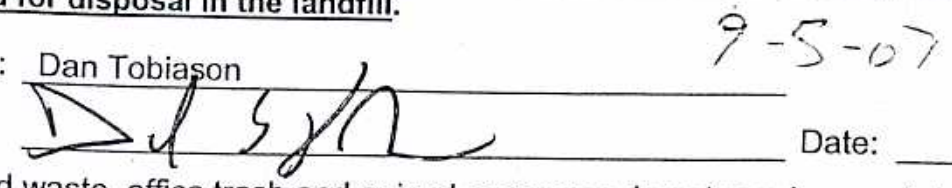

Date:

Note: "Food waste, office trash and animal carcasses do not require a radiologic must have signed removal certification statement with Load Verification."

Radiological Survey Release for Waste Disposal RCT Initials

( This container/load meets the criteria for no added man-made radioactive material This container/load meets the criteria for Radcon Manual Table 4.2 release limits. This container/load is exempt from survey due to orocess knowledge and origin.

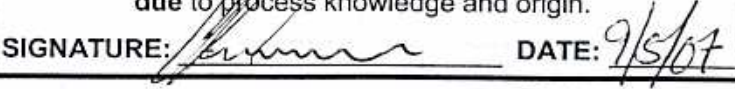

FRM-0646 (08/06)

SWO USE ONLY

Load Weight (net from scale of estimate): $20,0 \Omega$

9-5-07

Signature of Certifier:

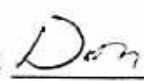


NSTec

Form

FRM-0918

NTS LANDFILL LOAD VERIFICATION

Page:

SWO USE (Select One) AREA

23

6

$\triangle 9$

$\triangle$ LANDFILL

For waste characterization; approval, and/or assistance, contact Solid Waste Operation (SWO) at 5-7898. REQUIRED: WASTE GERERATOR INFORMATION

(This form is for rolloffs, dump trucks, and other onsite disposal of materials.)

Waste Generator: Dan Tobiason

Phone Number: 295-6169

Location / Origin: T-Tunnel Lower Laydown Yard

Waste Category: (check one)

$\square$ Commercial

$\triangle$ Industrial Os 9/6lo 7

Waste Type: $\square$ NTS

$\square$ Putrescrible

$\triangle$ FFAGO-Onsite

$\square$ WAC Exception

(check one)

$\square$ Non-Putrescible

$\square$ Asbestos Containing Material

$\square$ FFACO-offsite

$\square$ Historic DOE/NV

Pollution Prevention Category: (check one) $\square$ Environmental management

Pollution Prevention Category: (check one) $\$ Clean-Up

Method of Characterization: (check one)

$\triangle$ Defense Projects

YMP

Prohibited Waste at all three

NTS landfills:

Additional Prohibited Waste

at the Area 9 U10C Landfill:

Radioactive waste; RCRA waste; Hazardous waste; Free liquids, PCBs above TSCA regulatory levels, and Medical wastes (needles, sharps, bloody clothing).

Sewage Sludge, Animal carcasses, Wet garbage (food waste); and Friable asbestos

REQUIRED: WASTE CONTENTS ALLOWABLE WASTES

Check all allowable wastes that are contained within this load:

NOTE: Waste disposal at the Area 6 Hydrocarbon Landfill must have come into contact with petroleum hydrocarbons or coolants, such as: gasoline (no benzene, lead); jet fuel; diesel fuel; lubricants and hydraulics; kerosene; asphaltic petroleum hydrocarbon; and ethylene glycol.
Acceptable waste at any NTS landfill:
$\triangle$ Paper
$\square$ Rocks / unaltered geologic materials
$\bigotimes$ Asphalt
$凶$ Metal
$\triangle$ Wood
$\bigotimes$ Soil
$\bigotimes$ Rubber (excluding tires)
区 Plastic
$凶$ Wire
$\triangle$ Cable
$\bigotimes$ Cloth
$\bigotimes$ Insulation (non-Asbestosform)

$凶$ Empty containers

$\bigotimes$ Demolition debris

$\triangle$ Manufactured items: (swamp coolers, furniture, rugs, carpet, electronic components, PPE, etc.)
Additional waste accepted at the Area 23 Mercury Landfill: $\square$ Office Waste
$\square$ Asbestos $\square$ Friable
Non-Friable (contact SWO if regulated load)
$\square$ Food Waste
Animal Carcasses
Quantity:

Additional waste accepted at the Area 9 U10c Landfill:

$\square$ Non-friable asbestos $\quad \square$ Drained automobiles and military vehicles
$\square$ Light ballasts (contact SWO) $\square$ Drained fuel filters (gas \& diesel)
$\square$ Hydrocarbons (contact SWO) $\square$ Other Drained generators/equipment

$\bigotimes$ Cement \& concrete

Additional waste accepted at the Area 6 Hydrocarbon Landfill:
$\square$ Septic sludge
$\square$ Plants
$\square$ Rags
$\square$ Drained fuel filters (gas \& diesel)
Soil
$\square$ Sludge from sand/oil/water separators REQUIRED: WASTE GENERATOR SIGNATURE
Crushed non-teme plated oil filters PCBs below 50 parts per million

Solid fractions from sand/oil/water

$\bigotimes$ Deconned Underground and Above

Ground Tanks

Initials: ___ (if initialed, no radiological clearance is necessary.)

The above mentioned waste was generated outside of a Controlled Waste Management Area (CWMA) and to the best of my knowledge, does not contain radiological materials.

To the best of my knowledge, the waste described above contains only those $\mathrm{r}$ site. I have verified this through the waste characterization method identified a prohibited and allowable waste items. I have contacted Property Management : is approved for disposal in the landfill.

Print Name: Dan Tobiason

Signature:
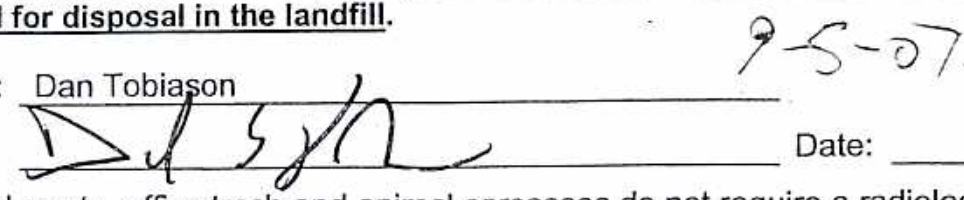

Note: "Food waste, office trash and animal carcasses do not require a radiologi must have signed removal certification statement with Load Verification."

Radiological Survey Release for Waste Disposal RCT Initials This container/load meets the criteria for no This container/loagmeets the criteria for Radcon Manual Table 4.2 release limits. This containgrhoad is exempt from survey due toprocess knowledge and origin. SIGNATURE: FRM-0646 (08/06) SWO USE ONLY

Load Weight (net from scale or estimate): 20,000

9-5- 07

Signature of Certifier: 
NSTec

Form

FRM-0918

NTS LANDFILL LOAD VERIFICATION

\begin{tabular}{|c|ccc|}
\hline SWO USE (Select One) AREA & A23 & $\square 6$ & 23 \\
\hline For waste characterization, approval, and/or assistance, contact Solid Waste Operation (SWO) at 5-7898.
\end{tabular}

REQUIRED: WASTE GERERATOR INFORMATION

(This form is for rolloffs, dump trucks, and other onsite disposal of materials.)

Waste Generator: Dan Tobiason

Phone Number: 295-6169

Location / Origin: T-Tunnel Lower Laydown Yard

Waste Category: (check one)

Waste Type: $\triangle$ NTS

(check one) $\quad \square$ Non-Putrescible

Pollution Prevention Category: (check one) $\square$ Environmental management

Pollution Prevention Category: (check one)

Method of Characterization: (check one)

$\square$ Commercial

$\square$ Putrescrible

$\triangle$ Clean-Up

$\square$ Sampling \& Analysis

Prohibited Wast

Additional Prohibited Waste

at the Area 9 U10C Landfill: Radioactive waste; RCRA waste; Hazardous waste; Free liquids, PCBs above TSCA regulatory
levels, and Medical wastes (needles, sharps, bloody clothing).

Sewage Sludge, Animal carcasses, Wet garbage (food waste); and Friable asbestos

\section{REQUIRED: WASTE CONTENTS ALLOWABLE WASTES}

Check all allowable wastes that are contained within this load:
NOTE: Waste disposal at the Area 6 Hydrocarbon Landfill must have come into contact with petroleum hydrocarbons or
coolants, such as: gasoline (no benzene, lead); jet fuel; diesel fuel; lubricants and hydraulics; kerosene; asphaltic coolants, such as: gasoline (no benzene, lead); jet fuel; diesel fuel; lubricants and hydraulics; kerosene; asphaltic petroleum hydrocarbon; and ethylene glycol.

Acceptable waste at any NTS landfill: $\triangle$ Paper

$\square$ Rocks / unaltered geologic materials

$\triangle$ Plastic $\quad$ Wire $\quad$ Cable $\triangle$ Cloth $\quad$ Rubber (excluding tires)

Insulation (non-Asbestosform)

Additional waste accepted at coolers, furniture, rugs, carpet, electronic components, PPE, etc.)
$\square$ Asbestos
$\square$ Friable
Area 23 Mercury Landfill:
$\square$ Non-Friable (contact Sw
$\square$ Office Waste
$\square$ Food Waste
Quantity:

Additional waste accepted at the Area 9 U10c Landfill:
Non-friable asbestos
Light ballasts (contact SwO)
$\square$ Drained automobiles and military vehicles
Drained fuel filters (gas \& diesel)
Hydrocarbons (contact SWO)
Drained generators/equipment

$\triangle$ Other

Additional waste accepted at the Area 6 Hydrocarbon Landfill:
$\square$ Septic sludge
Plants
$\square$ Rags
Soil
$\square$ Drained fuel filters (gas \& diesel)
$\square$ Sludge from sand/oil/water separators $\square$
Crushed non-teme plated oil filters PCBs below 50 parts per million

Solid fractions from sand/oil/water

$\triangle$ Deconned Underground and Above Ground Tanks

Initials: (if initialed, no radiological clearance is necessary.)

The above mentioned waste was generated outside of a Controlled Waste Management Area (CWMA) and to the best of my
knowledge, does not contain

To the best of my knowledge, the waste described above contains only those prohibited and alled this through the waste characterization method identifiec is approved for disposal in the landfil. I have contacted Property Managemer

Print Name:

Signature:
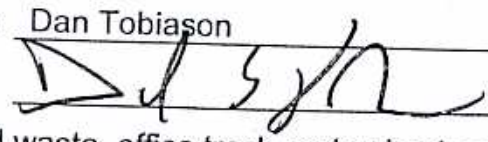
S- 601
Date: Radiological Survey Release for Waste Disposal RCT Initials

Note: "Food waste, office trash and animal carcasses do not require a radiolo must have signed removal certification statement with Load Verification." SWO USE ONLY Load Weight (net from scale of estimate): $L 15, \Omega \Omega 0$ Signature of Certifier - This container/load meets the criteria for no C. added man-made radioactive material This container/load meets the criteria for Radcon ManualTable 4.2 release limits. This containfilload is exempt from survey due to progess knowledge and origin. 
NSTec

Form

FRM-0918

NTS LANDFILL LOAD VERIFICATION

\begin{tabular}{lllll}
\hline SWO USE (Select One) & AREA & $\square 23$ & $\square 6$ & $\square 9$
\end{tabular}

For waste characterization, approval, and/or assistance, contact Solid Waste Operation (SWO) at 5-7898.

REQUIRED: WASTE GERERATOR INFORMATION

(This form is for rolloffs, dump trucks, and other onsite disposal of materials.)

Waste Generator: Dan Tobiason

Phone Number: 295-6169

Location / Origin: T-Tunnel Lower Laydown Yard

Waste Category: (check one)

Waste Type: $₫$ NTS

Pollution Prevention Category: (check one) $\square$ Environmental management

Pollution Prevention Category: (check one) $\triangle$ Clean-Up

Method of Characterization: (check one) $\square$ Sampling \& Analysis

Prohibited Waste at all three Radioactive wast RCRA waste; Hazarc

NTS landfills:

Additional Prohibited Waste

at the Area 9 U10C Landfill: levels, and Medical wastes (needles, sharps, bloody clothing).

$\triangle$ Industrial cos 9-10-07

$\triangle$ FFACO-Ansite $\square$ WAC Exception

$\square$ FFACO-offsite $\square$ Historic DOE/NV

$\triangle$ Defense Projects $\square$ YMP

$\square$ Routine

$\otimes$ Process Knowledge $\square$ Contents

Sewage Sludge, Animal carcasses, Wet garbage (food waste); and Friable asbestos

\section{REQUIRED: WASTE CONTENTS ALLOWABLE WASTES}

Check all allowable wastes that are contained within this load:

NOTE: Waste disposal at the Area 6 Hydrocarbon Landfill must have come into contact with petroleum hydrocarbons or coolants, such as: gasoline (no benzene, lead); jet fuel; diesel fuel; lubricants and hydraulics; kerosene; asphaltic petroleum hydrocarbon; and ethylene glycol.

Acceptable waste at any NTS landfill: $\triangle$ Paper

$\triangle$ Asphait $\square$ Metal $\otimes$ Wood $\square$ Soil

$\triangle$ Plastic $\quad$ Wire $\quad$ Cable $\quad$ Cloth

$\square$ Rocks / unaltered geologic materials

$\bigotimes$ Rubber (excluding tires)

$\triangle$ Insulation (non-Asbestosform)

$\triangle$ Empty containers

$\triangle$ Demolition debris

$\triangle$ Manufactured items: (swamp coolers, furniture, rugs, carpet, electronic components, PPE, etc.)

\section{Additional waste accepted at the Area 23 Mercury Landfill: $\square$ Office Waste}

$\square$ Asbestos

Friable

$\square$ Non-Friable (contact SWO if regulated load)

Food Waste

$\otimes$ Cement \& concrete

Additional waste accepted at the Area 9 U10c Landfill:

Non-friable asbestos

Light ballasts (contact SWO)

Hydrocarbons (contact SWO)

$\square$ Drained automobiles and military vehicles

Drained fuel filters (gas \& diesel)

$\triangle$ Other Drained generators/equipment

Quantity:

Animal Carcasses

Solid fractions from sand/oil/water

$\bigotimes$ Deconned Underground and Above Ground Tanks

Additional waste accepted at the Area 6 Hydrocarbon Landfill:
Septic sludge
$\square$ Rags
Plants
$\square$ Soil

$\square$ Drained fuel filters (gas \& diesel)

$\square$ Sludge from sand/oil/water separators REQUIRED: WASTE GENERATOR SIGNATURE

Crushed non-teme plated oil filters PCBs below 50 parts per million

Initials: (if initialed, no radiological clearance is necessary.)

The above mentioned waste was generated outside of a Controlled Waste Management Area (CWMA) and to the best of my
knowledge, does not contain radiological materials.

To the best of my knowledge, the waste described above contains only those $\mathrm{r}$ site. I have verified this through the waste characterization method identified a prohibited and allowable waste items. I have contacted Property Management : is approved for disposal in the landfill.

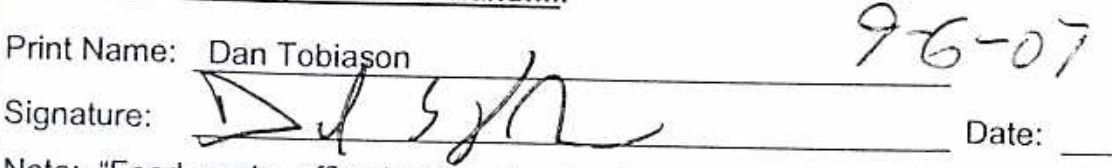

Note: "Food waste, office trash and animal carcasses do not require a radiologi must have signed removal certification statement with Load Verification." Radiological Survey Release for Waste Disposal - This container/load meets the criteria for no

P1 $\mathrm{N}$ added man-made radioactive material This container/load meets the criteria for Radcon Manual Table 4.2 release limits. This containerload is exempt from survey due to brocess knowlis exempt from survey SIGNATURE. DATE: $3 / 6 / / 7$ FRM-0646 (08/06) SWO USE ONLY Load Weight (net from scale of estimate): $8760 \quad \begin{gathered}9-6-67 \\ \text { Signature of Certifier }\end{gathered}$ 
NSTec

Form

FRM-0918

NTS LANDFILL LOAD VERIFICATION

Page

\begin{tabular}{lllll}
\hline SWO USE (Select One) & AREA & $\square 23$ & $\square 6$ & Q 9
\end{tabular}

For waste characterization, approval, and/or assistance, contact Solid Waste Operation (SWO) at 5-7898.

REQUIRED: WASTE GERERATOR INFORMATION

(This form is for rolloffs, dump trucks, and other onsite disposal of materials.)

Waste Generator: Dan Tobiason

Phone Number: 295-6169

Location / Origin: T-Tunnel Lower Laydown Yard

Waste Category: (check one)

Waste Type: $\square$ NTS

(check one)

$\square$ Non-Putrescible

$\square$ Commercial

Q. Industrial cos $9-10-07$

$\square$ Putrescrible

$\triangle$ AFACO-Onsite

$\square$ WAC Exception

Pollution Prevention Category: (check one) $\square$ Environmental management

Pollution Prevention Category: (check one) $\bigotimes$ Clean-Up

Method of Characterization: (check one)

Sampling \& Analysis

$\square$ FFACO-offsite

$\square$ Historic DOE/NV

Prohibited Waste at all three

NTS landfills:

Additional Prohibited Waste

at the Area 9 U10C Landfill:

Radioactive waste; RCRA waste; Hazardous waste; Free liquids, PCBs above TSCA regulatory levels, and Medical wastes (needles, sharps, bloody clothing).

Sewage Sludge, Animal carcasses, Wet garbage (food waste); and Friable asbestos

\section{REQUIRED: WASTE CONTENTS ALLOWABLE WASTES}

Check all allowable wastes that are contained within this load:

NOTE: Waste disposal at the Area 6 Hydrocarbon Landfill must have come into contact with petroleum hydrocarbons or coolants, such as: gasoline (no benzene, lead); jet fuel; diesel fuel; lubricants and hydraulics; kerosene; asphaltic petroleum hydrocarbon; and ethylene glycol.

Acceptable waste at any NTS landfill: $\bigotimes$ Paper
$\bigotimes$ Asphalt
$\otimes$ Metal
$凶$ Wood
$凶$ Soil
$凶$ Cloth
$\square$ Rocks / unaltered geologic materials
$\bigotimes$ Rubber (excluding tires)
$\bigotimes$ Insulation (non-Asbestosform)
$\triangle$ Plastic $\quad$ Wire $\quad \square$ Cable

$凶$ Empty containers

$\bigotimes$ Demolition debris

$\triangle$ Manufactured items: (swamp coolers, furniture, rugs, carpet, electronic components, PPE, etc.)

Additional waste accepted at the Area 23 Mercury Landfill: $\square$ Office Waste $\square$ Food Waste
$\square$ Asbestos $\square$ Friable $\square$ Non-Friable (contact SWO if regulated load) Quantity:

\ Cement \& concrete

Additional waste accepted at the Area 9 U10c Landfill:

$\square$ Non-friable asbestos

Light ballasts (contact SWO)

Drained automobiles and military vehicles

$\square$ Drained fuel filters (gas \& diesel)

Hydrocarbons (contact SWO)

$\bigotimes$ Other Drained generators/equipment

Solid fractions from sand/oil/water

$凶$ Deconned Underground and Above Ground Tanks

Additional waste accepted at the Area 6 Hydrocarbon Landfill:
$\square$ Septic sludge
$\square$ Rags
$\square$ Drained fuel filters (gas \& diesel)
Plants
Soil
$\square$ Sludge from sand/oil/water separators
REQUIRED: WASTE GENERATOR SIGNATURE
Crushed non-teme plated oil filters PCBs below 50 parts per million

Initials: (if initialed, no radiological clearance is necessary.)

The above mentioned waste was generated outside of a Controlled Waste Management Area (CWMA) and to the best of my knowledge, does not contain radiological materials.

To the best of my knowledge, the waste described above contains only those $m$ site. I have verified this through the waste characterization method identified a prohibited and allowable waste items. I have contacted Property Management : is approved for disposal in the landfill.

Print Name: Dan Tobiason

Radiological Survey Release for Waste Disposal RCT Initials

+ This container/load meets the criteria for no

1. added man-made radiøactive material This container/load meets the criteria for Radcon Manuar Table 4.2 release limits. This containeryload is exempt from survey due to process knowledge and origin.

Note: "Food waste, office trash and animal carcasses do not require a radiologic must have signed removal gertification statement with Load Verification."

\section{SWO USE ONLY}

Load Weight (net from scale or estimate): $10,000 \begin{gathered}9-6-07 \\ \text { Signature of Certifier: }\end{gathered}$ SIGNATURE: DATE: $9 / 6 / 27$ FRM-0646(08/06)

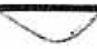




\begin{tabular}{|llllll}
\hline SWO USE (Select One) & AREA & $\square 23$ & $\square 6$ & AR & L LANDFILL
\end{tabular}

For waste characterization, approval, and/or assistance, contact Solid Waste Operation (SWO) at 5-7898.

REQUIRED: WASTE GERERATOR INFORMATION

(This form is for rolloffs, dump trucks, and other onsite disposal of materials.)

Waste Generator: Dan Tobiason

Phone Number: 295-6169

Location / Origin: T-Tunnel Lower Laydown Yard

Waste Category: (check one)

Waste Type: $\triangle$ NTS

(check one)

$\square$ Non-Putrescible

$\square$ Commercial
$\square$ Putrescrible
$\square$ Asbestos Containing Material
$\square$ Environmental management
$\square$ Clean-Up
$\square$ Sampling \& Analysis

$\triangle$ Industrial egs $9-12-07$

AFFACO-OISite $\square$ WAC Exception

Pollution Prevention Category: (check one)

Pollution Prevention Category: (check one)

Method of Characterization: (check one)

Sampling \& Analysis

$\square$ FFACO-offsite

$\square$ Historic DOE/NV

Prohibited Waste at all three

NTS landfills:

Additional Prohibited Waste

at the Area 9 U10C Landfill:

Radioactive waste; RCRA waste; Hazardous waste; Free liquids, PCBs above TSCA regulatory
levels, and Medical wastes (needles, sharps, bloody clothing).

Sewage Sludge, Animal carcasses, Wet garbage (food waste); and Friable asbestos

\section{REQUIRED: WASTE CONTENTS ALLOWABLE WASTES}

Check all allowable wastes that are contained within this load:

NOTE: Waste disposal at the Area 6 Hydrocarbon Landfill must have come into contact with petroleum hydrocarbons or coolants, such as: gasoline (no benzene, lead); jet fuel; diesel fuel; lubricants and hydraulics; kerosene; asphaltic petroleum hydrocarbon; and ethylene glycol.

Acceptable waste at any NTS landfill: $\triangle$ Paper
$\bigotimes$ Asphalt
$\otimes$ Metal
$\triangle$ Wood
$\otimes$ Soil
$\triangle$ Cloth
$\square$ Rocks / unaltered geologic materials
$\triangle$ Rubber (excluding tires)
$\bigotimes$ Insulation (non-Asbestosform)
Q Plastic
$凶$ Cable

$\triangle$ Empty containers

$\bigotimes$ Demolition debris

pet, electronic components, PPE, etc.)
Additional waste accepted at the Area 23 Mercury Landfill:
$\square$ Asbestos
Friable
Non-Friable (contact SWO if regulated load)
Food Waste
Animal Carcasses
Quantity:

Additional waste accepted at the Area 9 U10c Landfill:

$\square$ Non-friable asbestos

$\square$ Light ballasts (contact SWO)

Hydrocarbons (contact SWO)

$\square$ Drained automobiles and military vehicles

$\square$ Drained fuel filters (gas \& diesel)

$\bigotimes$ Other Drained generators/equipment

$\bigotimes$ Cement \& concrete

Additional waste accepted at the Area 6 Hydrocarbon Landfill:

$\square$ Septic sludge $\square$ Rags $\square$ Drained fuel filters (gas \& diesel)

Plants

Soil

$\square$ Sludge from sand/oil/water separators REQUIRED: WASTE GENERATOR SIGNATURE

Solid fractions from sand/oil/water

$\triangle$ Deconned Underground and Above Ground Tanks

Initials: (if initialed, no radiological clearance is necessary.)

The above mentioned waste was generated outside of a Controlled Waste Management Area (CWMA) and to the best of my
knowledge, does not contain radiological materials.

To the best of my knowledge, the waste described above contains only those ma site. I have verified this through the waste characterization method identified abc prohibited and allowable waste items. I have contacted Property Management an is approved for disposal in the landfill.

Print Name:

Signature:
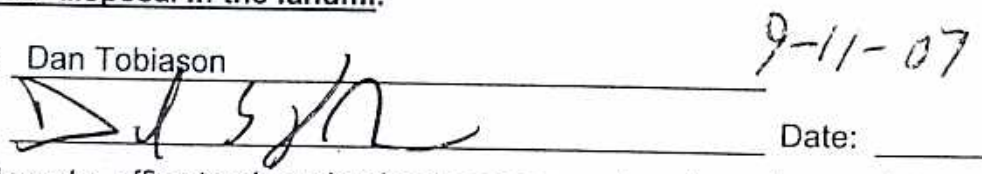

Note: "Food waste, office trash and animal carcasses do not require a radiological must have signed removal certification statement with Load Verification."
Radiological Survey Release for Waste Disposal RCT Initials

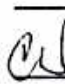

This container/load meets the criteria for no added man-made radioactive material This container/load meets the criteria for Radcon Manuar Tabie 4.2 release limits. This containefilload is exempt from survey due to process knowledge and origin. 


\begin{tabular}{|llllll}
\hline SWO USE (Select One) & AREA & $\square 23$ & $\square 6$ & AR & \ LANDFILL
\end{tabular}

For waste characterization, approval, and/or assistance, contact Solid Waste Operation (SWO) at 5-7898.

REQUIRED: WASTE GERERATOR INFORMATION

(This form is for rolloffs, dump trucks, and other onsite disposal of materials.)

Waste Generator: Dan Tobiason

Phone Number: 295-6169

Location / Origin: T-Tunnel Lower Laydown Yard

Waste Category: (check one)

Waste Type: $\otimes$ NTS

(check one)

$\square$ Non-Putrescible

Pollution Prevention Category: (check one)

Pollution Prevention Category: (check one)

Method of Characterization: (check one)

$\square$ Commercial
$\square$ Putrescrible
$\square$ Asbestos Containing Material

$\triangle$ Industrial eqs $9-12-07$

ZIFACO-Ongite

$\square$ FFACO-offsite

$\triangle$ Defense Projects

$\triangle$ Clean-Up

$\square$ Sampling \& Analysis

$\square$ Routine

$\triangle$ Process Knowledge $\square$ Contents

Prohibited Waste at all three

NTS landfilis:

Additional Prohibited Waste

at the Area 9 U10C Landfill:

Radioactive waste; RCRA waste; Hazardous waste; Free liquids, PCBs above TSCA regulatory levels, and Medical wastes (needles, sharps, bloody clothing).

Sewage Sludge, Animal carcasses, Wet garbage (food waste); and Friable asbestos

REQUIRED: WASTE CONTENTS ALLOWABLE WASTES

Check all allowable wastes that are contained within this load:

NOTE: Waste disposal at the Area 6 Hydrocarbon Landfill must have come into contact with petroleum hydrocarbons or coolants, such as: gasoline (no benzene, lead); jet fuel; diesel fuel; lubricants and hydraulics; kerosene; asphaltic petroleum hydrocarbon; and ethylene glycol.

Acceptable waste at any NTS landfill:

$\triangle$ Asphalt $\otimes$ Metal $\otimes$ Wood

$\triangle$ Soil

$\triangle$ Cable

Cloth

$\square$ Rocks / unaltered geologic materials

$\bigotimes$ Rubber (excluding tires)

$\triangle$ Insulation (non-Asbestosform)

$\triangle$ Empty containers

$\triangle$ Demolition debris

$\triangle$ Manufactured items: (swamp coolers, furniture, rugs, carpet, electronic components, PPE, etc.)

\section{Additional waste accepted at the Area 23 Mercury Landfill: $\square$ Office Waste}

Asbestos

Friable

Non-Friable (contact SWO if regulated load)

Food Waste

Animal Carcasses

Additional waste accepted at the Area 9 U10c Landfill:

$\square$ Non-friable asbestos

Light ballasts (contact SWO)

Drained automobiles and military vehicles

Drained fuel filters (gas \& diesel)

Hydrocarbons (contact SWO)

Other Drained generators/equipment

Quantity:

$\bigotimes$ Cement \& concrete

Additional waste accepted at the Area 6 Hydrocarbon Landfill:
$\square$ Septic sludge
$\square$ Rags
$\square$ Drained fuel filters (gas \& diesel)
Plants
$\square$ Soil
$\square$ Sludge from sand/oil/water separators
REQUIRED: WASTE GENERATOR SIGNATURE
Crushed non-teme plated oil filters PCBs below 50 parts per million

Solid fractions from sand/oil/water

$\triangle$ Deconned Underground and Above Ground Tanks

Initials: (if initialed, no radiological clearance is necessary.)

The above mentioned waste was generated outside of a Controlled Waste Man knowledge, does not contain radiological materials.

To the best of my knowledge, the waste described above contains only those $n$ site. I have verified this through the waste characterization method identified prohibited and allowable waste items. I have contacted Property Management is approved for disposal in the landfill.

Print Name: Dan Tobiason

Signature:

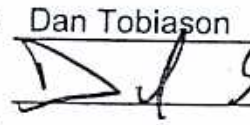

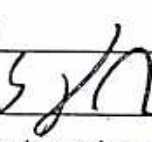

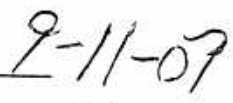

Date:

Note: "Food waste, office trash and animal carcasses do not require a radiological must have signed removal certification statement with Load Verification."

Radiological Survey Release for Waste Disposal RCT Initials

This container/load meets the criteria for no

Q added man-made radioactive material

C This container/load meets the criteria for Radcon. Manuar Jable 4.2 release limits. This contain rol hoad is exempt from survey due to precess knowledge and origin.

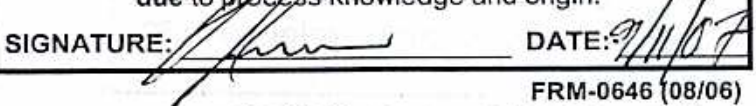
FRM-0646 (08/06) 


\begin{tabular}{|ccccc}
\hline SWO USE (Select One) & AREA \\
\hline For waste characterization, approval, and/or assistance, contact Solid Waste Operation (SWO) at 5.7898.
\end{tabular}

\section{REQUIRED: WASTE GERERATOR INFORMATION}

(This form is for rolloffs, dump trucks, and other onsite disposal of materials.)

Waste Generator: Dan Tobiason

Phone Number: 295-6169

Location / Origin: T-Tunnel Lower Laydown Yard

Waste Category: (check one)

Waste Type: $\square$ NTS

(check one)

$\square$ Non-Putrescible $\square$ Asbestos Containing Material

$\square$ Commercial

Q Industrial as 9-12-07

Pollution Prevention Category: (check one)

Pollution Prevention Category: (check one)

Method of Characterization: (check one)

$\square$ Environmental management

$\triangle$ Clean-Up

Sampling \& Analysis

XPFACO-Ongite $\square$ WAC Exception

Prohibited Waste at all three

NTS landfills:

Additional Prohibited Waste

at the Area 9 U10C Landfill:
Radioactive
levels, and $M e c$

Sampling \& Analysis

$\square$ FFACO-offsite

Historic DOE/NV

$\triangle$ Defense Projects

YMP

Routine

$Q$ Process Knowledge $\square$ Contents levels, and Medical wastes (needles, sharps, bloody clothing).

Sewage Sludge, Animal carcasses, Wet garbage (food waste); and Friable asbestos

\section{REQUIRED: WASTE CONTENTS ALLOWABLE WASTES}

Check all allowable wastes that are contained within this load:

NOTE: Waste disposal at the Area 6 Hydrocarbon Landfill must have come into contact with petroleum hydrocarbons or coolants, such as: gasoline (no benzene, lead); jet fuel; diesel fuel; lubricants and hydraulics; kerosene; asphaltic petroleum hydrocarbon; and ethylene glycol.

Acceptable waste at any NTS landfill: $\bigotimes$ Pape
$\bigotimes$ Asphalt
Q Metal
$\triangle$ Wood
凶 Soil
$\square$ Rocks / unaltered geologic materials
R Rubber (excluding tires)
$\triangle$ Plastic $\bigotimes$ Wire
$\bigotimes$ Cable
$凶$ Cloth
$\triangle$ Insulation (non-Asbestosform)

\section{Empty containers \\ $\bigotimes$ Demolition debris}

$\triangle$ Manufactured items: (swamp coolers, furniture, rugs, carpet, electronic components, PPE, etc.)
Aclditional waste accepted at the Area 23 Mercury Landfill:
Office Waste
Food Waste
Animal Carcasses
$\square$ Asbestos
Friable
Non-Friable (contact SWO if regulated load)
Quantity:

Additional waste accepted at the Area 9 U10 Landfill:

$\square$ Non-friable asbestos

$\square$ Light ballasts (contact SWO)

Hydrocarbons (contact SWO)

Drained automobiles and military vehicles

Drained fuel filters (gas \& diesel)

O Other

Drained generators/equipment
Solid fractions from sand/oil/water

$\triangle$ Deconned Underground and Above Ground Tanks

Additional waste accepted at the Area 6 Hydrocarbon Landfill:
$\square$ Septic sludge
$\square$ Rags
$\square$ Drained fuel filters (gas \& diesel)
Plants
$\square$ Soil
$\square$ Sludge from sand/oil/water separators
REQUIRED: WASTE GENERATOR SIGNATURE
Crushed non-teme plated oil filters
PCBs below 50 parts per million

Initials:

(if initialed, no radiological clearance is necessary.)

The above mentioned waste was generated outside of a Controlled Waste Management Area (CWMA) and to the hest nf mu

knowledge, does not contain radiological materials.

To the best of my knowledge, the waste described above contains only those $n$ site. I have verified this through the waste characterization method identified a prohibited and allowable waste items. I have contacted Property Management : is approved for disposal in the landfill.

Print Name
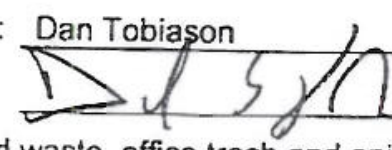

$7-i-i$

Signature:

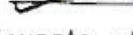

Radiological Survey Release for Waste Disposal

RCT Initials

1 This containerlload trieets the criteria for no

(i) added man-made fadioactive material

W This containerlload meets the criteria for Radcon Manual Table 4.2 release limits. This coninger/load is exempt from survey due to protess knowledge and origin.

Note: "Food waste, office trash and animal carcasses do not require a radiologic must have signed removal certification statement with Load Verification."

SWO USE ONLY

Load Weight (net from scale or @stimate):

$20,00129-11-07$

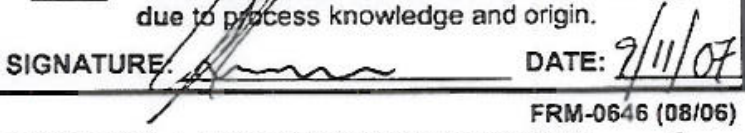
FRM-0646 (08/06)

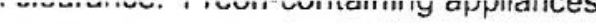


NSTec

Form

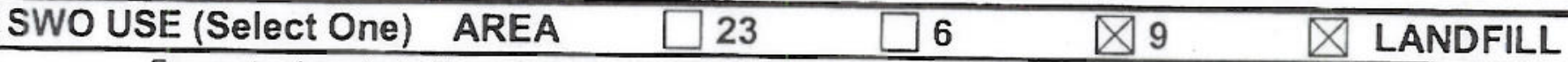

For waste characterization, approval, and/or assistance, contact Solid Waste Operation (SWO) at 5-7898.

REQUIRED: WASTE GERERATOR INFORMATION

(This form is for rolloffs, dump trucks, and other onsite disposal of materials.)

Waste Generator: Dan Tobiason

Phone Number: 295-6169

Location / Origin: T-Tunnel Lower Laydown Yard

Waste Category: (check one)

Waste Type: \NTS

(check one)

Non-Putrescible

Pollution Prevention Category: (check one)

Pollution Prevention Category: (check one)

Method of Characterization: (check one)

Prohibited Waste at all three

NTS landfills:

Additional Prohibited Waste

at the Area 9 U10C Landfill:

\begin{abstract}
Radioactive waste; RCRA waste; Hazardous waste; Free liquids, PCBs above TSCA regulatory levels, and Medical wastes (needles, sharps, bloody clothing).
\end{abstract}

Sewage Sludge, Animal carcasses, Wet garbage (food waste); and Friable asbestos

\section{REQUIRED: WASTE CONTENTS ALLOWABLE WASTES}

Check all allowable wastes that are contained within this load:

NOTE: Waste disposal at the Area 6 Hydrocarbon Landfill must have come into contact with petroleum hydrocarbons or coolants, such as: gasoline (no benzene, lead); jet fuel; diesel fuel; lubricants and hydraulics; kerosene; asphaltic petroleum hydrocarbon; and ethylene glyco:.
Acceptable waste at any NTS landfill:
$\bigotimes$ Paper
$\triangle$ Asphalt
$\triangle$ Metal
Wood
$\triangle$ Soil
区 Cable
$凶$ Cloth
Rocks / unaltered geologic materials
$\bigotimes$ Rubber (excluding tires)
\Insulation (non-Asbestosform)
$凶$ Plastic
$\triangle$ Wire

$\bigotimes$ Empty containers

$\bigotimes$ Demolition debris

\section{swamp coolers,}

冈 Cement \& concrete

\section{Additional waste accepted at the Area 23 Mercury Landfill: $\square$ Office Waste $\square$ Food Waste} Asbestos

$\square$ Friable

$\square$ Non-Friable (contact SWO if regulated load)

Quantity:
Additional waste accepted at the Area 9 U10c Landfill:

$\square$ Non-friable asbestos

Light ballasts (contact SWO)

$\square$ Drained automobiles and military vehicles

$\square$ Drained fuel filters (gas \& diesel)

Hydrocarbons (contact SwO) $\bigotimes$ Other Drained generators/equipment
Solid fractions from sand/oil/water

$\bigotimes$ Deconned Underground and Above Ground Tanks

Additional waste accepted at the Area 6 Hydrocarbon Landfill:

$\square$ Septic sludge $\quad \square$ Rags $\quad \square$ Drained fuel filters (gas \& diesel)

Plants

Soil

$\square$ Sludge from sand/oil/water separators

Crushed non-teme plated oil filters REQUIRED: WASTE GENERATOR SIGNATURE

PCBs below 50 parts per million

Initials: (if initialed, no radiological clearance is necessary.)

The above mentioned waste was generated outside of a Controlled Waste Management Area (CWMA) and to the best of mv knowledge, does not contain radiological materials.

To the best of my knowledge, the waste described above contains only those $\mathrm{m}$ site. I have verified this through the waste characterization method identified a prohibited and allowable waste items. I have contacted Property Management : is approved for disposal in the landfill.

Print Name: Dan Tobiason

Signature:
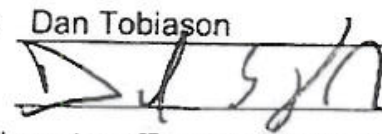

$9-1 /-i 7$

Date:
Radiological Survey Release for Waste Disposal RCT Initials

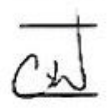

This container/load meets the criteria for no added man-made radioactive material This containerlload meets the criteria for Radcon Manual Table 4.2 release limits. This containetlload is exempt from survey due to proess knowledge and origin.

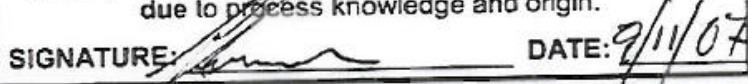

FRM-0646 (08/06)

Note: "Food waste, office trash and animal carcasses do not require a radiologic must have signed removal certification statement with Load Verification." 


\begin{tabular}{llllll}
\hline SWO USE (Select One) & AREA & $\square 23$ & $\square 6$ & Q 9 & Q LANDFILL
\end{tabular}

For waste characterization, approval, and/or assistance, contact Solid Waste Operation (SWO) at 5-7898.

REQUIRED: WASTE GERERATOR INFORMATION

(This form is for rolloffs, dump trucks, and other onsite disposal of materiais.)

Waste Generator: Dan Tobiason

Phone Number: 295-6169

Location / Origin: T-Tunnel Lower Laydown Yard

Waste Category: (check one)

Waste Type: $\triangle$ NTS

(check one)

$\quad \square$ Non-Putrescible $\quad \square$ Asbestos Containing Material

$\square$ Commercial

Q Industrial cas $9-12-07$

QFFACO-OISITE

$\square$ WAC Exception

Pollution Prevention Category: (check one)

Pollution Prevention Category: (check one)

Method of Characterization: (check one)

$\square$ Environmental management

$\otimes$ Clean-Up

FFACO-offsite

$\square$ Historic DOE/NV

Sampling \& Analysis

$\triangle$ Defense Projects

YMP

Routine

Prohibited Wast landfills:

Additional Prohibited Waste

at the Area 9 U10C Landfill:

levels, and waste; RCRA waste; Hazardous waste; Free liquids, PCBs above TSCA regulatory (needles, sharps, bloody clothing).

Sewage Sludge, Animal carcasses, Wet garbage (food waste); and Friable asbestos

\section{REQUIRED: WASTE CONTENTS ALLOWABLE WASTES}

Check all allowable wastes that are contained within this load:

NOTE: Waste disposal at the Area 6 Hydrocarbon Landfill must have come into contact with petroleum hydrocarbons or coolants, such as: gasoline (no benzene, lead); jet fuel; diesel fuel; lubricants and hydraulics; kerosene; asphaltic petroleum hydrocarbon; and ethylene glycol.

Acceptable waste at any NTS landfill: $\quad$ Pape
$\bigotimes$ Asphalt
Metal
$\triangle$ Wood
$\triangle$ Soil
$\square$ Rocks / unaltered geologic materials
Rubber (excluding tires)
$\triangle$ Plastic $\quad$ Wire
Q Cable
Cloth
Q Insulation (non-Asbestosform)

$\triangle$ Empty containers

$\bigotimes$ Demolition debris

Manufactured items: (swamp coolers, furniture, rugs, carpet, electronic components, PPE, etc.)
Additional waste accepted at the Area 23 Mercury Landfill:
Office Waste
Food Waste
$\square$ Asbestos
Friable
Non-Friable (contact SWO if regulated load)
Animal Carcasses
Quantity:

Additional waste accepted at the Area 9 U10c Landfill:

$\square$ Non-friable asbestos

$\square$ Light ballasts (contact SwO)

$\square$ Drained automobiles and military vehicles

Drained fuel filters (gas \& diesel)

Hydrocarbons (contact SWO)

$\triangle$ Other

Drained generators/equipment

$\otimes$ Cement \& concreie

Additional waste accepted at the Area 6 Hydrocarbon Landfill:

$\square$ Septic sludge $\quad \square$ Rags $\quad \square$ Drained fuel filters (gas \& diesel)

Plants $\square$ Soil

$\square$ Sludge from sand/oil/water separators

REQUIRED: WASTE GENERATOR SIGNATURE

Solid fractions from sand/oil/water

$\triangle$ Deconned Underground and Above Ground Tanks

Initials: (if initialed, no radiological clearance is necessary.)

The above mentioned waste was generated outside of a Controlled Waste Management Area (CWMA) and to the best of my knowledge, does not contain radiological materials.

To the best of my knowiedge, the waste described above contains only those ma site. I have verified this through the waste characterization method identified ab prohibited and allowable waste items. I have contacted Property Management ar is approved for disposal in the landfill.

Print Name: Dan Tobiason

Signature:
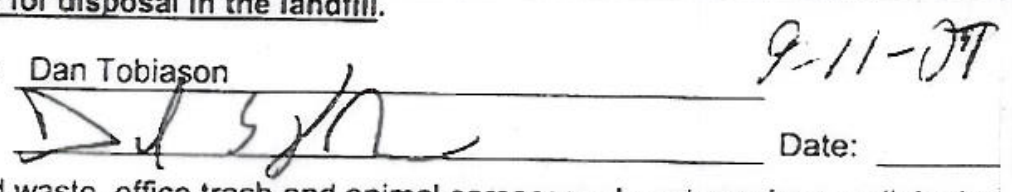

Note: "Food waste, office trash and animal carcasses do not require a radiologica' must have signed removal certification statement with Load Verification."
Crushed non-teme plated oil filters PCBs below 50 parts per million

\section{SWO USE ONLY}

Load Weight (net from scale of estimate) 10.1000

$9-11-07$

Sianature of Certifier: / $r=-$ RCT Initials

- This container/load meets the criteria for no

d. added man-made radioactive material This container/lgad meets the criteria for Radcon Manuz' Table 4.2 release limits. This containgerload is exempt from survey due toprocoss knowledge and origin.

SIGNATURE. Sh DATE: qflot FRM-0646 (08/06)

$\int_{x+2}^{\prime}$


Form

\begin{tabular}{|llllll} 
SWO USE (Select One) & AREA & $\square 23$ & $\square 6$ & $\square 9$ & $\square$ LANDFILL
\end{tabular}

For waste characterization, approval, and/or assistance, contact Solid Waste Operation (SWO) at 5-7898.

REQUIRED: WASTE GERERATOR INFORMATION

(This form is for rolloffs, dump trucks, and other onsite disposal of materials.)

Waste Generator: Dan Tobiason Phone Number: 295-6169

Location / Origin: T-Tunnel Lower Laydown Yard

Waste Category: (check one)

Waste Type: $\triangle$ NTS

(check one)

$\square$ Non-Putrescible

$\square$ Commercial

$\triangle$ Industrial $c Q 59-12-07$

$\square$ Asbestos Containing Material

Pollution Prevention Category: (check one) $\square$ Environmental management

Pollution Prevention Category: (check one) $\triangle$ Clean-Up

Method of Characterization: (check one)

Sampling \& Analysis

A-FFAGQ $\square$ WAC Exception

Prohibited Waste at all three

NTS landfills:

Additional Prohibited Waste

at the Area 9 U10C Landfill:

Radioactive waste; RCRA waste; Hazardous waste; Free liquids. PCBs above TSCA regulatory levels, and Medical wastes (needles, sharps, bloody clothing).

$\square$ Historic DOE/NV

$\triangle$ Defense Projects $\square$ YMP

$\square$ Routine

$\triangle$ Process Knowledge $\square$ Contents

Sewage Sludge, Animal carcasses, Wet garbage (food waste); and Friable asbestos

\section{REQUIRED: WASTE CONTENTS ALLOWABLE WASTES}

Check all allowable wastes that are contained within this load:

NOTE: Waste disposal at the Area 6 Hydrocarbon Landfill must have come into contact with petroleum hydrocarbons or coolants, such as: gasoline (no benzene, lead); jet fuel; diesel fuel; lubricants and hydraulics; kerosene; asphaltic petroleurn hydrocarbon; and ethylene glycol.

Acceptable waste at any NTS landfill: $\square$ Paper
$\triangle$ Asphalt
\Metal
$\triangle$ Wood
$\otimes$ Soil
$\triangle$ Plastic $\quad \square$ Wire
$\bigotimes$ Rubber (excluding tires)

\Cable

$\otimes$ Cloth

$\square$ Rocks / unaltered geologic materials

Insulation (non-Asbestosform)

$\triangle$ Empty containers

$\triangle$ Demolition debris

$\bigotimes$ Manufactured items: (swamp coolers, furniture, rugs, carpet, electronic components, PPE, etc.)
Additional was
$\square$ Friable
Area 23 Mercury Landfill:
Office Waste
Non-Friable (contact SWO if regulated load)
Food Waste
Quantity:
Animal Carcasses

$\bigotimes$ Cement \& concrete

Additional waste accepted at the Area 9 U10c Landfill:

$\square$ Non-friable asbestos

$\square$ Light ballasts (contact SWO)

Drained automobiles and military vehicles

Drained fuel filters (gas \& diesel)

Hydrocarbons (contact SWO)

$\triangle$ Other

Drained generators/equipment

Additional waste accepted at the Area 6 Hydrocarbon Landfill:
$\square$ Septic sludge
$\square$ Rags
$\square$ Drained fuel filters (gas \& diesel)
Plants
$\square$ Soil
Sludge from sand/oil/water separators

\section{REQUIRED: WASTE GENERATOR SIGNATURE}
Crushed non-teme plated oil filters
PCBs below 50 parts per million

Solid fractions from sand/oil/water

$\triangle$ Deconned Underground and Above Ground Tanks

Initials: (if initialed, no radiological clearance is necessary.) The above mentioned waste was generated outside of a Controlled Waste Management Area (CWMA) and to the best of my
knowledge, does not contain radiological materials.

To the best of my knowledge, the waste described above contains only those site. I have verified this through the waste characterization method identified prohibited and allowable waste items. I have contacted Property Managemen is approved for disposal in the landfill.

Print Name

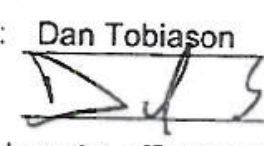

Signature:
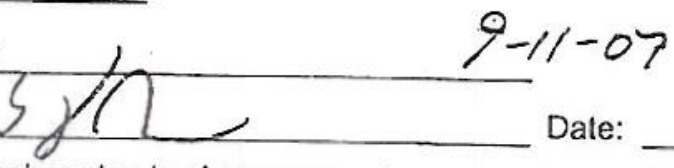

Note: "Food

must have, office trash and animal carcasses do not require a radiolog

Radiological Survey Release for Waste Disposal RCT Initials

1 This container/load meets the criteria for no

added man-made radioactive material

This container/loas meets the criteria for

Radcon Manual/ table 4.2 release limits.

This contofng lload is exempt from survey

due to progess knowledge and origin. 


\begin{tabular}{llllll}
\hline SWO USE (Select One) & AREA & $\square 23$ & $\square 6$ & Q 99 & $\square$ LANDFILL
\end{tabular}

For waste characterization, approval, and/or assistance, contact Solid Waste Operation (SWO) at 5-7898.

REQUIRED: WASTE GERERATOR INFORMATION

(This form is for rolloffs, dump trucks, and other onsite disposal of materials.)

Waste Generator: Dan Tobiason

Phone Number: 295-6169

Location / Origin: T-Tunnel Lower Laydown Yard

Waste Category: (check one)

Waste Type: $\square$ NTS

(check one)

$\square$ Non-Putrescible

Pollution Prevention Category: (check one)

Pollution Prevention Category: (check one)

Method of Characterization: (check one)

Prohibited Waste at all three

NTS landfills:

Additional Prohibited Waste

at the Area 9 U10C Landfill:

\begin{abstract}
Radioactive waste; RCRA waste; Hazardous waste; Free liquids, PCBs above TSCA regulatory levels, and Medical wastes (needles, sharps, bloody clothing).
\end{abstract}

Sewage Sludge, Animal carcasses, Wet garbage (food waste); and Friable asbestos

\section{REQUIRED: WASTE CONTENTS ALLOWABLE WASTES}

Check all allowable wastes that are contained within this load:
NOTE: Waste disposal at the Area 6 Hydrocarbon Landfill must have come into contact with petroleum hydrocarbons or coolants, such as: gasoline (no benzene, lead); jet fuel; diesel fuel; lubricants and hydraulics; kerosene; asphaltic petroleum hydrocarbon; and ethylene glycol.

Acceptable waste at any NTS landfill: $\triangle$ Paper
$\bigotimes$ Asphalt
$\bigotimes$ Metal
$凶$ Wood
$凶$ Soil
$\square$ Rocks / unaltered geologic materials
$\bigotimes$ Rubber (excluding tires)

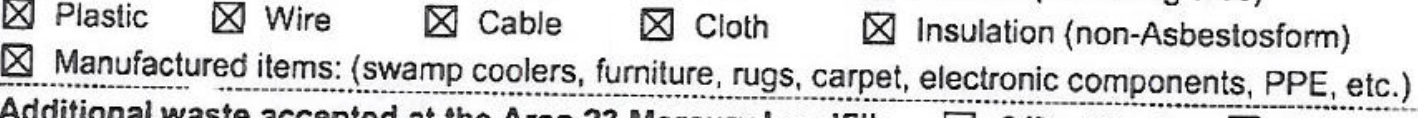

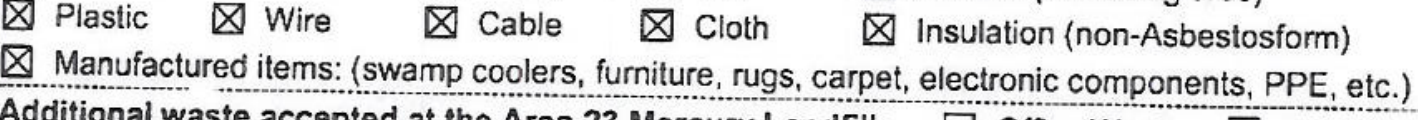

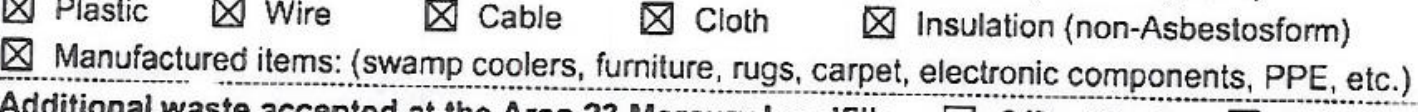
Additional was
$\square$ Asbestos
Friable
Area 23 Mercury Landfill:
$\square$ Non-Friable (contact SWO if regulated load)
Food Waste Quantity:

Additional waste accepted at the Area 9 U10c Landfill:

$\square$ Non-friable asbestos

$\square$ Light ballasts (contact Swo)

Hydrocarbons (contact SWO)

$\square$ Drained automobiles and military vehicles

$\square$ Drained fuel filters (gas \& diesel)

Other Drained generators/equipment
Solid fractions from sand/oil/water

$\triangle$ Deconned Underground and Above Ground Tanks

Additional waste accepted at the Area 6 Hydrocarbon Landfill:
$\square$ Septic sludge
$\square$ Rags
$\square$ Drained fuel filters (gas \& diesel)
Plants
Soil
$\square$ Sludge from sand/oil/water separators
REQUIRED: WASTE GENERATOR SIGNATURE
Crushed non-teme plated oil filters PCBs below 50 parts per million

Initials: (if initialed, no radiological clearance is necessary.) The above mentioned waste was generated outside of a Controlled Waste Management Area (CWMA) and to the best of my
knowledge, does not contain radiological materials.

To the best of my knowledge, the waste described above contains only those ma site. I have verified this through the waste characterization method identified ab. prohibited and allowable waste items. I have contacted Property Management ar is approved for disposal in the landfill.

Print Name:

Signature:
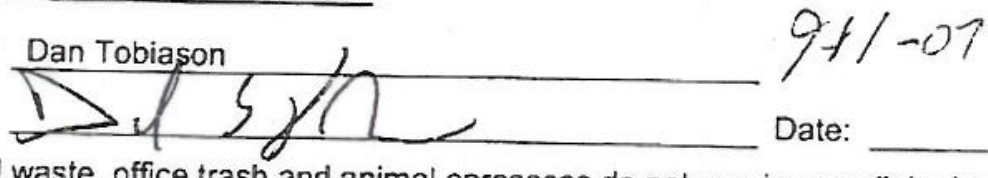

Note: "Food must have si

Date:

\section{SWO USE ONLY}

Load Weight (net from scale or)estimate):
Radiological Survey Release for Waste Disposa RCT Initials

This container/load meets the criteria for no

1) added man-made, redioactive material

This container/logd meets the criteria for Radcon Manuaf Table 4.2 release limits.

This confainerrload is exempt from survey

due to process knowledge and origin. SIGNATURE
DATE: DATE: $2 / 11 / 07$ FRM-0646 \{08/06) 


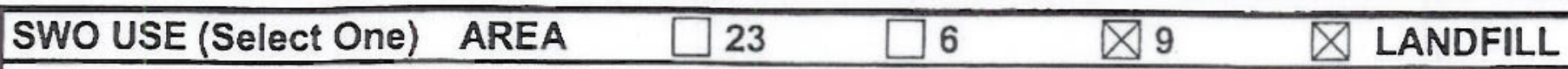

For waste characterization, approval, and/or assistance, contact Solid Waste Operation (SWO) at 5-7898.

REQUIRED: WASTE GERERATOR INFORMATION

(This form is for rolloffs, dump trucks, and other onsite disposal of materials.)

Waste Generator: Dan Tobiason Phone Number: 295-6169

Location / Origin: T-Tunnel Lower Laydown Yard

Waste Category: (check one)

Waste Type: $\triangle$ NTS

(check one) $\square$ Non-Putrescible

$\square$ Commercial

Pollution Prevention Category: (check one) $\square$ Environmiental management

Pollution Prevention Category: (check one) $Q$ Clean-Up

Method of Characterization: (check one)

Sampling \& Analysis

Putrescrible
Asbestos Containing Material
Environmental management
Clean-Up
Sampling \& Analysis

Q Industrial

$\triangle$ EFACO sie

$9 / 13 / 07$

Prohibited Waste at all three

NTS landfills:

Radioactive waste; RCRA waste; Hazardous waste; Free liquids, PCBs above TSCA regulatory

Additional Prohibited Waste

at the Area 9 U10C Landfill:

levels, and Medical wastes (needles, sharps, bloody clothing).

Sewage Sludge, Animal carcasses, Wet garbage (food waste); and Friable asbestos

\section{REQUIRED: WASTE CONTENTS ALLOWABLE WASTES}

Check all allowable wastes that are contained within this load:

NOTE: Waste disposal at the Area 6 Hydrocarbon Landfill must have come into contact with petroleum hydrocarbons or coolants, such as: gasoline (no benzene, lead); jet fuel; diesel fuel; lubricants and hydraulics; kerosene; asphaltic petroleum hydrocarbon; and ethylene glycol.
Acceptable waste at any NTS landfill:
Asphalt
Metal
Wood
$\triangle$ Paper
\Soil
$\triangle$ Cable
Cloth
Q Rubber (excluding tires)
$\bigotimes$ Insulation (non-Asbestosform)
Rocks / unaltered geologic materials
$\triangle$ Plastic $\quad$ Wire

$\triangle$ Empty containers

Demolition debris

: (swamp coolers, furniture, rugs, carpet,

t, electro
Additional waste accepted at the Area 23 Mercury Landfill: $\square$ Office Waste
$\square$ Asbestos
Friable
Non-Friable (contact SWO if regulated load)
Food Waste
Quantity:

Animal Carcasses

Additional waste accepted at the Area 9 U10c Landfill:

$\square$ Non-friable asbestos

$\square$ Light ballasts (contact SWO)

Hydrocarbons (contact SWO)

$\square$

Drained automobiles and military vehicles

Drained fuel filters (gas \& diesel)

Other Drained generators/equipment

\section{Additional waste accepted at the Area 6 Hydrocarbon Landfill:}
$\square$ Septic sludge
$\square$ Rags
$\square$ Drained fuel filters (gas \& diesel)
Soil
$\square$ Sludge from sand/oil/water separators
Crushed non-teme plated oil filters
Plants
REQUIRED: WASTE GENERATOR SIGNATURE
$\square$ Solid fractions from sand/oil/water
$\triangle$ Deconned Underground and Above Ground Tanks

Initials: (if initialed, no radiological clearance is necessary.)

The above mentioned waste was generated outside of a Controlled Waste Management Area (CWMA) and to the best of my knowledge, does not contain radiological materials.

To the best of my knowledge, the waste described above contains only those ma site. I have verified this through the waste characterization method identified ab prohibited and allowable waste items. I have contacted Property Management al is approved for disposal in the landfill.

Print Name: Dan Tobiason

Signature:
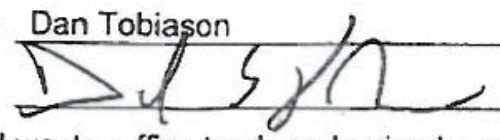

Date: $\{-i l-07$

Note: "Food waste, office trash and animal carcasses do not require a radiologica must have signed removal certification statement with Load Verification."

SWO USE ONLY

Load Weight (net from scale or estimate): 7, 000

$4 \cdot 12 \cdot 07$

Signature of Certifier:

Radiological Survey Release for Waste Disposal RCT Initials

- This containerlload meets the criteria for no added man-made radioactive material This containerload meets the criteria for Radcon ManuayTable 4.2 release limits. This containgtilload is exempt from survey due to progess knowledge and origin. 


\section{$\begin{array}{llllll}\text { SWO USE (Select One) } & \text { AREA } & \square 23 & \square 6 & \text { A } 9 & \text { L LANDFILL }\end{array}$}

For waste characterization, approval, and/or assistance, contact Solid Waste Operation (SWO) at 5-7898. REQUIRED: WASTE GERERATOR INFORMATION

(This form is for rolloffs, dump trucks, and other onsite disposal of materials.)

Waste Generator: Dan Tobiason

Phone Number: 295-6169

Location / Origin: T-Tunnel Lower Laydown Yard

Waste Category: (check one)

Waste Type: $\triangle$ NTS

(check one)

Non-Putrescible

Pollution Prevention Category: (check one)

Pollution Prevention Category: (check one)

Method of Characterization: (check one)

Prohibited Waste at all three

NTS landfilis:

Additional Prohibited Waste

at the Area 9 U10C Landfill: $\square$ Commercial

$\square$ Putrescrible

$\square$ Asbestos Containing Material

Environmental management

$\triangle$ Clean-Up

$\square$ Sampling \& Analysis

Radioactive waste; RCRA waste; Hazardóus waste; Free liquids, PCBs above TSCA regulatory levels, and Medical wastes (needles, sharps, bloody clothing).

Sewage Sludge, Animal carcasses, Wet garbage (food waste); and Friable asbestos

\section{REQUIRED: WASTE CONTENTS ALLOWABLE WASTES}

Check all allowable wastes that are contained within this load:

NOTE: Waste disposal at the Area 6 Hydrocarbon Landfill must have come into contact with petroleum hydrocarbons or coolants, such as: gasoline (no benzene, lead); jet fuel; diesel fuel; lubricants and hydraulics; kerosene; asphaltic petroleum hydrocarbon; and ethylene glycol.

Acceptable waste at any NTS landfill: $\triangle$ Paper

$\triangle$ Asphalt $\quad$ Metal $\quad$ Wood $\quad$ Soil

$\triangle$ Plastic $\otimes$ Wire

$凶$ Cable

$\triangle$ Cloth

$\square$ Rocks / unaltered geologic materials

$\bigotimes$ Rubber (excluding tires)

$\triangle$ Insulation (non-Asbestosform)

Empty containers

$\triangle$ Demolition debris

$\triangle$ Manufactured items: (swamp coolers, furniture, rugs, carpet, electronic components, PPE, etc.)

Additional waste accepted at the Area 23 Mercury Landfill: $\square$ Office Waste $\square$ Food Waste

$\bigotimes$ Cement \& concrete
$\square$ Asbestos
Friable
Non-Friable (contact SWO if regulated load)
Quantity:

\section{Additional waste accepted at the Area 9 U10c Landfill:}

$\square$ Non-friable asbestos

$\square$ Light ballasts (contact SWO)

$\square$ Hydrocarbons (contact SWO)

Q Drained automobiles and military vehicles Drained fuel filters (gas \& diesel)

Other Drained generators/equipment

Additional waste accepted at the Area 6 Hydrocarbon Landfill:

$\begin{array}{ll}\square \text { Septic sludge } & \square \text { Rags } \\ \square \text { Plants } & \square \text { Soil }\end{array}$ $\square$ Drained fuel filters (gas \& diesel)

$\square$ Sludge from sand/oil/water separators REQUIRED: WASTE GENERATOR SIGNATURE
Solid fractions from sand/oil/water

$\triangle$ Deconned Underground and Above Ground Tanks

Initials: (if initialed, no radiological clearance is necessary.)

The above mentioned waste was generated outside of a Controlled Waste Management Area (CWMA) and to the best of my knowledge, does not contain radiological materials.

To the best of my knowledge, the waste described above contains only those ma site. I have verified this through the waste characterization method identified abc prohibited and allowable waste items. I have contacted Property Management an is approved for disposal in the landfill.

Print Name: Dan Tobiason Signature:

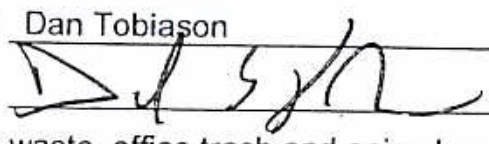
Date: $\{, 2-2\}$

Note: "Food waste, office trash and animal carcasses do not require a radiologica must have signed removal certification statement with Load Verification."

\section{SWO USE ONLY}

Load Weight (net from scale or estimate): $6,5 \Omega$
$4-12-07$ Signature of Certifier:
Radiological Survey Release for Waste Disposal RCT Initials

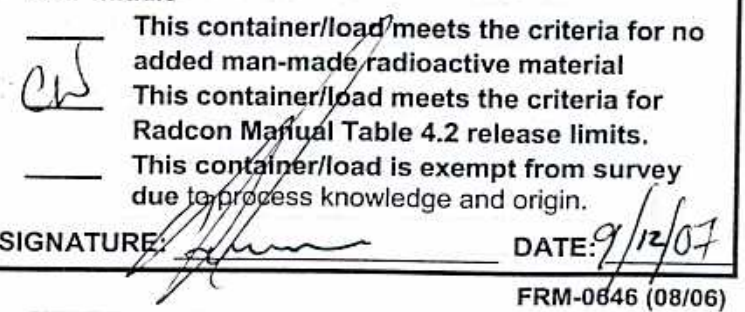
FRM-0646 (08/06) 


\section{\begin{tabular}{llllll}
\hline SWO USE (Select One) & AREA & $\square 23$ & $\square 6$ & $\square 9$ & $\square$ \\
\hline
\end{tabular}}

For waste characterization, approval, and/or assistance, contact Solid Waste Operation (SWO) at 5-7898.

\section{REQUIRED: WASTE GERERATOR INFORMATION}

(This form is for rolloffs, dump trucks, and other onsite disposal of materials.)

Waste Generator: Dan Tobiason

Phone Number: 295-6169

Location / Origin: T-Tunnel Lower Laydown Yard

Waste Category: (check one)

Waste Type: $\otimes$ NTS

$\square$ Commercial

Q Industrial cos $9 / 17 / 07$

(check one)

Non-Putrescible

$\square$ Asbestos Containing Material

$\triangle F F A C O-O n s i t e$

$\square$ WAC Exception

Pollution Prevention Category: (check one)

Pollution Prevention Category: (check one)

Method of Characterization: (check one)

Environmental management

$\triangle$ Clean-Up

$\square$ FFACO-offsite

$\square$ Historic DOE/NV

Prohibited Waste at all three Radioactive waste; RCRA waste; Hazardous waste; Free liquids, PCBs above TSCA regulatory

NTS landfills:

Additional Prohibited Waste

at the Area 9 U10C Landfill:

levels, and Medical wastes (needles, sharps, bloody clothing).

Sewage Sludge, Animal carcasses, Wet garbage (food waste); and Friable asbestos

REQUIRED: WASTE CONTENTS ALLOWABLE WASTES

Check all allowable wastes that are contained within this load:

NOTE: Waste disposal at the Area 6 Hydrocarbon Landfill must have come into contact with petroleum hydrocarbons or coolants, such as: gasoline (no benzene, lead); jet fuel; diesel fuel; lubricants and hydraulics; kerosene; asphaltic petroleum hydrocarbon; and ethylene glycol.

Acceptable waste at any NTS landfill: $\triangle$ Paper

$\bigotimes$ Asphalt $\quad$ Metal $\quad$ Wood $\quad$ Soil

Plastic $\quad$ Wire $\quad$ Cable $\quad$ Cloth

$\square$ Rocks / unaitered geologic materials

$\bigotimes$ Empty containers

$\bigotimes$ Rubber (excluding tires)

$\bigotimes$ Demolition debris

冈 Manufactured items:

$\bigotimes$ Insulation (non-Asbestosform)

$\triangle$ Cement \& concrete

Addinti......

Additional waste accepted at the Area 23 Mercury Landfill: $\square$ Office Waste

$\square$ Asbestos

$\square$ Friable

$\square$ Non-Friable (contact SWO if regulated load)

Food Waste

Animal Carcasses

Additional waste accepted at the Area 9 U10c Landfill:
$\square$ Non-friable asbestos
Light ballasts (contact Swo)
$\square$ Drained automobiles and military vehicles
Drained fuel filters (gas \& diesel)
Hydrocarbons (contact SWO)
Other Drained generators/equipment

Quantity:

Additional waste accepted at the Area 6 Hydrocarbon Landfill:
$\square$ Septic sludge
$\square$ Rags
$\square$ Drained fuel filters (gas \& diesel)
Crushed non-teme plated oil filters
Plants
Soil
$\square$ Sludge from sand/oil/water separators REQUIRED: WASTE GENERATOR SIGNATURE PCBs below 50 parts per million

Solid fractions from sand/oil/water

$\triangle$ Deconned Underground and Above

Ground Tanks

Initials:

(if initialed, no radiological clearance is necessary.)

The above mentioned waste was generated outside of a Controlled Waste Management Area (CWMA) and to the best of my knowledge, does not contain radiological materials.

To the best of my knowledge, the waste described above contains only those $n$ site. I have verified this through the waste characterization method identified a prohibited and allowable waste items. I have contacted Property Management is approved for disposal in the landfill.

Print Name: Dan Tobiason

Signature:

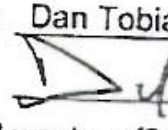

4
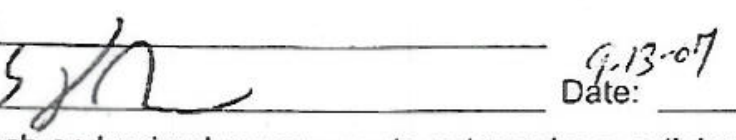

Note: "Food waste, office trash and animal carcasses do not require a radiolog must have signed removal certification statement with Load Verification." SWO USE ONLY

Load Weight (net from scale or estimate): $7,0 \Omega 2$
$9,13-07$

Signature of Certifier:
Radiological Survey Release for Waste Disposal RCT Initials

This containerfload meets the criteria for no

C $\sqrt{ }$ added man-made radjbactive material This container/loag/meets the criteria for Radcon Manyal Table 4.2 release limits. This containerload is exempt from surve due to.process knowledge and origin.

SIGNATURE:

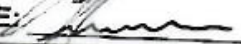

DATE:

FRM-0646 (08/06) 
For waste characterization, approval, and/or assistance, contact Solid Waste Operation (SWO) at 5-7898.

REQUIRED: WASTE GERERATOR INFORMATION

(This form is for rolloffs, dump trucks, and other onsite disposal of materials.)

Waste Generator: Dan Tobiason

Phone Number: 295-6169

\section{Location / Origin: T-Tunnel Lower Laydown Yard}

\begin{tabular}{|c|c|c|}
\hline Waste Category: (check one) & $\square$ Commercial & $\Delta$ Industrial $085 / 25 / 07$ \\
\hline Waste Type: & $\square$ Putrescrible & $\triangle$ FFACO-onsite $\square$ WAC Exception \\
\hline$\square$ Non-Putrescible & $\square$ Asbestos Containing Material & $\square$ FFACO-offsite \\
\hline Pollution Prevention Category: (check one) & $\square$ Environmental management & $\triangle$ Defense Projects \\
\hline Pollution Prevention Category: (check one) & $\mathrm{Q}$ Clean-Up & $\square$ Routine \\
\hline Method of Characterization: (check one) & $\square$ Sampling \& Analysis & $\triangle$ Process Knowledge $\square$ Contents \\
\hline
\end{tabular}

Additional Prohibited Waste at the Area 9 U10C Landfill:

Sewage Sludge, Animal carcasses, Wet garbage (food waste); and Friable asbestos

\section{REQUIRED: WASTE CONTENTS ALLOWABLE WASTES}

Check all allowable wastes that are contained within this load:

NOTE: Waste disposal at the Area 6 Hydrocarbon Landfill must have come into contact with petroleum hydrocarbons or coolants, such as: gasoline (no benzene, lead); jet fuel; diesel fuel; lubricants and hydraulics; kerosene; asphaltic petroleum hydrocarbon; and ethylene glycol.

$\bigotimes$ Asphalt

$\bigotimes$ Metal

$凶$ Wood

$\otimes$ Soil

$凶$ Cable

Cloth $\square$ Rocks / unaltered geologic materials

$\triangle$ Rubber (excluding tires)

$\bigotimes$ Insulation (non-Asbestosform) 区mpty containers

Demolition debris

$\bigotimes$ Cement \& concrete

$\triangle$ Manufactured items: (swamp coolers, furniture, rugs, carpet, electronic components, PPE, etc.)

Additional waste accepted at the Area 23 Mercury Landfill: $\square$ Office Waste

$\square$ Asbestos

Friable
Non-Friable (contact SWO if regulated load)

Animal Carcasses

Additional waste accepted at the Area 9 U10c Landfill:

$\square$ Non-friable asbestos

$\square$ Light ballasts (contact SWO)

Hydrocarbons (contact SWO)

$\square$

Additional waste accepted at the Area 6 Hydrocarbon Landfill:

$\begin{array}{ll}\square \text { Septic sludge } & \square \text { Rags } \\ \square \text { Plants } & \square \text { Soil }\end{array}$
Drained automobiles and military vehicles

Drained fuel filters (gas \& diesel)

Other Drained generators/equipment
Food Waste

Quantity:

Initials: (if initialed, no radiological clearance is necessary.)

The above mentioned waste was generated outside of a Controlled Waste Management Area (CWMA) and to the best of my knowledge, does not contain radiological materials.

To the best of my knowledge, the waste described above contains only those materials that are allowed for disposal at this site. I have verified this through the waste characterization method identified above and a review of the above-mentinnn-t prohibited and allowable waste items. I have contacted Property Management and have varifin.... is approved for disposal in the landfill.

Print Name: Dan Tobiason

Signature:

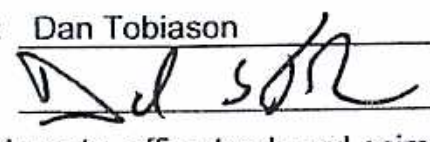

Date: $9|24| 0$

Note: "Food waste, office trash and animal carcasses do not require a radiological c must have signed removal certification statement with Load Verification." SWO USE ONLY Load Weight (net from scale or estimate): $9-24-07$ Signature of Certifier: Radiation Survey Release for Waste Disposal RCT Initials This containerlload is exempt This containeres knowledge and origin. This containerlload is free of radionalysis.
Thentamination based on radioana SIGNATURE:

Solid fractions from sand/oil/water Ground Tanks 


\section{NSTec \\ Form \\ FRM-0918

SWO USE (Select One) AREA

For waste characterization, approval, and/or assistance, contact Solid Waste Operation (SWO) at 5-7898.

REQUIRED: WASTE GERERATOR INFORMATION

(This form is for rolloffs, dump trucks, and other onsite disposal of materials.)

Waste Generator: Dan Tobiason

Phone Number: 295-6169

Location / Origin: T-Tunnel Lower Laydown Yard

Waste Category: (check one)

Waste Type: $\triangle$ NTS

(check one)

$\square$ Non-Putrescible

$\square$ Commercial

$\triangle$ Industrial ofs 9/25/07

Pollution Prevention Category: (check one)

Pollution Prevention Category: (check one)

Method of Characterization: (check one)

$\square$ Asbestos Containing Material

A-FFAEO-onsite

$\square$ WAC Exception

$\square$ Environmental management

FFACO-offsite

$\triangle$ Defense Projects

$\triangle$ Clean-Up

Prohibited Waste at all three

NTS landfills:

Additional Prohibited Waste

at the Area 9 U10C Landfill:

Radioactive waste; RCRA waste; Hazardous waste; Free liquids, PCBs above TSCA regulatory levels, and Medical wastes (needles, sharps, bloody clothing).

Sewage Sludge, Animal carcasses, Wet garbage (food waste); and Friable asbestos

\section{REQUIRED: WASTE CONTENTS ALLOWABLE WASTES}

NOTE: Waste disposal at the Area 6 Hydrocarbon allowable wastes that are contained within this load:

coolants, such as: gasoline (nodrocarbon Landfill must have come into contact with petroleum hydrocarbons or petroleum hydrocarbon; and ethylene glycol.

Acceptable waste at any NTS landfill: $\triangle$ Paper

$\triangle$ Asphalt $\quad$ Metal $\quad$ Wood $\quad$ Soil

$\triangle$ Plastic $\quad$ Wire $\quad$ Cable $\quad$ Cloth

$\square$ Rocks / unaltered geologic materials

$\square$ Rubber (excluding tires)

$\triangle$ Manufactured items: (swamp coolers, furniture, rugs, carpet, electronic (non-Asbestosform)

Pa

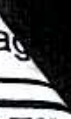

ILL

Additional waste accepted at the Area 23 Mercury Landfill:
$\square$ Asbestos
$\square$ Friable
$\square$ Non-Friable (contact SWO if regulated load)
$\square$ Food Waste
Quantity:

Additional waste accepted at the Area 9 U10c Landfill:

$\square$ Non-friable asbestos

Light ballasts (contact SWO)

Hydrocarbons (contact SWO)

$\square$ Drained automobiles and military vehicles

Drained fuel filters (gas \& diesel)

Other Drained generators/equipment
Solid fractions from sand/oil/water

$\otimes$ Deconned Underground and Above Ground Tanks

Additional waste accepted at the Area 6 Hydrocarbon Landfill:
$\square$ Septic sludge
Plants
$\square$ Rags
Soil
$\square$ Drained fuel filters (gas \& diesel)
$\square$ Sludge from sand/oil/water separators
$\square$ Crushed non-teme plated oil filters
$\square$ PCBs below 50 parts per million REQUIRED: WASTE GENERATOR SIGNATURE

$\bigotimes$ Empty containers
$\bigotimes$ Demolition debris
$\bigotimes$ Cement \& concrete

Initials: (if initialed, no radiological clearance is necessary.) The above mentioned waste was generated outside of a Controlled Waste Management Area (CWMA) and to the best of my
knowledge, does not contain radiological materials.

To the best of my knowledge, the waste described above contains only those materials that are allowed for disnosal at this site. I have verified this through the waste characterization method identified above prohibited and allowable waste items. I have contacted Property Management and $\mathrm{h}$;
is approved for disposal in the landfill.

Print Name: Dan Tobiason

Signature:
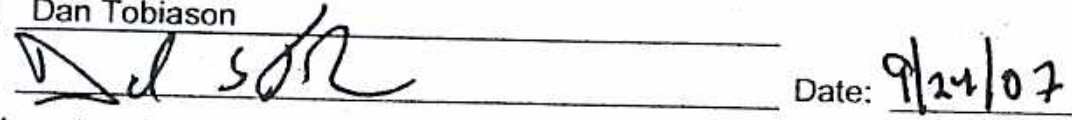

Note: "Food waste, office trash and animal carcasses do not require a radiological cle must have signed removal certification statement with Load Verification."

SWO USE ONLY

Load Weight (net from scale or estimate): $\angle / 520$

$9-24-07$

Signature of Certifier:

\begin{tabular}{l} 
Radiation Survey Release for Waste Dispos \\
RCT Initials \\
\hline TC This container/load is free of external radioacti \\
contamination. \\
This container/load is exempt from survey due \\
process knowledge and origin. \\
This container/load is free of radioactive \\
Contanination based on radioanalysis.
\end{tabular} $\longrightarrow$ 


\section{NSTec Form

\section{SWO USE (Select One) AREA \\ REQUIRED: WASTE \\ (This form is for rollaff: WASTE GERERATOR INFORMATION}

Waste Generator: Dan Tobiason

Location / Origin: T-Tunnel Lower Laydown Yard

Phone Number: 295-6169

Waste Category: (check one)

Waste Type: $\square$ NTS

(check one)

$\square$ Non-Putrescible

$\square$ Commercial
$\square$ Putrescrible
$\square$ Asbestos Containing Material
$\square$ Environmental management
$\square$ Clean-Up
$\square$ Sampling \& Analysis

$\triangle$ Industrial cos $9 / 25 / 07$

Pollution Prevention Category: (check one)

Pollution Prevention Category: (check one)

Method of Characterization: (check one)

Sampling \& Analysis

D-FFAGO-OAsite

$\square$ WAC Exception

Prohibited Waste at all three

NTS landfills:

Additional Prohibited Waste

at the Area 9 U10C Landfill:

Radioactive waste; RCRA waste; Hazardous waste; Free liquids RCBs $\square$ Contents

levels, and Medical wastes (needles, sharps, bloody clothing).

Sewage Sludge, Animal carcasses, Wet garbage (food waste); and Friable asbestos

\section{REQUIRED: WASTE CONTENTS ALLOWABLE WASTES}

NOTE: Waste disposal at the Area 6 Hyd allowable wastes that are contained within this load:

coolants, such as: gasoline (no benzene, lead); must have come into contact with petroleum hydrocarbons or petroleum hydrocarbon; and ethylene glycol.

Acceptable waste at any NTS landfill: $\triangle$ Paper
$\bigotimes$ Metal
$\triangle$ Wood
Soil
Manufactured items: (swamp coolers, fumiture
Manufactured items: (swamp coolers, fumiture
Rocks / unaltered geologic materials
$\bigotimes$ Rubber (excluding tires)
$\bigotimes$ Plastic $\otimes$ Wire $\otimes$ Cable $\triangle$ Cloth
$\triangle$ Insulation (non-Asbestosform)

Additional waste accepted at the Area 23 Mercury
$\square$ Asbestos
Friable
Non-Friable (contact SWO if regulated load)
$\square$ Food Waste
Quantity:

Additional waste accepted at the Area 9 U10c Landfill:

Non-friable asbestos

Light ballasts (contact SWO)

XHydrocarbons (contact SwO)

Drained automobiles and military vehicles

Drained fuel filters (gas \& diesel)

$\otimes$ Other

Drained generators/equipment

Solid fractions from sand/oil/water

$\bigotimes$ Deconned Underground and Above Ground Tanks

Additional waste accepted at the Area 6 Hydrocarbon Landfill:
$\square$ Septic sludge
Plants
$\square$ Rags
$\square$ Soil

$\square$ Drained fuel filters (gas \& diesel)

$\square$ Sludge from sand/oil/water separators $\square$

Initials: (if initialed, no radiological clearance is necessary.)

The above mentioned waste was generated outside of a Controlled Waste Management Area (CWMA) and to the best of my
knowledge, does not contain radiological materials.

To the best of my knowledge, the waste described above contains only those materials that are allowed for disposal at this prohibited and allowable waste items. I have contacted Property identified above and a review of the above-mentioned is approved for disposal in the landfill.

Print Name: Dan Tobiason

Signature:

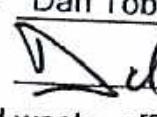

must have signed trash and animal carcasses do not require a radiological cle SWO USE ONLY

Load Weight (net from scale or estimate): 393 ov
$9-24-67$

Signature of Certifier: Radiation Survey Release for Waste Dispos
RCT Initials

DC This container/load is free of external radioactivi

process knowledge is exempt from survey due ts process knowledge and origin.

contamination based is free of radioactive comamination based gatradioanalysis. SIGNATURE:$$
\text { Samue } 1-20
$$ 


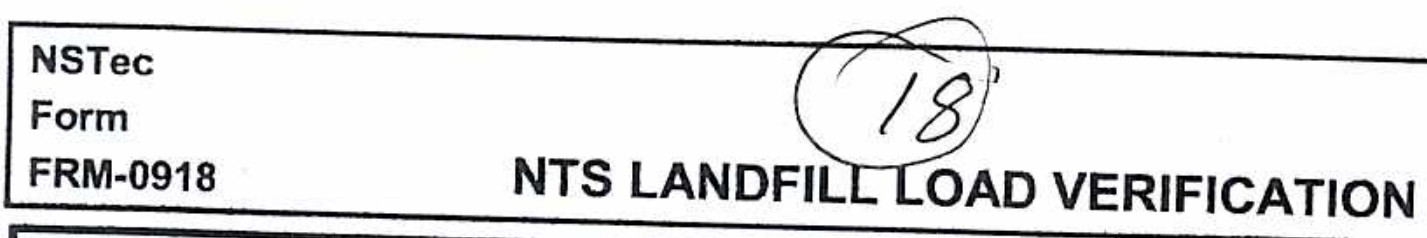

\section{SWO USE (Select One) AREA \\ For waste characterization, approval, an \\ $\triangle$ LANDFILL}

Page

REQUIRED: WASTE GERERATOR INFORMATION

(This form is for rolloffs, dump trucks, and other onsite disposal of materials.)

Waste Generator: Dan Tobiason

Location / Origin: T-Tunnel Lower Laydown Yard

Phone Number: 295-6169

Waste Category: (check one)

Waste Type: $\triangle$ NTS

Pollution Prevention Category: (check one) $\square$ Asbestos Containing Material

Pollution Prevention Category: (check $\square$ Environmental management

Method of Characterizategory: (check one) $\triangle$ Clean-Up

Method of Characterization: (check one)

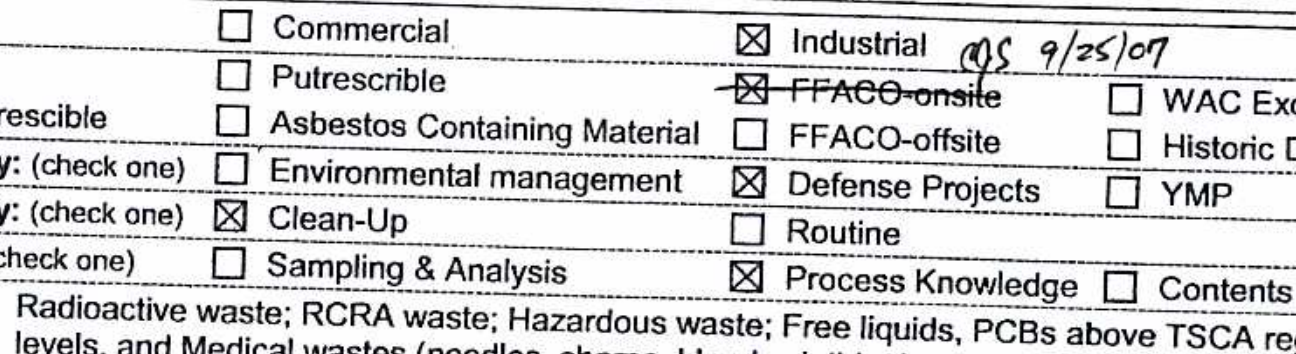

Prohibited Waste at all three

NTS landfills:

Additional Prohibited Waste

at the Area 9 U10C Landfill:

$\triangle$ Industrial Co5 9/25/07

$\square$ FFACO-offsite $\square$ Historic DOE/NV

$\triangle$ Defense Projects $\square$ YMP

$\square$ Routine

$\bigotimes$ Process

levels, and Medical wastes (needles, sharps, bloody clothing)

Sewage Sludge, Animal carcasses, Wet garbage (food waste); and Friable asbestos

\section{REQUIRED: WASTE CONTENTS ALLOWABLE WASTES}

NOTE: Waste disposal at the Area 6 ck all allowable wastes that are contained within this load:

coolants, such as: gasoline (no benzene, Landfill must have come into contact with petroleum hydrocarbons or

petroleum hydrocarbon; and ethylene glycol.

Acceptable waste at any NTS landfill:
$\bigotimes$ Asphalt
$\otimes$ Metal
W Wood
$\triangle$ Paper
Plastic
$\triangle$ Wire
Q Cable
\Soil
Cloth

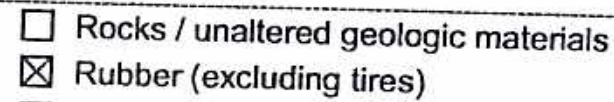
$\bigotimes$ Insulation (non-Asbestosform)
$\bigotimes$ Empty containers
Q Demolition debris
\Cement \& concrete

$\triangle$ Manufactured items: (swamp coolers, furniture, rugs, carpet, electronic components, PPE, etc.)

Additional waste accepted at the Area 23 Mercury Landfill: $\square$ Office Waste
$\square$ Asbestos $\square$ Friable $\square$ Non-Friable (contact SWO if reguled

Non-Friable (contact SWO if regulated load)

$\square$ Food Waste

Quantity:

\section{Additional waste accepted at the Area 9 U10c Landfill:}

Non-friable asbestos

Light ballasts (contact SWO)

Hydrocarbons (contact SWO)

$\square$ Drained automobiles and military vehicles

$\square$ Drained fuel filters (gas \& diesel)

Other Drained generators/equipment

Additional waste accepted at the Area 6 Hydrocarbon Landfill:

$\square$ Septic sludge $\square$ Rags
$\square$ Plants
a Soil

$\square$ Soil

$\square$ Drained fuel filters (gas \& diesel)

$\square$ Sludge from sand/oil/water separators REQUIRED: WASTE GENERATOR SIGNATURE
Solid fractions from sand/oil/water

$\otimes$ Deconned Underground and Above Ground Tanks

Initials: (if initialed, no radiological clearance is necessary.)

The above mentioned waste was generated outside of a Controlled Waste Management Area (CWMA) and to the best of my
knowledge, does not contain radiological materials.

To the best of my knowledge, the waste described above contains only those mater
site. I have verified this through the prohibited and allowab through the waste characterization method identified above is approved for disposal in the landfill.

Print Name: Dan Tobiason

Signature:
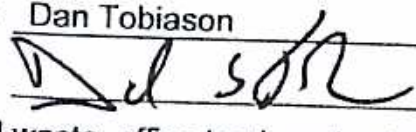

Date: $91 / 24 / 07$

must haste, office trash and animal carcasses do not require a radiological c SWO USE ONLY

Load Weight (net from scale of estimate)
$9-24-07$

Signature of Certifier:
Crushed non-teme plated oil filters PCBs below 50 parts per million

Animal Carcasses 
NSTec

Form

FRM-0918

NTS LANDFILL LOAD VERIFICATION

Page 1

\begin{tabular}{|c|c|c|c|c|c|}
\hline SWO USE (Select One) & AREA & 23 & 6 & $\overline{\triangle 9}$ & $\overline{\text { LANDFILL }}$ \\
\hline
\end{tabular}

For waste characterization, approval, and/or assistance, contact Solid Waste Operation (SWO) at 5-7898.

REQUIRED: WASTE GERERATOR INFORMATION

(This form is for rolloffs, dump trucks, and other onsite disposal of materials.)

Waste Generator: Dan Tobiason

Location / Origin: T-Tunnel Lower Laydown Yard A/2 os $1 / 26 / 07$

Waste Category: (check one)

Waste Type: $\triangle$ NTS

(check one)

$\square$ Non-Putrescible

$\square$ Commercial

$\square$ Asbestos Containing Material

Phone Number: 295-6169

Pollution Prevention Category: (check one)

Pollution Prevention Category: (check one)

Method of Characterization: (check one)

$\square$ Environmental management

$凶$ Clean-Up

Prohibited Waste at all three

NTS landfills:

Additional Prohibited Waste

at the Area 9 U10C Landfill:

Radioactive waste; RCRA waste; Hazardous waste; Free liquids, PCBs above TSCA regulatory levels, and Medical wastes (needles, sharps, bloody clothing).

$\triangle$ Industrial cgs $9 / 26 / 07$

A-FFAGQ-OAsite

WAC Exception

$\square$ FFACO-offsite

$\square$ Historic DOE/NV

$\triangle$ Defense Projects

YMP

$\square$ Routine

Process
aste; Free liquids

Sewage Sludge, Animal carcasses, Wet garbage (food waste); and Friable asbestos

REQUIRED: WASTE CONTENTS ALLOWABLE WASTES

Check all allowable wastes that are contained within this load:

NOTE: Waste disposal at the Area 6 Hydrocarbon Landfill must have come into contact with petroleum hydrocarbons or coolants, such as: gasoline (no benzene, lead); jet fuel; diesel fuel; lubricants and hydraulics; kerosene; asphaltic petroleum hydrocarbon; and ethylene glycol.

Acceptable waste at any NTS landfill: $\triangle$ Paper
$\otimes$ Asphalt
$\triangle$ Metal
$\triangle$ Wood
$\triangle$ Soil
$\triangle$ Cable
Cloth
$\square$ Rocks / unaltered geologic materials
$\triangle$ Rubber (excluding tires)
$\bigotimes$ Insulation (non-Asbestosform)
$\bigotimes$ Plastic $\quad$ Wire

$\triangle$ Manufactured items: (swamp coolers,

$\triangle$ Empty containers

$\triangle$ Demolition debris

$\bigotimes$ Cement \& concrete

rugs, carpet, electronic components, PPE, etc.)
$\square$ Asbestos
Friable
Area 23 Mercury Landfill:
Office Waste
$\square$ Non-Friable (contact SWO if regulated load)
Food Waste
Quantity:

Additional waste accepted at the Area 9 U10c Landfill:

$\square$ Non-friable asbestos

$\square$ Light ballasts (contact SWO)

E Hydrocarbons (contact SWO)

$\square$ Drained automobiles and military vehicles

$\square$ Drained fuel filters (gas \& diesel)

$\bigotimes$ Other Drained generators/equipment

Solid fractions from sand/oil/water

$\triangle$ Deconned Underground and Above Ground Tanks

Additional waste accepted at the Area 6 Hydrocarbon Landfill:

$\square$ Septic sludge $\square$ Rags
$\square$ Plants $\quad \square$ Soil

$\square$ Drained fuel filters (gas \& diesel)

$\square$ Sludge from sand/oil/water separators

REQUIRED: WASTE GENERATOR SIGNATURE

Crushed non-teme plated oil filters PCBs below 50 parts per million

Initials: (if initialed, no radiological clearance is necessary.) The above mentioned waste was generated outside of a Controlled Waste Management Area (CWMA) and to the best of my
knowledge, does not contain radiological materials.

To the best of my knowledge, the waste described above contains only those materials that are allowed for disposal at this site. I have verified this through the waste characterization method identified above and a review of the above-mentioned prohibited and allowable waste items. I have contacted Property Management and have verified that this material/equipment
is approved for disposal in the landfill.

Print Name:

Signature:
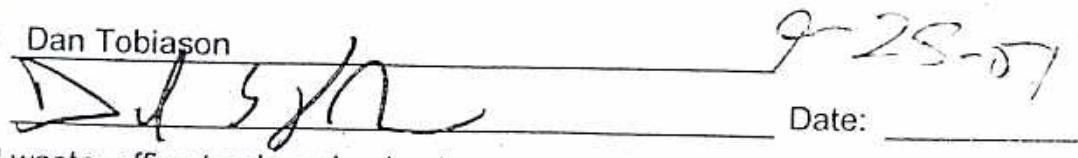

Note: "Food waste, office trash and animal carcasses do not require a radiological clea must have signed removal certification statement with Load Verification."

\section{SWO USE ONLY}

Load Weight (net from scale or)estimate):
$9.25=0.7$ Signature of Certifier:
Radiation Survey Release for Waste Dispo: RCT Initials

DC This container/load is free of external radioacti contamination.

This containerlload is exempt from survey due process knowledge and origin.

This container/load is free of radioactive

SIGNATURE: 5 contamination based gatradioanalysis. 99.25 


\section{NSTec \\ Form \\ FRM-0918 \\ NTS LANDFILL LOAD VERIFICATION}

\section{SWO USE (Select One) AREA \\ For waste characterization, approval, and/or assistance, contact Solid Waste Operation (SWO) at 5-7898}

REQUIRED: WASTE GERERATOR INFORMATION

Waste Generator: Dan Tobiason

(This form is for rolloffs, dump trucks, and other onsite disposal of materials.)

Location / Origin: T-Tunnel Lower Laydown Yard $A / 2$ of $9 / 26 / 07$

Phone Number: 295-6169

Waste Category: (check one)

Waste Type: $\square$ NTS

(check one)

Pollution Prevention Category: (check one)

Pollution Prevention Category: (check one)

Method of Characterization: (check one)

Prohibited Waste at all three

NTS landfills:

Additional Prohibited Waste

at the Area 9 U10C Landfill:
Radioactive waste; RCRA waste; Hazardous waste; Free liquids, PCBs above TSCA regulatory
levels, and Medical wastes (needles, sharps, bloody clothing).

$\triangle$ Industrial egs $9 / 26 / 07$

$\triangle$ FFACO-Onsite $\square$ WAC Exception

Asbestos Containing Material

FFACO-offsite

$\triangle$ Defense Projects

$\square$ Routine

$\triangle$ Clean-Up

Sewage Sludge, Animal carcasses, Wet garbage (food waste); and Friable asbestos

\section{REQUIRED: WASTE CONTENTS ALLOWABLE WASTES}

NOTE: Waste disposal at the Areck all allowable wastes that are contained within this load: coolants, such as: gasoline (no becarbon Landfill must have come into contact with petroleum hydrocarbons or petroleum hydrocarbon; and ethylene glycol.

Acceptable waste at any NTS landfill: $\triangle$ Pape
$\square$ Rocks / unaltered geologic materials

$\triangle$ Asphalt

$\otimes$ Metal

$\triangle$ Wood

$\bigotimes$ Paper

$\bigotimes$ Plastic

$\triangle$ Wire

$\triangle$ Cable

$\triangle$ Cloth

$\bigotimes$ Rubber (excluding tires)

$\triangle$ Insulation (non-Asbestosform)

Additional waste accepted at the Ars, furniture, rugs, carpet, electronic components, PPE, etc.)
$\square$ Asbestos
$\square$ Friable
Area 23 Mercury Landfill:
Office Waste
Non-Friable (contact SWO if regulated load)
Food Waste
Quantity:

Additional waste accepted at the Area 9 U10c Landfill:

$\square$ Non-friable asbestos

$\square$ Light ballasts (contact SWO)

Hydrocarbons (contact SWO)

Drained automobiles and military vehicles

Drained fuel filters (gas \& diesel)

Other Drained generators/equipment

Solid fractions from sand/oil/water

$\otimes$ Deconned Underground and Above Ground Tanks

Additional waste accepted at the Area 6 Hydrocarbon Landfill:
$\square$ Septic sludge
Plants
$\square$ Rags
Soil
$\square$ Drained fuel filters (gas \& diesel)
$\square$ Sludge from sand/oil/water separators $\square$
Crushed non-teme plated oil filters PCBs below 50 parts per million

Initials: (if initialed, no radiological clearance is necessary.)

The above mentioned waste was generated outside of a Controlled Waste Management Area (CWMA) and to the best of my
knowledge, does not contain radiological materials.

To the best of my knowledge, the waste described above contains only those materials that are allowed for disposal at this

prohibited and allowable waste the waste characterization method identified abc

is approved for disposal in the landfill. Ihave contacted Property Management an

.

Print Name: Dan Tobiason

Signature:
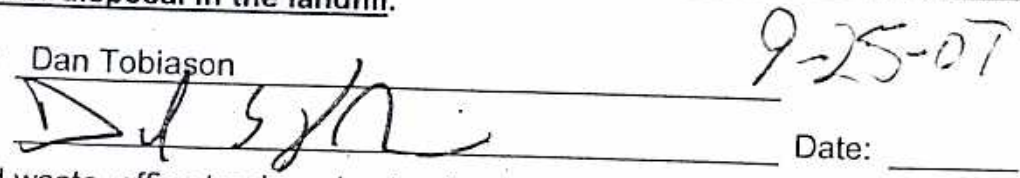

Note: "Food

must have, office trash and animal carcasses do not require a radiological

SWO USE ONLY

Load Weight (net from scale, or estimate)

9-25-07

Signature of Certifier:

Radiation Survey Release for Waste Disposal RCT Initials

Conis containerlload is free of external radioactive

This containon.

This container/load is exempt from survey due to

This container/load is orign.

contamination based is free of radioactive

SIGNATURE: — DATE: 2507 B $0.0646(09 / 99)$ 
NSTec

Form

FRM-0918

NTS LANDFILL LOAD VERIFICATION

Page 1

\begin{tabular}{|llllll}
\hline SWO USE (Select One) & AREA & $\square 23$ & $\square 6$ & 23 & LANDFILL \\
\hline For waste characterization, approval, and/or assistance, contact Solid Waste Operation (SWO) at 5-7898.
\end{tabular}

For waste characterization, approval, and/or assistance, contact Solid Waste Operation (SWO) at 5-7898.

REQUIRED: WASTE GERERATOR INFORMATION

(This form is for rolloffs, dump trucks, and other onsite disposal of materials.)

Waste Generator: Dan Tobiason

Phone Number: 295-6169

Location / Origin: T-Tunnel Lower Laydown Yard

Waste Category: (check one)

Waste Type: $\triangle$ NTS

(check one) $\quad \square$ Non-Putrescible $\square$ Asbestos Containing Material

$\square$ Commercial

$\triangle$ Industrial cas 9/2107

$\triangle F F A C O$-Onsite

$\square$ WAC Exception

Pollution Prevention Category: (check one)

Pollution Prevention Category: (check one)

Method of Characterization: (check one)

Environmental management

$\triangle$ Clean-Up

$\square$ FFACO-offsite

$\triangle$ Defense Projects

$\square$ Historic DOE/NV

Prohibited Waste at all three

NTS landfills:

Additional Prohibited Waste

at the Area 9 U10C Landfill:

levels, and Medical wastes (needles, sharps, bloody clothing).

Sewage Sludge, Animal carcasses, Wet garbage (food waste); and Friable asbestos

REQUIRED: WASTE CONTENTS ALLOWABLE WASTES

Check all allowable wastes that are contained within this load:

NOTE: Waste disposal at the Area 6 Hydrocarbon Landfill must have come into contact with petroleum hydrocarbons or coolants, such as: gasoline (no benzene, lead); jet fuel; diesel fuel; lubricants and hydraulics; kerosene; asphaltic petroleum hydrocarbon; and ethylene glycol.
Acceptable waste at any NTS landfill:
$\bigotimes$ Asphalt
$\otimes$ Metal
$\triangle$ Wood
$\triangle$ Paper
$\bigotimes$ Soil
$\square$ Rocks / unaltered geologic materials
$\triangle$ Plastic $\quad$ Wire
$\triangle$ Cable
$\triangle$ Cloth
$\bigotimes$ Rubber (excluding tires)
$\triangle$ Insulation (non-Asbestosform)
$\triangle$ Manufactured items: (swamp coolers, furniture, rugs, carpet, electronic components, PPE, etc.)

$\triangle$ Empty containers

$\triangle$ Demolition debris
Additional waste accepted at the Area 23 Mercury Landfill:
$\square$ Office Waste
Food Waste
Animal Carcasses
Asbestos
Friable
Non-Friable (contact SWO if regulated load)
Quantity:

Additional waste accepted at the Area 9 U10c Landfill:
$\square$ Non-friable asbestos
Light ballasts (contact SWO)
$\square$ Drained automobiles and military vehicles
$\square$ Drained fuel filters (gas \& diesel)
Hydrocarbons (contact SWO)
Other

Drained generators/equipment

$\square$ Solid fractions from sand/oil/water

$\bigotimes$ Deconned Underground and Above Ground Tanks

Additional waste accepted at the Area 6 Hydrocarbon Landfill:
Septic sludge
$\square$ Rags
$\square$ Drained fuel filters (gas \& diesel)
Crushed non-teme plated oil filters
Plants
Soil
Sludge from sand/oil/water separators
REQUIRED: WASTE GENERATOR SIGNATURE

Initials: (if initialed, no radiological clearance is necessary.)

The above mentioned waste was generated outside of a Controlled Waste Management Area (CWMA) and to the best of my knowledge, does not contain radiological materials.

To the best of my knowledge, the waste described above contains only those materials that are allowed for disposal at this site. I have verified this through the waste characterization method id :s:and above and a review of the above-mentioned prohibited and allowable waste items. I have contacted Property Man is approved for disposal in the landfill.

Print Name: Dan Tobiason

Signature:
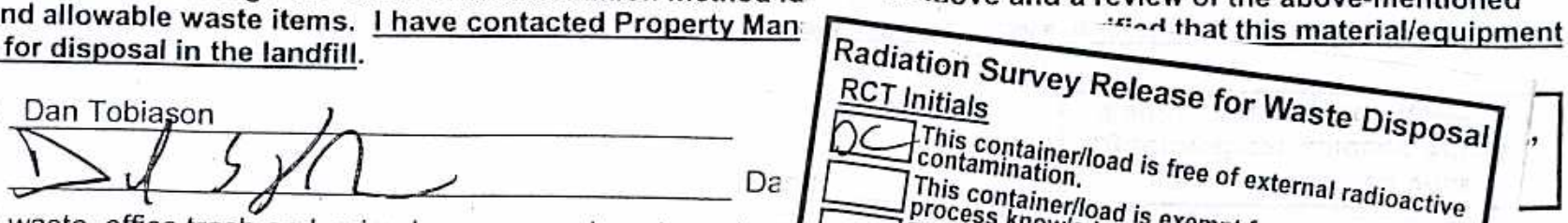

must have signed require SWO USE ONLY

Load Weight (net from scale or estimate)

ci, 5010

9.26 .07 RCT Initials a

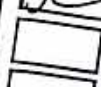
7 This contamination.
This containe is free of external radioactive
process know/load is exempt from This containerledge and origin. SIGNATURE: Contamination based on radioanalysis. Signature of Certifier: 
NSTec

Form

FRM-0918

\section{$\begin{array}{llllll}\text { SWO USE (Select One) } & \text { AREA } & \square 23 & \square 6 & \text { AR } & \text { LANDFILL }\end{array}$}

For waste characterization, approval, and/or assistance, contact Solid Waste Operation (SWO) at 5-7898.

\section{REQUIRED: WASTE GERERATOR INFORMATION}

(This form is for rolloffs, dump trucks, and other onsite disposal of materials.)

Waste Generator: Dan Tobiason

Phone Number: 295-6169

Location / Origin: T-Tunnel Lower Laydown Yard

Waste Category: (check one)

Waste Type: $\square$ NTS

(check one)

$\square$ Non-Putrescible

\section{$\square$ Commercial \\ $\square$ Putrescrible}

Pollution Prevention Category: (check one)

Pollution Prevention Category: (check one)

Method of Characterization: (check one)

$\square$ Asbestos Containing Material

$\square$ Environmental management

$凶$ Clean-Up

$\square$ Sampling \& Analysis

Prohibited Waste at all three

NTS landfills:

Additional Prohibited Waste

at the Area 9 U10C Landfill:

\begin{abstract}
Radioactive waste; RCRA waste; Hazardous waste; Free liquids, PCBs above TSCA regulatory levels, and Medical wastes (needles, sharps, bloody clothing).
\end{abstract}

Sewage Sludge, Animal carcasses, Wet garbage (food waste); and Friable asbestos

\section{REQUIRED: WASTE CONTENTS ALLOWABLE WASTES}

Check all allowable wastes that are contained within this load:

NOTE: Waste disposal at the Area 6 Hydrocarbon Landfill must have come into contact with petroleum hydrocarbons or coolants, such as: gasoline (no benzene, lead); jet fuel; diesel fuel; lubricants and hydraulics; kerosene; asphaltic petroleum hydrocarbon; and ethylene glycol.

Acceptable waste at any NTS landfill:
¿ Asphalt
区 Metal
$\triangle$ Wood
[] Plastic
$凶$ Wire
$\triangle$ Cable
Soil
Cloth

$\triangle$ Paper
$\square$ Rocks / unaltered geologic materials
$\triangle$ Rubber (exciuding tires)

$\triangle$ Insulation (non-Asbestosform)

$\bigotimes$ Empty containers
$\bigotimes$ Demolition debris
$\bigotimes$ Cement \& concrete

$\triangle$ Manufactured items: (swamp coolers, furniture, rugs, carpet, electronic components, PPE, etc.)
Additional waste accepted at the Area 23 Mercury Landfill:
Food Waste
Animal Carcasses

$\square$ Asbestos

Friable

Non-Friable (contact SWO if regulated load)

Additional waste accepted at the Area 9 U10c Landfill:
$\square$ Non-friable asbestos
Light ballasts (contact SWO)
$\square$ Drained automobiles and military vehicles
$\square$ Drained fuel filters (gas \& diesel)
Hydrocarbons (contact SWO)
$\triangle$ Other
Drained generators/equipment

Quantity:

Additional waste accepted at the Area 6 Hydrocarbon Landfill:
Septic sludge
Plants
$\square$ Rags
Soil
$\square$ Drained fuel filters (gas \& diesel)
$\square$ Sludge from sand/oil/water separators REQUIRED: WASTE GENERATOR SIGNATURE

Solid fractions from sand/oil/water

$\bigotimes$ Deconned Underground and Above Ground Tanks

Initials: (if initialed, no radiological clearance is necessary.) The above mentioned waste was generated outside of a Controlled Waste Management Area (CWMA) and to the best of my
knowiedge, does not contain radiological materials.

To the best of my knowledge, the waste described above contains only the site. I have verified this through the waste characterization method identif prohibited and allowable waste items. I have contacted Property Managem is approved for disposal in the landfill.

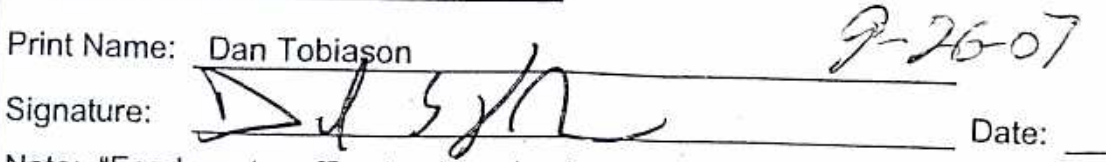

Note: "Food waste, office trash and animal carcasses do not require a radiol must have signed removal certification statement with Load Verificatio

Radiation Survey Release for Waste Disposal RCT Initials

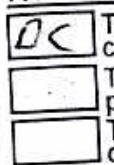

contamination.

This containerload is exempt from survey due to This containeriload is exempt fron.

process knowledge and origin.

This container/load is free of radioactive

SIGNATURE: 4. 0 DATE: 9.260 SWO USE ONLY

Load Weight (net from scale or estimate): Signature of Certifier 


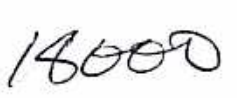

NSTec

Form

FRM-0918

NTS LANDFILL LOAD VERIFICATION

Page

\begin{tabular}{llllll}
\hline SWO USE (Select One) & AREA & $\square 23$ & $\square 6$ & Q 99 & LANDFILL
\end{tabular}

For waste characterization, approval, and/or assistance, contact Solid Waste Operation (SWO) at 5-7898.

REQUIRED: WASTE GERERATOR INFORMATION

(This form is for rolloffs, dump trucks, and other onsite disposal of materials.)

Waste Generator: Dan Tobiason

Phone Number: 295-6169

Location / Origin: T-Tunnel Lower Laydown Yard $4 / 2$

Waste Category: (check one)

Waste Type: $\square$ NTS

$\square$ Commercial

$\triangle$ Industrial ags o//107

(check one)

$\square$ Non-Putrescible

$\square$ Putrescrible

$\triangle$ FFACE-onsite

$\square$ WAC Exception

$\square$ Asbestos Containing Material

Pollution Prevention Category: (check one) $\square$ Environmental management

Pollution Prevention Category: (check one) $\triangle$ Clean-Up

Method of Characterization: (check one) $\square$ Sampling \& Analysis

$\square$ FFACO-offsite

$\square$ Historic DOE/NV

Prohibited Waste at all three

NTS landfills:

Additional Prohibited Waste

at the Area 9 U10C Landfill:

Radioactive waste; RCRA waste; Hazardous waste; Free liquids, PCBs above TSCA regulatory levels, and Medical wastes (needles, sharps, bloody clothing).

Sewage Sludge, Animal carcasses, Wet garbage (food waste); and Friable asbestos

\section{REQUIRED: WASTE CONTENTS ALLOWABLE WASTES}

Check all allowable wastes that are contained within this load:

NOTE: Waste disposal at the Area 6 Hydrocarbon Landfill must have come into contact with petroleum hydrocarbons or coolants, such as: gasoline (no benzene, lead); jet fuel; diesel fuel; lubricants and hydraulics; kerosene; asphaltic petroleum hydrocarbon; and ethylene glycol.
Acceptable waste at any NTS landfill:
$\triangle$ Paper
$凶$ Soil
$\square$ Rocks / unaltered geologic materials
$\bigotimes$ Rubber (excluding tires)
$\triangle$ Asphalt $\quad$ Metal $\quad$ Wood
$\triangle$ Cloth
$\bigotimes$ Insulation (non-Asbestosform)
$\bigotimes$ Empty containers
$\otimes$ Demolition debris
$凶$ Plastic
$\bigotimes$ Cable
$\triangle$ Manufactured items: (swamp coolers, furniture, rugs, carpet, electronic components, PPE, etc.)
$\bigotimes$ Cement \& concrete

$\triangle$ Manufactured items: (swamp coolers, furniture, rugs, carpet, electronic components, PPE, etc.)

Additional waste accepted at the Area 23 Mercury Landfill: $\square$ Office Waste $\square$ Food Waste
$\square$ Asbestos $\square$ Friable $\square$ Non-Friable (contact SWO if regulated load) Quantity:
$\square$ Non-Friable (contact SWO if regulated load)
Quantity:

Additional waste accepted at the Area 9 U10c Landfill:
$\square$ Non-friable asbestos
Light ballasts (contact SwO)
$\square$
Drained automobiles and military vehicles
Drained fuel filters (gas \& diesel)
Hydrocarbons (contact SWO)
$\bigotimes$ Other
Drained generators/equipment

Solid fractions from sand/oil/water

$\bigotimes$ Deconned Underground and Above Ground Tanks

Additional waste accepted at the Area 6 Hydrocarbon Landfill:
$\square$ Septic sludge
$\square$ Rags
$\square$ Drained fuel filters (gas \& diesel)
Crushed non-teme plated oil filters
Plants
Soil
$\square$ Sludge from sand/oil/water separators
REQUIRED: WASTE GENERATOR SIGNATURE
$\square$ PCBs below 50 parts per million

Initials: (if initialed, no radiological clearance is necessary.)

The above mentioned waste was generated outside of a Controlled Waste Management Area (CWMA) and to the best of my kriowledge, does not contain radiological materials.

To the best of my knowledge, the waste described above contains only th site. I have verified this through the waste characterization method identi prohibited and allowable waste items. I have contacted Property Managen is approved for disposal in the landfill.

Print Name: Dan Tobiason

Signature:
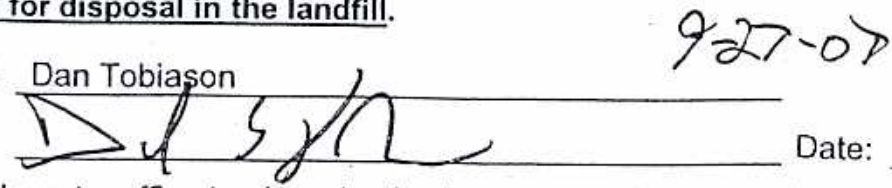

Note: "

Food waste, office trash and animal carcasses do not require a radiol must have signed removal certificatton statement with Load Verificatic RCT Initials

RCT Initials
This containerlload is free of external radioactive
This container/load is exempt from survey due to
process knowledge and origin.
This containerlload is free of radioactive
contamination based on radioanalysis.


NSTec

Form

FRM-0918

NTS LANDFILL LOAD VERIFICATION

Page

\begin{tabular}{|ccccc}
\hline SWO USE (Select One) & AREA \\
\hline For waste characterization, approval, and/or assistance, contact Solid Waste Operation (SWO) at 5-7898.
\end{tabular}

REQUIRED: WASTE GERERATOR INFORMATION

(This form is for rolloffs, dump trucks, and other onsite disposal of materials.)

Waste Generator: Dan Tobiason

Phone Number: 295-6169

Location / Origin: T-Tunnel Lower Laydown Yard $\quad A / Z$

Waste Category: (check one) $\square$ Commercial

Waste Type: $\triangle$ NTS $\square$ Putrescrible

(check one) $\square$ Non-Putrescible $\square$ Asbestos Containing Material

Pollution Prevention Category: (check one) $\square$ Environmental management

Pollution Prevention Category: (check one) $\triangle$ Clean-Up

Method of Characterization: (check one) $\square$ Sampling \& Analysis

Prohibited Waste at all three - Radioactive waste RCRA $\triangle$ Process Knowledge

$\triangle$ Industrial cos $10 / 1 / 07$

$\triangle$ FFACO-onsite $\square$ WAC Exception

NTS landfills:

Additional Prohibited Waste

at the Area 9 U10C Landfill:

levels, and Medical wastes (needles, sharps, bloody clothing).

Sewage Sludge, Animal carcasses, Wet garbage (food waste); and Friable asbestos

\section{REQUIRED: WASTE CONTENTS ALLOWABLE WASTES}

Check all allowable wastes that are contained within this load:

NOTE: Waste disposal at the Area 6 Hydrocarbork Landfill must have come into contact with petroleum hydrocarbons or coolants, such as: gasoline (no benzene, leàd); jet fuel; diesel fuel; lubricants and hydraulics; kerosene; asphaltic petroleum hydrocarbon; and ethylene glycol.

Acceptable waste at any NTS landfill: $\bigotimes$ Pape

$\triangle$ Asphalt $\square$ Metal $\otimes$ Wood $\square$ Soil

$\triangle$ Plastic $\quad$ Wire $\quad$ Cable $\quad$ Cloth

$\square$ Rocks / unaltered geologic materials

$\square$ Rubber (excluding tires)

Insulation (non-Asbestosform)

$\triangle$ Empty containers

$\bigotimes$ Demolition debris

$\triangle$ Manufactured items: (swamp coolers, furniture, rugs, carpet, electronic components, PPE, etc.)

Additional waste accepted at the Area 23 Mercury Landfill: $\square$ Office Waste

$\square$ Asbestos $\square$ Friable $\square$ Non-Friable (contact SWO if regulated load)

$\square$ Food Waste

$\bigotimes$ Cement \& concrete

Additional waste accepted at the Area 9 U10c Landfill:
$\square$ Non-friable asbestos
Light ballasts (contact SWO)
Drained automobiles and military vehicles
Drained fuel filters (gas \& diesel)

1. Hydrocarbons (contact SWO)

$\triangle$ Other Drained generators/equipment

Quantity:

Animal Carcasses

Additional waste accepted at the Area 6 Hydrocarbon Landfill:
$\square$ Septic sludge
Plants
$\square$ Rags
Soil
$\square$ Drained fuel filters (gas \& diesel)
$\square$ Sludge from sand/oil/water separators
REQUIRED: WASTE GENERATOR SIGNATURE

Solid fractions from sand/oil/water

$\bigotimes$ Deconned Underground and Above Ground Tanks

Initials: (if initialed, no radiological clearance is necessary.) The above mentioned waste was generated outside of a Controlled Waste Management Area (CWMA) and to the best of my
knowledge, does not contain radiological materials.

To the best of my knowledge, the waste described above contains only the site. I have verified this through the waste characterization method identif prohibited and allowable waste items. I have contacted Property Managen is approved for disposal in the landfill.

Print Name:

Signature:
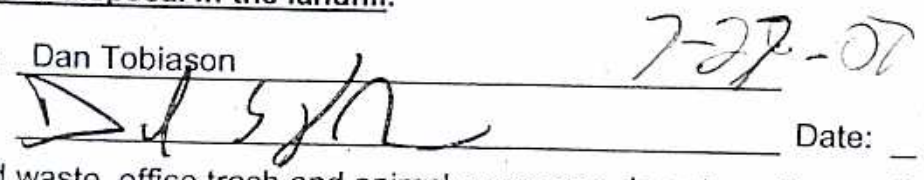

Note: "Food

must have, office trash and animal carcasses do not require a radit SWO USE ONLY

Load Weight (net from scale or estimate):

\section{Radiation Survey Release for Waste Disposal RCT Initials}

$\mathrm{OC}$ This container/load is free of external radioactive

This container/load is exempt from survey due to process knowledge and origin.

This containerlload is free of radioactive contamination based on radioanalysis.

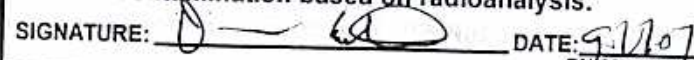
BN-0646 (09/99)

\section{1}




\section{SWO USE (Select One) AREA 23 \\ $\square 6$ \\ 凶9 \\ $\bigotimes$ LANDFILL}

For waste characterization, approval, and/or assistance, contact Solid Waste Operation (SWO) at 5-7898.

$$
\text { REQUIRED: WASTE GERERATOR INFORMATION }
$$

(This form is for rolloffs, dump trucks, and other onsite disposal of materials.)

Waste Generator: Dan Tobiason

Phone Number: 295-6169

Location / Origin: T-Tunnel Lower Laydown Yard $H / Z$

Waste Category: (check one)

Waste Type: $\triangle$ NTS

(check one)

$\square$ Non-Putrescible

$\square$ Commercial
$\square$ Putrescrible
$\square$ Asbestos Containing Material
$\square$ Environmental management
$\square$ Clean-Up
$\square$ Sampling \& Analysis

区 Industrial

X-FFACO-OIISTE

$5.10 / 2 / 07$

$\square$ WAC Exception

Pollution Prevention Category: (check one)

Pollution Prevention Category: (check one)

Method of Characterization: (check one)

Sampling \& Analysis

FFACO-offsite

$\square$ Historic DOE/NV

Prohibited Waste at all three

NTS landfills:

Additional Prohibited Waste

at the Area 9 U10C Landfill:

Radioactive waste; RCRA waste; Hazardous waste; Free liquids, PCBs above TSCA regulatory levels, and Medical wastes (needles, sharps, bloody clothing).

Sewage Sludge, Animal carcasses, Wet garbage (food waste); and Friable asbestos

\section{REQUIRED: WASTE CONTENTS ALLOWABLE WASTES}

Check all allowable wastes that are contained within this load:

NOTE: Waste disposal at the Area 6 Hydrocarbon Landfill must have come into contact with petroleum hydrocarbons or coolants, such as: gasoline (no benzene, lead); jet fuel; diesel fuel; lubricants and hydraulics; kerosene; asphaltic petroleum hydrocarbon; and ethylene glycol.
Acceptable waste at any NTS landfill:
$\triangle$ Asphalt
$\triangle$ Metal
$\triangle$ Wood
$\triangle$ Paper
$\bigotimes$ Soil
$\triangle$ Cloth
$\square$ Rocks / unaltered geologic materials
$\triangle$ Rubber (excluding tires)
$\bigotimes$ Empty containers
$\triangle$ Plastic $\otimes$ Wire
$\triangle$ Cable
$\bigotimes$ Insulation (non-Asbestosform)
$\triangle$ Demolition debris
$\bigotimes$ Cement \& concrete

$\bigotimes$ Manufactured items: (swamp coolers, furniture, rugs, carpet, electronic components, PPE, etc.)
Additional waste accepted at the Area 23 Mercury Landfill:
$\square$ Asbestos
Friable
$\square$ Non-Friable (contact Swo if regulated load)
$\square$ Food Waste
Quantity:
Animal Carcasses

Additional waste accepted at the Area 9 U10c Landfill:
$\square$ Non-friable asbestos
$\square$ Light ballasts (contact SWO)
$\square$ Drained automobiles and military vehicles
Drained fuel filters (gas \& diesel)

Hydrocarbons (contact SWO)

Other

Drained generators/equipment

Additional waste accepted at the Area 6 Hydrocarbon Landfill:
$\square$ Septic sludge
$\square$ Rags
$\square$ Drained fuel filters (gas \& diesel)
Plants
$\square$ Soil
$\square$ Sludge from sand/oil/water separators
REQUIRED: WASTE GENERATOR SIGNATURE

Solid fractions from sand/oil/water

$\triangle$ Deconned Underground and Above Ground Tanks

Initials: (if initialed, no radiological clearance is necessary.)

The above mentioned waste was generated outside of a Controlled Was ${ }^{2-. .}$ knowledge, does not contain radiological materials.

To the best of my knowledge, the waste described above contains only 1 site. I have verified this through the waste characterization method iden prohibited and allowable waste items. I have contacted Property Manag is approved for disposal in the landfill.

Print Name:

Signature:
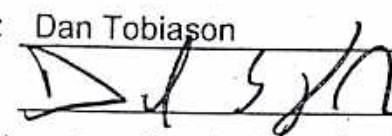

$10-1-07$

Date:
Radiation Survey Release for Waste Disposal RCT Initials

This container/load is free of external radioactive Contamination.

This container/load is exempt from survey due to process knowledge and origin.

This container/load is free of radioactive

contamination based on radioanalysis.

SIGNATURE: (4)

Note: "Food waste, office trash and animal carcasses do not require a radiological clearance. Freon-containing appliances SWO USE ONLY

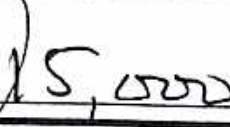

$10.1,07$

Signature of Certifier 


\section{$\begin{array}{llllll}\text { SWO USE (Select One) } & \text { AREA } & \square 23 & \square 6 & \text { (S) } & \text { LANDFILL }\end{array}$}

For waste characterization, approval, and/or assistance, contact Solid Waste Operation (SWO) at 5-7898.

REQUIRED: WASTE GERERATOR INFORMATION

(This form is for rolloffs, dump trucks, and other onsite disposal of materials.)

Waste Generator: Dan Tobiason

Phone Number: 295-6169

Location / Origin: T-Tunnel Lower Laydown Yard

$H / 2$

Waste Category: (check one)

Waste Type: $\square$ NTS

$\square$ Commercial

$\square$ Putrescrible

$\triangle$ Industrial gos 10/2/07

(check one)

$\square$ Non-Putrescible

$\square$ Asbestos Containing Material

Z-FFAGO-OAsite

WAC Exception

Pollution Prevention Category: (check one)

Pollution Prevention Category: (check one)

$\square$ Environmental management

$\square$ FFACO-offsite

$\square$ Historic DOE/NV

Method of Characterization: (check one)

$\triangle$ Clean-Up

Prohibited Waste at all three

NTS landfills:

Additional Prohibited Waste

at the Area 9 U10C Landfill:

Radioactive waste; RCRA waste; Hazardous waste; Free liquids, PCBs above TSCA regulatory levels, and Medical wastes (needles, sharps, bloody clothing).

Sewage Sludge, Animal carcasses, Wet garbage (food waste); and Friable asbestos

\section{REQUIRED: WASTE CONTENTS ALLOWABLE WASTES}

Check all allowable wastes that are contained within this load:

NOTE: Waste disposal at the Area 6 Hydrocarbon Landfill must have come into contact with petroleum hydrocarbons or coolants, such as: gasoline (no benzene, lead); jet fuel; diesel fuel; lubricants and hydraulics; kerosene; asphaltic petroleum hydrocarbon; and ethylene glycol.

Acceptable waste at any NTS landfill: $\triangle$ Paper $\square$ Rocks/ unaltered geologic materials

Asphait

$凶$ Metal

$\triangle$ Wood

\Soil

$\bigotimes$ Rubber (exciuding tires)

$\bigotimes$ Plastic $\quad$ Wire

$\triangle$ Cable

Cloth

$\triangle$ Insulation (non-Asbestosform)

$\triangle$ Empty containers

$\triangle$ Demolition debris

$\bigotimes$ Manufactured items: (swamp coolers, furniture, rugs, carpet, electronic components, PPE, etc.)

Additional waste accepted at the Area 23 Mercury Landfill: $\square$ Office Waste

$\square$ Asbestos

Friable

Non-Friable (contact SWO if regulated load)

$\square$ Food Waste

Animal Carcasses

Additional waste accepted at the Area 9 U10c Landfill:

$\square$ Non-friable asbestos

$\square$ Light ballasts (contact SWO)

Hydrocarbons (contact SWO)
Drained automobiles and military vehicles

Drained fuel filters (gas \& diesel)

Other Drained generators/equipment

Quantity:

Additional waste accepted at the Area 6 Hydrocarbon Landfill:
$\square$ Septic sludge
$\square$ Rags
$\square$ Drained fuel filters (gas \& diesel)
Plants
Soil
$\square$ Sludge from sand/oil/water separators
REQUIRED: WASTE GENERATOR SIGNATURE
Crushed non-teme plated oil filters
PCBs below 50 parts per million

Initials: (if initialed, no radiological clearance is necessary.)

The above mentioned waste was generated outside of a Controlled WasI knowledge, does not contain radiological materiais.

To the best of my knowledge, the waste described above contains only 1 site. I have verified this through the waste characterization method ider prohibited and allowable waste items. I have contacted Property Manag is approved for disposal in the landfill.

Print Name:
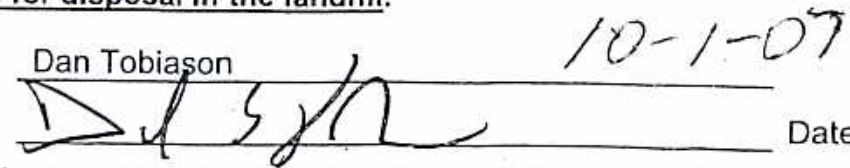

Signature:

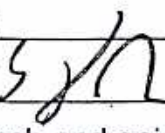

Note: "Food must have signed removal certification statement with Load Verification.

SWO USE ONLY

Load Weight (net from scale or estimate):

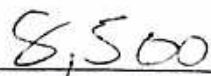

$10-1.07$ Signature of Certifier:

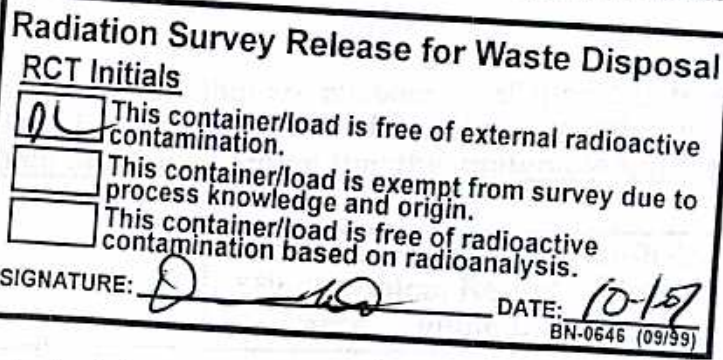

Deconned Underground and Above Ground Tanks

$\longrightarrow$ 
NSTec

Form

FRM-0918

NTS LANDFILL LOAD VERIFICATION

Rev. 0

SWO USE (Select One) AREA

23

$\square 6$

区9

$\triangle$ LANDFILL

For waste characterization, approval, and/or assistance, contact Solid Waste Operation (SWO) at 5-7898.

REQUIRED: WASTE GERERATOR INFORMATION

(This form is for rolloffs, dump trucks, and other onsite disposal of materials.)

Waste Generator: Dan Tobiason

Phone Number: 295-6169

Location / Origin: T-Tunnel Lower Laydown Yard $M / Z$

Waste Category: (check one) $\square$ Commercial

Waste Type: $\triangle$ NTS $\square$ Putrescrible

(check one) $\quad \square$ Non-Putrescible $\quad \square$ Asbestos Containing Material

Pollution Prevention Category: (check one) $\square$ Environmental management

Pollution Prevention Category: (check one) $\triangle$ Clean-Up

Method of Characterization: (check one)

1 Sampling \& Analysis

$\triangle$ Industrial egs $10 / 2 / 07$

AFFAGO-onsite

$\square$ WAC Exception

Prohibited Waste at all three Radioactive waste; RCRA waste; Hazard

NTS landfills:

Additional Prohibited Waste

at the Area 9 U10C Landfill:

levels, and Medical wastes (needles, sharps, bloody clothing).

Sewage Sludge, Animal carcasses, Wet garbage (food waste); and Friable asbestos

\section{REQUIRED: WASTE CONTENTS ALLOWABLE WASTES}

Check all allowable wastes that are contained within this load:

NOTE: Waste disposal at the Area 6 Hydrocarbon Landfill must have come into contact with petroleum hydrocarbons or coolants, such as: gasoline (no benzene, lead); jet fuel; diesel fuel; lubricants and hydraulics; kerosene; asphaltic petroleum hydrocarbon; and ethylene glycol.

Acceptable waste at any NTS landfill: $\square$ Paper

Asphalt $\square$ Metal

$\triangle$ Wood

$\bigotimes$ Soil

$\triangle$ Plastic

Q Wire

$\triangle$ Cable

$\bigotimes$ Cloth

$\square$ Rocks / unaltered geologic materials

$\bigotimes$ Rubber (excluding tires)

$\triangle$ Empty containers

$\triangle$ Demolition debris

$\triangle$ Manufactured items: (swamp coolers, furniture, rugs, carpet, electronic components, PPE, etc.)

Additional waste accepted at the Area 23 Mercury Landfill: $\square$ Office Waste

$\square$ Asbestos

Friable

Non-Friable (contact SWO if regulated load)

$\square$ Food Waste

$\triangle$ Cement \& concrete

Additional waste accepted at the Area 9 U10c Landfill:

$\square$ Non-friable asbestos

Light ballasts (contact SWO)

Hydrocarbons (contact SWO)

$\square$ Drained automobiles and military vehicles

Drained fuel filters (gas \& diesel)

Other Drained generators/equipment

Quantity:

Animal Carcasses

Additional waste accepted at the Area 6 Hydrocarbon Landfill:

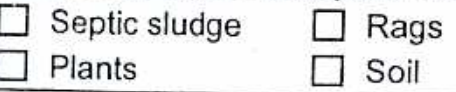

$\square$ Drained fuel filters (gas \& diesel)

$\square$ Sludge from sand/oil/water separators

REQUIRED: WASTE GENERATOR SIGNATURE
Solid fractions from sand/oil/water

$\bigotimes$ Deconned Underground and Above Ground Tanks

Initials: (if initialed, no radiological clearance is necessary.)

The above mentioned waste was generated outside of a Controlled Was! knowledge, does not contain radiological materials.

To the best of my knowledge, the waste described above contains only $t$ site. I have verified this through the waste characterization method iden prohibited and allowable waste items. I have contacted Property Manage is approved for disposal in the landfill.

Print Name: Dan Tobiason

Signature:
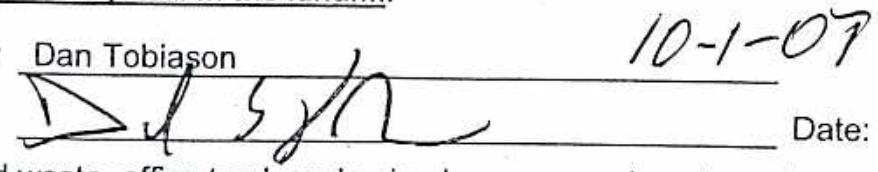

Note: "Food must have signed removal certification statement with Load Verification.

SWO USE ONLY

Load Weight (net from scale or estimato).

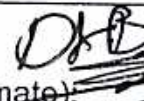




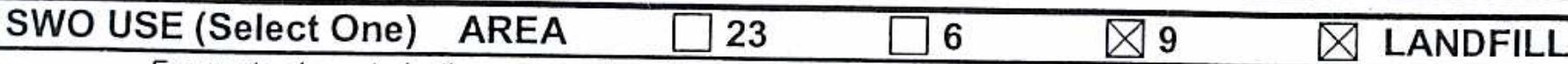

For waste characterization, approval, and/or assistance, contact Solid Waste Operation (SWO) at 5-7898.

REQUIRED: WASTE GERERATOR INFORMATION

(This form is for rolloffs, dump trucks, and other onsite disposal of materials.)

W'aste Generator: Dan Tobiason

Phone Number: 295-6169

Location / Origin: T-Tunnel Lower Laydown Yard niz

Waste Category: (check one)

Waste Type: $\triangle$ NTS

(check one)

$\square$ Non-Putrescible

$\square$ Commercial

Pollution Prevention Category: (check one)

Pollution Prevention Category: (check one)

Method of Characterization: (check one)

$\square$ Putrescrible

$\square$ Asbestos Containing Material

$\Delta$ Industrial ags $10 / 2 / 07$

$\square$ Environmental management

$\triangle$ FFACO-Onsite

$\square$ WAC Exception

Prohibited Waste at all thre

Clean-Up

NTS landfills:

Sampling \& Analysis

$\square$ FFACO-offsite

$\square$ Historic DOE/NV

Additional Prohibited Waste at the Area 9 U10C Landfill:

Radioactive waste; RCRA waste; Hazardôus waste; Free liquids, PCBs above TSCA regulatory levels, and Medical wastes (needles, sharps, bloody clothing).

Sewage Sludge, Animal carcasses, Wet garbage (food waste); and Friable asbestos

\section{REQUIRED: WASTE CONTENTS ALLOWABLE WASTES}

Check all allowable wastes that are contained within this load:

NOTE: Waste disposal at the Area 6 Hydrocarbon Landfill must have come into contact with petroleum hydrocarbons or coolants, such as: gasoline (no benzene, lead); jet fuel; diesel fuel; lubricants and hydraulics; kerosene; asphaltic petroleum hydrocarbon; and ethylene glycol.
Acceptable waste at any NTS landfill:
$\triangle$ Asphalt
$凶$ Metal
$\triangle$ Wood
$\triangle$ Paper
区 Soil
$\triangle$ Cable
$\otimes$ Cioth
$\square$ Rocks / unaltered geologic materials
$\bigotimes$ Rubber (excluding tires)
Insulation (non-Asbestosform)
$\triangle$ Empty containers
$\triangle$ Demolition debris
$\triangle$ Plastic $\otimes$ Wire
$\triangle$ Cement \& concrete

wamp coolers

carpet,

electronic components, PPE, etc.)

Additional waste accepted at the Area 23 Mercury Landfill: $\square$ Office Waste

$\square$ Asbestos

Friable

Non-Friable (contact SWO if regulated load)

$\square$ Food Waste

Additional waste accepted at the Area 9 U10c Landfill:

$\square$ Non-friable asbestos

Light ballasts (contact SWO)

Hydrocarbons (contact SWO)

$\square$ Drained automobiles and military vehicles

$\square$ Drained fuel filters (gas \& diesel)

$\otimes$ Other Drained generators/equipment

Quantity:

Animal Carcasses

\section{Additional waste accepted at the Area 6 Hydrocarbon Landfill:}
$\square$ Septic sludge
$\square$ Rags
Plants
Soil
$\square$ Drained fuel filters (gas \& diesel)
$\square$ Sludge from sand/oil/water separators
REQUIRED: WASTE GENERATOR SIGNATURE
Crushed non-teme plated oil filters PCBs below 50 parts per million

Solid fractions from sand/oil/water

$\triangle$ Deconned Underground and Above Ground Tanks

Initials: (if initialed, no radiological clearance is necessary.)

The above mentioned waste was generated outside of a Controlled Waste Management Area (CWMA) and to the best of my knowledge, does not contain radiological materials.

To the best of my knowledge, the waste described above contains only thos site. I have verified this through the waste characterization method identifie prohibited and allowable waste items. I have contacted Property Manageme is approved for disposal in the landfill.

Print Name: Dan Tobiason

Signature:
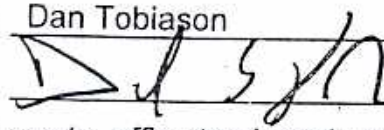

$10-1-127$

Note: "Food waste, office trash and animal carcasses do not require a radiol

must have signed removal certification statement with Load Verification."

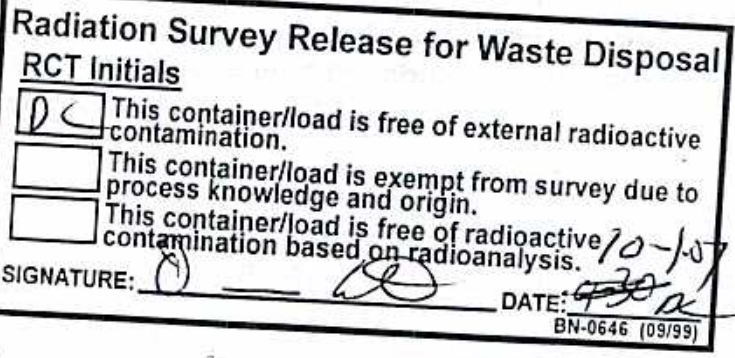

SWO USE ONLY

Load Weight (net from scale or estimate): 


\section{$\begin{array}{llllll}\text { SWO USE (Select One) } & \text { AREA } & \square 23 & \square 6 & \square 9 & \text { L LANDFILL }\end{array}$}

For waste characterization, approval, and/or assistance, contact Solid Waste Operation (SWO) at 5-7898.

REQUIRED: WASTE GERERATOR INFORMATION

(This form is for rolloffs, dump trucks, and other onsite disposal of materials.)

Waste Generator: Dan Tobiason

Phone Number: 295-6169

Location / Origin: T-Tunnel Lower Laydown Yard $A / Z$

Waste Category: (check one)

Waste Type: $\triangle$ NTS

$\square$ Commercial

(check one)

$\square$ Non-Putrescible

$\square$ Putrescrible

Industrial Cas 10/2/07

Pollution Prevention Category: (check one)

Pollution Prevention Category: (check one)

$\square$ Asbestos Containing Material

- - FFAGO-OAvite

$\square$ WAC Exception

Method of Characterization: (check one)

Environmental management

$\triangle$ Clean-Up

$\square$ FFACO-offsite

$\triangle$ Defense Projects

$\square$ Historic DOE/NV

Prohibited Waste at all three

NTS landfills:

Additional Prohibited Waste

at the Area 9 U10C Landfill:

Radioactive waste; RCRA waste; Hazardous waste; Free liquids,
levels, and Medical wastes (needles, sharps, bloody clothing).

Sewage Sludge, Animal carcasses, Wet garbage (food waste); and Friable asbestos

\section{REQUIRED: WASTE CONTENTS ALLOWABLE WASTES}

Check all allowable wastes that are contained within this load:

NOTE: Waste disposal at the Area 6 Hydrocarbon Landfill must have come into contact with petroleum hydrocarbons or coolants, such as: gasoline (no benzene, lead); jet fuel; diesel fuel; lubricants and hydraulics; kerosene; asphaltic petroleum hydrocarbon; and ethylene glycol.
Acceptable waste at any NTS landfill:
$\triangle$ Asphalt
$\triangle$ Metal
Q Wood
$\triangle$ Paper
$凶$ Soil
$\square$ Rocks / unaltered geologic materials
$\triangle$ Empty containers
$\triangle$ Plastic $\square$ Wire
$\triangle$ Cable
Cloth
$\bigotimes$ Rubber (excluding tires)
$\triangle$ Insulation (non-Asbestosform)
$\triangle$ Demolition debris
$\triangle$ Cement \& concrete

$\triangle$ Manufactured items: (swamp coolers, furniture, rugs, carpet, electronic components, PPE, etc.)

\section{Additional waste accepted at the Area 23 Mercury Landfill: $\square$ Office Waste}

Asbestos

Friable

$\square$ Non-Friable (contact SWO if regulated load)

$\square$ Food Waste

\section{Additional waste accepted at the Area 9 U10c Landfill:}

$\square$ Non-friable asbestos

Light ballasts (contact SWO)

Hydrocarbons (contact SWO

Drained automobiles and military vehicles

Drained fuel filters (gas \& diesel)

Other

Drained generators/equipment
Quantity:

Additional waste accepted at the Area 6 Hydrocarbon Landfill:
$\square$ Septic sludge
$\square$ Rags
$\square$ Drained fuel filters (gas \& diesel)
Plants
Soil
$\square$ Sludge from sand/oil/water separators
Crushed non-teme plated oil filters PCBs below 50 parts per million

Solid fractions from sand/oil/water

$\triangle$ Deconned Underground and Above

Ground Tanks

\section{REQUIRED: WASTE GENERATOR SIGNATURE}

Initials: (if initialed, no radiological clearance is necessary.)

The above mentioned waste was generated outside of a Controllec knowledge, does not contain radiological materials.

To the best of my knowledge, the waste described above contains site. I have verified this through the waste characterization metho prohibited and allowable waste items. I have contacted Property I is approved for disposal in the landfill.

Print Name

Signature:
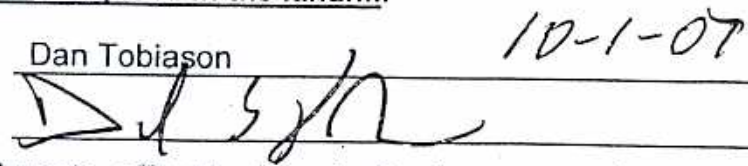

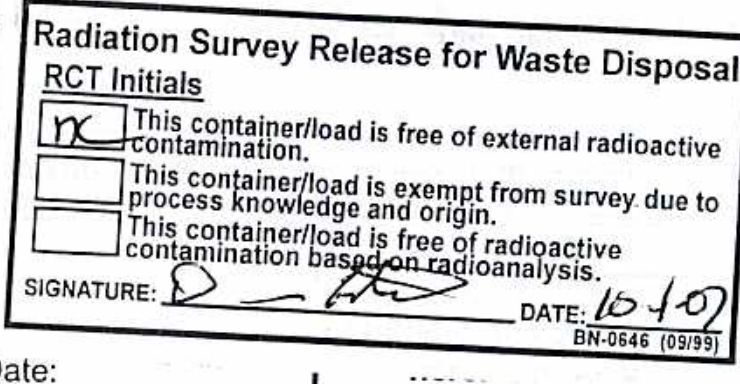
my

this ed jment j46, ker"

Note: "Food waste, office trash and animal carcasses do not require a radiological clearance. Freon-containing appliances must have signed removal certification statement with Load Verification." 


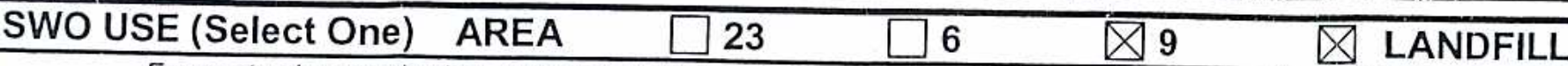

For waste characterization, approval, and/or assistance, contact Solid Waste Operation (SWO) at 5-7898.

REQUIRED: WASTE GERERATOR INFORMATION

(This form is for rolloffs, dump trucks, and other onsite disposal of materials.)

Waste Generator: Dan Tobiason

Phone Number: 295-6169

Location / Origin: T-Tunnel Lower Laydown Yard

Waste Category: (check one)

Waste Type: $\square$ NTS

$\Delta$ Industrial ggs $10 / 2 / 07$

(check one)

$\square$ Non-Putrescible

$\square$ Commercial

A-FFAGO-Ongite

$\square$ WAC Exception

Pollution Prevention Category: (check one)

Pollution Prevention Category: (check one)

Method of Characterization: (check one)

$\square$ Asbestos Containing Material

$\square$ FFACO-offsite

Environmental management

$\triangle$ Clean-Up

$\triangle$ Defense Projects

$\square$ Historic DOE/NV

$\square$ Routine

Prohibited Waste at all three

NTS landfills:

Additional Prohibited Waste

at the Area 9 U10C Landfill:

, waste; RCRA waste; Hazardous waste; Free liquids, PCBs above TSCA regulatory levels, and Medical wastes (needles, sharps, bloody clothing).

Sewage Sludge, Animal carcasses, Wet garbage (food waste); and Friable asbestos

\section{REQUIRED: WASTE CONTENTS ALLOWABLE WASTES}

Check all allowable wastes that are contained within this load:

NOTE: Waste disposal at the Area 6 Hydrocarbon Landfill must have come into contact with petroleum hydrocarbons or coolants, such as: gasoline (no benzene, lead); jet fuel; diesel fuel; lubricants and hydraulics; kerosene; asphaltic petroleum hydrocarbon; and ethylene glycol.
Acceptable waste at any NTS landfill:
$\triangle$ Paper
$\square$ Rocks / unaltered geologic materials
Empty containers
$\triangle$ Asphalt $\quad$ Metal $\quad$ Wood
$\triangle$ Soil
$\bigotimes$ Rubber (excluding tires)
$\bigotimes$ Plastic $\quad$ Wire
$凶$ Cable
$\triangle$ Cloth
$\bigotimes$ Insulation (non-Asbestosform)
$\bigotimes$ Demolition debris
$\otimes$ Cement \& concrete

$\bigotimes$ Manufactured items: (swamp coolers, furniture, rugs, carpet, electronic components, PPE, etc.)

Additional waste accepted at the Area 23 Mercury Landfill: $\square$ Office Waste $\square$ Food Waste

$\square$ Asbestos

Friable

$\square$ Non-Friable (contact SWO if regulated load)

Quantity:

Additional waste accepted at the Area 9 U10c Landfill:

Non-friable asbestos

Light ballasts (contact SWO)

Hydrocarbons (contact SWO)

Drained automobiles and military vehicles

Drained fuel filters (gas \& diesel)

Other

Drained generators/equipment
Solid fractions from sand/oil/water

$\triangle$ Deconned Underground and Above Ground Tanks

Additional waste accepted at the Area 6 Hydrocarbon Landfill:

Septic sludge $\quad[$ Rags

Plants

Soil $\square$ Drained fuel filters (gas \& diesel)

$\square$ Sludge from sand/oil/water separators
Crushed non-teme plated oil filters [ PCBs below 50 parts per million REQUIRED: WASTE GENERATOR SIGNATURE

Initials: (if initialed, no radiological clearance is necessary.)

The above mentioned waste was generated outside of a Controlled Waste Management Area (CWMA) and to the best of my knowledge, does not contain radiological materials.

To the best of my knowledge, the waste described above contains only t site. I have verified this through the waste characterization method ident prohibited and allowable waste items. I have contacted Property Manage is approved for disposal in the landfill.

Print Name: Dan Tobiason

Signature:
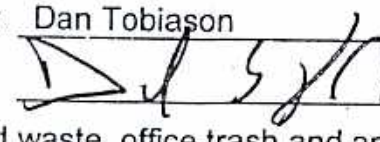
10-1.07

Note: "Food waste, office trash and animal carcasses do not require a rac must have signed removal certification statement with Load Verifice
SWO USE ONLY

Load Weight (net from/scale or estimate):
000

$101-07$

Signature of Certifier:
Radiation Survey Release for Waste Disposal RCT Initials

GC This container/load is free of external radioactive DC contamination.

This container/load is exempt from survey due to process knowledge and origin.

This container/load is free of radioactive

contamination based on radioanalysis.

Signature: 8 _

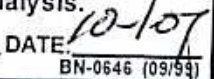


Form

\section{$\begin{array}{lllllll}\text { SWO USE (Select One) } & \text { AREA } & \square 23 & \square 6 & \text { A } & \text { (23 } & \text { LANDFILL }\end{array}$}

For waste characterization, approval, and/or assistance, contact Solid Waste Operation (SWO) at 5-7898.

REQUIRED: WASTE GERERATOR INFORMATION

(This form is for rolloffs, dump trucks, and other onsite disposal of materials.)

Waste Generator: Dan Tobiason

Phone Number: 295-6169

Location / Origin: T-Tunnel Lower Laydown Yard $\mathrm{AT} 2$

Waste Category: (check one)

Waste Type: $\square$ NTS

(check one) $\square$ Non-Putrescible $\square$ Asbestos Containing Material

(check one) $\square$ Non-Putrescible $\square$ Asbestos Containing Material

$\square$ Commercial

$\square$ Putrescrible

$\triangle$ Industrial cas $10 / 2 / 07$

Pollution Prevention Category: (check one) $\square$ Environmental management

Pollution Prevention Category: (check one) $\bigotimes$ Clean-Up

Method of Characterization: (check one)

$\square$ Sampling \& Analysis

- FFACO-UISite

$\square$ WAC Exception

Prohibited Waste at all three $\triangle$ Process Knowledge $\square$ Contents

NTS landfills:

Additional Prohibited Waste

at the Area 9 U10C Landfill:

levels, and Medical wastes (needles, sharps, bloody clothing).

Sewage Sludge, Animal carcasses, Wet garbage (food waste); and Friable asbestos

\section{REQUIRED: WASTE CONTENTS ALLOWABLE WASTES}

Check all allowable wastes that are contained within this load:

NOTE: Waste disposal at the Area 6 Hydrocarbon Landfill must have come into contact with petroleum hydrocarbons or coolants, such as: gasoline (no benzene, lead); jet fuel; diesel fuel; lubricants and hydraulics; kerosene; asphaltic petroleum hydrocarbon; and ethylene glycol.

Acceptable waste at any NTS landfill: $\bigotimes$ Paper

$\triangle$ Asphalt $\square$ Metal $\square$ Wood $\square$ Soil

Q Plastic $\quad$ Wire $\quad$ Cable

Cloth

$\square$ Rocks / unaltered geologic materials

$\bigotimes$ Rubber (excluding tires)

$\bigotimes$ Insulation (non-Asbestosform)

$\square$ Historic DOE/NV

$\triangle$ Manufactured items: (swamp coolers, furniture, rugs, carpet, electronic compcnents, PPE, etc.)
Acditional waste accepted at the Area 23 Mercury L.andfill:
$\square$ Asbestos
$\square$ Friable
Non-Friable (contact SWO if regulated load)
Food Waste
Animal Carcasses

Additional waste accepted at the Area 9 U10c Landfill:
Non-friable asbestos
Light ballasts (contact SwO)
$\square$ Drained automobiles and military vehicles
Solid fractions from sand/oil/water
Hydrocarbons (contact SWO)
Drained fuel filters (gas \& diesel)
$\bigotimes$ Deconned Underground and Above
Other Drained generators/equipment
Ground Tanks

Additional waste accepted at the Area 6 Hydrocarbon Landfill:
Septic sludge
$\square$ Rags
$\square$ Drained fuel filters (gas \& diesel)
Crushed non-teme plated oil filters
Plants
Soil
$\square$ Sludge from sand/oil/water separators REQUIRED: WASTE GENERATOR SIGNATURE
PCBs below 50 parts per million

Initials (if initialed, no radiological clearance is necessary.)

The above mentioned waste was generated outside of a Controlled Waste Management Area (CWMA) and to the best of my
knowledge, does not contain radiological materials.

To the best of my knowledge, the waste described above contains only those materials that are allowed for disposal at this site. I have verified this through the waste characterization method identified above and a review' of the above-mentinnad prohibited and allowable waste items. I have contacted Property Manag is approved for disposal in the landfill.

Print Name:

Signature:
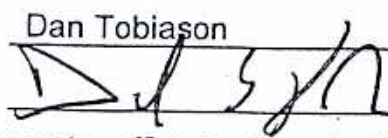

$107-0$

Date:

Note: "Food waste, office trash and animal carcasses do not require a rac must have signed removal certification statement with Load Verific:

Radiation Survey Release for Waste Disposal RCT Initials

This container/load is free of external radioactive contamination.

This container/load is exempt from survey due to process knowledge and origin.

This container/load is free of radioactive

contanination based on radioanalysis.

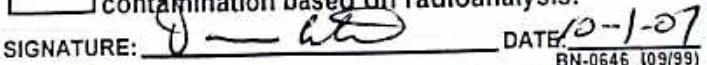




\begin{tabular}{llllll}
\hline SWO USE (Select One) & AREA & $\square 23$ & $\square 6$ & $\square 9$ & $\square$ LANDFILL
\end{tabular}

For waste characterization, approval, and/or assistance, contact Solid Waste Operation (SWO) at 5-7898.

REQUIRED: WASTE GERERATOR INFORMATION

(This form is for rolloffs, dump trucks, and other onsite disposal of materials.)

Waste Generator: Dan Tobiason

Phone Number: 295-6169

Location / Origin: T-Tunnel Lower Laydown Yard $49 / 2$

Waste Category: (check one)

Waste Type: $\triangle$ NTS

(check one)

Pollution Prevention Category: (check one)

Pollution Prevention Category: (check one)

Method of Characterization: (check one)

Prohibited Waste at all three

NTS landfills:

Additional Prohibited Waste

at the Area 9 U10C Landfill:

\section{Radioactive waste; RCRA waste; Hazardous waste; Free liquids, PCBs above TSCA regulatory levels, and Medical wastes (needles, sharps, bloody clothing).}

Sewage Sludge, Animal carcasses, Wet garbage (food waste); and Friable asbestos

\section{REQUIRED: WASTE CONTENTS ALLOWABLE WASTES}

Check all allowable wastes that are contained within this load:

NOTE: Waste disposal at the Area 6 Hydrocarbon Landfill must have come into contact with petroleum hydrocarbons or coolants, such as: gasoline (no benzene, lead); jet fuel; diesel fuel; lubricants and hydraulics; kerosene; asphaltic petroleum hydrocarbon; and ethylene glycol.
Acceptable waste at any NTS landfill:
$\bigotimes$ Paper
$\bigotimes$ Asphalt
$\bigotimes$ Metal
$凶$ Wood
$\triangle$ Soil
Cloth
Rocks / unaltered geologic materials
$\bigotimes$ Rubber (excluding tires)
$\bigotimes$ Insulation (non-Asbestosform)
$\bigotimes$ Empty containers
$\bigotimes$ Demolition debris
$\bigotimes$ Cement \& concrete

$\triangle$ Manufactured items: (swamp coolers, furniture, rugs, carpet, electronic components, PPE, etc.)
Additional waste accepted at the Area 23 Mercury Landfill:
$\checkmark$ Office Waste
Food Waste
Animal Carcasses
$\square$ Asbestos
Friable
Non-Friable (contact SWO if regulated load)
Quantity:

Additional waste accepted at the Area 9 U10c Landfill:

$\square$ Non-friable asbestos

Light ballasts (contact SWO)

$\square$ Drained automobiles and military vehicles

$\square$ Drained fuel filters (gas \& diesel)

Hydrocarbons (contact SWO) $\bigotimes$ Other Drained generators/equipment
Solid fractions from sand/oil/water

$\bigotimes$ Deconned Underground and Above Ground Tanks

Additional waste accepted at the Area 6 Hydrocarbon Landfill:

$\square$ Septic sludge $\square$ Rags $\quad \square$ Drained fuel filters (gas \& diesel)

Plants $\square$ Soil

$\square$ Sludge from sand/oil/water separators REQUIRED: WASTE GENERATOR SIGNATURE

Crushed non-teme plated oil filters PCBs below 50 parts per million

Initials: (if initialed, no radiological clearance is necessary.)

The above mentioned waste was generated outside of a Controlled Waste Manariemant $\Delta$ raa ICWMMAI and to tho hnot af mu. knowledge, does not contain radiological materials.

To the best of my knowledge, the waste described above contains only those site. I have verified this through the waste characterization method identified prohibited and allowable waste items. I have contacted Property Managemen is approved for disposal in the landfill.

Print Name:

Signature:
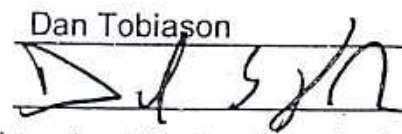

$$
|0-1-0\rangle
$$

Date:
Radiation Survey Release for Waste Disposal RCT Initials

This container/load is free of external radioactive $\mathrm{OC}$ contamination.

This container/load is exempt from survey due to process knowledge and origin.

This container/load is free of radioactive contamination based on radioanalysis. SIGNATURE:

Note: "Food waste, office trash and animal carcasses do not require a radiologıcal ciearance. r reon-contaınıng appliances must have signed removal certification statement with Load Verification."

SWO USE ONLY

Load Weight (net from scale or)estimate): 16,50
$10-1-07$

Signature of Certifient 
NSTec

\begin{tabular}{llllll}
\hline SWO USE (Select One) & AREA & $\square 23$ & $\square 6$ & Q 99 & L LANDFILL
\end{tabular}

For waste characterization, approval, and/or assistance, contact Solid Waste Operation (SWO) at 5-7898.

REQUIRED: WASTE GERERATOR INFORMATION

(This form is for rolloffs, dump trucks, and other onsite disposal of materials.)

Waste Generator: Dan Tobiason

Phone Number: $295-6169$

Location/Origin: T-Tunnel Lower Laydown Yard AIZ

Waste Category: (check one)

Waste Type: $\square$ NTS

(check one)

Pollution Prevention Category: (check one)

Pollution Prevention Category: (check one)

Method of Characterization: (check one)

$\square$ Commercial
$\square$ Putrescrible
$\square$ Asbestos Containing Material
$\square$ Environmental management
$\square$ Clean-Up
$\square$ Sampling \& Analysis

\ Industrial

A-FFAGO-OAsilo

$\square$ FFACO-offsite

$\triangle$ Defense Projects

$\square$ Routine

$\triangle$ Process Knowledge

Radioactive waste; RCRA waste; Hazardous waste; Free liquids, PCBs above TSCA regulatory levels, and Medical wastes (needles, sharps, bloody clothing).

NTS landfills:

Additional Prohibited Waste at the Area 9 U10C Landfill:

Sewage Sludge, Animal carcasses, Wet garbage (food waste); and Friable asbestos

REQUIRED: WASTE CONTENTS ALLOWABLE WASTES

Check all allowable wastes that are contained within this load:

NOTE: Waste disposal at the Area 6 Hydrocarbon Landfill must have come into contact with petroleum hydrocarbons or coolants, such as: gasoline (no benzene, lead); jet fuel; diesel fuel; lubricants and hydraulics; kerosene; asphaltic petroleum hydrocarbon; and ethylene glycol.
Acceptable waste at any NTS landfill:
$\bigotimes$ Paper
$凶$ Soil
$\square$ Rocks / unaltered geologic materials
$\triangle$ Empty containers
$\bigotimes$ Asphalt $\bigotimes$ Metal $\bigotimes$ Wood
\ Plastic
$\bigotimes$ Wire
$\otimes$ Cable
$\bigotimes$ Cloth
$\bigotimes$ Rubber (excluding tires)
$\bigotimes$ Insulation (non-Asbestosform)
$\bigotimes$ Demolition debris

$\triangle$ Manufactured items: (swamp coolers, furniture, rugs, carpet, electronic components, PPE, etc.)
Additional waste accepted at the Area 23 Mercury Landfill:
Office Waste
Food Waste
Animal Carcasses
Asbestos
Friable
Non-Friable (contact SWO if regulated load)
Quantity:

Additional waste accepted at the Area 9 U10c Landfill:

$\square$ Non-friable asbestos

Light ballasts (contact SWO)

$\square$ Drained automobiles and military vehicles

Hydrocarbons (contact SWO) $\bigotimes$ Other Drained generators/equipment

Drained fuel filters (gas \& diesel)

Solid fractions from sand/oil/water

$\bigotimes$ Deconned Underground and Above Ground Tanks

Additional waste accepted at the Area 6 Hydrocarbon Landfill:
$\square$ Septic sludge
$\square$ Rags
$\square$ Drained fuel filters (gas \& diesel)
Crushed non-teme plated oil filters
Plants
Soil
$\square$ Sludge from sand/oil/water separators
REQUIRED: WASTE GENERATOR SIGNATURE
PCBs below 50 parts per million

Initials: (if initialed, no radiological clearance is necessary.)

The above mentioned waste was generated outside of a Controlled Waste Mar knowledge, does not contain radiological materials.

To the best of my knowledge, the waste described above contains only those site. I have verified this through the waste characterization method identified prohibited and allowable waste items. I have contacted Property Managemen 1 is approved for disposal in the landfill.

Print Name: Dan Tobiason

Signature:
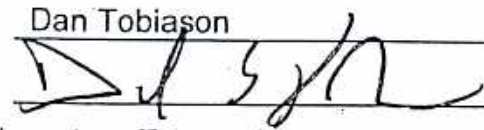

$10-1-07$ Date:

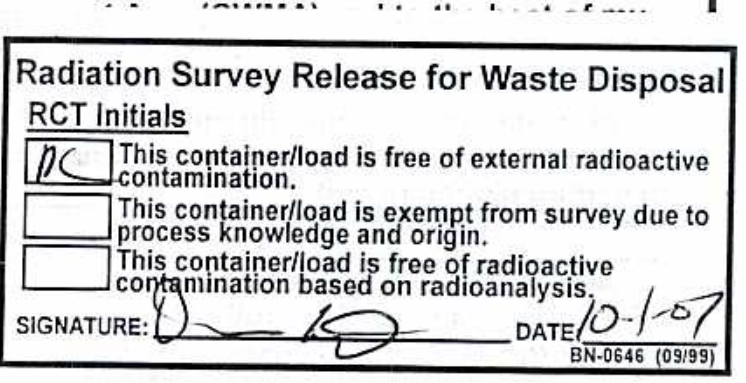

Note: "Food waste, office trash and animal carcasses do not require a radiological clearance. Freon-containing appliances must have signed removal certification statement with Load Verification." 
Form

Rev. 0

\section{$\begin{array}{llllll}\text { SWO USE (Select One) } & \text { AREA } & \square 23 & \square 6 & \square 9 & \text { L LANDFILL }\end{array}$}

For waste characterization, approval, and/or assistance, contact Solid Waste Operation (SWO) at 5-7898.

REQUIRED: WASTE GERERATOR INFORMATION

(This form is for rolloffs, dump trucks, and other onsite disposal of materials.)

Waste Generator: Dan Tobiason

Phone Number: 295-6169

Location / Origin: T-Tunnel Lower Laydown Yard

Waste Category: (check one)

Waste Type: \ NTS

(check one)

$\square$ Non-Putrescible

$\square$ Commercial

$\square$ Putrescrible

$\triangle$ Industrial cos 10/3/07

Pollution Prevention Category: (check one)

$\square$ Asbestos Containing Material

Pollution Prevention Category: (check one)

Method of Characterization: (check one)

$\square$ Environmental management

$凶$ Clean-Up

Sampling \& Analysis

¿-FFAGO-OAsite

$\square$ WAC Exception

Prohibited Waste at all three

NTS landfills:

Additional Prohibited Waste

at the Area 9 U10C Landfill:

Radioactive waste; RCRA waste; Hazardous waste; Free liquids, PCBs above TSCA regulatory levels, and Medical wastes (needles, sharps, bloody clothing).

$\square$ FFACO-offsite $\square$ Historic DOE/NV

$\triangle$ Defense Projects $\square$ YMP

$\square$ Routine

$\triangle$ Process Knowledge $\square$ Contents

Sewage Sludge, Animal carcasses, Wet garbage (food waste); and Friable asbestos

\section{REQUIRED: WASTE CONTENTS ALLOWABLE WASTES}

Check all allowable wastes that are contained within this load:

NOTE: Waste disposal at the Area 6 Hydrocarbon Landfill must have come into contact with petroleum hydrocarbons or coolants, such as: gasoline (no benzene, lead); jet fuel; diesel fuel; lubricants and hydraulics; kerosene; asphaltic petroleum riydrocarbon; and ethylene glycol.

Acceptable waste at any NTS landfill:
Asphalt
$\otimes$ Metal
$\bigotimes$ Wood
$\triangle$ Paper
$\triangle$ Soil
$\square$ Rocks / unaltered geologic materials
Q Plastic
区 Vire
区 Cable
Q Cloth
$\bigotimes$ Rubber (excluding tires)
$凶$ Insulation (non-Asbestosform)

$\bigotimes$ Empty containers

$\bigotimes$ Demolition debris

$\triangle$ Manufactured items: (swamp coolers, furniture, rugs, carpet, electronic components, PPE, etc.)
Additional waste accepted at the Area 23 Mercury Landfill:
$\square$ Office Waste
Food Waste
Animal Carcasses
$\square$ Asbestos
Friable
Non-Friable (contact SWO if regulated load)
Quantity:

Additional waste accepted at the Area 9 U10c Landfill:
$\square$ Non-friable asbestos
$\square$ Light ballasts (contact SWO)
$\square$ Drained automobiles and military vehicles
$\square$ Hydrocarbons (contact SWO
Drained fuel filters (gas \& diesel)
Other Drained generators/equipment

Solid fractions from sand/oil/water

$\otimes$ Deconned Underground and Above Ground Tanks

Additional waste accepted at the Area 6 Hydrocarbon Landfill:
$\square$ Septic sludge
$\square$ Rags
Plants
Soil

$\square$ Drained fuel filters (gas \& diesel)

$\square$ Sludge from sand/oil/water separators

REQUIRED: WASTE GENERATOR SIGNATURE

Crushed non-teme plated oil filters PCBs below 50 parts per million

Initials: (if initialed, no radiological clearance is necessary.) The above mentioned waste was generated outside of a Controlled Waste Management Area (CWMA) and to the best of my
knowledge, does not contain radiological materials.

To the best of my knowledge, the waste described above contains only the site. I have verified this through the waste characterization method identif prohibited and allowable waste items. I have contacted Property Managen is approved for disposal in the landfill.

Print Name:

Signature:

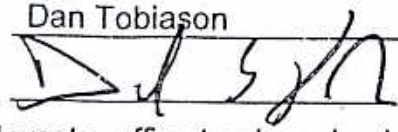

Date:

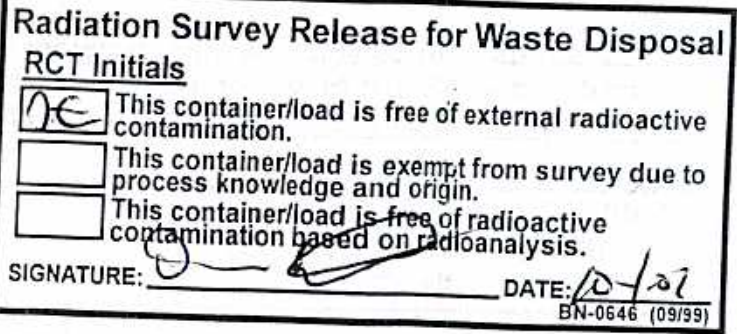

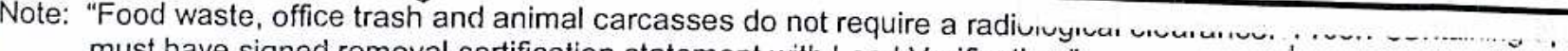
must have signed removal certification statement with Load Verification." 


\section{$\begin{array}{llllll}\text { SWO USE (Select One) } & \text { AREA } & \square 23 & \square 6 & \text { QR } & \text { Q LANDFILL }\end{array}$}

For waste characterization, approval, and/or assistance, contact Solid Waste Operation (SWO) at 5-7898.

REQUIRED: WASTE GERERATOR INFORMATION

(This form is for rolloffs, dump trucks, and other onsite disposal of materials.)

Waste Generator: Dan Tobiason

Phone Number: 295-6169

Location / Origin: T-Tunnel Lower Laydown Yard $A / Z$

Waste Category: (check one)

Waste Type: $\square$ NTS

(check one)

$\square$ Non-Putrescible

$\square$ Commercial

Pollution Prevention Category: (check one)

Pollution Prevention Category: (check one)

Method of Characterization: (check one)

$\square$ Putrescrible

$\square$ Asbestos Containing Material

$\triangle$ Industrial cos 10/3/07

$\triangle$ AFAGO-OAsite

WAC Exception

$\square$ Environmental management

FFACO-offsite

$\square$ Historic DOE/NV

Prohibited Waste at all three

NTS landfills:

Additional Prohibited Waste

at the Area 9 U10C Landfill:

Radioactive waste; RCRA waste; Hazardous waste; Free liquids, PCBs above TSCA regulatory levels, and Medical wastes (needles, sharps, bloody clothing).

Sewage Sludge, Animal carcasses, Wet garbage (food waste); and Friable asbestos

\section{REQUIRED: WASTE CONTENTS ALLOWABLE WASTES}

Check all allowable wastes that are contained within this load

NOTE: Waste disposal at the Area 6 Hydrocarbon Landfill must have come into contact with petroleum hydrocarbons or coolants, such as: gasoline (no benzene, lead); jet fuel; diesel fuel; lubricants and hydraulics; kerosene; asphaltic petroleum hydrocarbon; and ethylene glycol.

Acceptable waste at any NTS landfill:

$凶$ Asphalt

$凶$ Metal

$\triangle$ Wood

$\triangle$ Paper

$\triangle$ Soil

$\bigotimes$ Plastic

$\triangle$ Wire

$\bigotimes$ Cable

$凶$ Cloth

$\square$ Rocks / unaltered geologic materials

$\bigotimes$ Rubber (excluding tires)

$\bigotimes$ Insulation (non-Asbestosform) $\bigotimes$ Empty containers

$\bigotimes$ Demolition debris

$\bigotimes$ Cement \& concrete

$\triangle$ Manufactured items: (swamp coolers, furniture, rugs, carpet, electronic components, PPE, etc.)

Additional waste accepted at the Area 23 Mercury Landfill: $\square$ Office Waste

$\square$ Asbestos

Friable

Non-Friable (contact SWO if regulated load)

$\square$ Food Waste

Animal Carcasses

Additional waste accepted at the Area 9 U10c Landfill:

$\square$ Non-friable asbestos

Light ballasts (contact SWO)

Hydrocarbons (contact SWO) $\square$ Drained automobiles and military vehicles

Drained fuel filters (gas \& diesel)

Other Drained generators/equipment Quantity:

Additional waste accepted at the Area 6 Hydrocarbon Landfill:
$\square$ Septic sludge
$\square$ Rags
$\square$ Drained fuel filters (gas \& diesel)
Plants
$\square$ Soil
$\square$ Sludge from sand/oil/water separators REQUIRED: WASTE GENERATOR SIGNATURE
Crushed non-teme plated oil filters PCBs below 50 parts per million

Initials: (if initialed, no radiological clearance is necessary.) The above mentioned waste was generated outside of a Controlled Waste Management Area (CWMA) and to the best of my
knowledge, does not contain radiological materials.

To the best of my knowledge, the waste described above contains o site. I have verified this through the waste characterization method prohibited and allowable waste items. I have contacted Property $\mathrm{Ma}$ is approved for disposal in the landfill.

Print Name: Dan Tobiason Signature:
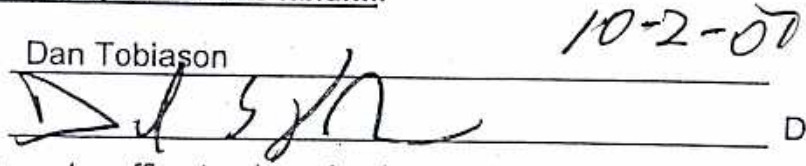

Note: "Fo

waste, office trash and animal carcasses do not require

Di

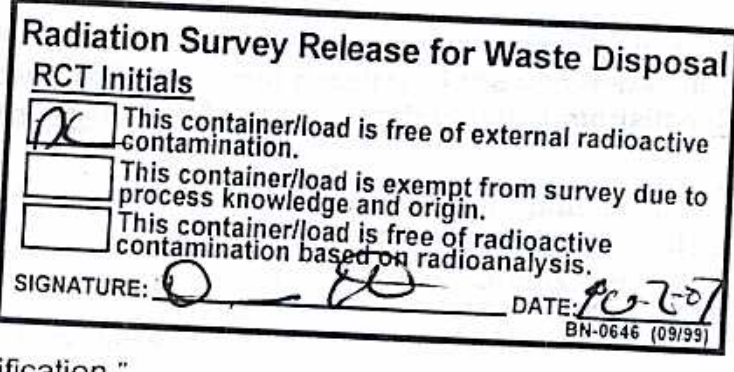




\section{$\begin{array}{llllll}\text { SWO USE (Select One) } & \text { AREA } & \square 23 & \square 6 & \square 9 & \text { Q LANDFILL }\end{array}$}

For waste characterization, approval, and/or assistance, contact Solid Waste Operation (SWO) at 5-7898.

REQUIRED: WASTE GERERATOR INFORMATION

(This form is for rolloffs, dump trucks, and other onsite disposal of materials.)

Waste Generator: Dan Tobiason Phone Number: 295-6169

Location / Origin: T-Tunnel Lower Laydown Yard A/Z

Waste Category: (check one) $\square$ Commercial

Waste Type: $\triangle$ NTS

(check one) $\quad \square$ Non-Putrescible

$\square$ Putrescrible

$\square$ Asbestos Containing Materia

Pollution Prevention Category: (check one)

Pollution Prevention Category: (check one)

Method of Characterization: (check one)

$凶$ Clean-Up

$\triangle$ Industrial egs $10 / 3 / 07$

Prohibited Waste at all three

NTS landfills:

Additional Prohibited Waste

at the Area 9 U10C Landfill:

Radioactive waste; RCRA waste; Hazardóus waste; Free liquids, PCBs above TSCA regulatory levels, and Medical wastes (needles, sharps, bloody clothing).

Sewage Sludge, Animal carcasses, Wet garbage (food waste); and Friable asbestos

\section{REQUIRED: WASTE CONTENTS ALLOWABLE WASTES}

Check all allowable wastes that are contained within this load:

NOTE: Waste disposal at the Area 6 Hydrocarbon Landfill must have come into contact with petroleum hydrocarbons or coolants, such as: gasoline (no benzene, lead); jet fuel; diesel fuel; lubricants and hydraulics; kerosene; asphaltic petroleum hydrocarbon; and ethylene glycol.

Acceptable waste at any NTS landfill: $\triangle$ Paper

$\bigotimes$ Asphalt $\bigotimes$ Metal . $\bigotimes$ Wood

$\triangle$ Soil

$\square$ Rocks / unaltered geologic materials

Q Plastic

$\triangle$ Wire

$\triangle$ Cable

Cloth

$\triangle$ Rubber (excluding tires)

$\triangle$ Insulation (non-Asbestosform)

$\triangle$ Empty containers

$\triangle$ Demolition debris

$\triangle$ Manufactured items: (swamp coolers, furniture, rugs, carpet, electronic components, PPE, etc.)
Additional waste accepted at the Area 23 Mercury Landfill:
$\square$ Asbestos
Friable
Non-Friable (contact SWO if regulated load)
Food Waste
Animal Carcasses

Additional waste accepted at the Area 9 U10c Landfill:
Non-friable asbestos
Light ballasts (contact SWO)
Drained automobiles and military vehicles
Solid fractions from sand/oil/water
Hydrocarbons (contact SWO)
Drained fuel filters (gas \& diesel)
$\triangle$ Deconned Underground and Above Ground Tanks

\section{Additional waste accepted at the Area 6 Hydrocarbon Landfill:}
Septic sludge
$\square$ Rags
$\square$ Drained fuel filters (gas \& diesel)
Crushed non-teme plated oil filters
Plants
Soil
$\square$ Sludge from sand/oil/water separators
REQUIRED: WASTE GENERATOR SIGNATURE
PCBs below 50 parts per million

Initials: (if initialed, no radiological clearance is necessary.)

The above mentioned waste was generated outside of a Controlled Waste Management Area (CWMA) and to the best of my
knowledge, does not contain radiological materials.

To the best of my knowledge, the waste described above contains on site. I have verified this through the waste characterization method ic prohibited and allowable waste items. I have contacted Property Man is approved for disposal in the landfill.

Print Name:

Signature:
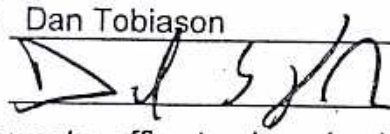

$10-2.07$

Note: "Food waste, office trash and animal carcasses do not require a must have signed removal certification statement with Load Verification." 


\begin{tabular}{llllll}
\hline SWO USE (Select One) & AREA & $\square 23$ & $\square 6$ & QR & Q LANDFILL
\end{tabular}

For waste characterization, approval, and/or assistance, contact Solid Waste Operation (SWO) at 5-1898.

REQUIRED: WASTE GERERATOR INFORMATION

(This form is for rolloffs, dump trucks, and other onsite disposal of materials.)

Waste Generator: Dan Tobiason

Phone Number: 295-61 (j9

Location / Origin: T-Tunnel Lower Laydown Yard A/乙

Waste Category: (check one)

Waste Type: $\triangle$ NTS

(check one)

$\square$ Non-Putrescible

$\square$ Commercial
$\square$ Putrescrible

$\Delta$ Industrial ogs $10 / 5 / 07$

Pollution Prevention Cate

(check one)

$\square$ Asbestos Containing Material

A-FFAGO-OAsite

[1 WAC Exception

Pollution Prevention Category: (check one)

Environmental management

$\square$ FFACO-offsite

$\square$ Historic DOE/NV

Method of Characterization: (check one)

$凶$ Clean-Up

Prohibited Waste at all three

NTS landfills:

$\square$ Sampling \& Analysis $\quad \triangle$ Process Knowledge
Radioactive waste; RCRA waste; Hazardous waste; Free liquids, PCBs a

$\triangle$ Defense Projects

YMP

$\square$ Routine

Contents

Additional Prohibited Waste at the Area 9 U10C Landfill: levels, and Medical wastes (needles, sharps, bloody clothing).

Sewage Sludge, Animal carcasses, Wet garbage (food waste); and Friable asbestos

REQUIRED: WASTE CONTENTS ALLOWABLE WASTES

Check all allowable wastes that are contained within this load:

NOTE: Waste disposal at the Area 6 Hydrocarbon Landfill must have come into contact with petroleum hydrocarbons or coolants, such as: gasoline (no benzene, lead); jet fuel; diesel fuel; lubricants and hydraulics; kerosene; asphaltic petroleum hydrocarbon; and ethylene glycol.

Acceptable waste at any NTS landfill:

$\bigotimes$ Asphalt $\square$ Metal $\bigotimes$ Wood

$\triangle$ Plastic $\quad$ Wire $\quad \square$ Cable

$\triangle$ Paper

$\triangle$ Soil

Cloth

$\square$ Rocks / unaltered geologic materials

$\bigotimes$ Rubber (excluding tires)

\Insulation (non-Asbestosform)

$\bigotimes$ Empty containers

$\triangle$ Demolition debris

$\bigotimes$ Cement \& concrete

$\triangle$ Manufactured items: (swamp coolers, furniture, rugs, carpet, electronic components, PPE, etc.)

Additional waste accepted at the Area 23 Mercury Landfill: $\square$ Office Waste Asbestos

Friable

$\square$ Non-Friable (contact SWO if regulated load)

Food Waste

Animal Carcasses

Additional waste accepted at the Area 9 U10c Landfill:

$\square$ Non-friable asbestos

Light ballasts (contact SWO)

Hydrocarbons (contact SWO) $\square$ Drained automobiles and military vehicles

$\square$ Drained fuel filters (gas \& diesel)

$\triangle$ Other Drained generators/equipment Quantity:

Additional waste accepted at the Area 6 Hydrocarbon Landfill:
$\square$ Septic sludge
$\square$ Rags
$\square$ Drained fuel filters (gas \& diesel)
Plants
Soil
$\square$ Sludge from sand/oil/water separators
REQUIRED: WASTE GENERATOR SIGNATURE
Crushed non-teme plated oil filters PCBs below 50 parts per million

Initials: (if initialed, no radiological clearance is necessary.)

The above mentioned waste was generated outside of a Controlled Waste Management Area (CWMA) and to the best of my knowledge, does not contain radiological materials.

To the best of my knowledge, the waste described above contains only those site. I have verified this through the waste characterization method identified prohibited and allowable waste items. I have contacted Property Managemen is approved for disposal in the landfill.

Print Name:

Signature:
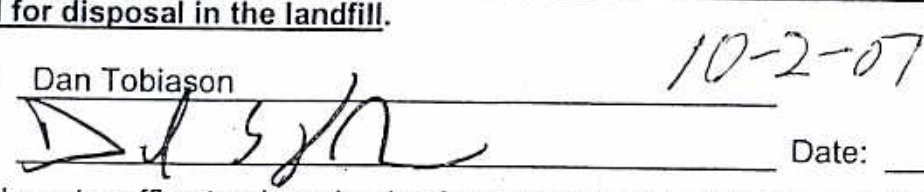

Note: "Food waste, office trash and animal carcasses do not require a radiolos must have signed removal certification statement with Load Verification."
Radiological Survey Release for Waste Disposal RCT Initials

- This container/load méets the criteria for no

C added man-made radioactive material fthrs container/load meets the criteria for Radcon Manuar Table 4.2 release limits. This containerlload is exempt from surve 2 ? due to prgass knowlegge and origin. 107 .

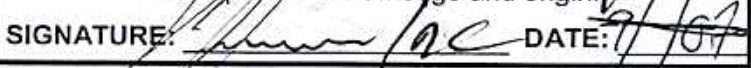

FRM-0646 (08/06)
SWO USE ONLY

Load Weight (net from scale or estimate):
$10-2-87$

Signature of Certifier:
, 


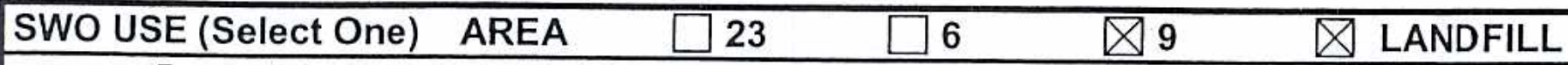

For waste characterization, approval, and/or assistance, contact Solid Waste Operation (SWO) at 5-7898.

REQUIRED: WASTE GERERATOR INFORMATION

(This form is for rolloffs, dump trucks, and other onsite disposal of materials.)

Waste Generator: Dan Tobiason

Phone Number: 295-6169

Location/Origin: T-Tunnel Lower Laydown Yard $\quad A / Z$

Waste Category: (check one)

Waste Type:

(check one)

冈 NTS

Non-Putrescible

Pollution Prevention Category: (check one)

Pollution Prevention Category: (check one)

Method of Characterization: (check one)

Prohibited Waste at all three

NTS landfills:

Additional Prohibited Waste

at the Area 9 U10C Landfill: Radioactive waste; RCRA waste; Hazardous waste; Free liquids, PCBs above TSCA regulatory
levels, and Medical wastes (needles, sharps, bloody clothing).

Sewage Sludge, Animal carcasses, Wet garbage (food waste); and Friable asbestos

REQUIRED: WASTE CONTENTS ALLOWABLE WASTES

Check all allowable wastes that are contained within this load:

NOTE: Waste disposal at the Area 6 Hydrocarbon Landfill must have come into contact with petroleum hydrocarbons or coolants, such as: gasoline (no benzene, lead); jet fuel; diesel fuel; lubricants and hydraulics; kerosene; asphaltic petroleum hydrocarbon; and ethylene glycol.
Acceptable waste at any NTS landfill:
$\triangle$ Paper
$\begin{array}{llll}\square \text { Asphalt } & \square \text { Metal } & \square \text { Wood } & \square \text { Soil } \\ \square \text { Plastic } & \square \text { Wire } & \square \text { Cable } & \square \text { Cloth }\end{array}$
Rocks / unaltered geologic materials
$\bigotimes$ Rubber (excluding tires)
$\bigotimes$ Insulation (non-Asbestosform)

$\bigotimes$ Empty containers

$\bigotimes$ Demolition debris

$\bigotimes$ Cement \& concrete

$\bigotimes$ Manufactured items: (swamp coolers, furniture, rugs, carpet, electronic components, PPE, etc.)

Additional waste accepted at the Area 23 Mercury Landfill: $\quad \square$ Office Waste $\square$ Food Waste

Animal Carcasses

$\square$ Asbestos

Friable

Non-Friable (contact SWO if regulated load)

Quantity:

Additional waste accepted at the Area 9 U10c Landfill:
$\square$ Non-friable asbestos
Drained automobiles and military vehicles
$\square$ Light ballasts (contact SWO)
$\square$ Drained fuel filters (gas \& diesel)
Hydrocarbons (contact SWO)
$\triangle$ Other
Drained generators/equipment

Solid fractions from sand/oil/water

$凶$ Deconned Underground and Above Ground Tanks

Additional waste accepted at the Area 6 Hydrocarbon Landfill:

$\begin{array}{lll}\square \text { Septic sludge } & \square \text { Rags } & \square \text { Drained fuel filters (gas \& diesel) } \\ \square \text { Plants } & \square \text { Soil } & \square \text { Sludge from sand/oil/water separators }\end{array}$ REQUIRED: WASTE GENERATOR SIGNATURE

Crushed non-teme plated oil filters PCBs below 50 parts per million

Initials: (if initialed, no radiological clearance is necessary.)

The above mentioned waste was generated outside of a Controlled Waste Management Area (CWMA) and to the best of my knowledge, does not contain radiological materials.

To the best of my knowledge, the waste described above contains only those $n$ site. I have verified this through the waste characterization method identified a prohibited and allowable waste items. I have contacted Property Management is approved for disposal in the landfill.

Print Name:

Signature:
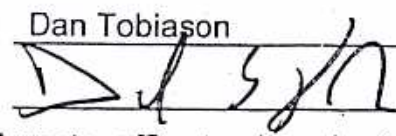

$12-07$

Date:

Note: "Food waste, office trash and animal carcasses do not require a radiologic must have signed removal certification statement with Load Verification."
Radiological Survey Release for Waste Disposal RCT Initials

This container/load meets the criteria for no

To added man-made radioactive material

If This container/log meets the criteria for Radcon Manuar Table 4.2 release limits. This contain tflload is exempt from suryey? due to process knowledge and origin/0-2 2

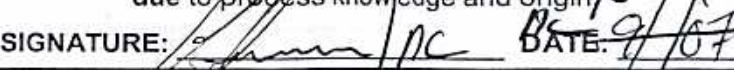

FRM-0646 (08/06)

\section{SWO USE ONLY}

Load Weight (net iroph scale or estimate): 5,000
$10-2-67$

Signature of Certifier: 


\begin{tabular}{|llllll}
\hline SWO USE (Select One) & AREA & $\square 23$ & $\square 6$ & $\square 9$ & $\square$ LANDFILL
\end{tabular}

For waste characterization, approval, and/or assistance, contact Solid Waste Operation (SWO) at 5-7898.

\section{REQUIRED: WASTE GERERATOR INFORMATION}

(This form is for rolloffs, dump trucks, and other onsite disposal of materials.)

Waste Generator: Dan Tobiason Phone Number: 295-6169

Location / Origin: T-Tunnel Lower Laydown Yard $A / Z$

Waste Category: (check one)

Waste Type:

(check one)

Pollution Prevention Category: (check one)

Pollution Prevention Category: (check one) Method of Characterization: (check one)

Prohibited Waste at all three NTS landfills:

Additional Prohlbited Waste at the Area 9 U10C Landfill:

\section{Radioactive waste; RCRA waste; Hazardous waste; Free liquids, PCBs above TSCA regulatory} levels, and Medical wastes (needles, sharps, bloody clothing).

Sewage Sludge, Animal carcasses, Wet garbage (food waste); and Friable asbestos

\section{REQUIRED: WASTE CONTENTS ALLOWABLE WASTES}

Check all allowable wastes that are contained within this load:

NOTE: Waste disposal at the Area 6 Hydrocarbon Landfill must have come into contact with petroleurn hydrocarbons or coolants, such as: gasoline (no benzene, lead); jet fuel; diesel fuel; lubricants and hydraulics; kerosene; asphaltic petroleum hydrocarbon; and ethylene glycol.

Acceptable waste at any NTS landfill: $\triangle$ Paper

$\otimes$ Asphalt $\quad$ Metal $\quad$ Wood $\quad$ Soil

$凶$ Cloth

$\square$ Rocks / unaltered geologic materials

$\triangle$ Rubber (excluding tires)

冈 Insulation (non-Asbestosform)

Empty containers

$\triangle$ Demolition debris

Plastic

$\bigotimes$ Cable

Carpet, electronic components, PPE, etc.)

Additional waste accepted at the Area 23 Mercury Landfill: $\square$ Office Waste

$\square$ Asbestos

$\square$ Friable

$\square$ Non-Friable (contact SWO if regulated load)

$\square$ Food Waste

Animal Carcasses

Additional waste accepted at the Area 9 U10c Landfill:

$\square$ Non-friable asbestos

$\square$ Drained automobiles and military vehicles

$\square$ Light ballasts (contact SWO)

$\square$ Drained fuel filters (gas \& diesel)

Hydrocarbons (contact SWO)

Other

Drained generators/equipment

Quantity:

\section{Additional waste accepted at the Area 6 Hydrocarbon Landfill:}
$\square$ Septic sludge
$\square$ Rags
$\square$ Drained fuel filters (gas \& diesel)
Plants
Soil
$\square$ Sludge from sand/oil/water separators
Crushed non-teme plated oil filters PCBs below 50 parts per million

Solid fractions from sand/oil/water

$\otimes$ Deconned Underground and Above Ground Tanks

Initials: (if initialed, no radiological clearance is necessary.)

The above mentioned waste was generated outside of a Controlled Waste Ma knowledge, does not contain radiological materials.

To the best of my knowledge, the waste described above contains only thosi site. I have verified this through the waste characterization method identifie prohibited and allowable waste items. I have contacted Property Manageme: is approved for disposal in the landfill.

Print Name: Dan Tobiason

Signature:

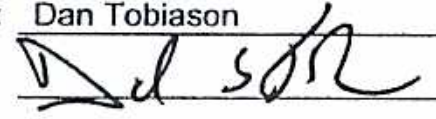

$$
10-2-07
$$<smiles>[R9]C(=O)C(=O)O</smiles>

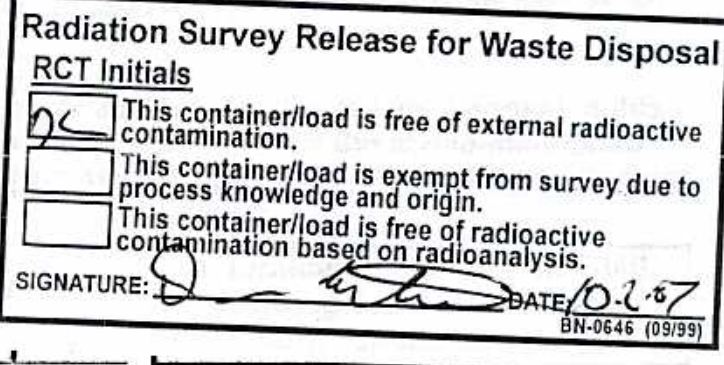

Note: "Food waste, office trash and animal carcasses do not require a radiological clearance. Freon-containing appliances must have signed removal certification statement with Load Verification."

Load Weight (net frorn scale of estimate): 12740
$10-2-07$

Signature of Certifier: Dor 


\begin{tabular}{|llllll}
\hline SWO USE (Select One) & AREA & $\square 23$ & $\square 6$ & 239 & Q LANDFILL
\end{tabular}

For waste characterization, approval, and/or assistance, contact Solid Waste Operation (SWO) at 5-7898.

REQUIRED: WASTE GERERATOR INFORMATION

(This form is for rolloffs, dump trucks, and other onsite disposal of materials.)

Waste Generator: Dan Tobiason

Phone Number: 295-6169

Location / Origin: T-Tunnel Lower Laydown Yard $\dot{A} / 2$

Waste Category: (check one)

$\square$ Commercial

Waste Type: $\square$ NTS

$\square$ Putrescrible

$\triangle$ Industrial CQS $10 / 3 / 07$

(check one)

$\square$ Non-Putrescible

$\square$ Asbestos Containing Material

QTFACO-onsite-

$\square$ WAC Exception

Pollution Prevention Category: (check one) $\square$ Environmental management

Pollution Prevention Category: (check one) $\triangle$ Clean-Up

Method of Characterization: (check one) $\square$ Sampling \& Analysis

$\square$ FFACO-offsite

$\square$ Historic DOE/NV

$\triangle$ Defense Projects

YMP

Prohibited Waste at all three

NTS landfills:

Additional Prohibited Waste

at the Area 9 U10C Landfill:

Radioactive waste; RCRA waste; Hazardous waste; Free liquids,
levels, and Medical wastes (needles, sharps, bloody clothing).

Sewage Sludge, Animal carcasses, Wet garbage (food waste); and Friable asbestos

\section{REQUIRED: WASTE CONTENTS ALLOWABLE WASTES}

Check all allowable wastes that are contained within this load:

NOTE: Waste disposal at the Area 6 Hydrocarbon Landfill must have come into contact with petroleum hydrocarbons or coolants, such as: gasoline (no benzene, lead); jet fuel; diesel fuel; lubricants and hydraulics; kerosene; asphaltic petroleum hydrocarbon; and ethylene glycol.

Acceptable waste at any NTS landfill: $\square$ Paper

$\triangle$ Asphalt $\otimes$ Metal $\quad$ Wood $\otimes$ Soil

$\square$ Rocks / unaltered geologic materials

$\triangle$ Empty containers

冈 Plastic

Wire

$\otimes$ Cable

$\triangle$ Cloth

$\triangle$ Rubber (excluding tires)

$\triangle$ Insulation (non-Asbestosform)

$\triangle$ Demolition debris

$\triangle$ Manufactured items: (swamp coolers, fumiture, rugs, carpet, electronic components, PPE, etc.)

Additional waste accepted at the Area 23 Mercury Landfill: $\square$ Office Waste $\square$ Food Waste $\square$ Animal Carcasses

$\square$ Asbestos

$\square$ Friable

Non-Friable (contact SWO if regulated load)

Quantity:

Additional waste accepted at the Area 9 U10c Landfill:

$\square$ Non-friable asbestos

$\square$ Light ballasts (contact SWO)

Hydrocarbons (contact SWO)

$\square$ Drained automobiles

Drained fuel filters (gas \& diesel)

Other Drained generators/equipment $\square$ Solid fractions from sand/oil/water

$\bigotimes$ Deconned Underground and Above Ground Tanks

\section{Additional waste accepted at the Area 6 Hydrocarbon Landfill:}
$\square$ Septic sludge
$\square$ Rags
$\square$ Drained fuel filters (gas \& diesel)
Crushed non-teme plated oil filters
Plants
$\square$ Soil
$\square$ Sludge from sand/oil/water separators
$\square$ PCBs below 50 parts per million
REQUIRED: WASTE GENERATOR SIGNATURE

Initials: (if initialed, no radiological clearance is necessary.)

The above mentioned waste was generated outside of a Controlled Waste Management Area (CWMA) and to the best of my knowledge, does not contain radiological materials.

To the best of my knowledge, the waste described above contains only those materials that are allowed for disposal at this site. I have verified this through the waste characterization method identified above and a review of the above-mentioned prohibited and allowable waste items. I have contacted Property Management and have verified that thic mmen-1 1 ..-......is approved for disposal in the landfill.

Print Name: Dan Tobiason

Note: "Food waste, office trash and animal carcasses do not require a radiolog must have signed removal certification statement with Load Verification.'

LWo USE ONLY Weight (net from scale, or estimate): 3,600 Signature of Certif

Radiation Survey Release for Waste Disposal RCT Initials

This container/load is free of external radioactive contamination.

This container/load is exempt from survey due to process knowledge and origin.

This container/load is free of radioactive SIGNATURE: 


\section{$\begin{array}{llllll}\text { SWO USE (Select One) } & \text { AREA } & \square 23 & \square 6 & \text { (23 } & \text { Q LANDFILL }\end{array}$}

For waste characterization, approval, and/or assistance, contact Solid Waste Operation (SWO) at 5-7898.

\section{REQUIRED: WASTE GERERATOR INFORMATION}

(This form is for rolloffs, dump trucks, and other onsite disposal of materials.)

Waste Generator: Dan Tobiason

Phone Number: 295-6169

Location / Origin: T-Tunnel Lower Laydown Yard A/2

Waste Category: (check one)

Waste Type:

$\triangle$ NTS $\square$ Putrescrible

(check one) $\quad \square$ Non-Putrescible $\quad \square$ Asbestos Containing Materia

Pollution Prevention Category: (check one)

Pollution Prevention Category: (check one)

Method of Characterization: (check one)

$\square$ Environmental management

$\triangle$ Clean-Up

Radioactive waste; RCRA waste; Hazardous waste; Free liquids, PCBs above TSCA regulatory levels, and Medical wastes (needles, sharps, bloody clothing).

NTS landfills:

Additional Prohibited Waste

at the Area 9 U10C Landfill:

Sewage Sludge, Animal carcasses, Wet garbage (food waste); and Friable asbestos

\section{REQUIRED: WASTE CONTENTS ALLOWABLE WASTES}

Check all allowable wastes that are contained within this load:

NOTE: Waste disposal at the Area 6 Hydrocarbon Landfill must have come into contact with petroleum hydrocarbons or coolants, such as: gasoline (no benzene, lead); jet fuel; diesel fuel; lubricants and hydraulics; kerosene; asphaltic petroleum hydrocarbon; and ethylene glycol.

Acceptable waste at any NTS landfill: $\triangle$ Pape

$\bigotimes$ Asphalt

$\otimes$ Metal

$\bigotimes$ Wood

$\bigotimes$ Soil

Plastic

$\triangle$ Wire

$\triangle$ Cable

Cloth

$\square$ Rocks / unaltered geologic materials

$\otimes$ Rubber (excluding tires)

$\bigotimes$ Insulation (non-Asbestosform)

$\triangle$ Empty containers

$\triangle$ Demolition debris

$\triangle$ Manufactured items: (swamp coolers, furniture, rugs, carpet, electronic components, PPE, etc.)

Additional waste accepted at the Area 23 Mercury Landfill: $\square$ Office Waste

$\square$ Asbestos

Friable

Non-Friable (contact SWO if regulated load)

$\square$ Food Waste

$\bigotimes$ Cement \& concrete

\section{Additional waste accepted at the Area 9 U10c Landfill:}

$\square$ Non-friable asbestos

$\square$ Light ballasts (contact SWO)

$\square$ Drained automobiles and military vehicles

Hydrocarbons (contact SWO)

Drained fuel filters (gas \& diesel)

Other Drained generators/equipment Quantity:

Animal Carcasses

Additional waste accepted at the Area 6 Hydrocarbon Landfill:
$\square$ Septic sludge
$\square$ Rags
$\square$ Drained fuel filters (gas \& diesel)
Plants
$\square$ Soil
$\square$ Sludge from sand/oil/water separators

REQUIRED: WASTE GENERATOR SIGNATURE

Solid fractions from sand/oil/water

$\otimes$ Deconned Underground and Above Ground Tanks

Initials: (if initialed, no radiological clearance is necessary.) The above mentioned waste was generated outside of a Controlled Waste Management Area (CWMA) and to the best of my
knowledge, does not contain radiological materials.

To the best of my knowledge, the waste described above contains only thos site. I have verified this through the waste characterization method identifie prohibited and allowable waste items. I have contacted Property Manageme! is approved for disposal in the landfill.

Print Name: Dan Tobiason

Signature:

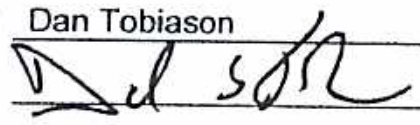

Date: 912

Note: "Food waste, office trash and animal carcasses do not require a radiolo Radiation Survey Release for Waste Disposal RCT Initials

This containeriload is free of external radioactive T) This container/

This container/load is exempt from survey due to process knowledge and origin.

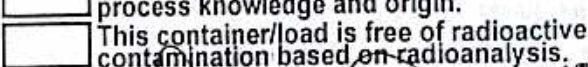

SIGNATURE: contemination based on radio DATE: must have signed removal certification statement with Load Verification. Load Weight (net from scale or estimate) : $20,0 \Omega 0 \begin{gathered}10-3-07 \\ \text { Signature of Certifier: }\end{gathered}$ 


\section{$\begin{array}{llllll}\text { SWO USE (Select One) } & \text { AREA } & \square 23 & \square 6 & \text { 23 } & \text { LANDFILL }\end{array}$}

For waste characterization, approval, and/or assistance, contact Solid Waste Operation (SWO) at 5-7898.

REQUIRED: WASTE GERERATOR INFORMATION

(This form is for rolloffs, dump trucks, and other onsite disposal of materials.)

Waste Generator: Dan Tobiason

Phone Number: 295-6169

Location / Origin: T-Tunnel Lower Laydown Yard $A / Z$

Waste Category: (check one) $\square$ Commercial

Waste Type: $₫$ NTS $\square$ Putrescrible

(check one) $\square$ Non-Putrescible $\square$ Asbestos Containing Material

Pollution Prevention Category: (check one)

Pollution Prevention Category: (check one)

Method of Characterization: (check one)

$\square$ Environmental management

$\triangle$ Clean-Up

Radioactive waste; RCRA waste; Hazardous waste; Free liquids, PCBs above TSCA regulatory NTS landfills:

Additional Prohibited Waste

at the Area 9 U10C Landfill:

levels, and Medical wastes (needles, sharps, bloody clothing).

$\triangle$ Industrial cos $10 / 4 / 07$

QFFACO-Onsite

$\square$ WAC Exception

$\square$ FFACO-offsite $\square$ Historic DOE/NV

$\triangle$ Defense Projects

$\square$ Routine

$\triangle$ Process Knowledge $\square$ Contents

\section{REQUIRED: WASTE CONTENTS ALLOWABLE WASTES}

Check all allowable wastes that are contained within this load:

NOTE: Waste disposal at the Area 6 Hydrocarbon Landfill must have come into contact with petroleum hydrocarbons or coolants, such as: gasoline (no benzene, lead); jet fuel; diesel fuel; lubricants and hydraulics; kerosene; asphaltic petroleum hydrocarbon; and ethylene glycol.

Acceptable waste at any NTS landfill:

$\bigotimes$ Asphalt $\quad$ Metal $\quad$ Wood $\quad$ Soil

$\triangle$ Plastic $\quad$ Wire $\quad$ Cable $\quad$ Cloth

$\square$ Rocks / unaltered geologic materials

$\bigotimes$ Rubber (excluding tires)

$\bigotimes$ Insulation (non-Asbestosform)

$\bigotimes$ Empty containers

Demolition debris

$\triangle$ Manufactured items: (swamp coolers, furniture, rugs, carpet, electronic components, PPE, etc.)
Additional waste accepted at the Area 23 Mercury Landfill: $\square$ Office Waste
Asbestos
Friable
Non-Friable (contact SWO if regulated load)
$\square$ Food Waste
Animal Carcasses
Quantity:

\section{Additional waste accepted at the Area 9 U10c Landfill:}

$\square$ Non-friable asbestos

$\square$ Light ballasts (contact SWO)

$\square$ Drained automobiles and military vehicles

$\square$ Drained fuel filters (gas \& diesel)

Hydrocarbons (contact SWO)

Other

Drained generators/equipment

\section{Additional waste accepted at the Area 6 Hydrocarbon Landfill:}
$\square$ Septic sludge
$\square$ Rags
$\square$ Drained fuel filters (gas \& diesel)
Plants
$\square$ Soil
$\square$ Sludge from sand/oil/water separators
REQUIRED: WASTE GENERATOR SIGNATURE

Solid fractions from sand/oil/water

Initials:

(if initialed, no radiological clearance is necessary.)

The above mentioned waste was generated outside of a Controlled Waste Management Area (CWMA) and to the best of my knowledge, does not contain radiological materials.

To the best of my knowledge, the waste described above contains only $f^{*}$ site. I have verified this through the waste characterization method iden prohibited and allowable waste items. I have contacted Property Manag! is approved for disposal in the landfill.

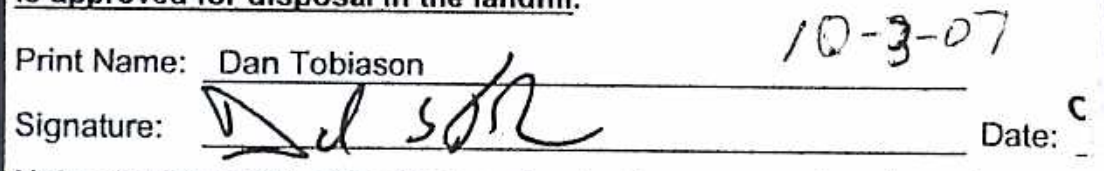

Note: "Food waste, office trash and animal carcasses do not require a rad must have signed removal certification statement with Load Verifica

\section{SWO USE ONLY}

Load Weight (net from scale or estimate):
10-3-07

Signature of Certifier:
Radiation Survey Release for Waste Disposal RCT Initials

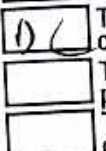

contamination.

is exempt from survey due to process knowledge and origin.

This container/load is free of radioactive ontamination based on radioanalysis.

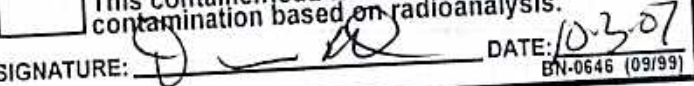




\begin{tabular}{llllll}
\hline SWO USE (Select One) & AREA & $\square 23$ & $\square 6$ & 23 & LANDFILL
\end{tabular}

For waste characterization, approval, and/or assistance, contact Solid Waste Operation (SWO) at 5-7898.

$$
\text { REQUIRED: WASTE GERERATOR INFORMATION }
$$

(This form is for rolloffs, dump trucks, and other onsite disposal of materials.)

Waste Generator: Dan Tobiason

Phone Number: 295-6169

Location / Origin: T-Tunnel Lower Laydown Yard A/Z

Waste Category: (check one)

Waste Type: $\square$ NTS

(check one)

$\square$ Non-Putrescible

Pollution Prevention Category: (check one)

Pollution Prevention Category: (check one)

Method of Characterization: (check one)

$\square$ Commercial

$\square$ Putrescrible

$\square$ Asbestos Containing Material

Industrial cas $10 / 4 / 07$

$\triangle F F A C O=0 n s i t e$

$\square$ WAC Exception

$\square$ Environmental management

$\triangle$ Clean-Up

Prohibited Waste at all three

NTS landfills:

Additional Prohibited Waste at the Area 9 U10C Landfill: $\square$ FFACO-offsite

$\square$ Historic DOE/NV

$\triangle$ Defense Projects

$\square$ Routine

$\triangle$ Process Knowledge $\square$ Contents levels, and Medical wastes (needles, sharps, bloody clothing).

Sewage Sludge, Animal carcasses, Wet garbage (food waste); and Friable asbestos

\section{REQUIRED: WASTE CONTENTS ALLOWABLE WASTES}

Check all allowable wastes that are contained within this load:

NOTE: Waste disposal at the Area 6 Hydrocarbon Landfill must have come into contact with petroleum hydrocarbons or coolants, such as: gasoline (no benzene, lead); jet fuel; diesel fuel; lubricants and hydraulics; kerosene; asphaltic petroleum hydrocarbon; and ethylene glycol.
Acceptable waste at any NTS landfill:
$\triangle$ Paper
$\square$ Rocks / unaltered geologic materials
$\triangle$ Empty containers
$\bigotimes$ Asphalt $\otimes$ Metal $\otimes$ Wood
Q Soil
$\bigotimes$ Rubber (excluding tires)
Plastic $\otimes$ Wire
$\triangle$ Cable
$\otimes$ Cloth
$\bigotimes$ Insulation (non-Asbestosform)
Q Demolition debris
$\bigotimes$ Cement \& concrete
$\triangle$ Manufactured items: (swamp coolers, furniture, rugs, carpet, electronic components, PPE, etc.)
Additional waste accepted at the Area 23 Mercury Landfill: $\square$ Office Waste
$\square$ Food Waste
Animal Carcasses

$\square$ Asbestos

Friable

$\square$ Non-Friable (contact SWO if regulated load)

Additional waste accepted at the Area 9 U10c Landfill:
$\square$ Non-friable asbestos
$\square$ Drained automobiles and military vehicles
$\square$ Light ballasts (contact SWO)
$\square$ Drained fuel filters (gas \& diesel)

$\square$ Hydrocarbons (contact SWO

$\triangle$ Other Drained generators/equipment

Quantity:

\section{Additional waste accepted at the Area 6 Hydrocarbon Landfill:}
$\square$ Septic sludge
$\square$ Rags
$\square$ Drained fuel filters (gas \& diesel)
Plants
$\square$ Soil
$\square$ Sludge from sand/oil/water separators
REQUIRED: WASTE GENERATOR SIGNATURE
Crushed non-teme plated oil filters PCBs below 50 parts per million

Solid fractions from sand/oil/water

$\otimes$ Deconned Underground and Above Ground Tanks

Initials: (if initialed, no radiological clearance is necessary.)

The above mentioned waste was generated outside of a Controlled Waste Management Area (CWMA) and to the best of my knowledge, does not contain radiological materials.

To the best of my knowledge, the waste described above contains only thos! site. I have verified this through the waste characterization method identifie prohibited and allowable waste items. I have contacted Property Manageme is approved for disposal in the landfill.

$$
\text { (C) }-3-07
$$

Print Name: Dan Tobiason

Signature:

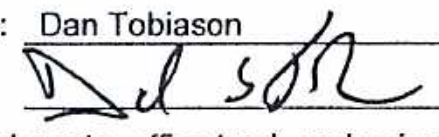

Date: $91 / 2$

Note: "Food waste, office trash and animal carcasses do not require a radiolc must have signed removal certification statement with Load Verification."

\begin{tabular}{l} 
Radiation Survey Release for Waste Disposal \\
RCT Initials \\
$D C \quad \begin{array}{l}\text { This container/load is free of external radioactive } \\
\text { contamination. }\end{array}$ \\
\hline $\begin{array}{l}\text { This container/load is exempt from survey due to } \\
\text { process knowledge and origin. }\end{array}$ \\
This container/load is free of radioactive \\
contamination based on radioanalysis. $20-307$
\end{tabular}

\section{SWO USE ONLY}

Load Weight (net from scale) or estimate):
$10-3-07$

Signature of Certifier: 
For waste characterization, approval, and/or assistance, contact Solid Waste Operation (SWO) at 5-7898.

\section{REQUIRED: WASTE GERERATOR INFORMATION}

(This form is for rolloffs, dump trucks, and other onsite disposal of materials.)

Waste Generator: Dan Tobiason

Phone Number: 295-6169

Location / Origin: T-Tunnel Lower Laydown Yard $A / 2$

Waste Category: (check one)

Waste Type: $\square$ NTS

(check one)

$\square$ Non-Putrescible

$\square$ Commercial

$\square$ Putrescrible

$\triangle$ Industrial

$\square$ Asbestos Containing Material

\FFAGO-ensite

$\operatorname{lgs} 10 / \mathrm{k} / 07$

Pollution Prevention Category: (check one)

Pollution Prevention Category: (check one)

Method of Characterization: (check one)

$\square$ Environmental management

$\otimes$ Clean-Up

$\square$ Sampling \& Analysis

$\square$ FFACO-offsite

$\square$ WAC Exception

$\triangle$ Defense Projects

$\square$ Historic DOE/NV

Prohibited Waste at all three

NTS landfills:

Additional Prohibited Waste

at the Area 9 U10C Landfill:

Radioactive waste; RCRA waste; Hazardous waste; Free liquids, PCBs above TSCA regulatory levels, and Medical wastes (needles, sharps, bloody clothing).

Sewage Sludge, Animal carcasses, Wet garbage (food waste); and Friable asbestos

\section{REQUIRED: WASTE CONTENTS ALLOWABLE WASTES}

Check all allowable wastes that are contained within this load:

NOTE: Waste disposal at the Area 6 Hydrocarbon Landfill must have come into contact with petroleum hydrocarbons or coolants, such as: gasoline (no benzene, lead); jet fuel; diesel fuel; lubricants and hydraulics; kerosene; asphaltic petroleum hydrocarbon; and ethylene glycol.
Acceptable waste at any NTS landfill:
$\triangle$ Paper
$\square$ Rocks / unaltered geologic materials
$\triangle$ Empty containers
$\bigotimes$ Asphalt $\otimes$ Metal
$\triangle$ Wood
\ Soil
$\bigotimes$ Rubber (excluding tires)
Demolition debris
Q Plastic $\otimes$ Wire
Q Cable
$\otimes$ Cloth
$\bigotimes$ Insulation (non-Asbestosform)
$\bigotimes$ Cement \& concrete

$\triangle$ Manufactured items: (swamp coolers, furniture, rugs, carpet, electronic components, PPE, etc.)
Additional
Area 23 Mercury Landfill:
Office Waste
$\square$ Food Waste
Animal Carcasses
$\square$ Asbestos $\square$ Friable
$\square$ Non-Friable (contact SWO if regulated load)
Quantity:

Additional waste accepted at the Area 9 U10c Landfill:
$\square$ Non-friable asbestos
$\square$ Drained automobiles and military vehicles
$\square$ Solid fractions from sand/oil/water
$\square$ Light ballasts (contact SWO)
$\square$ Drained fuel filters (gas \& diesel)
Deconned Underground and Above
Hydrocarbons (contact SWO)
Q Other Drained generators/equipment Ground Tanks

Additional waste accepted at the Area 6 Hydrocarbon Landfill:
$\square$ Septic sludge
$\square$ Rags
$\square$ Drained fuel filters (gas \& diesel)
Crushed non-teme plated oil filters
Plants
Soil
$\square$ Sludge from sand/oil/water separators
$\square$ PCBs below 50 parts per million
REQUIRED: WASTE GENERATOR SIGNATURE

Initials: (if initialed, no radiological clearance is necessary.)

The above mentioned waste was generated outside of a Controlled Waste Management Area (CWMA) and to the best of mu knowledge, does not contain radiological materials.

To the best of my knowledge, the waste described above contains only thc site. I have verified this through the waste characterization method identifl prohibited and allowable waste items. I have contacted Property Managem is approved for disposal in the landfill.

Print Name: Dan Tobiason

Signature:

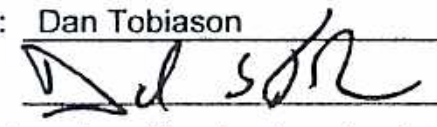

$$
10-3-17\rangle
$$

Note: "Food waste, office trash and animal carcasses do not require a radiolo must have signed removal certification statement with Load Verification

Load Weight (net from scale or estimate): 10,200
$10-3-07$

Signature of Certifier:
Radiation Survey Release for Waste Disposal
(1)

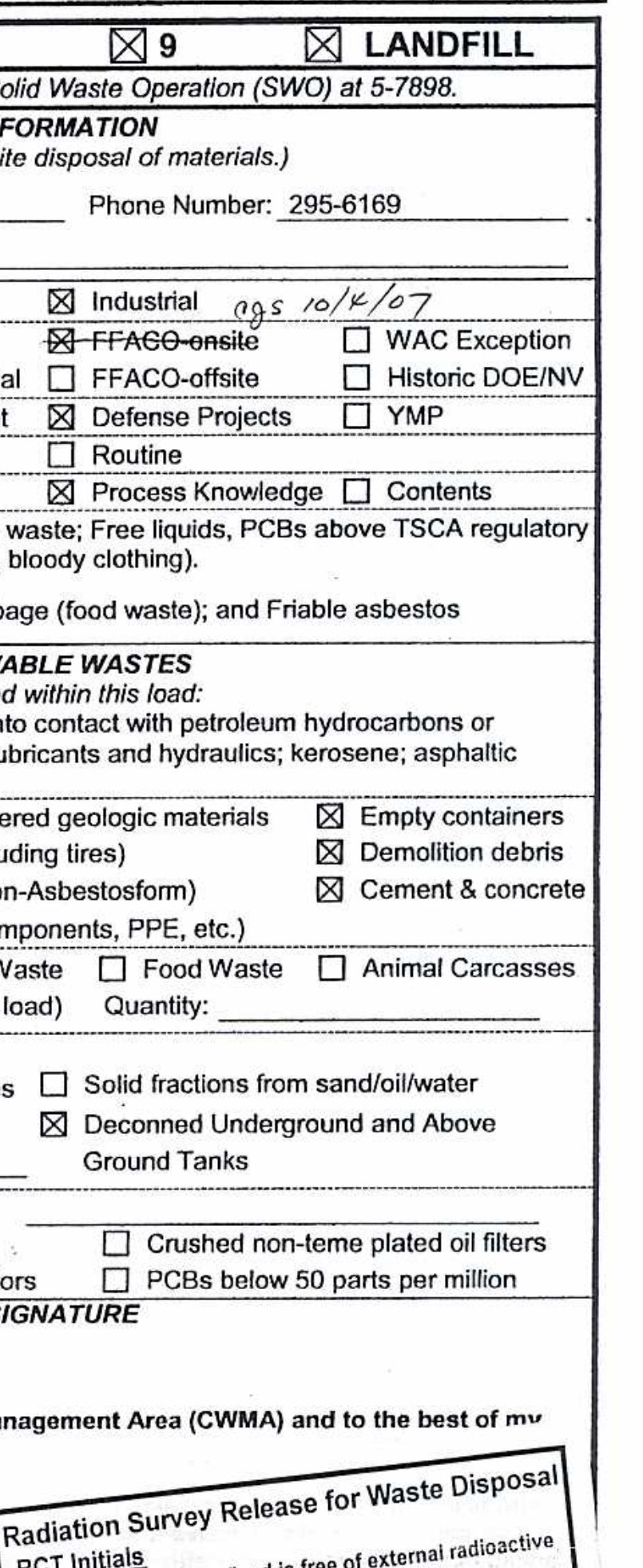




\section{$\begin{array}{lllllll}\text { SWO USE (Select One) } & \text { AREA } & \square 23 & \square 6 & \text { A } 39 & \square \text { LANDFILL }\end{array}$}

For waste characterization, approval, and/or assistance, contact Solid Waste Operation (SWO) at 5-7898.

\section{REQUIRED: WASTE GERERATOR INFORMATION}

(This form is for rolloffs, dump trucks, and other onsite disposal of materials.)

Waste Generator: Dan Tobiason Phone Number: 295-6169

Location / Origin: T-Tunnel Lower Laydown Yard

Waste Category: (check one)

$\square$ Commercial

$\triangle$ Industrial cos $10 / 8 / 07$

Waste Type: $\square$ NTS

$\square$ Putrescrible

A-FFACQ-Onsite

$\square$ WAC Exception

(check one)

$\square$ Non-Putrescible

$\square$ Asbestos Containing Material

$\square$ FFACO-offsite

$\square$ Historic DOE/NV

Pollution Prevention Category: (check one) $\square$ Environmental management

Pollution Prevention Category: (check one) $\triangle$ Clean-Up

Method of Characterization: (check one) $\square$ Sampling \& Analysis

$\triangle$ Defense Projects

YMP

Prohibited Waste at all three

NTS landfills:

Radioactive waste; RCRA waste; Hazardous waste; Free liquids, PCBs above TSCA regulatory

Additional Prohibited Waste

at the Area 9 U10C Landfill: levels, and Medical wastes (needles, sharps, bloody clothing).

Sewage Sludge, Animal carcasses, Wet garbage (food waste); and Friable asbestos

\section{REQUIRED: WASTE CONTENTS ALLOWABLE WASTES}

Check all allowable wastes that are contained within this load:

NOTE: Waste disposal at the Area 6 Hydrocarbon Landfill must have come into contact with petroleum hydrocarbons or coolants, such as: gasoline (no benzene, lead); jet fuel; diesel fuel; lubricants and hydraulics; kerosene; asphaltic petroleum hydrocarbon; and ethylene glycol.
Acceptable waste at any NTS landfill:
$\triangle$ Paper
$\square$ Rocks / unaltered geologic materials
Empty containers
Asphalt
$\otimes$ Metal
$\triangle$ Wood
Q Soil
$\otimes$ Rubber (excluding tires)
$\triangle$ Plastic $\otimes$ Wire
Q Cable
$\triangle$ Cloth
$\bigotimes$ Insulation (non-Asbestosform)
Demolition debris
$\bigotimes$ Manufactured items: (swamp coolers, furniture, rugs, carpet, electronic components, PPE, etc.)
Additional waste accepted at the Area 23 Mercury Landfill: $\square$ Office Waste
$\square$ Asbestos
Friable
$\square$ Non-Friable (contact SWO if regulated load)
$\square$ Food Waste
Animal Carcasses
Quantity:

\section{Additional waste accepted at the Area 9 U10c Landfill:}
$\square$ Non-friable asbestos
$\square$ Drained automobiles and military vehicles
$\square$ Light ballasts (contact SWO)
$\square$ Drained fuel filters (gas \& diesel)
$\square$ Hydrocarbons (contact SWO)

Other Drained generators/equipment
Additional waste accepted at the Area $\mathbf{6}$ Hydrocarbon Landfill:
$\square$ Septic sludge
$\square$ Rags
Plants
$\square$ Soil
$\square$ Drained fuel filters (gas \& diesel)
$\square$ Sludge from sand/oil/water separators

\section{REQUIRED: WASTE GENERATOR SIGNATURE}

Solid fractions from sand/oil/water

$\otimes$ Deconned Underground and Above

Ground Tanks

Initials: (if initialed, no radiological clearance is necessary.)

The above mentioned waste was generated outside of a Controlled $\mathrm{Wa}$ knowledge, does not contain radiological materials.

To the best of my knowledge, the waste described above contains only site. I have verified this through the waste characterization method id prohibited and allowable waste items. I have contacted Property Mans is approved for disposal in the landfill.

Print Name: Dan Tobiason

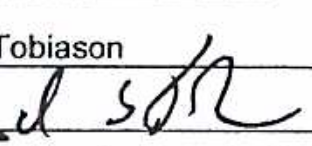
$10-6 \%$

Signature:

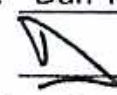

Radiation Survey Release for Waste Disposal RCT Initials

D This container/load is free of external radioactive contamination.

This container/load is exempt from survey due to process knowledge and origin.

This container/load is free of radioactive contanination based on radioanalysis.

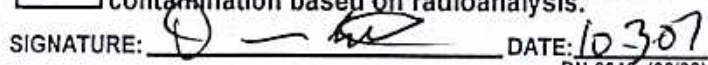
DATE: $10-307$

Note: "Food waste, office trash and animal carcasses do not require a radiological clearance. Freon-containing appliances must have signed removal certification statement with Load Verification."

LWO USE ONLY

$280^{\circ}$

$10-4-07$

Signature of Certifier

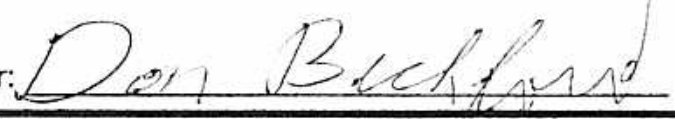


For waste characterization, approval, and/or assistance, contact Solid Waste Operation (SWO) at 5-7898.

\section{REQUIRED: WASTE GERERATOR INFORMATION}

(This form is for rolloffs, dump trucks, and other onsite disposal of materials.)

Waste Generator: Dan Tobiason Phone Number: 295-6169

Location / Origin: T-Tunnel Lower Laydown Yard

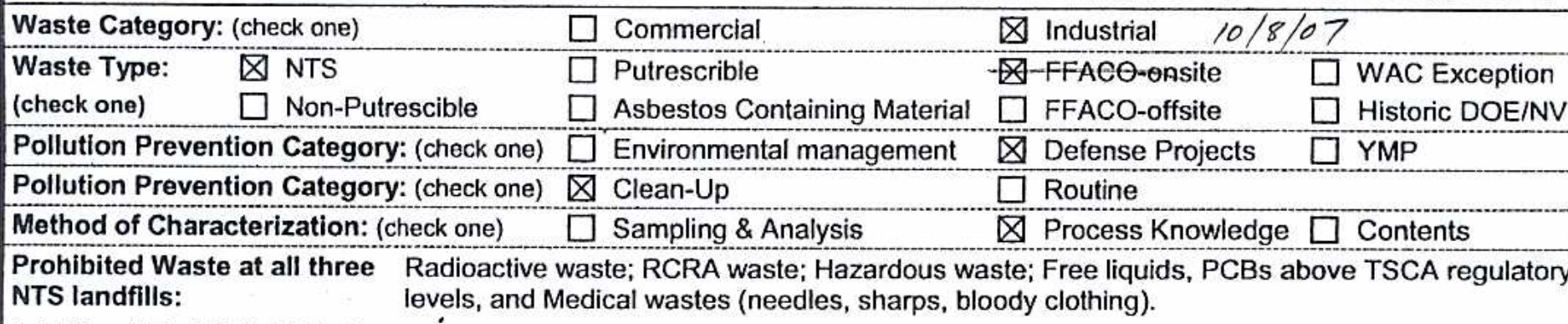

Additional Prohibited Waste at the Area 9 U10C Landfill:

Sewage Sludge, Animal carcasses, Wet garbage (food waste); and Friable asbestos

\section{REQUIRED: WASTE CONTENTS ALLOWABLE WASTES}

Check all allowable wastes that are contained within this load:

NOTE: Waste disposal at the Area 6 Hydrocarbon Landfill must have come into contact with petroleum hydrocarbons or coolants, such as: gasoline (no benzene, lead); jet fuel; diesel fuel; lubricants and hydraulics; kerosene; asphaltic petroleum hydrocarbon; and ethylene glycol.
Acceptable waste at any NTS landfill:
$\bigotimes$ Paper
$\square$ Rocks / unaltered geologic materials
$\triangle$ Empty containers
$\bigotimes$ Asphalt $\otimes$ Metal $\bigotimes$ Wood
\Soil
$\triangle$ Rubber (excluding tires)
$\triangle$ Plastic $\quad$ Wire
\Cable
Cloth
Insulation (non-Asbestosform)
$\bigotimes$ Demolition debris
囚 Cement \& concrete
Q Manufactured items: (swamp coolers, furniture, rugs, carpet, electronic components, PPE, etc.)
Additional waste accepted at the Area 23 Mercury Landfill: $\square$ Office Waste
Asbestos
Friable
$\square$ Non-Friable (contact SWO if regulated load)

\section{Additional waste accepted at the Area 9 U10c Landfill:}
$\square$ Non-friable asbestos $\quad \square$ Drained automobiles and military vehicles
$\square$ Light ballasts (contact SWO) $\square$ Drained fuel filters (gas \& diesel)
$\square$ Hydrocarbons (contact SWO)
$\square$ Other Drained generators/equipment

$\square$ Food Waste

Animal Carcasses

$\square$ Solid fractions from sand/oil/water

$\triangle$ Deconned Underground and Above Ground Tanks

Additional waste accepted at the Area 6 Hydrocarbon Landfill:
$\square$ Septic sludge
$\square$ Rags
$\square$ Drained fuel filters (gas \& diesel)
Plants
$\square$ Soil
$\square$ Sludge from sand/oil/water separators
$\square$ Crushed non-teme plated oil filters REQUIRED: WASTE GENERATOR SIGNATURE

Initials: (if initialed, no radiological clearance is necessary.)

The above mentioned waste was generated outside of a Controlled Waste Manage knowledge, does not contain radiological materials.

To the best of my knowledge, the waste described above contains only those mate site. I have verified this through the waste characterization method identified abov prohibited and allowable waste Items. I have contacted Property Management and is approved for disposal in the landfill.

Print Name: Dan Tobiason

Signature:

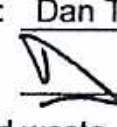

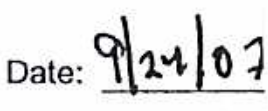

Radiation Survey Release for Waste Disposal RCT Initials

This container/load is free of external radioactive OC contamination.

This containerload is exempt from survey due to This containeriload is exempt

process knowledge and origin.

SIGNATURE: Contamination basedg radioanalysis.

Note: "Food waste, office trash and animal carcasses do not require a radiological clearance. Freon-containing appliances must have signed removal certification statement with Load Verification."

SWO USE ONLY

Load Weight (net from/scale or estimate):
$10-4-07$

Signature of Certifier: 


\begin{tabular}{|llllll}
\hline SWO USE (Select One) & AREA & $\square 23$ & $\square 6$ & Q 9 & L LANDFILL
\end{tabular}

For waste characterization, approval, and/or assistance, contact Solid Waste Operation (SWO) at 5-7898.

REQUIRED: WASTE GERERATOR INFORMATION

(This form is for rolloffs, dump trucks, and other onsite disposal of materials.)

Waste Generator: Dan Tobiason Phone Number: 295-6169

Location / Origin: T-Tunnel Lower Laydown Yard

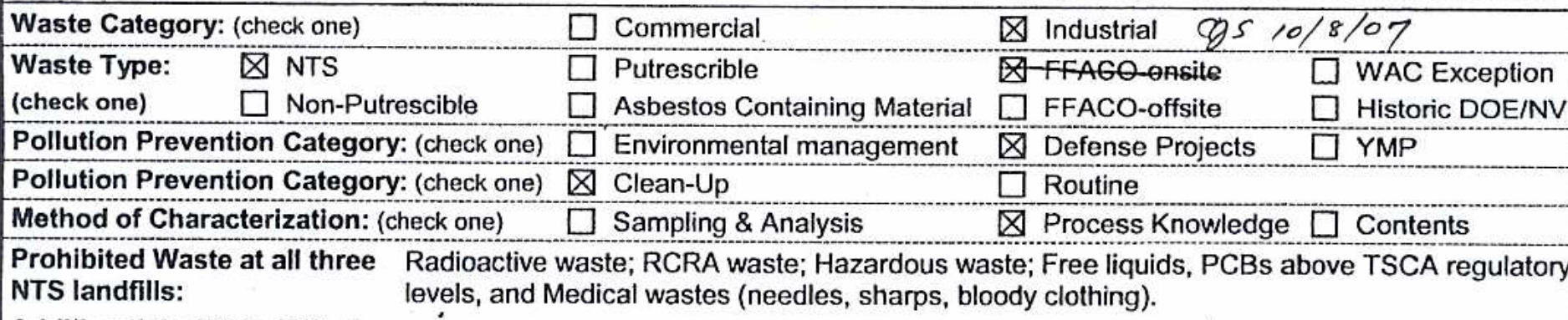

Additional Prohibited Waste at the Area 9 U10C Landfill:

Sewage Sludge, Animal carcasses, Wet garbage (food waste); and Friable asbestos

\section{REQUIRED: WASTE CONTENTS ALLOWABLE WASTES}

Check all allowable wastes that are contained within this load:

NOTE: Waste disposal at the Area 6 Hydrocarbon Landfill must have come into contact with petroleum hydrocarbons or coolants, such as: gasoline (no benzene, lead); jet fuel; diesel fuel; lubricants and hydraulics; kerosene; asphaltic petroleum hydrocarbon; and ethylene glycol.
Acceptable waste at any NTS landfill:
$\triangle$ Paper
$\square$ Rocks / unaltered geologic materials
区 Empty containers
$\triangle$ Asphalt $\otimes$ Metal $\otimes$ Wood
\Soil
$\bigotimes$ Rubber (excluding tires)
Q Plastic $\otimes$ Wire
Q Cable
Cloth
$\bigotimes$ Insulation (non-Asbestosform)
$\bigotimes$ Demolition debris
$\bigotimes$ Manufactured items: (swamp coolers, furniture, rugs, carpet, electronic components, PPE, etc.)
Additional waste accepted at the Area 23 Mercury Landfill: $\square$ Office Waste
$\square$ Asbestos
Friable
Non-Friable (contact SWO if regulated load)
$\square$ Food Waste
Animal Carcasses
Quantity:

Additional waste accepted at the Area 9 U10c Landfill:
$\square$ Non-friable asbestos
$\square$ Drained automobiles and military vehicles
$\square$ Light ballasts (contact SWO)
$\square$ Drained fuel filters (gas \& diesel)
Hydrocarbons (contact SWO)
$\otimes$ Other
Drained generators/equipment

Additional waste accepted at the Area 6 Hydrocarbon L.andfill:
$\square$ Septic sludge
$\square$ Rags
$\square$ Drained fuel filters (gas \& diesel)
Plants
$\square$ Soil
$\square$ Sludge from sand/oil/water separators
REQUIRED: WASTE GENERATOR SIGNATURE

Solid fractions from sand/oil/water

Initials: (if initialed, no radiological clearance is necessary.)

The above mentioned waste was generated outside of a Controlled Waste Management Area (CWMA) and to the best of my knowledge, does not contain radiological materials.

To the best of my knowledge, the waste described above contains only those materials that are alln......

site. I have verified this through the waste characterization method identifie -

prohibited and allowable waste items. I have contacted Property Manageme. is approved for disposal in the landfill.

Print Name: Dan Tobiason

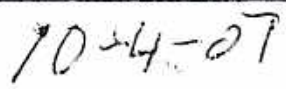

Signature:

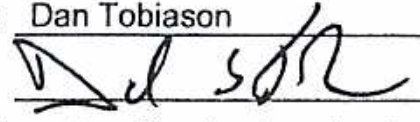

Note: "Food waste, office trash and animal carcasses do not require a radiolog must have signed removal certification statement with Load Verification.

\section{SWO USE ONLY}

Load Weight (net from scale of estimate):

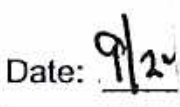

$10-\psi-07$

Radiation Survey Release for Waste Disposal
RCT Initials

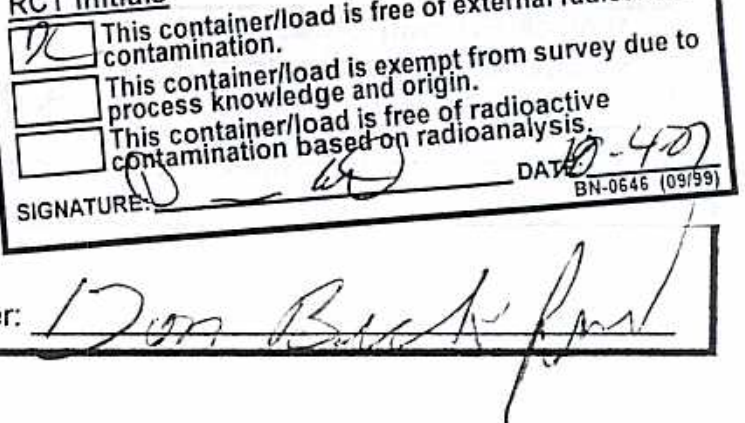


$\square 23$

$\square 6$

冈9

$\triangle$ LANDFILL

For waste characterization, approval, and/or assistance, contact Solid Waste Operation (SWO) at 5-7898.

REQUIRED: WASTE GERERATOR INFORMATION

(This form is for rolloffs, dump trucks, and other onsite disposal of materials.)

Waste Generator: Dan Tobiason

Phone Number: 295-6169

Location / Origin: T-Tunnel Lower Laydown Yard

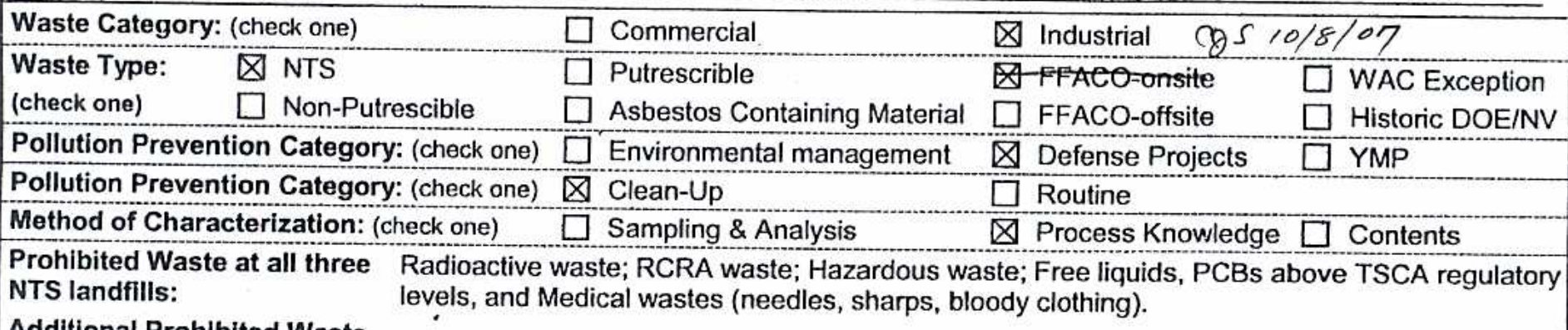

Additional Prohlbited Waste at the Area 9 U10C Landfill:

Sewage Sludge, Animal carcasses, Wet garbage (food waste); and Friable asbestos

\section{REQUIRED: WASTE CONTENTS ALLOWABLE WASTES}

Check all allowable wastes that are contained within this load:

NOTE: Waste disposal at the Area 6 Hydrocarbon Landfill must have come into contact with petroleum hydrocarbons or coolants, such as: gasoline (no benzene, lead); jet fuel; diesel fuel; lubricants and hydraulics; kerosene; asphaltic petroleum hydrocarbon; and ethylene glycol.

Acceptable waste at any NTS landfill: $\square$ Paper
Asphalt
Metal
Wood
$凶$ Soil
Q Plastic $\otimes$ Wire
Q Cable
Cloth
$\square$ Rocks / unaltered geologic materials
$\bigotimes$ Rubber (excluding tires)
\Insulation (non-Asbestosform)

$\bigotimes$ Empty containers
$\bigotimes$ Demolition debris
$\bigotimes$ Cement \& concrete

$\triangle$ Manufactured items: (swamp coolers, furniture, rugs, carpet, electronic components, PPE, etc.)
Additional was
$\square$ Asbestos
$\square$ Friable
Area 23 Mercury Landfill:
Office Waste
$\square$ Food Waste
Animal Carcasses
Quantity:

Additional waste accepted at the Area 9 U10c Landfill:

$\square$ Non-friable asbestos

$\square$ Light ballasts (contact SWO)

$\square$ Drained automobiles and military vehicles

Drained fuel filters (gas \& diesel)

Hydrocarbons (contact SWO)

Other

Drained generators/equipment

\section{Additional waste accepted at the Area 6 Hydrocarbon Landfill:}
$\square$ Septic sludge
$\square$ Rags
Plants
Soil

$\square$ Drained fuel filters (gas \& diesel)

$\square$ Sludge from sand/oil/water separators

Solid fractions from sand/oil/water

$\bigotimes$ Deconned Underground and Above

Ground Tanks

Initials: (if initialed, no radiological clearance is necessary.)

The above mentioned waste was generated outside of a Controlled Waste Management Area (CWMA) and to the best of my knowledge, does not contain radiological materials.

To the best of my knowledge, the waste described above contains only those ma site. I have verified this through the waste characterization method identified ab prohibited and allowable waste items. I have contacted Property Management al is approved for disposal in the landfill.

Print Name: Dan Tobiason

Signature:

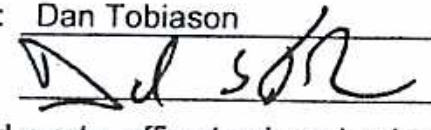

Note: "Food waste, office trash and animal carcasses do not require a radiologic: must have signed removal certification statement with Load Verification."

\section{SWO USE ONLY}

Load Weight (net from/scale or estimate): $15,0202 \begin{gathered}10-4-67 \\ \text { Signature of Certifie }\end{gathered}$
Radiation Survey Release for Waste Disposal RCT Initials

bC This container/load is free of external radioactive contamination.

This container/load is exempt from survey due to process knowledge and origin.

This container/load is free of radioactive

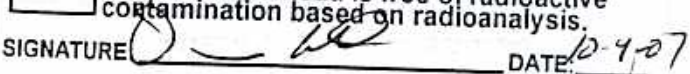
BN-0645 (09/99) 


\section{$\begin{array}{llllll}\text { SWO USE (Select One) } & \text { AREA } & \square 23 & \square 6 & \text { 23 } & \text { Q LANDFILL }\end{array}$}

For waste characterization, approval, and/or assistance, contact Solid Waste Operation (SWO) at 5-7898.

REQUIRED: WASTE GERERATOR INFORMATION

(This form is for rolloffs, dump trucks, and other onsite disposal of materials.)

Waste Generator: Dan Tobiason

Phone Number: 295-6169

Location / Origin: T-Tunnel Lower Laydown Yard

Waste Category: (check one)

Waste Type: $\square$ NTS

(check one)

$\square$ Non-Putrescible

Pollution Prevention Category: (check one)

Pollution Prevention Category: (check one)

Method of Characterization: (check one)

Prohibited Waste at all three

NTS landfills:

Additional Prohibited Waste

at the Area 9 U10C Landfill:

at the Are

$\square$ Commercial

$\square$ Putrescrible

$\square$ Asbestos Containing Material

$\square$ Environmental management

$\triangle$ Clean-Up

$\square$ Sampling \& Analysis

Page 1 of 2 levels, and Medical wastes (needles, sharps, bloody clothing).

Sewage Sludge, Animal carcasses, Wet garbage (food waste); and Friable asbestos

\section{REQUIRED: WASTE CONTENTS ALLOWABLE WASTES}

Check all allowable wastes that are contained within this load:

NOTE: Waste disposal at the Area 6 Hydrocarbon Landfill must have come into contact with petroleurn hydrocarbons or coolants, such as: gasoline (no benzene, lead); jet fuel; diesel fuel; lubricants and hydraulics; kerosene; asphaltic petroleum hydrocarbon; and ethylene glycol.
Acceptable waste at any NTS landfill:
$\triangle$ Paper
$\square$ Rocks / unaltered geologic materials
$\otimes$ Asphalt
$\otimes$ Metal
$\triangle$ Wood
$\otimes$ Soil
$\otimes$ Rubber (excluding tires)
$\otimes$ Plastic $\otimes$ Wire
Q Cable
$\triangle$ Cloth
$\triangle$ Insulation (non-Asbestosform)
$\triangle$ Empty containers
$凶$ Demolition debris
$\bigotimes$ Cement \& concrete

$\triangle$ Manufactured items: (swamp coolers, fumiture, rugs, carpet, electronic components, PPE, etc.)

\section{Additional waste accepted at the Area 23 Mercury Landfill: $\square$ Office Waste $\square$ Food Waste}
$\square$ Asbestos
Friable
$\square$ Non-Friable (contact SWO if regulated load)
Quantity:

Additional waste accepted at the Area 9 U10c Landfill:
$\square$ Non-friable asbestos
Light ballasts (contact SWO)
$\square$ Drained automobiles and military vehicles
Drained fuel filters (gas \& diesel)

Hydrocarbons (contact SWO)

Other

Drained generators/equipment

Solid fractions from sand/oil/water

$\otimes$ Deconned Underground and Above Ground Tanks

\section{Additional waste accepted at the Area 6 Hydrocarbon Landfill:}
$\square$ Septic sludge
$\square$ Rags
$\square$ Drained fuel filters (gas \& diesel)
Plants
$\square$ Soil
$\square$ Sludge from sand/oil/water separators
$\square$ Crushed non-teme plated oil filters
$\square$ PCBs below 50 parts per million REQUIRED: WASTE GENERATOR SIGNATURE

Initials: (if initialed, no radiological clearance is necessary.)

The above mentioned waste was generated outside of a Controlled Waste Management Area (CWMA) and to the best of my knowledge, does not contain radiological materials.

To the best of my knowledge, the waste described above contains only those materials that are allowed for disposal at this site. I have verified this through the waste characterization method identified above and a review of the above-mentioned prohibited and allowable waste Items. I have contacted Property Management and have verified that this material/equipment is approved for disposal in the landfill.

Print Name: Dan Tobiason

Signature:

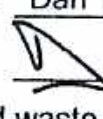

Note: "Food waste, office trash and animal carcasses do not require a radiol must have signed removal certification statement with Load Verificatic

\section{SWO USE ONLY}

Load Weight (net from scale or estimate): 3000

$10-4-07$

Signature of $\mathrm{Ce}$
Radiation Survey Release for Waste Disposal RCT Initials This containerlload is free of external radioactive

This container/load is exempt from survey due to This container/load is exempt fron
process knowledge and origin.

This container/load is free of radioactive contamination based on radioanalysis.

Signature: A) DATE: 20.90 
$\begin{array}{lllllll}\text { SWO USE (Select One) } & \text { AREA } & \square 23 & \square 6 & \nabla 9 & \text { Q LANDFILL }\end{array}$

For waste characterization, approval, and/or assistance, contact Solid Waste Operation (SWO) at 5-7898.

REQUIRED: WASTE GERERATOR INFORMATION

(This form is for rolloffs, dump trucks, and other onsite disposal of materials.)

Waste Generator: Dan Tobiason

Phone Number: 295-6169

Location / Origin: T-Tunnel Lower Laydown Yard

Waste Category: (check one)

Waste Type: $\bigotimes$ NTS

$\square$ Commercial

(check one)

$\square$ Non-Putrescible

$\square$ Putrescrible

$\bigotimes$ Industrial

Q5

$10 / 8 / 07$

Pollution Prevention Category: (check one)

$\square$ Asbestos Containing Material

Q-FFACO-Onsite

WAC Exception

Pollution Prevention Category: (check one)

Environmental management

$\square$ FFACO-offsite

$\square$ Historic DOE/NV

Method of Characterization: (check one)

\ Clean-Up

Prohibited Waste at all three

NTS landfills:

Additional Prohibited Waste

at the Area 9 U10C Landfill:

Radioactive waste; RCRA waste; Hazardous waste; Free liquids, PCBs above TSCA regulatory levels, and Medical wastes (needles, sharps, bloody clothing).

Sewage Sludge, Animal carcasses, Wet garbage (food waste); and Friable asbestos

\section{REQUIRED: WASTE CONTENTS ALLOWABLE WASTES}

Check all allowable wastes that are contained within this load:

NOTE: Waste disposal at the Area 6 Hydrocarbon Landfill must have come into contact with petroleurn hydrocarbons or coolants, such as: gasoline (no benzene, lead); jet fuel; diesel fuel; lubricants and hydraulics; kerosene; asphaltic petroleum hydrocarbon; and ethylene glycol.
Acceptable waste at any NTS landfill:
$\triangle$ Paper
$\square$ Rocks / unaltered geologic materials
Empty containers
Asphalt $\bigotimes$ Metal
$\triangle$ Wood
$\triangle$ Soil
$\triangle$ Rubber (excluding tires)
Cloth
$\bigotimes$ Insulation (non-Asbestosform)
$\bigotimes$ Demolition debris
$\triangle$ Plastic $\quad$ Wire $\quad$ Cable
$\triangle$ Manufactured items: (swamp coolers, furniture, rugs, carpet, electronic components, PPE, etc.)
Additional waste accepted at the Area 23 Mercury Landfill: $\square$ Office Waste
$\square$ Asbestos
Friable
$\square$ Non-Friable (contact SWO if regulated load)
$\square$ Food Waste
$\bigotimes$ Cement \& concrete
Quantity:

Additional waste accepted at the Area 9 U10c Landfill:
$\square$ Non-friable asbestos
Drained automobiles and military vehicles
$\square$ Light ballasts (contact SWO) $\square$ Drained fuel filters (gas \& diesel)
$\square$ Hydrocarbons (contact SWO) $\square$ Other Drained generators/equipment

Solid fractions from sand/oil/water

$\bigotimes$ Deconned Underground and Above Ground Tanks

Additional waste accepted at the Area 6 Hydrocarbon Landfill:
$\square$ Septic sludge
$\square$ Rags
$\square$ Drained fuel filters (gas \& diesel)
$\square$ Crushed non-teme plated oil filters
Plants
Soil
$\square$ Sludge from sand/oil/water separators
$\square$ PCBs below 50 parts per million
REQUIRED: WASTE GENERATOR SIGNATURE

Initials: (if initialed, no radiological clearance is necessary.)

The above mentioned waste was generated outside of a Controlled Waste Management Area (CWMA) and to the best of my knowledge, does not contain radiological materials.

To the best of my knowledge, the waste described above contains only those materials that are allowed for disposal at this site. I have verified this through the waste characterization method identified ahnus smed . _.........

prohibited and allowable waste items. I have contacted Property Manager is approved for disposal in the landfill.

Print Name: Dan Tobiason

Signature:
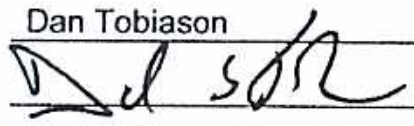

Date: q

Note: "Food waste, office trash and animal carcasses do not require a radic must have signed removal certification statement with Load Verificati

\section{SWO USE ONLY}

Load Weight (net from scale or estimate):

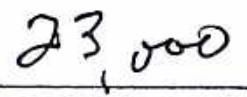

$10-4-07$

Signature of Certifier:
Radiation Survey Release for Waste Disposal RCT Initials

This containerload is free of external radioactive i) contamination.

This container/load is exempt from survey due to process knowledge and origin.

This container/load is free of radioactive

This containerload is radioanalysis.

SIGNATURE: Contapination based on radioanalysis. 


\begin{tabular}{|llllll}
\hline SWO USE (Select One) & AREA & $\square 23$ & $\square 6$ & (23 & LANDFILL
\end{tabular}

For waste characterization, approval, and/or assistance, contact Solid Waste Operation (SWO) at 5-7898.

REQUIRED: WASTE GERERATOR INFORMATION

(This form is for rolloffs, dump trucks, and other onsite disposal of materials.)

Waste Generator: Dan Tobiason

Phone Number: 295-6169

Location / Origin: T-Tunnel Lower Laydown Yard

\begin{tabular}{|c|c|c|c|}
\hline Waste Catego & (check one) & $\square$ Commercial & $\Delta$ Industrial cos $10 / 8 / 07$ \\
\hline Waste Type: & NTSS & $\square$ Putrescrible & X-FEAGQ-Onsito. \\
\hline (check one) & $\square$ Non-Putrescible & $\square$ Asbestos Containing Material & $\square$ FFACO-offsite \\
\hline Pollution Pre & tion Category: (check one) & $\square$ Environmental $\mathrm{m}$ & $\triangle$ Defense Projects \\
\hline Pollution PreI & tion Category: (check one) & $\triangle$ Clean-Up & $\square$ Routine \\
\hline Method of Ch & cterization: (check one) & $\square$ Sampling \& Analysis & Process Knowledge $\square$ Contents \\
\hline
\end{tabular}

Additional Prohibited Waste at the Area 9 U10C Landfill:

Sewage Sludge, Animal carcasses, Wet garbage (food waste); and Friable asbestos

REQUIRED: WASTE CONTENTS ALLOWABLE WASTES

Check all allowable wastes that are contained within this load:

NOTE: Waste disposal at the Area 6 Hydrocarbon Landfill must have come into contact with petroleurn hydrocarbons or coolants, such as: gasoline (no benzene, lead); jet fuel; diesel fuel; lubricants and hydraulics; kerosene; asphaltic petroleurn hydrocarbon; and ethylene glycol.

Acceptable waste at any NTS landfill: $\triangle$ Paper $\square$ Rocks / unaltered geologic materials

$\triangle$ Asphalt $\triangle$ Metal Wood

P Plastic $\otimes$ Wire $\quad$ Cable $\otimes$ Cloth

$\triangle$ Rubber (excluding tires)

\Insulation (non-Asbestosform)

Empty containers

Demolition debris

Manufactured items: (swamp coolers, fumiture, rugs, carpet, electronic components, PPE, etc.)

Additional waste accepted at the Area 23 Mercury Landfill: $\square$ Office Waste $\square$ Food Waste $\square$ Animal Carcasses

$\square$ Asbestos $\quad \square$ Friable $\quad \square$ Non-Friable (contact SWO if regulated load) Quantity:

Additional waste accepted at the Area 9 U10c Landfill:

$\square$ Non-friable asbestos $\quad \square$ Drained automobiles and military vehicles
$\square$ Light ballasts (contact SwO) $\square$ Drained fuel filters (gas \& diesel)
$\square$ Hydrocarbons (contact SWO) $\quad$ Other Drained generators/equipment

Solid fractions from sand/oil/water

冈 Deconned Underground and Above

Ground Tanks

Additional waste accepted at the Area 6 Hydrocarbon Landfill:
$\square$ Septic sludge
$\square$ Rags
$\square$ Drained fuel filters (gas \& diesel)
Crushed non-teme plated oil filters
Plants
Soil
$\square$ Sludge from sand/oil/water separators
REQUIRED: WASTE GENERATOR SIGNATURE
PCBs below 50 parts per million

Initials: ___ (if initialed, no radiological clearance is necessary.)

The above mentioned waste was generated outside of a Controlled Waste Management Area (CWMA) and to the best of my knowledge, does not contain radiological materials.

To the best of my knowledge, the waste described above contains only those materials that are allowed for disposal at this site. I have verified this through the waste characterization method identifined an_... _... _.... prohibited and allowable waste items. I have contacted Property Manag is approved for disposal in the landfill.

Print Name: Dan Tobiason

Note: "Food waste, office trash and animal carcasses do not require a raı must have signed removal certification statement with Load Verific:

SWO USE ONLY

Load Weight (net from/scale/or estimate): 3000
$10-4-07$

Signature of Certifier:
Radiation Survey Release for Waste Disposal RCT Initials

This container/load is free of external radioactive

$\square$ This container/load is exempt from survey due to process knowledge and origin.

This container/load is free of radioactive

This conination basedon radioanalysis.

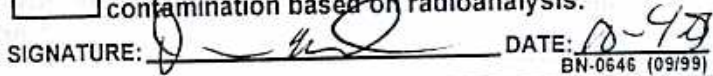




\begin{tabular}{lllllll}
\hline SWO USE (Select One) & AREA & $\square 23$ & $\square 6$ & Q 39 & LANDFILL
\end{tabular}

For waste characterization, approval, and/or assistance, contact Solid Waste Operation (SWO) at 5-7898.

\section{REQUIRED: WASTE GERERATOR INFORMATION}

(This form is for rolloffs, dump trucks, and other onsite disposal of materials.)

Waste Generator: Dan Tobiason

Phone Number: 295-6169

Location / Origin: T-Tunnel Lower Laydown Yard

Waste Category: (check one)

Waste Type: \NTS

(check one)

Non-Putrescible $\square$ Commercial

$\square$ Putrescrible

$\square$ Asbestos Containing Material $\triangle$ Industrial

7-FFAGO-OAsite

$10 / 8 / 07$

$\square$ FFACO-offsite

$\triangle$ Defense Projects

Pollution Prevention Category: (check one) $\square$ Environmental management

Pollution Prevention Category: (check one) $\bigotimes$ Clean-Up

Method of Characterization: (check one) $\square$ Sampling \& Analysis

$\square$ Routine

$\triangle$ Process Knowledge $\square$ Contents

Prohibited Waste at all three Radioactive waste; RCRA waste; Hazardous waste; Free liquids, PCBs above TSCA regulatory NTS landfills:

Additional Prohibited Waste at the Area 9 U10C Landfill:

levels, and Medical wastes (needles, sharps, bloody clothing).

Sewage Sludge, Animal carcasses, Wet garbage (food waste); and Friable asbestos

\section{REQUIRED: WASTE CONTENTS ALLOWABLE WASTES}

Check all allowable wastes that are contained within this load:

NOTE: Waste disposal at the Area 6 Hydrocarbon Landfill must have come into contact with petroleurn hydrocarbons or coolants, such as: gasoline (no benzene, lead); jet fuel; diesel fuel; lubricants and hydraulics; kerosene; asphaltic petroleum hydrocarbon; and ethylene glycol.

Acceptable waste at any NTS landfill: $\triangle$ Pape

Asphalt

$凶$ Metal

$\triangle$ Wood

$\triangle$ Soil

Cable $\square$ Rocks / unaltered geologic materials

$\bigotimes$ Rubber (excluding tires)

$凶$ Insulation (non-Asbestosform) $\triangle$ Empty containers

$\bigotimes$ Demolition debris

$\bigotimes$ Cement \& concrete

$\bigotimes$ Manufactured items: (swamp coolers, furniture, rugs, carpet, electronic components, PPE, etc.)

Additional waste accepted at the Area 23 Mercury Landfill: $\square$ Office Waste $\square$ Food Waste $\square$ Animal Carcasses
$\square$ Asbestos
Friable
$\square$ Non-Friable (contact SWO if regulated load)
Quantity:

Additional waste accepted at the Area 9 U10c Landfill:

$\square$ Non-friable asbestos

$\square$ Light ballasts (contact SWO)

$\square$ Drained automobiles and military vehicles

Hydrocarbons (contact SWO)
Solid fractions from sand/oil/water

$\bigotimes$ Deconned Underground and Above Ground Tanks

Additional waste accepted at the Area 6 Hydrocarbon Landfill:
$\square$ Septic sludge
$\square$ Rags
$\square$ Drained fuel filters (gas \& diesel)
$\square$ Crushed non-teme plated oil filters
Plants
Soil
$\square$ Sludge from sand/oil/water separators REQUIRED: WASTE GENERATOR SIGNATURE

Initials: (if initialed, no radiological clearance is necessary.)

The above mentioned waste was generated outside of a Controlled Waste Management Area (CWMA) and to the best of my knowledge, does not contain radiological materials.

To the best of my knowledge, the waste described above contains on/u thnse materials that are allowed for disposal at this site. I have verified this through the waste characterization method id prohibited and allowable waste Items. I have contacted Property Man is approved for disposal in the landfill.

Print Name: Dan Tobiason

Signature:

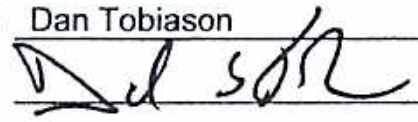
$\mathrm{Da}$

Note: "Food waste, office trash and animal carcasses do not require must have signed removal certification statement with Load Ve

SWO USE ONLY

Load Weight (net from scale or estimate)
$10-4-07$

Signature of Certifier: ....- -homamantioned

$$
\begin{aligned}
& \text { Radiation Survey Release for Waste Disposal } \\
& \text { RCT Initials } \\
& \hline \text { This container/load is free of external radioactive } \\
& \text { contamination. } \\
& \text { This container/load is exempt from survey due to } \\
& \text { process knowledge and origin. } \\
& \text { Chis container/load is free of radioactive } \\
& \text { Contanignation based on radtioanalysis. }
\end{aligned}
$$
BN.0646 109/99 
For waste characterization, approval, and/or assistance, contact Solid Waste Operation (SWO) at 5-7898.

\section{REQUIRED: WASTE GERERATOR INFORMATION}

(This form is for rolloffs, dump trucks, and other onsite disposal of materials.)

Waste Generator: Dan Tobiason

Phone Number: 295-6169

Location / Origin: T-Tunnel Lower Laydown Yard

Waste Category: (check one)

Waste Type: $\otimes$ NTS

(check one) $\quad \square$ Non-Putrescible

$\square$ Commercial

$\square$ Putrescrible

$\triangle$ Industrial $Q 2,10 / 8 / 0 ?$

$\square$ Asbestos Containing Material

Q FFACO-onsite

$\square$ WAC Exception

Pollution Prevention Category: (check one)

Pollution Prevention Category: (check one)

$\square$ Environmental management

$\square$ FFACO-offsite

$\square$ Historic DOE/NV

Method of Characterization: (check one)

$\triangle$ Clean-Up

$\triangle$ Defense Projects

YMP

Prohibited Waste at all three

NTS landfills:

Additional Prohlbited Waste

at the Area 9 U10C Landfill:

Radioactive waste; RCRA waste; Hazardous waste; Free liquids, PCBs above TSCA regulatory levels, and Medical wastes (needles, sharps, bloody clothing).

Sewage Sludge, Animal carcasses, Wet garbage (food waste); and Friable asbestos

\section{REQUIRED: WASTE CONTENTS ALLOWABLE WASTES}

Check all allowable wastes that are contained within this load:

NOTE: Waste disposal at the Area 6 Hydrocarbon Landfill must have come into contact with petroleum hydrocarbons or coolants, such as: gasoline (no benzene, lead); jet fuel; diesel fuel; lubricants and hydraulics; kerosene; asphaltic petroleum hydrocarbon; and ethylene glycol.
Acceptable waste at any NTS landfill:
$\triangle$ Paper
Soil
$\square$ Rocks / unaltered geologic materials
$\bigotimes$ Rubber (excluding tires)
Asphalt $\otimes$ Metal
$\triangle$ Wood
Cloth
$\bigotimes$ Insulation (non-Asbestosform)
Empty containers
$\triangle$ Demolition debris
$\triangle$ Plastic $\quad$ Wire $\quad$ Cable
Q Manufactured items: (swamp coolers, furniture, rugs, carpet, electronic components, PPE, etc.)
冈 Cement \& concrete

$\triangle$ Manufactured items: (swamp coolers, furniture, rugs, carpet, electronic components, PPE, etc.)
Additional waste accepted at the Area 23 Mercury Landfill:
$\square$ Office Waste
$\square$ Food Waste
Animal Carcasses
$\square$ Asbestos
Friable
Non-Friable (contact SWO if regulated load)
Quantity:

Additional waste accepted at the Area 9 U10c Landfill:
$\square$ Non-friable asbestos
$\square$ Drained automobiles and military vehicles
Light ballasts (contact SWO)
$\square$ Drail
Drained fuel filters (gas \& diesel)
Hydrocarbons (contact SWO)
Other
Drained generators/equipment

Solid fractions from sand/oil/water

$\triangle$ Deconned Underground and Above

Ground Tanks

Additional waste accepted at the Area 6 Hydrocarbon Landfill:
$\square$ Septic sludge
$\square$ Rags
$\square$ Drained fuel filters (gas \& diesel)
Crushed non-teme plated oil filters
Plants
Soil
$\square$ Sludge from sand/oil/water separators
$\square$ PCBs below 50 parts per million
REQUIRED: WASTE GENERATOR SIGNATURE

Initials: (if initialed, no radiological clearance is necessary.)

The above mentioned waste was generated outside of a Controlled Waste Management Area (CWMA) and to the best of my

knowledge, does not contain radiological materials.

To the best of my knowledge, the waste described above contains only those materials that are allowed for dienneat as al. site. I have verified this through the waste characterization method identifir- -1

prohibited and allowable waste Items. I have contacted Property Managemi is approved for disposal in the landfill.

Print Name: Dan Tobiason

Signature:

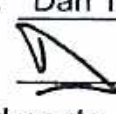

SW

Note: "Food waste, office trash and animal carcasses do not require a radiolc must have signed removal certification statement with Load Verificatio

SWO USE ONLY

Load Weight (net from scale or estimate):

20,16 Bsignature of Certifier:
Radiation Survey Release for Waste Disposal RCT Initials

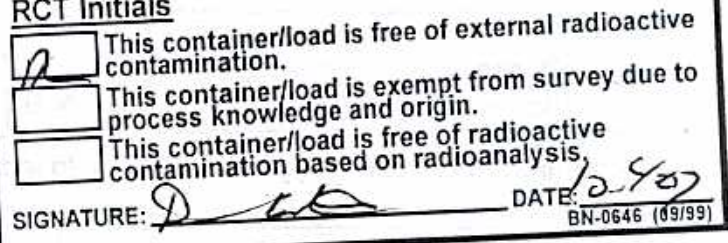




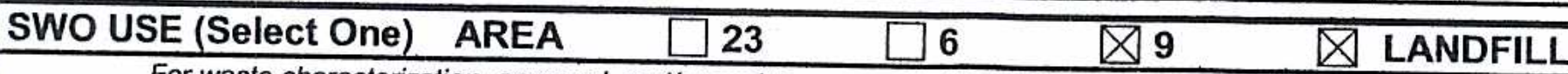

For waste characterization, approval, and/or assistance, contact Solid Waste Operation (SWO) at 5-7898.

REQUIRED: WASTE GERERATOR INFORMATION

(This form is for rolloffs, dump trucks, and other onsite disposal of materials.)

Waste Generator: Dan Tobiason

Phone Number: 295-6169

Location / Origin: T-Tunnel Lower Laydown Yard

Waste Category: (check one)

Waste Type: $\triangle$ NTS

(check one)

$\square$ Non-Putrescible

Pollution Prevention Category: (check one)

Pollution Prevention Category: (check one)

Method of Characterization: (check one)

Prohibited Waste at all three

NTS landfills:

Additional Prohibited Waste

at the Area 9 U10C Landfill:
Radioactive waste; RCRA waste; Hazardous waste; Free liquids, PCBs above TSCA regulatory

levels, and Medical wastes (needles, sharps, bloody clothing).

Sewage Sludge, Animal carcasses, Wet garbage (food waste); and Friable asbestos

\section{REQUIRED: WASTE CONTENTS ALLOWABLE WASTES}

Check all allowable wastes that are contained within this load:

NOTE: Waste disposal at the Area 6 Hydrocarbon Landfill must have come into contact with petroleum hydrocarbons or coolants, such as: gasoline (no benzene, lead); jet fuel; diesel fuel; lubricants and hydraulics; kerosene; asphaltic petroleum hydrocarbon; and ethylene glycol.
Acceptable waste at any NTS landfill:
Asphalt $\bigotimes$ Metal
$\triangle$ Wood
$\triangle$ Paper
$凶$ Soil
$\square$ Rocks / unaltered geologic materials
$\triangle$ Rubber (excluding tires)
$\otimes$ Plastic $\square$ Wire
区 Cable
$凶$ Cloth
\Insulation (non-Asbestosform)

$\triangle$ Empty containers

Demolition debris

$\triangle$ Manufactured items: (swamp coolers, furniture, rugs, carpet, electronic components, PPE, etc.)

Additional waste accepted at the Area 23 Mercury Landfill: $\square$ Office Waste

$\square$ Asbestos

$\square$ Friable

Non-Friable (contact SWO if regulated load)

$\square$ Food Waste

$\bigotimes$ Cement \& concrete

Additional waste accepted at the Area 9 U10 c Landfill:

$\square$ Non-friable asbestos

Light ballasts (contact SWO)

Hydrocarbons (contact SWO)

$\square$ Drained

Drained fuel filters (gas \& diesel)

$\bigotimes$ Other Drained generators/equipment

Quantity:

Additional waste accepted at the Area 6 Hydrocarbon Landfill:
$\square$ Septic sludge
$\square$ Rags
$\square$ Drained fuel filters (gas \& diesel)
$\square$ Sludge from sand/oil/water separators REQUIRED: WASTE GENERATOR SIGNATURE
$\square$ Plants
Crushed non-teme plated oil filters PCBs below 50 parts per million

Solid fractions from sand/oil/water

Deconned Underground and Above Ground Tanks
Initials: (if initialed, no radiological clearance is necessary.) The above mentioned waste was generated outside of a Controlled Waste Management Area (CWMA) and to the best of my
knowledge, does not contain radiological materials.

To the best of my knowledge, the waste described above contains only those materials that are allowed for disposal at this site. I have verified this through the waste characterization method identified prohibited and allowable waste items. I have contacted Property Managemen is approved for disposal in the landfill.

Print Name: Dan Tobiason

Signature:
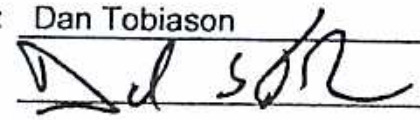

Note: "Food waste, office trash and animal carcasses do not require a radiolo must have signed removal certification statement with Load Verification

SWO USE ONLY

Load Weight (net from scale or estimate): $10-\psi-07$

Signature of Certifier: akn nhmus-mentioned 


\section{$\begin{array}{llllll}\text { SWO USE (Select One) } & \text { AREA } & \square 23 & \square 6 & \text { \9 } & \text { L LANDFILL }\end{array}$}

For waste characterization, approval, and/or assistance, contact Solid Waste Operation (SWO) at 5-7898.

\section{REQUIRED: WASTE GERERATOR INFORMATION}

(This form is for rolloffs, dump trucks, and other onsite disposal of materials.)

Waste Generator: Dan Tobiason

Phone Number: 295-6169

Location / Origin: T-Tunnel Lower Laydown Yard

Waste Category: (check one)

Waste Type: $\triangle$ NTS

(check one)

$\square$ Non-Putrescible

$\square$ Commercial

$\triangle$ Industrial

ags $10 / 9 / 07$

Pollution Prevention Category: (check one) $\square$ Environmental management

Pollution Prevention Category: (check one) $\otimes$ Clean-Up

Method of Characterization: (check one)

Sampling \& Analysis

$\triangle$ FFACO-onsite-

$\square$ WAC Exception

$\square$ FFACO-offsite

$\square$ Historic DOE/NV

Prohibited Waste at all three Radioactive waste; RCRA waste; Hazardous waste; Free liquids, PCBs above TSCA regulatory NTS landfills: levels, and Medical wastes (needles, sharps, bloody clothing).

Additional Prohibited Waste at the Area 9 U10C Landfill:

Sewage Sludge, Animal carcasses, Wet garbage (food waste); and Friable asbestos

\section{REQUIRED: WASTE CONTENTS ALLOWABLE WASTES}

Check all allowable wastes that are contained within this load:

NOTE: Waste disposal at the Area 6 Hydrocarbon Landfill must have come into contact with petroleum hydrocarbons or coolants, such as: gasoline (no benzene, lead); jet fuel; diesel fuel; lubricants and hydraulics; kerosene; asphaltic petroleum hydrocarbon; and ethylene glycol.

Acceptable waste at any NTS landfill: $\triangle$ Paper

Asphalt $\otimes$ Metal $\otimes$ Wood $\bigotimes$ Soil

$\square$ Rocks / unaltered geologic materials

$\bigotimes$ Empty containers

$\triangle$ Plastic $\quad$ Wire $\quad$ Cable $\quad$ Cloth

Q Rubber (excluding tires)

\Insulation (non-Asbestosform)

Demolition debris

$\triangle$ Manufactured items: (swamp coolers, furniture, rugs, carpet, electronic components, PPE, etc.)

Additional waste accepted at the Area 23 Mercury Landfill: $\square$ Office Waste $\square$ Food Waste $\square$ Animal Carcasses

$\square$ Asbestos $\square$ Friable $\quad \square$ Non-Friable (contact SWO if regulated load) Quantity:

Additional waste accepted at the Area 9 U10c Landfill:

$\square$ Non-friable asbestos $\quad \square$ Drained automobiles and military vehicles

$\square$ Light ballasts (contact SWO) $\square$ Drained fuel filters (gas \& diesel)

$\square$ Hydrocarbons (contact SWO) $\triangle$ Other Drained generators/equipment

$\square$ Solid fractions from sand/oil/water

$\triangle$ Deconned Underground and Above

Ground Tanks

Additional waste accepted at the Area 6 Hydrocarbon Landfill:
$\square$ Septic sludge
$\square$ Rags
$\square$ Drained fuel filters (gas \& diesel)
Crushed non-teme plated oil filters
Plants
Soil
$\square$ Sludge from sand/oil/water separators
$\square$ PCBs below 50 parts per million
REQUIRED: WASTE GENERATOR SIGNATURE

Initials: (if initialed, no radiological clearance is necessary.)

The above mentioned waste was generated outside of a Controlled Waste Management Area (CWMA) and to the best of my knowledge, does not contain radiological materials.

To the best of my knowledge, the waste described above contains only 1 site. I have verified this through the waste characterization method iden prohibited and allowable waste items. I have contacted Property Manag is approved for disposal in the landfill.

$$
10-6-0 T
$$

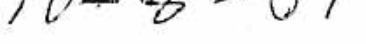

Print Name: Dan Tobiason

Signature:

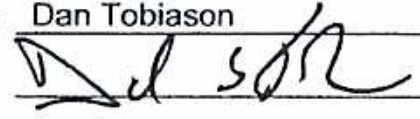

Note: "Food waste, office trash and animal carcasses do not require a ra Date: must have signed removal certification statement with Load Verificauvi.

\section{SWO USE ONLY}

Load Weight (net fron scale or ostimate): 42,500 Signature of Certifier: \begin{tabular}{l} 
Radiation Survey Release for Waste Disposal \\
RCT Initials \\
\hline DC This container/load is free of external radioactive \\
contamination. \\
This container/load is exempt from survey due to \\
process knowledge and origit. \\
This container/load is free of radioactive \\
contamination based on radioanalysis.
\end{tabular} BN-0646 (09/99) 


\begin{tabular}{|llllll}
\hline SWO USE (Select One) & AREA & $\square 23$ & $\square 6$ & (23 & L LANDFILL
\end{tabular}

For waste characterization, approval, and/or assistance, contact Solid Waste Operation (SWO) at 5-7898.

REQUIRED: WASTE GERERATOR INFORMATION

(This form is for rolloffs, dump trucks, and other onsite disposal of materials.)

Waste Generator: Dan Tobiason

Phone Number: 295-6169

Location / Origin: T-Tunnel Lower Laydown Yard

\begin{tabular}{|c|c|c|c|c|}
\hline \multicolumn{2}{|c|}{ Waste Category: (check one) } & \multirow{2}{*}{$\begin{array}{l}\square \text { Commercial } \\
\square \text { Putrescrible }\end{array}$} & \multicolumn{2}{|c|}{$\triangle$ Industrial \&5 10/9/07 } \\
\hline Waste Type: & $\triangle \mathrm{NTS}$ & & $\triangle F F A C Q$-Onsite & $\square$ WAC Exception \\
\hline (check one) & $\square$ Non-Putrescible & $\square$ Asbestos Containing Material & $\square$ FFACO-offsite & $\square$ Historic DOE/NV \\
\hline \multicolumn{2}{|c|}{ Pollution Prevention Category: (check one) } & $\square$ Environmental management & $\triangle$ Defense Projects & $\square$ YMP \\
\hline \multirow{2}{*}{\multicolumn{2}{|c|}{ Pollution Prevention Category: (check one) }} & $\triangle$ Clean-Up & $\square$ Routine & \\
\hline & Method of Characterization: (check one) & $\square$ Sampling \& & $\triangle$ Pro & ents \\
\hline
\end{tabular}

Prohibited Waste at all three Radioactive waste; RCRA waste; Hazardous waste; Free liquids, PCBs above TSCA regulatory NTS landfilis:

Additional Prohlbited Waste at the Area 9 U10C Landfill:

levels, and Medical wastes (needles, sharps, bloody clothing).

Sewage Sludge, Animal carcasses, Wet garbage (food waste); and Friable asbestos

\section{REQUIRED: WASTE CONTENTS ALLOWABLE WASTES}

Check all allowable wastes that are contained within this load:

NOTE: Waste disposal at the Area 6 Hydrocarbon Landfill must have come into contact with petroleum hydrocarbons or coolants, such as: gasoline (no benzene, lead); jet fuel; diesel fuel; lubricants and hydraulics; kerosene; asphaltic petroleum hydrocarbon; and ethylene glycol.

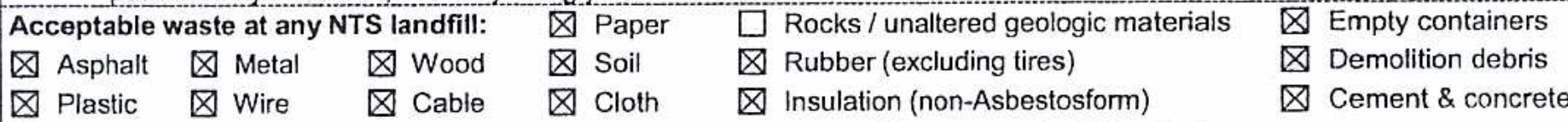
$\bigotimes$ Manufactured items: (swamp coolers, furniture, rugs, carpet, electronic components, PPE, etc.)

Additional waste accepted at the Area 23 Mercury Landfill: $\square$ Office Waste
$\square$ Asbestos
Friable
Non-Friable (contact SWO if regulated load)
Quantity:

Food Waste

Animal Carcasses

Additional waste accepted at the Area 9 U10c Landfill:
$\square$ Non-friable asbestos
$\square$ Drained automobiles and military vehicles
$\square$ Light ballasts (contact SWO)
$\square$ Drained fuel filters (gas \& diesel)
Hydrocarbons (contact SWO)
Other Drained generators/equipment

Solid fractions from sandioil/water

$\bigotimes$ Deconned Underground and Above

Ground Tanks

Additional waste accepted at the Area 6 Hydrocarbon Landfill:

$\begin{array}{lll}\square \text { Septic sludge } & \square \text { Rags } \quad \square \text { Drained fuel filters (gas \& diesel) } \\ \square \text { Plants } & \square \text { Soil } & \square \text { Sludge from sand/oil/water separators }\end{array}$

Initials: (if initialed, no radiological clearance is necessary.)

The above mentioned waste was generated outside of a Controlled Waste Management Area (CWMA) and to the best of my knowledge, does not contain radiological materials.

To the best of my knowledge, the waste described above contains only the site. I have verified this through the waste characterization method identif prohibited and allowable waste Items. I have contacted Property Managem is approved for disposal in the landflll.

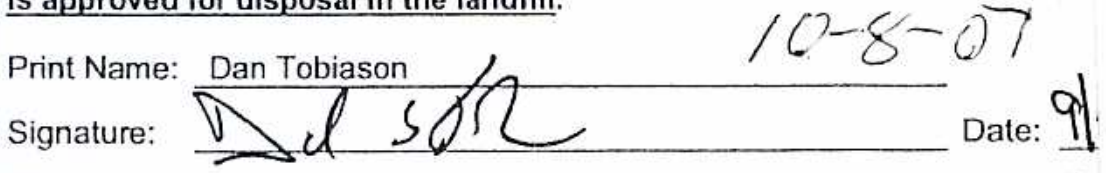

Radiation Survey Release for Waste Disposal RCT Initials

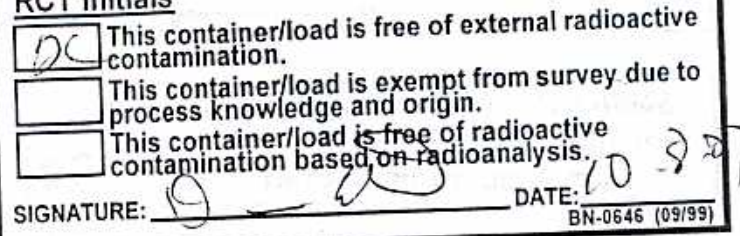

Note: "Food waste, office trash and animal carcasses do not require a radio must have signed removal certification statement with Load Verificatic...

\section{SWO USE ONLY}

Load Weight (net from scole of (estimate) $L, 17,(27)$
$10-8-07$ 


\begin{tabular}{|llllll}
\hline SWO USE (Select One) & AREA & $\square 23$ & $\square 6$ & 23 & Q LANDFILL
\end{tabular}

For waste characterization, approval, and/or assistance, contact Solid Waste Operation (SWO) at 5-7898.

REQUIRED: WASTE GERERATOR INFORMATION

(This form is for rolloffs, dump trucks, and other onsite disposal of materials.)

Waste Generator: Dan Tobiason

Phone Number: 295-6169

Location / Origin: T-Tunnel Lower Laydown Yard

Waste Category: (check one)

Waste Type: $\triangle$ NTS $\square$ Putrescrible

(check one) $\quad \square$ Non-Putrescible $\quad \square$ Asbestos Containing Material

Pollution Prevention Category: (check one)

$\square$ Environmental management

Pollution Prevention Category: (check one)

$\otimes$ Clean-Up

Method of Characterization: (check one)

Sampling \& Analysis

$\triangle$ Industrial 85 10/9/07

$\triangle$ FFACO-Ongite $\square$ WAC Exception

Prohibited Waste at all three Radioactive waste; RCRA waste; Hazardous waste; Free liquids, PCBs above TSCA regulatory NTS landfills:

Additional Prohibited Waste

at the Area 9 U10C Landfill:

levels, and Medical wastes (needles, sharps, bloody clothing).

Sewage Sludge, Animal carcasses, Wet garbage (food waste); and Friable asbestos

REQUIRED: WASTE CONTENTS ALLOWABLE WASTES

Check all allowable wastes that are contained within this load:

NOTE: Waste disposal at the Area 6 Hydrocarbon Landfill must have come into contact with petroleum hydrocarbons or coolants, such as: gasoline (no benzene, lead); jet fuel; diesel fuel; lubricants and hydraulics; kerosene; asphaltic petroleum hydrocarbon; and ethylene glycol.
Acceptable waste at any NTS landfill:
$\bigotimes$ Paper
$\square$ Rocks / unaltered geologic materials
$\bigotimes$ Empty containers
Asphalt $\otimes$ Metal
Q Wood
$\otimes$ Soil
Q Rubber (excluding tires)
Demolition debris
Plastic
Q Wire
Q Cable
$\triangle$ Cloth
\Insulation (non-Asbestosform)
凶 Cement \& concrete

$\triangle$ Manufactured items: (swamp coolers, furniture, rugs, carpet, electronic components, PPE, etc.)

Additional waste accepted at the Area 23 Mercury Landfill: $\square$ Office Waste

$\square$ Asbestos $\quad \square$ Friable $\quad \square$ Non-Friable (contact SWO if regulated load)

$\square$ Food Waste

Animal Carcasses

Additional waste accepted at the Area 9 U10c Landfill:
$\square$ Non-friable asbestos
$\square$ Drained automobiles and military vehicles
$\square$ Light ballasts (contact SWO)
Drained fuel filters (gas \& diesel)
$\square$ Hydrocarbons (contact SWO)
$\otimes$ Other Drained generators/equipment
Solid fractions from sand/oil/water
$\otimes$ Deconned Underground and Above
Ground Tanks

Quantity:

Additional waste accepted at the Area 6 Hydrocarbon Landfill:
$\square$ Septic sludge
$\square$ Rags
$\square$ Drained fuel filters (gas \& diesel)
Crushed non-teme plated oil filters
Plants
Soil
$\square$ Sludge from sand/oil/water separators
REQUIRED: WASTE GENERATOR SIGNATURE
PCBs below 50 parts per million

Initials: (if initialed, no radiological clearance is necessary.)

The above mentioned waste was generated outside of a Controlled Waste Management Area (CWMA) and to the best of my knowledge, does not contain radiological materials.

To the best of my knowledge, the waste described above contains only those materials that are allowed for disposal at this site. I have verified this through the waste characterization method identified - L.... mad a maviau of the above-mentioned prohibited and allowable waste items. I have contacted Property Management is approved for disposal in the landfill.

Print Name: Dan Tobiason

Signature: $\mathrm{N}$ SQl Date: 194

Note: "Food waste, office trash and animal carcasses do not require a radiolos must have signed removal certification statement with Load Verification.

SWO USE ONLY

Load Weight (net from scale or estimate): $42,802 \begin{gathered}10-8-07 \\ \text { Signature of Certifier: }\end{gathered}$

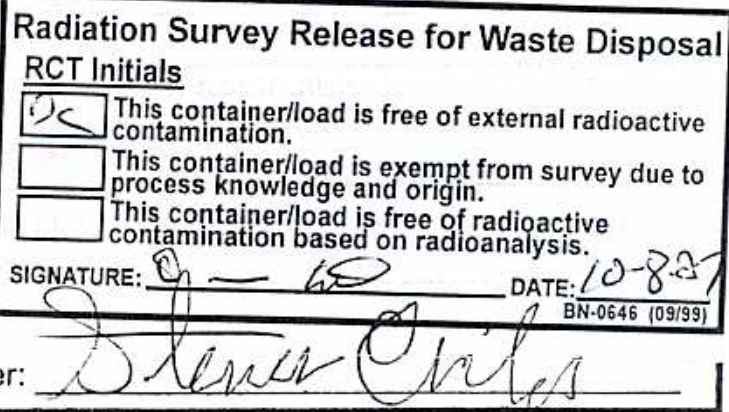




\begin{tabular}{llllll}
\hline SWO USE (Select One) & AREA & $\square 23$ & $\square 6$ & 23 & $\square$ LANDFILL
\end{tabular}

For waste characterization, approval, and/or assistance, contact Solid Waste Operation (SWO) at 5-7898.

REQUIRED: WASTE GERERATOR INFORMATION

(This form is for rolloffs, dump trucks, and other onsite disposal of materials.)

Waste Generator: Dan Tobiason

Phone Number: 295-6169

Location / Origin: T-Tunnel Lower Laydown Yard

Waste Category: (check one)

Waste Type: $\bigotimes$ NTS

$\square$ Commercial

$\triangle$ Industrial $8510 / 9 / 07$

(check one)

$\square$ Non-Putrescible

$\square$ Putrescrible

Q-FFACO-OASite

WAC Exception

Pollution Prevention Category: (check one)

Asbestos Containing Material

$\square$ FFACO-offsite

Pollution Prevention Category: (check one)

$\square$ Environmental management

$\bigotimes$ Defense Projects

$\square$ Historic DOE/NV

Method of Characterization: (check one)

$\triangle$ Clean-Up

Prohibited Waste at all three Radioactive waste; RCRA waste; Hazardous waste; Free liquids, PCBs above TSCA regulatory

NTS landfilis:

Additional Prohibited Waste

at the Area 9 U10C Landfill:

levels, and Medical wastes (needles, sharps, bloody clothing).

Sewage Sludge, Animal carcasses, Wet garbage (food waste); and Friable asbestos

\section{REQUIRED: WASTE CONTENTS ALLOWABLE WASTES}

Check all allowable wastes that are contained within this load:

NOTE: Waste disposal at the Area 6 Hydrocarbon Landfill must have come into contact with petroleurn hydrocarbons or coolants, such as: gasoline (no benzene, lead); jet fuel; diesel fuel; lubricants and hydraulics; kerosene; asphaltic petroleum hydrocarbon; and ethylene glycol.
Acceptable waste at any NTS landfill:
$\triangle$ Paper
$\square$ Rocks / unaltered geologic materials
$\bigotimes$ Empty containers
$\triangle$ Asphalt
$\bigotimes$ Metal
$\triangle$ Wood
\Soil
$\triangle$ Rubber (excluding tires)
$\bigotimes$ Plastic $\square$ Wire
$\bigotimes$ Cable
$\bigotimes$ Cloth
$\bigotimes$ Insulation (non-Asbestosform)
$\bigotimes$ Demolition debris

$\triangle$ Manufactured items: (swamp coolers, furniture, rugs, carpet, electronic components, PPE, etc.)
Additional waste accepted at the Area 23 Mercury Landfill: $\quad \square$ Office Waste
Food Waste
Animal Carcasses
$\square$ Asbestos
Friable
$\square$ Non-Friable (contact SWO if regulated load)
Quantity:

\section{Additional waste accepted at the Area 9 U10c Landfill:}

$\square$ Non-friable asbestos

$\square$ Light ballasts (contact SWO)

$\square$ Drained automobiles and military vehicles

$\square$ Drained fuel filters (gas \& diesel)

Hydrocarbons (contact SWO)

Other

Drained generators/equipment
Solid fractions from sand/oil/water

$\bigotimes$ Deconned Underground and Above Ground Tanks

Additional waste accepted at the Area 6 Hydrocarbon Landfill:

$\square$ Septic sludge $\square$ Rags
$\square$ Plants $\quad \square$ Soil

$\square$ Drained fuel filters (gas \& diesel)

Crushed non-teme plated oil filters

$\square$ Sludge from sand/oil/water separators PCBs below 50 parts per million

Initials: (if initialed, no radiological clearance is necessary.)

The above mentioned waste was generated outside of a Controlled Waste Management Area (CWMA) and to the best of my knowledge, does not contain radiological materials.

To the best of my knowledge, the waste described above contains only those materials that are allowed for disposal at this site. I have verified this through the waste characterization method identified above and a review of the above-mentioned prohibited and allowable waste Items. I have contacted Property Manage is approved for disposal in the landfill.

Print Name: Dan Tobiason

Signature:

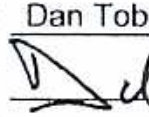

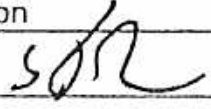$$
10-8 \rightarrow 0
$$

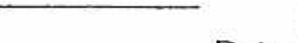

Note: "Food waste, office trash and animal carcasses do not require a ra must have signed removal Cerification statement with Load Verific SWO USE ONLY

Load Weight (net from scale of estimate): 8,602
$10-8-07$

Signature of Certifier:
Radiation Survey Release for Waste Disposal RTh Initials 2 This container/load is free of external radioactive This container/load is exempt from survey due to
process knowledge and origin This container/lge and origin. contamination bas is free of radioactive SIGNATURE: DATE: $10-807$ BN.0646 $109 / 99$ 


$\begin{array}{lllllll}\text { SWO USE (Select One) } & \text { AREA } & \square 23 & \square 6 & \square 9 & \text { Q LANDFILL }\end{array}$

For waste characterization, approval, and/or assistance, contact Solid Waste Operation (SWO) at 5-7898.

REQUIRED: WASTE GERERATOR INFORMATION

(This form is for rolloffs, dump trucks, and other onsite disposal of materials.)

Waste Generator: Dan Tobiason

Phone Number: 295-6169

Location / Origin: T-Tunnel Lower Laydown Yard

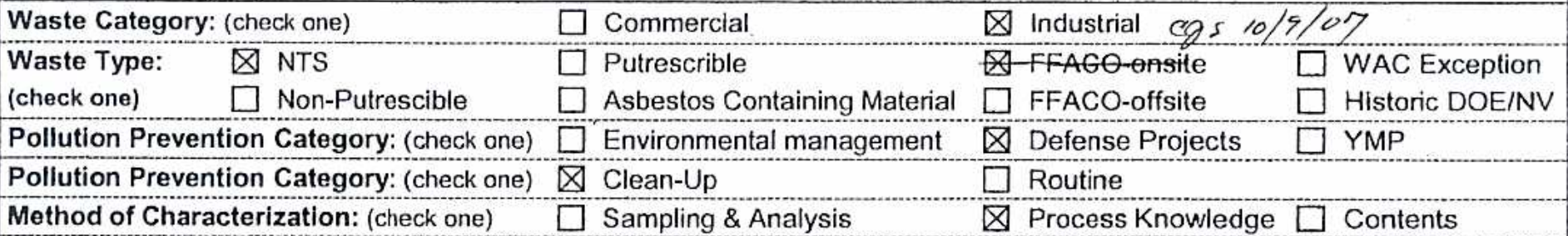

Prohibited Waste at all three Radioactive waste; RCRA waste; Hazardous waste; Free liquids, PCBs above TSCA regulatory NTS landfills:

Additional Prohibited Waste

at the Area 9 U10C Landfill:

levels, and Medical wastes (needles, sharps, bloody clothing).

Sewage Sludge, Animal carcasses, Wet garbage (food waste); and Friable asbestos

\section{REQUIRED: WASTE CONTENTS ALLOWABLE WASTES}

Check all allowable wastes that are contained within this load:

NOTE: Waste disposal at the Area 6 Hydrocarbon Landfill must have come into contact with petroleum hydrocarbons or coolants, such as: gasoline (no benzene, lead); jet fuel; diesel fuel; lubricants and hydraulics; kerosene; asphaltic petroleum hydrocarbon; and ethylene glycol.
Acceptable waste at any NTS landfill
Paper
$\square$ Rocks / unaltered geologic materials
$\bigotimes$ Empty containers
$\bigotimes$ Asphal
$\bigotimes$ Metal
$\bigotimes$ Wood
$凶$ Soil
$\otimes$ Rubber (excluding tires)
$\otimes$ Cloth
Insulation (non-Asbestosform)
$\bigotimes$ Demolition debris
$\triangle$ Plastic
$\bigotimes$ Cable
$\bigotimes$ Cement \& concrete

$\bigotimes$ Manufactured items: (swamp coolers, furniture, rugs, carpet, electronic components, PPE, etc.)
Additional waste accepted at the Area 23 Mercury Landfill: $\square$ Office Waste
Food Waste
Animal Carcasses
Asbestos
Friable
$\square$ Non-Friable (contact SWO if regulated load)
Quantity:

Additional waste accepted at the Area 9 U10c Landfill:
$\square$ Non-friable asbestos
Drained automobiles and military vehicles
$\square$ Light ballasts (contact SWO)
$\square$ Drained fuel filters (gas \& diesel)
$\bigotimes$ Other Drained generators/equipment
$\square$ Hydrocarbons (contact SWO)

Solid fractions from sand/oil/water

ydrocarbon Landfill:

Additional waste accepted at the Area 6 Hydrocarbon
$\square$ Septic sludge
$\square$ Rags
$\square$ Drained fuel filters (gas \& diesel)
Plants
Soil
$\square$ Sludge from sand/oil/water separators

\section{REQUIRED: WASTE GENERATOR SIGNATURE}
Crushed non-teme plated oil filters PCBs below 50 parts per million

$\bigotimes$ Deconned Underground and Above Ground Tanks

Initials : (if initialed, no radiological clearance is necessary.)

The above mentioned waste was generated outside of a Controlled Waste Management Area (CWMA) and to the best of my knowledge, does not contain radiological materials.

To the best of my knowledge, the waste described above contains only those materials that are allowed for disposal at this site. I have verified this through the waste characterization method identified above and a review of the above-mans:-

prohibited and allowable waste Items. I have contacted Property Management and have verifiod $\mathrm{AL}$.

is approved for disposal in the landfill.

Print Name: Dan Tobiason

Signature:
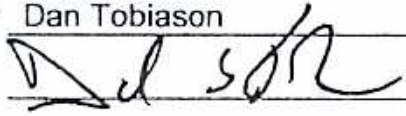

Date: $9|24|$

Note: "Food waste, office trash and animal carcasses do not require a radiologica must have signed removal certification statement with Load Verification."

\section{SWO USE ONLY}

Load Weight (net from scale or estimate)

Signature of Certifier:

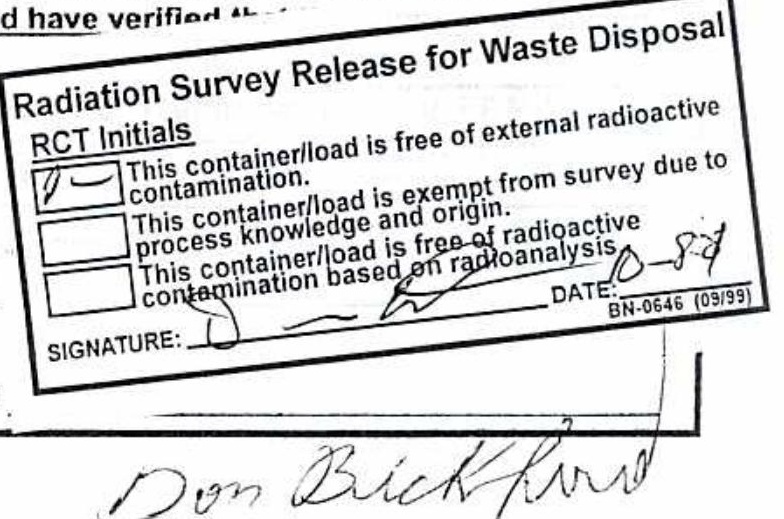




\begin{tabular}{llllll}
\hline SWO USE (Select One) & AREA & $\square 23$ & $\square 6$ & 23 & (SANDFILL
\end{tabular}

For waste characterization, approval, and/or assistance, contact Solid Waste Operation (SWO) at 5-7898.

REQUIRED: WASTE GERERATOR INFORMATION

(This form is for rolloffs, dump trucks, and other onsite disposal of materials.)

Waste Generator: Dan Tobiason

Phone Number: 295-6169

Location / Origin: T-Tunnel Lower Laydown Yard

Waste Category: (check one)

Waste Type: $\triangle$ NTS

$\square$ Commercial

$\triangle$ Industrial cos 10/10/07

(check one)

$\square$ Non-Putrescible

$\square$ Putrescrible

A-FFAGO-OAsite

WAC Exception

Pollution Prevention Category: (check one)

$\square$ Asbestos Containing Material

$\square$ FFACO-offsite

$\square$ Historic DOE/NV

Pollution Prevention Category: (check one)

Environmental management

$\triangle$ Defense Projects

YMP

Method of Characterization: (check one)

$\square$ Sampling \& Analysis

$\square$ Routine

Prohibited Waste at all three Radioactive waste; RCRA waste; Hazardous waste; Free liquids, PCBs above TSCA regulatory

NTS landfills:

Additional Prohibited Waste

at the Area 9 U10C Landfill:

levels, and Medical wastes (needles, sharps, bloody clothing).

Sewage Sludge, Animal carcasses, Wet garbage (food waste); and Friable asbestos

\section{REQUIRED: WASTE CONTENTS ALLOWABLE WASTES}

Check all allowable wastes that are contained within this load:

NOTE: Waste disposal at the Area 6 Hydrocarbon Landfill must have come into contact with petroleurn hydrocarbons or coolants, such as: gasoline (no benzene, lead); jet fuel; diesel fuel; lubricants and hydraulics; kerosene; asphaltic petroleum hydrocarbon; and ethylene glycol.
Acceptable waste at any NTS landfill:
$\bigotimes$ Paper
$\square$ Rocks / unaltered geologic materials
$\bigotimes$ Empty containers
$\triangle$ Asphalt $\quad$ Metal $\quad$ Wood $\quad$ Soil
区 Rubber (excluding tires)
$\triangle$ Plastic $\quad$ Wire
$\bigotimes$ Cable
$\triangle$ Cloth
$\bigotimes$ Insulation (non-Asbestosform)
$\bigotimes$ Demolition debris

$\triangle$ Manufactured items: (swamp coolers, fumiture, rugs, carpet, electronic components, PPE, etc.)
Additional waste accepted at the Area 23 Mercury Landfill: $\square$ Office Waste
Food Waste
Animal Carcasses
Asbestos
Friable
$\square$ Non-Friable (contact SWO if regulated load)
Quantity:

\section{Additional waste accepted at the Area 9 U10c Landfill:}

$\square$ Light ballasts (contact SwO)

$\square$ Drained automobiles and military vehicles

$\square$ Drained fuel filters (gas \& diesel)

Hydrocarbons (contact SWO)

$\triangle$ Other

Drained generators/equipment
Solid fractions from sand/oil/water

$\bigotimes$ Deconned Underground and Above Ground Tanks

Additional waste accepted at the Area 6 Hydrocarbon Landfill:

$\square$ Ser

$\begin{array}{ll}\text { Septic sludge } & \square \text { Rags } \\ \text { Plants } & \square \text { Soil }\end{array}$

$\square$ Drained fuel filters (gas \& diesel)

Crushed non-teme plated oil filters

$\square$ Sludge from sand/oil/water separators

$\square$ PCBs below 50 parts per million

Initials: (if initialed, no radiological clearance is necessary.)

The above mentioned waste was generated outside of a Controlled Waste Management Area (CWMA) and to the best of my knowledge, does not contain radiological materials.

To the best of my knowledge, the waste described above contains only those materiale that are allnwarl fan dienneal at thie site. I have verified this through the waste characterization method identified ab prohibited and allowable waste Items. I have contacted Property Management al is approved for disposal in the landfill.

Print Name: Dan Tobiason

Signature:
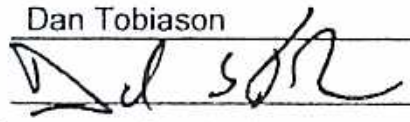

Date: $9|24| 1$

Note: "Food waste, office trash and animal carcasses do not require a radiologicé must have signed removal certification statement with Load Verification."

SWO USE ONLY

Load Weight (net from scale or estimate) 20,000
Radiation Survey Release for Waste Disposal RCT Initials

This container/load is free of external radioactive contamination.

This container/load is exempt from survey due to process knowledge and origin.

This container/load is free of radioactive contamination based on radioanalysis.

SIGNATURE: 8 DATE:D-9ə?
$10 \cdot 10-0.1$

Signature of Certifier: 


\section{SWO USE (Select One) $\quad$ AREA $\quad \square 23 \quad \square 6 \quad \square 90 \quad$ LANDFILL}

For waste characterization, approval, and/or assistance, contact Solid Waste Operation (SWO) at 5-7898. REQUIRED: WASTE GERERATOR INFORMATION

(This form is for rolloffs, dump trucks, and other onsite disposal of materials.)

Waste Generator: Dan Tobiason

Phone Number: 295-6169

Location / Origin: T-Tunnel Lower Laydown Yard

Waste Category: (check one)

Waste Type: $\triangle$ NTS

(check one)

Non-Putrescible ollution Prevention Category: (check one)

Pollution Prevention Category: (check one)

Method of Characterization: (check one)

Prohibited Waste at all three

NTS landfills:

Additional Prohlbited Waste

at the Area 9 U10C Landfill:

\section{levels, and Medical wastes (needles, sharps, bloody clothing).}

Sewage Sludge, Animal carcasses, Wet garbage (food waste); and Friable asbestos

\section{REQUIRED: WASTE CONTENTS ALLOWABLE WASTES}

Check all allowable wastes that are contained within this load:

NOTE: Waste disposal at the Area 6 Hydrocarbon Landfill must have come into contact with petroleum hydrocarbons or coolants, such as: gasoline (no benzene, lead); jet fuel; diesel fuel; lubricants and hydraulics; kerosene; asphaltic petroleum hydrocarbon; and ethylene glycol.

Acceptable waste at any NTS landfill $\square$ Paper $\square$ Rocks / unaltered geologic materials

$\triangle$ Asphalt $\quad$ Metal $\quad$ Wood $\quad$ Soil $\quad \square$ Rubber (excluding tires)

$\triangle$ Plastic $\quad$ Wire $\quad$ Cable $\quad$ Cloth $\quad \square$ insulation (non-Asbestosform)

$\triangle$ Empty containers

$\bigotimes$ Demolition debris

Q Manufactured items: (swamp coolers, furniture, rugs, carpet, electronic components, PPE, etc.)
Additional waste accepted at the Area 23 Mercury Landfill:
$\square$ Office Waste
$\square$ Food Waste
$\square$ Asbestos
Friable
$\square$ Non-Friable (contact SWO if regulated load)
Quantity:

$\bigotimes$ Cement \& concrete

Additional waste accepted at the Area 9 U10c Landfill:
$\square$ Non-friable asbestos
Drained automobiles and military vehicles
$\square$ Light ballasts (contact SWO)
Drained fuel filters (gas \& diesel)
Hydrocarbons (contact SWO)
Other Drained generators/equipment

Solid fractions from sand/oil/water

$\bigotimes$ Deconned Underground and Above

Ground Tanks

Additional waste accepted at the Area 6 Hydrocarbon Landfill:
$\square$ Septic sludge
$\square$ Rags
$\square$ Drained fuel filters (gas \& diesel)
Plants
Soil
$\square$ Sludge from sand/oil/water separators
REQUIRED: WASTE GENERATOR SIGNATURE
Crushed non-teme plated oil filters
PCBs below 50 parts per million

Initials (if initialed, no radiological clearance is necessary.)

The above mentioned waste was generated outside of a Controlled Waste Management Area (CWMA) and to the best of my knowledge, does not contain radiological materials.

To the best of my knowledge, the waste described above contains only tho site. I have verified this through the waste characterization method identifi prohibited and allowable waste items. I have contacted Property Manager is approved for disposal in the landfill.

Print Name: Dan Tobiason

Signature:
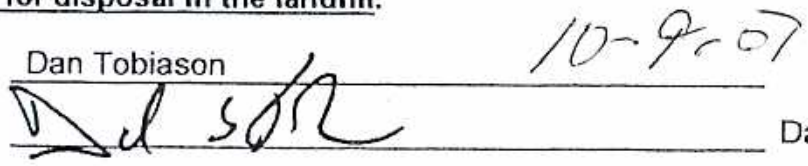

Note: "Food waste, office trash and animal carcasses do not require a rad. must have signed removal certification statement with Load Verification."

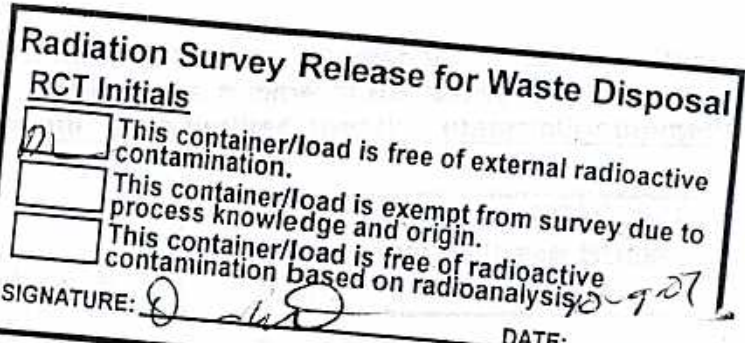
DATE; inances

\section{SWO USE ONLY}

$10-10-07$

Signature of Certifier: 
NSTec

Form

\section{SWO USE (Select One) AREA $\square 23 \quad \square 6 \quad \square 9 \quad \square$ LANDFILL}

For waste characterization, approval, and/or assistance, contact Solid Waste Operation (SWO) at 5-7898.

\section{REQUIRED: WASTE GERERATOR INFORMATION}

(This form is for rolloffs, dump trucks, and other onsite disposal of materials.)

Waste Generator: Dan Tobiason

Phone Number: 295-6169

\section{Location / Origin: T-Tunnel Lower Laydown Yard}

Waste Category: (check one)

$\square$ Putrescrible

$\triangle$ Industrial COS $10 / 10 / 07$

(check one)

$\triangle N T S$

$\square$ Asbestos Containing Material

Z-FFAGO-OASile

$\square$ WAC Exception

Pollution Prevention Category: (check one)

Environmental management

FFACO-offsite

$\square$ Historic DOE/NV

Pollution Prevention Category: (check one)

$\otimes$ Clean-Up

Method of Characterization: (check one)

Sampling \& Analysis

$\triangle$ Defense Projects

YMP

Prohibited Waste at all three Radioactive waste; RCRA waste; Hazardous waste; Free liquids, PCBs above TSCA regulatory

NTS landfills:

Additional Prohlbited Waste

at the Area 9 U10C Landfill:

levels, and Medical wastes (needles, sharps, bloody clothing).

Sewage Sludge, Animal carcasses, Wet garbage (food waste); and Friable asbestos

\section{REQUIRED: WASTE CONTENTS ALLOWABLE WASTES}

Check all allowable wastes that are contained within this load:

NOTE: Waste disposal at the Area 6 Hydrocarbon Landfill must have come into contact with petroleum hydrocarbons or coolants, such as: gasoline (no benzene, lead); jet fuel; diesel fuel; lubricants and hydraulics; kerosene; asphaltic petroleum hydrocarbon; and ethylene glycol.
Acceptable waste at any NTS landfill:
Paper
$\square$ Rocks / unaltered geologic materials
$\triangle$ Empty containers
Q Asphalt
$\otimes$ Metal
$\triangle$ Wood
$凶$ Soil
$\triangle$ Rubber (excluding tires)
$\triangle$ Plastic $\triangle$ Wire
Cable
$\triangle$ Cloth
$\triangle$ Insulation (non-Asbestosform)
$\bigotimes$ Demolition debris

$\triangle$ Manufactured items: (swamp coolers, furniture, rugs, carpet, electronic components, PPE, etc.)
Additional waste accepted at the Area 23 Mercury Landfill:
Office Waste
$\square$ Food Waste
Animal Carcasses
Asbestos $\square$ Friable
$\square$ Non-Friable (contact SWO if regulated load)
Quantity:

\section{Additional waste accepted at the Area 9 U10c Landfill:}
$\square$ Non-friable asbestos
Light ballasts (contact SWO)
Drained automobiles and military vehicles
Hydrocarbons (contact SWO)
Drained fuel filters (gas \& diesel)

Solid fractions from sand/oil/water

$\triangle$ Deconned Underground and Above

Ground Tanks

\section{Additional waste accepted at the Area 6 Hydrocarbon Landfill:}
$\square$ Septic sludge
$\square$ Rags
$\square$ Drained fuel filters (gas \& diesel)
Plants
Soil
$\square$ Sludge from sand/oil/water separators
$\square$ Crushed non-teme plated oil filters
REQUIRED: WASTE GENERATOR SIGNATURE

Initials: (if initialed, no radiological clearance is necessary.)

The above mentioned waste was generated outside of a Controlled Waste Management Area (CWMA) and to the best of my knowledge, does not contain radiological materials.

To the best of my knowledge, the waste described above contains only th site. I have verified this through the waste characterization method identi prohibited and allowable waste Items. I have contacted Property Manage is approved for disposal in the landfill.

$$
10-9-07
$$

Print Name: Dan Tobiason

Signature:

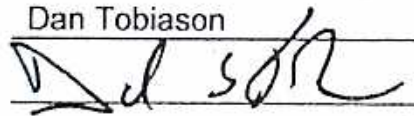

Date: 9

Radiation Survey Release for Waste Disposal RCT Initials

DC This container/load is free of external radioactive contamination.

This container/load is exempt from survey due to process knowledge and origin.

This container/load is free of radioactive contamination based on radioanalysis.

SIGNATURE: $1 \%$ DATE: $\frac{0.27}{\mathrm{~N}-0646 \text { (09) }}$

Note: "Food waste, office trash and animal carcasses do not require a rad must have signed removal certification statement with Load Verificatun.

\section{SWO USE ONLY}

Load Weight (net from scale or estimate):
$10-10-07$

Signature of Certifier: 
NSTec

$08 / 23 / 06$

Form

Rev. 0

FRM-0918

NTS LANDFILL LOAD VERIFICATION

Page 1 of 2

\begin{tabular}{|llllll}
\hline SWO USE (Select One) & AREA & $\square 23$ & $\square 6$ & $\square 9$ & $\square$ LANDFILL
\end{tabular}

For waste characterization, approval, and/or assistance, contact Solid Waste Operation (SWO) at 5-7898.

REQUIRED: WASTE GERERATOR INFORMATION

(This form is for rolloffs, dump trucks, and other onsite disposal of materials.)

Waste Generator: Dan Tobiason

Phone Number: 295-6169

Localion / Origin: T-Tunnel Lower Laydown Yard

Waste Category: (check one)

Waste Type: $\triangle$ NTS

(check one) $\quad \square$ Non-Putrescible

$\square$ Commercial

$\triangle$ Industrial QS $10 / 10 / 07$

$\square$ Putrescrible

A-FFAGQ-onsite

$\square$ WAC Exception

$\square$ Asbestos Containing Material

$\square$ FFACO-offsite

$\square$ Historic DOE/NV

Pollution Prevention Category: (check one) $\square$ Environmental management

Pollution Prevention Category: (check one) $\bigotimes$ Clean-Up

Method of Characterization: (check one)

Sampling \& Analysis

$\triangle$ Defense Projects

YMP

Prohibited Waste at all three

NTS landfills:

Additional Prohlbited Waste

at the Area 9 U10C Landfill:

Radioactive waste; RCRA waste; Hazardous waste; Free liquids, PCBs above TSCA regulatory levels, and Medical wastes (needles, sharps, bloody clothing).

Sewage Sludge, Animal carcasses, Wet garbage (food waste); and Friable asbestos

\section{REQUIRED: WASTE CONTENTS ALLOWABLE WASTES}

Check all allowable wastes that are contained within this load:

NOTE: Waste disposal at the Area 6 Hydrocarbon Landfill must have come into contact with petroleum hydrocarbons or coolants, such as: gasoline (no benzene, lead); jet fuel; diesel fuel; lubricants and hydraulics; kerosene; asphaltic petroleum hydrocarbon; and ethylene glycol.

Acceptable waste at any NTS landfill: $\triangle$ Paper
Asphalt $\otimes$ Metal
$\triangle$ Wood
$\otimes$ Soil
$\bigotimes$ Rubber (excluding tires)
$\triangle$ Plastic $\quad$ Wire
$\triangle$ Cable
$\triangle$ Cloth
$\triangle$ Insulation (non-Asbestosform)

$\square$ Rocks / unaltered geologic materials

区mpty containers

$\bigotimes$ Demolition debris

$\bigotimes$ Cement \& concrete

Manufactured items: (swamp coolers, furniture, rugs, carpet, electronic components, PPE, etc.)

Additional waste accepted at the Area 23 Mercury Landfill: $\square$ Office Waste $\square$ Food Waste

Animal Carcasses
$\square$ Asbestos
Friable
$\square$ Non-Friable (contact SWO if regulated load)
Quantity:

Additional waste accepted at the Area 9 U10c Landfill:

$\begin{array}{ll}\square \text { Non-friable asbestos } & \square \text { Drained automobiles and military vehicles } \\ \square \text { Light ballasts (contact SWO) } \\ \square \text { Drained fuel filters (gas \& diesel) }\end{array}$

Hydrocarbons (contact SWO) $\bigotimes$ Other Drained generators/equipment

Solid fractions from sand/oil/water

$\otimes$ Deconned Underground and Above

Ground Tanks

Additional waste accepted at the Area 6 Hydrocarbon Landfill:
$\square$ Septic sludge
$\square$ Rags
$\square$ Drained fuel filters (gas \& diesel)
Plants
Soil
$\square$ Sludge from sand/oil/water separators
REQUIRED: WASTE GENERATOR SIGNATURE
Crushed non-teme plated oil filters PCBs below 50 parts per million

Initials: (if initialed, no radiological clearance is necessary.)

The above mentioned waste was generated outside of a Controlled Waste Management Area (CWMA) and to the best of my knowledge, does not contain radiological materials.

To the best of my knowledge, the waste described above contains only those materials that are allowed for disposal at this site. I have verified this through the waste characterization method identified abovo and n ..................

prohibited and allowable waste Items. I have contacted Property Management and is approved for disposal in the landfill.

Print Name: Dan Tobiason

Signature:

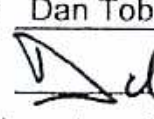

$\int S$

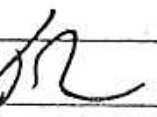

Date: 9|24|07

Note: "Food waste, office trash and animal carcasses do not require a radiological $\mathrm{cl}$ must have signed removal certification statement with Load Verification."

SWO USE ONLY
Load Weight (net from scale or estimate):

$10 \cdot 10 \cdot 07$

Signature of Certifier:
Radiation Survey Release for Waste Disposal RCT Initials

This containerlload is free of external radioactive
contamination.
This container/load is exempt from survey due to
process knowledge and origin.
This container/load is free of radioactive
contamination based on radioanalysis.



REQUIRED: WASTE GERERATOR INFORMATION

(This form is for rolloffs, dump trucks, and other onsite disposal of materials.)

Waste Generator: Dan Tobiason Phone Number: 295-6169

Location / Origin: T-Tunnel Lower Laydown Yard

Waste Category: (check one)

Waste Type: $\triangle$ NTS

(check one)

$\square$ Non-Putrescible

Pollution Prevention Category: (check one)

Pollution Prevention Category: (check one)

Method of Characterization: (check one)

$\square$ Commercial

$\square$ Putrescrible

$\square$ Asbestos Containing Material

$\square$ Environmental management

$\triangle$ Clean-Up

$\square$ Sampling \& Analysis

Prohibited Waste at all three Radioactive waste; RCRA waste; Hazardous waste; Free liquids, PCBs above TSCA regulator NTS landfills:

Additional Prohibited Waste at the Area 9 U10C Landfill:

$\triangle$ Industrial gas $10 / 10 / 07$

Z-FFAGQ-OAsite

FFACO-offsite

$\triangle$ Defense Projects

$\square$ Routine

$\triangle$ Process Knowledge $\square$ Contents levels, and Medical wastes (needles, sharps, bloody clothing).

Sewage Sludge, Animal carcasses, Wet garbage (food waste); and Friable asbestos

\section{REQUIRED: WASTE CONTENTS ALLOWABLE WASTES}

Check all allowable wastes that are contained within this load:

NOTE: Waste disposal at the Area 6 Hydrocarbon Landfill must have come into contact with petroleurn hydrocarbons or coolants, such as: gasoline (no benzene, lead); jet fuel; diesel fuel; lubricants and hydraulics; kerosene; asphaltic petroleum hydrocarbon; and ethylene glycol.

Acceptable waste at any NTS landfill: $\mathrm{Paper}$

Asphalt $\quad$ Metal $\quad$ Wood $\quad$ Soil

$\triangle$ Plastic $\quad$ Wire $\quad$ Cable $\quad$ Cloth

$\square$ Rocks / unaltered geologic materials

$\bigotimes$ Rubber (excluding tires)

\Insulation (non-Asbestosform)

$\triangle$ Empty containers

Demolition debris

$\bigotimes$ Cement \& concrete

$\triangle$ Manufactured items: (swamp coolers, furniture, rugs, carpet, electronic components, PPE, etc.)

Additional waste accepted at the Area 23 Mercury Landfill: $\square$ Office Waste

$\square$ Asbestos $\quad \square$ Friable $\quad \square$ Non-Friable (contact SWO if regulated load)

$\square$ Food Waste

Animal Carcasses

Additional waste accepted at the Area 9 U10c Landfill:

$\square$ Non-friable asbestos

$\square$ Drained automobiles and military vehicles

Quantity:

$\square$ Light ballasts (contact SWO)

Drained fuel filters (gas \& diesel)

Hydrocarbons (contact SWO) $\bigotimes$ Other Drained generators/equipment

Solid fractions from sand/oil/water

$\bigotimes$ Deconned Underground and Above Ground Tanks

Additional waste accepted at the Area 6 Hydrocarbon Landfill:
$\square$ Septic sludge
$\square$ Rags
$\square$ Drained fuel filters (gas \& diesel)
Plants
Soil
$\square$ Sludge from sand/oil/water separators
Crushed non-teme plated oil filters REQUIRED: WASTE GENERATOR SIGNATURE PCBs below 50 parts per million

Initials: (if initialed, no radiological clearance is necessary.)

The above mentioned waste was generated outside of a Controlled Waste Management Area (CWMA) and to the best of my knowledge, does not contain radiological materials.

To the best of my knowledge, the waste described above contains only those n site. I have verified this through the waste characterization method identified a prohibited and allowable waste Items. I have contacted Property Management. is approved for disposal in the landfill.

Print Name: Dan Tobiason

Signature:

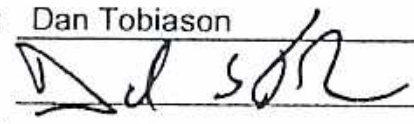

Date: 1124

Note: "Food waste, office trash and animal carcasses do not require a radiologi must have signed removal certification statement with Load Verification."

\section{SWO USE ONLY}

Load Weight (net frgm scale or estimate): 22,200
$10-10-07$

Signature of Eertifier:
Radiation Survey Release for Waste Disposa RCT Initials

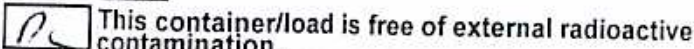
contamination.

This container/load is exempt from survey due to process knowledge and origin.

This container/load is free of radioactive conganination based on radioanalysis.

SIGNATURE DATE 0 - (3) 


\section{SWO USE (Select One) AREA $\quad \square 23 \quad \square 6 \quad \square 9 \quad$ LANDFILL}

For waste characterization, approval, and/or assistance, contact Solid Waste Operation (SWO) at 5-7898.

REQUIRED: WASTE GERERATOR INFORMATION

(This form is for rolloffs, dump trucks, and other onsite disposal of materials.)

Waste Generator: Dan Tobiason

Phone Number: 295-6169

Location / Origin: T-Tunnel Lower Laydown Yard

Waste Category: (check one)

Waste Type: $\square$ NTS

(check one) $\square$ Non-Putrescible

Pollution Prevention Category: (check one)

Pollution Prevention Category: (check one)

Method of Characterization: (check one)

Prohibited Waste at all three

NTS landfills:

Additional Prohlbited Waste

at the Area 9 U10C Landfill:

Radioactive waste; RCRA waste; Hazardous waste; Free liquids, PCBs above TSCA regulatory levels, and Medical wastes (needles, sharps, bloody clothing).

Sewage Sludge, Animal carcasses, Wet garbage (food waste); and Friable asbestos

\section{REQUIRED: WASTE CONTENTS ALLOWABLE WASTES}

Check all allowable wastes that are contained within this load.

NOTE: Waste disposal at the Area 6 Hydrocarbon Landfill must have come into contact with petroleum hydrocarbons or coolants, such as: gasoline (no benzene, lead); jet fuel; diesel fuel; lubricants and hydraulics; kerosene; asphaltic petroleum hydrocarbon; and ethylene glycol.

Acceptable waste at any NTS landfill: $\square$ Paper

$\triangle$ Asphalt $\quad$ Metal $\quad$ Wood $\quad$ Soil

$\triangle$ Plastic $\quad$ Wire $\quad \square$ Cable $\quad \square$ Cloth

$\square$ Rocks / unaltered geologic materials

$\bigotimes$ Rubber (excluding tires)

$\bigotimes$ Insulation (non-Asbestosform) $\triangle$ Empty containers

$\bigotimes$ Demolition debris

$\bigotimes$ Cement \& concrete

$\triangle$ Manufactured items: (swamp coolers, furniture, rugs, carpet, electronic components, PPE, etc.)

Additional waste accepted at the Area 23 Mercury Landfill: $\square$ Office Waste $\square$ Food Waste
$\square$ Asbestos
Friable
Non-Friable (contact SWO if regulated load)
Quantity:

Additional waste accepted at the Area 9 U10c Landfill:

$\square$ Non-friable asbestos

Light ballasts (contact SWO)

Drained automobiles and military vehicles

Drained fuel filters (gas \& diesel)

Solid fractions from sand/oil/water

Hydrocarbons (contact SWO)

Other Drained generators/equipment

$\bigotimes$ Deconned Underground and Above Ground Tanks

\section{Additional waste accepted at the Area 6 Hydrocarbon Landfill:}

$\square$ Septic sludge

Plants

$\square$ Rags

$\square$ Drained fuel filters (gas \& diesel)

Soil

$\square$ Sludge from sand/oil/water separators REQUIRED: WASTE GENERATOR SIGNATURE

Initials: (if initialed, no radiological clearance is necessary.)

The above mentioned waste was generated outside of a Controlled Wast knowledge, does not contain radiological materiais.

To the best of my knowledge, the waste described above contains only $t$ site. I have verified this through the waste characterization method iden prohibited and allowable waste Items. I have contacted Property Managi is approved for disposal in the landfill.

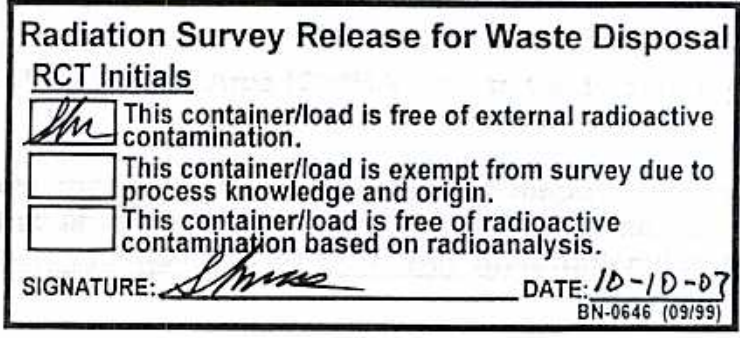

Print Name: Dan Tobiason Signature:
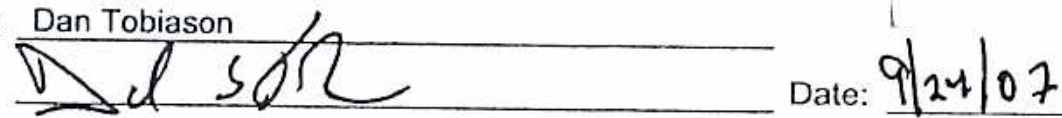

Crushed non-teme plated oil filters PCBs below 50 parts per million

Note: "Food waste, office trash and animal carcasses do not require a radiological clearance. Freon-containing appliances must have signed removal certification statement with Load Verification."

SWO USE ONLY

Load Weight (net from scale of estimate): 2,502

$10-10-07$

Signature of Certifier:

"Radiological Release Sticker" here. Onsite use only. 


\section{SWO USE (Select One) AREA

$\square 23 \quad \square 6$ \\ 凶9 \\ $\bigotimes$ LANDFILL. \\ For waste characterization, approval, and/or assistance, contact Solid Waste Operation (SWO) at 5-7898.}

REQUIRED: WASTE GERERATOR INFORMATION

(This form is for rolloffs, dump trucks, and other onsite disposal of materials.)

Waste Generator: Dan Tobiason

Phone Number: 295-6169

Location/Origin: T-Tunnel Lower Laydown Yard

Waste Category: (check one)

Waste Type: $\square$ NTS

(check one) $\square$ Non-Putrescible

Pollution Prevention Category: (check one)

Pollution Prevention Category: (check one)

Method of Characterization: (check one)

Prohibited Waste at all three

NTS landfills:

Additional Prohlbited Waste

at the Area 9 U10C Landfill:

\section{Commercial}

$\square$ Putrescrible

$\square$ Asbestos Containing Material

$\square$ Environmental management

$\triangle$ Clean-Up

$\square$ Sampling \& Analysis

Radioactive waste: RCRA levels, and Medical wastes (needles, sharps, bloody clothing)

Sewage Sludge, Animal carcasses, Wet garbage (food waste); and Friable asbestos

\section{REQUIRED: WASTE CONTENTS ALLOWABLE WASTES}

Check all allowable wastes that are contained within this load:

NOTE: Waste disposal at the Area 6 Hydrocarbon Landfill must have come into contact with petroleum hydrocarbons or coolants, such as: gasoline (no benzene, lead); jet fuel; diesel fuel; lubricants and hydraulics; kerosene; asphaltic petroleum hydrocarbon; and ethylene glycol.

Acceptable waste at any NTS landfill: $\square$ Paper
$\triangle$ Asphalt
$凶$ Metal
Wood
$\triangle$ Soil

Q Plastic $\square$ Wire

$\otimes$ Cable

Cloth
$\square$ Rocks / unaltered geologic materials
$\bigotimes$ Rubber (excluding tires)
$\triangle$ Insulation (non-Asbestosform

$\triangle$ Empty containers

$\bigotimes$ Demolition debris

$\bigotimes$ Cement \& concrete

rugs, carpet, electronic components, PPE, etc.

Additional waste accepted at the Area 23 Mercury Landfill: $\square$ Office Waste

$\square$ Asbestos $\square$ Friable

$\square$ Non-Friable (contact SWO if regulated load)

$\square$ Food Waste

Quantity:
Additional waste accepted at the Area 9 U10c Landfill:

$\square$ Non-friable asbestos

Light ballasts (contact SWO)

Hydrocarbons (contact SWO)

$\square$ Drained automobiles and military vehicles

$\square$ Drained fuel filters (gas \& diesel)

$\otimes$ Other Drained generators/equipment
Solid fractions from sand/oil/water

$\bigotimes$ Deconned Underground and Above Ground Tanks

\section{Additional waste accepted at the Area 6 Hydrocarbon Landfill}

Septic sludge $\square$ Rags $\square$ Drained fuel filters (gas \& diesel)

Plants

Soil

$\square$ Sludge from sand/oil/water separators REQUIRED: WASTE GENERATOR SIGNATURE

Initials: (if initialed, no radiological clearance is necessary.)

The above mentloned waste was generated outside of a Controlled Waste knowledge, does not contain radiological materials.

To the best of my knowledge, the waste described above contains only tho site. I have verified this through the waste characterization method identifi prohibited and allowable waste Items. I have contacted Property Managem is approved for disposal in the landfill.

Print Name:

Signature:
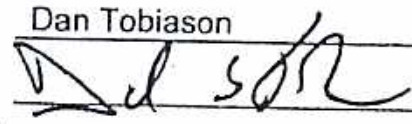

\section{Radiation Survey Release for Waste Disposal}

RCT Initials

This container/load is free of external radioactive contamination.

This container/load is exempt from survey due to process knowledge and origin. $\square$ This container/load is free of radioactive

SIGNATURE ontamination based on radioanalysis. DATE: $(\theta>10 \rightarrow 2$ BN-0646 (09/99)

"Radiological Release Sticker" here. Onsite use only. SWO USE ONLY 


\begin{tabular}{|llllll}
\hline SWO USE (Select One) & AREA & $\square 23$ & $\square 6$ & 23 & LANDFILL
\end{tabular}

For waste characterization, approval, and/or assistance, contact Solid Waste Operation (SWO) at 5-7898. REQUIRED: WASTE GERERATOR INFORMATION

(This form is for rolloffs, dump trucks, and other onsite disposal of materials.)

Waste Generator: Dan Tobiason Phone Number: 295-6169

Location / Origin: T-Tunnel Lower Laydown Yard

Waste Category: (check one)

Waste Type: $\triangle$ NTS

(check one)

Non-Putrescible

Pollution Prevention Category: (check one)

Pollution Prevention Category: (check one) Method of Characterization: (check one)

Prohibited Waste at all three NTS landfills:

Additional Prohlbited Waste at the Area 9 U10C Landfill:

\begin{abstract}
Radioactive waste; RCRA waste; Hazardous waste; Free liquids, PCBs above TSCA regulatory
\end{abstract} levels, and Medical wastes (needles, sharps, bloody clothing).

Sewage Sludge, Animal carcasses, Wet garbage (food waste); and Friable asbestos

\section{REQUIRED: WASTE CONTENTS ALLOWABLE WASTES}

Check all allowable wastes that are contained within this load:

NOTE: Waste disposal at the Area 6 Hydrocarbon Landfill must have come into contact with petroleum hydrocarbons or coolants, such as: gasoline (no benzene, lead); jet fuel; diesel fuel; lubricants and hydraulics; kerosene; asphaltic petroleum hydrocarbon; and ethylene glycol.

Acceptable waste at any NTS landfill: $\triangle$ Paper $\square$ Rocks / unaltered geologic materials

Q Wood

Q Soil

$\triangle$ Rubber (excluding tires)

Q Plastic $\square$ Wire

区 Cable

$\triangle$ Cloth

\Insulation (non-Asbestosform)

$\triangle$ Empty containers

Demolition debris

$\triangle$ Manufactured items: (swamp coolers, furniture, rugs, carpet, electronic components, PPE, etc.)

Additional waste accepted at the Area 23 Mercury Landfill: $\square$ Office Waste $\square$ Food Waste $\square$ Animal Carcasses
$\square$ Asbestos
Friable
$\square$ Non-Friable (contact SWO if regulated load)
Quantity:

\section{Additional waste accepted at the Area 9 U10c Landfill:}
$\square$ Non-friable asbestos
$\square$ Drained automobiles and military vehicles
$\square$ Light ballasts (contact SWO)
Drained fuel filters (gas \& diesel)
Hydrocarbons (contact SWO)
Other Drained generators/equipment

Solid fractions from sand/oil/water

$\triangle$ Deconned Underground and Above Ground Tanks

Additional waste accepted at the Area 6 Hydrocarbon Landfill:
$\square$ Septic sludge
$\square$ Rags
$\square$ Drained fuel filters (gas \& diesel)
Plants
$\square$ Soil
$\square$ Sludge from sand/oil/water separators
Crushed non-teme plated oil filters PCBs below 50 parts per million REQUIRED: WASTE GENERATOR SIGNATURE

Initials: (if initialed, no radiological clearance is necessary.)

The above mentioned waste was generated outside of a Controlled Waste Management Area (CWMA) and to the best of my knowledge, does not contain radiological materials.

To the best of my knowledge, the waste described above contains only tho site. I have verified this through the waste characterization method identifi prohibited and allowable waste Items. I have contacted Property Managem is approved for disposal in the landfill.

Print Name: Dan Tobiason

Signature:

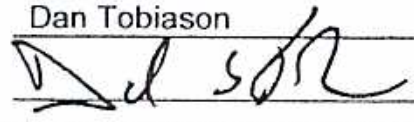
$10-16-07$

Note: "Food waste, office trash and animal carcasses do not require a radio

Radiation Survey Release for Waste Disposal RCT Initials

if $\%$ This container/load is free of external radioactive Contamination.

This container/load is exempt from survey due to process knowledge and origin.

This containerlload is free of radioactive

contamination based on yadioanalysis. SIGNATURE: must have signed removal certification statement with Load Verificatiun.

\section{SWO USE ONLY}

Load Weight (net from/scale or estimate): $10,5 \mathrm{Cr}$
$10-10-07$

Signature of Certifier: $20 \mathrm{ch}$ 


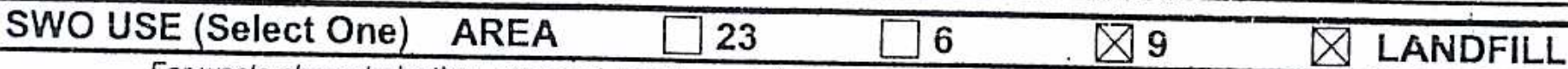

For waste characterization, approval, and/or assistance, contact Solid Waste Operation (SWO) at 5-7898.

REQUIRED: WASTE GERERATOR INFORMATION

(This form is for rolloffs, dump trucks, and other onsite disposal of materials.)

Waste Generator: Dan Tobiason

Phone Number: 295-6169

Location / Origin: T-Tunnel Lower Laydown Yard

Waste Category: (check one)

Waste Type: $\square$ NTS

(check one) $\square$ Non-Putrescible $\square$ Asbestos Containing Material

(check one) $\square$ Non-Putrescible $\square$ Asbestos Containing Material

$\square$ Commercial

$\square$ Putrescrible

$\triangle$ Industrial cos $10-11-07$

Pollution Prevention Category: (check one)

Pollution Prevention Category: (check one)

$\square$ Environmental management

Method of Characterization: (check one)

$\triangle$ Clean-Up

Prohibited Waste at all three

NTS landfills:

Additional Prohibited Waste

at the Area 9 U10C Landfill:

Radioactive waste; RCRA waste; Hazardous waste; Free liquids, PCBs above TSCA regulatory levels, and Medical wastes (needles, sharps, bloody clothing).

Sewage Sludge, Animal carcasses, Wet garbage (food waste); and Friable asbestos

\section{REQUIRED: WASTE CONTENTS ALLOWABLE WASTES}

Check all allowable wastes that are contained within this load:

NOTE: Waste disposal at the Area 6 Hydrocarbon Landfill must have come into contact with petroleum hydrocarbons or coolants, such as: gasoline (no benzene, lead); jet fuel; diesel fuel; lubricants and hydraulics; kerosene; asphaltic petroleum hydrocarbon; and ethylene glycol.
Acceptable waste at any NTS landfill: $\triangle$ Paper
$\bigotimes$ Asphalt
$\otimes$ Metal
$\triangle$ Wood
$\bigotimes$ Soil
Q Cable
Cloth
$\square$ Rocks / unaltered geologic materials
$\triangle$ Rubber (excluding tires)
$\triangle$ Plastic $\otimes$ Wire
Q Insulation (non-Asbestosform)
Manufactured items: (swamp coolers, furniture, rugs, carpet, electronic components, PPE, etc.)
Additional waste accepted at the Area 23 Mercury Landfill:
$\square$ Asbestos
Friable
Non-Friable (contact SWO if regulated load)
$\square$ Food Waste

Empty containers

Demolition debris

$\bigotimes$ Cement \& concrete

\section{Additional waste accepted at the Area 9 U10c Landfill:}
Light baliasts (contact SWO)
Hydrocarbons (contact SWO)
Drained automobiles and military vehicles
Drained fuel filters (gas \& diesel)

Other Drained generators/equipment

$\square$ Solid fractions from sand/oil/water

$\bigotimes$ Deconned Underground and Above

Ground Tanks

Additional waste accepted at the Area 6 Hydrocarbon Landfill:
$\square$ Septic sludge
$\square$ Rags
Soil
$\square$ Drained fuel filters (gas \& diesel)
Plants
$\square$ Sludge from sand/oil/water separators
REQUIRED: WASTE GENERATOR SIGNATURE
Crushed non-teme plated oil filters PCBs below 50 parts per million

Initials: (if initialed, no radiological clearance is necessary.)

The above mentioned waste was generated outside of a Controlled Waste $i$ knowledge, does not contain radiological materials.

To the best of my knowledge, the waste described above contains only the site. I have verified this through the waste characterization method identif prohibited and allowable waste Items. I have contacted Property Managen

Print Name:

Signature:
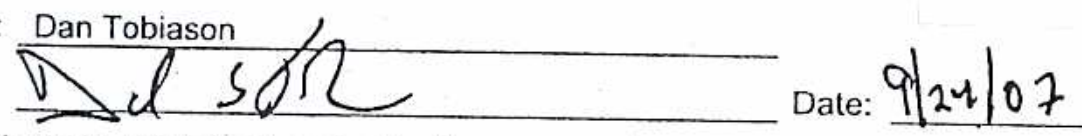

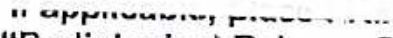

"Radiological Release Sticker" here. Onsite use only.

Note: "Food waste, office trash and animal carcasses do not require a radiological clearance. Freon-containing appliances must have signed removal certification statement with Load Verification."

\section{SWO USE ONLY}

Load Weight (net from scale or estimate) $, 2,0 \mathrm{c}$
$10-10-07$ Signature of Certifier: 


\begin{tabular}{|llllll}
\hline SWO USE (Select One) & AREA & $\square 23$ & $\square 6$ & 23 & Q LANDFILL
\end{tabular}

For waste characterization, approval, and/or assistance, contact Solid Waste Operation (SWO) at 5-7898.

REQUIRED: WASTE GERERATOR INFORMATION

(This form is for rolloffs, dump trucks, and other onsite disposal of materials.)

Waste Generator: Dan Tobiason

Phone Number: 295-6169

Location / Origin: T-Tunnel Lower Laydown Yard

Waste Category: (check one)

$\square$ Commercial.

$\triangle$ Industrial cos $10-11-07$

Waste Type: $\backslash$ NTS

$\square$ Putrescrible

A-FFACO=OASite

$\square$ WAC Exception

(check one)

Non-Putrescible

$\square$ Asbestos Containing Material

$\square$ FFACO-offsite

$\square$ Historic DOE/NV

Pollution Prevention Category: (check one) $\square$ Environmental management

Pollution Prevention Category: (check one) $\triangle$ Clean-Up

Method of Characterization: (check one)

Sampling \& Analysis

$\triangle$ Defense Projects

YMP

Prohibited Waste at all three Radioactive waste; RCRA waste; Hazardous waste; Free liquids, PCBs above TSCA regulatory NTS landfills:

Additional Prohibited Waste at the Area 9 U10C Landfill:

levels, and Medical wastes (needles, sharps, bloody clothing).

Sewage Sludge, Animal carcasses, Wet garbage (food waste); and Friable asbestos

\section{REQUIRED: WASTE CONTENTS ALLOWABLE WASTES}

Check all allowable wastes that are contained within this load:

NOTE: Waste disposal at the Area 6 Hydrocarbon Landfill must have come into contact with petroleum hydrocarbons or coolants, such as: gasoline (no benzene, lead); jet fuel; diesel fuel; lubricants and hydraulics; kerosene; asphaltic petroleum hydrocarbon; and ethylene glycol.

Acceptable waste at any NTS landfill: $\triangle$ Pape

凶 Soil

$\square$ Rocks / unaltered geologic materials

$\triangle$ Empty containers

Plastic $\bigotimes$ Wire

Cable

Cloth

$\bigotimes$ Rubber (excluding tires)

Demolition debris

$\triangle$ Manufactured items: (swamp coolers, fumiture, rugs, carpet, electronic components, PPE, etc.)

Additional waste accepted at the Area 23 Mercury Landfill: $\quad \square$ Office Waste $\square$ Food Waste $\square$ Animal Carcasses
$\square$ Asbestos
Friable
Non-Friable (contact SWO if regulated load)
Quantity:

\section{Additional waste accepted at the Area 9 U10c Landfill:}

$\square$ Non-friable asbestos $\quad \square$ Drained automobiles and military vehicles

$\square$ Light ballasts (contact SwO) $\square$ Drained fuel filters (gas \& diesel)

$\square$ Hydrocarbons (contact SWO) $\bigotimes$ Other Drained generators/equipment

$\square$ Solid fractions from sand/oil/water

Additional waste accepted at the Area 6 Hydrocarbon Landfill:
$\square$ Septic sludge
$\square$ Rags
$\square$ Drained fuel filters (gas \& diesel)
Plants
Soil
$\square$ Sludge from sand/oil/water separators
$\square$ Crushed non-teme plated oil filters REQUIRED: WASTE GENERATOR SIGNATURE

Initials: (if initialed, no radiological clearance is necessary.)

The above mentioned waste was generated outside of a Controlled Waste Management Area (CWMA) and to the best of my knowledge, does not contain radiological materials.

To the best of my knowledge, the waste described above contains only those materials that are allowed for disposal at this site. I have verified this through the waste characterization method identified above and a review of the above-mentioned prohibited and allowable waste Items. I have contacted Property Managen is approved for disposal in the landfill.

Print Name: Dan Tobiason

Signature:
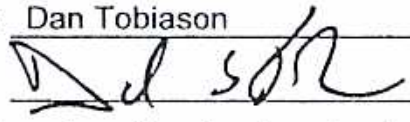$$
10.10-07
$$

Date:

Note: "Food waste, office trash and animal carcasses do not require a rad must have signed removal certification statement with Load Verifica

SWO USE ONLY

Load Weight (net from scale orestimater.

$10-10-07$

Signature of Certifier:
Radiation Survey Release for Waste Disposal RCT Initials

This container/load is free of external radioactive

contamination.

This container/load is exempt from survey due to Thisess knowledge and origin.

This container/load is free of radioactive

contamination based on radioanalysis. SIGNATURE.1 = DATE: (0 10.0 BN.0646 (09/95)

Won 3 iceplanst




$$
\text { REQUIRED: WASTE GERERATOR INFORMATION }
$$

(This form is for rolloffs, dump trucks, and other onsite disposal of materials.)

Waste Generator: Dan Tobiason

Phone Number: 295-6169

Location / Origin: T-Tunnel Lower Laydown Yard

Waste Category: (check one)

Waste Type: $\quad$ NTS (check one)

$\square$ Non-Putrescible

\section{$\square$ Commerclal \\ $\square$ Putrescrible}

Pollution Prevention Category: (check one)

Pollution Prevention Category: (check one)

Method of Characterization: (check one)

$\square$ Asbestos Containing Material

$\square$ Environmental management

$\triangle$ Clean-Up

$\square$ Sampling \& Analysis

Prohibited Waste at all three

NTS landfills:

Additional Prohibited Waste

at the Area 9 U10C Landfill:

Radioactive waste; RCRA waste; Hazardous waste; Free liquids
levels, and Medical wastes (needles, sharps, bloody clothing).

Sewage Sludge, Animal carcasses, Wet garbage (food waste); and Friable asbestos

\section{REQUIRED: WASTE CONTENTS ALLOWABLE WASTES}

Check all allowable wastes that are contained within this load:
NOTE: Waste disposal at the Area 6 Hydrocarbon Landfill must have come into contact with petroleum hydrocarbons or coolants, such as: gasoline (no benzene, lead); jet fuel; diesel fuel; lubricants and hydraulics; kerosene; asphaltic petroleum hydrocarbon; and ethylene glycol.
Acceptable waste at any NTS landfill:
$凶$ Asphalt
Metal
\Wood
$\triangle$ Paper
$凶$ Soil
$\triangle$ Plastic $\square$ Wire
区 Cable
$\triangle$ Cioth
$\square$ Rocks / unaltered geologic materials
$\bigotimes$ Rubber (excluding tires)
$\otimes$ Insulation (non-Asbesiosform)

$\triangle$ Manufactured items: (swamp coolers, fumiture, rugs, carpet, electronic components, PPE, etc.)

Additional waste accepted at the Area 23 Mercury Landfill: $\square$ Office Waste

$\square$ Asbestos

Friable

$\square$ Non-Friable (contact SWO if regulated load)

$\square$ Food Waste

Quantity:

\section{Additional waste accepted at the Area 9 U10 c Landfill:}

$\square$ Non-friable asbestos

$\square$ Light ballasts (contact SWO)

Hydrocarbons (contact SWO)
Drained automobiles and military vehicles

Drained fuel filters (gas \& diesel)

Other Drained generators/equipment
Solid fractions from sand/oil/water

$\otimes$ Deconned Underground and Above Ground Tanks

Additional waste accepted at the Area 6 Hydrocarbon Landfill:

$\square$ Septic sludge $\square$ Rags

Plants $\square$ Soil $\square$ Drained fuel filters (gas \& diesel)

$\square$ Sludge from sand/oil/water separators
Empty containers

$\bigotimes$ Demolition debris

$\bigotimes$ Cement \& concrete

Initials: REQUIRED: WASTE GENERATOR SIGNATURE

$\square$ Crushed non-teme plated oil filters PCBs below 50 parts per million (if initialed, no radiological clearance is necessary.)

The above mentioned waste was generated outside of a Controlled Waste knowledge, does not contain radiological materials.

To the best of my knowledge, the waste described above contains only thi site. I have verified this through the waste characterization method identif prohibited and allowable waste Items. I have contacted Property Managen is approved for disposal in the landfill.

Print Name: Dan Tobiason Signature:
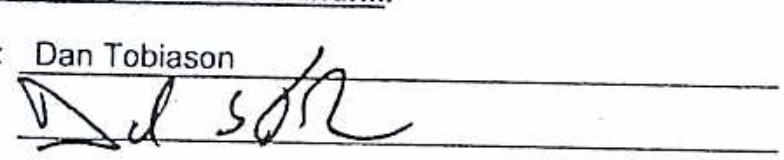

Note: "Food waste, office trash and animal carcasses do not require a radiological
must have signed removal certification statement with Load Verification."
SWO USE ONLY
Load Weight (net from scale of estimate): Radiation Survey Release for Waste Disposal
RCT Initials
This container/load is free of external radioactive
This container/load is exempt from survey due to
process knowledge and origin.
This container/load is free of radioactive
contaminakion based on radioanalysis.
SIGNATURE:_mpenes Date: $9 / 24 / 07 \quad\left[\begin{array}{c}\text { "Radiological Kelease sticker" } \\ \text { here. Onsite use only. }\end{array}\right.$ 


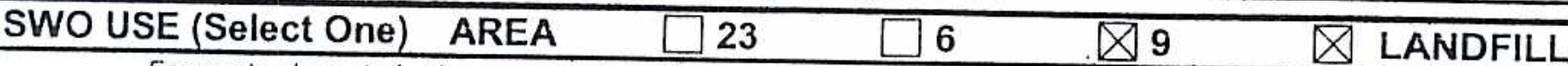

For waste characterization, approval, and/or assistance, contact Solid Waste Operation (SWO) at 5-7898.

\section{REQUIRED: WASTE GERERATOR INFORMATION}

(This form is for rolloffs, dump trucks, and other onsite disposal of materials.)

Waste Generator: Dan Tobiason

Phone Number: 295-6169

Location / Origin: T-Tunnel Lower Laydown Yard

Waste Category: (check one)

Waste Type: $\triangle$ NTS

(check one)

$\square$ Non-Putrescible

$\square$ Commercial

$\square$ Putrescrible

$\Delta$ Industrial cos $10 / 15 / 07$

$\square$ Asbestos Containing Material

Pollution Prevention Category: (check one)

Pollution Prevention Category: (check one)

Method of Characterization: (check one)

Environmental management

$\triangle$ Clean-Up

ATFAGQ-angile

$\square$ WAC Exception

Prohibited Waste at all three

NTS landfills:

Additional Prohibited Waste

at the Area 9 U10C Landfill:

Radioactive waste; RCRA waste; Hazardous waste; Free liquid
levels, and Medical wastes (needles, sharps, bloody clothing).

Sewage Sludge, Animal carcasses, Wet garbage (food waste); and Friable asbestos

\section{REQUIRED: WASTE CONTENTS ALLOWABLE WASTES}

Check all allowable wastes that are contained within this load:

NOTE: Waste disposal at the Area 6 Hydrocarbon Landfill must have come into contact with petroleum hydrocarbons or coolants, such as: gasoline (no benzene, lead); jet fuel; diesel fuel; lubricants and hydraulics; kerosene; asphaltic petroleum hydrocarbon; and ethylene glycol.
Acceptable waste at any NTS landfill:
$\bigotimes$ Paper
$\otimes$ Wood
$凶$ Soil
$\triangle$ Cable
Cloth
$\square$ Rocks / unaltered geologic materials
$\triangle$ Empty containers
$\otimes$ Asphalt
$\triangle$ Wire
$\triangle$ Rubber (excluding tires)
\Insulation (non-Asbestosform)
$\triangle$ Demolition debris
$\bigotimes$ Cement \& concrete

$\triangle$ Manufactured items: (swamp coolers, fumiture, rugs, carpet, electronic components, PPE, etc.)

\section{Additional waste accepted at the Area 23 Mercury Landfill: $\square$ Office Waste}

Asbestos

Friable

$\square$ Non-Friable (contact SWO if regulated load)

$\square$ Food Waste

\section{Additional waste accepted at the Area 9 U10c Landfill:}

$\square$ Non-friable asbestos

Light ballasts (contact SWO)

Hydrocarbons (contact SWO)
Drained automobiles and military vehicles

Drained fuel filters (gas \& diesel)

Other Drained generators/equipment

Quantity:

Animal Carcasses

Additional waste accepted at the Area 6 Hydrocarbon Landfill:
$\square$ Septic sludge
$\square$ Rags
$\square$ Drained fuel filters (gas \& diesel)
Plants
$\square$ Soil
$\square$ Sludge from sand/oil/water separators

\section{REQUIRED: WASTE GENERATOR SIGNATURE}

Solid fractions from sand/oil/water

$\otimes$ Deconned Underground and Above

Ground Tanks

Initials: (if initialed, no radiological clearance is necessary.)

The above mentioned waste was generated outside of a Controlled Waste Management Area (CWMA) and to the best of my knowledge, does not contain radiological materials.

To the best of my knowledge, the waste described above contains only those materials that are allowed for disposal at this site. I have verified this through the waste characterization method identified above and a review of the above-mentioneprohibited and allowable waste items. I have contacted Property Management and have verified that this mat-

is approved for disposal in the landfill.

Print Name: Dan Tobiason

Signature: Dote:

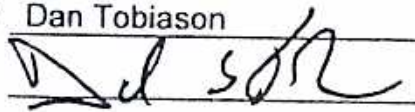

$10-11-2 T$ must have signed removal certification statement with Load Verification.

SWO USE ONLY

Load Weight (net frok scale or estimate): $\sum 4,000$

$10-11-07$

Signature of Certific

Radiation Survey Release for Waste Disposal

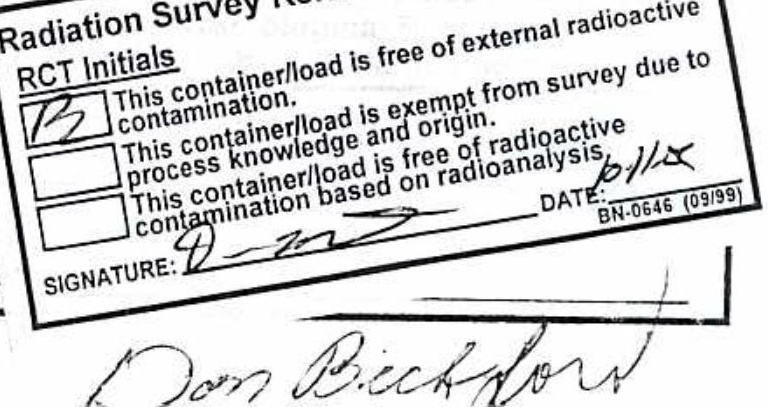




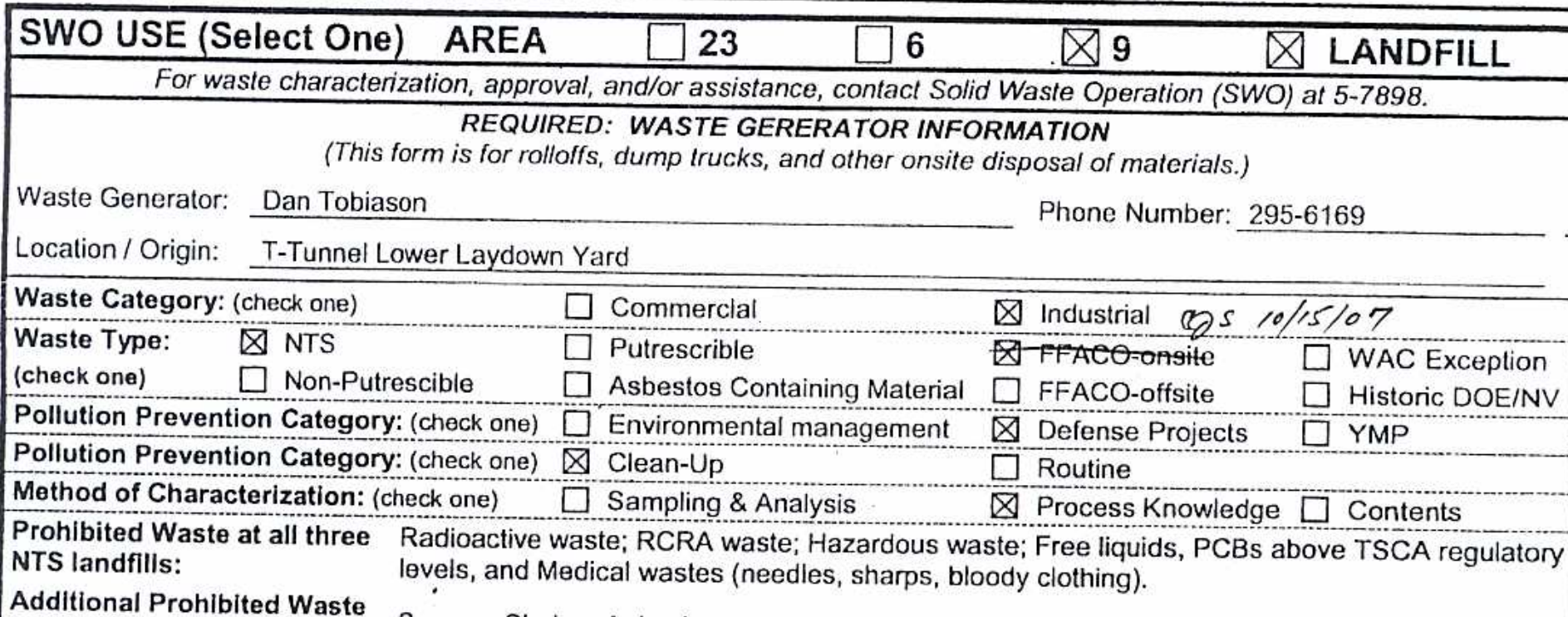

at the Area 9 U10C Landfill: Sewage Sludge, Animal carcasses, Wet garbage (food waste); and Friable asbestos

\section{REQUIRED: WASTE CONTENTS ALLOWABLE WASTES}

Check all allowable wastes that are contained within this load:

NOTE: Waste disposal at the Area 6 Hydrocarbon Landfill must have come into contact with petroleum hydrocart, ils or coolants, such as: gasoline (no benzene, lead); jet fuel; diesel fuel; lubricants and hydraulics; kerosene; asphaltic petroleum hydrocarbon; and ethylene glycol.
Acceptable waste at any NTS landfill:
$\triangle$ Asphalt
Metal
$\triangle$ Wood
$\triangle$ Paper
$\square$ Rocks / unaltered geologic materials
$\triangle$ Empty containers
$\bigotimes$ Plastic
$\otimes$ Cable
$\bigotimes$ Soil
$\triangle$ Rubber (excluding tires)
$\triangle$ Cloth
\Insulation (non-Asbestosform)
$凶$ Demolition debris
$\bigotimes$ Cement \& concrete

$\triangle$ Manufactured items: (swamp coolers, furniture, rugs, carpet, electronic components, PPE, etc.)
Additional was $\square$ Asbestos
Friable
Area 23 Mercury Landfill:
$\square$ Office Waste
Food Waste

Animal Carcasses

Additional waste accepted at the Area 9 U10c Landfill:

$\square$ Non-friable asbestos

Light ballasts (contact SWO)

Drained automobiles and military vehicles

Hydrocarbons (contact SWO)

$\square$ Drained fuel filters (gas \& diesel)

Other Drained generators/equipment

Quantity:

Additional waste accepted at the Area 6 Hydrocarbon Landfill:
Septic sludge
$\square$ Rags
Plants
Soil

$\square$ Drained fuel filters (gas \& diesel)
$\square$ Sludge from sand/oil/water separators

REQUIRED: WASTE GENERATOR SIGNATURE

Solid fractions from sand/oil/water

$\bigotimes$ Deconned Underground and Above Ground Tanks

Initials: (if initialed, no radiological clearance is necessary.)

The above mentioned waste was generated outside of a Controlled Waste Mianagement Area (CWMA) and to the best of my knowledge, does not contain radiological materiais.

To the best of my knowledge, the waste described above contains only the site. I have verified this through the waste characterization method identil prohibited and allowable waste items. I have contacted Property Managen is approved for disposal in the landfill.

Print Name: Dan Tobiason

Signature:

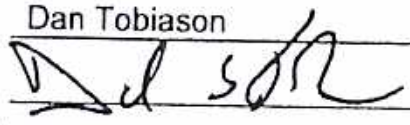

Date: $\underline{9}$

Note: "Food waste, office trash and animal carcasses do not require a radi must have signed removal certification statement with Load Verifica

LWO USE ONLY

Radiation Survey Release for Waste Disposal RCT Initials

$n \cup$ This container/load is free of external radioactive

This container/load is exempt from survey due to

This container/load and origin.

contanination basedoryadioanalysis.

SIGNATURE:

act)

DATE $10-110$ BN-0646 (09/99)

Load Weight (net from scale or estimate): 15,0200 Signature of 


\begin{tabular}{|rl}
\hline SWO USE (Select One) AREA & $\square 23$ \\
\hline For waste characterization, approval, and/or assistance, contact Solid Waste Operation (SWO) at 5-7898.
\end{tabular}

\section{REQUIRED: WASTE GERERATOR INFORMATION}

(This form is for rolloffs, dump trucks, and other onsite disposal of materials.)

Waste Generator: Dan Tobiason

Phone Number: 295-6169

Location / Origin: T-Tunnel Lower Laydown Yard

Waste Category: (check one)

Waste Type: $\square$ NTS

(check one)

$\square$ Non-Putrescible

Pollution Prevention Category: (check one)

Pollution Prevention Category: (check one)

Method of Characterization: (check one) $\square$ Commercial

$\square$ Putrescrible

$\square$ Asbestos Containing Material

$\square$ Environmental management

$凶$ Clean-Up

$\square$ Sampling \& Analysis
NTS landfilis:

Additional Prohlbited Waste

at the Area 9 U10C Landfill: levels, and Medical wastes (nee; Hazardous waste; Free liquids, PCBs above TSCA regulatory (needles, sharps, bloody clothing).

Sewage Sludge, Animal carcasses, Wet garbage (food waste); and Friable asbestos

\section{REQUIRED: WASTE CONTENTS ALLOWABLE WASTES}

Check all allowable wastes that are contained within this load:

NOTE: Waste disposal at the Area 6 Hydrocarbon Landfill must have come into contact with petroleum hydrocarbons or coolants, such as: gasoline (no benzene, lead); jet fuel; diesel fuel; lubricants and hydraulics; kerosene; asphaltic petroleum hydrocarbon; and ethylene glycol

Acceptable waste at any NTS landfill: $\triangle$ Paper

$\otimes$ Asphalt $\quad$ Metal $\quad$ Wood $\quad \square$ Soil

$\triangle$ Plastic $\quad$ Wire

Q Cable

Cloth

$\square$ Rocks / unaltered geologic materials

$\bigotimes$ Rubber (excluding tires)

$\triangle$ Insulation (non-Asbestosform) $\bigotimes$ Empty containers

$凶$ Demolition debris

$\bigotimes$ Cement \& concrete

$\triangle$ Manufactured items: (swamp coolers, furniture, rugs, carpet, electronic components, PPE, etc.)
Additional waste accepted at the Area 23 Mercury Landfill:
$\square$ Asbestos
Friable
Non-Friable (contact SWO if regulated load)
Food Waste
Animal Carcasses

Additional waste accepted at the Area 9 U10c Landfill:

$\square$ Non-friable asbestos

Light ballasts (contact SwO)

Hydrocarbons (contact SWO) $\square$ Drained automobiles and military vehicles

$\square$ Drained fuel filters (gas \& diesel)

Other Drained generators/equipment
Solid fractions from sand/oil/water

凶 Deconned Underground and Above Ground Tanks

Additional waste accepted at the Area 6 Hydrocarbon Landfill:

$\square$ Septic sludge $\quad \square$ Rags $\quad \square$ Drained fuel filters (gas \& diesel)

Plants $\square$ Soil

$\square$ Sludge from sand/oil/water separators REQUIRED: WASTE GENERATOR SIGNATURE

Crushed non-teme plated oil filters PCBs below 50 parts per million

Initials: (if initialed, no radiological clearance is necessary.)

The above mentioned waste was generated outside of a Controlled Waste Management Area (CWMA) and to the best of my
knowledge, does not contain radiological materials.

To the best of my knowledge, the waste described above contains only those materials that are allmuset fn. . site. I have verified this through the waste characterization method identifie prohibited and allowable waste Items. I have contacted Property Manageme is approved for disposal in the landfill.

Print Name: Dan Tobiason

Signature:
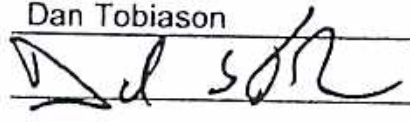

Date: $9 / 2$

Note: "Food waste, office trash and animal carcasses do not require a radiolc must have signed removal certification statement with Load Verificatior

SWO USE ONLY

Load Weight (net from scale or estimate): $200^{10-11-07} \begin{aligned} & 107 \\ & \text { Signature of Certifier }\end{aligned}$

Radiation Survey Release for Waste Disposal RCT Initials

This container/load is free of external radioactive
contamination.
This container/load is exempt from survey due to
process knowledge and origin.
This container/load is free of radioactive
contantination based on radioanalysis.




\begin{tabular}{|llllll}
\hline SWO USE (Select One) & AREA & $\square 23$ & $\square 6$ & 23 & $\square$ LANDFILL
\end{tabular}

For waste characterization, approval, and/or assistance, contact Solid Waste Operation (SWO) at 5-7898.

REQUIRED: WASTE GERERATOR INFORMATION

(This form is for rolloffs, dump trucks, and other onsite disposal of materials.)

Waste Generator: Dan Tobiason

Phone Number: 295-6169

Location / Origin: T-Tunnel Lower Laydown Yard

Waste Category: (check one)

Waste Type: $\square$ NTS

(check one)

$\square$ Non-Putrescible

Pollution Prevention Category: (check one)

Pollution Prevention Category: (check one)

Method of Characterization: (check one)

Prohibited Waste at all three

NTS landfilis:

Additional Prohibited Waste

at the Area 9 U10C Landfill:

Radioactive waste; RCRA waste; Hazardous waste; Free liquids, PCBs above TSCA regulatory levels, and Medical wastes (needles, sharps, bloody clothing).

Sewage Sludge, Animal carcasses, Wet garbage (food waste); and Friable asbestos

REQUIRED: WASTE CONTENTS ALLOWABLE WASTES

Check all allowable wastes that are contained within this load:

NOTE: Waste disposal at the Area 6 Hydrocarbon Landfill must have come into contact with petroleum hydrocarbons or coolants, such as: gasoline (no benzene, lead); jet fuel; diesel fuel; lubricants and hydraulics; kerosene; asphaltic petroleum hydrocarbon; and ethylene glycol.

Acceptable waste at any NTS landfill: $\triangle$ Paper $\square$ Rocks / unaltered geologic materials

Asphalt $\quad$ Metal $\quad$ Wood $\quad$ Soil

$\triangle$ Plastic $\square$ Wire

Cable

Cloth

区 Rubber (excluding tires)

$\bigotimes$ Insulation (non-Asbestosform)

$\bigotimes$ Empty containers

$\bigotimes$ Demolition debris

¿ Cement \& concrete

$\triangle$ Manufactured items: (swamp coolers, fumiture, rugs, carpet, electronic components, PPE, etc.)

Additional waste accepted at the Area 23 Mercury Landfill: $\quad \square$ Office Waste

$\square$ Asbestos

Friable

$\square$ Non-Friable (contact SWO if regulated load)

$\square$ Food Waste

Animal Carcasses

Additional waste accepted at the Area 9 U10c Landfill:

$\square$ Non-friable asbestos

Light ballasts (contact SWO)

Drained automobiles and military vehicles

Hydrocarbons (contact SWO)

Drained fuel filters (gas \& diesel)

Other Drained generators/equipment

Quantity:

Solid fractions from sand/oil/water

$\bigotimes$ Deconned Underground and Above Ground Tanks

Additional waste accepted at the Area 6 Hydrocarbon Landfill:
$\square$ Septic sludge
$\square$ Rags
$\square$ Drained fuel filters (gas \& diesel)
Soil
$\square$ Sludge from sand/oil/water separators
Plants REQUIRED: WASTE GENERATOR SIGNATURE
$\square$ Crushed non-teme plated oil filters PCBs below 50 parts per million

Initials: ___ (if initialed, no radiological clearance is necessary.)

The above mentioned waste was generated outside of a Controlled Waste Manage knowledge, does not contain radiological materials.

To the best of my knowledge, the waste described above contains only those mate site. I have verified this through the waste characterization method identified abov prohibited and allowable waste items. I have contacted Property Management and is approved for disposal in the landfill.

Print Name: Dan Tobiason

Signature:

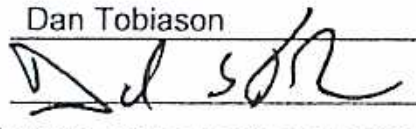

Date: $9 \mid 24 / 07$

Note: "Food waste, office trash and animal carcasses do not require a radiological clearance. Freon-containing appliances must have signed removal certification statement with Load Verification."

\section{SWO USE ONLY}

Load Weight (net from scale or estimate): $2 \mathrm{SO}^{\circ}=$

$10-11-07$ Signature of Certifier:

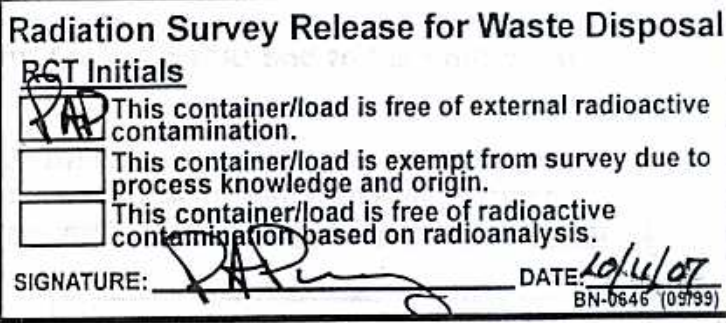

\section{| "radıoogıcaı Kelease Sticker" here. Onsite use only.}


For waste characterization, approval, and/or assistance, contact Solid Waste Operation (SWO) at 5-7898.

$$
\text { REQUIRED: WASTE GERERATOR INFORMATION }
$$

(This form is for rolloffs, dump trucks, and other onsite disposal of materials.)

Waste Generator: Dan Tobiason

Location / Origin: T-Tunnel Lower Laydown Yard

Phone Number: 295-6169

Waste Category: (check one)

Waste Type: $\otimes$ NTS (check one) Non-Putrescible

Pollution Prevention Category: (check one)

Pollution Prevention Category: (check one) Method of Characterization: (check one)

Prohibited Waste at all three NTS landfills:

Additional Prohlbited Waste at the Area 9 U10C Landfill:

Radioactive waste; RCRA waste; Hazardous waste; Free liquids, PCBs above TSCA regulatory lovels, and Medical wastes (needles, sharps, bloody clothing).

Sewage Sludge, Animal carcasses, Wet garbage (food waste); and Friable asbestos

\section{REQUIRED: WASTE CONTENTS ALLOWABLE WASTES}

Check all allowable wastes that are contained within this load:

NOTE: Waste disposal at the Area 6 Hydrocarbon Landfill must have come into contact with petroleum hydrocarbons or coolants, such as: gasoline (no benzene, lead); jet fuel; diesel fuel; lubricants and hydraulics; kerosene; asphaltic petroleum hydrocarbon; and ethylene glycol.

Acceptable waste at any NTS landfill:

$\triangle$ Plastic $\bigotimes$ Wire

$\otimes$ Cable

Cloth

Rocks / unaltered geologic materials

$\bigotimes$ Rubber (excluding tires)

$凶$ Insulation (non-Asbestosform)

$\triangle$ Manufactured items: (swamp coolers, furniture, rugs, carpet, electronic components, PPE, etc.)

Additional waste accepted at the Area 23 Mercury Landfill: $\square$ Office Waste
$\square$ Asbestos
Friable
Non-Friable (contact SWO if regulated load)

$\square$ Food Waste

Quantity:

Additional waste accepted at the Area 9 U10c Landfill:

Non-friable asbestos

Light ballasts (contact SwO)

Hydrocarbons (contact SWO

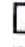
Drained automobiles and military vehicles

Drained fuel filters (gas \& diesel) Other Drained generators/equipment

\section{Additional waste accepted at the Area 6 Hydrocarbon Landfill:}

$\square$ Septic sludge $\square$ Rags

Plants

Soil $\square$ Drained fuel filters (gas \& diesel)

$\square$ Sludge from sand/oil/water separators
Solid fractions from sand/oil/water

$\bigotimes$ Deconned Underground and Above Ground Tanks

Initials: (if initialed, no radiological clearance is necessary.) The above mentioned waste was generated outside of a Controlled Waste Managen
knowledge, does not contain radiological materials.

To the best of my knowledge, the waste described above contains only those mate site. I have verified this through the waste characterization method identified abov prohibited and allowable waste items. I have contacted Property Management and is approved for disposal in the landfill.

Print Name: Dan Tobiason

Signature:

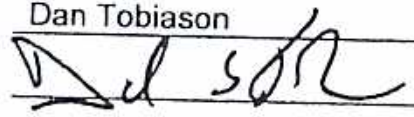
Note: "Food must have, of must have sign

SWO USE ONLY

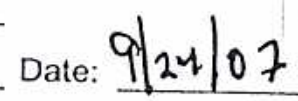

$\triangle$ Empty containers

$\bigotimes$ Demolition debris

$\bigotimes$ Cement \& concrete

Animal Carcasses 


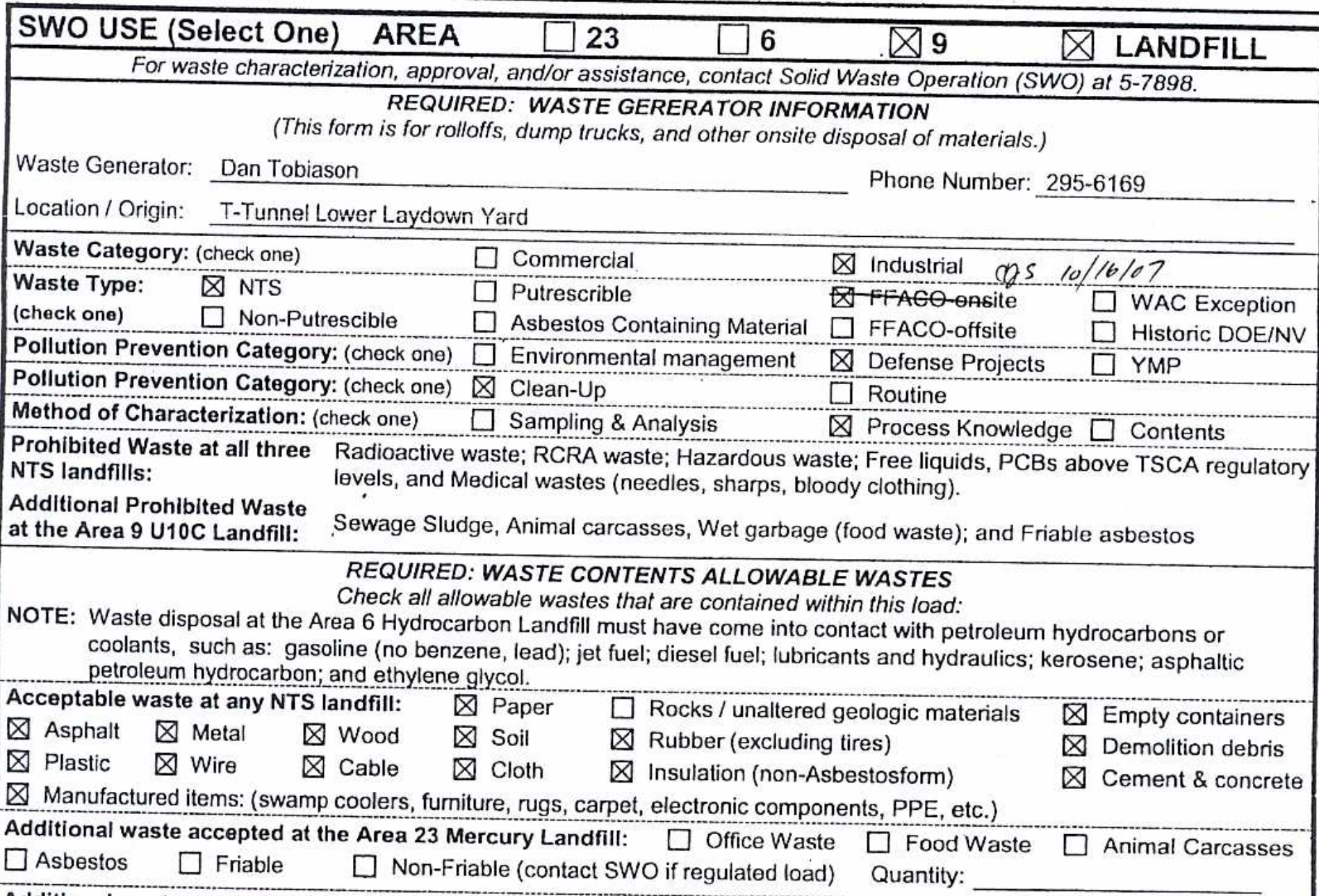

Additional waste accepted at the Area 9 U10c Landfill:

Non-friable asbestos

Light ballasts (contact SWO)

Hydrocarbons (contact SWO)

$\square$ Drained automobiles and military vehicles

Drained fuel filters (gas \& diesel)

$\otimes$ Other Drained generators/equipment
Solid fractions from sand/oil/water

$\bigotimes$ Deconned Underground and Above Ground Tanks

Additional waste accepted at the Area 6 Hydrocarbon Landfill:
$\square$ Septic sludge
$\square$ Rags
$\square$ Drained fuel filters (gas \& diesel)
Plants
$\square$ Soil
$\square$ Sludge from sand/oil/water separators
REQUIRED: WASTE GENERATOR SIGNATURE
Crushed non-teme plated oil filters PCBs below 50 parts per million

Initials: (if initialed, no radiological clearance is necessary.) The above mentloned waste was generated outside of a Controlled Waste Management Area (CWMA) and to the best of my
knowledge, does not contain radiological materials.

To the best of my knowledge, the waste described above contains only those materials that are allowed for disnosal at thin site. I have verified this through the waste characterization method identifind -L -

prohibited and allowable waste items. I have contacted Property Managen is approved for disposal in the landfill.

Print Name: Dan Tobiason

Signature:
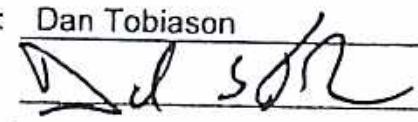

$10-15 ;-07$

Note: "Food waste, office trash and animal carcasses do not require a radio must have signed removal certification statement with Load Verificati

SWO USE ONLY

Load Weight (net from scale or estimate): 1,180
Radiation Survey Release for Waste Disposal RCT Initials

This container/load is free of external radioactive contamination.

This container/load is exempt from survey due to process knowledge and origin.

This container/load is free of radioactive Tontanination based on radioanalysis.

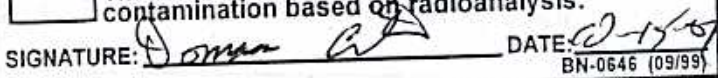


NSTec

Form

\begin{tabular}{|ccccc}
\hline SWO USE (Select One) AREA & $\square 23$ & $\square 6$ & Q & \\
\hline For waste characterization, approval, and/or assistance, contact Solid Waste Operation (SWO) at 5-7898.
\end{tabular}

\section{REQUIRED: WASTE GERERATOR INFORMATION}

(This form is for rolloffs, dump trucks, and other onsite disposal of materials.)

Waste Generator: Dan Tobiason

Phone Number: 295-6169

Location / Origin: T-Tunnel Lower Laydown Yard

Waste Category: (check one)

$\square$ Commerclal

Waste Type: $\triangle$ NTS

(check one)

$\square$ Non-Putrescible

$\square$ Putrescrible

$\square$ Asbestos Containing Material

Pollution Prevention Category: (check one) $\square$ Environmental management

Pollution Prevention Category: (check one)

Method of Characterization: (check one) $\square$ Sampling \& Analysis

$\triangle$ Clean-Up

Prohibited Waste at all three

NTS landfills:

Additional Prohlbited Waste

at the Area 9 U10C Landfill:

Radioactive waste; RCRA waste; Hazardous waste; Free liquids, PCBs above TSCA regulatory levels, and Medical wastes (needles, sharps, bloody clothing).

$\triangle$ Industrial $\operatorname{cgs} 10 / 16 / 07$

$\triangle$ FFAGQ-ensite

WAC Exception

$\square$ FFACO-offsite

$\triangle$ Defense Projects

Routine

$\otimes$ Process
ste; Free liquids
ody clothing)

Sewage Sludge, Animal carcasses, Wet garbage (food waste); and Friable asbestos

\section{REQUIRED: WASTE CONTENTS ALLOWABLE WASTES}

Check all allowable wastes that are contained within this load:

NOTE: Waste disposal at the Area 6 Hydrocarbon Landfill must have come into contact with petroleum hydrocarbons or coolants, such as: gasoline (no benzene, lead); jet fuel; diesel fuel; lubricants and hydraulics; kerosene; asphaltic petroleum hydrocarbon; and ethylene glycol.

Acceptable waste at any NTS landfill: $\triangle$ Paper

$\bigotimes$ Asphalt $\square$ Metal $\bigotimes$ Wood $\bigotimes$ Soil

$\triangle$ Plastic $\square$ Wire

$\bigotimes$ Cable

$\otimes$ Cloth

$\square$ Rocks / unaltered geologic materials

$\triangle$ Rubber (excluding tires)

$\triangle$ Insulation (non-Asbestosform)

$\triangle$ Empty containers

$\bigotimes$ Demolition debris

$\bigotimes$ Cement \& concrete

$\triangle$ Manufactured items: (swamp coolers, furniture, rugs, carpet, electronic components, PPE, etc.)

Additional waste accepted at the Area 23 Mercury Landfill: $\square$ Office Waste $\square$ Food Waste
Asbestos
$\square$ Friable
$\square$ Non-Friable (contact SWO if regulated load)
Quantity:

Additional waste accepted at the Area 9 U10c Landfill:

$\square$ Non-friable asbestos

Light ballasts (contact SwO)

Hydrocarbons (contact SWO)

$\square$ Drained automobiles and military vehicles

$\square$ Drained fuel filters (gas \& diesel)

Other Drained generators/equipment

Solid fractions from sand/oil/water

$\otimes$ Deconned Underground and Above Ground Tanks

Additional waste accepted at the Area 6 Hydrocarbon Landfill:

$\square$ Septic sludge

Plants

$\square$ Rags

$\square$ Drained fuel filters (gas \& diesel)

$\square$ Sludge from sand/oil/water separators REQUIRED: WASTE GENERATOR SIGNATURE

Crushed non-teme plated oil filters PCBs below 50 parts per million

Initials: (if initialed, no radiological clearance is necessary.)

The above mentioned waste was generated outside of a Controlled Waste Management Area (CWMA) and to the best of my
knowledge, does not contain radiological materials.

To the best of my knowledge, the waste described above contains only those site. I have verified this through the waste characterization method identified prohibited and allowable waste items. I have contacted Property Managemen! is approved for disposal in the landfill.

Print Name: Dan Tobiason

Signature:

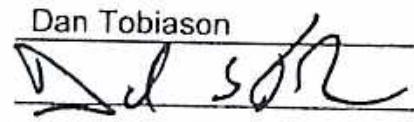

Date: $\underline{21}$

Note: "Food waste, office trash and animal carcasses do not require a radiolog must have signed removal certification statement with Load Verification.

SWO USE ONLY

Load Weight (net from scale or estimate): 204

$10 \cdot 15=07$

Signature of Certifier:

Radiation Survey Release for Waste Disposal RCT Initials

DC This container/load is free of external radioactive

This container/load is exempt from survey due to process knowledge and origin.

This container/load is free of radioactive

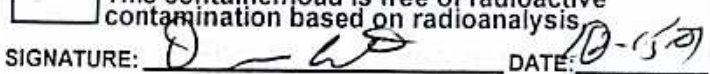
BN-0646 (09/99) 


\section{SWO USE (Select One) AREA \\ For waste characterization, approval, and/or assistance, contact Solid Waste Operation (SWO) at 5-7898.}

$$
\text { REQUIRED: WASTE GERERATOR INFORMATION }
$$

(This form is for rolloffs, dump trucks, and other onsite disposal of materials.)

Waste Generator: Dan Tobiason

Phone Number: 295-6169

\section{Location / Origin: T-Tunnel Lower Laydown Yard}

Waste Category: (check one)

Waste Type: $\square$ NTS

$$
\square \text { Non-Putrescible }
$$

\section{$\square$ Commercial \\ $\square$ Putrescrible}

Pollution Prevention Category: (check one)

Pollution Prevention Category: (check one)

Method of Characterization: (check one)

Prohibited Waste at all three

NTS landflils:

Additional Prohibited Waste

at the Area 9 U10C Landfill:

$\square$ Asbestos Containing Material

$\square$ Environmental management

$\otimes$ Clean-Up

$\square$ Sampling \& Analysis

Radioactive waste; RCRA waste; Hazardous waste; Free liquids
levels, and Medical wastes (needles, sharps, bloody clothing)

Sewage Sludge, Animal carcasses, Wet garbage (food waste); and Friable asbestos

\section{REQUIRED: WASTE CONTENTS ALLOWABLE WASTES}

Check all allowable wastes that are contained within this load:

NOTE: Waste disposal at the Area 6 Hydrocarbon Landfill must have come into contact with petroleum hydrocarbons or coolants, such as: gasoline (no benzene, lead); jet fuel; diesel fuel; lubricants and hydraulics; kerosene; asphaltic
petroleum hydrocarbon; and ethylene glycol.

\section{Acceptable waste at any NTS landfill: \ $\mathrm{Paper}$}

$\triangle$ Asphalt $\quad$ Metal $\quad$ Wood $\quad$ Soil

$\triangle$ Plastic $\square$ Wire

$\bigotimes$ Cable

Cloth
$\square$ Rocks / unaltered geologic materials
$\triangle$ Rubber (excluding tires)

\begin{tabular}{|c|c|}
\hline$\triangle$ Industrial $Q s$ & $2 / 16107$ \\
\hline 4-FFACO-Onsite & $\square$ WAC Exception \\
\hline$\square$ FFACO-offsite & $\square$ Historic DOE/NV \\
\hline$凶$ Defense Projects & $\square$ YMP \\
\hline Routine & \\
\hline
\end{tabular}
$\bigotimes$ Insulation (non-Asbestosform)

\section{$\bigotimes$ Empty containers \\ $\triangle$ Demolition debris \\ $\bigotimes$ Cement \& concrete}

Q Manufactured items: (swamp coolers, fumiture, rugs, carpet, electronic components, PPE, etc.)
Additional was
$\square$ Friable
Area 23 Mercury Landfill:
Non-Friable (contact SWO if regulated load)

Additional waste accepted at the Area 9 U10c Landfill:

$\square$ Non-friable asbestos

$\square$ Light ballasts (contact SwO)

Hydrocarbons (contact SwO)

$\square$ Drained automobiles and military vehicles

$\square$ Drained fuel filters (gas \& diesel)

Other Drained generators/equipment

Additional waste accepted at the Area 6 Hydrocarbon Landfill:
$\square$ Septic sludge
Plants
$\square$ Rags
$\square$ Soil
$\square$ Drained fuel filters (gas \& diesel)
$\square$ Sludge from sand/oil/water separators REQUIRED: WASTE GENERATOR SIGNATURE Crushed non-teme plated oil filters PCBs below 50 parts per million

Solid fractions from sand/oil/water

$\bigotimes$ Deconned Underground and Above Ground Tanks

Initials: (if initialed, no radiological clearance is necessary.)

The above mentioned waste was generated outside of a Controlled Waste Management Area (CWMA) and to the best of my
knowledge, does not contain radiological materials.

To the best of my knowledge, the waste described above contains only those mater site. I have verified this through the waste characterization method identified above prohibited and allowable waste Items. I have contacted Property Management and I is approved for disposal in the landflll.

Print Name: Dan Tobiason

Signature:
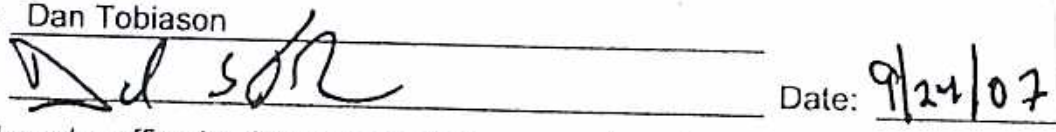

Note: "Food waste, office trash and animal carcasses do not require a radiological cle must have signed removal certification statement with Load Verification." RCT Initials This containerlload is free of external radioactive
contamination. This container/load is exempt in. process knowledge and origin. $\square$ This container/load is free of radioas SIGNATURE: 8 . $1<$ DATER: $0+3-2$ Signature of Certifier: 
NSTec

Form

\begin{tabular}{llllll}
\hline SWO USE (Select One) & AREA & $\square 23$ & $\square 6$ & Q 39 & LANDFILL
\end{tabular}

For waste characterization, approval, and/or assistance, contact Solid Waste Operation (SWO) at 5-7898. REQUIRED: WASTE GERERATOR INFORMATION

(This form is for rolloffs, dump trucks, and other onsite disposal of materials.)

Waste Generator: Dan Tobiason

Phone Number: 295-6169

Location / Origin: T-Tunnel Lower Laydown Yard

Waste Category: (check one)

Waste Type: $\square$ NTS

(check one)

$\square$ Non-Putrescible

Pollution Prevention Category: (check one)

Pollution Prevention Category: (check one)

Method of Characterization: (check one)

Prohibited Waste at all three NTS landfills:

Additional Prohlbited Waste at the Area 9 U10C Landfill: $\square$ Commercial

$\square$ Putrescrible

$\square$ Asbestos Containing Material

Environmental management

$\triangle$ Clean-Up

Sampling \& Analysis

Radioactive waste; RCRA waste; Hazardous waste; Free liquids
levels, and Medical wastes (needles, sharps, bloody clothing)

Sewage Sludge, Animal carcasses, Wet garbage (food waste); and Friable asbestos

\section{REQUIRED: WASTE CONTENTS ALLOWABLE WASTES}

NOTE: Waste disposal theck all allowable wastes that are contained within this load: 作 petrolant, such as: gasoline (no benzene, lead); jet fuel; diesel fuel; lubricants and hydraulics; kerosene; asphaltic petroleum hydrocarbon; and ethylene glycol.

Acceptable waste at any NTS landfill: $\square$ Paper

Asphalt $\square$ Metal $\bigotimes$ Wood $\bigotimes$ Soil

$\triangle$ Plastic $\quad$ Wire $\quad \square$ Cable $\quad$ Cloth

$\bigotimes$ Rubber (excluding tires)

$\square$ Rocks / unaltered geologic materials

$\triangle$ Insulation (non-Asbestosform)

$凶$ Empty containers

$\bigotimes$ Demolition debris

$\bigotimes$ Cement \& concrete

Q Manufactured items: (swamp coolers, furniture, rugs, carpet, electronic components, PPE, etc.)

Additional waste accepted at the Area 23 Mercury Landfill: $\square$ Office Waste

$\square$ Asbestos

Friable

Non-Friable (contact SWO if regulated load)

Food Waste

Animal Carcasses

Additional waste accepted at the Area 9 U10c Landfill:

$\square$ Non-friable asbestos

$\square$ Light ballasts (contact SWO)

Hydrocarbons (contact SWO) $\square$ Drained automobiles and military vehicles

$\square$ Drained fuel filters (gas \& diesel)

Other Drained generators/equipment

Additional waste accepted at the Area 6 Hydrocarbon Landfill:
$\square$ Septic sludge
Plants
$\square$ Rags
Soil
$\square$ Drained fuel filters (gas \& diesel)
Sludge from sand/oil/water separators
REQUIRED: WASTE GENERATOR SIGNATURE

Quantity:

Initials: (if initialed, no radiological clearance is necessary.)

The above mentioned waste was generated outside of a Controlled Waste Management Area (CWMA) and to the best of my
knowledge, does not contain radiological materials.

To the best of my knowledge, the waste described above contains only those materials that arm ...

site. I have verified this through the waste characterization method identified above prohibited and allowable waste Items. I have contacted Property Management and $h$ is approved for disposal in the landfill.

Print Name: Dan Tobiason

Signature:
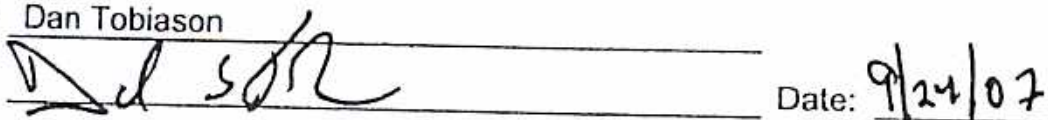

Note: "Food waste, office trash and animal carcasses do not require a radiological clear must have signed removal certification statement with Load Verification."

SWO USE ONLY

Load Weight (net from scale or estimate)

$10-15-0 \gg$

Signature of Certifier:

Radiation Survey Release for Waste Disposa RCT Initials
This containerlload is free of external radioactive
. 1 contamination. This containewledge and origin. process knowerload is free of radionsis.
This containerl based on radioanalysion b.

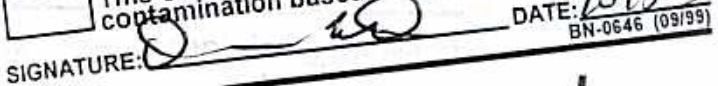




\begin{tabular}{|cccccc}
\hline SWO USE (Select One) AREA & $\square 23$ & $\square 6$ & AR & Q & LANDFILL \\
\hline For waste characterization, approval, and/or assistance, contact Solid Waste Operation (SWO) at 5-7898.
\end{tabular}

\section{REQUIRED: WASTE GERERATOR INFORMATION}

(This form is for rolloffs, dump trucks, and other onsite disposal of materials.)

Waste Generator: Dan Tobiason

Phone Number: 295-6169

Location / Origin: T-Tunnel Lower Laydown Yard

Waste Category: (check one)

Waste Type: $\square$ NTS

(check one)

$\square$ Non-Putrescible

$\square$ Commercial
$\square$ Putrescrible

$\square$ Asbestos Containing Material

\section{$\triangle$ Industrial gys $10 / 16 / 07$}

A-fFAeO-onsite

$\square$ FFACO-offsite Environmental management

Pollution Prevention Category: (check one)

Pollution Prevention Category: (check one)

Method of Characterization: (check one)

$凶$ Clean-Up

$\square$ Sampling \& Analysis

$\triangle$ Defense Projects

$\square$ Routine

$\triangle$ Process Knowledge $\square$ Contents

Prohibited Waste at all three Radioactive waste; RCRA waste: Hazardous waste; Free liquids, PCBs above TSCA regl NTS landfills:

Additional Prohlbited Waste

at the Area 9 U10C Landfill: levels, and Medical wastes (needles, sharps, bloody clothing)

Sewage Sludge, Animal carcasses, Wet garbage (food waste); and Friable asbestos

\section{REQUIRED: WASTE CONTENTS ALLOWABLE WASTES}

Check all allowable wastes that are contained within this load:

NOTE: Waste disposal at the Area 6 Hydrocarbon Landfill must have come into contact with petroleurn hydrocarbons or coolants, such as: gasoline (no benzene, lead); jet fuel; diesel fuel; lubricants and hydraulics; kerosene; asphaltic petroleum hydrocarbon; and ethylene glycol.

Acceptable waste at any NTS landfill: $\square$ Paper

$\triangle$ Asphalt $\quad$ Metal $\quad$ Wood $\square$ Soil

Plastic

Wire

$\bigotimes$ Cable

Cloth

$\square$ Rocks / unaltered geologic materials

$\bigotimes$ Rubber (excluding tires)

$\bigotimes$ Insulation (non-Asbestosform)

$\triangle$ Manufactured items: (swamp coolers, fumiture, rugs, carpet, electronic components, PPE, etc.)

Additional waste accepted at the Area 23 Mercury Landfill: $\square$ Office Waste

Asbestos

Friable

Non-Friable (contact SWO if regulated load)

Food Waste

Quantity:

Additional waste accepted at the Area 9 U10c Landfill:

$\square$ Non-friable asbestos

Light ballasts (contact SWO)

Hydrocarbons (contact SWO

$\square$

Drained automobiles and military vehicles

Drained fuel filters (gas \& diesel)

Other Drained generators/equipment
Solid fractions from sand/oil/water

$\bigotimes$ Deconned Underground and Above Ground Tanks

Additional waste accepted at the Area 6 Hydrocarbon Landfill:
Septic sludge
Plants
$\square$ Rags
$\square$ Soil

$\square$ Drained fuel filters (gas \& diesel)

Sludge from sand/oil/water separators REQUIRED: WASTE GENERATOR SIGNATURE

Crushed non-teme plated oil filters PCBs below 50 parts per million

Initials: (if initialed, no radiological clearance is necessary.)

The above mentioned waste was generated outside of a Controlled Waste Management Area (CWMA) and to the best of my
knowledge, does not contain radiological materials.

To the best of my knowledge, the waste described above contains only those matn-in . ....

site. I have verified this through the waste characterization method identifie prohibited and allowable waste items. I have contacted Property Manageme is approved for disposal in the landfill.

Print Name: Dan Tobiason

Signature:
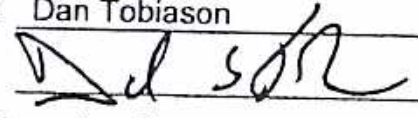

Date: 912

Note: "Food waste, office trash and animal carcasses do not require a radiolc must have signed removal certification statement with Load Verificatior

SWO USE ONLY
Load Weight (net from scale of estimate): 12,80

$10-15-07$

Signature of Certifier

Radiation Survey Release for Waste Disposal RCT Initials

This container/load is free of external radioactive C.t contamination.

This container/load is exempt from survey due to process knowledge and origin. This container/load is free of radioactive

SIGNATURE: contamination based on ra DATE:

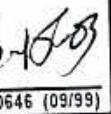




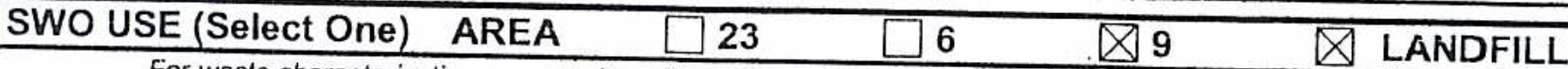

For waste characterization, approval, and/or assistance, contact Solid Waste Operation (SWO) at 5-7898.

REQUIRED: WASTE GERERATOR INFORMATION

(This form is for rolloffs, dump trucks, and other onsite disposal of materials.)

Waste Generator: Dan Tobiason

Phone Number: 295-6169

Location / Origin: T-Tunnel Lower Laydown Yard

Waste Category: (check one)

Waste Type: $\otimes$ NTS

$\square$ Putrescrible

$\triangle$ Industrial ogs $10 / 16 / 07$

(check one) $\square$ Non-Putrescible $\square$ Asbestos Containing Material

Pollution Prevention Category: (check one) $\square$ Environmental management

Pollution Prevention Category: (check one) $\triangle$ Clean-Up

Method of Characterization: (check one)

Sampling \& Analysis

AFFAGQ-OAgite

WAC Exception

Prohibited Waste at all three

NTS landfills:

Additional Prohlbited Waste

at the Area 9 U10C Landfill:

Radioactive waste; RCRA waste; Hazardous waste; Free liquids, PCBs above TSCA regulatory levels, and Medical wastes (needles, sharps, bloody clothing).

$\triangle$ Defense Projects

$\square$ Historic DOE/NV

Sewage Sludge, Animal carcasses, Wet garbage (food waste); and Friable asbestos

\section{REQUIRED: WASTE CONTENTS ALLOWABLE WASTES}

Check all allowable wastes that are contained within this load:

NOTE: Waste disposal at the Area 6 Hydrocarbon Landfill must have come into contact with petroleum hydrocarbons or coolants, such as: gasoline (no benzene, lead); jet fuel; diesel fuel; lubricants and hydraulics; kerosene; asphaltic petroleum hydrocarbon; and ethylene glycol
Acceptable waste at any NTS landfill:
$\triangle$ Paper
Rocks / unaltered geologic materials
$\bigotimes$ Empty containers
$\triangle$ Asphalt
Metal
$\bigotimes$ Wood
$\triangle$ Soil
$\triangle$ Rubber (excluding tires)
$\triangle$ Plastic $\otimes$ Wire
Q Cable
$\triangle$ Cloth
$\bigotimes$ Insulation (non-Asbestosform)
Demolition debris
$凶$ Cement \& concrets

$\triangle$ Manufactured items: (swamp coolers, furniture, rugs, carpet, electronic components, PPE, etc.)

Additional waste accepted at the Area 23 Mercury Landfill: $\square$ Office Waste $\square$ Food Waste
$\square$ Asbestos
Friable
Non-Friable (contact SWO if regulated load)
Quantity:

\section{Additional waste accepted at the Area 9 U10c Landfill:}

$\square$ Non-friable asbestos

Light ballasts (contact SWO)

Hydrocarbons (contact SWO)

$\square$ Drained automobiles and military vehicles

$\square$ Drained fuel filters (gas \& diesel)

Other Drained generators/equipment $\square$ Solid fractions from sand/oil/water

$\otimes$ Deconned Underground and Above Ground Tanks

Additional waste accepted at the Area 6 Hydrocarbon Landfill:

$\begin{array}{ll}\square \text { Septic sludge } & \square \text { Rags } \\ \square \text { Plants } & \square \text { Soil }\end{array}$ $\square$ Drained fuel filters (gas \& diesel)

$\square$ Sludge from sand/oil/water separators $\square$ Crushed non-teme plated oil filters PCBs below 50 parts per million

Initials: ___ (if initialed, no radiological clearance is necessary.) REQUIRED: WASTE GENERATOR SIGNATURE

Animal Carcasses

The above mentioned waste was generated outside of a Controlled Waste Management Area (CWMA) and to the best of my
knowledge, does not contain radiological materials.

$$
\text { knowledge, doas not contain radiological materials. }
$$

To the best of my knowledge, the waste described above contains only those materials that are allowed for disposal at this site. I have verified this through the waste characterization method identified above and a reviaw nc.. prohibited and allowable waste items. I have contacted Property Manage is approved for disposal in the landfill.

Print Name: Dan Tobiason

Signature:

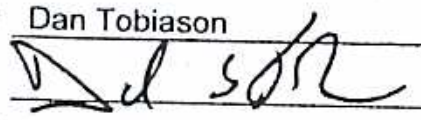

Note: "Food waste, office trash and animal carcasses do not require a radi must have signed removal certification statement with Load Verifica

SWO USE ONLY
Load Weight (net from scale or estimate):

$10-15-07$
Radiation Survey Release for Waste Disposal RCT Initials

This containerlload is free of external radioactive
contamination.
This container/load is exempt from survey due to
process knowledge and origin.
This container/load is free of radioactive
contamination based op ragioanalysis.
SIGNATURE:

Signature of $\mathrm{C}_{\text {crumer: }}$ 
Form

FRM-0918

NTS LANDFILL LOAD VERIFICATION

\begin{tabular}{|c|cc|}
\hline SWO USE (Select One) AREA $\quad \square 23 \quad \square 6 \quad \square 9 \quad \square$ LANDFILL \\
\hline For waste characterization, approval, and/or assistance, contact Solid Waste Operation (SWO) at 5-7898. \\
\hline REQUIRED: WASTE GERERATOR INFORMATION
\end{tabular}

(This form is for rolloffs, dump trucks, and other onsite disposal of materials.)

Waste Generator: Dan Tobiason

Phone Number: 295-6169

Location / Origin: T-Tunnel Lower Laydown Yard

Waste Category: (check one)

Waste Type: $\otimes$ NTS

(check one) $\square$ Non-Putrescible

$\square$ Commerclal

$\square$ Putrescrible

Pollution Prevention Category: (check one)

Method of Characterization: (check one)

$\square$ Environmental management

$\triangle$ Clean-Up

Prohibited Waste at all three

Sampling \& Analysis

Industrial

NTS landfills:

Additional Prohlbited Waste

at the Area 9 U10C Landfill:

Radioactive waste; RCRA waste; Hazardous waste; Free liquids, PCBs above TSCA regulatory levels, and Medical wastes (needles, sharps, bloody clothing).

Sewage Sludge, Animal carcasses, Wet garbage (food waste); and Friable asbestos

\section{REQUIRED: WASTE CONTENTS ALLOWABLE WASTES}

Check all allowable wastes that are contained within this load:

NOTE: Waste disposal at the Area 6 Hydrocarbon Landfill must have come into contact with petroleum hydrocarbons or coolants, such as: gasoline (no benzene, lead); jet fuel; diesel fuel; lubricants and hydraulics; kerosene; asphaltic petroleum hydrocarbon; and ethylene glycol.

Acceptable waste at any NTS landfill: $₫$ Paper
$\triangle$ Asphalt
$\otimes$ Metal
$\triangle$ Wood
$\bigotimes$ Soil
$\triangle$ Cloth
$\square$ Rocks / unaltered geologic materials
$\triangle$ Rubber (excluding tires)
Plastic
Q Cable
Insulation (non-Asbestosform)

$\triangle$ Empty containers

Demolition debris

$\triangle$ Manufactured items: (swamp coolers, furniture, rugs, carpet, electronic components, PPE, etc.)
Additional waste accepted at the Area 23 Mercury Landfill: $\square$ Office Waste
$\square$ Asbestos
Friable
Non-Friable (contact SWO if regulated load)
Food Waste
Animal Carcasses
Quantity:

Additional waste accepted at the Area 9 U10c Landfill:

$\square$ Non-friable asbestos

$\square$ Light ballasts (contact SWO)

$\square$ Drained automobiles and military vehicles

$\square$ Drained fuel filters (gas \& diesel)

Hydrocarbons (contact SWO) $\bigotimes$ Other Drained generators/equipment

$\bigotimes$ Cement \& concrete

Additional waste accepted at the Area 6 Hydrocarbon Landfill:
$\square$ Septic sludge
$\square$ Rags
$\square$ Drained fuel filters (gas \& diesel)
Plants
$\square$ Soil
$\square$ Sludge from sand/oil/water separators
REQUIRED: WASTE GENERATOR SIGNATURE
Crushed non-teme plated oil filters PCBs below 50 parts per million

Initials: (if initialed, no radiological clearance is necessary.)

The above mentioned waste was generated outside of a Controlled Waste Management Area (CWMA) and to the best of my
knowledge, does not contain radiological materials.

To the best of my knowledge, the waste described above contains only those materials that are allowed for disnnas at... site. I have verified this through the waste characterization method identified above and - ....

prohibited and allowable waste items. I have contacted Property Manageme is approved for disposal in the landfill.

Print Name: Dan Tobiason

Signature:
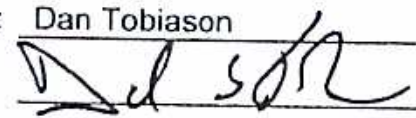

Note: "Food waste, office trash and animal carcasses do not require a radiolo must have signed removal certification statement with Load Verification

SWO USE ONLY

Load Weight (net from scale or estimate): 2360
Date: 912

Radiation Survey Release for Waste Disposal RCT Initials DL This container DC contamination. This containerload is exp origin. process knowledge and free of radioactive This containerlload is free radioanalysis COni

SIGNATURE: $10-15.07$

Signature of Certifier:
DATE 150 BN-0646 (09199) 


\begin{tabular}{|cccccc}
\hline SWO USE (Select One) AREA & $\square 23$ & $\square 6$ & A & 9 9 & LANDFILL
\end{tabular}

For waste characterization, approval, and/or assistance, contact Solid Waste Operation (SWO) at 5-7898.

REQUIRED: WASTE GERERATOR INFORMATION

(This form is for rolloffs, dump trucks, and other onsite disposal of materials.)

Waste Generator: Dan Tobiason

Phone Number: 295-6169

Location / Origin: T-Tunnel Lower Laydown Yard

Waste Category: (check one)

Waste Type: $\square$ NTS

(check one)

$\square$ Non-Putrescible

Pollution Prevention Category: (check one)

Pollution Prevention Category: (check one)

Method of Characterization: (check one)

Prohibited Waste at all three NTS landfills:

Additional Prohlbited Waste at the Area 9 U10C Landfill:

$\square$ Sampling \& Analysis $\square$ Commerclal

$\square$ Putrescrible $\triangle$ Industrial

$\square$ Asbestos Containing Material

D. FFAGQ-OAsito

$\square$ Environmental management

$\triangle$ Clean-Up

$\square$ FFACO-offsite

$\triangle$ Defense Projects

$\square$ Routine

$\triangle$ Process Knowledge $\square$ Contents levels, and Medical wastes (needles, sharps, bloody clothing).

Sewage Sludge, Animal carcasses, Wet garbage (food waste); and Friable asbestos

\section{REQUIRED: WASTE CONTENTS ALLOWABLE WASTES}

Check all allowable wastes that are contained within this load:

NOTE: Waste disposal at the Area 6 Hydrocarbon Landfill must have come into contact with petroleum hydrocarbons or coolants, such as: gasoline (no benzene, lead); jet fuel; diesel fuel; lubricants and hydraulics; kerosene; asphaltic petroleum hydrocarbon; and ethylene glycol.
Acceptable waste at any NTS landfill:
$\bigotimes$ Asphalt $\square$ Metal
Wood
$\triangle$ Paper
¿ Soil
$\bigotimes$ Cable
$\bigotimes$ Cloth
$\square$ Rocks / unaltered geologic materials
$\bigotimes$ Rubber (excluding tires)
$\bigotimes$ Insulation (non-Asbestosform)

$\triangle$ Empty containers

$\bigotimes$ Demolition debris

$凶$ Cement \& concreta

$\triangle$ Manufactured items: (swamp coolers, furniture, rugs, carpet, electronic components, PPE, etc.)

Additional waste accepted at the Area 23 Mercury Landfill: $\square$ Office Waste
$\square$ Asbestos
Friable
Non-Friable (contact SWO if regulated load)

$\square$ Food Waste

Animal Carcasses

Additional waste accepted at the Area 9 U10c Landfill:

$\square$ Non-friable asbestos

Light ballasts (contact SWO)

Hydrocarbons (contact SWO)

$\square$

Drained automobiles and military vehicles

Drained fuel filters (gas \& diesel)

Other Drained generators/equipment

Quantity:

Additional waste accepted at the Area 6 Hydrocarbon Landfill:
$\square$ Septic sludge
$\square$ Rags
$\square$ Drained fuel filters (gas \& diesel)
Plants
Soil
$\square$ Sludge from sarid/oil/water separators
REQUIRED: WASTE GENERATOR SIGNATURE

Solid fractions from sand/oil/water

$\bigotimes$ Deconned Underground and Above Ground Tanks

Initials: (if initialed, no radiological clearance is necessary.)

The above mentioned waste was generated outside of a Controlled Waste Mianagement Area (CWMA) and to the best of my knowledge, does not contain radiological materials.

To the best of my knowledge, the waste described above contains only those materials that are allowed for disposal at this site. I have verified this through the waste characterization method identified ahnuo am. _.....

prohibited and allowable waste items. I have contacted Property Managen is approved for disposal in the landfill.

Print Name: Dan Tobiason

Signature: $\mathrm{D}$ Date: Q1

Note: "Food waste, office trash and animal carcasses do not require a radic must have signed removal certification statement with Load Verificatiı

SWO USE ONLY

Load Weight (net from scale or estimate)

$10-15-07$

Radiation Survey Release for Waste Disposal RCT Initials

This container/load is free of external radioactive Dontamination.

This container/load is exempt from survey due to This container/ead is and origin.

process knowledge and of readioactive This container/load is free of radioactive

contamination based on radioanalysis.

Signature of Certifier: 
NSTec

Form

\begin{tabular}{|llllll}
\hline SWO USE (Select One) & AREA & $\square 23$ & $\square 6$ & . 9 & L LANDFILL
\end{tabular}

For waste characterization, approval, and/or assistance, contact Solid Waste Operation (SWO) at 5-7898.

REQUIRED: WASTE GERERATOR INFORMATION

(This form is for rolloffs, dump trucks, and other onsite disposal of materials.)

Waste Generator: Dan Tobiason

Phone Number: 295-6169

Location / Origin: T-Tunnel Lower Laydown Yard

Waste Category: (check one)

Waste Type: $₫$ NTS

(check one)

$\square$ Non-Putrescible

$\square$ Commercial

$\square$ Putrescrible

$\triangle$ Industrial ghs $10 / 16 / 07$

$\square$ Asbestos Containing Material

Pollution Prevention Category: (check one)

Pollution Prevention Category: (check one)

Method of Characterization: (check one)

$\square$ Environmental management

$\otimes$ Clean-Up

$\square$ Sampling \& Analysis

\#-FFAGQ-onsite $\square$ WAC Exception

Prohibited Waste at all three

NTS landfills:

Additional Prohibited Waste

at the Area 9 U10C Landfill:

Radioactive waste; RCRA waste; Hazardous waste; Free liquids, PCBs above TSCA regulatory levels, and Medical wastes (needles, sharps, bloody clothing).

Sewage Sludge, Animal carcasses, Wet garbage (food waste); and Friable asbestos

REQUIRED: WASTE CONTENTS ALLOWABLE WASTES

Check all allowable wastes that are contained within this load:

NOTE: Waste disposal at the Area 6 Hydrocarbon Landfill must have come into contact with petroleum hydrocarbons or coolants, such as: gasoline (no benzene, lead); jet fuel; diesel fuel; lubricants and hydraulics; kerosene; asphaltic petroleum hydrocarbon; and ethylene glycol.
Acceptable waste at any NTS landfill:
$\triangle$ Asphalt
$\otimes$ Metal
$\triangle$ Wood
$\bigotimes$ Paper
$\square$ Rocks / unaltered geologic materials
$\bigotimes$ Soil
$\triangle$ Rubber (excluding tires)
$\triangle$ Plastic $\triangle$ Wire
$\triangle$ Cable
$\triangle$ Cloth
$\triangle$ Insulation (non-Asbestosform)
$\triangle$ Empty containers
$\bigotimes$ Demolition debris
$\otimes$ Cement \& concrete

$\triangle$ Manufactured items: (swamp coolers, furniture, rugs, carpet, electronic components, PPE, etc.)

Additional waste accepted at the Area 23 Mercury Landfill: $\square$ Office Waste $\square$ Food Wast

$\square$ Asbestos

$\square$ Friable

$\square$ Non-Friable (contact SWO if regulated load)

Quantity:

Additional waste accepted at the Area 9 U10c Landfill:

Non-friable asbestos

Light ballasts (contact SWO)

Hydrocarbons (contact SWO)
Drained automobiles and military vehicles

Drained fuel filters (gas \& diesel)

Other Drained generators/equipment $\square$ Solid fractions from sand/oil/water

$\otimes$ Deconned Underground and Above Ground Tanks

Additional waste accepted at the Area 6 Hydrocarbon Landfill:

$\square$ Septic sludge $\square$ Rags

Plants

Soil

$\square$ Drained fuel filters (gas \& diesel)

$\square$ Sludge from sand/oil/water separators REQUIRED: WASTE GENERATOR SIGNATURE

'Crushed non-teme plated oil filters PCBs below 50 parts per million

Initials: (if initialed, no radiological clearance is necessary.)

The above mentioned waste was generated outside of a Controlled Waste Management Area (CWMA) and to the best of my knowledge, does not contain radiological materials.

To the best of my knowledge, the waste described above contains only those materials that are allowed for disposal at this site. I have verified this through the waste characterization method identified above and a review of the above-mentioned prohibited and allowable waste items. I have contacted Property Managemer

- is approved for disposal in the landfill.

Print Name: Dan Tobiason

Signature:
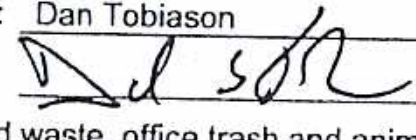

Note: "Food waste, office trash and animal carcasses do not require a radiolo! must have signed removal certification statement with Load Verification

\section{SWO USE ONLY}

Load Weight (net from (scale br estimate):
Date: $912=$

$10.15-07$

Radiation Survey Release for Waste Disposal RCT Initials

IIC This container/load is free of external radioactive contamination.

This container/load is exempt from survey due to process knowledge and origin.

This container/load is free of radioactive

SIGNATURE: O _ DATE: 0.150

Signature of Certmer: 
Form

\begin{tabular}{|llllll}
\hline SWO USE (Select One) & AREA & $\square 23$ & $\square 6$ & 23 & Q LANDFILL
\end{tabular}

For waste characterization, approval, and/or assistance, contact Solid Waste Operation (SWO) at 5-7898.

\section{REQUIRED: WASTE GERERATOR INFORMATION}

(This form is for rolloffs, dump trucks, and other onsite disposal of materials.)

Waste Generator: Dan Tobiason Phone Number: 295-6169

Location / Origin: T-Tunnel Lower Laydown Yard

Waste Category: (check one)

Waste Type: $\triangle$ NTS (check one)

$\square$ Non-Putrescible

Pollution Prevention Category: (check one)

Pollution Prevention Category: (check one)

Method of Characterization: (check one)

Prohibited Waste at all three NTS landfills:

Addltional Prohibited Waste at the Area 9 U10C Landfill: $\square$ Commercial

$\square$ Putrescrible

$\square$ Asbestos Containing Material

$\square$ Environmental management

$\triangle$ Clean-Up

$\square$ Sampling \& Analysis $\triangle$ industrial gs $10 / 16 / 07$

Q-FFACQ-Ongite $\square$ WAC Exception

$\square$ FFACO-offsite $\square$ Historic DOEINV

$\triangle$ Defense Projects $\square$ YMP

$\square$ Routine

$\triangle$ Process Knowledge $\square$ Contents

Radioactive waste; RCRA waste; Hazardous waste; Free liquids, PCBs above TSCA regulatory levels, and Medical wastes (needles, sharps, bloody clothing).

Sewage Sludge, Animal carcasses, Wet garbage (food waste); and Friable asbestos

\section{REQUIRED: WASTE CONTENTS ALLOWABLE WASTES}

Check all allowable wastes that are contained within this load:

NOTE: Waste disposal at the Area 6 Hydrocarbon Landfill must have come into contact with petroleum hydrocarbons or coolants, such as: gasoline (no benzene, lead); jet fuel; diesel fuel; lubricants and hydraulics; kerosene; asphaltic petroleum hydrocarbon; and ethylene glycol.

Acceptable waste at any NTS landfill: $\triangle$ Paper $\square$ Rocks / unaltered geologic materials

$\triangle$ Asphalt $\quad$ Metal $\quad$ Wood $\quad$ Soil

$\triangle$ Plastic $\quad$ Wire $\quad$ Cable $\quad$ Cloth

$\triangle$ Rubber (excluding tires)

$\bigotimes$ Insulation (non-Asbestosform)

$\triangle$ Empty containers

Demolition debris

$\triangle$ Manufactured items: (swamp coolers, furniture, rugs, carpet, electronic components, PPE, etc.)

Additional waste accepted at the Area 23 Mercury Landfill: $\square$ Office Waste

$\square$ Asbestos

Friable

Non-Friable (contact SWO if regulated load)

$\square$ Food Waste

$\bigotimes$ Cement \& concrete

Additional waste accepted at the Area 9 U10c Landfill:

$\square$ Non-friable asbestos

Light ballasts (contact SWO)

$\square$ Drained automobiles and military vehicles

Hydrocarbons (contact SWO)

Drained fuel filters (gas \& diesel)

Other Drained generators/equipment

Quantity:

Animal Carcasses

Additional waste accepted at the Area 6 Hydrocarbon Landfill:
$\square$ Septic sludge
$\square$ Rags
$\square$ Drained fuel filters (gas \& diesel)
Plants
Soil
$\square$ Sludge from sand/oil/water separators
REQUIRED: WASTE GENERATOR SIGNATURE

Solid fractions from sand/oil/water

$\bigotimes$ Deconned Underground and Above Ground Tanks

Initials: (if initialed, no radiological clearance is necessary.)

The above mentioned waste was generated outside of a Controlled Waste Management Area (CWMA) and to the best of my knowledge, does not contain radiological materials.

To the best of my knowledge, the waste described above contains only those । site. I have verified this through the waste characterization method identified prohibited and allowable waste Items. I have contacted Property Management is approved for disposal in the landfill.

Print Name: Dan Tobiason

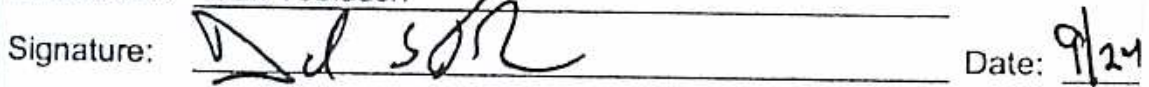

Note: "Food waste, office trash and animal carcasses do not require a radiolos must have signed removal certification statement with Load Verification.
Radiation Survey Release for Waste Disposal RCT Initials

DC This container/load is free of external radioactive D.

This containeriload is exempt from survey due to process knowledge and origin.

This container/load is free of radioactive

SIGNATURE: (1) 


\section{$\begin{array}{llllll}\text { SWO USE (Select One) } & \text { AREA } & \square 23 & \square 6 & \text {. } 39 & \text { L LANDFILL }\end{array}$}

For waste characterization, approval, and/or assistance, contact Solid Waste Operation (SWO) at 5-7898.

REQUIRED: WASTE GERERATOR INFORMATION

(This form is for rolloffs, dump trucks, and other onsite disposal of materials.)

Waste Generator: Dan Tobiason

Phone Number: 295-6169

Location / Origin: T-Tunnel Lower Laydown Yard

Waste Category: (check one)

Waste Type: $\square$ NTS

(check one)

$\square$ Non-Putrescible

Pollution Prevention Category: (check one)

Pollution Prevention Category: (check one)

Method of Characterization: (check one) $\square$ Commercial

$\square$ Putrescrible

$\square$ Asbestos Containing Material

$\square$ Environmental management

$\triangle$ Clean-Up

$\square$ Sampling \& Analysis

NTS landfilis:

Additional Prohibited Waste

at the Area 9 U10C Landfill: $\triangle$ Process Knowledge $\square$ Contents

$\triangle$ Industrial of $10 / 16 / 07$

A-FFAGO-OASite

WAC Exception

$\square$ FFACO-offsite

$\triangle$ Defense Projects

$\square$ Routine
Sewage Sludge, Animal carcasses, Wet garbage (food waste); and Friable asbestos

\section{REQUIRED: WASTE CONTENTS ALLOWABLE WASTES}

Check all allowable wastes that are contained within this load:

NOTE: Waste disposal at the Area 6 Hydrocarbon Landfill must have come into contact with petroleurn hydrocarbons or coolants, such as: gasoline (no benzene, lead); jet fuel; diesel fuel; lubricants and hydraulics; kerosene; asphaltic petroleum hydrocarbon; and ethylene glycol.
Acceptable waste at any NTS landfill:
$\triangle$ Paper
\Soil
$\triangle$ Wood
$\bigotimes$ Cloth
$\square$ Rocks / unaltered geologic materials
$\bigotimes$ Rubber (excluding tires)
$\triangle$ Insulation (non-Asbestosform)
$\bigotimes$ Plastic
$\triangle$ Wire
Cable

$\triangle$ Empty containers

$\bigotimes$ Demolition debris

$\bigotimes$ Manufactured items: (swamp coolers, furniture, rugs, carpet, electronic components, PPE, etc.)

$\bigotimes$ Cement \& concrete
Additional was
Friable
Area 23 Mercury Landfil:
Office Waste
Food Waste
Animal Carcasses
Quantity:

Additional waste accepted at the Area 9 U10c Landfill:

$\square$ Non-friable asbestos

Light ballasts (contact SWO)

Drained automobiles and military vehicles

Hydrocarbons (contact SWO)

Drained fuel filters (gas \& diesel)

Other Drained generators/equipment

\section{Additional waste accepted at the Area 6 Hydrocarbon Landfill:}
$\square$ Septic sludge
$\square$ Rags
$\square$ Drained fuel filters (gas \& diesel)
Plants
$\square$ Soil
$\square$ Sludge from sand/oil/water separators
REQUIRED: WASTE GENERATOR SIGNATURE
Crushed non-teme plated oil filters PCBs below 50 parts per million

Initials: (if initialed, no radiological clearance is necessary.)

The above mentioned waste was generated outside of a Controlled Waste Management Area (CWMA) and to the best of my knowledge, does not contain radiological materials.

To the best of my knowledge, the waste described above contains only those materials that are allowed for disposal at a. site. I have verified this through the waste characterization method identified above and a review of th-

prohibited and allowable waste Items. I have contacted Property Management and h...

is approved for disposal in the landfill.

Print Name: Dan Tobiason Signature:
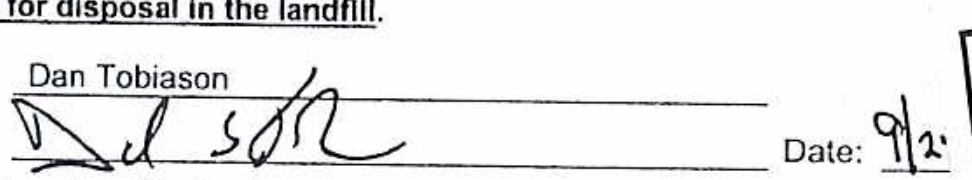

Note: "Food waste, office trash and animal carcasses do not require a radiolos must have signed removal certification statement with Load Verification.

SWO USE ONLY

Load Weight (net from scale or estimate):
$10-15-07$

Signature of Certifi
Radiation Survey Release for Waste Disposal RCT Initials RCT Initials
DCC This containerlload is free of external ramion.
contamination. process knowledge an free of radioactive gad is free of radioalysis. This containerlioased on radion bas

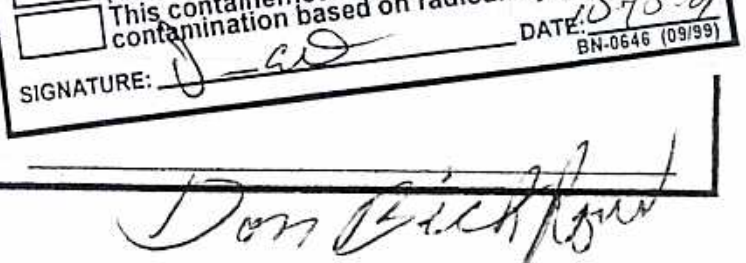




\section{$\begin{array}{llllll}\text { SWO USE (Select One) } & \text { AREA } & \square 23 & \square 6 & \square 9 & \square \text { LANDFILL }\end{array}$}

For waste characterization, approval, and/or assistance, contact Solid Waste Operation (SWO) at 5-7898.

REQUIRED: WASTE GERERATOR INFORMATION

(This form is for rolloffs, dump trucks, and other onsite disposal of materials.)

Waste Generator: Dan Tobiason

Phone Number: 295-6169

Location / Origin: T-Tunnel Lower Laydown Yard

Waste Category: (check one)

Waste Type: \NTS

\section{$\square$ Commercial}

$\square$ Putrescrible

Non-Putrescible

$\square$ Asbestos Containing Material

Pollution Prevention Category: (check one) $\square$ Environmental management

Pollution Prevention Category: (check one)

Method of Characterization: (check one)

$\triangle$ Clean-Up

$\square$ Sampling \& Analysis

Prohibited Waste at all three

NTS landfills:

Additional Prohibited Waste

at the Area 9 U10C Landfill:

$\triangle$ Industrial ces $10 / 17 / 07$
$\square$ FfAGO-omsite-
$\square$ FFACO-offsite

$\triangle$ Defense Projects

$\square$ Routine

$\triangle$ Process Knowledge $\square$ Contents Radioactive waste; RCRA waste; Hazardous waste; Free liquids, PCBs above TSCA regulatory levels, and Medical wastes (needles, sharps, bloody clothing).

Sewage Sludge, Animal carcasses, Wet garbage (food waste); and Friable asbestos

\section{REQUIRED: WASTE CONTENTS ALLOWABLE WASTES}

Check all allowable wastes that are contained within this load:

NOTE: Waste disposal at the Area 6 Hydrocarbon Landfill must have come into contact with petroleurn hydrocarbons or coolants, such as: gasoline (no benzene, lead); jet fuel; diesel fuel; lubricants and hydraulics; kerosene; asphaltic petroleum hydrocarbon; and ethylene glycol

Acceptable waste at any NTS landfill: $\square$ Paper

$\triangle$ Asphalt $\quad$ Metal $\square$ Wood $\square$ Soil

$\triangle$ Plastic $\quad$ Wire $\quad \square$ Cable $\quad$ Cloth

$\square$ Rocks / unaltered geologic materials

$\bigotimes$ Rubber (excluding tires)

$\bigotimes$ Insulation (non-Asbestosform)

$\bigotimes$ Empty containers

$\bigotimes$ Demolition debris

$\bigotimes$ Manufactured items: (swamp coolers, fumiture, rugs, carpet, electronic components, PPE, etc.)

Additional waste accepted at the Area 23 Mercury Landfill: $\square$ Office Waste $\square$ Food Waste
Asbestos
Friable
Non-Friable (contact SWO if regulated load)
Quantity:

Additional waste accepted at the Area 9 U10c Landfill:

Non-friable asbestos

Light ballasts (contact SWO)

Drained automobiles and military vehicles

Hydrocarbons (contact SWO)

Drained fuel filters (gas \& diesel)

Other Drained generators/equipment

$\bigotimes$ Cement \& concrete

Additional waste accepted at the Area 6 Hydrocarbon Landfill:

$\square$ Septic sludge $\square$ Rags

Plants

Soil

$\square$ Drained fuel filters (gas \& diesel)

$\square$ Sludge from sand/oil/water separators

REQUIRED: WASTE GENERATOR SIGNATURE

Crushed non-teme plated oil filters PCBs below 50 parts per million

Initials: (if initialed, no radiological clearance is necessary.)

The above mentioned waste was generated outside of a Controlled Waste Management Area (CWMA) and to the best of my knowledge, does not contain radiological materials.

To the best of my knowledge, the waste described above contains only those materials that are allowed for disposal at this site. I have verified this through the waste characterization method identified ahnue and a rawia... n............ prohibited and allowable waste Items. I have contacted Property Management is approved for disposal in the landfill.

Print Name: Dan Tobiason

Signature:

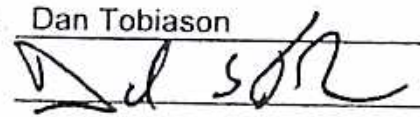

Note: must have signed removal certification statement with Load Verification.

SWO USE ONLY
Load Weight (net from/scale or estimate): $10 . \mathrm{COO}$
Radiation Survey Release for Waste Disposal RCT Initials

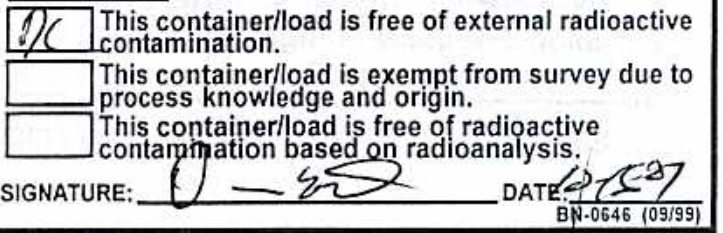

$10-16-07$

Signature of Certifier: 
NSTec

Form

Rev. 0

FRM-0918

\begin{tabular}{|c|cccc}
\hline SWO USE (Select One) AREA & $\square 23$ & $\square 6$ & A 39 & LANDFILL
\end{tabular}

For waste characterization, approval, and/or assistance, contact Solid Waste Operation (SWO) at 5-7898.

REQUIRED: WASTE GERERATOR INFORMATION

(This form is for rolloffs, dump trucks, and other onsite disposal of materials.)

Waste Generator: Dan Tobiason

Phone Number: 295-6169

Location / Origin: T-Tunnel Lower Laydown Yard

Waste Category: (check one)

Waste Type: \NTS

(check one) $\square$ Non-Putrescible

Pollution Prevention Category: (check one)

Pollution Prevention Category: (check one)

Method of Characterization: (check one)

$\square$ Commerclal

$\square$ Putrescrible

$\square$ Asbestos Containing Material

$\triangle$ Industrial og $5107 / 07$

$\square$ Environmental management

$\triangle$-FFAGQ-ancile

$\square$ FFACO-offsite

$\triangle$ Defense Projects

$\square$ WAC Exception

$\triangle$ Clean-Up

Prohibited Waste at all three

NTS landfills:

Additional Prohibited Waste

at the Area 9 U10C Landfill:

Radioactive waste; RCRA waste; Hazardous waste; Free liquids, PCBs above TSCA re levels, and Medical wastes (needles, sharps, bloody clothing).

Sewage Sludge, Animal carcasses, Wet garbage (food waste); and Friable asbestos

\section{REQUIRED: WASTE CONTENTS ALLOWABLE WASTES}

Check all allowable wastes that are contained within this load:

NOTE: Waste disposal at the Area 6 Hydrocarbon Landfill must have come into contact with petroleum hydrocarbons or coolants, such as: gasoline (no benzene, lead); jet fuel; diesel fuel; lubricants and hydraulics; kerosene; asphaltic petroleum hydrocarbon; and ethylene glycol.

Acceptable waste at any NTS landfill: $\square$ Paper
Asphalt
Metal
$\triangle$ Wood
$凶$ Soil

叉 Plastic

Wire

$\bigotimes$ Cable

$\bigotimes$ Cloth

$\square$ Rocks / unaltered geologic materials

$\bigotimes$ Rubber (excluding tires)

$\bigotimes$ Insulation (non-Asbestosform)

$\triangle$ Empty containers

$凶$ Demolition debris

区 Cement \& concrete

$\triangle$ Manufactured items: (swamp coolers, fumiture, rugs, carpet, electronic components, PPE, etc.)

Additional waste accepted at the Area 23 Mercury Landfill: $\square$ Office Waste $\square$ Food Waste
$\square$ Asbestos
Friable
Non-Friable (contact SWO if regulated load)
Quantity:

Additional waste accepted at the Area 9 U10 c Landfill:
Non-friable asbestos
Light ballasts (contact SwO)
$\square$ Drained automobiles and military vehicles
Drained fuel filters (gas \& diesel)

Q. Hydrocarbons (contact SWO)

$\bigotimes$ Other

Drained generators/equipment
$\square$ Solid fractions from sand/oil/water
$\bigotimes$ Deconned Underground and Above Ground Tanks

Additional waste accepted at the Area 6 Hydrocarbon Landfill

$\square$ Septic sludge $\square$ Rags $\square$ Drained fuel filters (gas \& diesel)

Plants

$\square$ Soil

$\square$ Sludge from sand/oil/water separators

REQUIRED: WASTE GENERATOR SIGNATURE

Crushed non-teme plated oil filters

PCBs below 50 parts per million

Initials: (if initialed, no radiological clearance is necessary.)

The above mentioned waste was generated outside of a Controlled Waste Management Area (CWMA) and to the best of mv
knowledge, does not contain radiological materials.

To the best of my knowledge, the waste described above contains only those materials $\mathrm{m}$. .

site. I have verified this through the waste characterization method identified al prohibited and allowable waste Items. I have contacted Property Management a is approved for disposal in the landfill.

Print Name: Dan Tobiason

Signature:

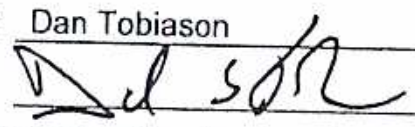

$$
10^{2}-10-2^{3}
$$
Radiation Survey Release for Waste Disposal
RCT Initials M This containerim.

Animal Carcasses Animal Carcasses

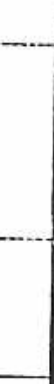

Note: "Food waste, office trash and animal carcasses do must have signed removal certification statement with Load Verification."

SWO USE ONLY

Load Weight (net from scale or estimate):

$10-16-07$

Signature of Certifier:

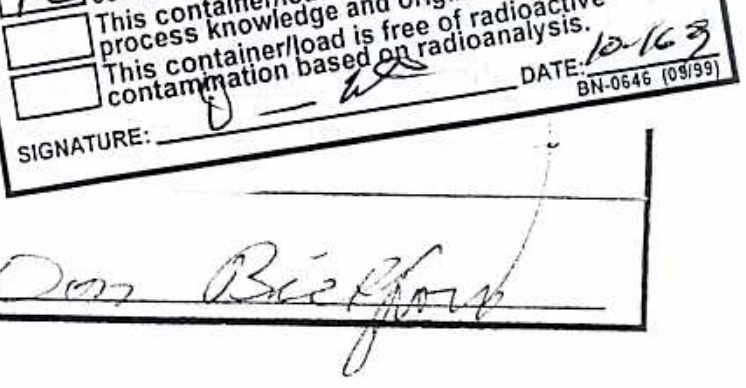




\begin{tabular}{|c|cc|c|}
\hline SWO USE (Select One) AREA $\square 23$ & $\square 6$ & \9 9 \\
\hline For waste characterization, approval, and/or assistance, contact Solid Waste Operation (SWO) at 5-7898. \\
\hline REQUIRED: WASTE GERERATOR INFORMATION
\end{tabular}

(This form is for rolloffs, dump trucks, and other onsite disposal of materials.)

Waste Generator: Dan Tobiason Phone Number: 295-6169

Location / Origin: T-Tunnel Lower Laydown Yard

Waste Category: (check one)

Waste Type: $\triangle$ NTS

(check one) $\square$ Non-Putrescible

$\square$ Commercial

$\square$ Asbestos Containing Material

Pollution Prevention Category: (check one) $\square$ Environmental management

Pollution Prevention Category: (check one)

Method of Characterization: (check one)

$\triangle$ Clean-Up

Sampling \& Analysis

$\triangle$ Industrial Q Q $510 / 17 / 07$

Prohibited Wast
NTS landfills:

Additional Prohlbited Waste

at the Area 9 U10C Landfill:

Radioactive waste; RCRA waste; Hazardous waste; Free liquids, PCBs above TSCA regulatory
levels, and Medical wastes (needles, sharps, bloody clothing).

Sewage Sludge, Animal carcasses, Wet garbage (food waste); and Friable asbestos

\section{REQUIRED: WASTE CONTENTS ALLOWABLE WASTES}

Check all allowable wastes that are contained within this load:

NOTE: Waste disposal at the Area 6 Hydrocarbon Landfill must have come into contact with petroleum hydrocarbons or coolants, such as: gasoline (no benzene, lead); jet fuel; diesel fuel; lubricants and hydraulics; kerosene; asphaltic petroleum hydrocarbon; and ethylene glycol.
Acceptable waste at any NTS landfill: $\bigotimes$ Paper
$\otimes$ Asphalt
$\otimes$ Metal
$\triangle$ Wood
Soil
Plastic
$\triangle$ Wire
$\otimes$ Cable
$\triangle$ Cloth
$\square$ Rocks / unaltered geologic materials
$\triangle$ Rubber (excluding tires)
$\triangle$ Insulation (non-Asbestosform)
$\bigotimes$ Empty coitainers
$\bigotimes$ Demolition debris
$\bigotimes$ Cement a. concrete

$\triangle$ Manufactured items: (swamp coolers, furmiture, rugs, carpet, electronic components, PPE, etc.)
Additional waste accepted at the Area 23 Mercury Landfill:
$\square$ Asbestos
Friable
Non-Friable (contact SWO if regulated load)
Food Waste
Animal Carcasses
Quantity:

Additional waste accepted at the Area 9 U10c Landfill:

$\square$ Non-friable asbestos

$\square$ Light ballasts (contact SWO)

$\square$ Drained automobiles and military vehicles

Drained fuel filters (gas \& diesel)

Hydrocarbons (contact SWO)

$\otimes$ Other

Drained generators/equipment

Additional waste accepted at the Area 6 Hydrocarbon Landfill:
$\square$ Septic sludge
$\square$ Rags
$\square$ Drained fuel filters (gas \& diesel)
Plants
Soil
$\square$ Sludge from sand/oil/water separators
REQUIRED: WASTE GENERATOR SIGNATURE
Crushed non-teme plated oil filters PCBs below 50 parts per million

Solid fractions from sand/oil/water

$\triangle$ Deconned Underground and Above

Ground Tanks

Initials: (if initialed, no radiological clearance is necessary.)

The above mentioned waste was generated outside of a Controlled Waste Management Area (CWMA) and to the best of my
knowledge, does not contain radiological materials.

To the best of my knowledge, the waste described above contains only those materials that are allowed for disposal at this site. I have verified this through the waste characterization method identified above and a review of the above-mentioned prohibited and allowable waste items. I have contacted Property Management al
is approved for disposal in the landfill.

Print Name:

Signature:

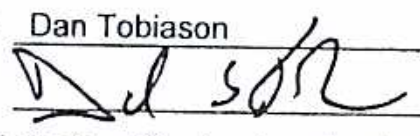

Date: $9|24|$

Note: "Food waste, office trash and animal carcasses do not require a radiologic must have signed removal certification statement with Load Verification."

SWO USE ONLY

Load Weight (net from scale or estimate): $1000 \%$

$10-16-07$

Area (CWMA) and to the best of my
a review of the above-mentioned \begin{tabular}{l} 
Radiation Survey Release for Waste Disposal \\
RCT Initials \\
\hline \hline This container/load is free of external radioactive \\
contamination. \\
\hline This container/load is exempt from survey due to \\
process knowledge and origin. \\
conts containger/load is free of radioactive \\
SIGNATURE:
\end{tabular} Signature of Certifiter. 


\section{$\begin{array}{llllll}\text { SWO USE (Select One) } & \text { AREA } & \square 23 & \square 6 & \text { \9 } & \text { Q LANDFILL }\end{array}$}

For waste characterization, approval, and/or assistance, contact Solid Waste Operation (SWO) at 5-7898.

REQUIRED: WASTE GERERATOR INFORMATION

(This form is for rolloffs, dump trucks, and other onsite disposal of materials.)

Waste Generator: Dan Tobiason

Phone Number: 295-6169

Location / Origin: T-Tunnel Lower Laydown Yard

Waste Category: (check one)

Waste Type: $\otimes$ NTS

(check one) $\square$ Non-Putrescible $\square$ Asbestos Containing Material

Pollution Prevention Category: (check one) $\square$ Environmental management

Pollution Prevention Category: (check one) $\triangle$ Clean-Up

Method of Characterization: (check one)

Sampling \& Analysis

$\begin{array}{ll}\triangle \text { Industrial os } 10 / 17 / 07 \\ \square \text { FfFACO-onsite } & \square \text { WAC Exception } \\ \square \text { FFACO-offsite } & \square \text { Historic DOE/NV }\end{array}$

NTS landfills:

Additional Prohlbited Waste

at the Area 9 U10C Landfill:

Radioactive waste; RCRA waste; Hazardous waste; Free liquids, PCBs above TSCA regulatory levels, and Medical wastes (needles, sharps, bloody clothing).

Sewage Sludge, Animal carcasses, Wet garbage (food waste); and Friable asbestos

REQUIRED: WASTE CONTENTS ALLOWABLE WASTES

Check all allowable wastes that are contained within this load:

NOTE: Waste disposal at the Area 6 Hydrocarbon Landfill must have come into contact with petroleurn hydrocarbons or coolants, such as: gasoline (no benzene, lead); jet fuel; diesel fuel; lubricants and hydraulics; kerosene; aspi altic petroleum hydrocarbon; and ethylene glycol.

Acceptable waste at any NTS landfill: $\square$ Paper

$\triangle$ Asphalt $\quad$ Metal $\quad \square$ Wood $\quad \square$ Soil

$\triangle$ Plastic $\square$ Wire

$\bigotimes$ Cable

Cloth

$\square$ Rocks / unaltered geologic materials

$\otimes$ Rubber (excluding tires)

$\bigotimes$ Insulation (non-Asbestosform) $\triangle$ Empty containers

$\bigotimes$ Demolit. nn debris

$\bigotimes$ Cement \& concrete

$\bigotimes$ Manufactured items: (swamp coolers, furniture, rugs, carpet, electronic components, PPE, etc.)

Additional waste accepted at the Area 23 Mercury Landfill: $\square$ Office Waste $\square$ Food Waste $\square$ Animal Carcasses $\square$ Asbestos $\quad \square$ Friable $\quad \square$ Non-Friable (contact SWO if regulated load) Quantity:

Additional waste accepted at the Area 9 U10c Landfill:

Non-friable asbestos $\quad \square$ Drained automobiles and military vehicles

Light ballasts (contact SWO) $\square$ Drained fuel filters (gas \& diesel)

Hydrocarbons (contact SWO) $\bigotimes$ Other Drained generators/equipment

$\square$ Solid fractions from sand/oil/water

$\bigotimes$ Deconned Underground and Above Ground Tanks

Additional waste accepted at the Area 6 Hydrocarbon Landfill:
Septic sludge
$\square$ Rags
Plants
$\square$ Soil
$\square$ Drained fuel filters (gas \& diesel)
$\square$ Sludge from sand/oil/water separators
$\square$ Crushed non-teme plated oil filters
$\square$ PCBs below 50 parts per million

\section{REQUIRED: WASTE GENERATOR SIGNATURE}

Initials: (if initialed, no radiological clearance is necessary.)

The above mentioned waste was generated outside of a Controlled Waste $\mathrm{M}_{\text {: }}$ knowledge, does not contain radiological materials.

To the best of my knowledge, the waste described above contains only tho site. I have verified this through the waste characterization method identifi prohibited and allowable waste Items. I have contacted Property Managem is approved for disposal in the landfill.

Print Name:

Signature:

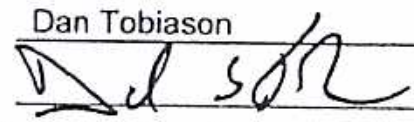
$10-15-07$

Note: "F

$C_{1}$

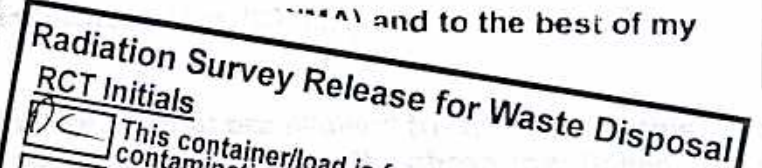
must have signed removal certification statement with Load Verification."

SWO USE ONLY
Load Weight (net from scale or estimate)

$10-16-07$

Signature of Certifier: 


\section{$\begin{array}{llllll}\text { SWO USE (Select One) } & \text { AREA } & \square 23 & \square 6 & \text { (23 } & \text { (S LANDFILL }\end{array}$}

For waste characterization, approval, and/or assistance, contact Solid Waste Operation (SWO) at 5-7898.

REQUIRED: WASTE GERERATOR INFORMATION

(This form is for rolloffs, dump trucks, and other onsite disposal of materials.)

Waste Generator: Dan Tobiason

Phone Number: 295-6169

Location / Origin: T-Tunnel Lower Laydown Yard

Waste Category: (check one)

Waste Type: $\otimes$ NTS

$\square$ Commercial

Industrial of $510 / 17 / 67$

(check one)

$\square$ Non-Putrescible

$\square$ Asbestos Containing Material

$\triangle$ fFACO-onsite

$\square$ WAC Exception

Pollution Prevention Category: (check one)

Pollution Prevention Category: (check one)

$\square$ Environmental management

Method of Characterization: (check one)

$\triangle$ Clean-Up

P Sampling \& Analysis

$\square$ FFACO-offsite

Q Defense Projects

$\square$ Historic DOE/NV

Prohibited Waste at all three

NTS landfllis:

Additional Prohlbited Waste

at the Area 9 U10C Landfill:

Radioactive waste; RCRA waste; Hazardous waste; Free liquids, PCBs above TSCA regulatory
levels, and Medical wastes (needles, sharps, bloody clothing).

$\square$ Routine

$\triangle$ Process Knowledge YMP

Sewage Sludge, Animal carcasses, Wet garbage (food waste); and Friable asbestos

\section{REQUIRED: WASTE CONTENTS ALLOWABLE WASTES}

Check all allowable wastes that are contained within this load:

NOTE: Waste disposal at the Area 6 Hydrocarbon Landfill must have come into contact with petroleurn hydrocarbons or coolants, such as: gasoline (no benzene, lead); jet fuel; diesel fuel; lubricants and hydraulics; kerosene; asphaitic petroleum hydrocarbon; and ethylene glycol.

Acceptable waste at any NTS landfill:

$\triangle$ Asphalt $\triangle$ Metal $\bigotimes$ Wood

$\triangle$ Plastic $\quad$ Wire $\quad$ Cable

$\triangle$ Paper

\ Soil

$\bigotimes$ Cloth

$\square$ Rocks / unaltered geologic materials

$\triangle$ Rubber (excluding tires)

$\triangle$ Empty containers

$\bigotimes$ Demolition debris

Insulation (non-Asbestosform)

$\bigotimes$ Cement \& concrete

(umiture, rugs, carpet, electronic components, PPE, etc.)
Additional was
Friable
Area 23 Mercury Landfill:
$\square$ Office Waste
$\square$ Food Waste
Animal Carcasses
Quantity:

Additional waste accepted at the Area 9 U10c Landfill:

$\square$ Non-friable asbestos

Light ballasts (contact SWO)

Hydrocarbons (contact SWO)

$\square$ Drained automobiles and military vehicles

Drained fuel filters (gas \& diesel)

$\bigotimes$ Other Drained generators/equipment

\section{Additional waste accepted at the Area 6 Hydrocarbon Landfill:
$\square$ Rags
$\square$ Drained fuel filters (gas \& diesel) \\ $\square$ Septic sludge \\ Plants \\ Soil \\ $\square$ Sludge from sand/oil/water separators \\ REQUIRED: WASTE GENERATOR SIGNATURE}

Solid fractions from sand/oil/water

$\otimes$ Deconned Underground and Above Ground Tanks

Initials: (if initialed, no radiological clearance is necessary.) The above mentioned waste was generated outside of a Controlled Waste Management Area (CWMA) and to the best of my
knowledge, does not contain radiological materials.

To the best of my knowledge, the waste described above contains only those materials that are allowed for disnneal $-t$ this site. I have verified this through the waste characterization method identified above and a revin....... prohibited and allowable waste items. I have contacted Property Mananom...

\section{is approved for disposal in the landfill.}

Print Name:

Signature:
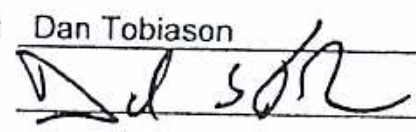

$$
10-16-07
$$

Note: "Food waste, office trash and animal carcasses do not require must have signed removal certification statement with Load $V_{t}$

\section{SWO USE ONLY}

Load Weight (net from/scale or estimate): $20,000 \begin{array}{r}1076-07 \\ \text { Signatur }\end{array}$
Radiation Survey Release for Waste Disposal RCT Initials
TUThis containerlload is free of external radioactive
TComination.

D 1. Contamination. This containerlload is exempt fror process knowledge and or in. This containerlload is free of radioactive contamination basedgn rad SIGNATURE: pment 


\begin{tabular}{|llllll}
\hline SWO USE (Select One) & AREA & $\square 23$ & $\square 6$ & (S) & L LANDFILL
\end{tabular}

For waste characterization, approval, and/or assistance, contact Solid Waste Operation (SWO) at 5-7898.

REQUIRED: WASTE GERERATOR INFORMATION

(This form is for rolloffs, dump trucks, and other onsite disposal of materials.)

Waste Generator: Dan Tobiason

Phone Number: 295-6169

Location / Origin: T-Tunnel Lower Laydown Yard

Waste Category: (check one)

Waste Type: $\triangle$ NTS

(check one) $\square$ Non-Putrescible

$\square$ Commerclal

$\triangle$ Industrial of $10 / 17 / 17$

$\square$ Putrescrible

QFFAEO-ensite

$\square$ WAC Exception

Pollution Prevention Category: (check one)

Pollution Prevention Category: (check one)

Method of Characterization: (check one)

$\square$ Asbestos Containing Material

$\square$ Environmental management

$\square$ FFACO-offsite

$\square$ Historic DOE/NV

Prohibited Waste at all three Redicactive NTS landfills:

Additional Prohibited Waste at the Area 9 U10C Landfill:

levels, and Medical wastes (needles, sharps, bloody clothing).

Sewage Sludge, Animal carcasses, Wet garbage (food waste); and Friable asbestos

\section{REQUIRED: WASTE CONTENTS ALLOWABLE WASTES}

Check all allowable wastes that are contained within this load:

NOTE: Waste disposal at the Area 6 Hydrocarbon Landfill must have come into contact with petroleum hydrocarbons or coolants, such as: gasoline (no benzene, lead); jet fuel; diesel fuel; lubricants and hydraulics; kerosene; asphaltic petroleum hydrocarbon; and ethylene glycol.
Acceptable waste at any NTS landfill: $\square$ Paper
Asphalt
Мetal
$\triangle$ Wood
$\triangle$ Soil
$\square$ Rocks / unaltered geologic materials
Q Empty containers
$\triangle$ Plastic $\otimes$ Wire
¿ Cable
$\triangle$ Cloth
$\triangle$ Rubber (excluding tires)
$\triangle$ Insulation (non-Asbestosform)
Q Demolition debris
$\bigotimes$ Manufactured items: (swamp coolers, furniture, rugs, carpet, electronic components, PPE, etc.)
$\triangle$ Cement \& concrete
Additional waste accepted at the Area 23 Mercury Landfill:
$\square$ Office Waste
$\square$ Food Waste

$\square$ Asbestos

Friable

$\square$ Non-Friable (contact SWO if regulated load)

Quantity:

Additional waste accepted at the Area 9 U10c Landfill:
$\square$ Non-friable asbestos
Drained automobiles and military vehicles
$\square$ Light ballasts (contact SWO)
$\square$ Drained fuel filters (gas \& diesel)
$\square$ Hydrocarbons (contact SWO)

Other

Drained generators/equipment

$\square$ Solid fractions from sand/oil/water

$\triangle$ Deconned Underground and Above Ground Tanks

Additional waste accepted at the Area 6 Hydrocarbon Landfill:
$\square$ Septic sludge
$\square$ Rags
$\square$ Drained fuel filters (gas \& diesel)
Plants
$\square$ Soil
$\square$ Crushed non-teme plated oil filters
PCBs below 50 parts per million $\square$ Sludge from sand/oil/water separators $\square$

Initials: (if initialed, no radiological clearance is necessary.)

The above mentioned waste was generated outside of a Controlled Waste Management Area (CWMA) and to the best of my knowledge, does not contain radiological materials.

To the best of my knowledge, the waste described above contains only those materials that are allowed for disposal at this site. I have verified this through the waste characterization method identified above and a review of the above-mentioner prohibited and allowable waste items. I have contacted Property Management and have verified that as:

is approved for disposal in the landfill.

Print Name: Dan Tobiason

Signature:

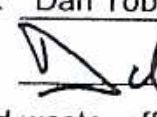

Note: "For must have signed removal certification statement with Load Verification. SWO USE ONLY
Load Weight (net fropt scale or estimate): 20,000
$10-16-8>$ Signature of Certil
Radiation Survey Release for Waste Disposal RCT Initials

This containerlload is free of external radioactive contamination.

This containerlload is exempt $f$.

process knowledge and origin.

$\square$ This containerloas on rad

SIGNATURE: C DATE: Of(c) L 


\section{$\begin{array}{llllll}\text { SWO USE (Select One) } & \text { AREA } & \square 23 & \square 6 & \text { \9 } & \text { \ LANDFILL }\end{array}$}

For waste characterization, approval, and/or assistance, contact Solid Waste Operation (SWO) at 5-7898.

REQUIRED: WASTE GERERATOR INFORMATION

(This form is for rolloffs, dump trucks, and other onsite disposal of materials.)

Waste Generator: Dan Tobiason

Phone Number: 295-6169

Location / Origin: T-Tunnel Lower Laydown Yard

Waste Category: (check one)

Waste Type: $\triangle$ NTS $\square$ Putrescrible

(check one) $\square$ Non-Putrescible $\square$ Asbestos Containing Material

Pollution Prevention Category: (check one) $\square$ Environmental management

Pollution Prevention Category: (check one) $\otimes$ Clean-Up

Method of Characterization: (check one)

$\square$ Sampling \& Analysis

Page 1 of 2

Prohibited Waste at all three
NTS landfills:

Additional Prohlbited Waste

at the Area 9 U10C Landfill:

Radioactive waste; RCRA waste; Hazardous waste; Free liquids, PCBs above TSCA regulatory levels, and Medical wastes (needles, sharps, bloody clothing).

Sewage Sludge, Animal carcasses, Wet garbage (food waste); and Friable asbestos

\section{REQUIRED: WASTE CONTENTS ALLOWABLE WASTES}

Check all allowable wastes that are contained within this load:

NOTE: Waste disposal at the Area 6 Hydrocarbon Landfill must have come into contact with petroleum hydrocarbons or coolants, such as: gasoline (no benzene, lead); jet fuel; diesel fuel; lubricants and hydraulics; kerosene; asphaltic petroleum hydrocarbon; and ethylene glycol.

Acceptable waste at any NTS landfill:

$\triangle$ Asphalt $\quad$ Metal $\quad$ Wood $\quad$ Soil

$\triangle$ Plastic $\quad \square$ Wire $\quad \square$ Cable $\quad \square$ Cloth

$\square$ Rocks / unaltered geologic materials

$\bigotimes$ Rubber (excluding tires)

$\triangle$ Empty containers

Demolition debris

$\triangle$ Manufactured items: (swamp coolers, furniture, rugs, carpet, electronic components, PPE, etc.)

Additional waste accepted at the Area 23 Mercury Landfill: $\square$ Office Waste

$\square$ Asbestos $\square$ Friable $\square$ Non-Friable (contact SWO if regulated load)

$\square$ Food Waste

$\bigotimes$ Cement \& concruie

Additional waste accepted at the Area 9 U10c Landfill:

Non-friable asbestos

Light ballasts (contact SWO)

Hydrocarbons (contact SWO)

$\square$ Drained automobiles and military vehicles

Drained fuel filters (gas \& diesel)

$\triangle$ Other Drained generators/equipment

Additional waste accepted at the Area 6 Hydrocarbon Landfill:
$\square$ Septic sludge
$\square$ Rags
Plants
Soil
$\square$ Drained fuel filters (gas \& diesel)
$\square$ Sludge from sand/oil/water separators

REQUIRED: WASTE GENERATOR SIGNATURE

Quantity:

Initials: (if initialed, no radiological clearance is necessary.)

The above mentioned waste was generated outside of a Controlled Waste Management Area (CWMA) and to the best of my
knowledge, does not contain radiological materials.

To the best of my knowledge, the waste described above contains only those materials that are nlla............

site. I have verified this through the waste characterization method identified a

is approved for disposie waste Items. I have contacted Property Management

is approved for disposal in the landfill.

Print Name: Dan Tobiason

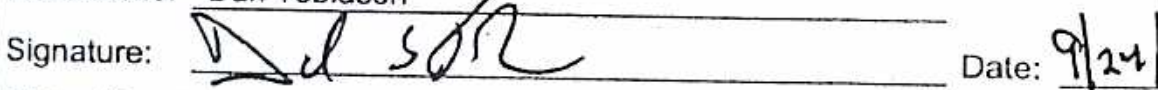

Note: "Food waste, office trash and animal carcasses do not require a radiologic must have signed removal certification statement with Load Verification."

SWO USE ONLY

Load Weight (net from scale or estimate): $\angle, 5$

$10 \cdot 16-07$

Signature of Certifier:

Radiation Survey Release for Waste Disposal RCT Initials

This containerlload is free of external radioactive
contamination.
This container/load is exempt from survey due to
process knowledge and origin.
This container/load is free of radioactive
Contamination based on radioanalysis.
SIGNATURE:




\section{$\begin{array}{llllll}\text { SWO USE (Select One) } & \text { AREA } & \square 23 & \square 6 & \square 9 & \square \text { LANDFILL }\end{array}$}

For waste characterization, approval, and/or assistance, contact Solid Waste Operation (SWO) at 5-7898.

REQUIRED: WASTE GERERATOR INFORMATION

(This form is for rolloffs, dump trucks, and other onsite disposal of materials.)

Waste Generator: Dan Tobiason Phone Number: 295-6169

Location / Origin: T-Tunnel Lower Laydown Yard

Waste Category: (check one)

Waste Type: $\otimes$ NTS $\square$ Commercial

$\triangle$ Industrial os $10 / 18 / 07$

(check one)

$\square$ Non-Putrescible

$\square$ Putrescrible

DFFACO-Onsile

$\square$ WAC Exception

Pollution Prevention Category: (check one)

Pollution Prevention Category: (check one)

Asbestos Containing Material

$\square$ FFACO-offsite

Environmental management

$\triangle$ Defense Projects

$\square$ Historic DOE/NV

Method of Characterization: (check one)

$\triangle$ Clean-Up

$\triangle$ Process Knowledge $\square$ Contents

Prohibited Waste at all three Radioactive waste; RCRA waste; Hazardous waste; Free liquids, PCBs above TSCA regulatory NTS landfills:

Additional Prohibited Waste at the Area 9 U10C Landfill: levels, and Medical wastes (needles, sharps, bloody clothing).

Sewage Sludge, Animal carcasses, Wet garbage (food waste); and Friable asbestos

\section{REQUIRED: WASTE CONTENTS ALLOWABLE WASTES}

Check all allowable wastes that are contained within this load:

NOTE: Waste disposal at the Area 6 Hydrocarbon Landfill must have come into contact with petroleum hydrocarbons or coolants, such as: gasoline (no benzene, lead); jet fuel; diesel fuel; lubricants and hydraulics; kerosene; asphaltic petroleum hydrocarbon; and ethylene glycol.

Acceptable waste at any NTS landfill: $\triangle$ Paper $\square$ Rocks / unaltered geologic materials

$\bigotimes$ Asphalt $\quad$ Metal $\quad$ Wood $\quad$ Soil $\quad \square$ Rubber (excluding tires)

$\triangle$ Plastic $\quad$ Wire $\quad$ Cable $\quad$ Cloth $\quad$ Insulation (non-Asbestosform)

$\bigotimes$ Empty containers

Demolition debris

$\triangle$ Manufactured items: (swamp coolers, fumiture, rugs, carpet, electronic components, PPE, etc.)
Additional waste accepted at the Area 23 Mercury Landfill: $\square$ Office Waste
Food Waste
Animal Carcasses

$\square$ Asbestos

Friable

Non-Friable (contact SWO if regulated load)

Additional waste accepted at the Area 9 U10c Landfill:

Light ballasts (contact SWO)

$\square$ Drained automobiles and military vehicles

$\square$ Drained fuel filters (gas \& diesel)

Hydrocarbons (contact SWO) $\bigotimes$ Other Drained generators/equipment

Quantity:

$\bigotimes$ Cement \& concrete

Additional waste accepted at the Area 6 Hydrocarbon Landfill:
$\square$ Septic sludge
$\square$ Rags
$\square$ Drained fuel filters (gas \& diesel)
Plants
Soil
$\square$ Sludge from sand/oil/water separators
REQUIRED: WASTE GENERATOR SIGNATURE
Crushed non-teme plated oil filters PCBs below 50 parts per' million

Initials: (if initialed, no radiological clearance is necessary.)

The above mentioned waste was generated outside of a Controlled Waste Management Area (CWMA) and to the best of my knowledge, does not contain radiological materials.

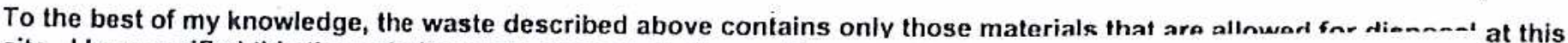
site. I have verified this through the waste characterization metl prohibited and allowable waste Items. I have contacted Propert is approved for disposal in the landfill.

Print Name: Dan Tobiason

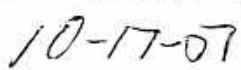

Signature:

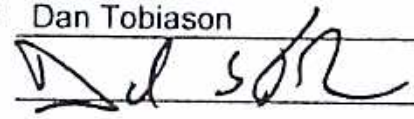

Note: "Food waste, office trash and animal carcasses do not requ must have signed removal certification statement with Loa

SWO USE ONLY

Radiation Survey Release for Waste Disposal RCT Initials

Th This container/load is free of external radioactive Contamination.

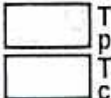

This container/load is exempt from survey due to process knowledge and origin.

This container/load is free of radioactive

SIGNATURE: (1) DATE $\frac{0-176)}{0.0646(0999)}$ oned uipment

.0646 icker" y. nces

Load Weight (net from scale or estimate): $\$ 560$

$10-17-07$ Signature of Certifier: 


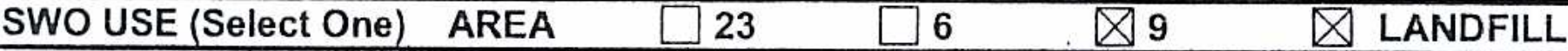

For waste characterization, approval, and/or assistance, contact Solid Waste Operation (SWO) at 5-7898.

\section{REQUIRED: WASTE GERERATOR INFORMATION}

(This form is for rolloffs, dump trucks, and other onsite disposal of materials.)

Waste Generator: Dan Tobiason

Phone Number: 295-6169

Location / Origin: T-Tunnel Lower Laydown Yard

Waste Category: (check one)

Waste Type: $\triangle$ NTS

$\square$ Commercial

$\square$ Putrescrible

(check one)

$\square$ Non-Putrescible

$\square$ Asbestos Containing Material

Pollution Prevention Category: (check one)

Pollution Prevention Category: (check one)

Method of Characterization: (check one)

Environmental management

¿ Clean-Up

Prohibited Waste at all three NTS landfills:

Additional Prohibited Waste at the Area 9 U10C Landfill:

Radioactive waste; RCRA waste; Hazardous waste; Free liquids, PCBs above TSCA regulatory levels, and Medical wastes (needles, sharps, bloody clothing).

Sewage Sludge, Animal carcasses, Wet garbage (food waste); and Friable asbestos

\section{REQUIRED: WASTE CONTENTS ALLOWABLE WASTES}

Check all allowable wastes that are contained within this load:

NOTE: Waste disposal at the Area 6 Hydrocarbon Landfill must have come into contact with petroleum hydrocarbons or coolants, such as: gasoline (no benzene, lead); jet fuel; diesel fuel; lubricants and hydraulics; kerosene; asphaltic petroleum hydrocarbon; and ethylene glycol.
Acceptable waste at any NTS landfill:
Paper
$\square$ Rocks / unaltered geologic materials
$\triangle$ Empty containers
$\triangle$ Asphalt $\quad$ Metal $\quad$ Wood $\quad$ Soil
$\triangle$ Plastic $\square$ Wire
$\triangle$ Cable
$\bigotimes$ Cloth
$\otimes$ Rubber (excluding tires)
$\bigotimes$ Insulation (non-Asbestosform)
$凶$ Demolition debris
$\triangle$ Manufactured items: (swamp coolers, furniture, rugs, carpet, electronic components, PPE, etc.)
Additional waste accepted at the Area 23 Mercury Landfill: $\square$ Office Waste
Asbestos
Friable
Non-Friable (contact SWO if regulated load)
Food Waste
Animal Carcasses
Quantity:
$\bigotimes$ Cement \& concrete

Additional waste accepted at the Area 9 U10c Landfill:

$\square$ Non-friable asbestos

Light ballasts (contact SWO)

Drained automobiles and military vehicles

$\square$ Drained fuel filters (gas \& diesel)

Hydrocarbons (contact SWO)

Other Drained generators/equipment

Additional waste accepted at the Area 6 Hydrocarbon Landfill:
$\square$ Septic sludge
$\square$ Rags
$\square$ Drained fuel filters (gas \& diesel)
Plants
Soil
$\square$ Sludge from sand/oil/water separators REQUIRED: WASTE GENERATOR SIGNATURE

Solid fractions from sand/oil/water

$\bigotimes$ Deconned Underground and Above Ground Tanks

Initials: (if initialed, no radiological clearance is necessary.)

The above mentioned waste was generated outside of a Controlled Waste Management Area (CWMA) and to the best of my knowledge, does not contain radiological materials.

To the best of my knowledge, the waste described above contains only those materials that are allnwor far din..... .... . site. I have verified this through the waste characterization method identified prohibited and allowable waste items. I have contacted Property Managemen is approved for disposal in the landfill.

$1(1)-17-0\rangle$

Print Name: Dan Tobiason

Signature:

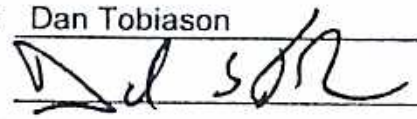

Date: 9124

Note: "Food waste, office trash and animal carcasses do not require a radiologi must have signed removal certification statement with Load Verification."

\section{SWO USE ONLY}

Load Weight (net from scale fr estimate): $3328 \begin{gathered}10-17-07 \\ \text { Signature of Certifier: }\end{gathered}$

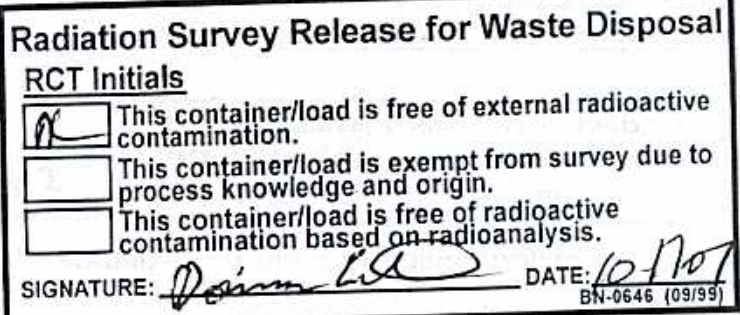




\begin{tabular}{|c|}
\hline SWO USE (Select One) AREA $\square 23$ \\
\hline For wasle characterization, approval, and/or assistance, contact Solid Waste Operation (SWO) at 5-7898. \\
\hline REQUIRED: WASTE GERERATOR INFORMATION \\
(This form is for rolloffs, dump trucks, and other onsite disposal of materials.)
\end{tabular}

Waste Generator: Dan Tobiason

Phone Number: 295-6169

Location / Origin: T-Tunnel Lower Laydown Yard

Waste Category: (check one)

Waste Type: $\triangle$ NTS

Pollution Prevention Containing Material

ention Category: (check one)

Pollution Prevention Category: (check one)

$\square$ Environmental management

Method of Characterization: (check one) $\square$ Sampling \& Analysis

Prohibited Waste at all three

NTS landfills:

Additional Prohlbited Waste

at the Area 9 U10C Landfill:

Radioactive waste; RCRA waste; Hazardous waste; Free liquids, PCBs above TSCA regulatory
levels, and Medical wastes (needles, sharps, bloody clothing). levels, and Medical wastes (needles, sharps, bloody clothing).

$\triangle$ Industrial cos $10 / 18 / 07$

$\triangle$ FFACO-ansite

$\square$ WAC Exception

$\square$ FFACO-offsite

$\triangle$ Defense Projects

$\square$ Routine

Routine

Sewage Sludge, Animal carcasses, Wet garbage (food waste); and Friable asbestos

REQUIRED: WASTE CONTENTS ALLOWABLE WASTES

Check all allowable wastes that are contained within this load:

NOTE: Waste disposal at the Area 6 Hydrocarbon Walfill coolants, such as: gasoline (nydroct pelroum hydrocarbons or petroleum hydrocarbon; and ethylene glycol.
Acceptable waste at any NTS
Asphalt
$凶$ Metal
$\triangle$ Wood
$\triangle$ Paper
S Soil
Cloth
$\square$ Rocks / unaltered geologic materials
$\triangle$ Rubber (excluding tires)
冈 Insulation (non-Asbestosform)
$\triangle$ Empty containers
$\triangle$ Demolition debris:
$\bigotimes$ Cement \& concrete

$\triangle$ Manufactured items: (swamp coolers, furniture, rugs, carpet, electronic components, PPE, etc.)

Additional waste accepted at the Area 23 Mercury Landfill: $\square$ Office Waste $\square$ Food Waste

$\square$ Asbestos $\square$ Friable $\square$ Non-Friable (contact SWO if regulated load) Quantity:

Additional waste accepted at the Area 9 U10c Landfill:

$\square$ Non-friable asbestos

Light ballasts (contact SWO)

Hydrocarbons (contact SWO

Drained automobiles and military vehicles

Drained fuel filters (gas \& diesel)

Other Drained generators/equipment

Solid fractions from sand/oil/water

$\otimes$ Deconned Underground and Above Ground Tanks

Additional waste accepted at the Area 6 Hydrocarbon Landfill:

$\square$ Septic sludge $\square$ Rags

Plants $\square$ Soil

$\square$ Drained fuel filters (gas \& diesel)

$\square$ Sludge from sand/oil/water separators

Crushed non-teme plated oil filters PCBs below 50 parts per million REQUIRED: WASTE GENERATOR SIGNATURE

Initials: (if initialed, no radiological clearance is necessary.)

The above mentioned waste was generated outside of a Controlled Waste Management Area (CWMA) and to the best of my knowledge, does not contain radiological materials.

To the best of my knowledge, the waste described above contains only those site. I have verified this through the waste characterization method identified prohibited and allowable waste Items. I have contacted Property Management is approved for disposal in the landfill.

Print Name: Dan Tobiason

Signature:

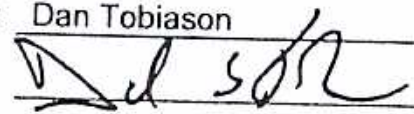

Date: 9 ?t24

Note: "Food waste, office trash and animal carcasses do not require a radiolos must have signed removah certification statement with Load Verification

SWO USE ONLY

Load Weight (net from scale or estimate): 19,960

$10-17-07$ Signature of Certifier:

\section{Trers}

C $\_$This container/load is free of external radioactive

This conta

process knowledge and origin. from survey due to This container/load origin.

contamination based-qn radioanalysis.

SIGNATURE:\& _ DATE: 2.1 12

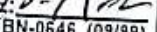

Radiation Survey Release for Waste Disposal
RCT Initials 
NSTec

Form

\begin{tabular}{|c|}
\hline SWO USE (Select One) AREA $\square 23$ \\
\hline For waste characterization, approval, and/or assistance, contact Solid Waste Operation (SWO) at 5-7898. \\
REQUIRED: WASTE GERERATOR INFORMATION \\
(This form is for rolloffs, dump trucks, and other onsite disposal of materials.)
\end{tabular}

Waste Generator: Dan Tobiason

Phone Number: 295-6169

Location / Origin: T-Tunnel Lower Laydown Yard

Waste Category: (check one)

Waste Type: $\triangle$ NTS

$\triangle$ Industrial cgs 10/25/67

Pollution Prevention Category: (check on $\theta$ )

Pollution Prevention Category: (check one)

$\square$ Environmental management

4-FFAGQansite

$\square$ WAC Exception

Method of Characterization: (check one)

$\triangle$ Clean-Up

$\square$ FFACO-offsite

$\triangle$ Defense Projects

[] Historic DOE/NV

ne) $\square$ Sampling \& Analysis

$\square$ Routine

Prohibited Waste at all three

NTS landfills:

Additional Prohlbited Waste

at the Area 9 U10C Landfill:

levels, and waste; RCRA waste; Hazardous waste; Free liquids, PCBs above TSCA regulatory evels, and Medical wastes (needles, sharps, bloody clothing).

Sewage Sludge, Animal carcasses, Wet garbage (food waste); and Friable asbestos

\section{REQUIRED: WASTE CONTENTS ALLOWABLE WASTES}

Check all allowable wastes that are contained within this load:

NOTE: Waste disposal at the Area 6 Hydrocarbon Landfill must have come into contact with petroleum hydrocarbons or coolants, such as: gasoline (no benzene, lead); jet fuel; diesel fuel; lubricants and hydraulics; kerosene; asphaltic petroleum hydrocarbon; and ethylene glycol.
Acceptable waste at any NTS landfill:
Asphalt
$\otimes$ Metal
$\bigotimes$ Wood
$\triangle$ Paper
\Soil
$\bigotimes$ Cloth
$\square$ Rocks / unaltered geologic materials
Q Rubber (excluding tires)
$\bigotimes$ Insulation (non-Asbestosform)

$\triangle$ Manufactured items: (swamp coolers, fumiture, rugs, carpet, electronic components, PPE, etc.)
Additional waste accepted at the Area 23 Mercury Landfill:
Asbestos
$\square$ Friable
$\square$ Non-Friable (contact SWO if regulated load)
Food Waste
Quantity:

Additional waste accepted at the Area 9 U10 C Landfill:

\section{$\square$ Non-friable asbestos}

$\square$ Light ballasts (contact SWO)

Hydrocarbons (contact SWO)

$\square$ Drained automobiles and military vehicles

$\square$ Drained fuel filters (gas \& diesel)

Other Drained generators/equipment
Solid fractions from sand/oil/water

$\bigotimes$ Deconned Underground and Above Ground Tanks

Additional waste accepted at the Area 6 Hydrocarbon Landfill:
$\square$ Septic sludge
$\square$ Rags
Plants
Soil

$\square$ Drained fuel filters (gas \& diesel)
$\square$ Sludge from sand/oil/water separators REQUIRED: WASTE GENERATOR SIGNATURE

Initials: (if initialed, no radiological clearance is necessary.)

The above mentioned waste was generated outside of a Controlled Waste $M_{i}$ knowiedige, does not contain radiological materials.

To the best of my knowledge, the waste described above contains only thos site. I have verified this through the waste characterization method identifie prohibited and allowable waste Items. I have contacted Property Manageme is approved for disposal in the landfill.

Print Name: Dan Tobiason

Signature:
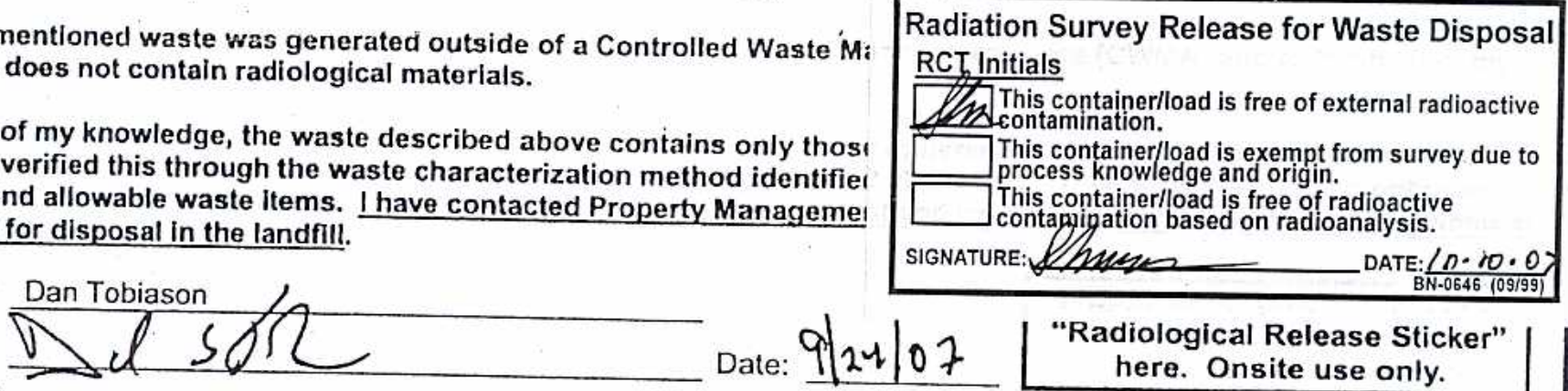
must have signed removal certification statement with require a radiologica

\section{SWO USE ONLY}

Load Weight (net from scale or estimate) 20,130
$10-22-07$

Signature of Certifier:
Crushed non-teme plated oil filters PCBs below 50 parts per million 


\section{SWO USE (Select One) AREA 23 6 \\ Х9 \\ LANDFILL}

For waste characterization, approval, and/or assistance, contact Solid Waste Operation (SWO) at 5-7898.

REQUIRED: WASTE GERERATOR INFORMATION

(This form is for rolloffs, dump trucks, and other onsite disposal of materials.)

Waste Generator: Dan Tobiason Phone Number: 295-6169

Location/ Origin: T-Tunnel Lower Laydown Yard

Waste Category: (check one)

Waste Type: $\bigotimes$ NTS

(check one) $\square$ Non-Putrescible

Pollution Prevention Category: (check one)

Pollution Prevention Category: (check one)

Method of Characterization: (check one)

Prohibited Waste at all three

NTS landfilis:

Additional Prohibited Waste

at the Area 9 U10C Landfill:

\begin{abstract}
Radioactive waste; RCRA waste; levels, and Medical wastes (needles, sharps, bloody clothing).
\end{abstract}

Sewage Sludge, Animal carcasses, Wet garbage (food waste); and Friable asbestos

REQUIRED: WASTE CONTENTS ALLOWABLE WASTES

Check all allowable wastes that are contained within this load:

NOTE: Waste disposal at the Area 6 Hydrocarbon Landfill must have come into contact with petroleum hydrocarbons or coolants, such as: gasoline (no benzene, lead); jet fuel; diesel fuel; lubricants and hydraulics; kerosene; asphaltic petroleum hydrocarbon; and ethylene glycol.
Acceptable waste at any NTS landfill:
$\triangle$ Paper
$\triangle$ Asphalt $\quad$ Metal $\quad \square$ Wood
$\triangle$ Soil
$\triangle$ Plastic
\Cable
Cloth
$\square$ Rocks / unaltered geologic materials
Q Rubber (excluding tires)
$\bigotimes$ Insulation (non-Asbestosform)
$\bigotimes$ Empty containers
$\bigotimes$ Demolition debris
$\bigotimes$ Cement \& concrete
$\triangle$ Manufactured items: (swamp coolers, fumiture, rugs, carpet, electronic components, PPE, etc.)
Additional waste accepted at the Area 23 Mercury Landfill: $\square$ Office Waste
$\square$ Asbestos
Friable
$\square$ Non-Friable (contact SWO if regulated load)
$\square$ Food Waste
Quantity:
Animal Carcasses

\section{Additional waste accepted at the Area 9 U10c Landfill:}

$\square$ Non-friable asbestos

$\square$ Light ballasts (contact SWO)

Hydrocarbons (contact SWO)

$\square$ Drained automobiles and military vehicles

Drained fuel filters (gas \& diesel)

Other Drained generators/equipment
Solid fractions from sand/oil/water

$\bigotimes$ Deconned Underground and Above Ground Tanks

Additional waste accepted at the Area 6 Hydrocarbon Landfill:
$\square$ Septic sludge
$\square$ Rags
$\square$ Drained fuel filters (gas \& diesel)
Plants
Soil
$\square$ Sludge from sand/oil/water separators
REQUIRED: WASTE GENERATOR SIGNATURE
Crushed non-teme plated oil filters PCBs below 50 parts per million

Initials: (if initialed, no radiological clearance is necessary.)

The above mentioned waste was generated outside of a Controlled Wast knowledge, does not contain radiological materials.

To the best of my knowledge, the waste described above contains only $t$ site. I have verified this through the waste characterization method iden prohibited and allowable waste Items. I have contacted Property Manag is approved for disposal in the landfill.

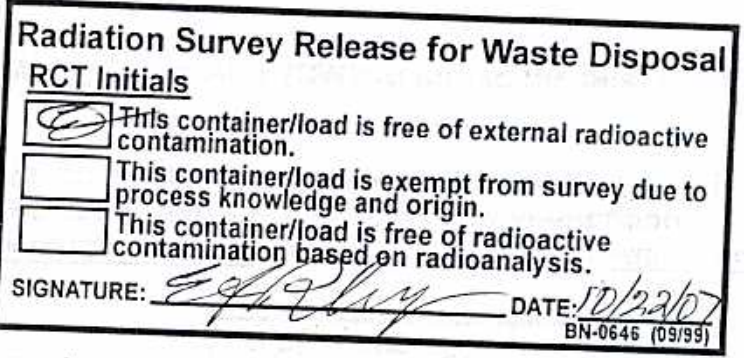

Print Name: Dan Tobiason

Signature:

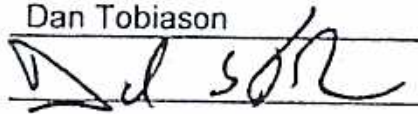

Date: $9|24| 07$

"Radiological kelease suckeı here. Onsite use only.

Note: "Food waste, office trash and animal carcasses do not require a radiological clearance. Freon-containing appliances must have signed removal certification statement with Load Verification."

\section{SWO USE ONLY}

Load Weight (net fropi scale, or estimate):
$10-22-07$

Signature of Certifier: 


\begin{tabular}{|c|}
\hline SWO USE (Select One) AREA $\square 23$ \\
\hline For waste characterization, approval, and/or assistance, contact Solid Waste Operation (SWO) at 5-7898. \\
REQUIRED: WASTE GERERATOR INFORMATION \\
(This form is for rolloffs, dump trucks, and other onsite disposal of materials.)
\end{tabular}

Waste Generator: Dan Tobiason Phone Number: 295-6169

Location / Origin: T-Tunnel Lower Laydown Yard

Waste Category: (check one)

Waste Type: $\square$ NTS

$\square$ Commercial

$\triangle$ Industrial

$\square$ Putrescrible

Q-FFAGQ-ansite

2S $10 / 23 / 07$

(check one)

$\square$ Non-Putrescible

$\square$ Asbestos Containing Material

Pollution Prevention Category: (check one)

Pollution Prevention Category: (check one)

$\square$ Environmental management

$\triangle$ Clean-Up

Method of Characterization: (check one)

7 Sampling \& Analysis.

$\square$ FFACO-offsite

$\square$ WAC Exception

Prohibited Waste at all three

NTS landfills:

Additional Prohibited Waste

at the Area 9 U10C Landfill:

levels, and Medical wastes (needles, sharps, bloody clothing).

Sewage Sludge, Animal carcasses, Wet garbage (food waste); and Friable asbestos

\section{REQUIRED: WASTE CONTENTS ALLOWABLE WASTES}

Check all allowable wastes that are contained within this load:

NOTE: Waste disposal at the Area 6 Hydrocarbon Landfill must have come into contact with petroleum hydrocarbons or coolants, such as: gasoline (no benzene, lead); jet fuel; diesel fuel; lubricants and hydraulics; kerosene; asphaltic petroleum hydrocarbon; and ethylene glycol.
Acceptable waste at any NTS landfill: $\triangle$ Paper
$\bigotimes$ Asphalt
$\otimes$ Metal
$\otimes$ Wood
$\bigotimes$ Soil
$\triangle$ Cable
$\otimes$ Cloth
$\square$ Rocks / unaltered geologic materials
$\triangle$ Rubber (excluding tires)
$\triangle$ Plastic $\triangle$ Wire
$\triangle$ Manufactured items: (swamp coolers, furniture, rugs, carpet, electronic components, PPE, etc.)
$\triangle$ Insulation (non-Asbestosform)
$\triangle$ Empty containers
$\bigotimes$ Demolition debris
$\otimes$ Cement \& concrete

Additional waste accepted at the Area 23 Mercury Landfill: $\square$ Office Waste $\square$ Food Waste

$\square$ Asbestos

Friable

Non-Friable (contact SWO if regulated load)

Quantity:

Additional waste accepted at the Area 9 U10c Landfill:
$\square$ Non-friable asbestos
Drained automobiles and military vehicles
Light ballasts (contact SWO)
Drained fuel filters (gas \& diesel)

Hydrocarbons (contact SWO)

Other

Drained generators/equipment

$\square$ Solid fractions from sand/oil/water

$\triangle$ Deconned Underground and Above Ground Tanks

\section{Additional waste accepted at the Area 6 Hydrocarbon Landfill:}
Septic sludge
$\square$ Rags
$\square$ Drained fuel filters (gas \& diesel)
Plants
Soil
$\square$ Sludge from sand/oil/water separators

Initials: ___ (if initialed, no radiological clearance is necessary.)

Animal Carcasses

The above mentioned waste was generated outside of a Controlled $W$ : knowledge, does not contain radiological materials.

To the best of my knowledge, the waste described above contains onl site. I have verified this through the waste characterization method id prohibited and allowable waste Items. I have contacted Property Man: is approved for disposal in the landfill.

Radiation Survey Release for Waste Disposal
RCT Initials
$\begin{aligned} & \text { This container/load is free of external radioactive } \\ & \text { contamination. }\end{aligned}$
This container/load is exempt from survey due to
process knowledge and origin.
This container/load is free of radioactive
contamination based on radioanalysis.

Print Name: Dan Tobiason

Signature:
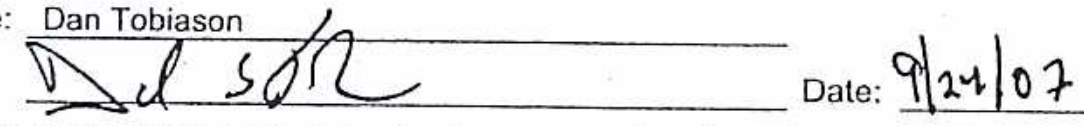

$\square$ Crushed non-teme plated oil filters PCBs below 50 parts per million

Note: "Food waste, office trash and animal carcasses do not require a radiological clearance. Freon-containing appliances must have signed removal certification statement with Load Verification."

LWO USE ONLY Weight (net from scale or estimate): 8,300

$10-22-07$

Signature of Certifier

If applicable, place FRM-0646,

"Radiological Release Sticker" here. Onsite use only.

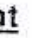


NSTec

Form

\section{SWO USE (Select One) AREA $\square 23 \quad \square 6 \quad . \quad 96$ LANDFILL}

For waste characterization, approval, and/or assistance, contact Solid Waste Operation (SWO) at 5-7898.

REQUIRED: WASTE GERERATOR INFORMATION

(This form is for rolloffs, dump trucks, and other onsite disposal of materials.)

Waste Generator: Dan Tobiason

Phone Number: 295-6169

Location / Origin: T-Tunnel Lower Laydown Yard

Waste Category: (check one)

Waste Type: $\triangle$ NTS

(check one)

$\square$ Non-Putrescible

$\square$ Commercial

$\square$ Putrescrible

$\square$ Asbestos Containing Material

Pollution Prevention Category: (check one)

Pollution Prevention Category: (check one)

Method of Characterization: (check one) $\square$ Sampling \& Analysis

$\square$ Environmental management

$\triangle$ Clean-Up

$\triangle$ Industrial Cos 10/23/07

Q7FACO-Onsite $\square$ WAC Exception

$\square$ FFACO-offsite

$\triangle$ Defense Projects

$\square$ Historic DOE/NV

$\square$ Routine

Q Process Knowledge

Contents

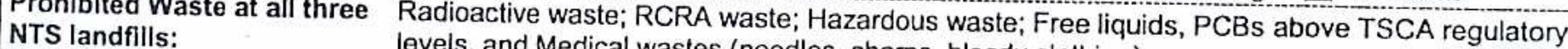

Additional Prohlbited Waste

at the Area 9 U10C Landfill:

Sewage Sludge, Animal carcasses, Wet garbage (food waste); and Friable asbestos

\section{REQUIRED: WASTE CONTENTS ALLOWABLE WASTES}

Check all allowable wastes that are contained within this load:

NOTE: Waste disposal at the Area 6 Hydrocarbon Landfill must have come into contact with petroleum hydrocarbons or coolants, such as: gasoline (no benzene, lead); jet fuel; diesel fuel; lubricants and hydraulics; kerosene; aspha!tic petroleum hydrocarbon; and ethylene glycol.

Acceptable waste at any NTS landfill: $\triangle$ Paper $\square$ Rocks / unaltered geologic materials

$\begin{array}{lllll}\triangle \text { Asphalt } & \square \text { Metal } & \square \text { Wood } & \square \text { Soil } & \square \text { Rubber (excluding tires) }\end{array}$

$\bigotimes$ Insulation (non-Asbestosform)

Empty containers

$\bigotimes$ Demolition debris

$\triangle$ Manufactured items: (swamp coolers, fumiture, rugs, carpet, electronic components, PPE, etc.)

Additional waste accepted at the Area 23 Mercury Landfill: $\square$ Office Waste $\square$ Food Waste
$\square$ Asbestos $\square$ Friable $\square$ Non-Friable (contact SWO if regulated load) Quantity:

$凶$ Cement \& concrete
Quantity:

\section{Additional waste accepted at the Area 9 U10 c Landfill:}

$\square$ Light ballasts (contact

Hydromo)

Drained automobiles and military vehicles

$\square$ Drained fuel filters (gas \& diesel)

Other Drained generators/equipment

$\square$ Solid fractions from sand/oiliwater

$\bigotimes$ Deconned Underground and Above Ground Tanks

Additional waste accepted at the Area 6 Hydrocarbon Landfill:
$\square$ Septic sludge
Plants
$\square$ Rags
Soil
$\square$ Drained fuel filters (gas \& diesel)
$\square$ Sludge from sand/oil/water separators REQUIRED: WASTE GENERATI

Initials: (if initialed, no radiological clearance is necessary.)

The above mentioned waste was generated outside of a Controlled Was knowledge, does not contain radiological materials.

To the best of my knowledge, the waste described above contains only site. I have verified this through the waste characterization method ider prohibited and allowable waste items. I have contacted Property Manag is approved for disposal in the landfill.

Radiation Survey Release for Waste Disposal RCT Initials This container/load is free of external radioactive
contamination.

This container/load is exempt from survey due to process knowledge and origin.

This container/load is free of radioactive contamination based on radioanalysis. SIGNATURE: BN-0646 (09/99)

Print Name: Dan Tobiason Signature:

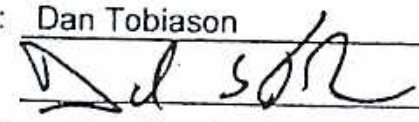

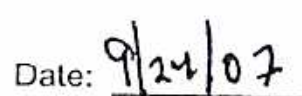

If applicable, place FRM-0646,

"Radiological Release Sticker" here. Onsite use only.

Note: "Food waste, office trash and animal carcasses do not require a radiological clearance. Freon-containing appliances must have signed removal certification statement with Load Verification."

\section{SWO USE ONLY}

Load Weight (net from scale of estimate):
$10-22-67$

Signature of Certifier. 
Form

\begin{tabular}{|llllll}
\hline SWO USE (Select One) & AREA & $\square 23$ & $\square 6$ & (23 & L LANDFILL
\end{tabular}

For waste characterization, approval, and/or assistance, contact Solid Waste Operation (SWO) at 5-7898.

REQUIRED: WASTE GERERATOR INFORMATION

(This form is for rolloffs, dump trucks, and other onsite disposal of materials.)

Waste Generator: Dan Tobiason

Phone Number: 295-6169

Location / Origin: T-Tunnel Lower Laydown Yard

Waste Category: (check one)

Waste Type: $\triangle$ NTS

$\square$ Commercial

$\triangle$ Industrial \&s

$10 / 23 / 07$

(check one)

Non-Putrescible

$\square$ Putrescrible

$\triangle$ AFACO-Onsite

$\square$ WAC Exception

Pollution Prevention Category: (check one)

$\square$ Asbestos Containing Material

$\square$ FFACO-offsite

$\square$ Historic DOE/NV

Pollution Prevention Category: (check one)

Method of Characterization: (check one)

$\square$ Environmental management

$\triangle$ Defense Projects

$\triangle$ Clean-Up

$\square$ Routine

$\triangle$ Process Knowledge

YMP

NTS landflils:

Additional Prohlbited Waste

at the Area 9 U10C Landfill:

levels, and Medical wastes (needles, sharps, bloody clothing).

Sewage Sludge, Animal carcasses, Wet garbage (food waste); and Friable asbestos

REQUIRED: WASTE CONTENTS ALLOWABLE WASTES

Check all allowable wastes that are contained within this load:

NOTE: Waste disposal at the Area 6 Hydrocarbon Landfill must have come into contact with petroleum hydrocarbons or coolants, such as: gasoline (no benzene, lead); jet fuel; diesel fuel; lubricants and hydraulics; kerosene; asphaltic petroleum hydrocarbon; and ethylene glycol.

Acceptable waste at any NTS landfill: $\triangle$ Paper

$\triangle$ Asphalt $\quad$ Metal $\quad$ Wood $\quad$ W Soil

$\triangle$ Plastic $\otimes$ Wire $\quad$ Cable $\quad$ Cloth

$\square$ Rocks / unaltered geologic materials

$\triangle$ Rubber (excluding tires)

$\triangle$ Insulation (non-Asbestosform)

$\bigotimes$ Empty containers

Demolition debris

$\triangle$ Manufactured items: (swamp coolers, furniture, rugs, carpet, electronic components, PPE, etc.)

Additional waste accepted at the Area 23 Mercury Landfill: $\square$ Office Waste

$\square$ Asbestos $\square$ Friable

$\square$ Non-Friable (contact SWO if regulated load)

$\square$ Food Waste

$\bigotimes$ Cement \& concrete

Additional waste accepted at the Area 9 U10c Landfill:

$\square$ Non-friable asbestos

Light ballasts (contact SWO)

Drained automobiles and military vehicles

Hydrocarbons (contact SwO)

Drained fuel filters (gas \& diesel)

Other

Drained generators/equipment

Quantity:

Additional waste accepted at the Area 6 Hydrocarbon Landfill:
$\square$ Septic sludge
$\square$ Rags
$\square$ Drained fuel filters (gas \& diesel)
Plants
Soil
Sludge from sand/oil/water separators REQUIRED: WASTE GENERATOR S

Initials: (if initialed, no radiological clearance is necessary.)

The above mentioned waste was generated outside of a Controlled Waste $\mathrm{M}=$ knowledge, does not contain radiological materials.

To the best of my knowledge, the waste described above contains only thost site. I have verified this through the waste characterization method identifie prohibited and allowable waste Items. I have contacted Property Manageme is approved for disposal in the landfill.

$\square$ Solid fractions from sand/oil/water

$\bigotimes$ Deconned Underground and Above Ground Tanks

Print Name: Dan Tobiason

Signature:
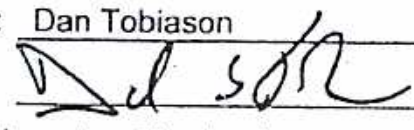

Note: "Food must have sigr

SWO USE ONLY
Load Weight (net from scale or estimate): 10,800

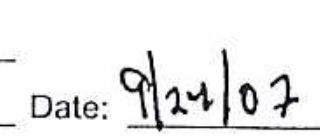

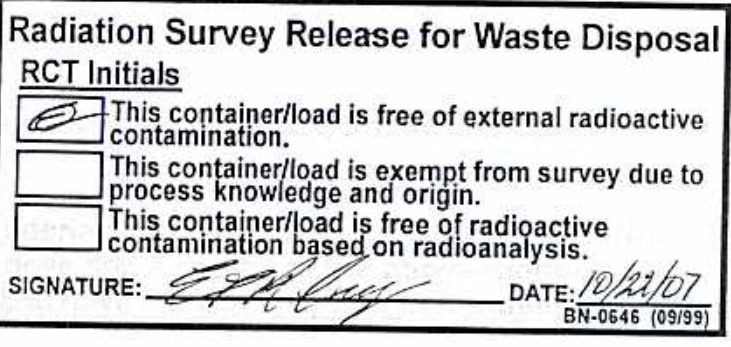

$\square$ Crushed non-teme plated oil filters
$\square$ PCBs below 50 parts per million 


\section{$\begin{array}{llllll}\text { SWO USE (Select One) } & \text { AREA } & \square 23 & \square 6 & \text { \9 } & \text { (23 LANDFILL }\end{array}$}

For waste characterization, approval, and/or assistance, contact Solid Waste Operation (SWO) at 5-7898.

REQUIRED: WASTE GERERATOR INFORMATION

(This form is for rolloffs, dump trucks, and other onsite disposal of materials.)

Waste Generator: Dan Tobiason

Phone Number: 295-6169

Location / Origin: T-Tunnel Lower Laydown Yard

Waste Category: (check one)

Waste Type: $\bigotimes$ NTS

(check one)

$\square$ Non-Putrescible

$\square$ Commercial

$\square$ Putrescrible

$Q$ Industrial cgs 10-24-07

Pollution Prevention Category: (check one)

Pollution Prevention Category: (check one)

Method of Characterization: (check one)

$\square$ Asbestos Containing Material

$\square$ Environmental management

$\triangle$ Clean-Up

ZFFAGO-Ongite

$\square$ FFACO-offsite

$\triangle$ Defense Projects

口 WAC Exception

Prohibited Waste at all three

NTS landfills:

Additional Prohibited Waste

at the Area 9 U10C Landfill:

Radioactive waste; RCRA waste; Hazardous waste; Free liquids, PCBs above TSCA regulatory levels, and Medical wastes (needles, sharps, bloody clothing).

Sewage Sludge, Animal carcasses, Wet garbage (food waste); and Friable asbestos

\section{REQUIRED: WASTE CONTENTS ALLOWABLE WASTES}

Check all allowable wastes that are contained within this load:

NOTE: Waste disposal at the Area 6 Hydrocarbon Landfill must have come into contact with petroleum hydrocarbons or coolants, such as: gasoline (no benzene, lead); jet fuel; diesel fuel; lubricants and hydraulics; kerosene; asphaltic petroleum hydrocarbon; and ethylene glycol.
Acceptable waste at any NTS landfill:
$\bigotimes$ Asphalt
$\triangle$ Metal
Q Wood
$\triangle$ Paper
Q Soil
Cable
$\otimes$ Cloth
$\square$ Rocks / unaltered geologic materials
$\triangle$ Rubber (excluding tires)
$\triangle$ Plastic $\quad$ Wire
$\triangle$ Insulation (non-Asbestosform)
$\triangle$ Manufactured items: (swamp coolers, furniture, rugs, carpet, electronic components, PPE, etc.)

$\triangle$ Empty containers

Demolition debris

Additional waste accepted at the Area 23 Mercury Landfill: $\square$ Office Waste $\square$ Food Waste
$\square$ Asbestos $\square$ Friable $\square$ Non-Friable (contact SWO if regulated load) Quantity:

$凶$ Cement \& concrete

Non-Friable (contact SWO if regulated load)

Quantity:

\section{Additional waste accepted at the Area 9 U10c Landfill:}

$\square$ Non-friable asbestos

$\square$ Light ballasts (contact SWO)

Drained automobiles and military vehicles

Hydrocarbons (contact SWO)

Drained fuel filters (gas \& diesel)

Other Drained generators/equipment

Additional waste accepted at the Area 6 Hydrocarbon Landfill:

$\square$ Septic sludge $\square$ Rags

Plants

$\square$ Soil

$\square$ Drained fuel filters (gas \& diesel)

$\square$ Sludge from sand/oil/water : REQUIRED: WASTE GENERA

Initials: (if initialed, no radiological clearance is necessary.)

The above mentioned waste was generated outside of a Controlled $W$ knowledge, does not contain radiological materials.

To the best of my knowledge, the waste described above contains on site. I have verified this through the waste characterization method ic prohibited and allowable waste Items. I have contacted Property Mar is approved for disposal in the landfill.

$\square$ Solid fractions from sand/oil/water

$\bigotimes$ Deconned Underground and Above Ground Tanks

Print Name: Dan Tobiason

Signature:
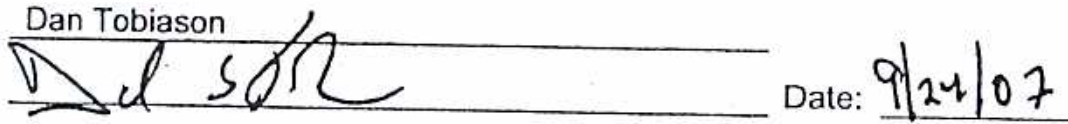

Radiation Survey Release for Waste Disposal
RCT Initials

Crushed non-teme plated oil filters

Th This container/load is free of external radioactive

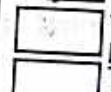

This contain

process knowledge is exempt f

This containerload is frigin.

SIGNATURE: contamination based on radioanalysis.

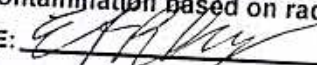
DATE:

Note: "Food waste office trash and animal carcasses do not require must have signed removal certification carcasses do not require a radiological clearance. Freon-containing appliances SWO USE ONLY

Load Weight (net from scale or estimate): $=5,800$

$10-23-07$

Signature of Certifier:

If applicable, place FRM-0646, "Radiological Release Sticker" here Onsite use only. 


\section{SWO USE (Select One) AREA $\square 23 \quad \square 6 \quad$ \9}

For waste characterization, approval, and/or assistance, contact Solid Waste Operation (SWO) at 5-7898.

REQUIRED: WASTE GERERATOR INFORMATION

(This form is for rolloffs, dump trucks, and other onsite disposal of materials.)

Waste Generator: Dan Tobiason

Phone Number: 295-6169

\section{Location / Origin: T-Tunnel Lower Laydown Yard}

Waste Category: (check one)

Waste Type: $₫$ NTS

(check one)

$\square$ Non-Putrescible $\quad \square$ Asbestos Containing Material

$\square$ Commerclal

$\triangle$ Industrial cqs $10 / 24 / 07$

Pollution Prevention Category: (check one)

Pollution Prevention Category: (check one)

1 Environmental management

Method of Characterization: (check one)

$\otimes$ Clean-Up

Sampling \& Analysis

NTS landfills:

Additional Prohibited Waste

at the Area 9 U10C Landfill:

Radioactive waste; RCRA waste; Hazardous waste; Free liquids, PCBs above TSCA regulatory levels, and Medical wastes (needles, sharps, bloody clothing).

X-FFACO-Onsite

WAC Exception

$\square$ FFACO-offsite $\square$ Historic DOE/NV

$\triangle$ Defense Projects

YMP

$\square$ Routine

Sewage Sludge, Animal carcasses, Wet garbage (food waste); and Friable asbestos

\section{REQUIRED: WASTE CONTENTS ALLOWABLE WASTES}

Check all allowable wastes that are contained within this load:

NOTE: Waste disposal at the Area 6 Hydrocarbon Landfill must have come into contact with petroleum hydrocarbons or coolants, such as: gasoline (no benzene, lead); jet fuel; diesel fuel; lubricants and hydraulics; kerosene; asphaltic petroleum hydrocarbon; and ethylene glycol.
Acceptable waste at any NTS landfill:
Asphalt
$\otimes$ Metal
$\triangle$ Wood
$\triangle$ Paper
$\bigotimes$ Soil
Rocks / unaltered geologic materials
叉 Plastic
$\triangle$ Wire
$凶$ Cable
$\triangle$ Cloth
$\bigotimes$ Rubber (excluding tires)
\Insulation (non-Asbestosform)

$\triangle$ Empty containers

Q Demolition debris

$\bigotimes$ Manufactured items: (swamp coolers, furniture, rugs, carpet, electronic components, PPE, etc.)
Additional waste accepted at the Area 23 Mercury Landfill:
$\square$ Asbestos
$\square$ Friable
Non-Friable (contact SWO if regulated load)
Food Waste
Quantity:
Animal Carcasses

$\bigotimes$ Cement \& concrete

Additional waste accepted at the Area 9 U10c Landfill:
$\square$ Non-friable asbestos
Light ballasts (contact SWO)
Drained automobiles and military vehicles
$\square$ Drained fuel filters (gas \& diesel)

$\square$ Hydrocarbons (contact SWO) $\bigotimes$ Other Drained generators/equipment

$\square$ Hydrocarbons (contact SWO) $\bigotimes$ Other Drained generators/equipment

Additional waste accepted at the Area 6 Hydrocarbon Landfill:
$\square$ Septic sludge
$\square$ Rags
Plants
Soil
$\square$ Drained fuel filters (gas \& diesel)
$\square$ Sludge from sand/oil/water separators

REQUIRED: WASTE GENERA

Initials: (if initialed, no radiological clearance is necessary.)

The above mentioned waste was generated outside of a Controlled Wa knowledge, does not contain radiological materials.

To the best of my knowledge, the waste described above contains onl site. I have verified this through the waste characterization method idi prohibited and allowable waste Items. I have contacted Property Mans is approved for disposal in the landfill.

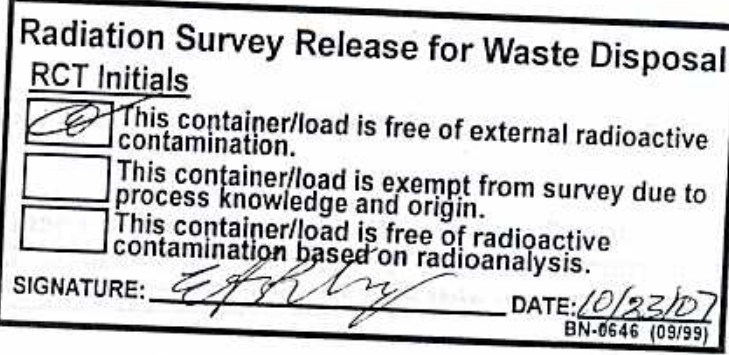

Crushed non-teme plated oil filters PCBs below 50 parts per million

Solid fractions from sand/oil/water

$\otimes$ Deconned Underground and Above Ground Tanks

Print Name: Dan Tobiason

Signature:
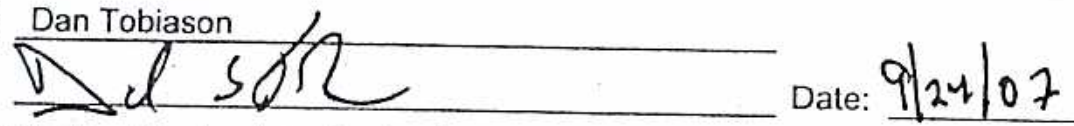

If applicable, place FRM-0646,

"Radiological Release Sticker" here. Onsite use only.

Note: "Food waste, office trash and animal carcasses do not require a radiological clearance. Freon-containing appliances must have signed removal certification statement with Load Verification." 


\title{
SWO USE (Select One) $\quad$ AREA $\quad \square 23 \quad \square 6 \quad \square 9 \quad \square$ LANDFILL
}

For waste characterization, approval, and/or assistance, contact Solid Waste Operation (SWO) at 5-7898:

\section{REQUIRED: WASTE GERERATOR INFORMATION}

(This form is for rolloffs, dump trucks, and other onsite disposal of materials.)

Waste Generator: Dan Tobiason

Phone Number: 295-6169

Location / Origin: T-Tunnel Lower Laydown Yard

Waste Category: (check one)

Waste Type: $\square$ NTS

(check one)

$\square$ Non-Putrescible

\author{
$\square$ Commercial
}

$\square$ Putrescrible

$\triangle$ Industrial ofs $10-24-07$

Pollution Prevention Category: (check one)

Pollution Prevention Category: (check one)

Method of Characterization: (check one)

$\square$ Asbestos Containing Material

Q-FFACO-Onsite-

$\square$ WAC Exception

$\square$ Environmental management

$\triangle$ Clean-Up

$\square$ FFACO-offsite

$\square$ Historic DOE/NV

Prohibited Waste at all three

NTS landfills:

Additional Prohibited Waste

at the Area 9 U10C Landfill:

\section{levels, and Medical wastes (needles, sharps, bloody clothing).}

$\square$ Routine

$\square$ Sampling \& Analysis

$\triangle$ Process Knowledge $\square$ Contents

Sewage Sludge, Animal carcasses, Wet garbage (food waste); and Friable asbestos

\section{REQUIRED: WASTE CONTENTS ALLOWABLE WASTES}

Check all allowable wastes that are contained within this load:

NOTE: Waste disposal at the Area 6 Hydrocarbon Landfill must have come into contact with petroleum hydrocarbons or coolants, such as: gasoline (no benzene, lead); jet fuel; diesel fuel; lubricants and hydraulics; kerosene; asphaltic petroleum hydrocarbon; and ethylene glycol.
Acceptable waste at any NTS landfill:
Asphalt
Metal
$\otimes$ Wood
$凶$ Paper
冈 Soil
$\square$ Rocks / unaltered geologic materials
Empty containers
$\triangle$ Plastic $\triangle$ Wire
$\otimes$ Cable
$\triangle$ Cloth
$\bigotimes$ Rubber (excluding tires)
Insulation (non-Asbestosform)
$凶$ Demolition debris
$\bigotimes$ Cement \& concrete

$\triangle$ Manufactured items: (swamp coolers, furniture, rugs, carpet, electronic components, PPE, etc.)
Additional was
$\square$ Asbestos
Friable
Area 23 Mercury Landfill:
$\square$ Office Waste
$\square$ Food Waste

Additional waste accepted at the Area 9 U10c Landfill:
$\square$ Non-friable asbestos
Drained automobiles and military vehicles
$\square$ Light ballasts (contact SWO)
Drained fuel filters (gas \& diesel)
$\square$ Hydrocarbons (contact SWO)

Other Drained generators/equipment

Additional waste accepted at the Area 6 Hydrocarbon Landfill:
$\square$ Septic sludge $\square$ Rags
$\square$ Drained fuel filters (gas \& diesel)
Plants
Soil
$\square$ Sludge from sand/oil/water separators
REQUIRED: WASTE GENERATOR SIINAIA TIIIT

\section{Crushed non-teme plated oil filters} PCBs below 50 parts per million

Initials: (if initialed, no radiological clearance is necessary.)

The above mentioned waste was generated outside of a Controlled Waste $\mathrm{Ma}$ knowledge, does not contain radiological materials.

To the best of my knowledge, the waste described above contains only those site. I have verified this through the waste characterization method identified prohibited and allowable waste Items. I have contacted Property Managemen is approved for disposal in the landfill.

Radiation Survey Release for Waste Disposal RCT Initials

This container/load is free of external radioactive
contamination.
This container/load is exempt from survey due to
process knowledge and origin.
This container/load is free of radioactive
contamination based on radioanalysis.
SIGNATURE:

Print Name: Dan Tobiason

Signature:
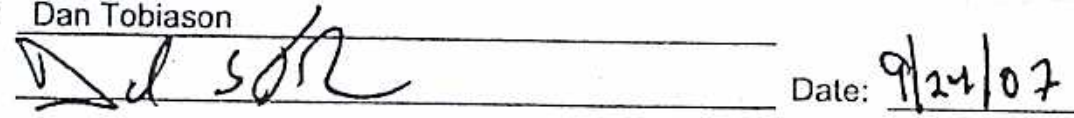

If applicable, place FRM-0646,

"Radiological Release Sticker" here. Onsite use only.

Note: "Food waste, office trash and animal carcasses do not require a radiological clearance. Freon-containing appliances must have signed removal certification statement with Load Verification."

\section{SWO USE ONLY}

Load Weight (net from scale)or estimate):
$10-23-07$

Signature of Certifier: 


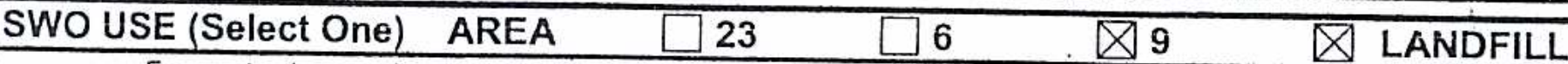

For waste characterization, approval, and/or assistance, contact Solid Waste Operation (SWO) at 5-7898.'

REQUIRED: WASTE GERERATOR INFORMATION

(This form is for rolloffs, dump trucks, and other onsite disposal of materials.)

Waste Generator: Dan Tobiason

Phone Number: 295-6169

Location / Origin: T-Tunnel Lower Laydown Yard

Waste Category: (check one)

(check one) $\square$ Non-Putrescible $\square$ Asbestos Containing Material

Pollution Prevention Category: (check one)

Pollution Prevention Category: (check one)

Method of Characterization: (check one)

Environmental management

$\triangle$ Clean-Up

Sampling \& Analysis

$\triangle$ Process Knowledge $\square$ Contents

Prohibited Waste at all three Radioactive waste; RCRA waste; Hazardous waste; Free liquids, PCBs above TSCA regulatory
NTS landfllis:

Additional Prohibited Waste

at the Area 9 U10C Landfill:

Sewage Sludge, Animal carcasses, Wet garbage (food waste); and Friable asbestos

\section{REQUIRED: WASTE CONTENTS ALLOWABLE WASTES}

Check all allowable wastes that are contained within this load:

NOTE: Waste disposal at the Area 6 Hydrocarbon Landfill must have come into contact with petroleum hydrocarbons or coolants, such as: gasoline (no benzene, lead); jet fuel; diesel fuel; lubricants and hydraulics; kerosene; asphaltic petroleum hydrocarbon; and ethylene glycol.

\begin{tabular}{|c|c|c|c|c|}
\hline \multicolumn{3}{|c|}{ Acceptable waste at any NTS landfill: } & $\triangle$ Paper & $\square$ Rocks / unaltered geologic materials \\
\hline$\bigotimes$ Asphalt & $\otimes$ Metal & $\triangle$ Wood & 凶 Soil & $\nabla$ Rubber (excluding tires) \\
\hline$\bigotimes$ Plastic & $\triangle$ Wire & $\otimes$ Cable & $\bigotimes$ Cloth & $凶$ Insulation (non-Asbestosform) \\
\hline
\end{tabular}

$\bigotimes$ Manufactured items: (swamp coolers, furniture, rugs, carpet, electronic components, PPE, etc.)
Additional waste accepted at the Area 23 Mercury Landfill:
$\square$ Food Waste

Asbestos

Friable

$\square$ Non-Friable (contact SWO if regulated load)

Empty containers

$\bigotimes$ Demolition debris

$\bigotimes$ Cement \& concrete

Additional waste accepted at the Area 9 U10c Landfill:
$\square$ Non-friable asbestos
$\square$ Drained austomobiles and military vehicles
$\square$ Light ballasts (contact SWO)
$\square$ Drained fuel filters (gas \& diesel)
Hydrocarbons (contact SWO)
Other
Drained generators/equipment

$\square$ Solid fractions from sand/oil/water

$\triangle$ Deconned Underground and Above Ground Tanks

\section{Additional waste accepted at the Area 6 Hydrocarbon Landfill:}
$\square$ Septic sludge
$\square$ Rags
Soil
$\square$ Drained fuel filters (gas \& diesel)
Plants
$\square$ Sludge from sand/oil/water separators
REQUIRED: WASTE GENERATOR SIG

Initials: (if initialed, no radiological clearance is necessary.)

The above mentloned waste was generated outside of a Controlled Waste Mana knowledge, does not contain radiological materials.

To the best of my knowledge, the waste described above contains only those $m$ site. I have verified this through the waste characterization method identified at prohibited and allowable waste Items. I have contacted Property Management a is approved for disposal in the landfill.

Print Name: Dan Tobiason

Signature:
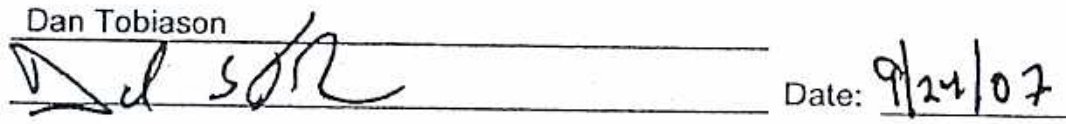

Crushed non-teme plated oil filters

PCBs below 50 Darts nar millinn

Radiation Survey Release for Waste Disposal RCT Initials

This container/load is free of external radioactive \&2 This container/lo

This container/load is exempt from survey due to process knowledge and origin.

This container/load is free of radioactive contamination based on radioanalysis.

SIGNATURE:

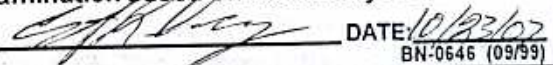

Note: "Food waste, office trash and animal carcases do nol require a radiological clearance. Freon must have signed removal certification statement with Load Verification."

SWO USE ONLY
Load Weight (net from scale or (estimate): $2600 \mathrm{Cl}$
$10-23-07$

Signature of Certifier:
If applicable, place FRM-0646,
"Radiological Release Sticker" here. Onsite use only. 


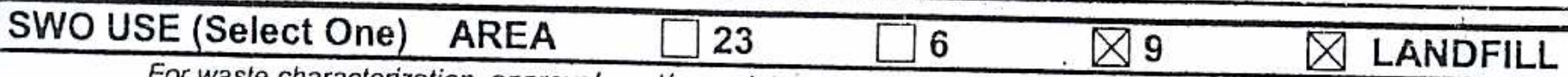 \\ For waste characterization, approval, and/or assistance, contact Solid Waste Operation (SWO) at 5-7898.}

$$
\text { REQUIRED: WASTE GERERATOR INFORMATION }
$$

(This form is for rolloffs, dump trucks, and other onsite disposal of materials.)

Waste Generator: Dan Tobiason

Phone Number: 295-6169

Location / Origin: T-Tunnel Lower Laydown Yard

Waste Category: (check one)

Waste Type: $\triangle$ NTS

(check one)

$\square$ Non-Putrescible

Pollution Prevention Category: (check one)

Pollution Prevention Category: (check one)

Method of Characterization: (check one)

Prohibited Waste at all three

NTS landfills:

Additional Prohibited Waste

at the Area 9 U10C Landfill:
Radioactive waste; RCRA waste; Hazardous waste; Free liquids, PCBs above TSCA regulatory
levels, and Medical wastes (needles, sharps, bloody clothing).

Sewage Sludge, Animal carcasses, Wet garbage (food waste); and Friable asbestos

\section{REQUIRED: WASTE CONTENTS ALLOWABLE WASTES}

Check all allowable wastes that are contained within this load:
NOTE: Waste disposal at the Area 6 Hydrocarbon Landfill must have come into contact with petroleum hydrocarbons or coolants, such as: gasoline (no benzene, lead); jet fuel; diesel fuel; lubricants and hydraulics; kerosene; asphaltic petroleum hydrocarbon; and ethylene glycol.
Acceptable waste at any NTS landfill:
$\triangle$ Asphalt
$\otimes$ Metal
$\bigotimes$ Wood
$\triangle$ Paper
$凶$ Soil
$\triangle$ Cable
Cloth
Rocks / unaltered geologic materials
$\bigotimes$ Rubber (excluding tires)
\insulation (non-Asbestosform)

$\bigotimes$ Manufactured items: (swamp coolers, fumiture, rugs, carpet, electronic components, PPE, etc.)

Additional waste accepted at the Area 23 Mercury Landfill: $\square$ Office Waste $\square$ Food Waste
$\square$ Asbestos $\square$ Friable $\square$ Non-Friable (contact SWO if regulated load)

Non-Friable (contact SWO if regulated load)

Quantity:

Additional waste accepted at the Area 9 U10c Landfill:

$\square$ Non-friable asbestos $\quad \square$ Drained automobiles and military vehicles

$\square$ Light ballasts (contact SWO)

Hydrocarbons (contact SwO)

$\square$ Drained fuel filters (gas \& diesel)

Other

Drained generators/equipment

Additional waste accepted at the Area 6 Hydrocarbon Landfill:
$\square$ Septic sludge
$\square$ Rags
Plants
Soil
$\square$ Drained fuel filters (gas \& diesel)
$\square$ Sludge from sand/oil/water separators REQUIRED: WASTE GENERA

Initials: (if initialed, no radiological clearance is necessary.)

The above mentioned waste was generated outside of a Controlled $\mathrm{Wa}$ knowledge, does not contain radiological materials.

To the best of my knowledge, the waste described above contains onl site. I have verified this through the waste characterization method idi prohibited and allowable waste Items. I have contacted Property Manz is approved for disposal in the landfill.

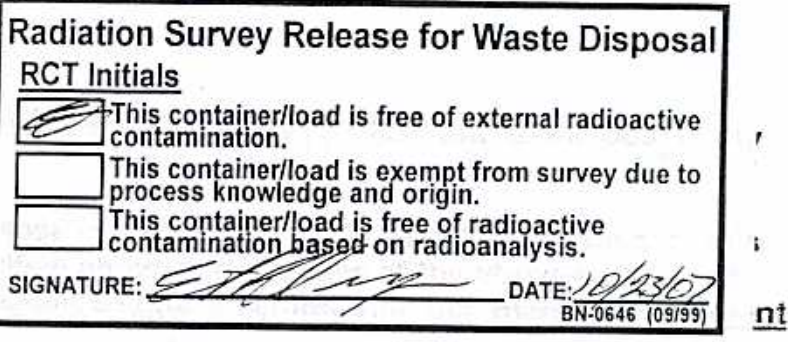

Print Name: Dan Tobiason

Signature:
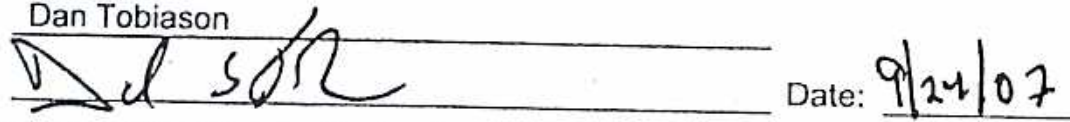

Solid fractions from sand/oil/water

$\bigotimes$ Deconned Underground and Above Ground Tanks

Note: "Food waste, office trash and animal carcasses do not require a radiological clearance. Freon-containing appliances
must have signed removal certification statement with Load Verification"

SWO USE ONLY

Load Weight (net froph scale of estimate):
$10-23-07$

Signature of Certifier:
If applicable, place FRM-0646,

"Radiological Release Sticker" here. Onsite use only.
Crushed non-teme plated oil filters PCBs below 50 parts per million $\triangle$ Empty containers

$\triangle$ Demolition debris

$\bigotimes$ Cement \& concrete

\begin{tabular}{|c|c|}
\hline$\triangle$ Industrial eqS & $10 / 24 / 07$ \\
\hline$\triangle$ FFACO-Onsite & $\square$ WAC Exception \\
\hline$\square$ FFACO-offsite & $\square$ Historic DOE/NV \\
\hline$Q$ Defense Projects & $\square$ YMP \\
\hline$\square$ Routine & \\
\hline$\triangle$ Process Knowledg & $\square$ Contents \\
\hline
\end{tabular}

Animal Carcasses 


$\begin{array}{llllll}\text { SWO USE (Select One) } & \text { AREA } & \square 23 & \square 6 & \square 9 & \text { Q LANDFILL }\end{array}$

For waste characterization, approval, and/or assistance, contact Solid Waste Operation (SWO) at 5-7898.

\section{REQUIRED: WASTE GERERATOR INFORMATION}

(This form is for rolloffs, dump trucks, and other onsite disposal of materials.)

Waste Generator: Dan Tobiason

Phone Number: 295-6169

Location / Origin: T-Tunnel Portal Area

\begin{tabular}{|c|c|c|c|}
\hline Waste Category: (check one) & $\square$ Commercial & Q Industrial & \\
\hline Waste Type: & $\square$ Putrescrible & $\square$ FFACO-onsite & $\square$ WAC Exception \\
\hline$\square$ Non-Putrescible & $\square$ Asbestos Containing Material & $\square$ FFACO-offsite & $\square$ Historic DOE/NV \\
\hline Pollution Prevention Category: (check one) & $\square$ Environmental management & $\otimes$ Defense Projects & $\square$ YMP \\
\hline Pollution Prevention Category: (check one) & $\triangle$ Clean-Up & $\square$ Routine & \\
\hline Method of Characterization: (check one) & $\square$ Sampling \& Analysis & $\triangle$ Process & $\square$ Contents \\
\hline
\end{tabular}

Prohibited Waste at all three Radioactive waste; RCRA waste; Hazardous waste; Free liquids, PCBs above TSCA regulatory NTS landfills:

levels, and Medical wastes (needles, sharps, bloody clothing).

Additional Prohibited Waste
at the Area 9 U10C Landfill: Sewage Sludge, Animal carcasses, Wet garbage (food waste); and Friable asbestos

REQUIRED: WASTE CONTENTS ALLOWABLE WASTES

Check all allowable wastes that are contained within this load:

NOTE: Waste disposal at the Area 6 Hydrocarbon Landfill must have come into contact with petroleum hydrocarbons or coolants, such as: gasoline (no benzene, lead); jet fuel; diesel fuel; lubricants and hydraulics; kerosene; asphaltic petroleum hydrocarbon; and ethylene glycol.
Acceptable waste at any NTS landfill:
Q Paper
$\square$ Rocks / unaltered geologic materials
$\bigotimes$ Empty containers
$\square$ Asphalt
$凶$ Metal
W Wood
$\square$ Soil
$\bigotimes$ Rubber (excluding tires)
$\triangle$ Plastic $\square$ Wire
区 Cable
Cloth
$\square$ Insulation (non-Asbestosform)
$\bigotimes$ Demolition debris
$\triangle$ Cement \& concrete
$\triangle$ Manufactured items: (swamp coolers, furniture, rugs, carpet, electronic components, PPE, etc.)
Additional was
$\square$ Asbestos
Area 23 Mercury Landfill:
Office Waste
$\square$ Food Waste
Animal Carcasses
Quantity:

Additional waste accepted at the Area 9 U10c Landfill:
$\square$ Non-friable asbestos
Drained automobiles and military vehicles
Light ballasts (contact SWO)
Drained fuel filters (gas \& diesel)
$\square$ Hydrocarbons (contact SWO) $\square$ Other

Solid fractions from sand/oil/water

Deconned Underground and Above Ground Tanks

\section{Additional waste accepted at the Area 6 Hydrocarbon Landfill:
$\square$ Septic sludge
$\square$ Rags
$\square$ Drained fuel filters (gas \& diesel)
$\square$ Crushed non-teme plated oil filters
Plants
Soil
$\square$ Sludge from sand/oil/water separators
$\square$ PCBs below 50 parts per million

\section{Initials: 15 (if initialed, no radiological clearance is necessary.)}

The above mentioned waste was generated outside of a Controlled Waste Management Area (CWMA) and to the best of my knowledge, does not contain radiological materials.

To the best of my knowledge, the waste described above contains only $t \mid$ site. I have verified this through the waste characterization method iden I prohibited and allowable waste items. I have contacted Property Managt is approved for disposal in the landfill.

Print Name: Dan Tobiason

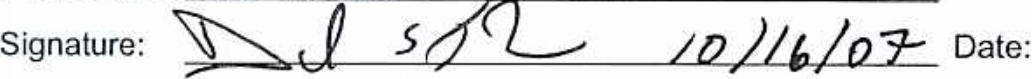

Note: "Food waste, office trash and animal carcasses do not require a ra must have signed removal certification statement with Load Verific

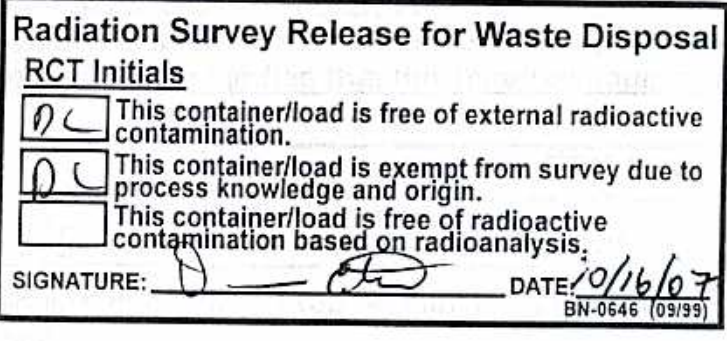

SWO USE ONLY

Load Weight (net from (scale)or estimate): $2,4,0$

$10-24-07$

Signature of Certifier: 


\section{SWO USE (Select One) AREA \\ 23 \\ 凶9 \\ $\triangle$ LANDFILL}

For waste characterization, approval, and/or assistance, contact Solid Waste Operation (SWO) at 5-7898.'

\section{REQUIRED: WASTE GERERATOR INFORMATION}

(This form is for rolloffs, dump trucks, and other onsite disposal of materials.)

Waste Generator:

Location / Origin:
Dan Tobiason

T-Tunnel Lower Laydown Yard

\section{Phone Number: 295-6169}

Waste Category: (check one)

Waste Type: $\otimes$ NTS

(check one)

$\square$ Non-Putrescible

$\square$ Commercial

$\square$ Putrescrible

$\square$ Asbestos Containing Material

Pollution Prevention Category: (check one)

Pollution Prevention Category: (check one)

Method of Characterization: (check one)

$\square$ Environmental management

$\triangle$ Clean-Up

Sampling \& Analysis

Prohibited Waste at all three

NTS landfills:

Additional Prohibited Waste

at the Area 9 U10C Landfill:

Radioactive waste; RCRA waste; Hazardous waste; Free liquids, PCBs above TSCA regulatory levels, and Medical wastes (needles, sharps, bloody clothing).

Sewage Sludge, Animal carcasses, Wet garbage (food waste); and Friable asbestos

\section{REQUIRED: WASTE CONTENTS ALLOWABLE WASTES}

Check all allowable wastes that are contained within this load:

NOTE: Waste disposal at the Area 6 Hydrocarbon Landfill must have come into contact with petroleum hydrocarbons or coolants, such as: gasoline (no benzene, lead); jet fuel; diesel fuel; lubricants and hydraulics; kerosene; asphaltic petroleum hydrocarbon; and ethylene glycol.
Acceptable waste at any NTS landfill:
$\bigotimes$ Asphalt
Metal
Wood
$\triangle$ Paper
$\triangle$ Soil
$\triangle$ Cable
$\otimes$ Cloth
$\square$ Rocks / unaltered geologic materials
$\triangle$ Rubber (excluding tires)
$\otimes$ Insulation (non-Asbestosform)
Q Manufactured items: (swamp coolers, fumiture, rugs, carpet, electronic components, PPE, etc.)

$\triangle$ Empty containers

$\bigotimes$ Demolition debris

$\bigotimes$ Cement \& concrete

Additional waste accepted at the Area 23 Mercury Landfill: $\square$ Office Waste

$\square$ Asbestos

Friable

Non-Friable (contact SWO if regulated load)

Food Waste

Animal Carcasses

\section{Additional waste accepted at the Area 9 U10c Landfill:}

$\square$ Non-friable asbestos

$\square$ Light ballasts (contact SWO)

Drained automobiles and military vehicles

Hydrocarbons (contact SWO

Drained fuel filters (gas \& diesel)

Other Drained generators/equipment

$\square$ Solid fractions from sand/oil/water

$\otimes$ Deconned Underground and Above

Ground Tanks

Additional waste accepted at the Area 6 Hydrocarbon Landfill:

$\square$ Septic sludge $\square$ Rags

Plants

$\square$ Soil

$\square$ Drained fuel filters (gas \& diesel)

$\square$ Sludge from sand/oil/water separators REQUIRED: WASTE GENERATO

Initials: (if initialed, no radiological clearance is necessary.)

The above mentioned waste was generated outside of a Controlled Waste knowledge, does not contain radiological materials.

To the best of my knowledge, the waste described above contains only tr site. I have verified this through the waste characterization method ident prohibited and allowable waste items. I have contacted Property Manage is approved for disposal in the landfill.

Radiation Survey Release for Waste Disposal RCT Initials

(5) This container/load is free of external radioactive contamination.

This container/load is exempt from survey due to process knowledge and origin.

This container/load is free of radioactive

SIGNATURE: ntanination based on radioanalysis.

Print Name: Dan Tobiason

Signature:
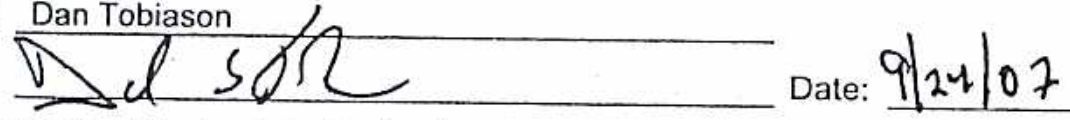

Ext2 2 _DATE: $20 / 24 / 02$ BN-0646 (09/99)

Note: "Food waste, office trash and animal carcasses do not require a radiological clearance. Freon-containing appliances must have signed removal certification statement with Load Verification."

SWO USE ONLY

Load Weight (net from scale or estimate) $y 2,000 \quad \begin{array}{r}10-24-07 \\ \text { Signature of Certifier: }\end{array}$

If applicable, place FRM-0646,

"Radiological Release Sticker" here. Onsite use only. 
Form

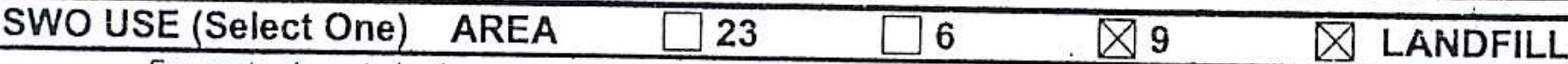

For waste characterization, approval, and/or assistance, contact Solid Waste Operation (SWO) at 5-7898.

REQUIRED: WASTE GERERATOR INFORMATION

(This form is for rolloffs, dump trucks, and other onsite disposal of materials.)

Waste Generator: Dan Tobiason

Phone Number: 295-6169

Location / Origin: T-Tunnel Lower Laydown Yard

\begin{tabular}{|c|c|c|}
\hline Waste Category: (check one) & $\square$ Commercial & $\triangle$ Industrial ogs $10 / 25 / 07$ \\
\hline Waste Type: & $\square$ Putrescrible & $\triangle$ EEACQ-onsits $\square$ WAC Exception \\
\hline (check one) $\square$ Non-Putrescible & $\square$ Asbestos Containing Material & $\square$ Historic DOE/NV \\
\hline Pollution Prevention Category: (check one) & $\square$ Environmental management & $\triangle$ Defense Projects \\
\hline Pollution Prevention Category: (check one) & $\triangle$ Clean-Up & $\square$ Routine \\
\hline Method of Characterization: (check one) & $\square$ Sampling \& An & cess \\
\hline
\end{tabular}

Prohibited Waste at all three Radioective waste; RCRA waste; Hazardo..................................... NTS landfills:

Additional Prohlbited Waste

at the Area 9 U10C Landfill:

levels, and Medical wastes (needles, sharps, bloody clothing).

Sewage Sludge, Animal carcasses, Wet garbage (food waste); and Friable asbestos

REQUIRED: WASTE CONTENTS ALLOWABLE WASTES

Check all allowable wastes that are contained within this load:

NOTE: Waste disposal at the Area 6 Hydrocarbon Landfill must have come into contact with petroleum hydrocarbons or coolants, such as: gasoline (no benzene, lead); jet fuel; diesel fuel; lubricants and hydraulics; kerosene; asphaltic petroleum hydrocarbon; and ethylene glycol.

Acceptable waste at any NTS landfill: $\triangle$ Pape

$\triangle$ Asphalt $\quad$ Metal $\quad$ Wood $\quad$ Soil

$\triangle$ Plastic $\quad$ Wire $\quad \square$ Cable $\quad \square$ Cloth

$\square$ Rocks / unaltered geologic materials

$\triangle$ Rubber (excluding tires)

$\bigotimes$ Insulation (non-Asbestosform)

$\triangle$ Empty containers

$\triangle$ Demolition debris

$\triangle$ Manufactured items: (swamp coolers, fumiture, rugs, carpet, electronic components, PPE, etc.)
Additional waste accepted at the Area 23 Mercury Landfill:
$\square$ Asbestos
$\square$ Friable
Non-Friable (contact SWO if regulated load)
Food Waste
Animal Carcasses
Quantity:

Additional waste accepted at the Area 9 U10c Landfill:
$\square$ Non-friable asbestos
Light ballasts (contact SWO)
$\square$ Drained automobiles and military vehicles
$\square$ Drained fuel filters (gas \& diesel)
Hydrocarbons (contact SWO)
Other
Drained generators/equipment

$凶$ Cement \& concrete

Additional waste accepted at the Area 6 Hydrocarbon Landfill:
$\square$ Septic sludge
Plants
$\square$ Rags
$\square$ Soil
$\square$ Drained fuel filters (gas \& diesel)
$\square$ Sludge from sand/oil/water separators REQUIRED: WASTE GENERAT

Initials: (if initialed, no radiological clearance is necessary.)

The above mentioned waste was generated outside of a Controlled Was knowledge, does not contain radiological materials.

To the best of my knowledge, the waste described above contains only site. I have verified this through the waste characterization method ide prohibited and allowable waste items. I have contacted Property Mana is approved for disposal in the landfill.

Solid fractions from sand/oil/water

$\bigotimes$ Deconned Underground and Above Ground Tanks
Print Name: Dan Tobiason

Signature:

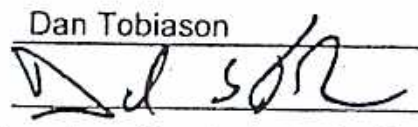

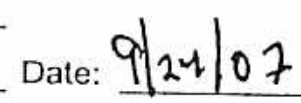

Crushed non-teme plated oil filters PCBs below 50 parts per million

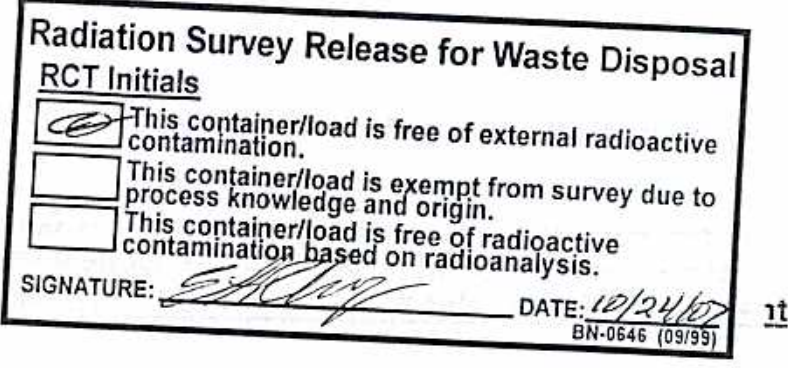

If applicable, place FRM-0646, "Radiological Release Sticker" here. Onsite use only.

Note: "Food waste, office trash and animal carcasses do not require a radiological clearance. Freon-containing appliances must have signed removal certification statement with Load Verification."

\section{SWO USE ONLY}

Load Weight (net from scale or estimate): 19,150
$10-24.07$

Signature of Certifier: 
NSTec

\section{SWO USE (Select One) AREA 23 \\ 6 \\ Х9 \\ $\triangle$ LANDFILL}

For waste characterization, approval, and/or assistance, contact Solid Waste Operation (SWO) at 5-7898.' REQUIRED: WASTE GERERATOR INFORMATION

(This form is for rolloffs, dump trucks, and other onsite disposal of materials.)

Waste Generator: Dan Tobiason Phone Number: 295-6169

Location / Origin: T-Tunnel Lower Laydown Yard.

\begin{tabular}{|c|c|c|}
\hline Waste Category: (check one) & $\square$ Commercial & $\otimes$ Industrial go $10 / 25 / 07$ \\
\hline Waste Type: & $\square$ Putrescrible & DEEAGQ-onsite $\square W A$ \\
\hline$\square$ Non-Putrescible & $\square$ Asbestos Containing Material & $\square$ FFACO-offsite \\
\hline Pollution Prevention Category: (check one) & $\square$ Environmental management & $\triangle$ Defense Projects \\
\hline Pollution Prevention Category: (check one) & $\otimes$ Clean-Up & $\square$ Routine \\
\hline Method of Characterization: (check one) & $\square$ Sampling \& Analysis & Process Knowled \\
\hline
\end{tabular}

Prohibited Waste at all three NTS landfills:

Additional Prohlbited Waste at the Area 9 U10C Landfill: levels, and Medical wastes (needles, sharps, bloody clothing).

Sewage Sludge, Animal carcasses, Wet garbage (food waste); and Friable asbestos

\section{REQUIRED: WASTE CONTENTS ALLOWABLE WASTES}

Check all allowable wastes that are contained within this load:

NOTE: Waste disposal at the Area 6 Hydrocarbon Landfill must have come into contact with petroleum hydrocarbons or coolants, such as: gasoline (no benzene, lead); jet fuel; diesel fuel; lubricants and hydraulics; kerosene; asphaltic petroleum hydrocarbon; and ethylene glycol.
Acceptable waste at any NTS landfill:
$\bigotimes$ Paper
$\triangle$ Asphalt $\otimes$ Metal
¿] Wood
\Soil
¿ Plastic
$\triangle$ Wire
$\bigotimes$ Cable
$\otimes$ Cloth
$\square$ Rocks / unaltered geologic materials
$\bigotimes$ Rubber (excluding tires)
$\bigotimes$ Insulation (non-Asbestosform)

Empty containers

$\triangle$ Demolition debris

$\bigotimes$ Cement \& concrete

rugs, carpet, electronic components, PPE, etc.)
Additional waste accepted at the Area 23 Mercury Landfill:
$\square$ Office Waste
$\square$ Food Waste
Animal Carcasses
$\square$ Asbestos
Friable
$\square$ Non-Friable (contact SWO if regulated load)
Quantity:

Additional waste accepted at the Area 9 U10c Landfill:
$\square$ Non-friable asbestos
$\square$ Light ballasts (contact SWO)
$\square$ Drained automobiles and military vehicles
$\square$ Drained fuel filters (gas \& diesel)
Hydrocarbons (contact SWO)
Other Drained generators/equipment

Solid fractions from sand/oil/water

$\bigotimes$ Deconned Underground and Above Ground Tanks

\section{Additional waste accepted at the Area 6 Hydrocarbon Landfill:}
$\square$ Septic sludge
$\square$ Rags
$\square$ Drained fuel filters (gas \& diesel)
Plants
Soil
$\square$ Sludge from sand/oil/water separators

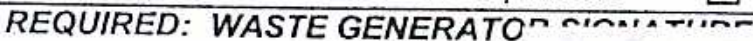
$\square$ Crushed non-teme plated oil filters
$\square$ PCBs below 50 parts per million

Initials: (if initialed, no radiological clearance is necessary.)

The above mentioned waste was generated outside of a Controlled Waste knowledge, does not contain radiological materials.

To the best of my knowledge, the waste described above contains only th site. I have verified this through the waste characterization method ident prohibited and allowable waste Items. I have contacted Property Manage is approved for disposal in the landfill.

Radiation Survey Release for Waste Disposal
RCT Initials
This container/load is free of external radioactive
contamination.
This container/load is exempt from survey due to
process knowledge and origin.
This containeriload is free of radioactive
contanination based on radioanalysis.
SIGNATURE:

Print Name: Dan Tobiason

Signature:

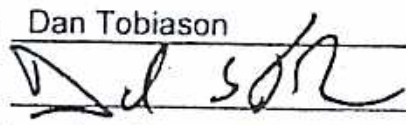

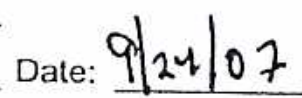

If applicable, place FRM-0646, "Radiological Release Sticker" here. Onsite use only.

Note: "Food waste, office trash and animal carcasses do not require a radiological clearance. Freon-containing appliances must have signed removal certification statement with Load Verification."

\section{SWO USE ONLY}




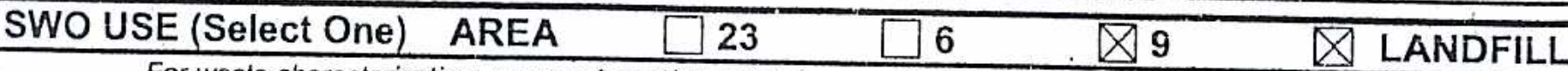

For waste characterization, approval, and/or assistance, contact Solid Waste Operation (SWO) at 5-7898.

REQUIRED: WASTE GERERATOR INFORMATION

(This form is for rolloffs, dump trucks, and other onsite disposal of materials.)

Waste Generator: Dan Tobiason

Phone Number: 295-6169

Location / Origin: T-Tunnel Lower Laydown Yard

Waste Category: (check one)

Waste Type: $\otimes$ NTS

(check one)

$\square$ Non-Putrescible

$\square$ Commercial

$\square$ Putrescrible

$\triangle$ Industrial cos $10 / 25 / 07$

$\square$ Asbestos Containing Material

$\triangle F F A C O=0$ msite

$\square$ WAC Exception

Pollution Prevention Category: (check one)

Pollution Prevention Category: (check one)

Method of Characterization: (check one)

$\square$ Environmental management

$\triangle$ Clean-Up

$\square$ FFACO-offsite

$\square$ Historic DOE/NV

$\triangle$ Defense Projects

YMP

Prohibited Waste at all three Radioactive $\triangle$ Process Knowledge $\square$ Contents NTS landfills:

Additional Prohlbited Waste at the Area 9 U10C Landfill:

levels, and Medical wastes (needles, sharps, bloody clothing).

Sewage Sludge, Animal carcasses, Wet garbage (food waste); and Friable asbestos

\section{REQUIRED: WASTE CONTENTS ALLOWABLE WASTES}

Check all allowable wastes that are contained within this load:

NOTE: Waste disposal at the Area 6 Hydrocarbon Landfill must have come into contact with petroleum hydrocarbons or coolants, such as: gasoline (no benzene, lead); jet fuel; diesel fuel; lubricants and hydraulics; kerosene; asphaltic petroleum hydrocarbon; and ethylene glycol.

Acceptable waste at any NTS landfill: $\triangle$ Paper

$\triangle$ Asphalt $\triangle$ Metal $\otimes$ Wood $\otimes$ Soil

$\triangle$ Plastic $\quad$ Wire $\quad$ Cable $\quad$ Cloth

$\square$ Rocks / unaltered geologic materials

$\triangle$ Rubber (excluding tires)

Insulation (non-Asbestosform)

$\triangle$ Empty containers

$\triangle$ Manufactured items: (swamp coolers, furniture, rugs, carpet, electronic components, PPE, etc.)

Additional waste accepted at the Area 23 Mercury Landfill: $\square$ Office Waste $\square$ Food Waste

Demolition debris

$\bigotimes$ Cement \& concrete

$\square$ Asbestos $\quad \square$ Friable $\quad \square$ Non-Friable (contact SWO if regulated load) Quantity:

Additional waste accepted at the Area 9 U10c Landfill:

$\square$ Non-friable asbestos

$\square$ Light ballasts (contact SwO)

$\square$ Drained automobiles and military vehicles

Hydrocarbons (contact SWO)

Drained fuel filters (gas \& diesel)

Other Drained generators/equipment

$\square$ Solid fractions from sand/oil/water

$\triangle$ Deconned Underground and Above

Ground Tanks

\section{Additional waste accepted at the Area 6 Hydrocarbon Landfill:}
$\square$ Septic sludge
$\square$ Rags
$\square$ Drained fuel filters (gas \& diesel)
Plants
Soil
$\square$ Sludge from sand/oil/water separators

\section{Crushed non-teme plated oil filters} REQUIRED: WASTE GENERA

Initials: (if initialed, no radiological clearance is necessary.)

The above mentloned waste was generated outside of a Controlled W: knowledge, does not contain radiological materials.

To the best of my knowledge, the waste described above contains onl site. I have verified this through the waste characterization method id prohibited and allowable waste items. I have contacted Property Man: is approved for disposal in the landfill.

Radiation Survey Release for Waste Disposal RCT Initials This container/load is free of external radioactive
contamination.

This container/load is exempt from survey due to process knowledge and origin.

This container/load is free of radioactive contamination based on radioanalysis.

SIGNATUR DATE: $10 / 24 / 07$ BN.0646 (09/99) int

Print Name: Dan Tobiason

Signature:
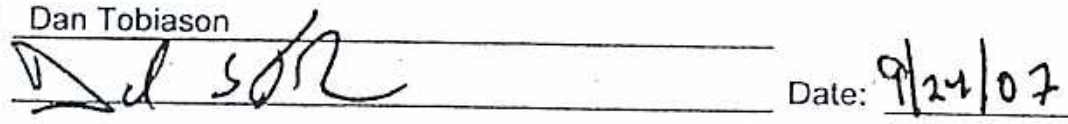

If applicable, place FRM-0646,

"Radiological Release Sticker" here. Onsite use only.

Note: "Food waste, office trash and animal carcasses do not require a radiological clearance. Freon-containing appliances must have signed removal certification statement with Load Verification."

SWO USE ONLY

Load Weight (net from scale of estimate)!

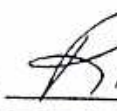




$\begin{array}{llllll}\text { SWO USE (Select One) } & \text { AREA } & \square 23 & \square 6 & \square 9 & \square \text { LANDFILL }\end{array}$

For waste characterization, approval, and/or assistance, contact Solid Waste Operation (SWO) at 5-7898.

$$
\text { REQUIRED: WASTE GERERATOR INFORMATION }
$$

(This form is for rolloffs, dump trucks, and other onsite disposal of materials.)

Waste Generator: Dan Tobiason

Phone Number: 295-6169

Location / Origin: T-Tunnel Lower Laydown Yard

Waste Category: (check one)

Waste Type: $\square$ NTS

$\square$ Commercial.

$\triangle$ Industrial

QS

$10 / 29107$

(check one)

$\square$ Non-Putrescible

$\square$ Putrescrible

A-FFAGQ-Onsite-

$\square$ WAC Exception

Pollution Prevention Category: (check one)

Pollution Prevention Category: (check one)

$\square$ Asbestos Containing Material

Method of Characterization: (check one)

Environmental management

$\otimes$ Clean-Up

FFACO-offsite

$\square$ Historic DOE/NV

Prohibited Waste at all three

NTS landfills:

Additional Prohibited Waste

at the Area 9 U10C Landfill:

levels, and Medical wastes (needles, sharps, bloody clothing).

Sewage Sludge, Animal carcasses, Wet garbage (food waste); and Friable asbestos

REQUIRED: WASTE CONTENTS ALLOWABLE WASTES

Check all allowable wastes that are contained within this load:

NOTE: Waste disposal at the Area 6 Hydrocarbon Landfill must have come into contact with petroleum hydrocarbons or coolants, such as: gasoline (no benzene, lead); jet fuel; diesel fuel; lubricants and hydraulics; kerosene; asphaltic petroleum hydrocarbon; and ethylene glycol.
Acceptable waste at any NTS landfill: $\triangle$ Paper
Asphalt $\otimes$ Metal
$\triangle$ Wood
$\triangle$ Soil
$\square$ Rocks / unaltered geologic materials
$\triangle$ Empty containers
$\triangle$ Plastic $\otimes$ Wire
$\triangle$ Cable
$\triangle$ Cloth
$\triangle$ Rubber (excluding tires)
$\bigotimes$ Insulation (non-Asbestosform)
$\bigotimes$ Demolition debris
Manufactured items: (swamp coolers, furniture, rugs, carpet, electronic components, PPE, etc.)
$\bigotimes$ Cement \& concrete

Additional waste accepted at the Area 23 Mercury Landfill: $\square$ Office Waste $\square$ Food Waste
$\square$ Asbestos
Friable
$\square$ Non-Friable (contact SWO if regulated load)
Quantity:

Additional waste accepted at the Area 9 U10c Landfill:
$\square$ Non-friable asbestos
Drained automobiles and military vehicles
Light ballasts (contact SWO)
Drained fuel filters (gas \& diesel)
Hydrocarbons (contact SWO)

Other Drained generators/equipment
$\square$ Solid fractions from sand/oil/water
$\triangle$ Deconned Underground and Above Ground Tanks

Additional waste accepted at the Area 6 Hydrocarbon Landfill:

$\begin{array}{lll}\square \text { Septic sludge } & \square \text { Rags } \\ \square \text { Plants } & \square \text { Soil } & \square \text { Drained fuel filters (gas \& diesel) } \\ & & \text { REQUIRED: WASTE GENERAT }\end{array}$

Initials: (if initialed, no radiological clearance is necessary.)

The above mentioned waste was generated outside of a Controlled Was knowledge, does not contain radiological materials.

To the best of my knowledge, the waste described above contains only site. I have verified this through the waste characterization method ide prohibited and allowable waste Items. I have contacted Property Manac is approved for disposal in the landflll.

\section{Radiation Survey Release for Waste Disposal} RCT Initials (E) This container/load is free of external radioactive

This container/load is exempt from survey due to process knowledge and origin.

This container/load is free of radioactive contamination based on radioanalysis. SIGNATURE: EqI 3 eve DATE: $10 / 25 / 107$
Print Name: Dan Tobiason

Signature:

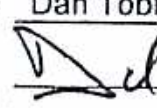

d
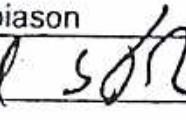

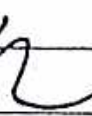

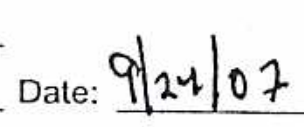

If applicable, place FRM-0646,

"Radiological Release Sticker" here. Onsite use only.

Note: "Food waste, office trash and animal carcasses do not require a radiological clearance. Freon-containing appliances must have signed removal certification statement with Load Verification."

SWO USE ONLY

Load Weight (net from scale or estimate): 12300

$10.25 \cdot 07$ Signature of Certifier:

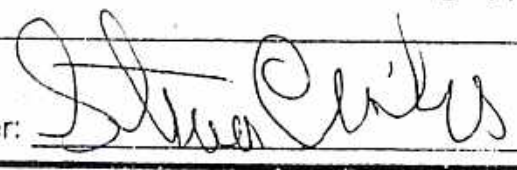




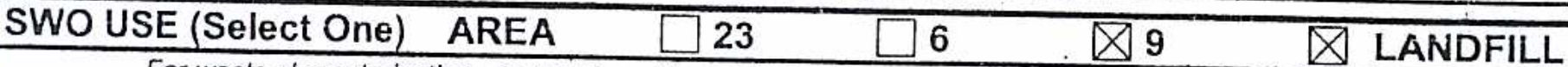

For waste characterization, approval, and/or assistance, contact Solid Waste Operation (SWO) at 5-7898.

REQUIRED: WASTE GERERATOR INFORMATION

(This form is for rolloffs, dump trucks, and other onsite disposal of materials.)

Waste Generator: Dan Tobiason

Phone Number: 295-6169

Location / Origin: T-Tunnel Lower Laydown Yard

Waste Category: (check one)

Waste Type: $\square$ NTS

(check one)

$\square$ Non-Putrescible

Pollution Prevention Category: (check one)

Pollution Prevention Category: (check one)

Method of Characterization: (check one)

Prohibited Waste at all three

NTS landfills:

Additional Prohibited Waste

at the Area 9 U10C Landfill:

$\square$ Sampling \& Analysis

$\square$ Commerclal

$\square$ Putrescrible

$凶$ Clean-Up $\square$ Asbestos Containing Material

$\square$ Environmental management

levels, and Medical wastes (needles, sharps, bloody clothing).

$\triangle$ Industrial cas $10 / 29107$

XFFAGQAnsite $\square$ WAC Exception

$\square$ FFACO-offsite $\square$ Historic DOE/NV

$\triangle$ Defense Projects $\square$ YMP

$\square$ Routine

$\triangle$ Process Knowledge $\square$ Contents

Sewage Sludge, Animal carcasses, Wet garbage (food waste); and Friable asbestos

\section{REQUIRED: WASTE CONTENTS ALLOWABLE WASTES}

Check all allowable wastes that are contained within this load:

NOTE: Waste disposal at the Area 6 Hydrocarbon Landfill must have come into contact with petroleum hydrocarbons or coolants, such as: gasoline (no benzene, lead); jet fuel; diesel fuel; lubricants and hydraulics; kerosene; asphaltic petroleum hydrocarbon; and ethylene glycol.
Acceptable waste at any NTS landfill:
Asphalt
$\otimes$ Metal
$\triangle$ Wood
Q Paper
$\bigotimes$ Soil
$\bigotimes$ Cable
Cloth
Rocks / unaltered geologic materials
$\bigotimes$ Rubber (excluding tires)
$\bigotimes$ Insulation (non-Asbestosform)
$\bigotimes$ Plastic $\otimes$ Wire
$\triangle$ Cloth

$\triangle$ Empty containers

Q Manufactured items: (swamp coolers, fumiture, rugs, carpet, electronic components, PPE, etc.)

Demolition debris

$\bigotimes$ Cement \& concrete
Additional was
$\square$ Asbestos
Friable
Area 23 Mercury Landfill:
$\square$ Office Waste
Non-Friable (contact SWO if regulated load)
Food Waste
Animal Carcasses
Quantity:

Additional waste accepted at the Area 9 U10c Landfill:

$\square$ Non-friable asbestos $\square$ Drained automobiles and military vehicles
$\square$ Light ballasts (contact SwO) $\square$ Drained fuel filters (gas \& diesel)

$\square$ Hydrocarbons (contact SWO) $\bigotimes$ Other Drained generators/equipment

Additional waste accepted at the Area 6 Hydrocarbon Landfill:
$\square$ Septic sludge
$\square$ Rags
Plants
Soil
$\square$ Drained fuel filters (gas \& diesel)
$\square$ Sludge from sand/oil/water separators
REQUIRED: WASTE GENERATOR

Initials: (if initialed, no radiological clearance is necessary.)

The above mentioned waste was generated outside of a Controlled Waste knowledge, does not contain radiological materials.

To the best of my knowledge, the waste described above contains only tho site. I have verified this through the waste characterization method identifi prohibited and allowable waste items. I have contacted Property Managem is approved for disposal in the landfill.

Solid fractions from sand/oil/water

$\bigotimes$ Deconned Underground and Above Ground Tanks

Print Name: Dan Tobiason

Signature:
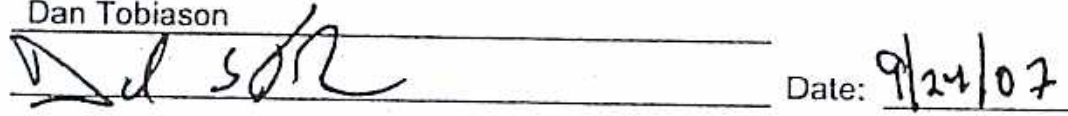

Radiation Survey Release for Waste Disposal RCT Initials

(e) This containerlload is free of external radioactive contamination.

This container/load is exempt from survey due to process knowledge and origin.

This container/load is free of radioactive contamination based on radioanalysis. DATE: $10 / 25 / 07$ $\mathrm{BN}-0646(09 / 99)$

Note: "Food waste, office trash and animal carcasses do not require a radiological clearance. Freon-containing appliances must have signed removal certification statement with Load Verification."

SWO USE ONLY

Load Weight (net from scale or/estimate) 197 (7) $10-25-07$ Signature of Certifier:

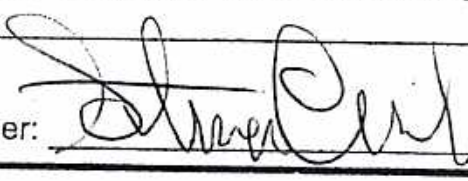

If applicable, place FRM-0646, "Radiological Release Sticker" here. Onsite use only. 


\section{SWO USE (Select One) $\quad$ AREA $\quad \square 23 \quad \square 6 \quad \square 9 \quad$ LANDFILL}

For waste characterization, approval, and/or assistance, contact Solid Waste Operation (SWO) at 5-7898.

REQUIRED: WASTE GERERATOR INFORMATION

(This form is for rolloffs, dump trucks, and other onsite disposal of materials.)

Waste Generator: Dan Tobiason

Phone Number: 295-6169

Location / Origin: T-Tunnel Lower Laydown Yard

\begin{tabular}{|c|c|c|}
\hline Waste Category: (check one) & $\square$ Commercial & $\Delta$ Industrial $g^{5} 10 / 29 / 07$ \\
\hline Waste Type: & $\square$ Putrescrible & 4-FPACO-OnSite $\square \mathrm{WAC}$ \\
\hline$\square$ Non-Putrescible & $\square$ Asbestos Containing Material & $\square$ FFACO-offsite \\
\hline Pollution Prevention Category: (check one) & $\square$ Environmental management & $Q$ Defense Projects \\
\hline Pollution Prevention Category: (check one) & $\bigotimes$ Clean-Up & $\square$ Routine \\
\hline Method of Characterization: (check one) & Sampling \& Analysis & $\triangle$ Process Knowledge $\square$ Contents \\
\hline
\end{tabular}

Prohibited Waste at all three NTS landfills:

Additional Prohibited Waste at the Area 9 U10C Landfill: levels, and Medical wastes (needles, sharps, bloody clothing).

Sewage Sludge, Animal carcasses, Wet garbage (food waste); and Friable asbestos

\section{REQUIRED: WASTE CONTENTS ALLOWABLE WASTES}

Check all allowable wastes that are contained within this load:

NOTE: Waste disposal at the Area 6 Hydrocarbon Landfill must have come into contact with petroleum hydrocarbons or coolants, such as: gasoline (no benzene, lead); jet fuel; diesel fuel; lubricants and hydraulics; kerosene; asphaltic petroleum hydrocarbon; and ethylene glycol.

Acceptable waste at any NTS landfill: $\bigotimes$ Pape

$\bigotimes$ Asphalt $\otimes$ Metal $\otimes$ Wood $\otimes$ Soil

$\triangle$ Plastic $\quad \square$ Wire $\quad$ Cable $\quad$ Cloth

$\square$ Rocks / unaltered geologic materials

$\otimes$ Rubber (excluding tires)

Insulation (non-Asbestosform)

$\triangle$ Empty containers

Demolition debris

$\bigotimes$ Manufactured items: (swamp coolers, fumiture, rugs, carpet, electronic components, PPE, etc.)

Additional waste accepted at the Area 23 Mercury Landfill: $\square$ Office Waste $\square$ Food Waste
$\square$ Asbestos $\square$ Friable $\square$ Non-Friable (contact SWO if regulated load) Quantity:

$凶$ Cement \& concrete

\section{Additional waste accepted at the Area $9 \mathrm{U10c}$ Landfill:}

$\square$ Non-friable asbestos $\quad \square$ Drained automobiles and military vehicles

$\square$ Light ballasts (contact SWO)

$\square$ Drained fuel filters (gas \& diesel)

Hydrocarbons (contact SWO) $\otimes$ Other Drained generators/equipment

$\square$ Solid fractions from sand/oil/water

$\otimes$ Deconned Underground and Above Ground Tanks

\section{Additional wasté accepted at the Area 6 Hydrocarbon Landfill:}
$\square$ Septic sludge
$\square$ Rags
Plants
Soil
$\square$ Drained fuel filters (gas \& diesel)
$\square$ Sludge from sand/oil/water separators
REQUIRED: WASTE GENERATOR
Crushed non-teme plated oil filters PCBs below 50 parts per million

Initials: (if initialed, no radiological clearance is necessary.)

The above mentioned waste was generated outside of a Controlled Waste $i$ knowledge, does not contain radiological materials.

To the best of my knowledge, the waste described above contains only the site. I have verified this through the waste characterization method identif prohibited and allowable waste items. I have contacted Property Managen is approved for disposal in the landfill.

Print Name: Dan Tobiason

Signature:

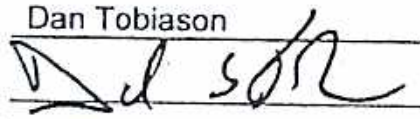

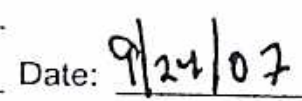

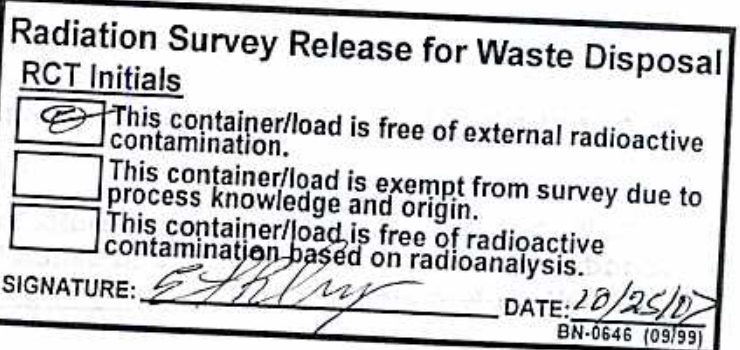

If applicable, place rкM-U040,

"Radiological Release Sticker" here. Onsite use only.

Note: "Food waste, office trash and animal carcasses do not require a radiological clearance. Freon-containing appliances must have signed removal certification statement with Load Verification."

\section{SWO USE ONLY}

Load Weight (net from scale or estimate):
$10-25-07$

Signature of Certifier:
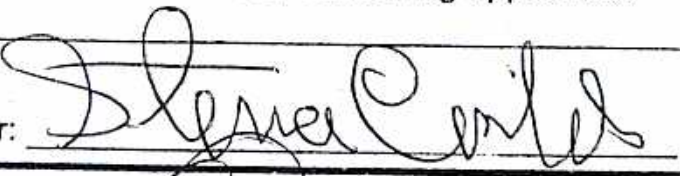
NSTec

Form

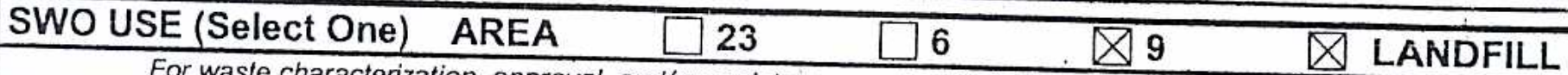 \\ For waste characterization, approval, and/or assistance, contact Solid Waste Operation (SWO) at 5-7898.}

REQUIRED: WASTE GERERATOR INFORMATION

(This form is for rolloffs, dump trucks, and other onsite disposal of materials.)

Waste Generator: Dan Tobiason

Phone Number: 295-6169

Location / Origin: T-Tunnel Lower Laydown Yard

Waste Category: (check one)

Waste Type: $\square$ Commercla

NTS $\square$ Putrescrible

(check one) $\quad \square$ Non-Putrescible

$\square$ Asbestos Containing Material

Pollution Prevention Category: (check one) $\square$ Environmental management

Pollution Prevention Category: (check one) $\triangle$ Clean-Up

Method of Characterization: (check one)

$\square$ Sampling \& Analysis
Radioactive waste; RCRA waste; Hazardous waste; Free liquids, PCBs above TSCA
levels, and Medical wastes (needles, sharps, bloody clothing).
Sewage Sludge, Animal carcasses, Wet garbage (food waste); and Friable asbestos

Prohibited Waste at all three

NTS landfills:

Additional Prohibited Waste

at the Area 9 U10C Landfill:

\section{REQUIRED: WASTE CONTENTS ALLOWABLE WASTES}

Check all allowable wastes that are contained within this load:
NOTE: Waste disposal at the Area 6 Hydrocarbon Landfill must have come into contact with petroleum hydrocarbons or
coolants, such as: gasoline (no benzent; coolants, such as: gasoline (no benzene, lead); jet fuel; diesel fuel; lubricants and hydraulics; kerosene; asphaltic
petroleum hydrocarbon; and ethylene glycol.

Acceptable waste at any NTS landfill: $\square$ Paper
Asphalt
$\triangle$ Metal
Wood
$\triangle$ Soil
$\bigotimes$ Plastic $\square$ Wire
$\triangle$ Cable
$\triangle$ Cloth
$\square$ Rocks / unaltered geologic materials
$\bigotimes$ Rubber (excluding tires)
$\triangle$ Insulation (non-Asbestosform)

$\bigotimes$ Empty containers

$\bigotimes$ Demolition debris

$\triangle$ Manufactured items: (swamp coolers, furniture, rugs, carpet, electronic components, PPE, etc.)

Additional waste accepted at the Area 23 Mercury Landfill: $\square$ Office Waste $\square$ Food Waste
$\square$ Asbestos $\square$ Friable $\square$ Non-Friable (contact SWO if regulated load) Quantity:

$\bigotimes$ Cement \& concrete

Quantity:

Additional waste accepted at the Area 9 U10c Landfill:

$\square$ Non-friable asbestos

$\square$ Light ballasts (contact SWO)

Hydrocarbons (contact SWO)

$\square$ Drained automobiles and military vehicles

$\square$ Drained fuel filters (gas \& diesel)

Other Drained generators/equipment

Additional waste accepted at the Area 6 Hydrocarbon Landfill:
$\square$ Septic sludge
Plants
$\square$ Rags
$\square$ Soil

$\square$ Drained fuel filters (gas \& diesel)

$\square$ Sludge from sand/oil/water separators REQUIRED: WASTE GENER/

Initials: (if initialed, no radiological clearance is necessary.)

The above mentioned waste was generated outside of a Controlled $W$ knowledge, does not contain radiological materials.

To the best of my knowledge, the waste described above contains on site. I have verified this through the waste characterization method id prohibited and allowable waste Items. I have contacted Property Man is approved for disposal in the landfill.

$\begin{aligned} & \text { Radiation Survey Release for Waste Disposal } \\ & \text { RCT Initials }\end{aligned}$
$\begin{aligned} & \text { This container/load is free of external radioactive } \\ & \text { contamination. }\end{aligned}$
$\begin{aligned} & \text { This container/load is exempt from survey due to } \\ & \text { process knowledge and origin. } \\ & \text { This container/load is free of radioactive } \\ & \text { contamination based on radioanalysis. }\end{aligned}$

Print Name: Dan Tobiason

Signature:
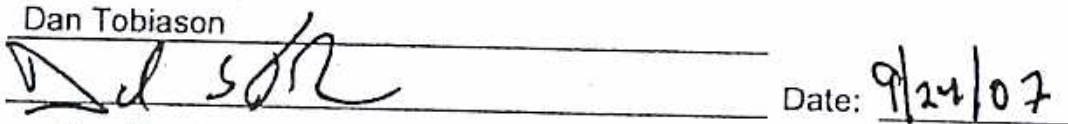

Solid fractions from sand/oii/water

$\bigotimes$ Deconned Underground and Above Ground Tanks

If applicable, place FRM-0646,
"Radiological Release Sticker"

Crushed non-teme plated oil filters PCBs below 50 parts per million Note: "Food waste, office trash and animal carcasses do not require a radiological clearance. Freon-containing appliances
must have signed removal certification statement with Load Verification."

SWO USE ONLY

Load Weight (net from scale or estimate)?

$10-25-07$

Signature of Certifier:

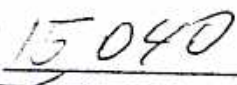




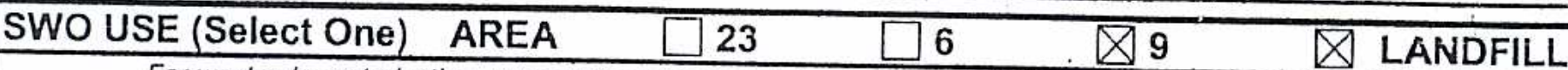

For waste characterization, approval, and/or assistance, contact Solid Waste Operation (SWO) at 5-7898.

\section{REQUIRED: WASTE GERERATOR INFORMATION}

(This form is for rolloffs, dump trucks, and other onsite disposal of materials.)

Waste Generator: Dan Tobiason

Phone Number: 295-6169

Location / Origin: T-Tunnel Lower Laydown Yard

Waste Category: (check one)

Waste Type: $\triangle$ NTS

(check one)

$\square$ Non-Putrescible $\quad \square$ Asbestos Containing Material

$\square$ Commercial

$\square$ Putrescrible

$\triangle$ Industrial $82510 / 29107$

Pollution Prevention Category: (check one)

Pollution Prevention Category: (check one)

Method of Characterization: (check one)

$\square$ Environmental management

$\triangle$ Clean-Up

$\triangle$ FFACO-Onsite

$\square$ FFACO-offsite

$\triangle$ Defense Projects

$\square$ WAC Exception

Prohibited Waste at all three

NTS landfills:

Additional Prohlbited Waste

at the Area 9 U10C Landfill:

Radioactive waste; RCRA waste; Hazardous waste; Free liquids, PCBs above TSCA regulatory levels, and Medical wastes (needles, sharps, bloody clothing).

Sewage Sludge, Animal carcasses, Wet garbage (food waste); and Friable asbestos

\section{REQUIRED: WASTE CONTENTS ALLOWABLE WASTES}

Check all allowable wastes that are contained within this load:

NOTE: Waste disposal at the Area 6 Hydrocarbon Landfill must have come into contact with petroleum hydrocarbons or coolants, such as: gasoline (no benzene, lead); jet fuel; diesel fuel; lubricants and hydraulics; kerosene; asphaltic petroleum hydrocarbon; and ethylene glycol.
Acceptable waste at any NTS landfill:
$\bigotimes$ Asphalt
Metal
$\bigotimes$ Wood
$凶$ Paper
\Soil
$\triangle$ Plastic $\triangle$ Wire $\triangle$ Cable
$\triangle$ Cloth
$\square$ Rocks / unaltered geologic materials
$\triangle$ Rubber (excluding tires)
Insulation (non-Asbestosform)
$\triangle$ Empty containers
Q Demolition debris
fumiture, rugs, carpet, electronic components, PPE, etc.)
$\bigotimes$ Cement \& concrete

Additional waste accepted at the Area 23 Mercury Landfill: $\square$ Office Waste

Asbestos

Friable

$\square$ Non-Friable (contact SWO if regulated load)

$\square$ Food Waste

Animal Carcasses

\section{Additional waste accepted at the Area 9 U10c Landfill:}

$\square$ Non-friable asbestos

$\square$ Drained automobiles and military vehicles

Light ballasts (contact SWO)

Drained fuel filters (gas \& diesel)

Hydrocarbons (contact SWO)

Other

Drained generators/equipment

$\square$ Solid fractions from sand/oil/water

$\bigotimes$ Deconned Underground and Above Ground Tanks

\section{Additional waste accepted at the Area 6 Hydrocarbon Landfill:}
$\square$ Septic sludge
$\square$ Rags
Plants
Soil
$\square$ Drained fuel filters (gas \& diesel)
$\square$ Sludge from sand/oil/water separators
Crushed non-teme plated oil filters REQUIRED: WASTE GENERATOR SIGNATURE

Initials: (if initialed, no radiological clearance is necessary.

The above mentioned waste was generated outside of a Controlled $h$ knowledge, does not contain radiological materiais.

To the best of my knowledge, the waste described above contains or site. I have verified this through the waste characterization method $i$ prohibited and allowable waste items. I have contacted Property Mai is approved for disposal in the landfill.

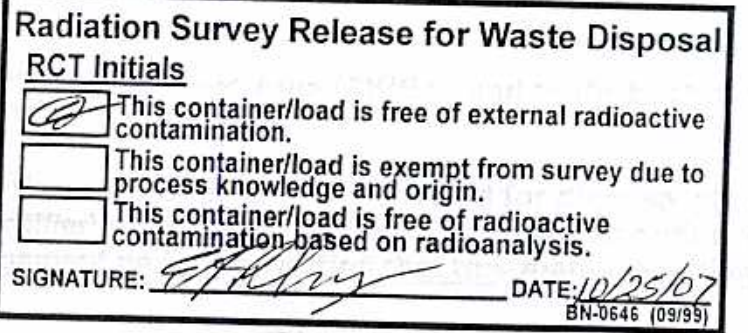

Print Name: Dan Tobiason

Signature:
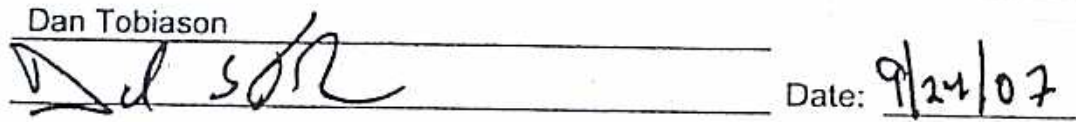

"appruanic, prave ' . . "Radiological Release Sticker" here. Onsite use only.

Note: "Food waste, office trash and animal carcasses do not require a radiological clearance, Freon-containing appliances must have signed removal certification statement with Load Verification."

SWO USE ONLY

Load Weight (net from scale or estimate):

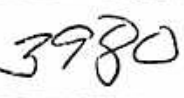

$10-25-07$ Signature of Certifier:

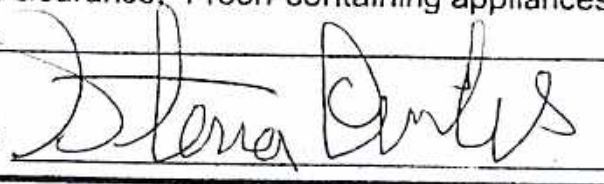




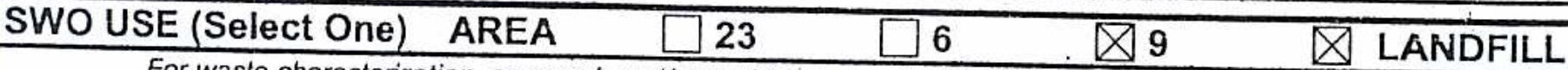

For waste characterization, approval, and/or assistance, contact Solid Waste Operation (SWO) at 5-7898.

REQUIRED: WASTE GERERATOR INFORMATION

(This form is for rolloffs, dump trucks, and other onsite disposal of materials.)

Waste Generator: Dan Tobiason

Phone Number: $295-6169$

Location / Origin: T-Tunnel Lower Laydown Yard

Waste Category: (check one)

Waste Type: $\triangle$ NTS

(check one)

$\square$ Non-Putrescible

$\square$ Commercial

$\square$ Putrescrible

$\triangle$ Industrial egs $18 / 30 / 07$

Pollution Prevention Category: (check one)

Pollution Prevention Category: (check one)

$\square$ Asbestos Containing Material

$\triangle$ FFACO-onsite

$\square$ WAC Exception

Method of Characterization: (check one)

$\square$ Environmental management

$\square$ FFACO-offsite

$\triangle$ Clean-Up

(check one) $\square$ Sampling \& Analysis

$\triangle$ Defense Projects

$\square$ Historic DOE/NV

Prohibited Waste at all three

NTS landfills:

Additional Prohlbited Waste

at the Area 9 U10C Landfill:

Radioactive waste; RCRA waste; Hazardous waste; Free liquids, PCBs above TSCA regulatory levels, and Medical wastes (needles, sharps, bloody clothing).

Sewage Sludge, Animal carcasses, Wet garbage (food waste); and Friable asbestos

\section{REQUIRED: WASTE CONTENTS ALLOWABLE WASTES}

Check all allowable wastes that are contained within this load:

NOTE: Waste disposal at the Area 6 Hydrocarbon Landfill must have come into contact with petroleum hydrocarbons or coolants, such as: gasoline (no benzene, lead); jet fuel; diesel fuel; lubricants and hydraulics; kerosene; asphaltic petroleum hydrocarbon; and ethylene glycol.

Acceptable waste at any NTS landfill: $\triangle$ Paper
$\bigotimes$ Asphalt
Metal
W Wood
$\otimes$ Soil
Plastic
$\triangle$ Wire
$\triangle$ Cable
$\triangle$ Cloth
$\square$ Rocks / unaltered geologic materials
$\triangle$ Rubber (excluding tires)
$\triangle$ Insulation (non-Asbestosform)

$\bigotimes$ Empty containers
$\bigotimes$ Demolition debris
$\bigotimes$ Cement \& concrete

$\bigotimes$ Manufactured items: (swamp coolers, furniture, rugs, carpet, electronic components, PPE, etc.)
Additional waste accepted at the Area 23 Mercury Landfill:
$\square$ Asbestos
Friable
Non-Friable (contact SWO if regulated load)
Food Waste
Animal Carcasses
Quantity:

Additional waste accepted at the Area 9 U10c Landfill:
$\square$ Non-friable asbestos
Light ballasts (contact SWO)
$\square$ Drained automobiles and military vehicles
$\square$ Drained fuel filters (gas \& diesel)

Hydrocarbons (contact SWO)

Other Drained generators/equipment

Additional waste accepted at the Area 6 Hydrocarbon Landfill:
$\square$ Septic sludge
$\square$ Rags
$\square$ Drained fuel filters (gas \& diesel)
Plants
Soil
$\square$ Sludge from sand/oil/water separators REQUIRED: WASTE GENE
Crushed non-teme plated oil filters PCBs below 50 parts per million

Initials: (if initialed, no radiological clearance is necessar

The above mentioned waste was generated outside of a Controlled knowledge, does not contain radiological materials.

To the best of my knowledge, the waste described above contains site. I have verified this through the waste characterization method prohibited and allowable waste Items. I have contacted Property M is approved for disposal in the landfill.

\section{Radiation Survey Release for Waste Disposal \\ RCT Initials}

This container/load is free of external radioactive

contamination.

This container/load is exempt from survey due to process knowledge and origin.

Print Name: Dan Tobiason

Signature:
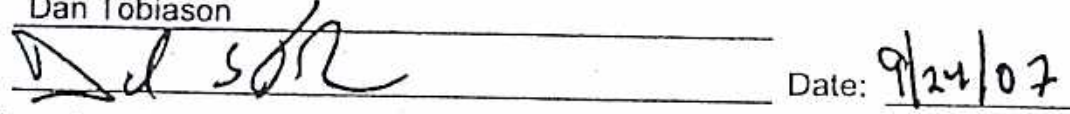

This containerlload is free of radioactive

SIGNATURE: Contamination based on radioanalysis.

Note: "Food waste, office trash and animal carcasses do not require a radiological clearance. Freon-containing appliances must have signed removal certification statement with Load Verification."

LWO USE ONLY
$10-29-07$

Signature of Certifier:
If applicable, place FRM-0646,

"Radiological Release Sticker" here. Onsite use only. 


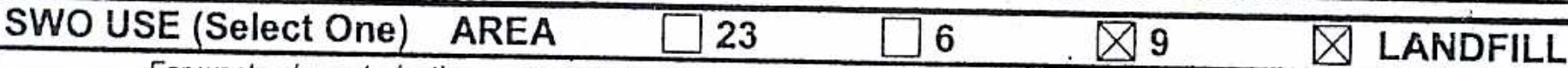

For waste characterization, approval, and/or assistance, contact Solid Waste Operation (SWO) at 5-7898.

REQUIRED: WASTE GERERATOR INFORMATION

(This form is for rolloffs, dump trucks, and other onsite disposal of materials.)

Waste Generator: Dan Tobiason

Phone Number: 295-6169

Location / Origin: T-Tunnel Lower Laydown Yard

\begin{tabular}{|c|c|c|}
\hline Waste Category: (check one) & $\square$ Commerclal & $\Delta$ Industrial $0510 / 30 / 07$ \\
\hline Waste Type: & $\square$ Putrescrible & $\triangle F F A G Q$-nsile $\square$ WAC \\
\hline$\square$ Non-Putrescible & $\square$ Asbestos Containing Material & $\square$ Historic DOE/NV \\
\hline Pollution Prevention Category: (check one) & $\square$ Environmental management & Q Defense Projects \\
\hline Pollution Prevention Category: (check one) & $\triangle$ Clean-Up & $\square$ Routine \\
\hline Method of Characterization: (check one) & $\square$ Sampling \& Analysis & $\triangle$ Process Knowledge $\square$ Contents \\
\hline
\end{tabular}
NTS landfills:

Additional Prohibited Waste at the Area 9 U10C Landfill: levels, and Medical wastes (needles, sharps, bloody clothing).

Sewage Sludge, Animal carcasses, Wet garbage (food waste); and Friable asbestos

\section{REQUIRED: WASTE CONTENTS ALLOWABLE WASTES}

Check all allowable wastes that are contained within this load:

NOTE: Waste disposal at the Area 6 Hydrocarbon Landfill must have come into contact with petroleum hydrocarbons or coolants, such as: gasoline (no benzene, lead); jet fuel; diesel fuel; lubricants and hydraulics; kerosene; asphaltic petroleum hydrocarbon; and ethylene glycol.

Acceptable waste at any NTS landfill: $\triangle$ Paper $\square$ Rocks / unaltered geologic materials

$\bigotimes$ Asphalt $\quad$ Metal $\quad$ Wood $\quad$ Soil $\quad$ Rubber (excluding tires)

$\triangle$ Plastic $\quad$ Wire $\quad$ Cable $\quad$ Cloth $\quad$ Insulation (non-Asbestosform)

$\bigotimes$ Manufactured items: (swamp coolers, fumiture, rugs, carpet, electronic components, PPE, etc.)

Additional waste accepted at the Area 23 Mercury Landfill: $\square$ Office Waste $\square$ Food Wast

$\bigotimes$ Empty containers

Demolition debris

$\bigotimes$ Cement \& concrete
$\square$ Asbestos
Friable
Non-Friable (contact SWO if regulated load)
Quantity:

\section{Additional waste accepted at the Area 9 U10c Landfill:}

$\begin{array}{ll}\square \text { Non-friable asbestos } & \square \text { Drained automobiles and military vehicles } \\ \square \text { Light ballasts (contact SWO) } & \square \text { Drained fuel filters (gas \& diesel) }\end{array}$ Hydrocarbons (contact SWO)

Other Drained generators/equipment
门 Solid fractions from sand/oil/water

$\triangle$ Deconned Underground and Above Ground Tanks

\section{Additional waste accepted at the Area 6 Hydrocarbon Landfill:}
$\square$ Septic sludge
$\square$ Rags
Plants
Soil
$\square$ Drained fuel filters (gas \& diesel)
$\square$ Sludge from sand/oil/water separators
REQUIRED: WASTE GENERATI

Initials: (if initialed, no radiological clearance is necessary.)

The above mentioned waste was generated outside of a Controlled Was knowledge, does not contain radiological materials.

To the best of my knowledge, the waste described above contains only I site. I have verified this through the waste characterization method iden prohibited and allowable waste items. I have contacted Property Manag is approved for disposal in the landflll.

Radiation Survey Release for Waste Disposal RCT Initials

Print Name: Dan Tobiason

Signature:
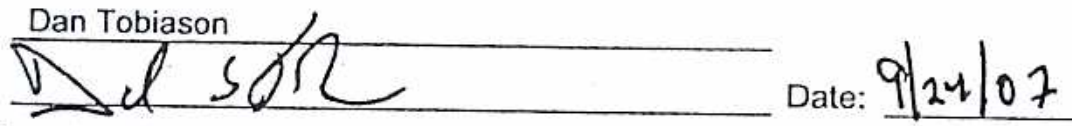

$\square$ Crushed non-teme plated oil filters

$\square$ PCBs below 50 parts per million

Note: "Food waste, office trash and animal carcasses do not require a radiological clearance. Freon-containing appliances must have signed removal certification statement with Load Verification."

\section{SWO USE ONLY}

Load Weight (net from
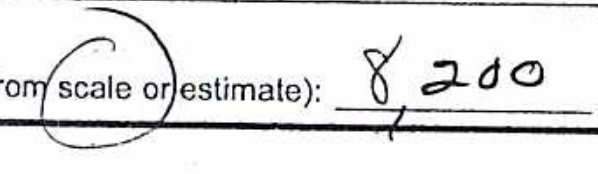

$10-29-07$

If applicable, place FRM-0646, "Radiological Release Sticker" here. Onsite use only. 


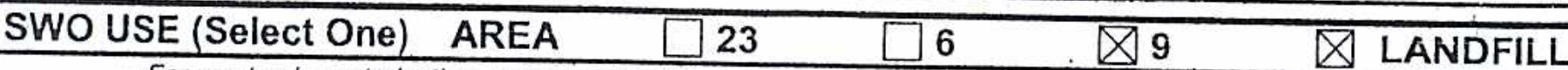

For waste characterization, approval, and/or assistance, contact Solid Waste Operation (SWO) at 5-7898.

\section{REQUIRED: WASTE GERERATOR INFORMATION}

(This form is for rolloffs, dump trucks, and other onsite disposal of materials.)

Waste Generator: Dan Tobiason

Phone Number: 295-6169

Location / Origin: T-Tunnel Lower Laydown Yard

Waste Category: (check one)

Waste Type: $\triangle$ NTS

(check one) $\square$ Non-Putrescible $\square$ Asbestos Containing Material

Pollution Prevention Category: (check one)

Pollution Prevention Category: (check one)

Method of Characterization: (check one)

$\square$ Environmental management

$\triangle$ Clean-Up

$\square$ Commerclal

Process Knowledge $\square$ Contents

Prohibited Waste at all three Radioactive waste; RCRA waste; Hazardous waste; Free liquids, PCBs above TSCA regulatory
NTS landfills: Additional Prohlbited Waste at the Area 9 U10C Landfill: levels, and Medical wastes (needles, sharps, bloody clothing).

Sewage Sludge, Animal carcasses, Wet garbage (food waste); and Friable asbestos

\section{REQUIRED: WASTE CONTENTS ALLOWABLE WASTES}

Check all allowable wastes that are contained within this load:

NOTE: Waste disposal at the Area 6 Hydrocarbon Landfill must have come into contact with petroleum hydrocarbons or coolants, such as: gasoline (no benzene, lead); jet fuel; diesel fuel; lubricants and hydraulics; kerosene; asphaltic petroleum hydrocarbon; and ethylene glycol.

\begin{tabular}{|c|c|c|c|c|}
\hline Acceptable & laste at an & TS landfill: & $\triangle$ Paper & $\square$ Rocks / unaltered geologic materials \\
\hline$\triangle$ Asphalt & Metal & $凶$ Wood & $\triangle$ Soil & $\bigotimes$ Rubber (excluding tires) \\
\hline$\triangle$ Plastic & $\bigotimes$ Wire & $\triangle$ Cable & $\bigotimes$ Cloth & $凶$ Insulation (non-Asbestosform) \\
\hline
\end{tabular}

Additional waste accepted at the Area 23 Mercury Landfill: $\square$ Office Waste

Asbestos

Friable

$\square$ Non-Friable (contact SWO if regulated load)

$\square$ Food Waste

$\bigotimes$ Empty containers

$\bigotimes$ Demolition debris

$\bigotimes$ Cement \& concrete

\section{Additional waste accepted at the Area 9 U10c Landfill:}

$\square$ Non-friable asbestos

$\square$ Light ballasts (contact SWO)

Hydrocarbons (contact SWO)
Drained automobiles and military vehicles

Drained fuel filters (gas \& diesel)

Other Drained generators/equipment $\square$ Solid fractions from sand/oil/water

$\bigotimes$ Deconned Underground and Above Ground Tanks

\section{Additional waste accepted at the Area 6 Hydrocarbon Landfill:}
$\square$ Septic sludge
$\square$ Rags
Plants
Soil
$\square$ Drained fuel filters (gas \& diesel)
$\square$ Sludge from sand/oil/water separators REQUIRED: WASTE GENER,

Initials: (if initialed, no radiological clearance is necessary.

The above mentioned waste was generated outside of a Controlled $n$ knowledge, does not contain radiological materials.

To the best of my knowledge, the waste described above contains or site. I have verified this through the waste characterization method $i$ prohibited and allowable waste Items. I have contacted Property Mas is approved for disposal in the landfill.

$\begin{aligned} & \text { Radiation Survey Release for Waste Disposal } \\ & \text { RCT Initials }\end{aligned}$
$\begin{aligned} & \text { This containerlload is free of external radioactive } \\ & \text { contamination. }\end{aligned}$
$\begin{aligned} & \text { This containerlload is exempt from survey due to } \\ & \text { process knowledge and origin. }\end{aligned}$
This container/load is free of radioactive
Contamination hased on radioanalysis.

Print Name: Dan Tobiason

Signature:
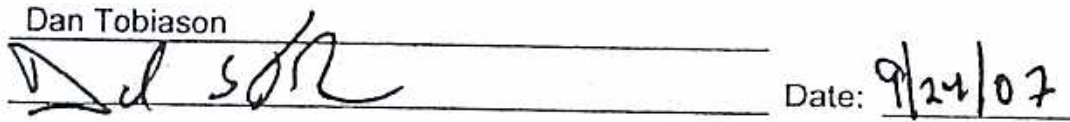

If applicable, place FRM-0646,

"Radiological Release Sticker" here. Onsite use only.

Note: "Food waste, office trash and animal carcasses do not require a radiological clearance. Freon-containing appliances must have signed removal certification statement with Load Verification."

\section{SWO USE ONLY}

Load Weight (net from scale or estimate
$10-24-0 T$ Signature of Certifier: 
For waste characterization, approval, and/or assistance, contact Solid Waste Operation (SWO) at 5-7898.

REQUIRED: WASTE GERERATOR INFORMATION

(This form is for rolloffs, dump trucks, and other onsite disposal of materials.)

Waste Generator: Dan Tobiason

Phone Number: 295-6169

Location / Origin: T-Tunnel Lower Laydown Yard

Waste Category: (check one)

Waste Type:

(check one)

Q NTS

Pollution Prevention Category: (check one)

Pollution Prevention Category: (check one)

Method of Characterization: (check one)

Prohibited Waste at all three

NTS landfills:

Additional Prohibited Waste at the Area 9 U10C Landfill:

\begin{abstract}
Radioactive waste; RCRA waste; Hazardous waste; Free liquids, PCBs above TSCA regulatory levels, and Medical wastes (needles, sharps, bloody clothing).
\end{abstract}

Sewage Sludge, Animal carcasses, Wet garbage (food waste); and Friable asbestos

\section{REQUIRED: WASTE CONTENTS ALLOWABLE WASTES}

Check all allowable wastes that are contained within this load:

NOTE: Waste disposal at the Area 6 Hydrocarbon Landfill must have come into contact with petroleum hydrocarbons or coolants, such as: gasoline (no benzene, lead); jet fuel; diesel fuel; lubricants and hydraulics; kerosene; asphaltic petroleum hydrocarbon; and ethylene glycol.

Acceptable waste at any NTS landfill:
$\bigotimes$ Asphalt $\otimes$ Metal
$\triangle$ Wood
¿ Soil
$\square$ Rocks / unaltered geologic materials
$\bigotimes$ Rubber (excluding tires)

$\triangle$ Paper

$\otimes$ Plastic $\otimes$ Wire $\otimes$ Cable $\square$ Cloth $\square$ Insulation (non-Asbestosform)
$\square$ Manufactured items: (swamp coolers, furniture, rugs, carpet, electronic components, PPE, etc.)

$\otimes$ Plastic $\otimes$ Wire $\otimes$ Cable $\square$ Cloth $\square$ Insulation (non-Asbestosform)
$\square$ Manufactured items: (swamp coolers, furniture, rugs, carpet, electronic components, PPE, etc.)

$\bigotimes$ Empty containers
$\bigotimes$ Demolition debris
$\bigotimes$ Cement \& concrete
Additional waste accepted at the Area 23 Mercury Landfill:
$\square$ Asbestos
Friable
Non-Friable (contact SwO if regulated load)
Food Waste
Animal Carcasses
Quantity:

Additional waste accepted at the Area 9 U10c Landfill:
$\square$ Non-friable asbestos
$\square$ Light ballasts (contact SWO)
$\square$ Drained automobiles and military vehicles
$\square$ Drained fuel filters (gas \& diesel)
Hydrocarbons (contact SWO)
Other Drained generators/equipment

Additional waste accepted at the Area 6 Hydrocarbon Landfill:
$\square$ Septic sludge
Plants
$\square$ Rags
$\square$ Drained fuel filters (gas \& diesel)
$\square$ Sludge from sand/oil/water separators REQUIRED: WASTE GENERATO

Initials: (if initialed, no radiological clearance is necessary.)

The above mentioned waste was generated outside of a Controlled Waste knowledge, does not contain radiological materiais.

To the best of my knowledge, the waste described above contains only thi site. I have verified this through the waste characterization method identif prohibited and allowable waste Items. I have contacted Property Managen is approved for disposal in the landfill.

Print Name: Dan Tobiason Signature:

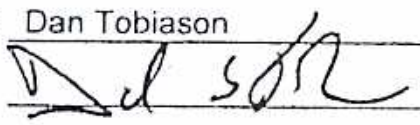

Date: 124.07

Note: "Food waste, office trash and animal carcasses do not require a radiological clearance. Freon-containing appliances must have signed removal certification statement with Load Verification."

SWO USE ONLY

Load Weight (net from scale/or estimate): $\angle 32 / 0$

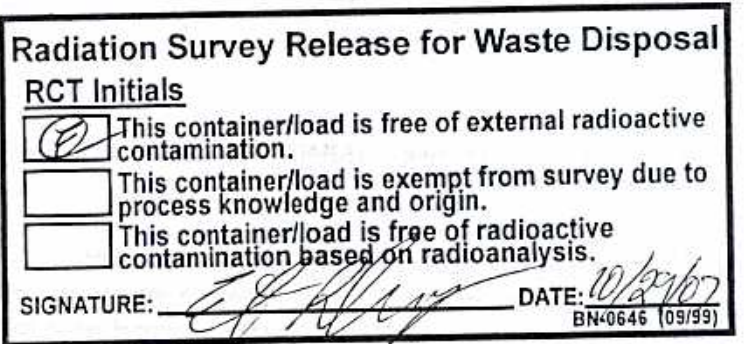

\section{Crushed non-teme plated oil filters}

$\square$ pr:Re hoin... En .............

If applicable, place FRM-0646,

"Radiological Release Sticker" here. Onsite use only.
Solid fractions from sand/oil/water

$\bigotimes$ Deconned Underground and Above Ground Tanks 


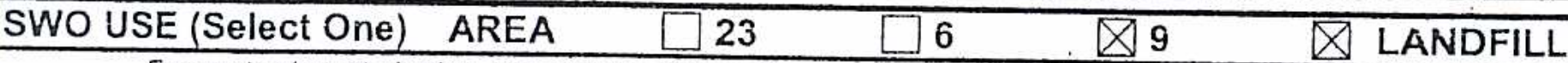

For waste characterization, approval, and/or assistance, contact Solid Waste Operation (SWO) at 5-7898.

REQUIRED: WASTE GERERATOR INFORMATION

(This form is for rolloffs, dump trucks, and other onsite disposal of materials.)

Waste Generator: Dan Tobiason

Phone Number: 295-6169

Location / Origin: T-Tunnel Lower Laydown Yard

Waste Category: (check one)

Waste Type: $\triangle$ NTS

(check one) $\square$ Non-Putrescible $\square$ Asbestos Containing Material

Pollution Prevention Category: (check one)

Pollution Prevention Category: (check ane)

1 Environmental management

$\triangle$ Clean-Up

$\square$ Commercial

$\triangle$ Industrial

ZFEAGO-onsite

OS $10 / 31 / 0 ?$

Method of Characterization: (check one)

$\square$ Sampling \& Analysis

$\square$ FFACO-offsite

$\triangle$ Defense Projects

$\square$ WAC Exception

Prohibited Waste at all three

NTS landfills:

Additional Prohibited Waste

at the Area 9 U10C Landfill:

levels, and Medical wastes (needles, sharps, bloody clothing).

Sewage Sludge, Animal carcasses, Wet garbage (food waste); and Friable asbestos

\section{REQUIRED: WASTE CONTENTS ALLOWABLE WASTES}

Check all allowable wastes that are contained within this load:

NOTE: Waste disposal at the Area 6 Hydrocarbon Landfill must have come into contact with petroleum hydrocarbons or coolants, such as: gasoline (no benzene, lead); jet fuel; diesel fuel; lubricants and hydraulics; kerosene; asphaltic petroleum hydrocarbon; and ethylene glycol.
Acceptable waste at any NTS landfill:
$\triangle$ Asphalt
$\otimes$ Metal
$\triangle$ Wood
$\triangle$ Paper
S Soil
$\triangle$ Cable
$\triangle$ Cloth
$\square$ Rocks / unaltered geologic materials
$\otimes$ Rubber (excluding tires)
$\bigotimes$ Insulation (non-Asbestosform)
$\triangle$ Plastic $\otimes$ Wire
$\triangle$ Cloth

$\triangle$ Empty containers

$\triangle$ Manufactured items: (swamp coolers, fumiture, rugs, carpet, electronic components, PPE, etc.)

$\bigotimes$ Demolition debris
$\square$ Asbestos
Friable
Area 23 Mercury Landfill:
Office Waste
$\square$ Food Waste
Animal Carcasses
Quantity:

Additional waste accepted at the Area 9 U10c Landfill:

$\square$ Non-friable asbestos $\quad \square$ Drained automobiles and military vehicles

$\Pi$ Liaht hallasts irnntact Swan

M Mrainart fual filtare Inoe \&. Hiacoll

Hydrocarbons (contact SWO) $\bigotimes$ Other Drained generators/equipment

Additional waste accepted at the Area 6 Hydrocarbon Landfill:
Septic sludge
$\square$ Rags
$\square$ Drained fuel filters (gas \& diesel)
Plants
Soil
$\square$ Sludge from sand/oil/water separators
$\square$ Solid fractions from sand/oii/water

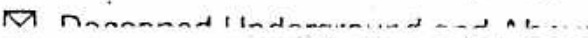
REQUIRED: WASTE GL

Initials: ___ (if initialed, no radiological clearance is nece:

The above mentioned waste was generated outside of a Contro

knowledge, does not contain radiological materials.

To the best of my knowledge, the waste described above contal site. I have verified this through the waste characterization met prohibited and allowable waste items. I have contacted Propert is approved for disposal in the landfill.

Radiation Survey Release for Waste Disposal RCT Initials

This container/load is free of external radioactive This container.
contamination.

This container/load is exempt from
process knowledge and origin.

process knowledge and origin.

This containeri|oad is free of radioactive
contamination based on radioanalysis.

SIGNATURE DATE: $\frac{10 / 30 / 07}{B N \cdot 0646 \text { (09/9) }}$

st of my

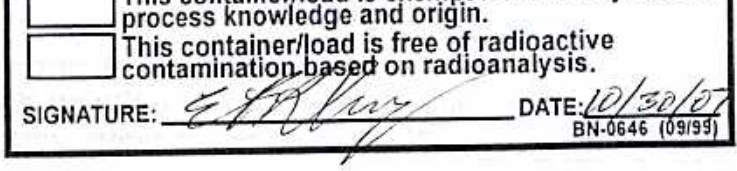

al at this itioned Iquipment
Print Name

Signature:

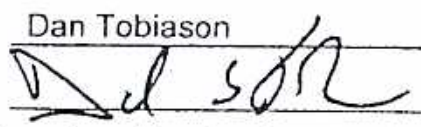

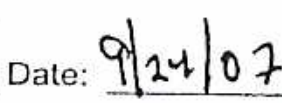

If applicable, place FRM-0646,

"Radiological Release Sticker" here. Onsite use only.

Note: "Food waste, office trash and animal carcasses do not require a radiological clearance. Freon-containing appliances must have signed removal certification statement with Load Verification."

\section{SWO USE ONLY}

Load Weight (net from scale or estimate):
$10-30-07$

Signature of Certifier: on 


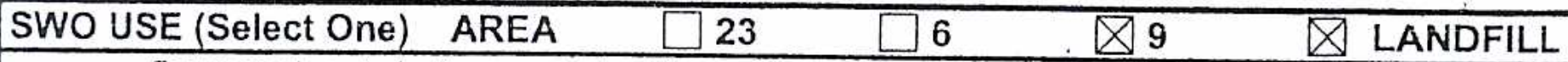

For waste characterization, approval, and/or assistance, contact Solid Waste Operation (SWO) at 5-7898.

\section{REQUIRED: WASTE GERERATOR INFORMATION}

(This form is for rolloffs, dump trucks, and other onsite disposal of materials.)

Waste Generator: Dan Tobiason

Phone Number: 295-6169

Location / Origin: T-Tunnel Lower Laydown Yard

Waste Category: (check one)

Waste Type:

(check one)

$\triangle$ NTS

Pollution Prevention Category: (check one)

Pollution Prevention Category: (check one)

Method of Characterization: (check one)

Prohibited Waste at all three

NTS landfills:

Additional Prohlbited Waste at the Area 9 U10C Landfill:
Radioactive waste; RCRA waste; Hazardous waste; Free liquids, PCBs above TSCA regulatory levels, and Medical wastes (needles, sharps, bloody clothing).

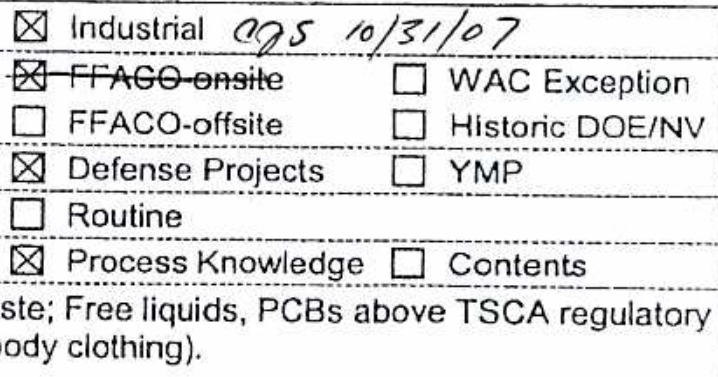

Sewage Sludge, Animal carcasses, Wet garbage (food waste); and Friable asbestos

\section{REQUIRED: WASTE CONTENTS ALLOWABLE WASTES}

Check all allowable wastes that are contained within this load:

NOTE: Waste disposal at the Area 6 Hydrocarbon Landfill must have come into contact with petroleum hydrocarbons or coolants, such as: gasoline (no benzene, lead); jet fuel; diesel fuel; lubricants and hydraulics; kerosene; asphaltic petroleum hydrocarbon; and ethylene glycol.

Acceptable waste at any NTS landfill:
$\bigotimes$ Asphalt $\otimes$ Metal
$\triangle$ Wood
$凶$ Soil
$\triangle$ Cloth
$\square$ Rocks / unaltered geologic materials
$\bigotimes$ Rubber (excluding tires)
$\bigotimes$ Insulation (non-Asbestosform)
$\triangle$ Plastic $\quad$ Wire $\quad$ Cable

$\triangle$ Paper

$\triangle$ Empty containers

Demolition debris

Q Manufactured items: (swamp coolers, furniture, rugs, carpet, electronic components,

Additional waste accepted at the Area 23 Mercury Landfill: $\square$ Office Waste

$\square$ Asbestos

$\square$ Friable

Non-Friable (contact SWO if regulated load)
Food Waste
Quantity:

Additional waste accepted at the Area 9 U10c Landfill:
$\square$ Non-friable asbestos
$\square$ Drained automobiles and military vehicles
Light ballasts (contact SWO)
Drained fuel filters (gas \& diesel)
Hydrocarbons (contact SWO)
Drained generators/equipment

$\bigotimes$ Other

Solid fractions from sand/oii/water

$\triangle$ Deconned Underground and Above Ground Tanks

Additional waste accepted at the Area 6 Hydrocarbon Landfill:
$\square$ Septic sludge
$\square$ Rags
$\square$ Drained fuel filters (gas \& diesel)
Plants
Soil
$\square$ Sludge from sand/oil/water separators
REQUIRED: WASTE GENERATO
$\square$ Crushed non-teme plated oil filters
$\square$ PCBs below 50 parts per million

Initials: (if initialed, no radiological clearance is necessary.)

The above mentioned waste was generated outside of a Controlled Wast $\epsilon$ knowledge, does not contain radiological materials.

To the best of my knowledge, the waste described above contains only th site. I have verified this through the waste characterization method identi prohibited and allowable waste Items. I have contacted Property Manage is approved for disposal in the landfill.

Print Name: Dan Tobiason Signature:
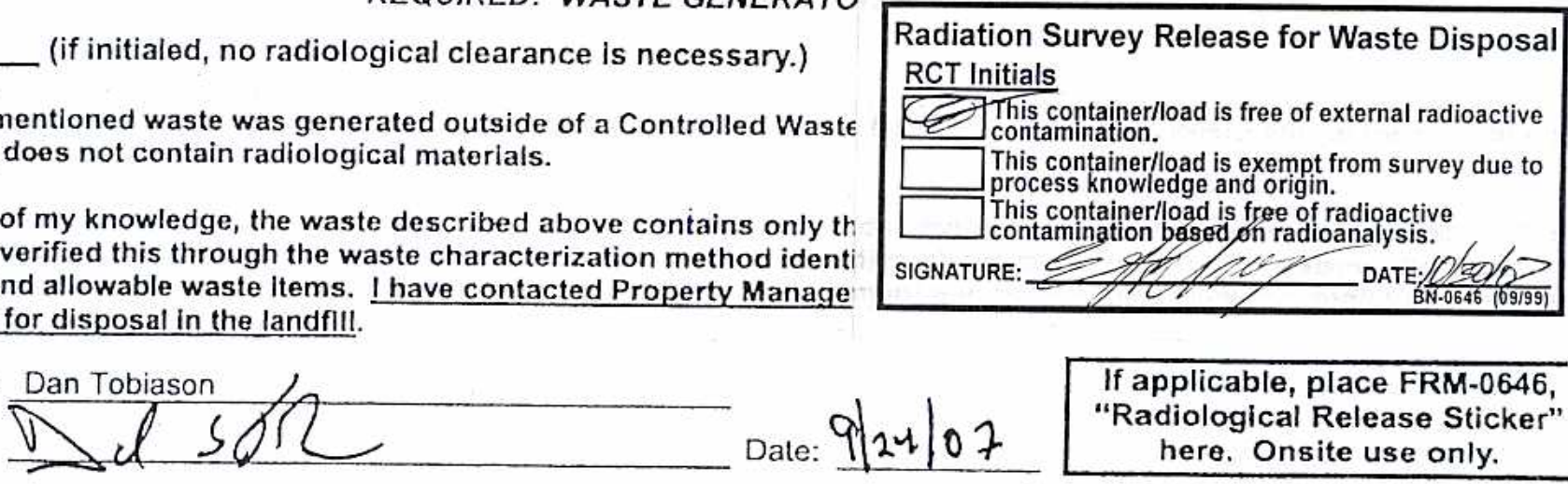

Note: "Food waste, office trash and animal carcasses do not require a radiological clearance. Freon-containing appliances must have signed removal certification statement with Load Verification."

SWO USE ONLY
Load Weight (net from scale or \&stimate): 3620
$10-30-07$

Signature of Certifier:
If applicable, place FRM-0646, "Radiological Release Sticker" here. Onsite use only. 


\section{SWO USE (Select One) $\quad$ AREA $\quad \square 23 \quad \square 6 \quad \square 9 \quad \square$ LANDFILL}

For waste characterization, approval, and/or assistance, contact Solid Waste Operation (SWO) at 5-7898.

REQUIRED: WASTE GERERATOR INFORMATION

(This form is for rolloffs, dump trucks, and other onsite disposal of materials.)

Waste Generator: Dan Tobiason

Phone Number: 295-6169

Location / Origin: T-Tunnel Lower Laydown Yard

Waste Category: (check one)

Waste Type: $Q$ NTS

(check one) $\square$ Non-Putrescible $\square \quad \square$ Asbestos Containing Material

Pollution Prevention Category: (check one) $\square$ Environmental management

Pollution Prevention Category: (check one)

Method of Characterization: (check one)

$\bigotimes$ Clean-Up

Sampling \& Analysi

Q Industrial O25 10/31/07

Z-FFAGQ-OASito

$\square$ WAC Exception

Prohibited Waste at all three

NTS landfills:

Additional Prohlbited Waste

at the Area 9 U10C Landfill:

Radioactive waste; RCRA waste; Hazardous waste; Free liquids, PCBs above TSCA regulatory levels, and Medical wastes (needles, sharps, bloody clothing).

ACO-offsite

$\square$ Historic DOE/NV

$\triangle$ Defense Projects $\square$ YMP

$\square$ Routine

$凶$ Process Knowledge $\square$ Contents

Sewage Sludge, Animal carcasses, Wet garbage (food waste); and Friable asbestos

\section{REQUIRED: WASTE CONTENTS ALLOWABLE WASTES}

Check all allowable wastes that are contained within this load:

NOTE: Waste disposal at the Area 6 Hydrocarbon Landfill must have come into contact with petroleum hydrocarbons or coolants, such as: gasoline (no benzene, lead); jet fuel; diesel fuel; lubricants and hydraulics; kerosene; asphaltic petroleum hydrocarbon; and ethylene glycol.
Acceptable waste at any NTS landfill:
$\triangle$ Paper
$\square$ Rocks / unaltered geologic materials
Soil
$\bigotimes$ Rubber (excluding tires)
$\bigotimes$ Asphalt $\quad$ Metal $\quad$ Wood
$\otimes$ Cloth
$\triangle$ Insulation (non-Asbestosform)
$\triangle$ Empty containers
$\bigotimes$ Demolition debris
$\otimes$ Cable
$\triangle$ Manufactured items: (swamp coolers, furniture, rugs, carpet, electronic components, PPE, etc.)
Additional waste accepted at the Area 23 Mercury Landfill: $\square$ Office Waste $\square$ Food Waste
$\otimes$ Cement \& concrete
$\square$ Asbestos
Friable
Non-Friable (contact SWO if regulated load)
Quantity:

Additional waste accepted at the Area 9 U10c Landfill:
$\square$ Non-friable asbestos
$\square$ Drained automobiles and military vehicles
Solid fractions from sand/oii/water
$\square$ Light ballasts (contact SWO)
Drained fuel filters (gas \& diesel)
Hydrocarbons (contact SWO)
$\triangle$ Other Drained generators/equipment
$\bigotimes$ Deconned Underground and Above Ground Tanks

Additional waste accepted at the Area 6 Hydrocarbon Landfill:

$\square$ Septic sludge $\quad \square$ Rags $\quad \square$ Drained fuel filters (gas \& diesel)

Plants $\square$ Soil

$\square$ Sludge from sand/oil/water separators REQUIRED: WASTE GENE

Initials: (if initialed, no radiological clearance is necessa!

The above mentioned waste was generated outside of a Controlled knowledge, does not contain radiological materials.

To the best of my knowledge, the waste described above contains , site. I have verified this through the waste characterization methoc prohibited and allowable waste items. I have contacted Property $M$ is approved for disposal in the landfill.

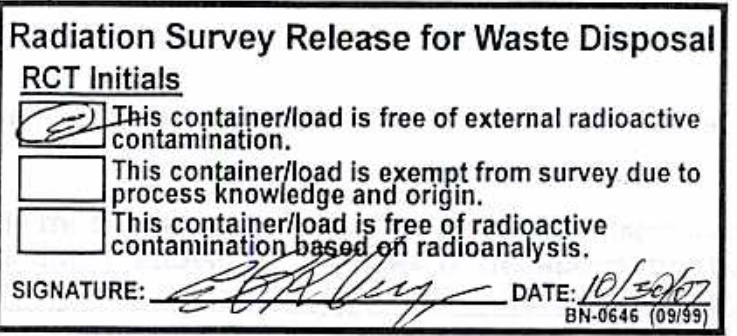
PCBs below 50 parts per million

Print Name: Dan Tobiason

Signature:

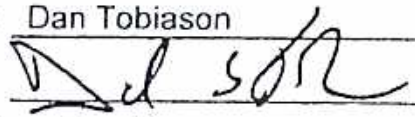

Date: $9124 / 07$

If applicable, place FRM-0646,

"Radiological Release Sticker" here. Onsite use only.

Note: "Food waste, office trash and animal carcasses do not require a radiological clearance. Freon-containing appliances must have signed removal certification statement with Load Verification."

SWO USE ONLY

Load Weight (net from scale orestimate). 020
$10-30-07$

Signature of Certifier: 


\section{SWO USE (Select One) $\quad$ AREA $\quad \square 23 \quad \square 6 \quad \square 9 \quad \square$ LANDFILL}

For waste characterization, approval, and/or assistance, contact Solid Waste Operation (SWO) at 5-7898.

REQUIRED: WASTE GERERATOR INFORMATION

(This form is for rolloffs, dump trucks, and other onsite disposal of materials.)

Waste Generator: Dan Tobiason

Phone Number: 295-6169

Location / Origin: T-Tunnel Lower Laydown Yard

Waste Category: (check one) $\square$ Commercial $\triangle$ Industrial M5 11/12/07

Waste Type: $\triangle$ NTS $\square$ Putrescrible $\square$ EFACQ-ansite WAC Exception

(check one) $\square$ Non-Putrescible $\square$ Asbestos Containing Material $\square$ FFACO-offsite $\square$ Historic DOE/NV

Pollution Prevention Category: (check one) $\square$ Environmental management $\triangle$ Defense Projects $\square$ YMP

Pollution Prevention Category: (check one) $\triangle$ Clean-Up $\square$ Routine

Method of Characterization: (check one) $\square$ Sampling \& Analysis $\square$ Process Knowledge $\square$ Contents

Prohibited Waste at all three Radioactive waste; RCRA waste; Hazardous waste; Free liquids, PCBs above TSCA regulatory NTS landfills:

Addltional Prohlbited Waste

at the Area 9 U10C Landfill:

levels, and Medical wastes (needles, sharps, bloody clothing).

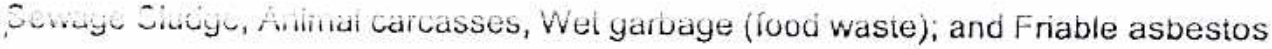

\section{REQUIRED: WASTE CONTENTS ALLOWABLE WASTES}

Check all allowable wastes that are contained within this load:

NOTE: Waste disposal at the Area 6 Hydrocarbon Landfill must have come into contact with petroleum hydrocarbons or coolants, such as: gasoline (no benzene, lead); jet fuel; diesel fuel; lubricants and hydraulics; kerosene; asphaltic petroleum hydrocarbon; and ethylene glycol.
Acceptable waste at any NTS landfill:
$\triangle$ Asphalt $\square$ Metal
Wood
$\triangle$ Paper
$凶$ Soil
$\square$ Rocks / unaltered geologic materials
$\triangle$ Plastic $\square$ Wire
$\triangle$ Cable
$\otimes$ Cloth
$\bigotimes$ Rubber (excluding tires)
$\bigotimes$ Insulation (non-Asbestosform)
$\triangle$ Empty containers
$\bigotimes$ Demolition debris
$\triangle$ Manufactured items: (swamp coolers, fumiture, rugs, carpet, electronic components, PPE, etc.)
Additional waste accepted at the Area 23 Mercury Landfill:
Asbestos
Friable
Non-Friable (contact SWO if regulated load)
Food Waste
Animal Carcasses

Additional waste accepted at the Area 9 U10c Landfill:

$\square$ Non-friable asbestos
$\square$ Light ballasts (contact SWO) $\square$ Drained automobiles and military vehicles
$\square$ Hydrocarbons (contact SWO)

Additinnal wacta arrantad ot tho Aras a Wudromahom i andfill. i

$\square$ Septic sludge $\square$ Rags

Plants

$\square$ Soil

$\square$ Drained fuel filters (gas \& diesel)

$\square$ Sludge from sand/oil/water separators REQUIRED: WASTE GENEF

Initials: (if initialed, no radiological clearance is necessary

The above mentloned waste was generated outside of a Controlled $\mathrm{f}$ knowledge, does not contain radiological materials.

To the best of my knowledge, the waste described above contains o site. I have verified this through the waste characterization method prohibited and allowable waste Items. I have contacted Property $\mathrm{Ma}$ is approved for disposal in the landfill.

Radiation Survey Release for Waste Disposal RCF/nitials

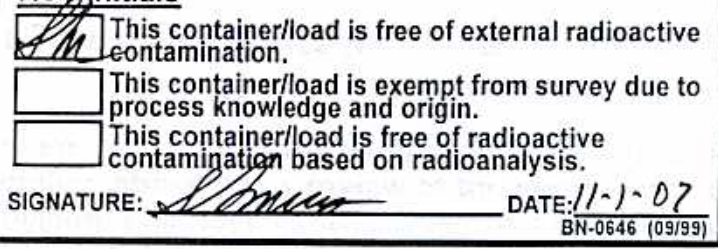

Print Name: Dan Tobiason

Signature:
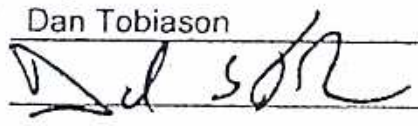

If applicable, place FRM-0646,

"Radiological Release Sticker" here. Onsite use only.

Note: "Food waste, office trash and animal carcasses do not require a radiological clearance. Freon-containing appliances must have signed removal certification statement with Load Verification."

\section{SWO USE ONLY}

Load Weight (net from scale or estimate) il-1-or

Signature of Certifier: 


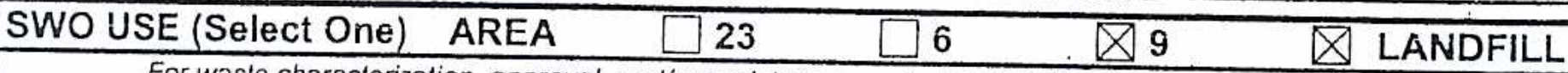

For waste characterization, approval, and/or assistance, contact Solid Waste Operation (SWO) at 5-7898.

\section{REQUIRED: WASTE GERERATOR INFORMATION}

(This form is for rolloffs, dump trucks, and other onsite disposal of materials.)

Waste Generator: Dan Tobiason

Phone Number: 295-6169

Location/Origin: T-Tunnel Lower Laydown Yard

Waste Category: (check one)

Waste Type: $\otimes$ NTS

(check one) $\square$ Non-Putrescible

Pollution Prevention Category: (check one)

Pollution Prevention Category: (check one)

Method of Characterization: (check one)

Prohibited Waste at all three

NTS landfilis:

Additional Prohibited Waste

at the Area 9 U10C Landfill:

\begin{tabular}{|c|c|}
\hline$\Delta$ industrial & $1 / 12107$ \\
\hline QFFACO-omsite & $\square$ WAC Exception \\
\hline$\square$ FFACO-offsite & $\square$ Historic DOE/N \\
\hline$\triangle$ Defense Projects & $\square$ YMP \\
\hline$\square$ Routine & \\
\hline
\end{tabular}

$\square$ Commercial

$\square$ Putrescrible

$\square$ Asbestos Containing Material

$\square$ Environmental management

$\triangle$ Clean-Up

$\square$ Sampling \& Analysis

Radioactive waste; RCRA waste; Hazardous waste; Free liquids, PCBs above TSCA regulatory levels, and Medical wastes (needles, sharps, bloody clothing).

Sewage Sludge, Animal carcasses, Wet garbage (food waste); and Friable asbestos

\section{REQUIRED: WASTE CONTENTS ALLOWABLE WASTES}

Check all allowable wastes that are contained within this load
NOTE: Waste disposal at the Area 6 Hydrocarbon Landfill must have come into contact with petroleum hydrocarbons or coolants, such as: gasoline (no benzene, lead); jet fuel; diesel fuel; lubricants and hydraulics; kerosene; asphaltic petroleum hydrocarbon; and ethylene glycol.

Acceptable waste at any NTS landfill:
$\bigotimes$ Asphalt
$\triangle$ Metal
$\triangle$ Wood
$\triangle$ Paper
$\triangle$ Soil
$\triangle$ Plastic
Q Cable
$\triangle$ Cloth
$\square$ Rocks / unaltered geologic materials
$\triangle$ Rubber (excluding tires)
$\triangle$ Insulation (non-Asbestosform)

$\triangle$ Empty containers

Demolition debris

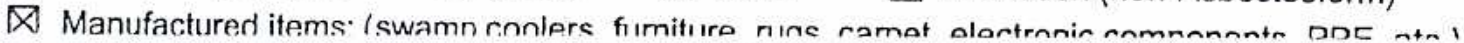

Q Cement \& concrete
Additional waste accepted at the Area 23 Mercury Landfill: $\square$ Office Waste
$\square$ Asbestos
Friable
$\square$ Non-Friable (contact SWO if regulated load)
Food Waste
Animal Carcasses
Quantity:

Additional waste accepted at the Area 9 U10 Candfill:
$\square$ Non-friable asbestos
$\square$ Light ballasts (contact SWO)
$\square$ Drained automobiles and military vehicles
Drained fuel filters (gas \& diesel)
Hydrocarbons (contact SWO)
Other Drained generators/equipment

\section{Additional waste accepted at the Area 6 Hydrocarbon Landfill:}
$\square$ Septic sludge
Plants
$\square$ Rags
Soil
$\square$ Drained fuel filters (gas \& diesel)
$\square$ Sludge from sand/oil/water separators REQUIRED: WASTE GENEI

Initials: (if initialed, no radiological clearance is necessar

The above mentloned waste was generated outside of a Controlled knowledge, does not contain radiological materials.

To the best of my knowledge, the waste described above contains ( site. I have verified this through the waste characterization method prohibited and allowable waste Items. I have contacted Property $M_{\text {: }}$ is approved for disposal in the landfill.

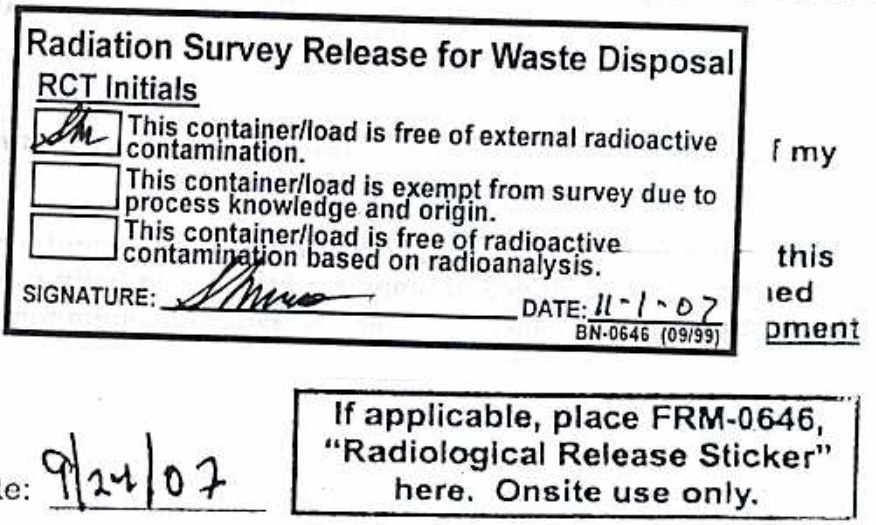

Print Name: Dan Tobiason

Signature:

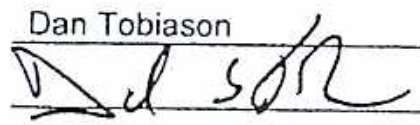

Crushed non-teme plated oil filters

PCBs below 50 parts per million
Solid fractions from sand/oil/water

$\triangle$ Deconned Underground and Above Ground Tanks ivote: "Food waste, ofice trasn and anmal carcasses do not require a radiological clearance. Freon-containing appliances
must have signed removal certification statement with Load Verification."

\section{SWO USE ONLY}

$11-1-0 \eta$

Signature of Certifier: 


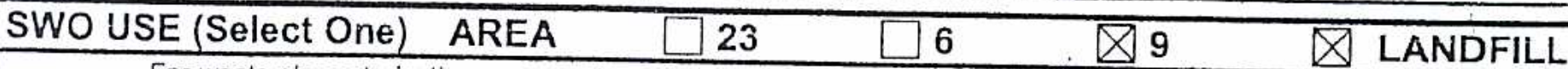

For waste characterization, approval, and/or assistance, contact Solid Waste Operation (SWO) at 5-7898.

\section{REQUIRED: WASTE GERERATOR INFORMATION}

(This form is for rolloffs, dump trucks, and other onsite disposal of materials.)

Waste Generator: Dan Tobiason

Phone Number: 295-6169

Location / Origin: T-Tunnel Lower Laydown Yard

Waste Category: (check one)

Waste Type: $\otimes$ NTS

(check one)

$\square$ Non-Putrescible

Pollution Prevention Category: (check one)

Pollution Prevention Category: (check one)

Method of Characterization: (check one)

Prohibited Waste at all three

NTS landfills:

Additional Prohlbited Waste

at the Area 9 U10C Landfill:

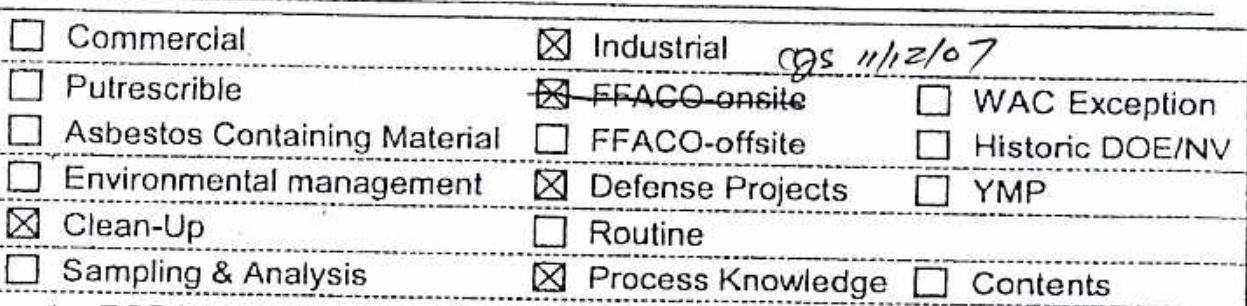

$\square$ Commercial

$\square$ Putrescrible

ste; Free liquids, PCBs above TSCA regulatory levels, and Medical wastes (needles, sharps, bloody clothing).

Sewage Sludge, Animal carcasses, Wet garbage (food waste); and Friable asbestos

\section{REQUIRED: WASTE CONTENTS ALLOWABLE WASTES}

Check all allowable wastes that are contained within this load:

NOTE: Waste disposal at the Area 6 Hydrocarbon Landfill must have come into contact with petroleum hydrocarbons or coolants, such as: gasoline (no benzene, lead); jet fuel; diesel fuel; lubricants and hydraulics; kerosene; asphaltic petroleum hydrocarbon; and ethylene glycol.
Acceptable waste at any NTS landfill:
Asphalt $\bigotimes$ Metal
$\triangle$ Wood
$\bigotimes$ Paper
凶Soil
$\otimes$ Cable
$\bigotimes$ Cloth
$\square$ Rocks / unaltered geologic materials
$\bigotimes$ Rubber (excluding tires)
$\triangle$ Plastic $\quad$ Wire
\Insulation (non-Asbestosform)
$\triangle$ Empty containers
$\triangle$ Demolition debris
$\triangle$ Manufactured items: (swamp coolers, fumiture, rugs, carpet, electronic components, PPE, etc.)
$\bigotimes$ Cement \& concrete
Additional waste accepted at the Area 23 Mercury Landfill:
Asbestos
Friable
Food Waste

Non-Friable (contact SWO if regulated load)

Additional waste accepted at the Area 9 U10c Landfill:
$\square$ Non-friable asbestos
$\square$ Drained automobiles and military vehicles
Light ballasts (contact SWO)
$\square$ Drained fuel filters (gas \& diesel)

Hydrocarbons (contact SWO)

$\bigotimes$ Other

Drained generators/equipment

Additional waste accepted at the Area 6 Hydrocarbon Landfill:
Septic sludge
Plants
$\square$ Rags
Soil
$\square$ Drained fuel filters (gas \& diesel)
$\square$ Sludge from sand/oil/water separators REQUIRED: WASTE GENERAT

Initials: (if initialed, no radiological clearance is necessary.)

The above mentloned waste was generated outside of a Controlled Wa: knowledge, does not contain radiological materials.

To the best of my knowledge, the waste described above contains only site. I have verified this through the waste characterization method ide prohibited and allowable waste items. I have contacted Property Mana is approved for disposal in the landfill.

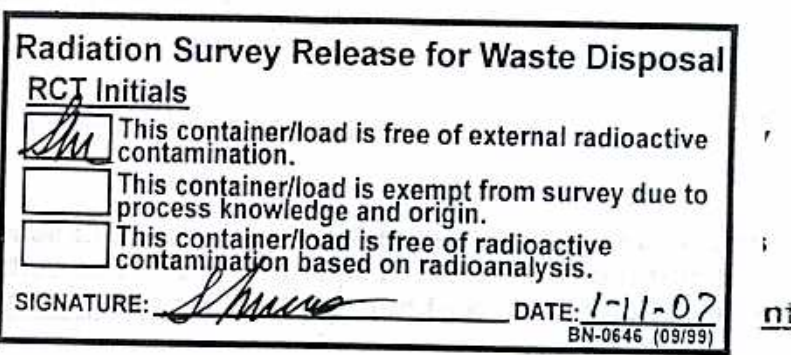

Print Name: Dan Tobiason

Signature:

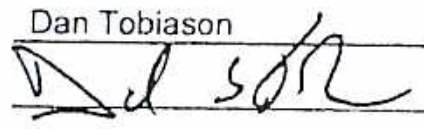

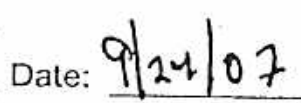

Solid fractions from sand/oii/water

$\bigotimes$ Deconned Underground and Above Ground Tanks

Note: "Food waste, office trash and animal carcasses do not require a radiological clearance. Freon-containing appliances SWO USE ONLY Load Weight (net from scale or estimate): 


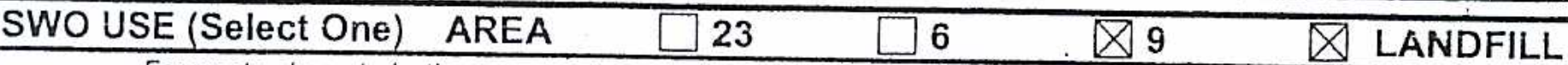

For waste characterization, approval, and/or assistance, contact Solid Waste Operation (SWO) at 5-7898. REQUIRED: WASTE GERERATOR INFORMATION

(This form is for rolloffs, dump trucks, and other onsite disposal of materials.)

Waste Generator: Dan Tobiason

Phone Number: 295-6169

Location / Origin: T-Tunnel Lower Laydown Yard

Waste Category: (check one)

Waste Type: $\square$ NTS (check one)

$\square$ Non-Putrescible

Pollution Prevention Category: (chock one)

Pollution Prevention Category: (check one)

Method of Characterization: (check one)

Prohibited Waste at all three NTS landfilis:

Additional Prohlbited Waste at the Area 9 U10C Landfill:

\section{Radioactive waste; RCRA waste; Hazan}

$\square$ Commerclal

$\square$ Putrescrible

$\square$ Asbestos Containing Material

$\square$ Environmental management

$\otimes$ Clean-Up

$\square$ Sampling \& Analysis leveis, and Medical wastes (needles, sharps, bloody clothing).

Sewage Sludge, Animal carcasses, Wet garbage (food waste); and Friable asbestos $\triangle$ Industrial gs $11 / 2 / 07$

XfFACO-Onsite $\square$ WAC Exception

$\square$ FFACO-offsite

$\triangle$ Defense Projects

$\square$ Routine

$凶$ Process Knowledge $\square$ Contents

\section{REQUIRED: WASTE CONTENTS ALLOWABLE WASTES}

Check all allowable wastes that are contained within this load:

NOTE: Waste disposal at the Area 6 Hydrocarbon Landfill must have come into contact with petroleum hydrocarbons or coolants, such as: gasoline (no benzene, lead); jet fuel; diesel fuel; lubricants and hydraulics; kerosene; asphaltic petroleum hydrocarbon; and ethylene glycol.

Acceptable waste at any NTS landfill: $\triangle$ Paper $\square$ Rocks / unaltered cenlnoir materials
$凶$ Asphalt $\otimes$ Metal
$\triangle$ Wood
$\triangle$ Soil
$\bigotimes$ Cable
Cloth
Q Rubber (exciuding tires)
\Insulation (non-Asbestosform)
$\triangle$ Plastic $\square$ Wire
$\triangle$ Manufactured items: (swamp coolers, furniture, rugs, carpet, electronic components, PPE, etc.)
$\triangle$ Cloth
$\triangle$ Manufactured items: (swamp coolers, furniture, rugs, carpet, electronic components, PPE, etc.)

DI Fmnturentainare

$\bigotimes$ Demolition debris

$\bigotimes$ Cement \& concrete
Additional was
Friable
Non-Friable (contact SWO if regulated load)
Quantity:

Additional waste accepted at the Area 9 U10c Landfill:

$\square$ Non-friable asbestos $\square$ Drained automobiles and military vehicles

$\square$ Light ballasts (contact SWO)

$\square$ Hydrocarbons (contact SWO) $\bigotimes$ Other Drained generators/equipment

Additional waste accepted at the Area 6 Hydrocarbon Landfill:

$\square$ Septic sludge $\square$ Rags

Plants

$\square$ Soil

$\square$ Drained fuel filters (gas \& diesel)

$\square$ Sludge from sand/oil/water separators REQUIRED: WASTE GENERATOI

Initials: (if initialed, no radiological clearance is necessary.)

The above mentioned waste was generated outside of a Controlled Waste knowledge, does not contain radiological materials.

To the best of my knowledge, the waste described above contains only th site. I have verified this through the waste characterization method identi prohibited and allowable waste items. I have contacted Property Manager is approved for disposal in the landfill.

\begin{tabular}{|c|c|}
\hline $\begin{array}{l}\text { Radia } \\
\text { RCT I }\end{array}$ & $\begin{array}{l}\text { tion Survey Release for Waste Disposal } \\
\text { nitials }\end{array}$ \\
\hline & $\begin{array}{l}\text { This container/load is free of external radioactive } \\
\text { contamination. }\end{array}$ \\
\hline & $\begin{array}{l}\text { This container/load is exempt from survey due to } \\
\text { process knowledge and origin. }\end{array}$ \\
\hline & $\begin{array}{l}\text { This container/load is free of radioactive } \\
\text { contamination based on radioanalysis. }\end{array}$ \\
\hline & DATE: $\frac{\| 1-1-07}{\text { BN-0646 (09/99) }}$ \\
\hline
\end{tabular}

Print Name

Signature:
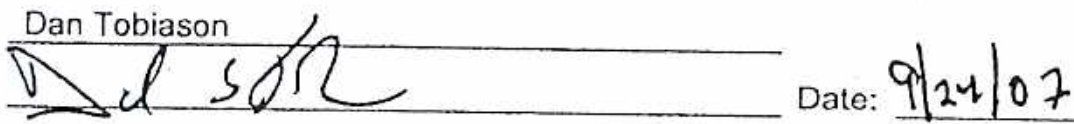

If applicable, place FRM-0646. "Radiological Release Sticker" here. Onsite use only.

Note: "Food waste, office trash and animal carcasses do not require a radiological clearance. Freon-containina aooliances

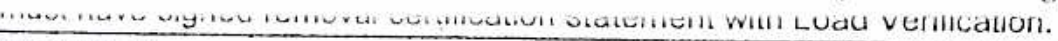




\title{
SWO USE (Select One) AREA
}

For waste characterization, approval, and/or assistance, contact Solid Waste Operation (SWO) at 5-7898.

For waste characterization, approval, and/or assistance, contact Solid Waste Operation (SWO) at 5-7898.
REQURD

For waste characterization, approval, and/or assistance, contact Solid Waste Operation (SWO) at 5-7898. Page 1 of 2 REQUIRED: WASTE GERERATOR INFORMATION

(This form is for rolloffs, dump trucks, and other onsite disposal of materials.)

Waste Generator: Dan Tobiason Phone Number: 295-6169

Location/Origin: T-Tunnel Lower Laydown Yard

Waste Category: (check one)

Waste Type: $\square$ NTS

(check one)

$\square$ Non-Putrescible

$\square$ Commercial
$\square$ Putrescrible
$\square$ Asbestos Containing Material
$\square$ Environmental management
$\square$ Clean-Up
$\square$ Sampling \& Analysis

Q Industrial Cos $11 / 12 / 07$

A-FFACOFonsite

$\square$ WAC Exception

Pollution Prevention Category: (check one)

Pollution Prevention Category: (check one)

Method of Characterization: (check one)

Prohibited Waste at all three

NTS landfilis:

Additional Prohibited Waste

at the Area 9 U10C Landfill:

\begin{abstract}
levels, and Medical wastes (needles, sharps, bloody clothing)
\end{abstract}
Sewage Sludge, Animal carcasses, Wet garbage (food waste); and Friable asbestos

\section{REQUIRED: WASTE CONTENTS ALLOWABLE WASTES}

Check all allowable wastes that are contained within this load:
NOTE: Waste disposal at the Area 6 Hydrocarbon Landfill must have come into contact with petroleum hydrocarbons or coolants, such as: gasoline (no benzene, lead); jet fuel; diesel fuel; lubricants and hydraulics; kerosene; asphaltic petroleum hydrocarbon; and ethylene glycol.

Acceptable waste at any NTS landfill: $\triangle$ Paper
$\triangle$ Asphalt
Metal
$\otimes$ Wood
$凶$ Soil

Q Plastic

$\otimes$ Wire

$\triangle$ Cable

$\bigotimes$ Cloth
$\square$ Rocks / unaltered geologic materials
$\triangle$ Rubber (excluding tires)
区 Insulation (non-Asbestosform)

$\triangle$ Empty containers

$\bigotimes$ Demolition debris

$\triangle$ Manufactured items: (swamp coolers, furniture, rugs, carpet, electronic components, PPE, etc.)

Additional waste accepted at the Area 23 Mercury Landfill: $\square$ Office Waste
$\square$ Asbestos
Friable
$\square$ Non-Friable (contact SWO if regulated load)
Additional waste accepted at the Area 9 U10c Landfill:
$\square$ Non-friable asbestos
Light ballasts (contact SWO)
Hydrocarbons (contact SWO)
$\square$ Drained automobiles and military vehicles
$\square$ Drained fuel filters (gas \& diesel)
$\otimes$ Other Drainedgenerators/equipment

$\square$ Food Waste

Quantity:

Solid fractions from sand/oii/water

$\bigotimes$ Deconned Underground and Above Ground Tanks

Additional waste accented at the $\Delta$ rea 6 Hudromarhon I andfill-
$\square$ Septic sludge
Plants
Rags
Soil
$\square$ Drained fuel filters (gas \& diesel)
$\square$ Sludge from sand/oil/water separators REQUIRED: WASTE GENERAT On NInAATIIn
Crushed non-teme plated oil filters PCBs below 50 parts per million

Initials: (if initialed, no radiological clearance is necessary.)

The above mentioned waste was aenerated outside of a rentrnlled wae knowiedge, does not contain radiological materiais.

To the best of my knowledge, the waste described above contains only site. I have verified this through the waste characterization method ider prohibited and allowable waste items. I have contacted Property Manag is approved for disposal in the landfill.

Radiation Survey Release for Waste Disposal
RCT Initials
This container/load is free of external radioactive
contamination.
phis container/load is exempt from survey due to
process knowledge and origin.
This container/load is free of radioactive
Contamination based on radioanalysis.
SIGNATURE:
DATE: $\frac{11-1-07}{\mathrm{~N}-0646}(09 / 99)$

Print Name: Dan Tobiason Signature:

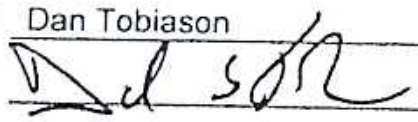

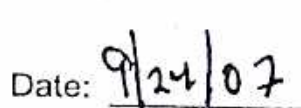

If applicable, place FRM-0646, "Radiological Release Sticker" here. Onsite use only.

Note: "Food waste, office trash and animal carcasses do not require a radiological clearance. Freon-containing appliances must have signed removal certification statement with Load Verification."

SWO USE ONLY

Load Weight (net from scale of estimate):
$11-1-017$

Signature of Certifier: 


\section{$\begin{array}{llllll}\text { SWO USE (Select One) } & \text { AREA } & \square 23 & \square 6 & \square 9 & \square \text { LANDFILL }\end{array}$}

For waste characterization, approval, and/or assistance, contact Solid Waste Operation (SWO) at 5-7898.

\section{REQUIRED: WASTE GERERATOR INFORMATION}

(This form is for rolloffs, dump trucks, and other onsite disposal of materials.)

Waste Generator: Dan Tobiason

Phone Number: 295-6169

Location / Origin: T-Tunnel Lower Laydown Yard

\begin{tabular}{|c|c|c|c|}
\hline Waste Category: (check one) & Commercial & $\bigotimes$ Industrial & 07 \\
\hline Waste Type: & Putrescrible & $\triangle-F F A C \theta$-Ongite & WAC Exception \\
\hline$\square$ Non-Putrescible & Asbestos Containing Material & $\square$ FFACO-offsite & Historic DOE/NV \\
\hline Pollution Prevention Category: (check one) & Environmental management & $\triangle$ Defense Projects & YMP \\
\hline Pollution Prevention Category: (check one) & $\triangle$ Clean-Up & $\square$ Routine & \\
\hline Method of Characterization: (check one) & $\square$ Sampling \& Analysis & Q Process Kno & Cor \\
\hline
\end{tabular}

Prohibited Waste at all three Radioactive waste; RCRA waste; Hazardous waste; Free liquids, PCBs above TSCA regulatory NTS landfills: levels, and Medical wastes (needles, sharps, bloody clothing).

Additional Prohibited Waste at the Area 9 U10C Landfill:

Sewage Sludge, Animal carcasses, Wet garbage (food waste); and Friable asbestos

\section{REQUIRED: WASTE CONTENTS ALLOWABLE WASTES}

Check all allowable wastes that are contained within this load:

NOTE: Waste disposal at the Area 6 Hydrocarbon Landfill must have come into contact with petroleum hydrocarbons or coolants, such as: gasoline (no benzene, lead); jet fuel; diesel fuel; lubricants and hydraulics; kerosene; asphaltic petroleum hydrocarbon; and ethylene glycol.
Acceptable waste at any NTS landfill: $\square$ Paper
\ Asphalt
$\bigotimes$ Metal
$\bigotimes$ Wood
$\bigotimes$ Soil
$\square$ Rocks / unaltered geologic materials
Empty containers
$\bigotimes$ Plastic $\otimes$ Wire
$\bigotimes$ Cable
$\bigotimes$ Cloth
$\bigotimes$ Rubber (excluding tires)
$\bigotimes$ Demolition debris
$\bigotimes$ Cement \& concrete

$\bigotimes$ Manufactured items: (swamp coolers, furniture, rugs, carpet, electronic components, PPE, etc.)

Additional waste accepted at the Area 23 Mercury Landfill: $\square$ Office Waste

$\square$ Asbestos

Friable

Non-Friable (contact SWO if regulated load)

$\square$ Food Waste

Animal Carcasses

Additional waste accepted at the Area 9 U10c Landfill:
$\square$ Non-friable asbestos
$\square$ Drained automobiles and military vehicles
$\square$ Light ballasts (contact SWO)
$\square$ Hydrocarbons (contact SWO)
Drained fuel filters (gas \& diesel)
Other Drained generators/equipment

Quantity:

\section{Solid fractions from sand/oil/water \\ $\bigotimes$ Deconned Underground and Above} Ground Tanks

Additional waste accepted at the Area 6 Hydrocarbon Landfill:
$\square$ Septic sludge
$\square$ Rags
$\square$ Drained fuel filters (gas \& diesel)
Plants
Soil
$\square$ Sludge from sand/oil/water separators REQUIRED: WASTE GENER.

Initials: (if initialed, no radiological clearance is necessary

The above mentioned waste was generated outside of a Controlled $V$ knowledge, does not contain radiological materials.

To the best of my knowledge, the waste described above contains ol site. I have verified this through the waste characterization method $i$ prohibited and allowable waste items. I have contacted Property Ma is approved for disposal in the landfill.

\section{Radiation Survey Release for Waste Disposal} RCT Initials

This containerlload is free of external radioactive
contamination.

Print Name: Dan Tobiason

Signature:

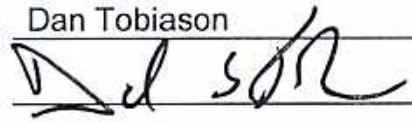

Date: $9 \nmid 24 \mid 07$

If applicable, place FRM-0646,

"Radiological Release Sticker" here. Onsite use only.

Note: "Food waste, office trash and animal carcasses do not require a radiological clearance. Freon-containing appliances must have signed removal certification statement with Load Verification." 
NSTec

Form

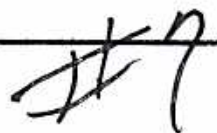

08/23/06

Rev. 0

FRM-0918

NTS LANDFILL LOAD VERIFICATION

Page 1 of 2

\begin{tabular}{llllll}
\hline SWO USE (Select One) & AREA & $\square 23$ & $\square 6$ & Q 39 & LANDFILL
\end{tabular}

For waste characterization, approval, and/or assistance, contact Solid Waste Operation (SWO) at 5-7898.

REQUIRED: WASTE GERERATOR INFORMATION

(This form is for rolloffs, dump trucks, and other onsite disposal of materials.)

Waste Generator: Dan Tobiason

Phone Number: 295-6169

Location / Origin: T-Tunnel Lower Laydown Yard

Waste Category: (check one) $\square$ Commercial $\quad \square$ Industrial os $11 /$ z/0

Waste Type: $\triangle$ NTS $\square$ Putrescrible $\square$ FFACO-ongite $\square$ WAC Exception

(check one) $\quad \square$ Non-Putrescible $\quad \square$ Asbestos Containing Material $\square$ FFACO-offsite $\square$ Historic DOE/NV

Pollution Prevention Category: (check one) $\square$ Environmental management $\triangle$ Defense Projects $\square$ YMP

Pollution Prevention Category: (check one) $\triangle$ Clean-Up $\square$ Routine

Method of Characterization: (check one) $\square$ Sampling \& Analysis $\triangle$ Process Knowledge $\square$ contents

Prohibited Waste at all three Radioactive waste; RCRA waste; Hazardous waste; Free liquids, PCBs above TSCA regulatory NTS landfills:

Additional Prohibited Waste

at the Area 9 U10C Landfill:

levels, and Medical wastes (needles, sharps, bloody clothing).

Sewage Sludge, Animal carcasses, Wet garbage (food waste); and Friable asbestos

\section{REQUIRED: WASTE CONTENTS ALLOWABLE WASTES}

Check all allowable wastes that are contained within this load:

NOTE: Waste disposal at the Area 6 Hydrocarbon Landfill must have come into contact with petroleum hydrocarbons or coolants, such as: gasoline (no benzene, lead); jet fuel; diesel fuel; lubricants and hydraulics; kerosene; asphaltic petroleum hydrocarbon; and ethylene glycol.
Acceptable waste at any NTS landfill:
Paper
$\square$ Rocks / unaltered geologic materials
区mpty containers
$\bigotimes$ Asphalt
$\bigotimes$ Metal
$\triangle$ Wood
$\triangle$ Soil
$\triangle$ Rubber (excluding tires)
$\otimes$ Plastic
$\triangle$ Cable
Cloth
$\otimes$ Insulation (non-Asbestosform)
Demolition debris

$\triangle$ Manufactured items: (swamp coolers, furniture, rugs, carpet, electronic components, PPE, etc.)
Additional waste accepted at the Area 23 Mercury Landfill: $\square$ Office Waste
Asbestos
Friable
Non-Friable (contact SWO if regulated load)
Food Waste
Animal Carcasses Quantity

Additional waste accepted at the Area 9 U10c Landfill:

$\square$ Drained automobiles and military vehicles

Solid fractions from sand/oil/water

$\square$ Light ballasts (contact SWO)

$\square$ Drained fuel filters (gas \& diesel)

$\triangle$ Deconned Underground and Above

Hydrocarbons (contact SWO) $\bigotimes$ Other Drained generators/equipment

Ground Tanks

Additional waste accepted at the Area 6 Hydrocarbon Landfill:

$\square$ Septic sludge $\quad \square$ Rags $\quad \square$ Drained fuel filters (gas \& diesel)

Plants $\square$ Soil

$\square$ Sludge from sand/oil/water separators

REQUIRED: WASTE GENERA

Initials: (if initialed, no radiological clearance is necessary.)

The above mentioned waste was generated outside of a Controlled Wa knowledge, does not contain radiological materials.

To the best of my knowledge, the waste described above contains onl site. I have verified this through the waste characterization method id prohibited and allowable waste items. I have contacted Property Mane is approved for disposal in the landfill.

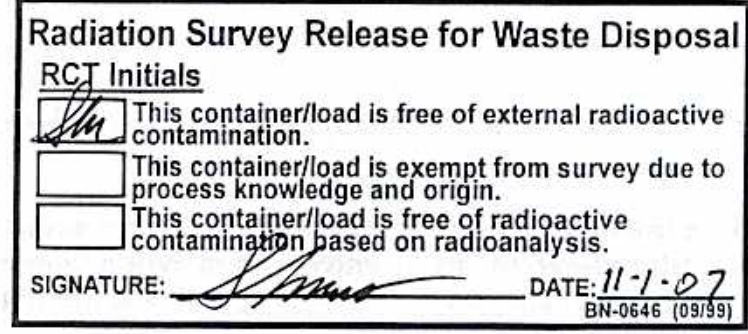

Crushed non-teme plated oil filters

$\square$ PCBs below 50 parts per million

Print Name: Dan Tobiason

Signature:

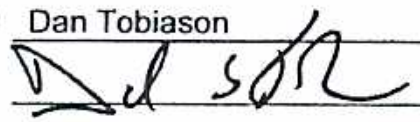

Date: $9 / 24 \mid 07$

If applicable, place FRM-0646,

"Radiological Release Sticker" here. Onsite use only.

Note: "Food waste, office trash and animal carcasses do not require a radiological clearance. Freon-containing appliances must have signed removal certification statement with Load Verification."

SWO USE ONLY

Load Weight (net from scale or estimate):

$11-1-07$

Signature of Certifier: $C_{C}$
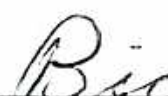


\section{$\begin{array}{llllll}\text { SWO USE (Select One) } & \text { AREA } & \square 23 & \square 6 & \square 9 & \text { Q LANDFILL }\end{array}$}

For waste characterization, approval, and/or assistance, contact Solid Waste Operation (SWO) at 5-7898.

\section{REQUIRED: WASTE GERERATOR INFORMATION}

(This form is for rolloffs, dump trucks, and other onsite disposal of materials.)

Waste Generator: Dan Tobiason

Phone Number: 295-6169

Location / Origin: T-Tunnel Lower Laydown Yard - CAU 481

Waste Category: (check one)

Waste Type: $\square$ NTS

(check one) $\square$ Non-Putrescible

Pollution Prevention Category: (check one)

Pollution Prevention Category: (check one)

Method of Characterization: (check one)

Prohibited Waste at all three

NTS landfills:

Additional Prohibited Waste

at the Area 9 U10C Landfill: levels, and Medical wastes (needles, sharps, bloody clothing).

Sewage Sludge, Animal carcasses, Wet garbage (food waste); and Friable asbestos

\section{REQUIRED: WASTE CONTENTS ALLOWABLE WASTES}

Check all allowable wastes that are contained within this load:

NOTE: Waste disposal at the Area 6 Hydrocarbon Landfill must have come into contact with petroleum hydrocarbons or coolants, such as: gasoline (no benzene, lead); jet fuel; diesel fuel; lubricants and hydraulics; kerosene; asphaltic petroleum hydrocarbon; and ethylene glycol.

Acceptable waste at any NTS landfill: $\triangle$ Pape

$\bigotimes$ Asphalt

$\bigotimes$ Metal

$\triangle$ Wood

$\bigotimes$ Soil

$\triangle$ Cable

$\triangle$ Cloth

$\square$ Rocks / unaltered geologic materials

$\triangle$ Rubber (excluding tires)

$\bigotimes$ Plastic $\bigotimes$ Wire

$\bigotimes$ Insulation (non-Asbestosform)

Empty containers

$\bigotimes$ Demolition debris

$\triangle$ Manufactured items: (swamp coolers, furniture, rugs, carpet, electronic components, PPE, etc.)

Additional waste accepted at the Area 23 Mercury Landfill: $\square$ Office Waste

$\square$ Asbestos $\square$ Friable

Non-Friable (contact SWO if regulated load)

Food Waste

$\bigotimes$ Cement \& concrete

Additional waste accepted at the Area 9 U10c Landfill:

Non-friable asbestos

Light ballasts (contact SWO)

Hydrocarbons (contact SWO)
Drained automobiles and military vehicles

Drained fuel filters (gas \& diesel)

Other Drained generators/equipment
Solid fractions from sand/oil/water

$\bigotimes$ Deconned Underground and Above Ground Tanks

\section{Additional waste accepted at the Area 6 Hydrocarbon Landfill:}
$\square$ Septic sludge
$\square$ Rags
$\square$ Drained fuel filters (gas \& diesel)
Plants
Soil
$\square$ Sludge from sand/oil/water separators REQUIRED: WASTE GENERATOR SIGNATURE
Crushed non-teme plated oil filters PCBs below 50 parts per million

Initials: (if initialed, no radiological clearance is necessary.)

The above mentioned waste was generated outside of a Controlled Waste Management Area (CWMA) and to the best of my knowledge, does not contain radiological materials.

To the best of my knowledge, the waste described above contains only those mate site. I have verified this through the waste characterization method identified abov prohibited and allowable waste items. I have contacted Property Management and is approved for disposal in the landfill.

Print Name: Dan Tobiason

Signature:
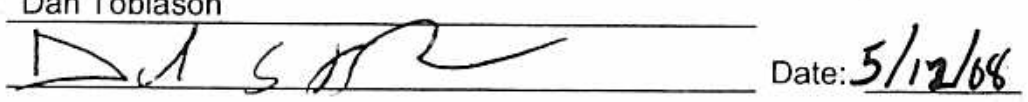

Note: "Food waste, office trash and animal carcasses do not require a radiological c must have signed removal certification statement with Load Verification."

\section{SWO USE ONLY}

Load Weight (net from scale or estimate):

$$
5 / 12 / 08
$$

Signature of Certifier:
Radiological Survey Release for Waste Disposal RCT Initials

This container/load meets the criteria for no added man-made radioactive material This container/load meets the criteria for Radcon Manual Table 4.2 release limits. This container/load is exempt from survey due to prgcess knowledge and origin.

SIGNATURE: DATE: $5 \div 2-05$ $\mathrm{BN}-0646$ (10/05)

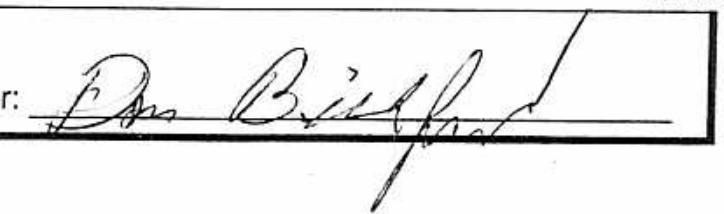


For waste characterization, approval, and/or assistance, contact Solid Waste Operation (SWO) at 5-7898.

\section{REQUIRED: WASTE GERERATOR INFORMATION}

(This form is for rolloffs, dump trucks, and other onsite disposal of materials.)

Waste Generator: Dan Tobiason

Phone Number: 295-6169

Location / Origin: T-Tunnel Lower Laydown Yard - CAU 481

Waste Category: (check one)

Waste Type: $\triangle$ NTS

(check one)

$\square$ Non-Putrescible

Pollution Prevention Category: (check one)

Pollution Prevention Category: (check one)

Method of Characterization: (check one)

Prohibited Waste at all three

NTS landfills:

Additional Prohibited Waste

at the Area 9 U10C Landfill:

Radioactive waste; RCRA waste; Hazardous waste; Free liquids, PCBs above TSCA regulatory levels, and Medical wastes (needles, sharps, bloody clothing).

Sewage Sludge, Animal carcasses, Wet garbage (food waste); and Friable asbestos

\section{REQUIRED: WASTE CONTENTS ALLOWABLE WASTES}

Check all allowable wastes that are contained within this load:

NOTE: Waste disposal at the Area 6 Hydrocarbon Landfill must have come into contact with petroleum hydrocarbons or coolants, such as: gasoline (no benzene, lead); jet fuel; diesel fuel; lubricants and hydraulics; kerosene; asphaltic petroleum hydrocarbon; and ethylene glycol.

Acceptable waste at any NTS landfill: $\triangle$ Paper.: $\square$ Rocks / unaltered geologic materials

$\triangle$ Asphalt $\triangle$ Metal $\triangle$ Wood $\square$ Soil.

$\triangle$ Plastic $\triangle$ Wire

$\triangle$ Cable

$\triangle$ Rubber (excluding tires)

$\triangle$ Cloth

$\bigotimes$ Insulation (non-Asbestosform)

$\triangle$ Empty containers

$\triangle$ Demolition debris

$\triangle$ Manufactured items: (swamp coolers, furniture, rugs, carpet, electronic components, PPE, etc.)
Additional waste accepted at the Area 23 Mercury Landfill: $\square$ Office Waste
$\square$ Asbestos
Friable
$\square$ Non-Friable (contact SWO if regulated load)
Food Waste
Animal Carcasses
Quantity:

\section{Additional waste accepted at the Area 9 U10c Landfill:}
Non-friable asbestos
$\square$ Drained automobiles and military vehicles

Light ballasts (contact SWO)

Drained fuel filters (gas \& diesel)

Hydrocarbons (contact SWO)

Other Drained generators/equipment

Additional waste accepted at the Area 6 Hydrocarbon Landfill:
Septic sludge
$\square$ Rags
$\square$ Drained fuel filters (gas \& diesel)
Plants
Soil
Sludge from sand/oil/water separators

\section{REQUIRED: WASTE GENERATOR SIGNATURE}

Solid fractions from sand/oil/water

$\triangle$ Deconned Underground and Above

Ground Tanks

Initials: (if initialed, no radiological clearance is necessary.)

The above mentioned waste was generated outside of a Controlled Waste Management Area (CWMA) and to the best of my knowledge, does not contain radiological materials.

To the best of my knowledge, the waste described above contains only those materi ${ }^{-}$ site. I have verified this through the waste characterization method identified above prohibited and allowable waste items. I have contacted Property Management and $\mathrm{h}$ is approved for disposal in the landfill.

Print Name: Dan Tobiason

Signature:
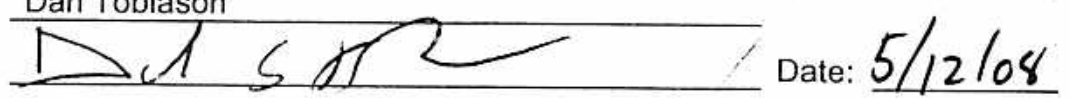

Note: "Food waste, office trash and animal carcasses do not require a radiological cle: must have signed removal certification statement with Load Verification."

\section{SWO USE ONLY}

Load Weight (net from scale or estimate) 18,000

$$
5 / 12 / 08
$$

Signature of Certifier:
Radiological Survey Release for Waste Disposal RCT Initials This container/load meets the criteria for no This containerive radioactive material added man-made radioactive material for This container/load meets the criteria for Radcon Manual Table 4.2 release limits. This container/load is exempt from sur

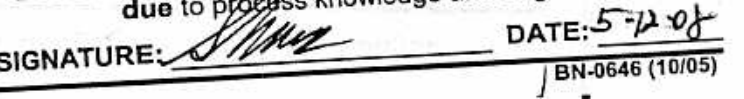




\section{$\begin{array}{llllll}\text { SWO USE (Select One) } & \text { AREA } & \square 23 & \square 6 & \square 9 & \square \text { LANDFILL }\end{array}$}

For waste characterization, approval, and/or assistance, contact Solid Waste Operation (SWO) at 5-7898.

REQUIRED: WASTE GERERATOR INFORMATION

(This form is for rolloffs, dump trucks, and other onsite disposal of materials.)

Waste Generator: Dan Tobiason

Phone Number: 295-6169

Location / Origin: T-Tunnel Lower Laydown Yard - CAU 481

Waste Category: (check one) $\square$ Commercial

Waste Type: $\triangle$ NTS $\square$ Putrescrible

$\square$ Non-Putrescible

$\square$ Asbestos Containing Material

$\triangle$ Industrial

(check one)

Pollution Prevention Category: (check one)

$\square$ Environmental management

$\triangle$ FFACO-onsite

Pollution Prevention Category: (check one)

$\triangle$ Clean-Up

Method of Characterization: (check one)

$\triangle$ Sampling \& Analysis

$\square$ FFACO-offsite

$\triangle$ Defense Projects

$\square$ Routine

Prohibited Waste at all three Radioactive waste; RCRA waste; Hazardous waste; Free liquids, PCBs above TSCA regulatory NTS landfills:

Additional Prohibited Waste

at the Area 9 U10C Landfill:

levels, and Medical wastes (needles, sharps, bloody clothing).

Sewage Sludge, Animal carcasses, Wet garbage (food waste); and Friable asbestos

\section{REQUIRED: WASTE CONTENTS ALLOWABLE WASTES}

Check all allowable wastes that are contained within this load:

NOTE: Waste disposal at the Area 6 Hydrocarbon Landfill must have come into contact with petroleum hydrocarbons or coolants, such as: gasoline (no benzene, lead); jet fuel; diesel fuel; lubricants and hydraulics; kerosene; asphaltic petroleum hydrocarbon; and ethylene glycol.

Acceptable waste at any NTS landfill: $\square$ Paper $\square$ Rocks / unaltered geologic materials

$\triangle$ Asphalt $\quad$ Metal $\quad$ Wood $\quad$ Soil

Plastic $\square$ Wire

$\triangle$ Cable

$\triangle$ Rubber (excluding tires)

$\bigotimes$ Cloth

$\bigotimes$ Insulation (non-Asbestosform)

$\triangle$ Empty containers

$\bigotimes$ Demolition debris

$\triangle$ Manufactured items: (swamp coolers, furniture, rugs, carpet, electronic components, PPE, etc.)

Additional waste accepted at the Area 23 Mercury Landfill: $\square$ Office Waste

Asbestos

Friable

Non-Friable (contact SWO if regulated load)

$\square$ Food Waste

Animal Carcasses

Additional waste accepted at the Area 9 U10c Landfill:

$\square$ Non-friable asbestos

Light ballasts (contact SWO)

Hydrocarbons (contact SWO)
Drained automobiles and military vehicles

Drained fuel filters (gas \& diesel)

Other Drained generators/equipment

Quantity:

Additional waste accepted at the Area 6 Hydrocarbon Landfill:

$\square$ Septic sludge $\square$ Rags

Plants

Soil

$\square$ Drained fuel filters (gas \& diesel)

$\square$ Sludge from sand/oil/water separators REQUIRED: WASTE GENERATOR SIGNATURE

$\square$ Solid fractions from sand/oil/water

$\bigotimes$ Deconned Underground and Above Ground Tanks (if initialed, no radiological clearance is necessary.)

The above mentioned waste was generated outside of a Controlled Waste Management Area (CWMA) and to the best of my knowledge, does not contain radiological materials.

To the best of my knowledge, the waste described above contains only those materi: site. I have verified this through the waste characterization method identified above prohibited and allowable waste items. I have contacted Property Management and $h$ is approved for disposal in the landfill.

Print Name: Dan Tobiason

Signature:
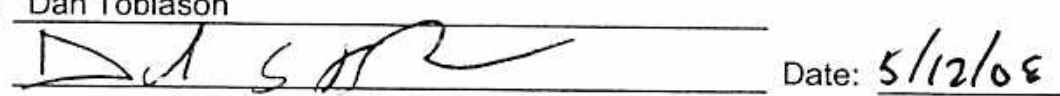

Note: "Food waste, office trash and animal carcasses do must have signed removal certification statement with Load Verification."
SWO USE ONLY

Load Weight (net from scale of estimate)

$$
5 / 12 / 08
$$

Radiological Survey Release for Waste Disposal RCT Initials

This containerlload meets the criteria for no added man-made radioactive material added man-made rad meets the criteria for This container/load meets the criteria for Radcon Manual Table 4.2 release lim survey This container/load is exempt from

due SIGNATURE:

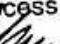

Ie. DATE: $\frac{5-12-\theta 8}{8 N-0646(10 / 05)}$ 


\section{$\begin{array}{llllll}\text { SWO USE (Select One) } & \text { AREA } & \square 23 & \square 6 & \text { Q } 39 & \square \text { LANDFILL }\end{array}$}

For waste characterization, approval, and/or assistance, contact Solid Waste Operation (SWO) at 5-7898.

REQUIRED: WASTE GERERATOR INFORMATION

(This form is for rolloffs, dump trucks, and other onsite disposal of materials.)

Waste Generator: Dan Tobiason

Phone Number: 295-6169

Location / Origin: T-Tunnel Lower Laydown Yard - CAU 481

Waste Category: (check one)

Waste Type: $\square$ NTS

(check one)

$\square$ Non-Putrescible

Pollution Prevention Category: (check one)

Pollution Prevention Category: (check one)

Method of Characterization: (check one)

$\square$ Commercial

$\square$ Putrescrible

$\square$ Asbestos Containing Material

Environmental management

$\triangle$ Clean-Up

$\triangle$ Sampling \& Analysis
NTS landfills:

Additional Prohibited Waste

at the Area 9 U10C Landfill: levels, and Medical wastes (needles, sharps, bloody clothing).

Sewage Sludge, Animal carcasses, Wet garbage (food waste); and Friable asbestos

\section{REQUIRED: WASTE CONTENTS ALLOWABLE WASTES}

Check all allowable wastes that are contained within this load:

NOTE: Waste disposal at the Area 6 Hydrocarbon Landfill must have come into contact with petroleum hydrocarbons or coolants, such as: gasoline (no benzene, lead); jet fuel; diesel fuel; lubricants and hydraulics; kerosene; asphaltic petroleum hydrocarbon; and ethylene glycol.

Acceptable waste at any NTS landfill: $\bigotimes$ Pape

$\bigotimes$ Asphalt

$凶$ Metal

$\bigotimes$ Wood

$\bigotimes$ Soil

$\bigotimes$ Plastic

$\bigotimes$ Wire

$\otimes$ Cable

Cloth

$\square$ Rocks / unaltered geologic materials

$\bigotimes$ Rubber (excluding tires)

$\bigotimes$ insulation (non-Asbestosform)

$\bigotimes$ Empty containers

$\triangle$ Demolition debris

$\triangle$ Manufactured items: (swamp coolers, furniture, rugs, carpet, electronic components, PPE, etc.)
Additional waste accepted at the Area 23 Mercury Landfill: $\quad \square$ Office Waste
Asbestos
$\square$ Friable
Non-Friable (contact SWO if regulated load)
Food Waste
Animal Carcasses

Additional waste accepted at the Area 9 U10c Landfill:

Non-friable asbestos

Light ballasts (contact SWO)

Hydrocarbons (contact SWO
Drained automobiles and military vehicles

Drained fuel filters (gas \& diesel)

Other Drained generators/equipment
Solid fractions from sand/oil/water

$\bigotimes$ Deconned Underground and Above Ground Tanks

Additional waste accepted at the Area 6 Hydrocarbon Landfill:

$\square$ Septic sludge $\square$ Rags

$\square$ Drained fuel filters (gas \& diesel)

$\square$ Sludge from sand/oil/water separators

REQUIRED: WASTE GENERATOR SIGNATURE

Crushed non-teme plated oil filters PCBs below 50 parts per million

Initials: (if initialed, no radiological clearance is necessary.)

The above mentioned waste was generated outside of a Controlled Waste Management Area (CWMA) and to the best of my knowledge, does not contain radiological materials.

To the best of my knowledge, the waste described above contains only those mate site. I have verified this through the waste characterization method identified abo prohibited and allowable waste items. I have contacted Property Management and is approved for disposal in the landfill.

Print Name: Dan Tobiason

Signature:
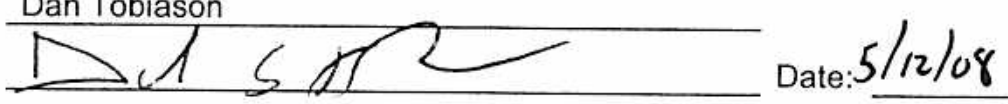

Note: "Food waste, office trash and animal carcasses do not require a radiological must have signed removal certification statement with Load Verification."

\section{SWO USE ONLY}

Load Weight (net from scale of estimate):

$$
5 / 12 / 08
$$

Signature of Certifier:
Radiological Survey Release for Waste Disposal RCT Initials

- This container/load meets the criteria for no added man-made radioactive material This container/load meets the criteria for Radcon Manual Table 4.2 release limits. This containerlload is exempt from survey due to progss knowledge and origin.

SIGNATURE:

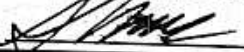
DATE: $\frac{5-1208}{B N-0646(10 / 05)}$

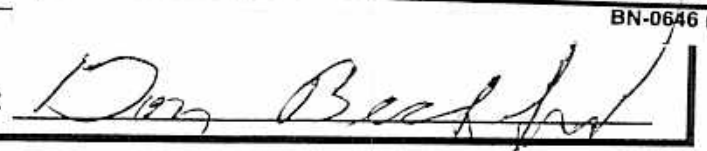




\section{$\begin{array}{llllll}\text { SWO USE (Select One) } & \text { AREA } & \square 23 & \square 6 & \square 9 & \text { Q LANDFILL }\end{array}$}

For waste characterization, approval, and/or assistance, contact Solid Waste Operation (SWO) at 5-7898.

\section{REQUIRED: WASTE GERERATOR INFORMATION}

(This form is for rolloffs, dump trucks, and other onsite disposal of materials.)

Waste Generator: Dan Tobiason

Phone Number: 295-6169

Location / Origin: T-Tunnel Lower Laydown Yard - CAU 481

Waste Category: (check one) $\square$ Commercial

Waste Type: $\square$ NTS $\square$ Putrescrible

$\square$ Non-Putrescible

$\square$ Asbestos Containing Material

$\triangle$ Industrial

(check one)

$\square$ Environmental management

$\triangle$ FFACO-onsite

WAC Exception

Pollution Prevention Category: (check one)

Pollution Prevention Category: (check one)

$\bigotimes$ Clean-Up

Method of Characterization: (check one) $\triangle$ Sampling \& Analysis

$\square$ FFACO-offsite

$\square$ Historic DOE/NV

Prohibited Waste at all three Radioactive waste; RCRA waste; Hazardous waste; Free liquids, PCBs above TSCA regulatory NTS landfills:

levels, and Medical wastes (needles, sharps, bloody clothing).

Additional Prohibited Waste

at the Area 9 U10C Landfill:

Sewage Sludge, Animal carcasses, Wet garbage (food waste); and Friable asbestos

\section{REQUIRED: WASTE CONTENTS ALLOWABLE WASTES}

Check all allowable wastes that are contained within this load:

NOTE: Waste disposal at the Area 6 Hydrocarbon Landfill must have come into contact with petroleum hydrocarbons or coolants, such as: gasoline (no benzene, lead); jet fuel; diesel fuel; lubricants and hydraulics; kerosene; asphaltic petroleum hydrocarbon; and ethylene glycol.
Acceptable waste at any NTS landfill:
$\bigotimes$ Paper
$\square$ Rocks / unaltered geologic materials
$\bigotimes$ Asphalt
$\bigotimes$ Metal
Q Wood
$\triangle$ Soil
$\triangle$ Rubber (excluding tires)
$\triangle$ Plastic $\bigotimes$ Wire
$\bigotimes$ Cable
Cloth
$\bigotimes$ Insulation (non-Asbestosform)

$\bigotimes$ Empty containers

$\triangle$ Demolition debris

$\triangle$ Manufactured items: (swamp coolers, furniture, rugs, carpet, electronic components, PPE, etc.)
Additional waste accepted at the Area 23 Mercury Landfill: $\square$ Office Waste
Asbestos
Friable
Non-Friable (contact SWO if regulated load)
Food Waste
Animal Carcasses
Quantity:

Additional waste accepted at the Area 9 U10c Landfill:

$\square$ Non-friable asbestos

$\square$ Light ballasts (contact SWO)

Hydrocarbons (contact SWO)

Drained automobiles and military vehicles

Drained fuel filters (gas \& diesel)

Other Drained generators/equipment

\section{Additional waste accepted at the Area 6 Hydrocarbon Landfill:}
Septic sludge
$\square$ Rags
$\square$ Drained fuel filters (gas \& diesel)
Crushed non-teme plated oil filters
Plants
Soil
Sludge from sand/oil/water separators
PCBs below 50 parts per million

\section{REQUIRED: WASTE GENERATOR SIGNATURE}

Initials: (if initialed, no radiological clearance is necessary.)

The above mentioned waste was generated outside of a Controlled Waste Management.Area (CWMA) and to the best of my knowledge, does not contain radiological materials.

To the best of my knowledge, the waste described above contains only those mater site. I have verified this through the waste characterization method identified above prohibited and allowable waste items. I have contacted Property Management and I is approved for disposal in the landfill.

Print Name: Dan Tobiason

Signature:
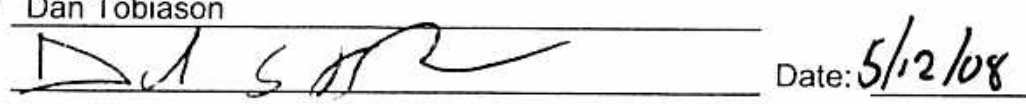

Note: "Food waste, office trash and animal carcasses do not require a radiological cl must have signed removal certification statement with Load Verification."

\section{SWO USE ONLY}

3,700

Load Weight (net from scale or estimate)

$$
5 / 12 / 08
$$

Signature of Certifier:
Radiological Survey Release for Waste Disposal RCT Initials

This container/load meets the criteria for no added man-made radioactive material This container/load meets the criteria for Radcon Manual Table 4.2 release limits. This container/load is exempt from survey due to prpcess knowledge and origin.

SIGNATURE:

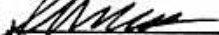
DATE: $5-2 \approx 8$ $\mathrm{BN}-0646(10 / 05)$ 


\section{$\begin{array}{llllll}\text { SWO USE (Select One) } & \text { AREA } & \square 23 & \square 6 & \nabla 9 & \square \text { LANDFILL }\end{array}$}

For waste characterization, approval, and/or assistance, contact Solid Waste Operation (SWO) at 5-7898.

REQUIRED: WASTE GERERATOR INFORMATION

(This form is for rolloffs, dump trucks, and other onsite disposal of materials.)

Waste Generator: Dan Tobiason

Phone Number: 295-6169

Location / Origin: T-Tunnel Lower Laydown Yard - CAU 481

\begin{tabular}{|c|c|c|c|c|}
\hline \multicolumn{2}{|c|}{ Waste Category: (check one) } & \multirow{2}{*}{$\begin{array}{l}\square \text { Commercial } \\
\square \text { Putrescrible }\end{array}$} & \multicolumn{2}{|l|}{$\triangle$ Industrial } \\
\hline Waste Type: & $\triangle N T S$ & & $\triangle$ FFACO-onsite & $\square$ WAC Exception \\
\hline (check one) & $\square$ Non-Putrescible & $\square$ Asbestos Containing Material & $\square$ FFACO-offsite & $\square$ Historic DOE/NV \\
\hline \multicolumn{2}{|c|}{ Pollution Prevention Category: (check one) } & $\square$ Environmental management & $\triangle$ Defense Projects & $\square$ YMP \\
\hline \multicolumn{2}{|c|}{ Pollution Prevention Category: (check one) } & Clean-Up & $\square$ Routine & \\
\hline \multicolumn{2}{|c|}{ Method of Characterization: (check one) } & $\triangle$ Sampling \& Analysis & $\triangle$ Process Knowledg & $\square$ Contents \\
\hline
\end{tabular}

Prohibited Waste at all three Radioactive waste; RCRA waste; Hazardous waste; Free liquids, PCBs above TSCA regulatory NTS landfills:

Additional Prohibited Waste

at the Area 9 U10C Landfill:

levels, and Medical wastes (needles, sharps, bloody clothing).

Sewage Sludge, Animal carcasses, Wet garbage (food waste); and Friable asbestos

REQUIRED: WASTE CONTENTS ALLOWABLE WASTES

Check all allowable wastes that are contained within this load:

NOTE: Waste disposal at the Area 6 Hydrocarbon Landfill must have come into contact with petroleum hydrocarbons or coolants, such as: gasoline (no benzene, lead); jet fuel; diesel fuel; lubricants and hydraulics; kerosene; asphaltic petroleum hydrocarbon; and ethylene glycol.

Acceptable waste at any NTS landfill: $\square$ Paper $\square$ Rocks / unaltered geologic materials

$\triangle$ Asphalt $\quad$ Metal $\quad$ Wood $\quad$ Soil

$\triangle$ Plastic $\quad$ Wire $\quad$ Cable $\quad$ Cloth

$\triangle$ Rubber (excluding tires)

$\bigotimes$ Insulation (non-Asbestosform)

$\triangle$ Empty containers

$\otimes$ Demolition debris

$\triangle$ Manufactured items: (swamp coolers, furniture, rugs, carpet, electronic components, PPE, etc.)

Additional waste accepted at the Area 23 Mercury Landfill: $\square$ Office Waste $\square$ Food Waste $\square$ Animal Carcasses

$\square$ Asbestos

Friable

$\square$ Non-Friable (contact SWO if regulated load)

Quantity:

Additional waste accepted at the Area 9 U10c Landfill:
Non-friable asbestos
Drained automobiles and military vehicles
Light ballasts (contact SWO)
Drained fuel filters (gas \& diesel)
Hydrocarbons (contact SWO)
Other
Drained generators/equipment
Solid fractions from sand/oil/water
$\triangle$ Deconned Underground and Above
Ground Tanks

Additional waste accepted at the Area 6 Hydrocarbon Landfill:
Septic sludge
$\square$ Rags
$\square$ Drained fuel filters (gas \& diesel)
Plants
$\square$ Soil
$\square$ Sludge from sand/oil/water separators
$\square$ Crushed non-teme plated oil filters PCBs below 50 parts per million REQUIRED: WASTE GENERATOR SIGNATURE

Initials: (if initialed, no radiological clearance is necessary.)

The above mentioned waste was generated outside of a Controlled Waste Management Area (CWMA) and to the best of my knowledge, does not contain radiological materials.

To the best of my knowledge, the waste described above contains only those mate site. I have verified this through the waste characterization method identified abov prohibited and allowable waste items. I have contacted Property Management and is approved for disposal in the landfill.

Print Name: Dan Tobiason

Signature:
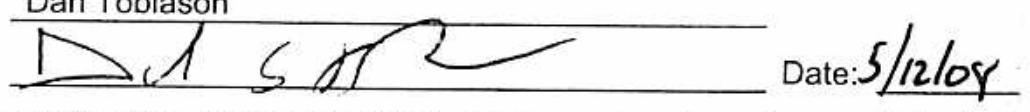

Note: "Food waste, office trash and animal carcasses do not require a radiological . must have signed removal certification statement with Load Verification."

\section{SWO USE ONLY}

Load Weight (net from scale or estimate): 99800

$$
5 / 12 / 08
$$

Signature of Certifier:

Radiological Survey Release for Waste Disposal RCT Initials

This container/load meets the criteria for no added man-made radioactive material This container/load meets the criteria for Radcon Manual Table 4.2 release limits. This container/load is exempt from survey due to process knowledge and origin.

SIGNATURE: DATE: $5-12-0 P$ 
For waste characterization, approval, and/or assistance, contact Solid Waste Operation (SWO) at 5-7898.

\section{REQUIRED: WASTE GERERATOR INFORMATION}

(This form is for rolloffs, dump trucks, and other onsite disposal of materials.)

Waste Generator: Dan Tobiason

Phone Number: 295-6169

Location / Origin: T-Tunnel Lower Laydown Yard - CAU 481

Waste Category: (check one)

Waste Type: $\triangle$ NTS

(check one)

$\square$ Non-Putrescible

Pollution Prevention Category: (check one)

Pollution Prevention Category: (check one)

Method of Characterization: (check one)

Prohibited Waste at all three

NTS landfills:

Additional Prohibited Waste

at the Area 9 U10C Landfill: $\square$ Commercial

$\square$ Putrescrible

$\square$ Asbestos Containing Material

$\square$ Environmental management

$\triangle$ Clean-Up

$\triangle$ Sampling \& Analysis $\triangle$ Industrial

$\triangle$ FFACO-onsite

FFACO-offsite

$\triangle$ Defense Projects

Routine

$\triangle$ Process Knowledge $\square$ Contents
WAC Exception

Historic DOE/NV

YMP levels, and Medical wastes (needles, sharps, bloody clothing).

Sewage Sludge, Animal carcasses, Wet garbage (food waste); and Friable asbestos

\section{REQUIRED: WASTE CONTENTS ALLOWABLE WASTES}

Check all allowable wastes that are contained within this load:

NOTE: Waste disposal at the Area 6 Hydrocarbon Landfill must have come into contact with petroleum hydrocarbons or coolants, such as: gasoline (no benzene, lead); jet fuel; diesel fuel; lubricants and hydraulics; kerosene; asphaltic petroleum hydrocarbon; and ethylene glycol.

Acceptable waste at any NTS landfill:

$\triangle$ Asphalt

$\otimes$ Metal

$\triangle$ Wood

$\triangle$ Soil

Rocks / unaltered geologic materials

Plastic

Q Wire

$\otimes$ Cable

$\otimes$.Cloth

$\bigotimes$ Rubber (excluding tires)

$\triangle$ Insulation (non-Asbestosform)

$\triangle$ Manufactured items: (swamp coolers, furniture, rugs, carpet, electronic components, PPE, etc.)
Additional was
$\square$ Asbestos
$\square$ Friable
Area 23 Mercury Landfill:
$\square$ Office Waste
Food Waste
Quantity:

Additional waste accepted at the Area 9 U10c Landfill:

$\square$ Non-friable asbestos

Light ballasts (contact SWO)

Drained automobiles and military vehicles

Drained fuel filters (gas \& diesel)

Hydrocarbons (contact SWO)

Other Drained generators/equipment

Solid fractions from sand/oil/water

$\triangle$ Deconned Underground and Above Ground Tanks

Additional waste accepted at the Area 6 Hydrocarbon Landfill:
$\square$ Septic sludge
$\square$ Rags
$\square$ Drained fuel filters (gas \& diesel)
Plants
Soil
$\square$ Sludge from sand/oil/water separators
Crushed non-teme plated oil filters REQUIRED: WASTE GENERATOR SIGNATURE
PCBs below 50 parts per million

Initials: (if initialed, no radiological clearance is necessary.)

The above mentioned waste was generated outside of a Controlled Waste Management Area (CWMA) and to the best of my knowledge, does not contain radiological materials.

To the best of my knowledge, the waste described above contains only those materials that are allowed for disposal at this site. I have verified this through the waste characterization method identified above prohibited and allowable waste items. I have contacted Property Management and h is approved for disposal in the landfill.

Print Name: Dan Tobiason

Signature:
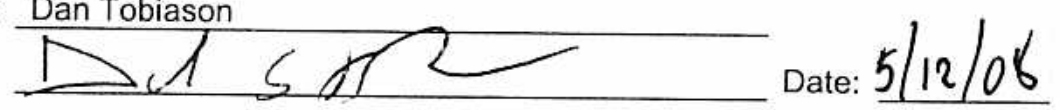

Note: "Food waste, office trash and animal carcasses do not require a radiological clt must have signed removal certification statement with Load Verification."

\section{SWO USE ONLY}

Load Weight (net from scale fr estimate): $7, \mathrm{OCO}^{\circ}$

$5 / 12 / 08$

Signature of Certifier:

Radiological Survey Release for Waste Disposal RCT Initials

- This container/load meets the criteria for no

Lin added man-made radioactive material This container/load meets the criteria for Radcon Manual Table 4.2 release limits. This container/load is exempt from survey due to prgeess knowledge and origin.

signature: DATE: $5-12-08$

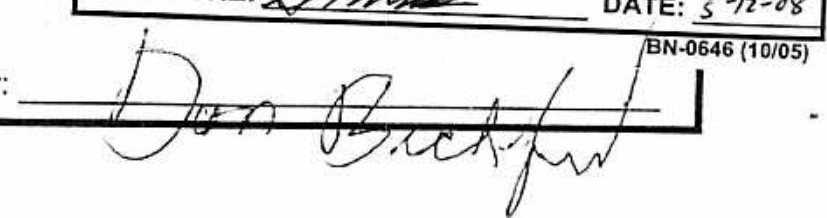




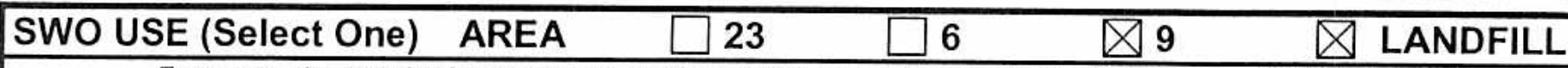

For waste characterization, approval, and/or assistance, contact Solid Waste Operation (SWO) at 5-7898.

REQUIRED: WASTE GERERATOR INFORMATION

(This form is for rolloffs, dump trucks, and other onsite disposal of materials.)

Waste Generator: Dan Tobiason

Phone Number: 295-6169

Location / Origin: T-Tunnel Lower Laydown Yard - CAU 481

Waste Category: (check one)

Waste Type: $\triangle$ NTS

(check one)

Pollution Prevention Category: (check one)

Pollution Prevention Category: (check one)

Method of Characterization: (check one)

Prohibited Waste at all three

NTS landfills:

Additional Prohibited Waste

at the Area 9 U10C Landfill:
Radioactive waste; RCRA waste; Hazardous waste; Free liquids, PCBs above TSCA regulatory levels, and Medical wastes (needles, sharps, bloody clothing).

Sewage Sludge, Animal carcasses, Wet garbage (food waste); and Friable asbestos

Check all allowable wastes that are contained within this load:

NOTE: Waste disposal at the Area 6 Hydrocarbon Landfill must have come into contact with petroleum hydrocarbons or coolants, such as: gasoline (no benzene, lead); jet fuel; diesel fuel; lubricants and hydraulics; kerosene; asphaitic petroleum hydrocarbon; and ethylene glycol.

Acceptable waste at any NTS landfill: $\triangle$ Pape

$\bigotimes$ Asphalt $\bigotimes$ Metal $\bigotimes$ Wood

$\bigotimes$ Soil

Rocks / unaltered geologic materials

Plastic

$\triangle$ Wire

$\triangle$ Cable

$\triangle$ Cloth

$\triangle$ Rubber (excluding tires)

$\triangle$ Insulation (non-Asbestosform)

$\triangle$ Empty containers

$\triangle$ Demolition debris

$\bigotimes$ Cement \& concrete

$\triangle$ Manufactured items: (swamp coolers, furniture, rugs, carpet, electronic components, PPE, etc.)

Additional waste accepted at the Area 23 Mercury Landfill: $\square$ Office Waste $\square$ Food Waste

Animal Carcasses

$\square$ Asbestos

Friable

Non-Friable (contact SWO if regulated load)

Quantity:

Additional waste accepted at the Area 9 U10c Landfill:
Non-friable asbestos
Light ballasts (contact SWO)
Drained automobiles and military vehicles
Drained fuel filters (gas \& diesel)

Hydrocarbons (contact SWO)

Other Drained generators/equipment

Solid fractions from sand/oil/water

$\triangle$ Deconned Underground and Above Ground Tanks

Additional waste accepted at the Area 6 Hydrocarbon Landfill:

$\square$ Septic sludge $\quad \square$ Rags $\quad \square$ Drained fuel filters (gas \& diesel)

Plants

Soil

$\square$ Sludge from sand/oil/water separators

Crushed non-teme plated oil filters REQUIRED: WASTE GENERATOR SIGNATURE

Initials: (if initialed, no radiological clearance is necessary.)

The above mentioned waste was generated outside of a Controlled Waste Management Area (CWMA) and to the best of my knowledge, does not contain radiological materials.

To the best of my knowledge, the waste described above contains only those materia site. I have verified this through the waste characterization method identified above : prohibited and allowable waste items. I have contacted Property Management and hi is approved for disposal in the landfill.

Print Name: Dan Tobiason

Signature:
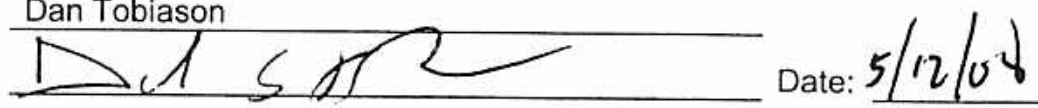

Note: "Food waste, office trash and animal carcasses do not require a radiological cle must have signed removal certification statement with Load Verification."

\section{SWO USE ONLY}

Load Weight (net from scale or estimate).

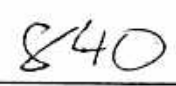

Radiological Survey Release for Waste Disposal
RCT Initials

This container/load meets the criteria for no added man-made radioactive material Radcon Manulload meets the criteria for This container/ Table 4.2 release limits. due to prosess know is exempt from survey IGNATURE: Yus DATE: $5,12,68$
$5 / 13 / 08$ Signature of Certifier. 


\begin{tabular}{llllll}
\hline SWO USE (Select One) & AREA & $\square 23$ & $\square 6$ & A 39 & LANDFILL
\end{tabular}

For waste characterization, approval, and/or assistance, contact Solid Waste Operation (SWO) at 5-7898.

REQUIRED: WASTE GERERATOR INFORMATION

(This form is for rolloffs, dump trucks, and other onsite disposal of materials.)

Waste Generator: Dan Tobiason Phone Number: 295-6169

Location / Origin: T-Tunnel Lower Laydown Yard - CAU 481

Waste Category: (check one)

Waste Type: $\bigotimes$ NTS

(check one)

Non-Putrescible

Pollution Prevention Category: (check one)

Pollution Prevention Category: (check one)

Method of Characterization: (check one)

Prohibited Waste at all three

NTS landfills:

Additional Prohibited Waste

at the Area 9 U10C Landfill:

$\square$ Commercial
$\square$ Putrescrible
$\square$ Asbestos Containing Material
$\square$ Environmental management
$\square$ Clean-Up
$\square$ Sampling \& Analysis

区 Industrial

$\triangle$ FFACO-onsite

$\square$ FFACO-offsite

$\bigotimes$ Defense Projects

$\square$ Routine

$\triangle$ Process Knowledge levels, and Medical wastes (needles, sharps, bloody clothing).

Sewage Sludge, Animal carcasses, Wet garbage (food waste); and Friable asbestos

REQUIRED: WASTE CONTENTS ALLOWABLE WASTES

Check all allowable wastes that are contained within this load:

NOTE: Waste disposal at the Area 6 Hydrocarbon Landfill must have come into contact with petroleum hydrocarbons or coolants, such as: gasoline (no benzene, lead); jet fuel; diesel fuel; lubricants and hydraulics; kerosene; asphaltic petroleum hydrocarbon; and ethylene glycol.
Acceptable waste at any NTS landfill:
$\triangle$ Paper
$\square$ Rocks / unaltered geologic materials
$\triangle$ Soil
$\triangle$ Asphalt
$\bigotimes$ Metal
$\triangle$ Wood
$凶$ Cloth
$\triangle$ Rubber (excluding tires)
$\triangle$ Plastic $\quad \square$ Wire $\quad \square$ Cable
$\bigotimes$ Insulation (non-Asbestosform)

$\bigotimes$ Empty containers
$\square$ Demolition debris
$\square$ Cement \& concrete

$\triangle$ Manufactured items: (swamp coolers, furniture, rugs, carpet, electronic components, PPE, etc.)
Additional waste accepted at the Area 23 Mercury Landfill: Office Waste
Asbestos
Friable
Non-Friable (contact SWO if regulated load)
Food Waste
Animal Carcasses
Quantity:

Additional waste accepted at the Area 9 U10c Landfill:
$\square$ Non-friable asbestos
Light ballasts (contact SWO)
Drained automobiles and military vehicles
Drained fuel filters (gas \& diesel)
Hydrocarbons (contact SWO)
Other Drained generators/equipment

Additional waste accepted at the Area 6 Hydrocarbon Landfill:
$\square$ Septic sludge
$\square$ Rags
$\square$ Drained fuel filters (gas \& diesel)
Plants
Soil
$\square$ Sludge from sand/oil/water separators

\section{REQUIRED: WASTE GENERATOR SIGNATURE}

\section{Crushed non-teme plated oil filters} PCBs below 50 parts per million

Solid fractions from sand/oil/water

$\bigotimes$ Deconned Underground and Above Ground Tanks

Initials: (if initialed, no radiological clearance is necessary.)

The above mentioned waste was generated outside of a Controlled Waste Management Area (CWMA) and to the best of my knowledge, does not contain radiological materials.

To the best of my knowledge, the waste described above contains only those materiale th........

site. I have verified this through the waste characterization method identified abov prohibited and allowable waste items. I have contacted Property Management and is approved for disposal in the landfill.

Print Name: Dan Tobiason

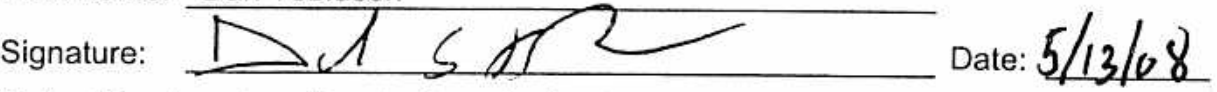

Note: "Food waste, office trash and animal carcasses do not require a radiological cl must have signed removal certification statement with Load Verification."

SWO USE ONLY

Load Weight (net from scale or estimate) S, C C
Radiological Survey Release for Waste Disposal RCT Initials

This container/load meets the criteria for no added man-made radioactive material This container/load meets the criteria for Radcon Manual Table 4.2 release limits. This container/load is exempt from survey due to propess knowledge and origin.

SIGNATURE: $5 \longdiv { 3 / 0 8 }$ Signature of Certifier: $/)_{2 n}$ 


\begin{tabular}{|llllll}
\hline SWO USE (Select One) & AREA & $\square 23$ & $\square 6$ & Q 9 & $\square$ LANDFILL
\end{tabular}

For waste characterization, approval, and/or assistance, contact Solid Waste Operation (SWO) at 5-7898.

REQUIRED: WASTE GERERATOR INFORMATION

(This form is for rolloffs, dump trucks, and other onsite disposal of materials.)

Waste Generator: Dan Tobiason

Phone Number: 295-6169

Location / Origin: T-Tunnel Lower Laydown Yard - CAU 481

Waste Category: (check one)

Waste Type: $\triangle$ NTS

(check one)

$\square$ Commercial
$\square$ Putrescrible
$\square$ Asbestos Containing Material
$\square$ Environmental management
$\square$ Clean-Up
$\square$ Sampling \& Analysis

$\triangle$ Industrial

$\triangle$ FFACO-onsite $\square$ WAC Exception

$\square$ FFACO-offsite

Pollution Prevention Category: (check one)

Pollution Prevention Category: (check one)

Method of Characterization: (check one)

$\triangle$ Defense Projects

$\square$ Routine

$\triangle$ Process Knowledge $\square$ Contents

Prohibited Waste at all three

NTS landfills:

Additional Prohibited Waste

at the Area 9 U10C Landfill:

Radioactive waste; RCRA waste; Hazardous waste; Free liquids, PCBs above TSCA regulatory levels, and Medical wastes (needles, sharps, bloody clothing).

Sewage Sludge, Animal carcasses, Wet garbage (food waste); and Friable asbestos

\section{REQUIRED: WASTE CONTENTS ALLOWABLE WASTES}

Check all allowable wastes that are contained within this load:

NOTE: Waste disposal at the Area 6 Hydrocarbon Landfill must have come into contact with petroleum hydrocarbons or coolants, such as: gasoline (no benzene, lead); jet fuel; diesel fuel; lubricants and hydraulics; kerosene; asphaltic petroleum hydrocarbon; and ethylene glycol.

Acceptable waste at any NTS landfill:

$\triangle$ Asphalt $\bigotimes$ Metal $\bigotimes$ Wood

$凶$ Paper

$\bigotimes$ Plastic

$\triangle$ Wire

$凶$ Cable

$\bigotimes$ Soil

$\triangle$ Cloth

$\square$ Rocks / unaltered geologic materials

$\triangle$ Rubber (excluding tires)

$\bigotimes$ Insulation (non-Asbestosform)

$\triangle$ Empty containers

$\triangle$ Demolition debris

$\bigotimes$ Cement \& concrete

$\triangle$ Manufactured items: (swamp coolers, furniture, rugs, carpet, electronic components, PPE, etc.)
Additional was
$\square$ Asbestos
$\square$ Friable
$\square$
Area 23 Mercury Landfill:
$\square$ Office Waste
Non-Friable (contact SWO if regulated load)
Food Waste
Animal Carcasses

Additional waste accepted at the Area 9 U10c Landfill:

$\square$ Non-friable asbestos

Light ballasts (contact SWO)

Hydrocarbons (contact SWO) $\square$ Drained automobiles and military vehicles

Drained fuel filters (gas \& diesel)

Other Drained generators/equipment
Solid fractions from sand/oil/water

$\triangle$ Deconned Underground and Above Ground Tanks

Additional waste accepted at the Area 6 Hydrocarbon Landfill:

$\square$ Septic sludge $\square$ Rags $\quad \square$ Drained fuel filters (gas \& diesel)

Plants $\square$ Soil

$\square$ Sludge from sand/oil/water separators

REQUIRED: WASTE GENERATOR SIGNATURE

Crushed non-teme plated oil filters PCBs below 50 parts per million

Initials: (if initialed, no radiological clearance is necessary.)

The above mentioned waste was generated outside of a Controlled Waste Management Area (CWMA) and to the best of my knowledge, does not contain radiological materials.

To the best of my knowledge, the waste described above contains only those materials that are allowed for disposal at this site. I have verified this through the waste characterization method identified abo prohibited and allowable waste items. I have contacted Property Management an is approved for disposal in the landfill.

Print Name: Dan Tobiason

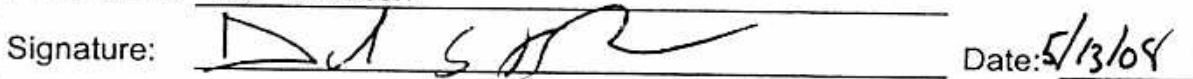

Note: "Food waste, office trash and animal carcasses do not require a radiological must have signed removal certification statement with Load Verification."

SWO USE ONLY

Load Weight (net from scale or estimate)?
$5 / 13 / 08$ Signature of Certifier:
Radiological Survey Release for Waste Disposal RCT Initials

This container/load meets the criteria for no added man-made radioactive material This container/load meets the criteria for Radcon Manual Table 4.2 release limits. This container/load is exempt from survey due to progess knowledge and origin.

SIGNATURE: DATE: $5,17,64$ 


\section{$\begin{array}{llllll}\text { SWO USE (Select One) } & \text { AREA } & \square 23 & \square 6 & \square 9 & \square \text { LANDFILL }\end{array}$}

For waste characterization, approval, and/or assistance, contact Solid Waste Operation (SWO) at 5-7898.

\section{REQUIRED: WASTE GERERATOR INFORMATION}

(This form is for rolloffs, dump trucks, and other onsite disposal of materials.)

Waste Generator: Dan Tobiason

Phone Number: 295-6169

Location / Origin: T-Tunnel Lower Laydown Yard - CAU 481

Waste Category: (check one)

Waste Type: $₫$ NTS

(check one)

Non-Putrescible

$\square$ Commercial

$\triangle$ Industrial

$\triangle$ FFACO-onsite

Asbestos Containing Material

$\square$ FFACO-offsite

Pollution Prevention Category: (check one) $\square$ Environmental management

Pollution Prevention Category: (check one)

$\triangle$ Clean-Up

Method of Characterization: (check one) $\triangle$ Sampling \& Analysis

$\triangle$ Defense Projects

$\square$ Routine

Prohibited Waste at all three

NTS landfills:

Additional Prohibited Waste

at the Area 9 U10C Landfill:

Radioactive waste; RCRA waste; Hazardous waste; Free liquids, PCBs above TSCA regulatory evels, and Medical wastes (needles, sharps, bloody clothing).

Sewage Sludge, Animal carcasses, Wet garbage (food waste); and Friable asbestos

\section{REQUIRED: WASTE CONTENTS ALLOWABLE WASTES}

Check all allowable wastes that are contained within this load:

NOTE: Waste disposal at the Area 6 Hydrocarbon Landfill must have come into contact with petroleum hydrocarbons or coolants, such as: gasoline (no benzene, lead); jet fuel; diesel fuel; lubricants and hydraulics; kerosene; asphaltic petroleum hydrocarbon; and ethylene glycol.

Acceptable waste at any NTS landfill:

$\triangle$ Asphalt $\triangle$ Metal $\bigotimes$ Wood

$\triangle$ Paper

$\bigotimes$ Soil

Plastic

$\triangle$ Wire

$\triangle$ Cable

Cloth
$\square$ Rocks / unaltered geologic materials
$\triangle$ Rubber (excluding tires)
$\triangle$ Insulation (non-Asbestosform)

$\triangle$ Empty containers

$\triangle$ Demolition debris

$\triangle$ Cement \& concrete

$\bigotimes$ Manufactured items: (swamp coolers, furniture, rugs, carpet, electronic components, PPE, etc.)
Additional was $\square$ Asbestos
$\square$ Friable
the Area 23 Mercury Landfill:
Office Waste
Non-Friable (contact SWO if regulated load)
Food Waste
Animal Carcasses Quantity:

Additional waste accepted at the Area 9 U10c Landfill:

$\square$ Non-friable asbestos

Light ballasts (contact SWO)

Hydrocarbons (contact SWO)

$\square$ Drained automobiles and military vehicles

Drained fuel filters (gas \& diesel)

$\bigotimes$ Other Drained generators/equipment

Additional waste accepted at the Area 6 Hydrocarbon Landfill:
$\square$ Septic sludge
$\square$ Rags
Plants
Soil
$\square$ Drained fuel filters (gas \& diesel)
$\square$ Sludge from sand/oil/water separators
REQUIRED: WASTE GENERATOR SIGNATURE
Crushed non-teme plated oil filters PCBs below 50 parts per million

Solid fractions from sand/oil/water

$\triangle$ Deconned Underground and Above Ground Tanks

Initials: (if initialed, no radiological clearance is necessary.) The above mentioned waste was generated outside of a Controlled Waste Management Area (CWMA) and to the best of my
knowledge, does not contain radiological materials.

To the best of my knowledge, the waste described above contains only those mate site. I have verified this through the waste characterization method identified abov prohibited and allowable waste items. I have contacted Property Management and is approved for disposal in the landfill.

Print Name: Dan Tobiason

Signature:
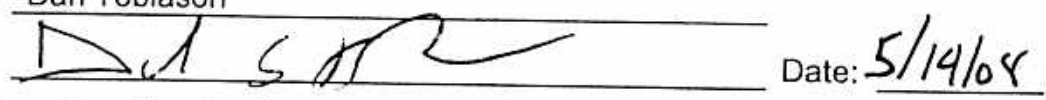

Note: "Food waste, office trash and animal carcasses do not require a radiological cli Radiological Survey Release for Waste Disposal RCT Initials must have signed removal certification statement with Load Verification."

\section{SWO USE ONLY}

Load Weight (net from scale or estimate). 48,000

$$
5 / 14 / 08
$$

Signature of Certifier
This container/load meets the criteria for no added man-made radioactive material This containeriload meets the criteria for Radcon Manual Table 4.2 release limits. This container/load is exempt from survey due to process knowledge and origin. SIGNATURE: L llime DATE: $5 / 2 \%$ los 
NSTec

Form

FRM-0918

NTS LANDFILL LOAD VERIFICATION

SWO USE (Select One) AREA 23

6

Х9

$\triangle$ LANDFILL

For waste characterization, approval, and/or assistance, contact Solid Waste Operation (SWO) at 5-7898.

\section{REQUIRED: WASTE GERERATOR INFORMATION}

(This form is for rolloffs, dump trucks, and other onsite disposal of materials.)

Waste Generator: Dan Tobiason

Phone Number: 295-6169

Location / Origin: T-Tunnel Lower Laydown Yard - CAU 481

Waste Category: (check one)

Waste Type:

$\triangle$ NTS

$\square$ Commercial

区 Industrial

(check one)

Non-Putrescible

$\square$ Putrescrible

Pollution Prevention Category: (check one)

$\square$ Asbestos Containing Material

$\triangle$ FFACO-onsite

WAC Exception

Pollution Prevention Category: (check one)

$\square$ Environmental management

$\square$ FFACO-offsite

$\square$ Historic DOE/NV

Method of Characterization: (check one)

$\triangle$ Clean-Up

Prohibited Waste at all three

NTS landfills:

¿ Sampling \& Analysis

$\triangle$ Defense Projects

YMP

Routine

Radioactive waste; RCRA waste; Hazardous waste; Free liquids, PCBs above TSCA regulatory

Additional Prohibited Waste

at the Area 9 U10C Landfill:

levels, and Medical wastes (needles, sharps, bloody clothing).

Sewage Sludge, Animal carcasses, Wet garbage (food waste); and Friable asbestos

REQUIRED: WASTE CONTENTS ALLOWABLE WASTES

Check all allowable wastes that are contained within this load:

NOTE: Waste disposal at the Area 6 Hydrocarbon Landfill must have come into contact with petroleum hydrocarbons or coolants, such as: gasoline (no benzene, lead); jet fuel; diesel fuel; lubricants and hydraulics; kerosene; asphaltic petroleum hydrocarbon; and ethylene glycol.

Acceptable waste at any NTS landfill: $\bigotimes$ Pape

$\triangle$ Asphalt $\quad$ Metal $\quad$ Wood $\bigotimes$ Soil

$\triangle$ Plastic $\quad$ Wire $\quad$ Cable

Cloth

$\square$ Rocks / unaltered geologic materials

$\triangle$ Rubber (excluding tires)

$\bigotimes$ Manufactured items: (swamp coolers, furniture, rugs, carpet, electronic components, PPE, etc.)

Additional waste accepted at the Area 23 Mercury Landfill: $\quad \square$ Office Waste

$\square$ Asbestos

Friable

$\square$ Non-Friable (contact SWO if regulated load)

Food Waste

Quantity:

Additional waste accepted at the Area 9 U10c Landfill:

$\square$ Non-friable asbestos

Light ballasts (contact SWO)

Drained automobiles and military vehicles

Hydrocarbons (contact SWO)

Drained fuel filters (gas \& diesel)

Solid fractions from sand/oil/water

Other Drained generators/equipment

$\bigotimes$ Deconned Underground and Above Ground Tanks

Additional waste accepted at the Area 6 Hydrocarbon Landfill:
Septic sludge
$\square$ Rags
$\square$ Drained fuel filters (gas \& diesel)
Plants
Soil
Sludge from sand/oil/water separators
REQUIRED: WASTE GENERATOR SIGNATURE
Crushed non-teme plated oil filters PCBs below 50 parts per million

Initials: (if initialed, no radiological clearance is necessary.)

The above mentioned waste was generated outside of a Controlled Waste Management Area (CWMA) and to the best of my knowledge, does not contain radiological materials.

To the best of my knowledge, the waste described above contains only those materials site. I have verified this through the waste characterization method identified above ar prohibited and allowable waste items. I have contacted Property Management and hav is approved for disposal in the landfill.

Print Name: Dan Tobiason

Signature: $\mathrm{D}_{\mathrm{N}} \mathrm{D}$ Date: $5 / 14 / 06$

Note: "Food waste, office trash and animal carcasses do not require a radiological clea must have signed removal certification statement with Load Verification."
Radiological Survey Release for Waste Disposal RCT Initials

This container/load meets the criteria for no added man-made radioactive material This container/load meets the criteria for Radcon Manual Table 4.2 release limits. This container/load is exempt from survey due to process knowledge and origin.

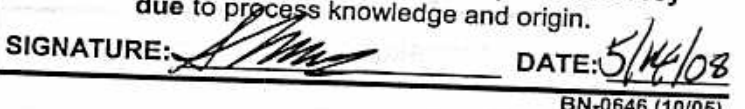

SWO USE ONLY

Load Weight (net from scale or estimate)
$5 / 14 / 08$

Signature of Certifier: 


\section{SWO USE (Select One) AREA \\ 23 \\ 凶9 \\ $\triangle$ LANDFILL}

For waste characterization, approval, and/or assistance, contact Solid Waste Operation (SWO) at 5-7898.

REQUIRED: WASTE GERERATOR INFORMATION

(This form is for rolloffs, dump trucks, and other onsite disposal of materials.)

Waste Generator: Dan Tobiason

Phone Number: 295-6169

Location / Origin: T-Tunnel Lower Laydown Yard - CAU 481

Waste Category: (check one)

Waste Type: $\triangle$ NTS

(check one)

$\square$ Non-Putrescible

$\square$ Commercial

$\triangle$ industrial

Pollution Prevention Category: (check one) $\square$ Environmental management

Pollution Prevention Category: (check one)

$\triangle$ Clean-Up

Method of Characterization: (check one)

$\triangle$ Sampling \& Analysis

$\triangle$ FFACO-onsite

WAC Exception

$\square$ FFACO-offsite

$\square$ Historic DOE/NV

\section{Prohibited Waste at all three}

NTS landfills:

Radioactive waste; RCRA waste; Hazardous waste; Free liquids, PCBs above TSCA regulatory

Additional Prohibited Waste

at the Area 9 U10C Landfill:

.

Sewage Sludge, Animal carcasses, Wet garbage (food waste); and Friable asbestos

REQUIRED: WASTE CONTENTS ALLOWABLE WASTES

Check all allowable wastes that are contained within this load:

NOTE: Waste disposal at the Area 6 Hydrocarbon Landfill must have come into contact with petroleum hydrocarbons or coolants, such as: gasoline (no benzene, lead); jet fuel; diesel fuel; iubricants and hydraulics; kerosene; asphaltic petroleum hydrocarbon; and ethylene glycol.
Acceptable waste at any NTS landfill:
$\triangle$ Paper
$\square$ Rocks / unaltered geologic materials
$\triangle$ Empty containers
$\triangle$ Asphalt $\otimes$ Metal
$\triangle$ Wood
$\otimes$ Soil
$\triangle$ Rubber (excluding tires)
$\triangle$ Plastic
$\triangle$ Wire
$\triangle$ Cable
$凶$ Cloth
$\triangle$ Insulation (non-Asbestosform)
$\triangle$ Demolition debris
$\triangle$ Cement \& concrete

$\triangle$ Manufactured items: (swamp coolers, furniture, rugs, carpet, electronic components, PPE, etc.)
Additional waste accepted at the Area 23 Mercury Landfill:
Office Waste
$\square$ Food Waste
Animal Carcasses
Asbestos
$\square$ Friable
$\square$ Non-Friable (contact SWO if regulated load)
Quantity:

\section{Additional waste accepted at the Area 9 U10c Landfill:}

Non-friable asbestos

Light ballasts (contact SwO)

$\square$ Drained automobiles and military vehicles

$\square$ Drained fuel filters (gas \& diesel)

Hydrocarbons (contact SWO)
Other Drained generators/equipment

Solid fractions from sand/oil/water

$\triangle$ Deconned Underground and Above Ground Tanks

Additional waste accepted at the Area 6 Hydrocarbon Landfill:

$\square$

Septic sludge $\square$ Rags

$\square$ Drained fuel filters (gas \& diesel)

Crushed non-teme plated oil filters

Plants

Soil

$\square$ Sludge from sand/oil/water separators

$\square$ PCBs below 50 parts per million

REQUIRED: WASTE GENERATOR SIGNATURE

Initials: (if initialed, no radiological clearance is necessary.)

The above mentioned waste was generated outside of a Controlled Waste Management Area (CWMA) and to the best of my knowledge, does not contain radiological materials.

To the best of my knowledge, the waste described above contains only those $m$ site. I have verified this through the waste characterization method identified a prohibited and allowable waste items. I have contacted Property Management : is approved for disposal in the landfill.

Print Name: Dan Tobiason

Signature:

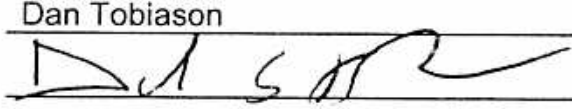

Note: "Food waste, office trash and animal carcasses do not require a radiologic must have signed removal certification statement with Load Verification."
Radiological Survey Release for Waste Disposal RCT Initials

This container/load meets the criteria for no added man-made radioactive material This container/load meets the criteria for Radcon Manual Table $\mathbf{4 . 2}$ release limits. This container/load is exempt from survey due to progess knowledge and origin.

SIGNATURE DATE: $5 / / 4108$

\section{SWO USE ONLY}

Load Weight (net from scale ofestimate? 15,000

$$
5 / 14108
$$

Signature of Certifier: $>$ in 


\section{$\begin{array}{llllll}\text { SWO USE (Select One) } & \text { AREA } & \square 23 & \square 6 & \square 9 & \square \text { LANDFILL }\end{array}$}

For waste characterization, approval, and/or assistance, contact Solid Waste Operation (SWO) at 5-7898.

\section{REQUIRED: WASTE GERERATOR INFORMATION}

(This form is for rolloffs, dump trucks, and other onsite disposal of materials.)

Waste Generator: Dan Tobiason

Phone Number: 295-6169

Location / Origin: T-Tunnel Lower Laydown Yard - CAU 481

Waste Category: (check one)

$\square$ Commercial

$\triangle$ industrial

Waste Type: $\triangle$ NTS

$\square$ Asbestos Containing Material

$\triangle$ FFACO-onsite

(check one)

Non-Putrescible

Environmental management

Pollution Prevention Category: (check one)

Pollution Prevention Category: (check one)

$\triangle$ Clean-Up

Method of Characterization: (check one)

$\bigotimes$ Sampling \& Analysis

$\square$ FFACO-offsite

WAC Exception

Prohibited Waste at all three Radioactive waste; RCRA waste; Hazardous waste; Free liquids, PCBs above TSCA regulatory

NTS landfills:

Additional Prohibited Waste

at the Area 9 U10C Landfill:

levels, and Medical wastes (needles, sharps, bloody clothing).

Sewage Sludge, Animal carcasses, Wet garbage (food waste); and Friable asbestos

\section{REQUIRED: WASTE CONTENTS ALLOWABLE WASTES}

Check all allowable wastes that are contained within this load:

NOTE: Waste disposal at the Area 6 Hydrocarbon Landfill must have come into contact with petroleum hydrocarbons or coolants, such as: gasoline (no benzene, lead); jet fuel; diesel fuel; lubricants and hydraulics; kerosene; asphaitic petroleum hydrocarbon; and ethylene glycol.

Acceptable waste at any NTS landfill: $\quad$ Paper

$\triangle$ Asphalt $\quad$ Metal $\quad$ Wood $\quad$ W Soil

$\triangle$ Plastic $\otimes$ Wire

$\triangle$ Cable

Cloth

$\square$ Rocks / unaltered geologic materials

$\triangle$ Empty containers

$\triangle$ Demolition debris

$\triangle$ Manufactured items: (swamp coolers, furniture, rugs, carpet, electronic components, PPE, etc.)
Additional waste accepted at the Area 23 Mercury Landfill:
Office Waste
$\square$ Food Waste
Animal Carcasses

$\square$ Asbestos

Friable

$\square$ Non-Friable (contact SWO if regulated load)

Quantity:

\section{Additional waste accepted at the Area 9 U10 c Landfill:}
Non-friable asbestos
Drained automobiles and military vehicles
Light ballasts (contact SWO)
Drained fuel filters (gas \& diesel)
Hydrocarbons (contact SWO)
Other
Drained generators/equipment
Solid fractions from sand/oil/water
$\triangle$ Deconned Underground and Above Ground Tanks

Additional waste accepted at the Area 6 Hydrocarbon Landfill:
Septic sludge
$\square$ Rags
Drained fuel filters (gas \& diesel)
Crushed non-teme plated oil filters
Plants
Soil
$\square$ Sludge from sand/oil/water separators
PCBs below 50 parts per million
REQUIRED: WASTE GENERATOR SIGNATURE

Initials: (if initialed, no radiological clearance is necessary.)

The above mentioned waste was generated outside of a Controlled Waste Management Area (CWMA) and to the best of my knowledge, does not contain radiological materials.

To the best of my knowledge, the waste described above contains only those materia site. I have verified this through the waste characterization method identified above prohibited and allowable waste items. I have contacted Property Management and hi is approved for disposal in the landfill.

Print Name: Dan Tobiason

Signature:
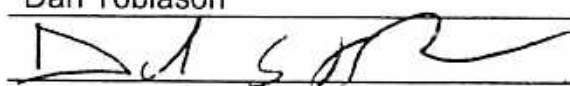

Note: "Food waste, office trash and animal carcasses do not require a radiological cle must have signed removal certification statement with Load Verification."

\section{SWO USE ONLY}

Load Weight (net from scale of estimate):
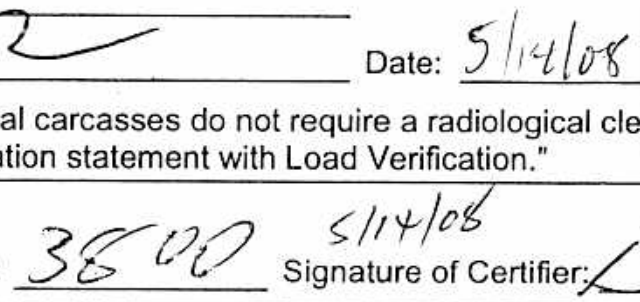

$5 / 14 / 08$

Signature of Certifier: $>$ ?

Radiological Survey Release for Waste Disposal RCT Initials

This container/load meets the criteria for no added man-made radioactive material

This container/load meets the criteria for Radcon Manual Table 4.2 release limits. This container/load is exempt from survey due to process knowledge and origin.

SIGNATURE: DATE: $5 /(2) / O$ BN-0646 (10/05) 
SWO USE (Select One) AREA For waste characterization, approval, and/or assistance, contact Solid Waste Operation (SWO) at 5-7898.

\section{REQUIRED: WASTE GERERATOR INFORMATION}

(This form is for rolloffs, dump trucks, and other onsite disposal of materials.)

Waste Generator: Dan Tobiason Phone Number: 295-6169

Location / Origin: T-Tunnel Lower Laydown Yard - CAU 481

Waste Category: (check one)

Waste Type:

(check one)

$\triangle$ NTS

Pollution Prevention Category: (check one)

Pollution Prevention Category: (check one)

Method of Characterization: (check one)

Prohibited Waste at all three

NTS landfills:

Additional Prohibited Waste at the Area 9 U10C Landfill: Commercial

$\square$ Putrescrible

$\square$ Asbestos Containing Material Environmental management

$\triangle$ Clean-Up

Sampling \& Analysis

$\triangle$ Process Knowledge

\ Industrial

$\triangle$ FFACO-onsite

$\square$ FFACO-offsite

$\triangle$ Defense Projects

$\square$ Routine levels, and Medical wastes (needles, sharps, bloody clothing)

Sewage Sludge, Animal carcasses, Wet garbage (food waste); and Friable asbestos

\section{REQUIRED: WASTE CONTENTS ALLOWABLE WASTES}

Check all allowable wastes that are contained within this load:

NOTE: Waste disposal at the Are

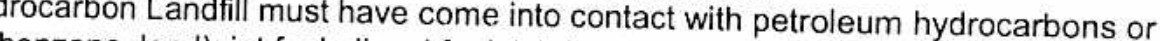
coolants, such as: gasoline (no benzene, lead); jet fuel; diesel fuel; lubricants and hydraulics; kerosene; asphaitic petroleum hydrocarbon; and ethylene glycol.

Acceptable waste at any NTS landfill:

$\triangle$ Asphalt $\quad$ Metal $\quad$ Wood $\quad$ Soil

凶 Plastic

$\bigotimes$ Wire

$\bigotimes$ Cable

$\otimes$ Cloth

$\square$ Rocks / unaltered geologic materials

$\triangle$ Rubber (excluding tires)

$\bigotimes$ Insulation (non-Asbestosform)

$\triangle$ Manufactured items: (swamp coolers, furniture, rugs, carpet, electronic components, PPE, etc.)

Additional waste accepted at the Area 23 Mercury Landfill: $\square$ Office Waste $\square$ Food Wast
$\square$ Asbestos
Friable
$\square$ Non-Friable (contact SWO if regulated load)
Quantity:

Additional waste accepted at the Area 9 U10c Landfill:

$\square$ Non-friable asbestos

$\square$ Light ballasts (contact SwO)

Hydrocarbons (contact SWO)

$\square$ Drained automobiles and military vehicles

Drained fuel filters (gas \& diesel)

Other Drained generators/equipment
Solid fractions from sand/oil/water

$\bigotimes$ Deconned Underground and Above Ground Tanks

\section{Additional waste accepted at the Area 6 Hydrocarbon Landfill:}

$\begin{array}{ll}\square \text { Septic sludge } & \square \text { Rags } \\ \square \text { Plants } & \square \text { Soil }\end{array}$ $\square$ Drained fuel filters (gas \& diesel)

$\square$ Sludge from sand/oil/water separators REQUIRED: WASTE GENERATOR SIGNATURE $\triangle$ Empty containers

$\triangle$ Demolition debris

$\bigotimes$ Cement \& concrete

Initials: (if initialed, no radiological clearance is necessary.)

The above mentioned waste was generated outside of a Controlled Waste Management Area (CWMA) and to the best nf m. knowledge, does not contain radiological materials.

To the best of my knowledge, the waste described above contains only those materials site. I have verified this through the waste characterization method identified above anc prohibited and allowable waste items. I have contacted Property Management and have is approved for disposal in the landfill.

Print Name: Dan Tobiason

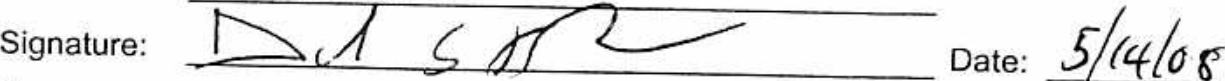

Note: "Food waste, office trash and animal carcasses do not require a radiological clearan must have signed removal certification statement with Load Verification."

Radiological Survey Release for Waste Disposal RCT Initials This container/load meets the criterial added man-made radioactive material for This container/load meets the criteria for Radcon Manual Table 4.2 release lim survey This container/load is exempt origin. due to progess

SIGNATURE: .........y appirances

\section{SWO USE ONLY}

Load Weight (net from scale or estimate): $\rightarrow 00$
$5 / 14 / 68$ Signature of Certifier 


$\begin{array}{llllll}\text { SWO USE (Select One) } & \text { AREA } & \square 23 & \square 6 & \square 9 & \square \text { LANDFILL }\end{array}$

For waste characterization, approval, and/or assistance, contact Solid Waste Operation (SWO) at 5-7898.

\section{REQUIRED: WASTE GERERATOR INFORMATION}

(This form is for rolloffs, dump trucks, and other onsite disposal of materials.)

Waste Generator: Dan Tobiason

Phone Number: 295-6169

Location / Origin: $\quad$ T-Tunnel Lower Laydown Yard - CAU 481

Waste Category: (check one)

Waste Type: $\triangle$ NTS

(check one)

Non-Putrescible

Pollution Prevention Category: (check one)

Pollution Prevention Category: (check one)

Method of Characterization: (check one)

Prohibited Waste at all three

NTS landfills:

Additional Prohibited Waste at the Area 9 U10C Landfill:

Radioactive waste; RCRA waste; Hazardous waste; Free liquids, PCBs above TSCA regulatory levels, and Medical wastes (needles, sharps, bloody clothing).

Sewage Sludge, Animal carcasses, Wet garbage (food waste); and Friable asbestos

REQUIRED: WASTE CONTENTS ALLOWABLE WASTES

Check all allowable wastes that are contained within this load:

NOTE: Waste disposal at the Area 6 Hydrocarbon Landfill must have come into contact with petroleum hydrocarbons or coolants, such as: gasoline (no benzene, lead); jet fuel; diesel fuel; lubricants and hydraulics; kerosene; asphaltic petroleum hydrocarbon; and ethylene glycol.

Acceptable waste at any NTS landfill: $\quad$ Paper $\quad \square$ Rocks / unaltered geologic materials

$\triangle$ Asphalt Metal

$\bigotimes$ Plastic $\bigotimes$ Wire

$\bigotimes$ Cable

$\otimes$ Soil

$\bigotimes$ Rubber (excluding tires)

Cloth

$\bigotimes$ Insulation (non-Asbestosform)

$\bigotimes$ Manufactured items: (swamp coolers, furniture, rugs, carpet, electronic components, PPE, etc.)

Additional waste accepted at the Area 23 Mercury Landfill: $\quad \square$ Office Waste $\square$ Food Wast

$\square$ Asbestos

$\square$ Friable

$\square$ Non-Friable (contact SWO if regulated load)

Quantity:

Additional waste accepted at the Area 9 U10c Landfill:
Non-friable asbestos
Drained automobiles and military vehicles
Light ballasts (contact SWO)
Drained fuel filters (gas \& diesel)

Hydrocarbons (contact SWO) $\bigotimes$ Other Drained generators/equipment
\ Empty containers

$\bigotimes$ Demolition debris

$\bigotimes$ Cement \& concrete
Animal Carcasses

Additional waste accepted at the Area 6 Hydrocarbon Landfill:
$\square$ Septic sludge
$\square$ Rags
$\square$ Drained fuel filters (gas \& diesel)
Crushed non-teme plated oil filters
Plants
Soil
$\square$ Sludge from sand/oil/water separators
$\square$ PCBs below 50 parts per million REQUIRED: WASTE GENERATOR SIGNATURE

Initials: (if initialed, no radiological clearance is necessary.)

The above mentioned waste was generated outside of a Controlled Waste Management Area (CWMA) and to the best of my knowledge, does not contain radiological materials.

To the best of my knowledge, the waste described above contains only those material site. I have verified this through the waste characterization method identified above a prohibited and allowable waste items. I have contacted Property Management and ha' is approved for disposal in the landfill.

Print Name: Dan Tobiason

Signature:
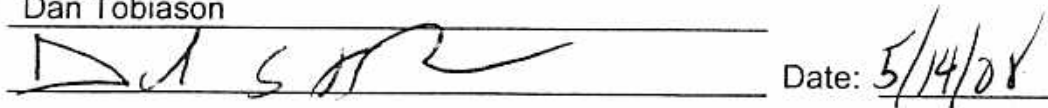

Note: "Food waste, office trash and animal carcasses do not require a radiological cle must have signed removal certification statement with Load Verification."
SWO USE ONLY

Load Weight (net from scale or estimate): $\angle \mathbb{O} 60$
$5 / 14 / 08$

Signature of Certifier:
RCT Initials Survey Release for Waste Disposal nitials

This container/load meets the criteria for no This conan-made radioactive material Radcontainer/load meets the criteria for This containual Table 4.2 release limits. due to process knowledge anpt from survey SIGNATURE: DATE: 


\title{
$\begin{array}{llllll}\text { SWO USE (Select One) } & \text { AREA } & \square 23 & \square 6 & \square 9 & \square \text { LANDFILL }\end{array}$
}

For waste characterization, approval, and/or assistance, contact Solid Waste Operation (SWO) at 5-7898.

\section{REQUIRED: WASTE GERERATOR INFORMATION}

(This form is for rolloffs, dump trucks, and other onsite disposal of materials.)

Waste Generator: Dan Tobiason

Phone Number: 295-6169

Location / Origin: T-Tunnel Lower Laydown Yard - CAU 481

Waste Category: (check one)

Waste Type: $\triangle$ NTS

(check one)

Non-Putrescible

Pollution Prevention Category: (check one)

Pollution Prevention Category: (check one)

Method of Characterization: (check one)

Prohibited Waste at all three

NTS landfills:

Additional Prohibited Waste

at the Area 9 U10C Landfill:

\begin{abstract}
Radioactive waste; RCRA waste; Hazardous waste; Free liquids, PCBs above TSCA regulatory levels, and Medical wastes (needles, sharps, bloody clothing).
\end{abstract}

Sewage Sludge, Animal carcasses, Wet garbage (food waste); and Friable asbestos

REQUIRED: WASTE CONTENTS ALLOWABLE WASTES

Check all allowable wastes that are contained within this load:

NOTE: Waste disposal at the Area 6 Hydrocarbon Landfill must have come into contact with petroleum hydrocarbons or coolants, such as: gasoline (no benzene, lead); jet fuel; diesel fuel; lubricants and hydraulics; kerosene; asphaltic petroleum hydrocarbon; and ethylene glycol.

Acceptable waste at any NTS landfill

$\triangle$ Asphalt $\quad$ Metal $\quad$ Wood

$\triangle$ Paper

$\otimes$ Soil

$\square$ Rocks / unaltered geologic materials

Q Plastic

$\triangle$ Cable

$\triangle$ Cloth

$\triangle$ Rubber (excluding tires)

$\triangle$ Insulation (non-Asbestosform)

$\bigotimes$ Empty containers

$\triangle$ Demolition debris

$\otimes$ Cement \& concrete

$\bigotimes$ Manufactured items: (swamp coolers, furniture, rugs, carpet, electronic components, PPE, etc.)

\section{Additional waste accepted at the Area 23 Mercury Landfill: $\square$ Office Waste}

$\square$ Asbestos

$\square$ Friable

$\square$ Non-Friable (contact SWO if regulated load)

Food Waste

Animal Carcasses

Additional waste accepted at the Area 9 U10c Landfill:
Non-friable asbestos
Drained automobiles and military vehicles
Light ballasts (contact SwO)
Drained fuel filters (gas \& diesel)
Hydrocarbons (contact SWO)
Other

Drained generators/equipment

Quantity:

\section{Additional waste accepted at the Area 6 Hydrocarbon Landfill:}
Septic sludge
$\square$ Rags
Plants
Soil
$\square$ Drained fuel filters (gas \& diesel)
$\square$ Sludge from sand/oil/water separators
Crushed non-teme plated oil filters

$\square$ Solid fractions from sand/oil/water
$\square$ Deconned Underground and Above
Ground Tanks REQUIRED: WASTE GENERATOR SIGNATURE

Initials: (if initialed, no radiological clearance is necessary.)

The above mentioned waste was generated outside of a Controlled Waste Management Area (CWMA) and to the best of my knowledge, does not contain radiological materials.

To the best of my knowledge, the waste described above contains only those mal site. I have verified this through the waste characterization method identified abc prohibited and allowable waste items. I have contacted Property Management an is approved for disposal in the landfill.

Print Name: Dan Tobiason

Signature:
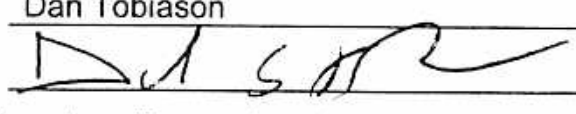

Note: "Food waste, office trash and animal carcasses do not require a radiological must have signed removal certification statement with Load Verification."

SWO USE ONLY

Load Weight (net from scale or estimate):
Date: $5 / 14 / 08$

Radiological Survey Release for Waste Disposal RCT Initials

This container/load meets the criteria for no added man-made radioactive material This container/load meets the criteria for Radcon Manual Table 4.2 release limits. This container/load is exempt from survey due to process knowledge and origin.

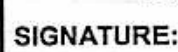

$$
5 / 14 / 08
$$

Signature of Certifier. 
SWO USE (Select One) AREA 23

Х9

$\triangle$ LANDFILL

For waste characterization, approval, and/or assistance, contact Solid Waste Operation (SWO) at 5-7898.

REQUIRED: WASTE GERERATOR INFORMATION

(This form is for rolloffs, dump trucks, and other onsite disposal of materials.)

Waste Generator: Dan Tobiason Phone Number: 295-6169

Location / Origin: T-Tunnel Lower Laydown Yard - CAU 481

Waste Category: (check one)

Waste Type: $\square$ NTS

(check one)

$\square$ Non-Putrescible

Pollution Prevention Category: (check one)

Pollution Prevention Category: (check one)

Method of Characterization: (check one)

Prohibited Waste at all three

NTS landfills:

Additional Prohibited Waste

at the Area 9 U10C Landfill:

$\square$ Commercial
$\square$ Putrescrible
$\square$ Asbestos Containing Material
$\square$ Environmental management
$\square$ Clean-Up
$\triangle$ Sampling \& Analysis

$\triangle$ Sampling \& Analysis $\triangle$ Industrial

$\triangle$ FFACO-onsite $\square$ WAC Exception

$\square$ FFACO-offsite Historic DOE/NV YMP

$\square$ Routine

$\triangle$ Process Knowledge $\square$ Contents

Radioactive waste; RCRA waste; Hazardous waste; Free liquids, PCBs above TSCA regulatory levels, and Medical wastes (needles, sharps, bloody clothing).

Sewage Sludge, Animal carcasses, Wet garbage (food waste); and Friable asbestos

REQUIRED: WASTE CONTENTS ALLOWABLE WASTES

Check all allowable wastes that are contained within this load:

NOTE: Waste disposal at the Area 6 Hydrocarbon Landfill must have come into contact with petroleum hydrocarbons or coolants, such as: gasoline (no benzene, lead); jet fuel; diesel fuel; lubricants and hydraulics; kerosene; asphaltic petroleum hydrocarbon; and ethylene glycol.

Acceptable waste at any NTS landfill:

$\triangle$ Asphalt $\quad$ Metal $\quad$ Wood

$\triangle$ Paper

$\bigotimes$ Soil

$\square$ Rocks / unaltered geologic materials

$\bigotimes$ Rubber (excluding tires)

$\bigotimes$ Plastic $\square$ Wire

$\triangle$ Cable

Cloth

$\bigotimes$ Insulation (non-Asbestosform)

$\bigotimes$ Empty containers

$\bigotimes$ Demolition debris

$\triangle$ Manufactured items: (swamp coolers, furniture, rugs, carpet, electronic components, PPE, etc.)
Additional waste accepted at the Area 23 Mercury Landfill:
$\square$ Office Waste
$\square$ Food Waste
Animal Carcasses
$\square$ Asbestos
$\square$ Friable
Non-Friable (contact SWO if regulated load)
Quantity:

Additional waste accepted at the Area 9 U10c Landfill:
Non-friable asbestos
Light ballasts (contact SWO)
Drained automobiles and military vehicles
Drained fuel filters (gas \& diesel)

Hydrocarbons (contact SWO) $\bigotimes$ Other Drained generators/equipment

Solid fractions from sand/oil/water

$\bigotimes$ Deconned Underground and Above Ground Tanks

Additional waste accepted at the Area 6 Hydrocarbon Landfill:
Septic sludge
Plants
$\square$ Rags
$\square$ Soil

$\square$ Drained fuel filters (gas \& diesel)

$\square$ Sludge from sand/oil/water separators REQUIRED: WASTE GENERATOR SIGNATURE

Crushed non-teme plated oil filters PCBs below 50 parts per million

Initials: (if initialed, no radiological clearance is necessary.)

The above mentioned waste was generated outside of a Controlled Waste Management Area (CWMA) and to the best of my knowledge, does not contain radiological materials.

To the best of my knowledge, the waste described above contains only those ma site. I have verified this through the waste characterization method identified abc prohibited and allowable waste items. I have contacted Property Management an is approved for disposal in the landfill.

Print Name: Dan Tobiason

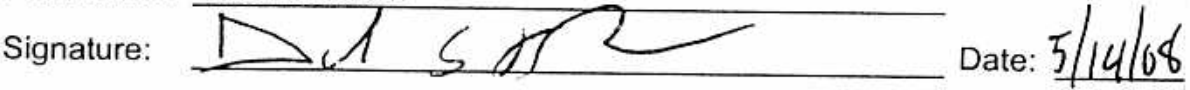

Note: "Food waste, office trash and animal carcasses do not require a radiological must have signed removal certification statement with Load Verification."

Radiological Survey Release for Waste Disposal RCT Initials

This container/load meets the criteria for no added man-made radioactive material This container/load meets the criteria for Radcon Manual Table 4.2 release limits. This container/load is exempt from survey due to process knowledge and origin.

\section{SIGNATURE:} DATE: $5 / 14 \sqrt{108}$

\section{SWO USE ONLY}

Load Weight (net from (scale or estimate): $3,2-0$

$$
5 /, 5 / 08
$$

Signature of Certifier 


\begin{tabular}{llllll}
\hline SWO USE (Select One) & AREA & $\square 23$ & $\square 6$ & AR & L LANDFILL
\end{tabular}

For waste characterization, approval, and/or assistance, contact Solid Waste Operation (SWO) at 5-7898. REQUIRED: WASTE GERERATOR INFORMATION

(This form is for rolloffs, dump trucks, and other onsite disposal of materials.)

Waste Generator: Dan Tobiason Phone Number: 295-6169

Location / Origin: T-Tunnel Lower Laydown Yard - CAU 481

Waste Category: (check one)

Waste Type:

(check one)

NTS

Non-Putrescible

Pollution Prevention Category: (check one)

Pollution Prevention Category: (check one)

Method of Characterization: (check one)

Prohibited Waste at all three

NTS landfills:

Additional Prohibited Waste

at the Area 9 U10C Landfill:

\section{Radioactive waste; RCRA waste; Hazardous waste; Free liquids, PCBs above TSCA regulatory} levels, and Medical wastes (needles, sharps, bloody clothing).

Sewage Sludge, Animal carcasses, Wet garbage (food waste); and Friable asbestos

REQUIRED: WASTE CONTENTS ALLOWABLE WASTES

Check all allowable wastes that are contained within this load:

NOTE: Waste disposal at the Area 6 Hydrocarbon Landfill must have come into contact with petroleum hydrocarbons or coolants, such as: gasoline (no benzene, lead); jet fuel; diesel fuel; lubricants and hydraulics; kerosene; asphaltic petroleum hydrocarbon; and ethylene glycol.

Acceptable waste at any NTS landfill: $\triangle$ Pape

\Asphalt $\bigotimes$ Metal $\bigotimes$ Wood

Soil

$\square$ Rocks / unaltered geologic materials

$\triangle$ Plastic $\quad$ Wire

Cable

$\bigotimes$ Cloth

$\bigotimes$ Rubber (excluding tires)

$\bigotimes$ Insulation (non-Asbestosform)

$\triangle$ Empty containers

$\bigotimes$ Demolition debris

$\otimes$ Cement \& concrete

$\bigotimes$ Manufactured items: (swamp coolers, furniture, rugs, carpet, electronic components, PPE, etc.)
Additional waste accepted at the Area 23 Mercury Landfill:
$\square$ Office Waste
$\square$ Food Waste
Animal Carcasses

$\square$ Asbestos

Friable

$\square$ Non-Friable (contact SWO if regulated load)

Quantity:

Additional waste accepted at the Area 9 U10c Landfill:

$\square$ Non-friable asbestos

Light ballasts (contact SWO)

Drained automobiles and military vehicles

Hydrocarbons (contact SWO)

Drained fuel filters (gas \& diesel)

Solid fractions from sand/oil/water

$\bigotimes$ Deconned Underground and Above Ground Tanks

Additional waste accepted at the Area 6 Hydrocarbon Landfill:
$\square$ Septic sludge
$\square$ Rags
$\square$ Drained fuel filters (gas \& diesel)
Crushed non-teme plated oil filters
Plants
Soil
$\square$ Sludge from sand/oil/water separators
REQUIRED: WASTE GENERATOR SIGNATURE
PCBs below 50 parts per million

Initials:

(if initialed, no radiological clearance is necessary.)

The above mentioned waste was generated outside of a Controlled Waste Management Area (CWMA) and to the best of my knowledge, does not contain radiological materials.

To the best of my knowledge, the waste described above contains only those materials that are allowed for diennn $\ldots . .$. site. I have verified this through the waste characterization method identified above : prohibited and allowable waste items. I have contacted Property Management and ha is approved for disposal in the landfill.

Print Name: Dan Tobiason

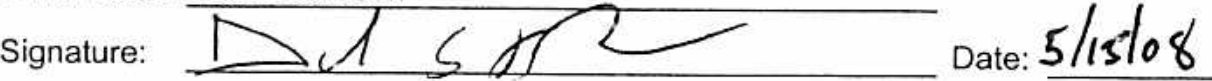

Note: "Food waste, office trash and animal carcasses do not require a radiological clea must have signed removal certification statement with Load Verification."

\section{SWO USE ONLY}

Load Weight (net from scale or estimate):

$$
5 / 15 / 08
$$

Signature of Certifier:
Radiological Survey Release for Waste Disposal RCT Initials meets the criteria for no This container/load meactive material added man-made radioactive material for This container/load meets the criteriase limits. Radcon Manual Table 4.2 release fim survey This container/load is exempt from due to progess knowledge and origin. 
For waste characterization, approval, and/or assistance, contact Solid Waste Operation (SWO) at 5-7898.

\section{REQUIRED: WASTE GERERATOR INFORMATION}

(This form is for rolloffs, dump trucks, and other onsite disposal of materials.)

Waste Generator: Dan Tobiason

Phone Number: 295-6169

Location / Origin: T-Tunnel Lower Laydown Yard - CAU 481

Waste Category: (check one)

Waste Type:

(check one)

¿ NTS

Pollution Prevention Category: (check one)

Pollution Prevention Category: (check one)

Method of Characterization: (check one)

$\square$ Commercial
$\square$ Putrescrible
$\square$ Asbestos Containing Material
$\square$ Environmental management
$\square$ Clean-Up
$\square$ Sampling \& Analysis

$\bigotimes$ Industrial

$\triangle$ FFACO-onsite

$\square$ FFACO-offsite

$\bigotimes$ Defense Projects

$\square$ Routine

$\triangle$ Process Knowledge $\square$ Contents

Prohibited Waste at all three NTS landfills:

Additional Prohibited Waste at the Area 9 U10C Landfill: levels, and Medical wastes (needles, sharps, bloody clothing)

Sewage Sludge, Animal carcasses, Wet garbage (food waste); and Friable asbestos

\section{REQUIRED: WASTE CONTENTS ALLOWABLE WASTES}

Check all allowable wastes that are contained within this load:

NOTE: Waste disposal at the Area 6 Hydrocarbon Landfill must have come into contact with petroleum hydrocarbons or coolants, such as: gasoline (no benzene, lead); jet fuel; diesel fuel; lubricants and hydraulics; kerosene; asphaltic petroleum hydrocarbon; and ethylene glycol.

Acceptable waste at any NTS landfill:

$\bigotimes$ Asphalt

$\triangle$ Metal

Wood

$\triangle$ Paper

$\bigotimes$ Plastic

$\bigotimes$ Wire

$\bigotimes$ Cable

$\bigotimes$ Soil

$\triangle$ Cloth

$\square$ Rocks / unaltered geologic materials

$\triangle$ Rubber (excluding tires)

$\bigotimes$ Insulation (non-Asbestosform) $\bigotimes$ Empty containers

Demolition debris

$\bigotimes$ Cement \& concrete

$\bigotimes$ Manufactured items: (swamp coolers, furniture, rugs, carpet, electronic components, PPE, etc.)

Additional waste accepted at the Area 23 Mercury Landfill: $\quad \square$ Office Waste

Asbestos

Friable

$\square$ Non-Friable (contact SWO if regulated load)

$\square$ Food Waste Quantity:
Additional waste accepted at the Area 9 U10c Landfill:

$\square$ Non-friable asbestos

Light ballasts (contact SWO)

Hydrocarbons (contact SWO)

Drained automobiles and military vehicles

Drained fuel filters (gas \& diesel)

Other Drained generators/equipment
Solid fractions from sand/oil/water

$\bigotimes$ Deconned Underground and Above Ground Tanks

Additional waste accepted at the Area 6 Hydrocarbon Landfill:
$\square$ Septic sludge
$\square$ Rags
$\square$ Drained fuel filters (gas \& diesel)
Plants
Soil
Sludge from sand/oil/water separators
Crushed non-teme plated oil filters PCBs below 50 parts per million REQUIRED: WASTE GENEF

Initials: (if initialed, no radiological clearance is necessar)

The above mentioned waste was generated outside of a Controlled knowledge, does not contain radiological materials.

To the best of my knowledge, the waste described above contains o site. I have verified this through the waste characterization method prohibited and allowable waste items. I have contacted Property $\mathrm{Ma}$ is approved for disposal in the landfill.

Radiological Survey Release for Waste Disposal RCT Initials

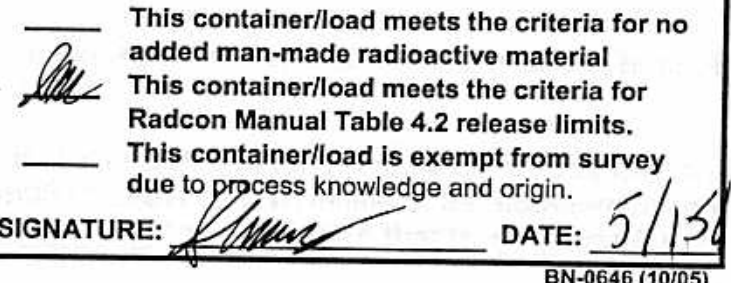

Print Name: Dan Tobiason

Signature:
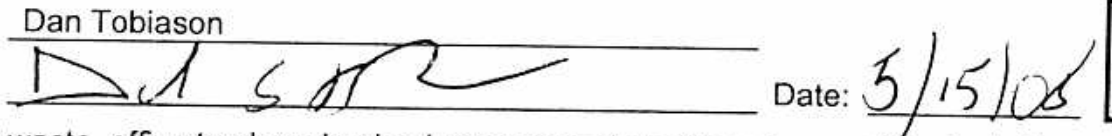

If applicable, place FRM-0646

"Radiological Release Sticker" here. Onsite use only. Note: "Food waste, office trash and animal carcasses do not require a radiological clearance. Freon-containing appliances
must have signed removal certification statement with Load Verification."

\section{SWO USE ONLY}

Load Weight (net from scale or estimate): 3200
$5 / 15 / 08$ Signature of Certifier: $\longrightarrow$

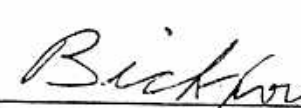


For waste characterization, approval, and/or assistance, contact Solid Waste Operation (SWO) at 5-7898.

\section{REQUIRED: WASTE GERERATOR INFORMATION}

(This form is for rolloffs, dump trucks, and other onsite disposal of materials.)

Waste Generator: Dan Tobiason

Phone Number: 295-6169

Location / Origin: T-Tunnel Lower Laydown Yard - CAU 481

Waste Category: (check one)

Waste Type: $\triangle$ NTS

(check one)

$\square$ Non-Putrescible

Pollution Prevention Category: (check one)

Pollution Prevention Category: (check one)

Method of Characterization: (check one)

Prohibited Waste at all three

NTS landfills:

Additional Prohibited Waste

at the Area 9 U10C Landfill:

Radioactive waste; RCRA waste; Hazardous waste; Free liquids, PCBs above TSCA regulatory levels, and Medical wastes (needles, sharps, bloody clothing).

Sewage Sludge, Animal carcasses, Wet garbage (food waste); and Friable asbestos

\section{REQUIRED: WASTE CONTENTS ALLOWABLE WASTES}

Check all allowable wastes that are contained within this load:

NOTE: Waste disposal at the Area 6 Hydrocarbon Landfill must have come into contact with petroleum hydrocarbons or coolants, such as: gasoline (no benzene, lead); jet fuel; diesel fuel; lubricants and hydraulics; kerosene; asphaltic petroleum hydrocarbon; and ethylene glycol.

Acceptable waste at any NTS landfill: $\square$ Paper

$\triangle$ Asphalt $\triangle$ Metal $\triangle$ Wood $\triangle$ Soil

$\triangle$ Plastic $\quad$ Wire $\quad$ Cable $\quad$ Cloth

$\square$ Rocks / unaltered geologic materials

$\triangle$ Rubber (excluding tires)

$\triangle$ Insulation (non-Asbestosform) $\triangle$ Empty containers

$\triangle$ Demolition debris

$\bigotimes$ Cement \& concrete

$\triangle$ Manufactured items: (swamp coolers, furniture, rugs, carpet, electronic components PPE, etc)

Additional waste accepted at the Area 23 Mercury Landfill: $\square$ Office Waste

$\square$ Asbestos

Friable

$\square$ Non-Friable (contact SWO if regulated load)

Additional waste accepted at the Area $9010 \mathrm{c}$ Landfill:

$\square$ Non-friable asbestos

$\square$ Light ballasts (contact SWO)

$\square$ Drained automobiles and military vehicles

$\square$ Drained fuel filters (gas \& diesel)

Hydrocarbons (contact SWO)

\section{$\square$ Septic sludge \\ Plants \\ $\square$ Rags
$\square$ Soil \\ $\square$ Drained fuel filters (gas \& diesel) $\square$ Sludge from sand/oil/water separators REQUIRED: WASTE GENERATI}

Initials: (if initialed, no radiological clearance is necessary.)

The above mentioned waste was generated outside of a Controlled Was knowledge, does not contain radiological materials.

To the best of my knowledge, the waste described above contains only site. I have verified this through the waste characterization method ider prohibited and allowable waste items. I have contacted Property Manag is approved for disposal in the landfill.

Print Name: Dan Tobiason

Signature:

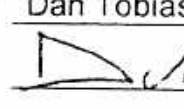

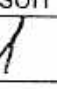

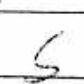

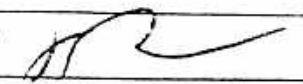

Date:

\section{Note: "Food waste, office trash and animal carcasses do not require a radiological clearance. Freon-containing appliances} must have signed removal certification statement with Load Verification."

\section{SWO USE ONLY}

Load Weight (net from scale or estimate
$5 / 27 / 08$

Signature of Certifier: $\square$ Food Waste

Quantity:
Animal Carcasses

Solid fractions from sand/oil/water

$\otimes$ Deconned Underground and Above Ground Tanks

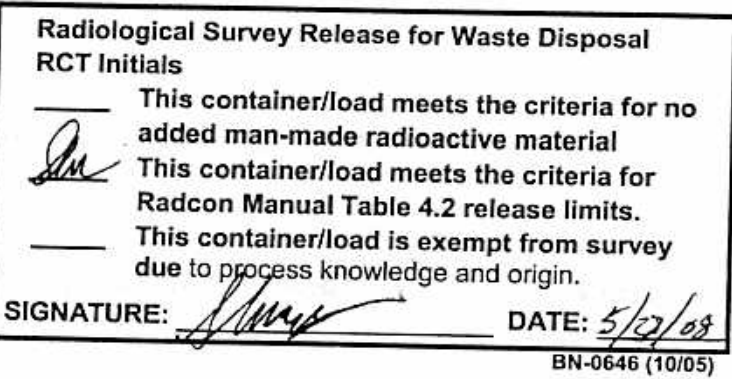

If applicable, place FRM-0646,

"Radiological Release Sticker" here. Onsite use only.

Crushed non-teme plated oil filters PCBs below 50 parts per million 


\begin{tabular}{|llllll}
\hline SWO USE (Select One) & AREA & $\square 23$ & $\square 6$ & $\not 9$ & LANDFIL \\
\hline For waste characterization, approval, and/or assistance, contact Solid Waste Operation (SWO) at 5-7898.
\end{tabular}

For waste characterization, approval, and/or assistance, contact Solid Waste Operation (SWO) at 5-7898.

\section{REQUIRED: WASTE GERERATOR INFORMATION}

Waste Generator:

(This form is for rolloffs, dump trucks, and other onsite disposal of materials.)

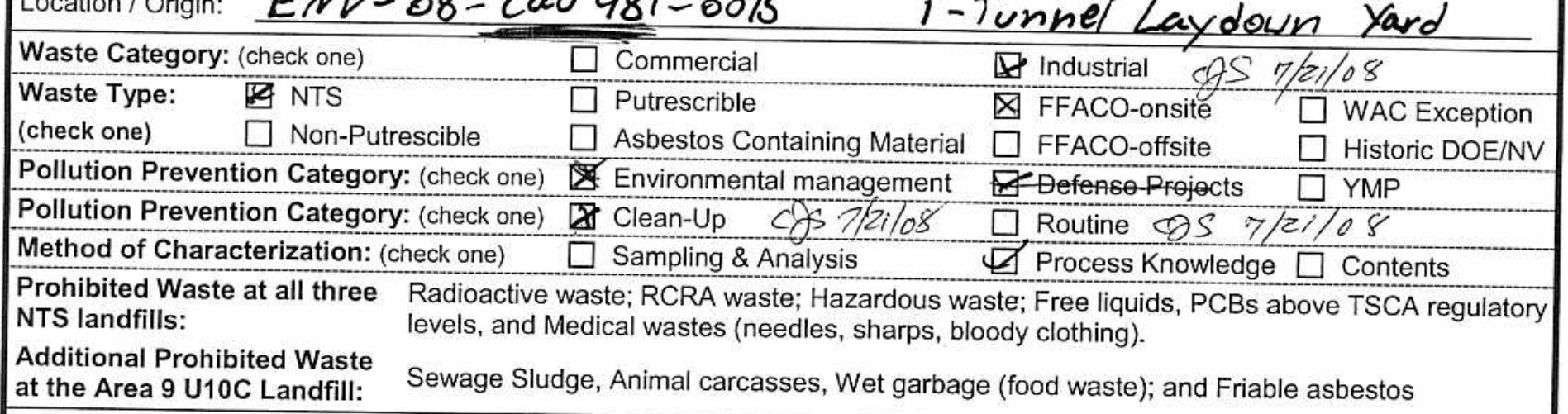

Christopher MGGovin
EM-08-cau 481-0015 T-Tunnel Laydown Yard

\section{REQUIRED: WASTE CONTENTS ALLOWABLE WASTES}

Check all allowable wastes that are contained within this load:

NOTE: Waste disposal at the Area 6 Hydrocarbon Landfill must have come into contact with petroleum hydrocarbons or coolants, such as: gasoline (no benzene, lead); jet fuel; diesel fuel; lubricants and hydraulics; kerosene; asphaltic petroleum hydrocarbon; and ethylene glycol.

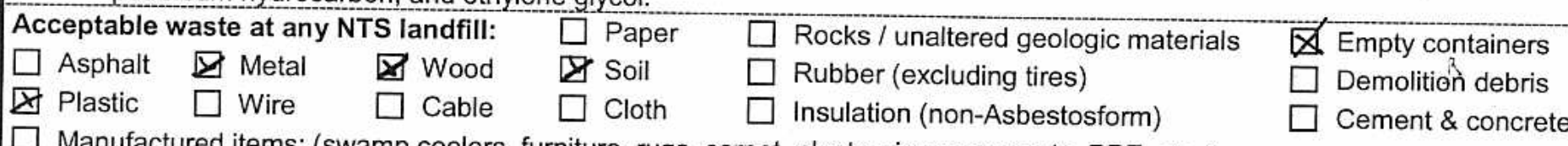
$\square$ Manufactured items: (swamp coolers, furniture, rugs, carpet, electronic components, PPE, etc.)

Additional waste accepted at the Area 23 Mercury Landfill: $\square$ Office Waste $\square$ Asbestos $\square$ Friable $\square$ Non-Friable (contact SWO if regulated load) Quantity:

Additional waste accepted at the Area 9 U10c Landfill:

$\square$ Non-friable asbestos

$\square$ Light ballasts (contact SwO)

Hydrocarbons (contact SWO)

$\square$ Drained automobiles and military vehicles

$\square$ Drained fuel filters (gas \& diesel)

Other
Solid fractions from sand/oil/water

Deconned Underground and Above Ground Tanks

Additional waste accepted at the Area 6 Hydrocarbon Landfill:

\begin{tabular}{ll}
$\square$ Septic sludge & $\square$ Rags \\
$\square$ Plants & $\square$ Soil \\
\hline
\end{tabular}

Initials: (if initialed, no radiological clearance is necessa

The above mentioned waste was generated outside of a Controlled knowledge, does not contain radiological materials.

To the best of my knowledge, the waste described above contains site. I have verified this through the waste characterization methoc prohibited and allowable waste items. I have contacted Property M is approved for disposal in the landfill.

Print Name: Christopler McGowin Signature: Christigher Mrowih

Note: "Food waste, office trash and animal carcasses do not require a radiological cleara must have signed removal certification statement with Load Verification."

LWO USE ONLY $7 / 17 / 08$ Signature of Certifier. $x$, on
Radiological Survey Release for Waste Disposal RCT Initials

This container/load meets the criteria for no added man-made radioactive material This container/load meets the criteria for Radcon Manual Table 4.2 release limits. This container/load is exempt from survey due to process $\mathrm{kng}$ 价edge and origin.
DATE: $\geq 7-16-00$ FRM-0646 (08/06) lent
If applicable, place FRM-0646, "Radiological Release Sticker" here. Onsite use only. 
CAU 481 Closure Report

Section: Appendix B

Revision: 0

Date: November 2008

\section{LOW-LEVEL WASTE}


CAU 481 Closure Report

Section: Appendix B

Revision: 0

Date: November 2008

THIS PAGE INTENTIONALLY LEFT BLANK 
Certificate of Disposal

This is to certify that the, Waste Stream No., LRY5LLFY07002 package numbers 08L019, 08L020, 08L021, 08L022, 08L023, and 08L036 were shipped and received at the Nevada Test Site Radioactive Waste Management Complex in Area 5 for disposal as stated below.

Theresa Hale

Shipped by

Thereat Hale

Signature

Nancy ETheridge

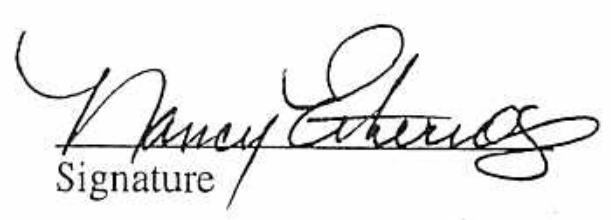

NSTec Waste Generator Services

Organization

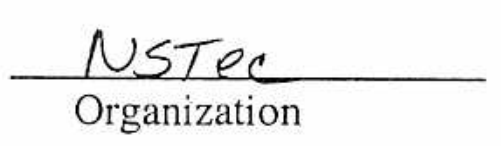

Senior Technical Staff

Title

$\frac{7-8.08}{\text { Date }}$

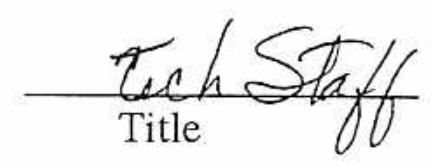

$\frac{7.8 .08}{\text { Date }}$ 
Certificate of Disposal

This is to certify that the, Waste Stream No., LRY5LLFY07002 package number 08L031, was shipped and received at the Nevada Test Site Radioactive Waste Management Complex in Area 5 for disposal as stated below.

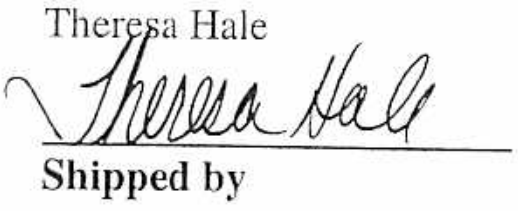

Yhereen Hale

Nancy ETheriogs

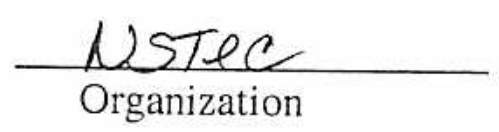

Senior Technical Staff

Title
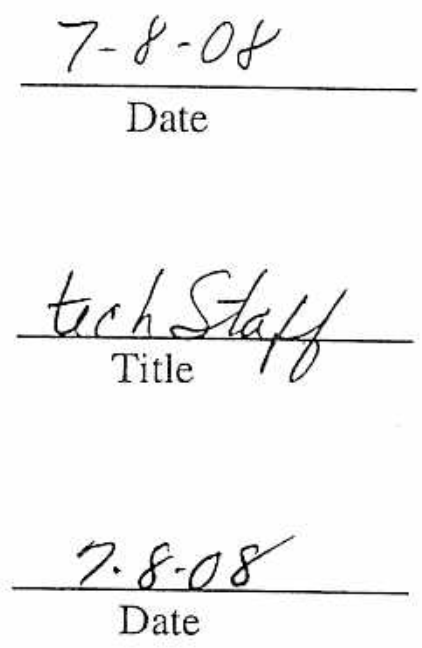


\section{Certificate of Disposal}

This is to certify that the Waste Stream No. LRY5LLFY07002 package numbers 08L024 and 08L030, were shipped and received at the Nevada Test Site, Area 5 Radioactive Waste Management Complex for disposal as stated below.

Theresa Hale

Shipped by

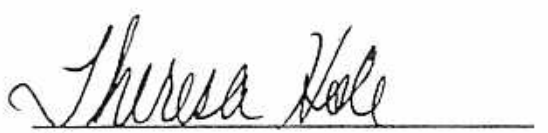

Signature

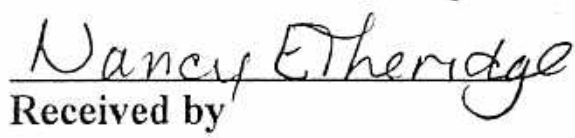

$\frac{\text { NSTeC }}{\text { Organization }}$

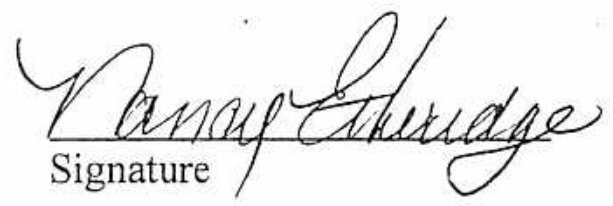

WGS

Organization
Senior Technical Support

Title
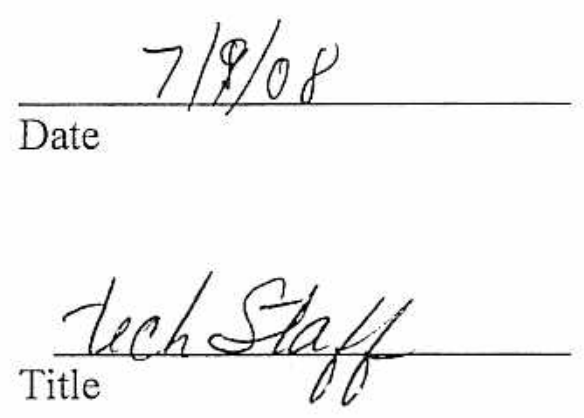

Date 7.9 .08 
Certificate of Disposal

This is to certify that the Waste Stream No. LRY5LLFY07002 package numbers 08L025 and 08L032, were shipped and received at the Nevada Test Site, Area 5 Radioactive Waste Management Complex for disposal as stated below.

Theresa Hale

Shipped by
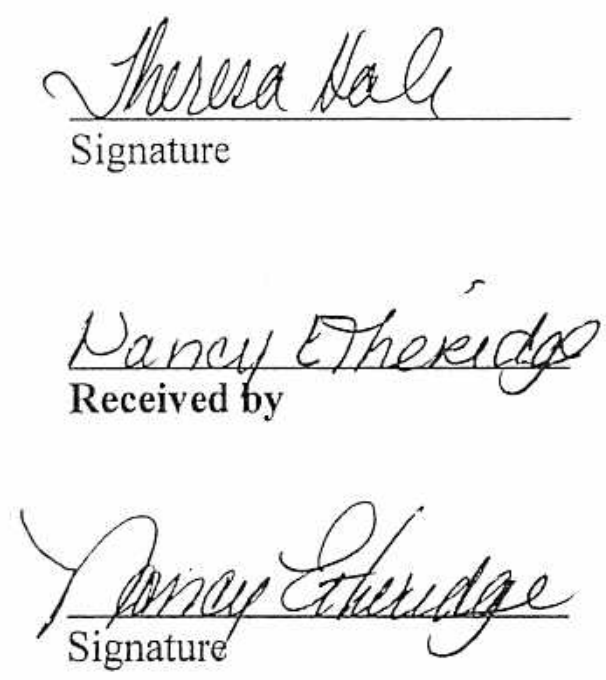

$\frac{\text { WaS }}{\text { Organization }}$

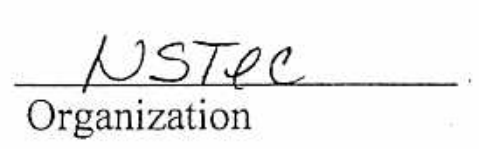

Senior Technical Support Title

$7 / 9 / 08$

Date

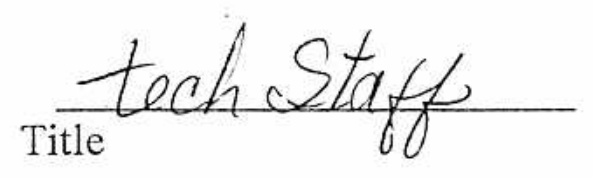

Date 7.9 .08 
Certificate of Disposal

This is to certify that the Waste Stream No. LRY 5LLFY07002 package numbers 08L026. 08L035, 08L037, 710907, and 710915 were shipped and received at the Nevada Test Site, Area 5 Radioactive Waste Management Complex for disposal as stated below.

$\underline{\text { Ken Courville }}$

Shipped by

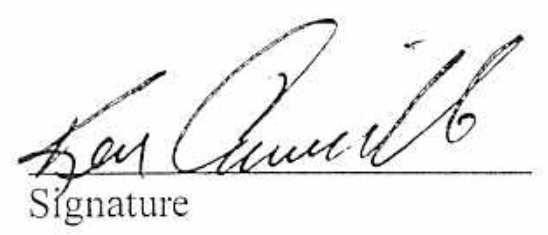

$\frac{\text { Bunt on Fro Se }}{\text { Received by }}$

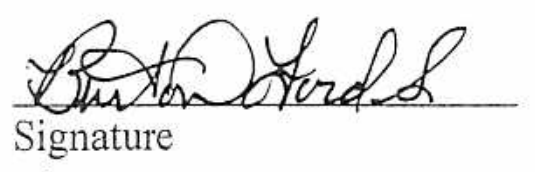

WaS

Organization

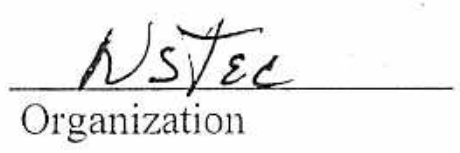

Organization
Senior Scientist

Title

$7-10^{-08}$

Date

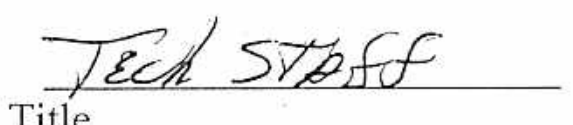

Title

Date $7 / 1 \phi / \phi 8$ 


\section{Certificate of Disposal}

This is to certify that the Waste Stream No. LRY5LLFY07002 package numbers 08L027. 08L033, 08L038, and 08L039, were shipped and received at the Nevada Test Site, Area 5 Radioactive Waste Management Complex for disposal as stated below.

Theresa Hale

Shipped by

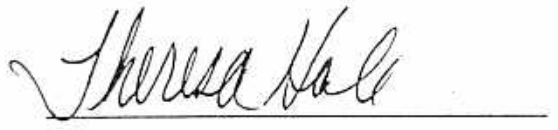

Signature

BuRTEN FORDSR Received by

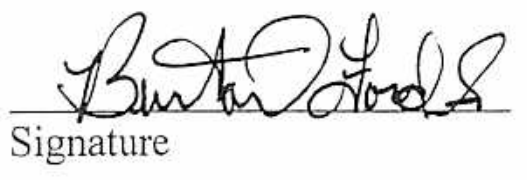

WGS

Organization

Senior Technical Support

Title

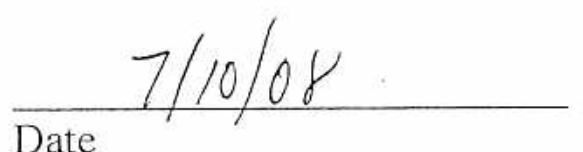

Date

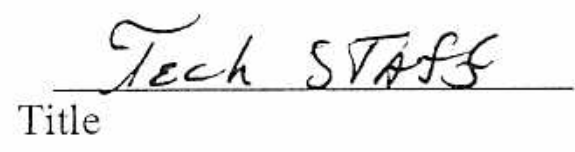

Date $7 / 20 / 075$ 
Certificate of Disposal

This is to certify that the Waste Stream No. LRY5LLFY07002 package numbers 08L034 and 08L042, were shipped and received at the Nevada Test Site, Area 5 Radioactive Waste Management Complex for disposal as stated below.

Ken Courville

Shipped by

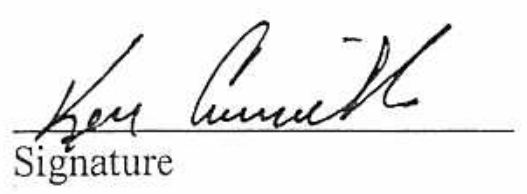

Nancy ETherege
Received by

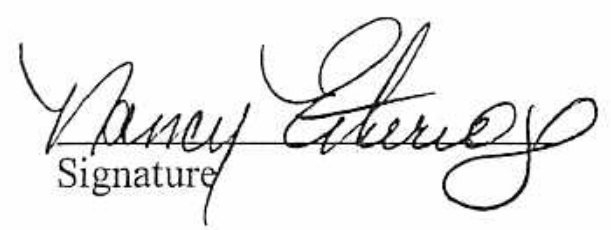

$\frac{\text { WaS }}{\text { Organization }}$

$\frac{\text { dUsted }}{\text { Organization }}$
Senior Scientist

Title

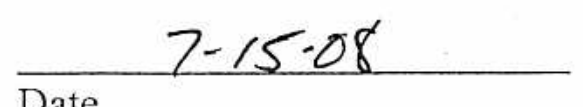

Date

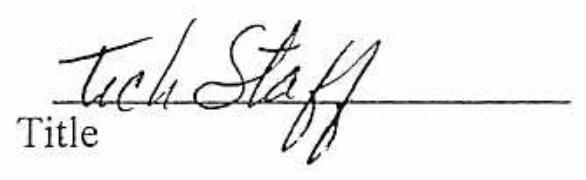

Date $7 \cdot 15 \cdot 08$ 
Certificate of Disposal

This is to certify that the Waste Stream No. LRY5LLFY07002 package numbers 08 L040 and 08L041, were shipped and received at the Nevada Test Site. Area 5 Radioactive Waste Management Complex for disposal as stated below.

Ken Courville

Shipped by

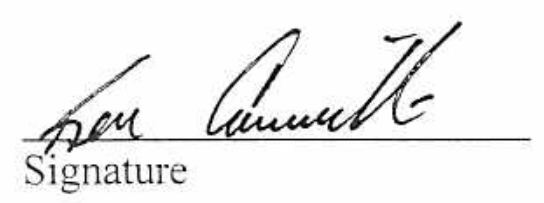

Button FORD Se

Received by

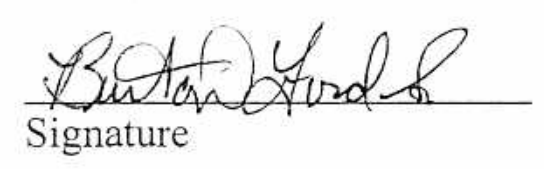

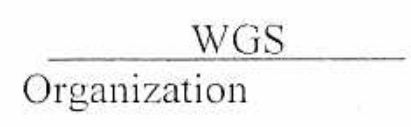

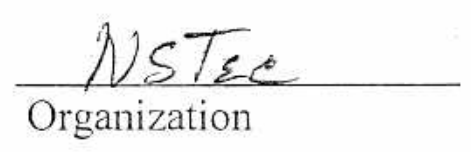

Senior Scientist

Title
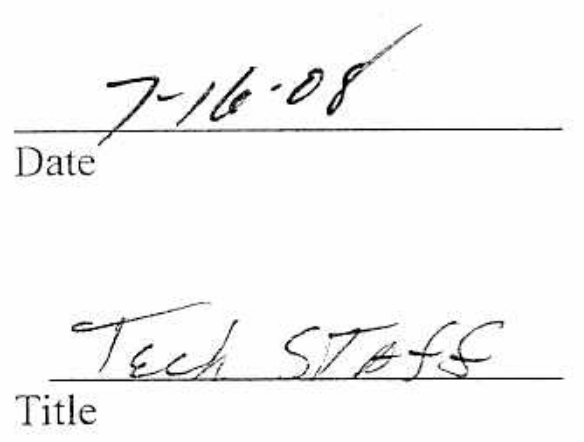

Date $3 / 16 / 108$ 


\section{Certificate of Disposal}

This is to certify that the Waste Stream No. LRY5LLFY07002 package number 204653 was shipped and received at the Nevada Test Site. Area 5 Radioactive Waste Management Complex for disposal as stated below.

Ken Courville Shipped by
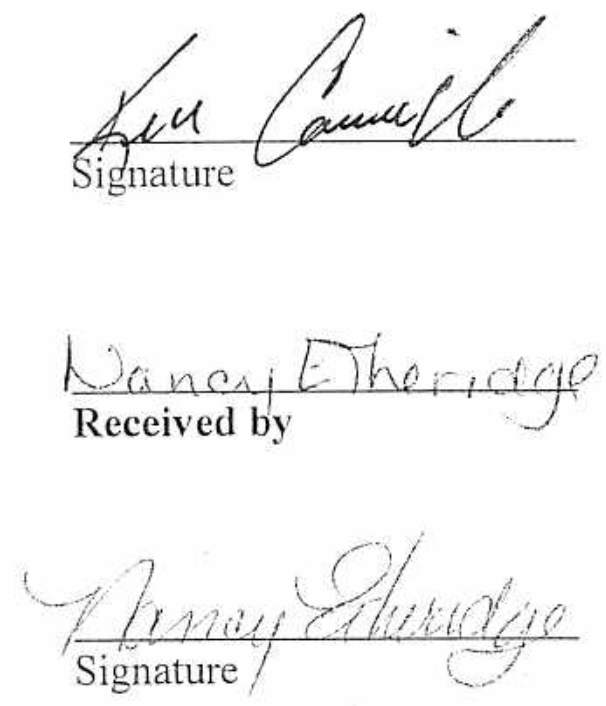

$\frac{\text { WGS }}{\text { Organization }}$
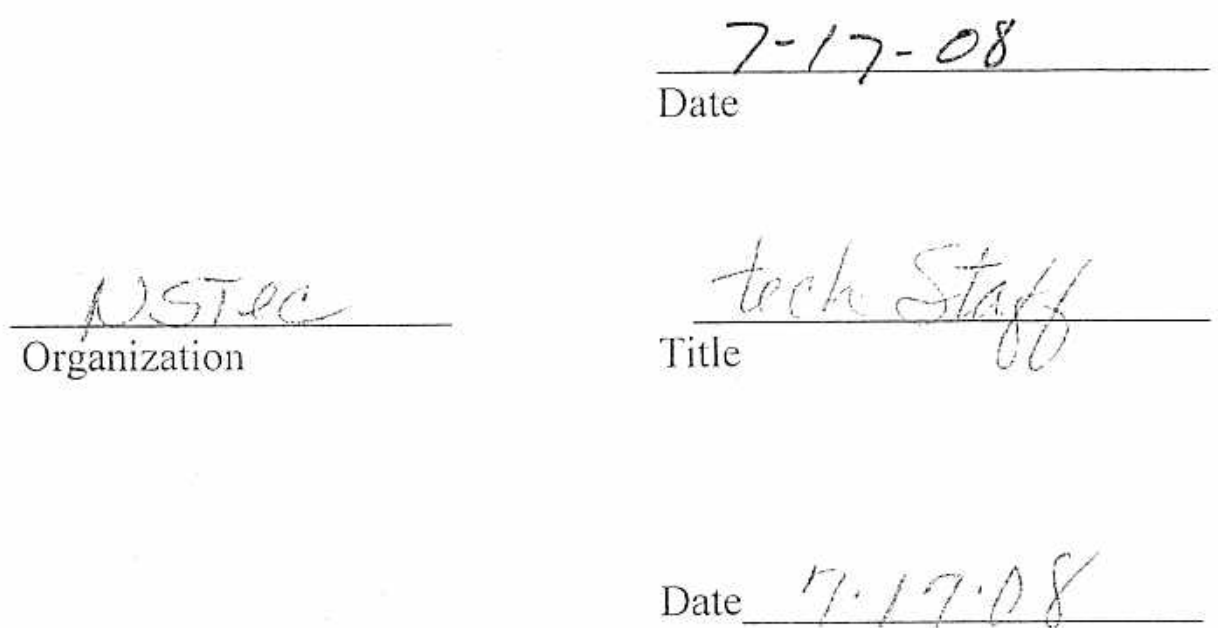
CAU 481 Closure Report

Section: Appendix B

Revision: 0

Date: November 2008

THIS PAGE INTENTIONALLY LEFT BLANK 
CAU 481 Closure Report

Section: Appendix B

Revision: 0

Date: November 2008

\section{OFF-SITE RECYCLING}


CAU 481 Closure Report

Section: Appendix B

Revision: 0

Date: November 2008

THIS PAGE INTENTIONALLY LEFT BLANK 
National Security Technologies LLC

EXCESS REMOVAL REQUEST

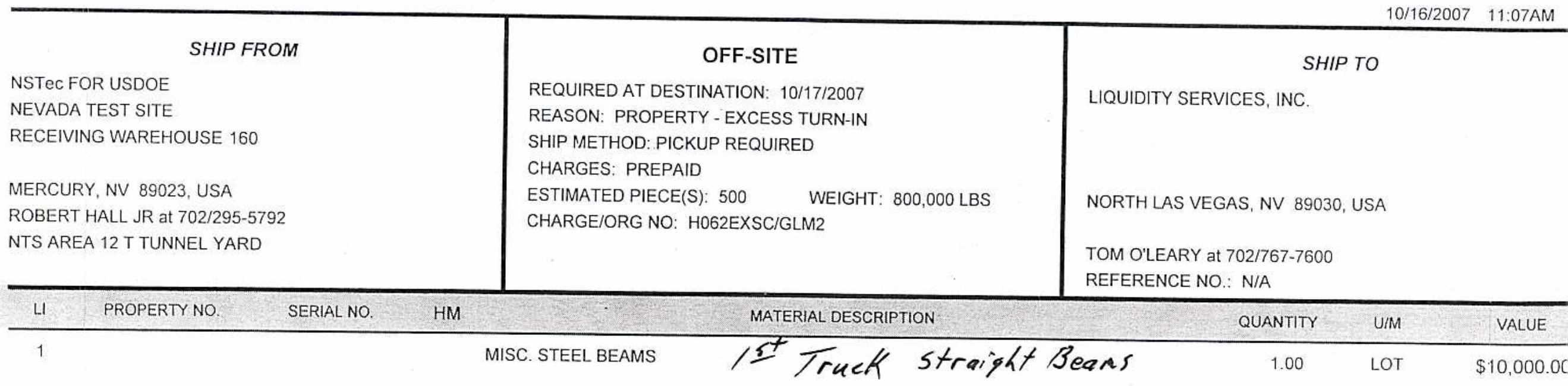

EXCESS CONDITION: PROPERTY WITH NO VALUE EXCEPT BASIC MAT

THESE STEEL BEAMS ARE CONSIDERED SCRAP AND ARE TO BE DISPOSED OF.

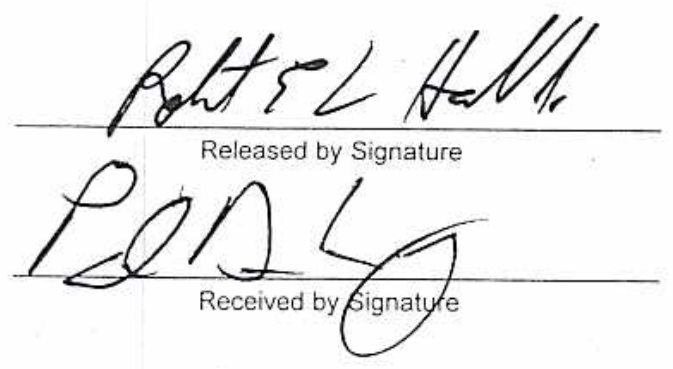

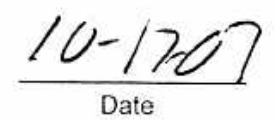

$\frac{10-17.07}{\text { Date }}$

$\frac{10.17 .07}{\text { Date }}$
10/16/2007 11:07 AM
NO. 2075740
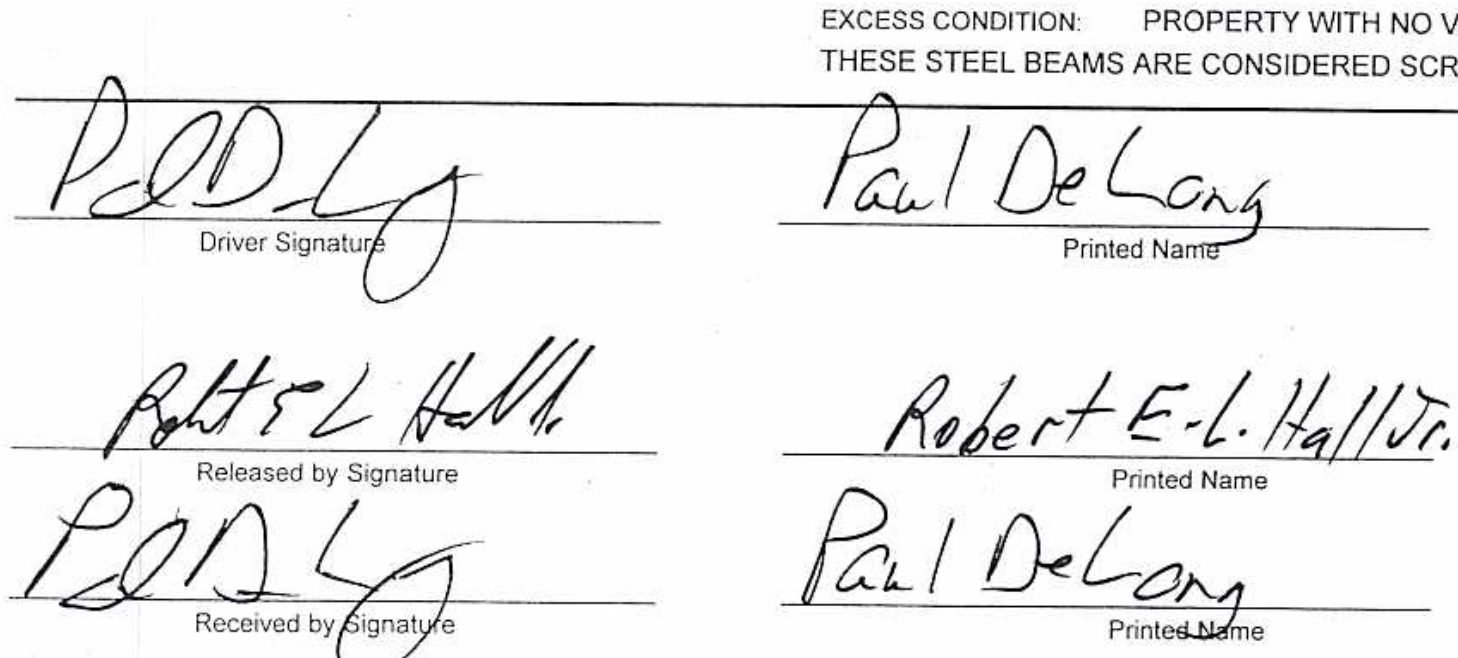

Truck $\# 32550 \mathrm{~A}$
Truk $\# 51412 \mathrm{~T}$ 


\section{BECHTEL NEVADA}

P.0. BOX 98521

LAS VEGAS, NV 89193-8521

DATE $/ 0-17-07$

COMMODITY EXkes

DELIVER TO $L S$,

DRIVER'S SIGNATURE (IN)

DRIVER'S SIGNATURE (OUT)

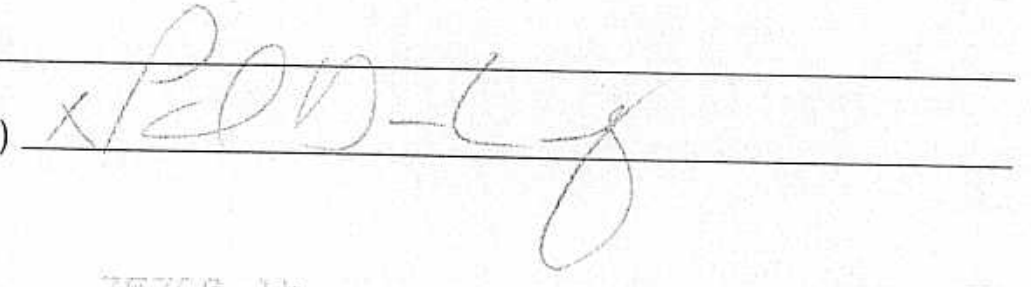

LBS GROSS - DRIVER OFF

LBS TARE - DRIVER OFF

LBS NET

PROPERTY REMOVAL

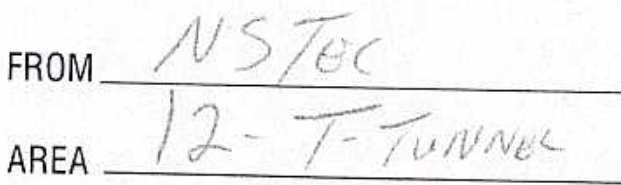
TRUCK NO SHIPPER
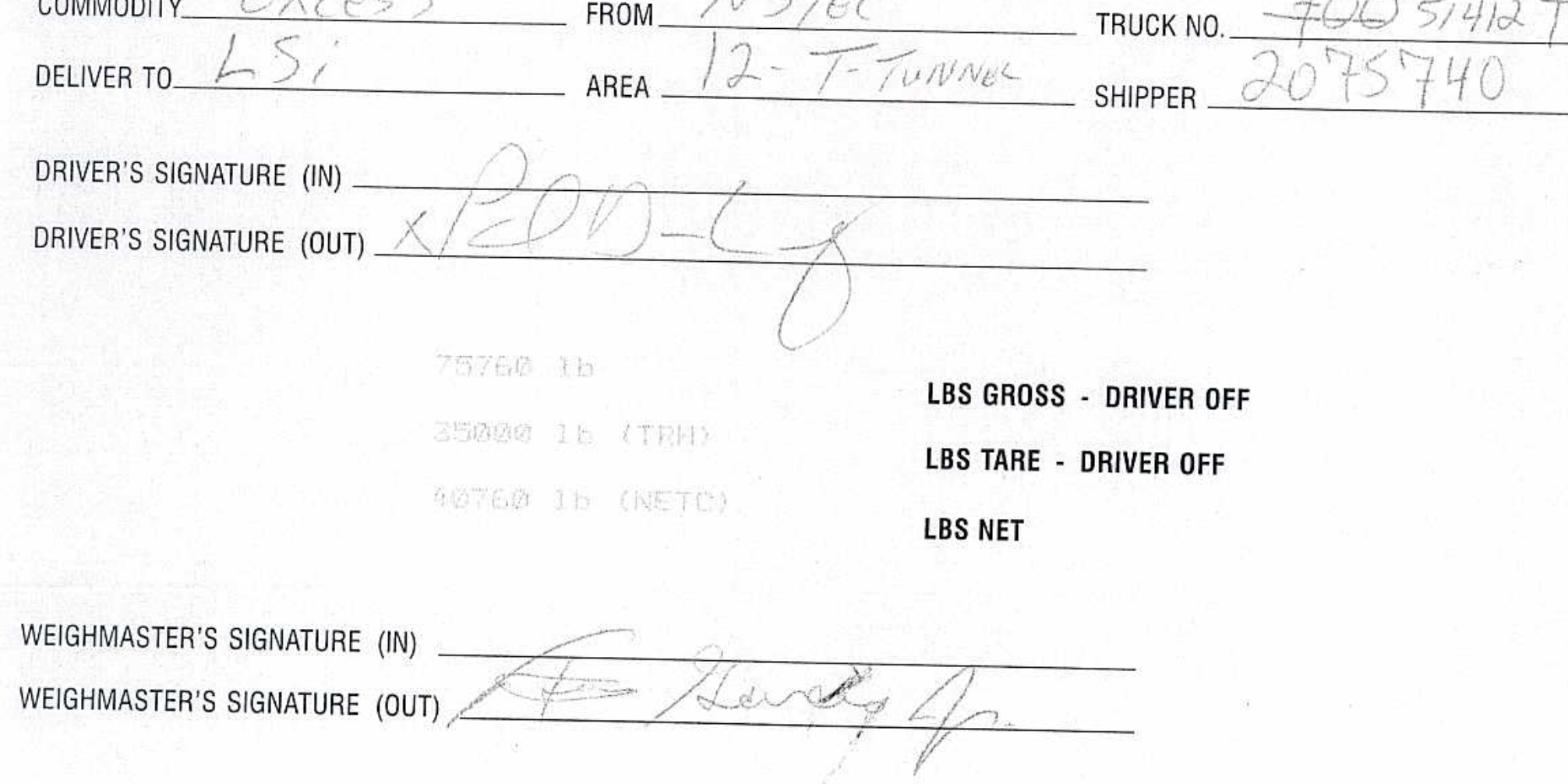
National Security Technologies ${ }^{L L C}$

EXCESS REMOVAL REQUEST

NO. 2075740

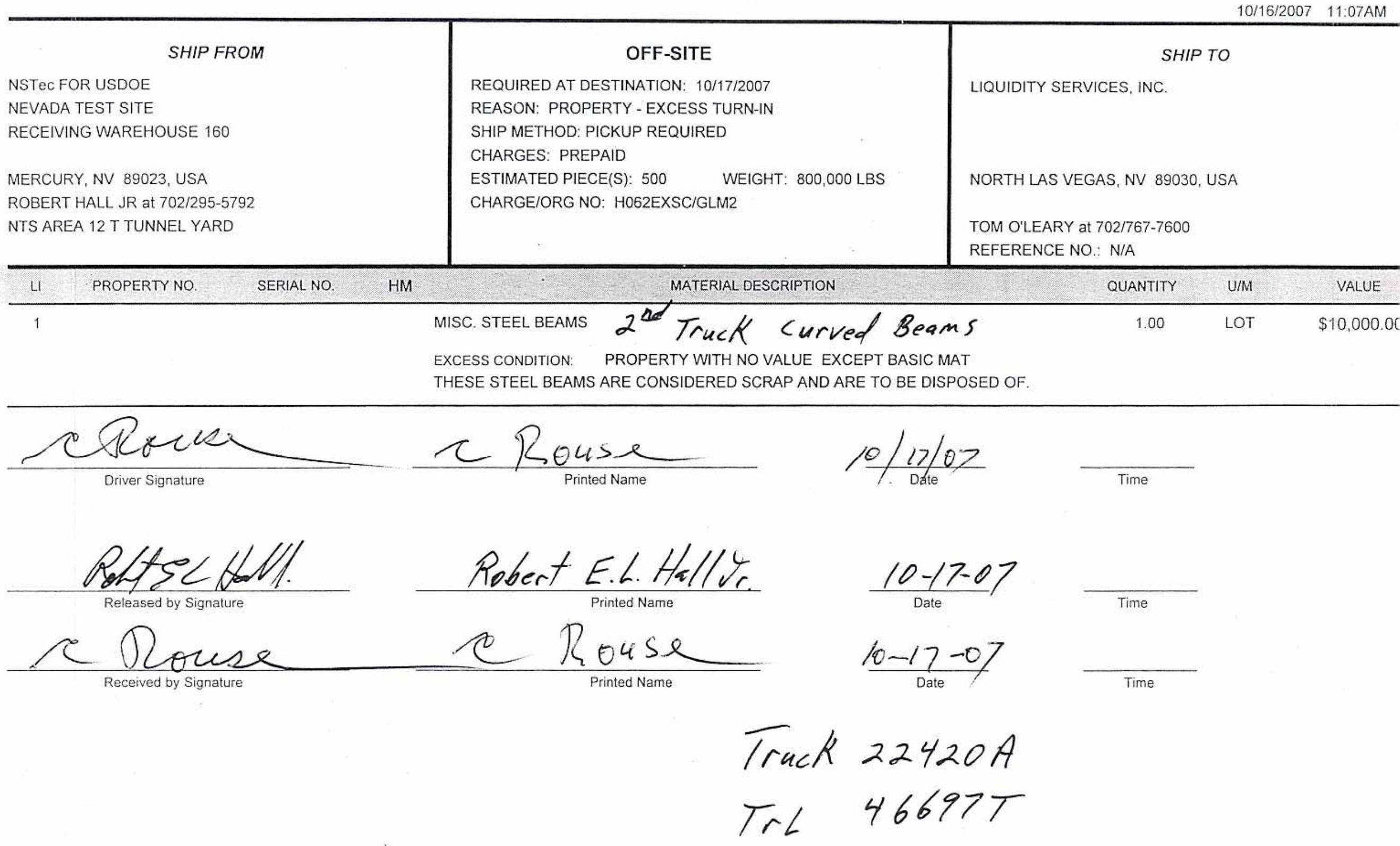




\section{BECHTE: NEVADA}

P.O. BOX 98521

LAS VEGAS, NV 89193-8521

WEIGH TICKET

08174

GATE 100 INSPECTION STATION

DATE $10-/ 7-07$

COMMODITY $\frac{\operatorname{CLCSS}}{2 S S i}$

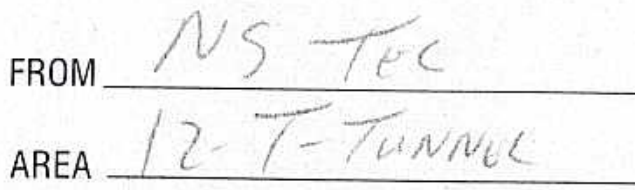

PROPERTY REMOVAL $\frac{2075740}{224201}$

TRUCK NO.

SHIPPER

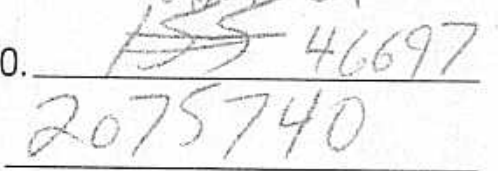

DRIVER'S SIGNATURE (IN)

DRIVER'S SIGNATURE (OUT)

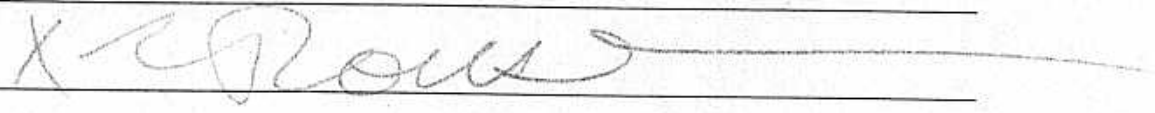

92730 :

3 sibate in (Thit)

LBS GROSS - DRIVER OFF

LBS TARE - DRIVER OFF

LBS NET

WEIGHMASTER'S SIGNATURE (IN)

WEIGHMASTER'S SIGNATURE (OUT)

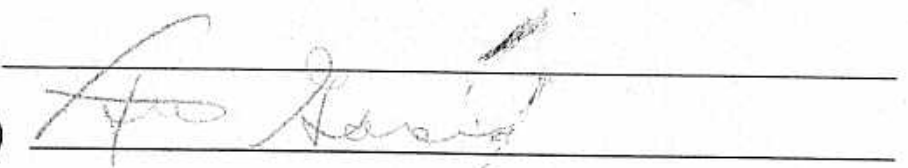


National Security Technologies ${ }^{L L C}$

EXCESS REMOVAL REQUEST

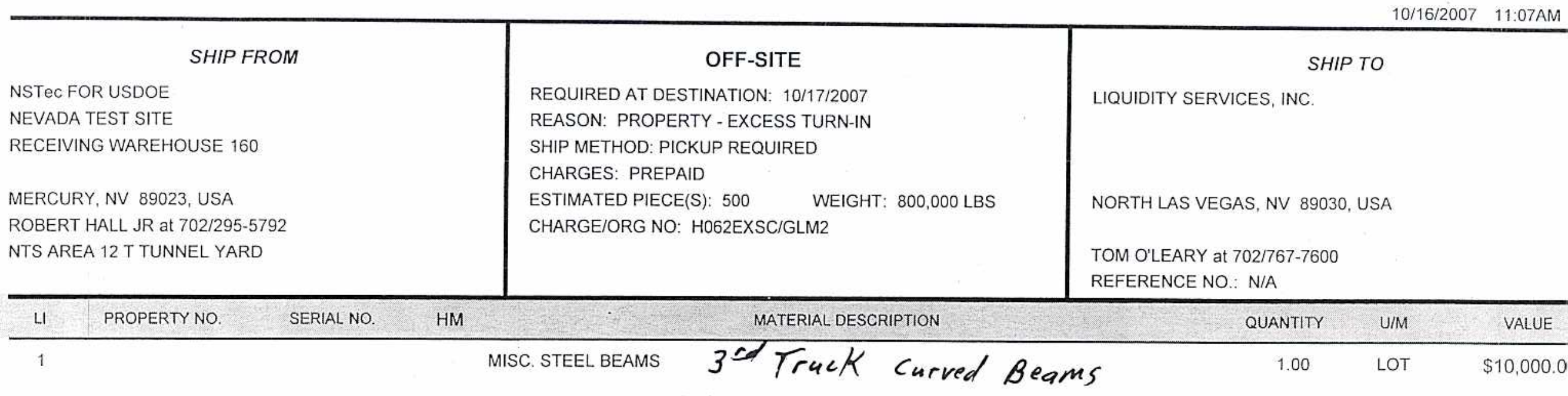

EXCESS CONDITION: PROPERTY WITH NO VALUE EXCEPT BASIC MAT

THESE STEEL BEAMS ARE CONSIDERED SCRAP AND ARE TO BE DISPOSED OF.
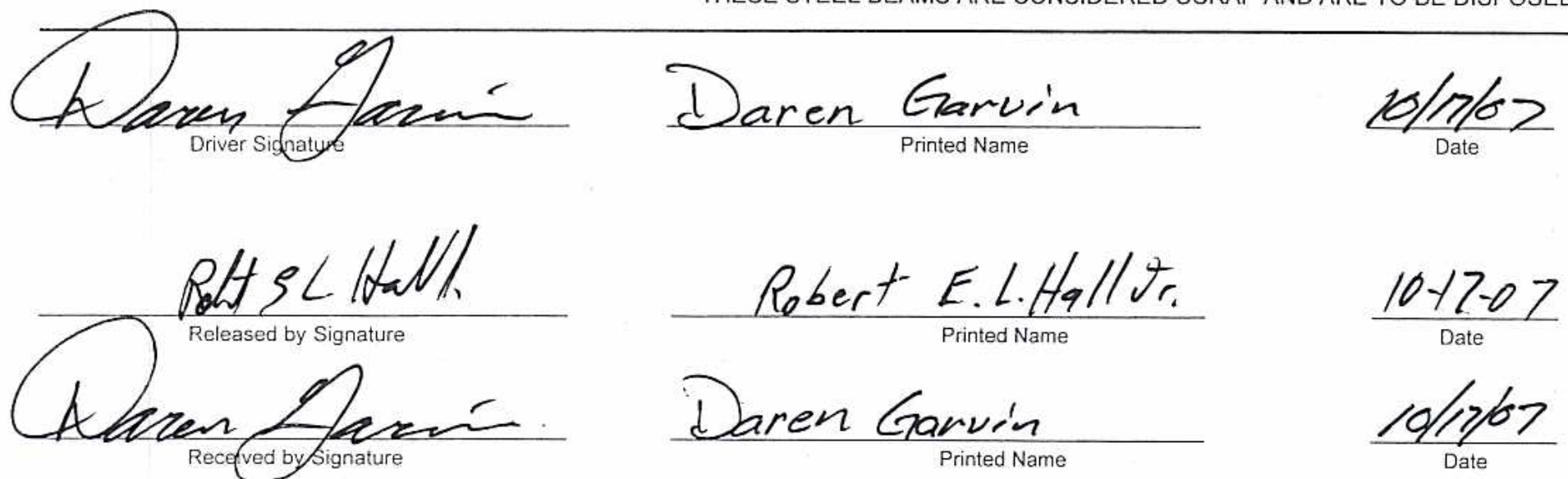

$\begin{array}{ll}\text { Truck } & 30234 \mathrm{~A} \\ \text { Tel. } & 32839 \mathrm{~T}\end{array}$

NO. 2075740

10/16/2007 11:07 AM

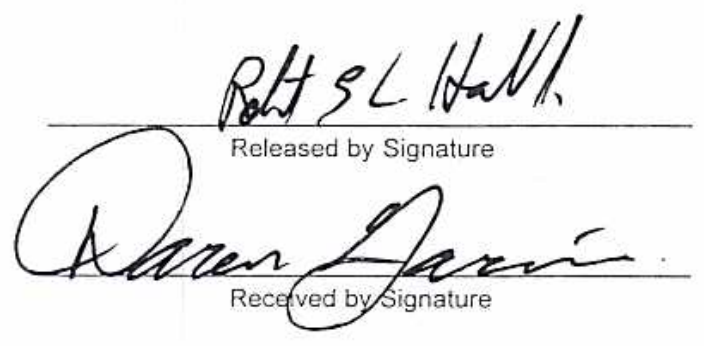

Page 1 of 1

$B N$. 


\section{BECHTEL NEVADA}

P.0. B0X 98521

LAS VEGAS, NV 89193-8521

Date $/ 0-17-07$

commodity EXLESS

DELIVER TO $S$

DRIVER'S SIGNATURE (IN)

DRIVER'S SIGNATURE (OUT)

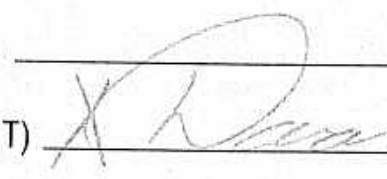

Cetper 36

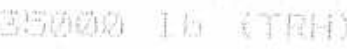

27469 in METC
WEIGH TICKET

GATE 100 INSPECTION STATION

PROPERTY REMOVAL

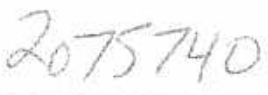

$30234 \mathrm{~A}$

TRUCK N0. 328397

SHIPPER
LBS GROSS - DRIVER OFF

LBS TARE - DRIVER OFF

LBS NET

WEIGHMASTER'S SIGNATURE (IN)

WEIGHMASTER'S SIGNATURE (OUT)

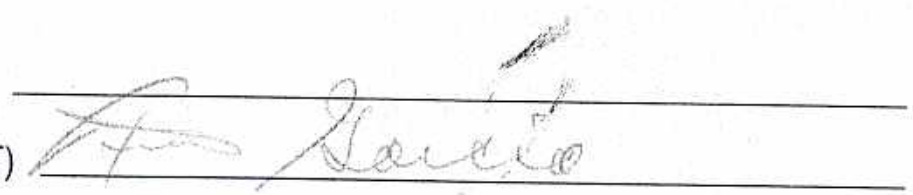




\section{SHIP FROM}

NSTEC FOR USDOE NEVADA TEST SITE

RECEIVING WAREHOUSE 160

MERCURY, NV 89023, USA

ROBERT HALL JR at 702/295-5792

NTS AREA 12 T TUNNEL YARD

\section{OFF-SITE}

REQUIRED AT DESTINATION: 10/17/2007

REASON: PROPERTY - EXCESS TURN-IN

SHIP METHOD: PICKUP REQUIRED

CHARGES: PREPAID

ESTIMATED PIECE(S): $500 \quad$ WEIGHT: 800,000 LBS

CHARGE/ORG NO: H062EXSC/GLM2
SHIP TO

LIQUIDITY SERVICES, INC

NORTH LAS VEGAS, NV 89030, USA

TOM O'LEARY at 702/767-7600

REFERENCE NO:: N/A

\begin{tabular}{llll}
\hline LI PROPERTYNO. & SERIAL NO & HM \\
\hline 1 &
\end{tabular}

MATERIAL DESCRIPTION

QUANTITY

U/M

VALUE

MISC. STEEL BEAMS

1.00

LOT

$\$ 10,000.0$

EXCESS CONDITION: PROPERTY WITH NO VALUE EXCEPT BASIC MAT

THESE STEEL BEAMS ARE CONSIDERED SCRAP AND ARE TO BE DISPOSED OF.

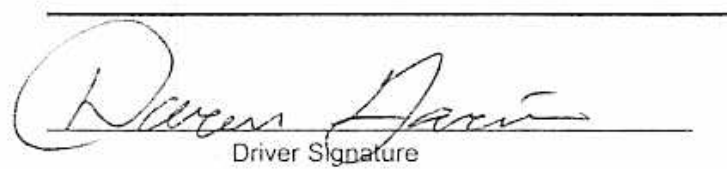

Driver Signature
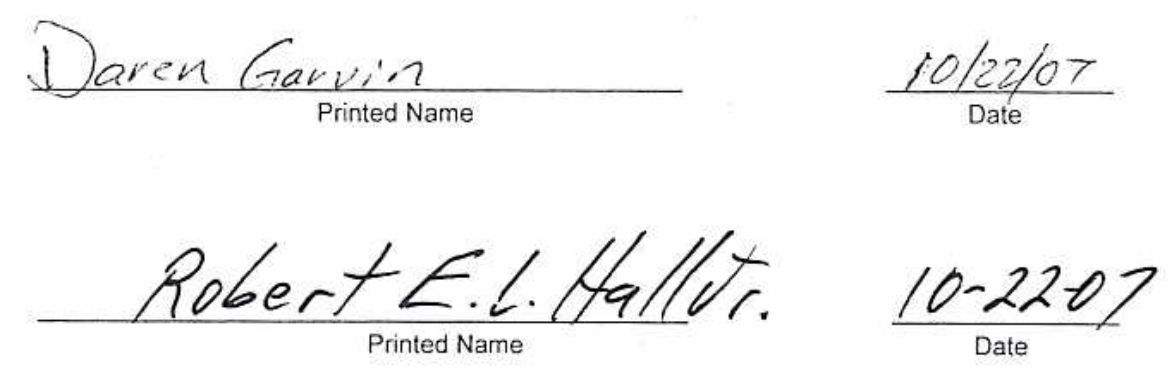

Released by Signature
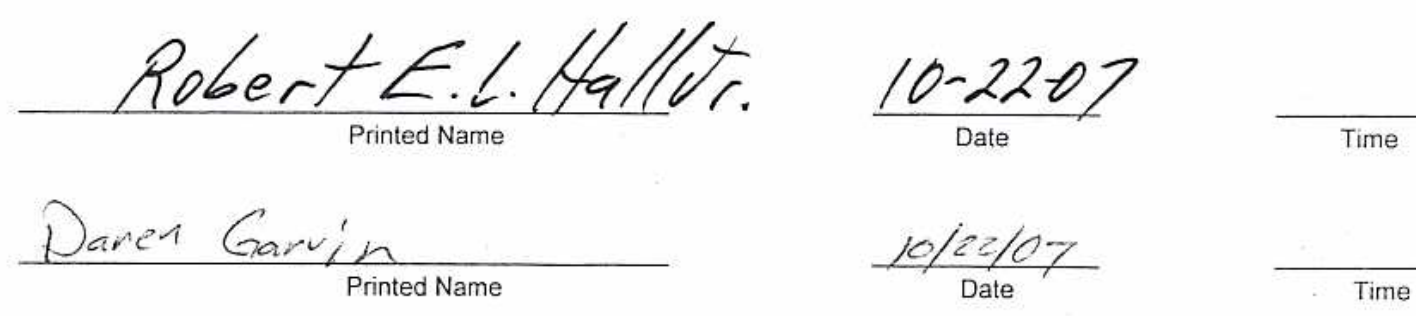

Time

$$
\begin{aligned}
& \text { Truek \#30234A } \\
& \text { TrL. \#45.775-T }
\end{aligned}
$$




\section{BECHTEL NEVADA}

P.O. BOX 98521

LAS VEGAS, NV 89193-8521

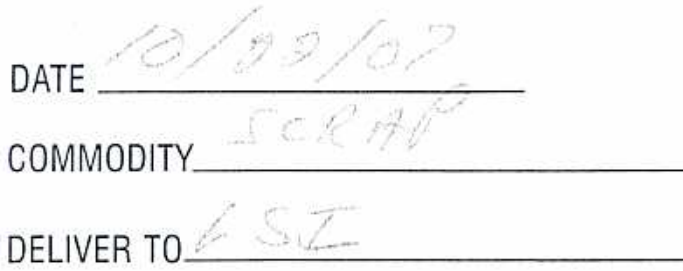

WEIGH TICKET

GATE 100 INSPECTION STATION

PROPERTY REMOVAL

TRUCK NO.

SHIPPER

DRIVER'S SIGNATURE (IN)

DRIVER'S SIGNATURE (OUT)

LBS GROSS - DRIVER OFF

LBS TARE - DRIVER OFF

LBS NET

WEIGHMASTER'S SIGNATURE (IN)
WEIGHMASTER'S SIGNATURE (OUT) 


\section{SHIP FROM}

NSTEC FOR USDOE NEVADA TEST SITE

RECEIVING WAREHOUSE 160

MERCURY, NV 89023, USA

ROBERT HALL JR at 702/295-5792

NTS AREA 12 T TUNNEL YARD

\section{OFF-SITE}

REQUIRED AT DESTINATION: 10/17/2007

REASON: PROPERTY - EXCESS TURN-IN

SHIP METHOD: PICKUP REQUIRED

CHARGES: PREPAID

ESTIMATED PIECE(S): 500 WEIGHT: 800,000 LBS

CHARGE/ORG NO: H062EXSC/GLM2

\section{SHIP TO}

LIQUIDITY SERVICES, INC.

NORTH LAS VEGAS, NV 89030, USA

TOM O'LEARY at $702 / 767-7600$

REFERENCE NO: N/A

\begin{tabular}{ll}
\hline PROPERTYNO. & SERIAL NO. \\
\hline 1 & \\
\hline
\end{tabular}

Driver Signature

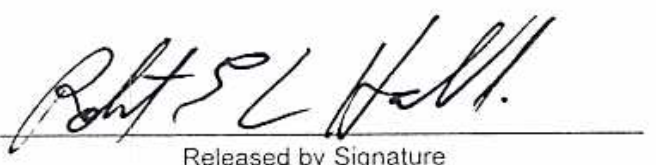

Released by Signature

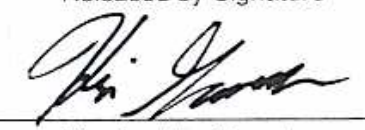

Received by Signature
$\mathrm{HM}$

MISC. STEEL BEAMS

EXCESS CONDITION:

THESE STEEL BEAMS ARE CONSIDERED SCRAP AND ARE TO BE DISPOSED OF.
MATERIAL DESCRIPTION

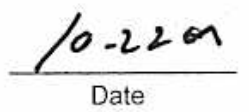

$$
\frac{10 \cdot 22 \cdot 07}{\text { Date }}
$$

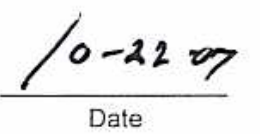

VALUE

QUANTITY UIM

$\$ 10,000.0$

1.00

LOT

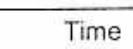

me

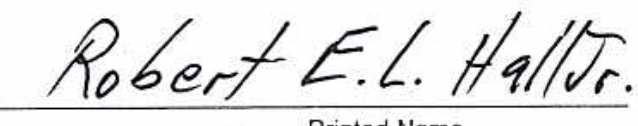

Pevin Costier

$\frac{10-2207}{\text { Date }}$




\section{BECHTEL NEVADA}

\section{P.0. BOX 98521}

LAS VEGAS, NV 89193-8521

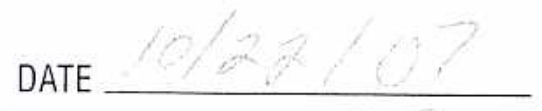

COMMODITY

DELIVER TO
WEIGH TICKET

GATE 100 INSPECTION STATION

PROPERTY REMOVAL

TRUCK NO.

SHIPPER

DRIVER'S SIGNATURE (IN)

DRIVER'S SIGNATURE (OUT)

T)

LBS GROSS - DRIVER OFF

LBS TARE - DRIVER OFF

LBS NET

WEIGHMASTER'S SIGNATURE (IN)

WEIGHMASTER'S SIGNATURE (OUT) 


\section{SHIP FROM}

NSTEC FOR USDOE NEVADA TEST SITE

RECEIVING WAREHOUSE 160

MERCURY, NV 89023, USA

ROBERT HALL JR at 702/295-5792

NTS AREA 12 T TUNNEL YARD

\section{OFF-SITE}

REQUIRED AT DESTINATION: 10/17/2007

REASON: PROPERTY - EXCESS TURN-IN

SHIP METHOD: PICKUP REQUIRED

CHARGES: PREPAID

ESTIMATED PIECE(S): 500 WEIGHT: 800,000 LBS

CHARGE/ORG NO: HO62EXSC/GLM2

\section{SHIP TO}

LIQUIDITY SERVICES, INC.

NORTH LAS VEGAS, NV 89030, USA

TOM O'LEARY at 702/767-7600

REFERENCE NO: N/A

PROPERTY NO.

HM

MATERIAL DESCRIPTION

QUANTITY

U/M

VALUE

MISC. STEEL BEAMS

1.00

LOT

$\$ 10,000.00$

EXCESS CONDITION: PROPERTY WITH NO VALUE EXCEPT BASIC MAT

THESE STEEL BEAMS ARE CONSIDERED SCRAP AND ARE TO BE DISPOSED OF.

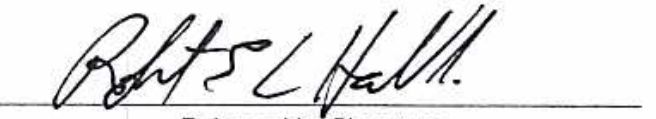

Released by Signature

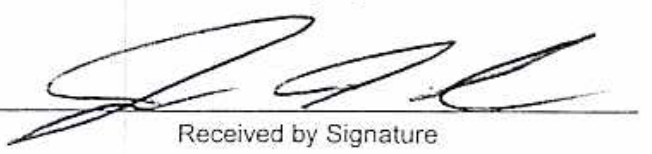

Jameson $_{\substack{\text { Printed Name } \\ \text { Jeel }}}$

Robert E.L. Hall $\overline{F r}_{\text {Printed Name }}$

$\operatorname{Jameson}_{\text {Printed Name }}$

$$
\frac{10-22}{\text { Date }}
$$

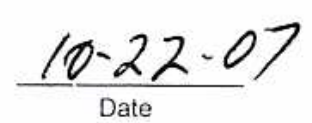

Date

Time

$\frac{10-22}{\text { Date }}$

Time

$$
\begin{aligned}
& \text { Truck } \# 35028-A \\
& \text { TrL \# 51285.T }
\end{aligned}
$$




\section{BECHTEL NEVADA}

P.O. BOX 98521

LAS VEGAS, NV 89193-8521

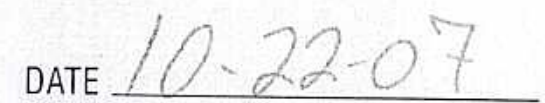

COMMODITY EXCESS

DELIVER TO \& $>i$

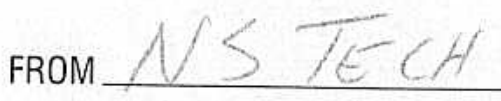

AREA $/ 2-\sqrt{1-\pi N N N E}$.

DRIVER'S SIGNATURE (IN)

DRIVER'S SIGNATURE (OUT)

\section{WEIGH TICKET}

GATE 100 INSPECTION STATION

PROPERTY REMOVAL

TRUCK NO

N

SHIPPER
54648715

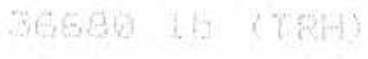

LBS GROSS - DRIVER OFF

LBS TARE - DRIVER OFF

LBS NET

WEIGHMASTER'S SIGNATURE (IN)

WEIGHMASTER'S SIGNATURE (OUT)

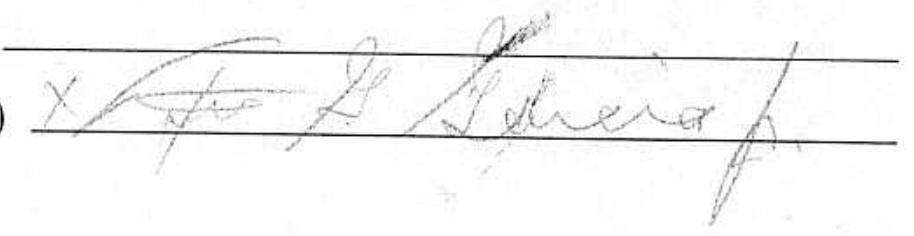


Rational Security Technologies ${ }^{L L C}$

EXCESS REMOVAL REQUEST

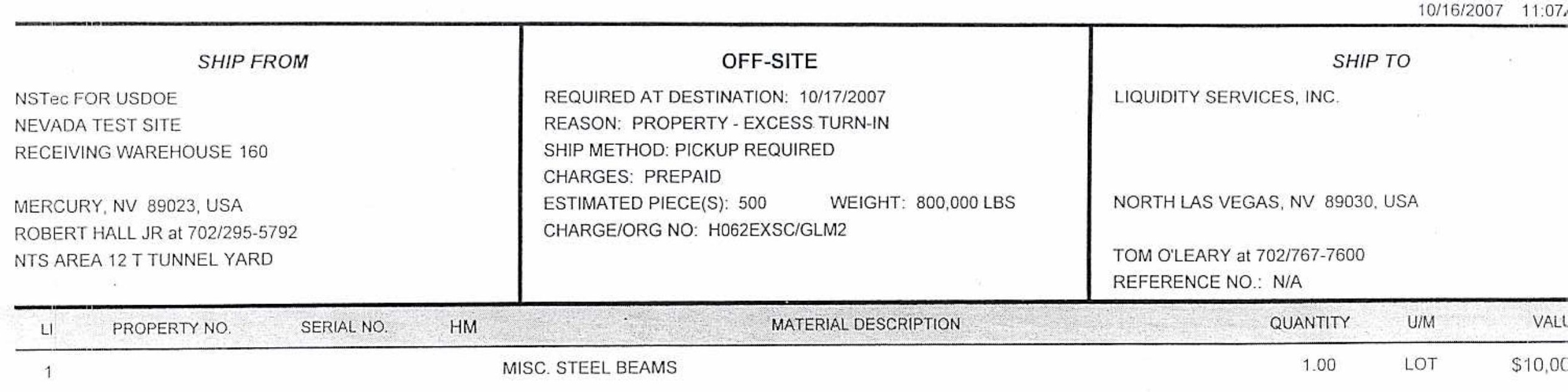

EXCESS CONDITION: PROPERTY WITH NO VALUE EXCEPT BASIC MAT

THESE STEEL BEAMS ARE CONSIDERED SCRAP AND ARE TO BE DISPOSED OF.
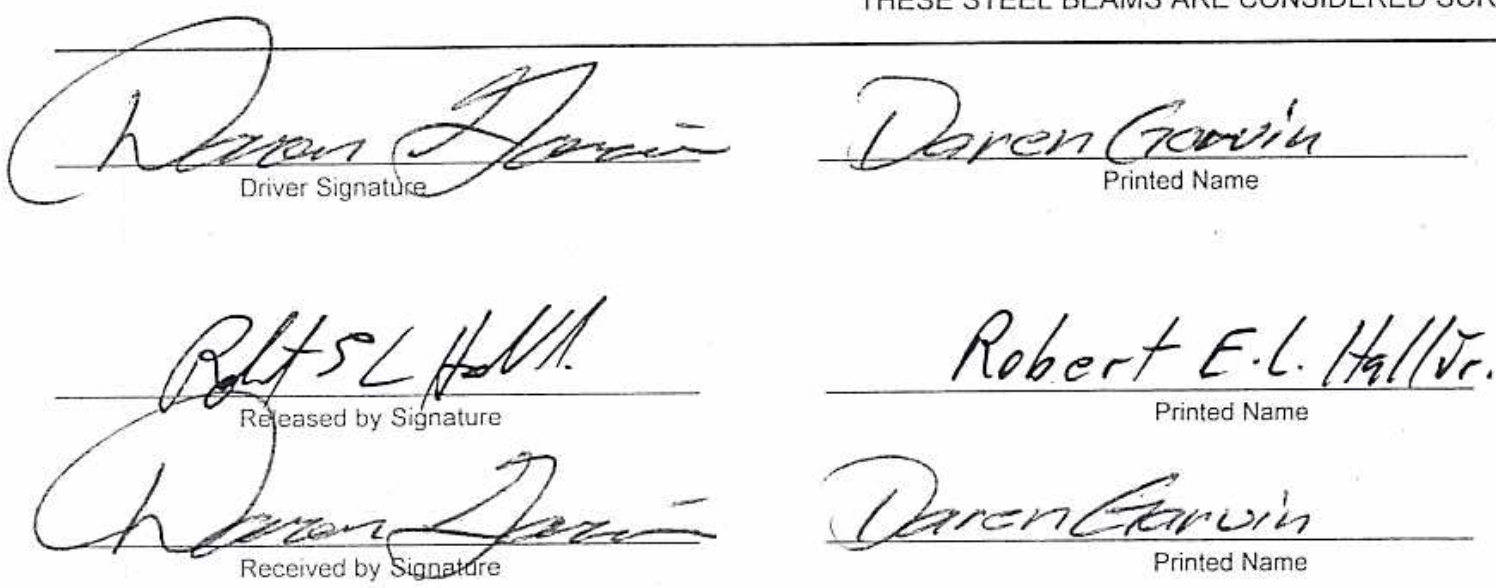

NO. 2075740

10/16/2007 11:07
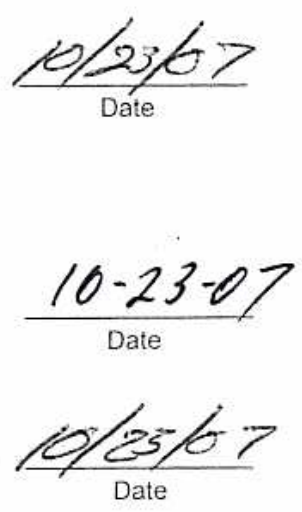

IrK H $30234-4$

Tale $45778-7$

$10^{\prime}$ Foot Twin 


\section{BECHTEL NEVADA}

P.0. BOX 98521

LAS VEGAS, NV 89193-8521

WEIGH TICKET

08191

GATE 100 INSPECTION STATION

$\operatorname{DATE}\langle 0-23-0\rangle$

commodity $E$ S Ces 5

DELIVER TO LS

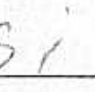

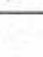
FROM NSTeCH AREA $/ 2-T-T \omega N N$ PROPERTY REMOVAL

$$
T=302344
$$
TRUCK NO.TRALER $=45778 \mathrm{~T}$ SHIPPER

DRIVER'S SIGNATURE (IN)

DRIVER'S SIGNATURE (OUT)

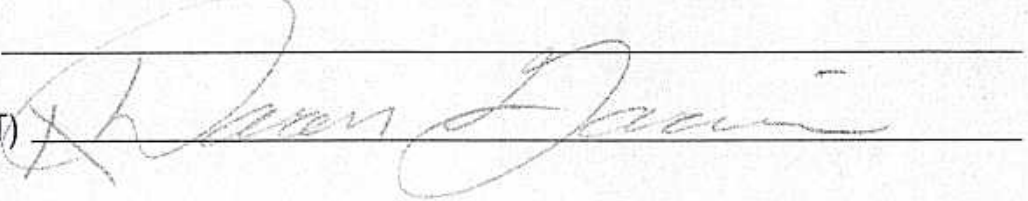

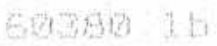

LBS GROSS - DRIVER OFF

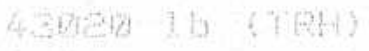

LBS TARE - DRIVER OFF

LBS NET

WEIGHMASTER'S SIGNATURE (IN)

WEIGHMASTER'S SIGNATURE (OUT)

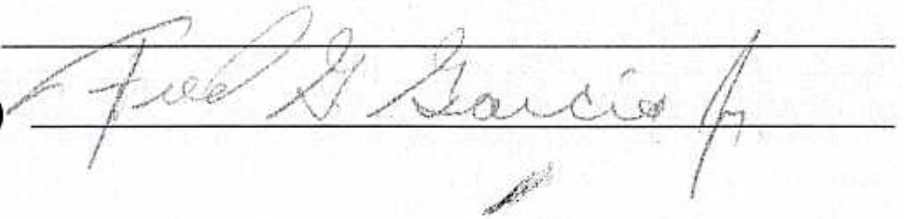


SHIP FROM

NSTEC FOR USDOE

NEVADA TEST SITE

RECEIVING WAREHOUSE 160

MERCURY, NV 89023, USA

ROBERT HALL JR at 702/295-5792

NTS AREA 12 T TUNNEL YARD

\section{OFF-SITE}

REQUIRED AT DESTINATION: 10/17/2007

REASON: PROPERTY - EXCESS TURN-IN

SHIP METHOD: PICKUP REQUIRED

CHARGES: PREPAID

ESTIMATED PIECE(S): 500 WEIGHT: 800,000 LBS

CHARGE/ORG NO: H062EXSC/GLM2
SHIP TO

LIQUIDITY SERVICES, INC.

NORTH LAS VEGAS, NV 89030 , USA

TOM O'LEARY at 702/767-7600

REFERENCE NO: N/A

PROPERTYNO. SERIALNO.

$\mathrm{HM}$

MATERIAL DESCRIPTION

MISC. STEEL BEAMS

QUANTITY

EXCESS CONDITION:

PROPERTY WITH NO VALUE EXCEPT BASIC MAT

THESE STEEL BEAMS ARE CONSIDERED SCRAP AND ARE TO BE DISPOSED OF.
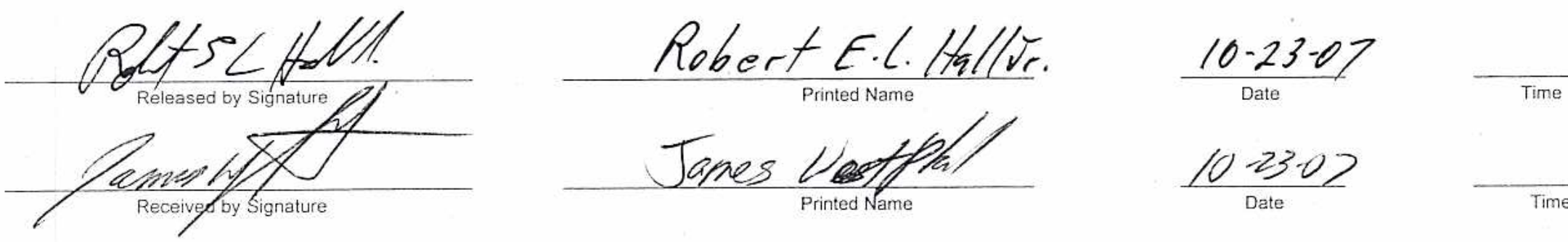

$$
\begin{aligned}
& \text { TrK\# 23370.iA } \\
& \text { TrIRH 45779-T }
\end{aligned}
$$




\section{BECHTEL NEVADA}

P.0. BOX 98521

LAS VEGAS, NV 89193-8521
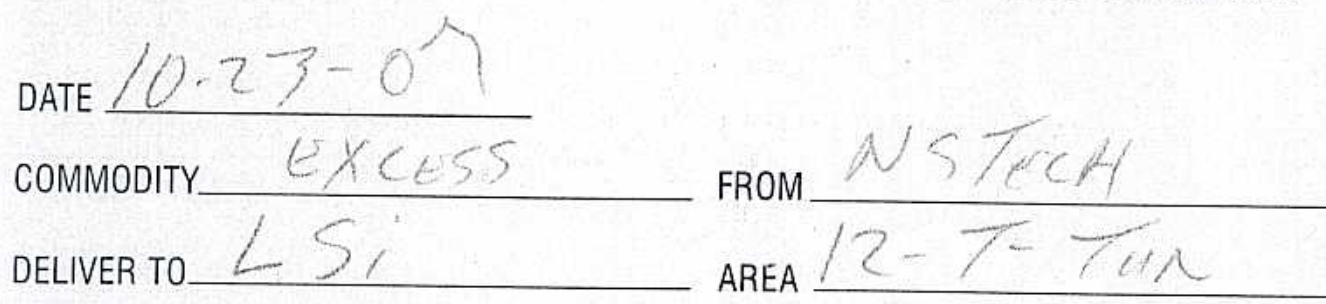

PROPERTY REMOVAL

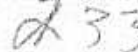
TRUCK NO. 457797 SHIPPER

DRIVER'S SIGNATURE (IN)

DRIVER'S SIGNATURE (OUT)

LBS GROSS - DRIVER OFF

LBS TARE - DRIVER OFF

LBS NET

WEIGHMASTER'S SIGNATURE (IN)

WEIGHMASTER'S SIGNATURE (OUT)

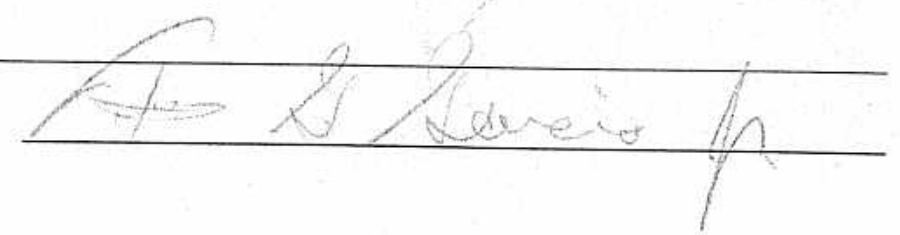


SHIP FROM

NSTEC FOR USDOE

NEVADA TEST SITE

RECEIVING WAREHOUSE 160

MERCURY, NV 89023, USA

ROBERT HALL JR at 702/295-5792

NTS AREA 12 T TUNNEL YARD

\section{OFF-SITE}

REQUIRED AT DESTINATION: 10/17/2007

REASON: PROPERTY - EXCESS TURN-IN

SHIP METHOD; PICKUP REQUIRED

CHARGES: PREPAID

ESTIMATED PIECE(S): 500 WEIGHT: 800,000 LBS

CHARGE/ORG NO: H062EXSC/GLM2
SHIP TO

LIQUIDITY SERVICES, INC

NORTH LAS VEGAS, NV 89030, USA

TOM O'LEARY at 702/767-7600

REFERENCE NO:: N/A

PROPERTYNO. SERIAL NO.

$\mathrm{HM}$

MATERIAL DESCRIPTION

U/M

MISC. STEEL BEAMS

1.00

LOT

EXCESS CONDITION: PROPERTY WITH NO VALUE EXCEPT BASIC MAT

THESE STEEL BEAMS ARE CONSIDERED SCRAP AND ARE TO BE DISPOSED OF.
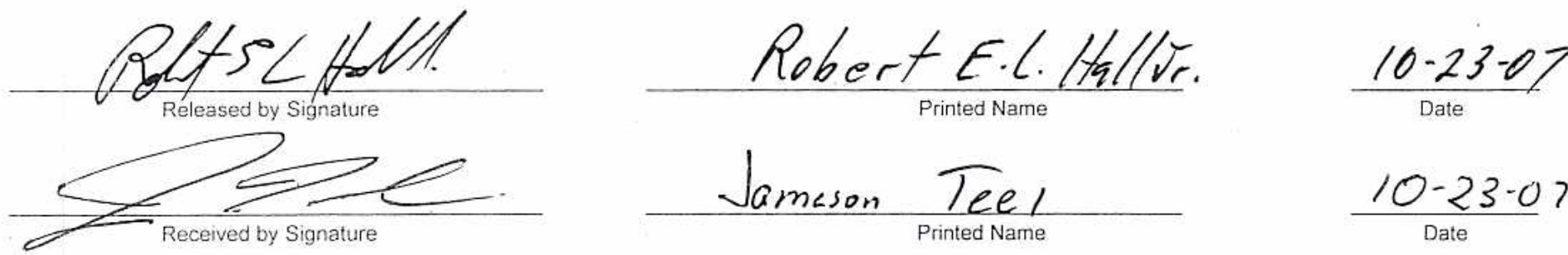

$\frac{10-23-07}{\text { Date }}$

Time

$\int_{a \text { meson Tec } /}$

Date

$$
\begin{aligned}
& \text { Tr/R 35028-A } \\
& \text { TH/WH 5/285-7 }
\end{aligned}
$$




\section{BECHTEL NEVADA}

P.O. BOX 98521

LAS VEGAS, NV 89193-8521

\section{WEIGH TICKET}

GATE 100 INSPECTION STATION
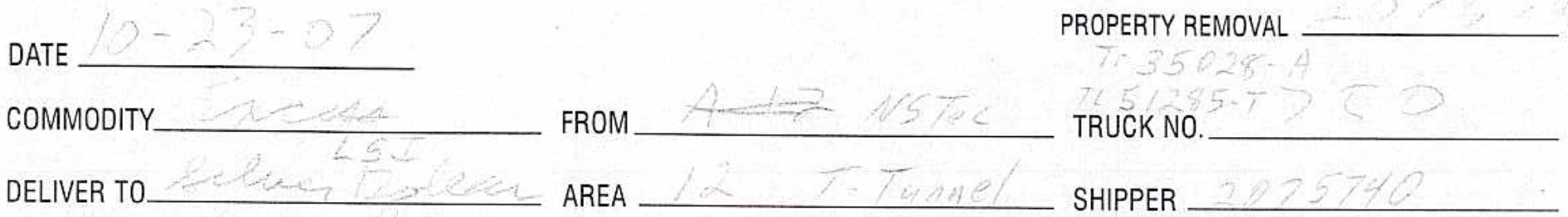

DRIVER'S SIGNATURE (IN)

DRIVER'S SIGNATURE (OUT)

$X+\cdots$

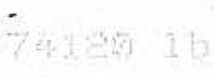

TEGAP 20 (THA)

37440 ib SNETL:
LBS GROSS - DRIVER OFF

LBS TARE - DRIVER OFF

LBS NET

WEIGHMASTER'S SIGNATURE (IN)

WEIGHMASTER'S SIGNATURE (OUT) 


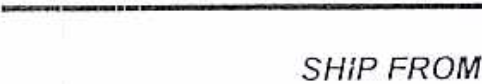

NSTEC FOR USDOE NEVADA TEST SITE

RECEIVING WAREHOUSE 160

MERCURY, NV 89023, USA

ROBERT HALL JR at 702/295-5792

NTS AREA 12 T TUNNEL YARD

\section{OFF-SITE}

REQUIRED AT DESTINATION: 10/17/2007

REASON: PROPERTY - EXCESS TURN-IN

SHIP METHOD: PICKUP REQUIRED

CHARGES: PREPAID

ESTIMATED PIECE(S): 500 WEIGHT: 800,000 LBS

CHARGEIORG NO: H062EXSC/GLM2
SHIP TO

LIQUIDITY SERVICES, INC

NORTH LAS VEGAS, NV 89030, USA

TOM O'LEARY at 702/767-7600

REFERENCE NO:: N/A

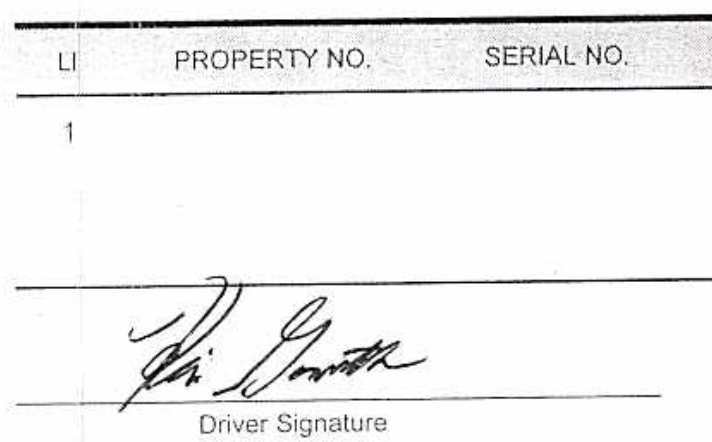

M

1

REFERENCENO.: N/A

MISC. STEEL BEAMS

MATERIAL DESCRIPTION

QUANTITY

U/M

MSC. STEEL BEAMS

EXCESS CONDITION: PROPERTY WITH NO VALUE EXCEPT BASIC MAT
THESE STEEL BEAMS ARE CONSIDERED SCRAP AND ARE TO BE DISPOSED OF.

$\operatorname{Linin}_{\text {Printed Name }} \quad 10-23-0>\frac{1125}{\text { Date }}$
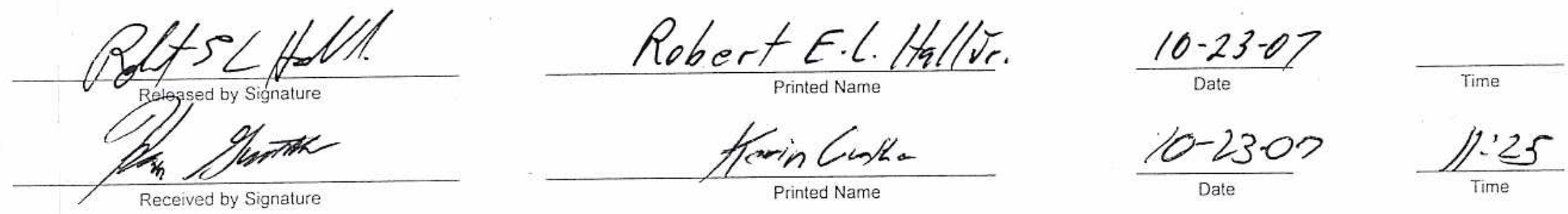

$$
\begin{aligned}
& \text { Trk 3i219-A } \\
& \text { Tola S1412-T }
\end{aligned}
$$




\section{BECHTEL NEVADA}

P.0. BOX 98521

LAS VEGAS, NV 89193-8521

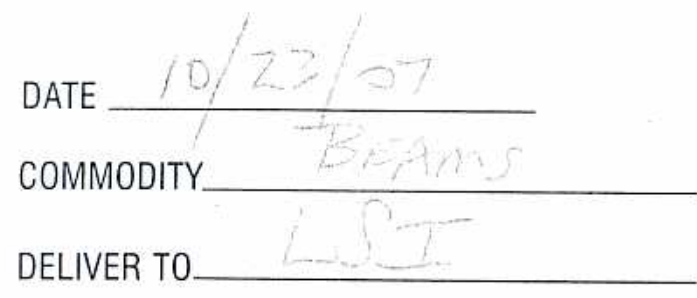

WEIGH TICKET

GATE 100 INSPECTION STATION

PROPERTY REMOVAL

TRUCK NO.

SHIPPER

DRIVER'S SIGNATURE (IN)

DRIVER'S SIGNATURE (OUT)

FROM

AREA

LBS GROSS - DRIVER OFF

LBS TARE - DRIVER OFF

LBS NET

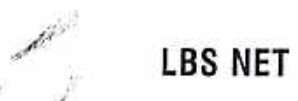

WEIGHMASTER'S SIGNATURE (IN)

WEIGHMASTER'S SIGNATURE (OUT) 
National Security Technologies LLC

EXCESS REMOVAL REQUEST

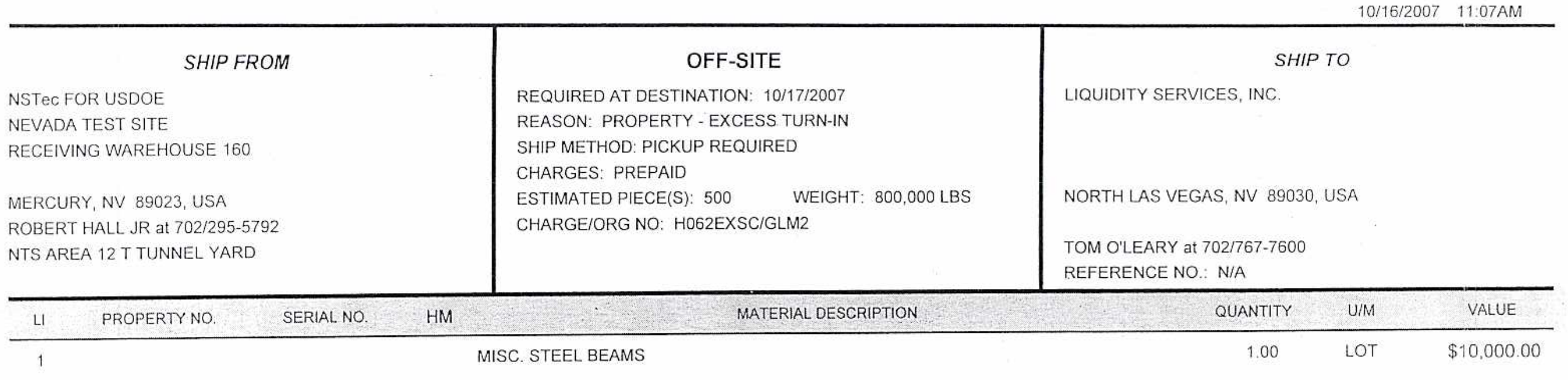

EXCESS CONDITION: PROPERTY WITH NO VALUE EXCEPT BASIC MAT

THESE STEEL BEAMS ARE CONSIDERED SCRAP AND ARE TO BE DISPOSED OF.
NO. 2075740

10/16/2007 11:07 AM

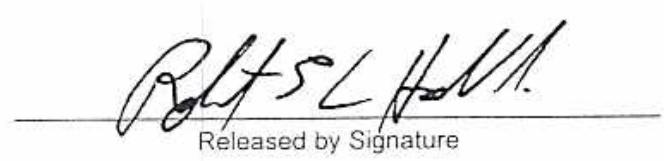

Wiccan Water

Received by Signature
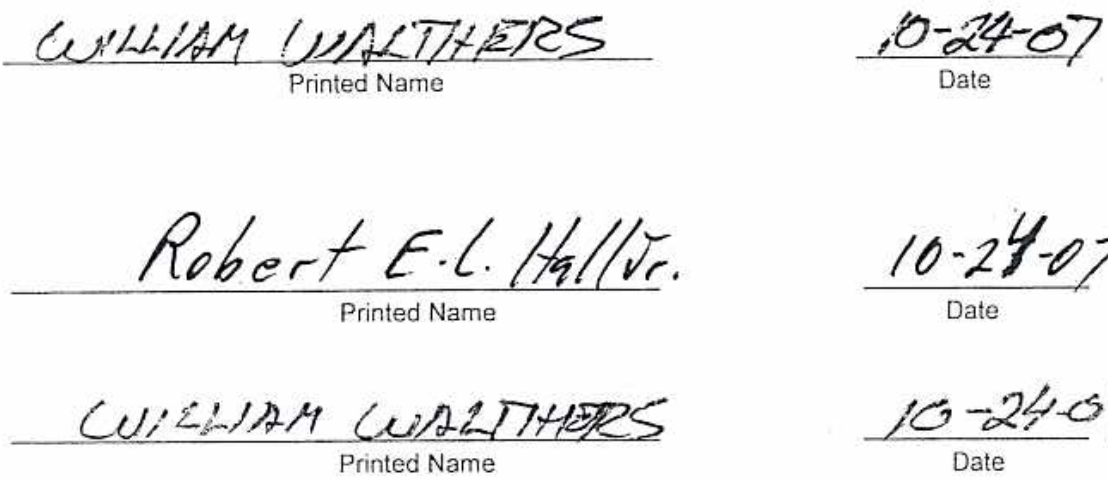

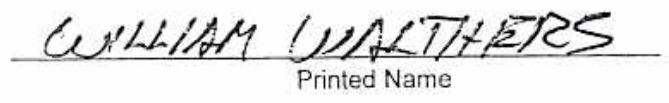

$$
\frac{\text { Robert E.L. Hall Jr. }}{\text { Printed Name }} \quad \frac{10-24-07}{\text { Date }}
$$
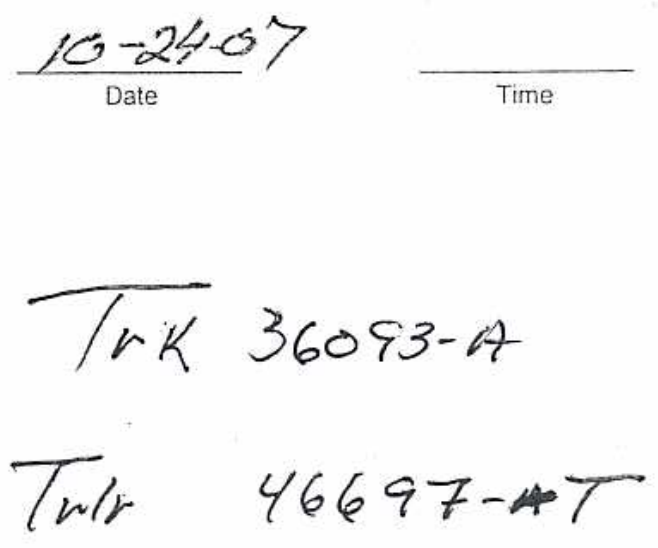

Page 1 of 1

BN- 


\section{BECYTEL NEVADA}

P.O. BOX 98521

LAS VEGAS, NV 89193-8521

DATE $/ 0-24-07$

commodity Excess S\%,

DELIVER TO
WEIGH TICKET

GATE 100 INSPECTION STATION

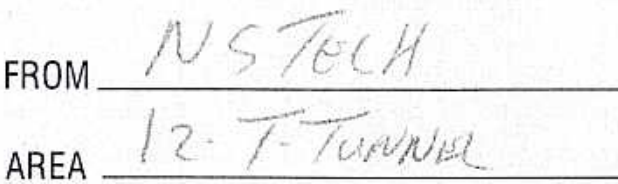

08200

PROPERTY REMOVAL

TRACATON TRUCK NO.

SHIPPER

DRIVER'S SIGNATURE (IN)

DRIVER'S SIGNATURE (OUT)

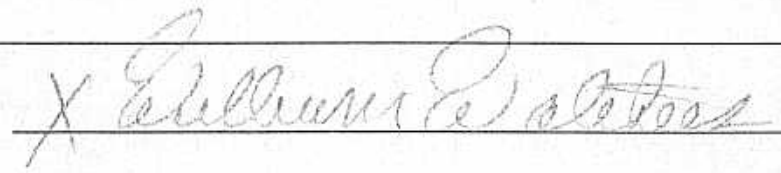

LBS GROSS - DRIVER OFF

LBS TARE - DRIVER OFF

LBS NET

WEIGHMASTER'S SIGNATURE (IN)

WEIGHMASTER'S SIGNATURE (OUT)
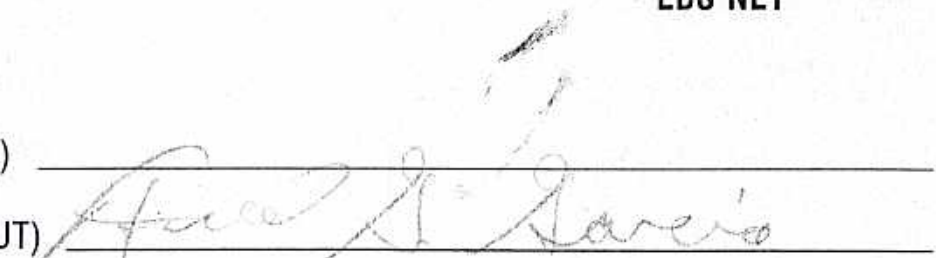
National Security Technologies $^{\text {"Lc }}$ EXCESS REMOVAL REQUEST

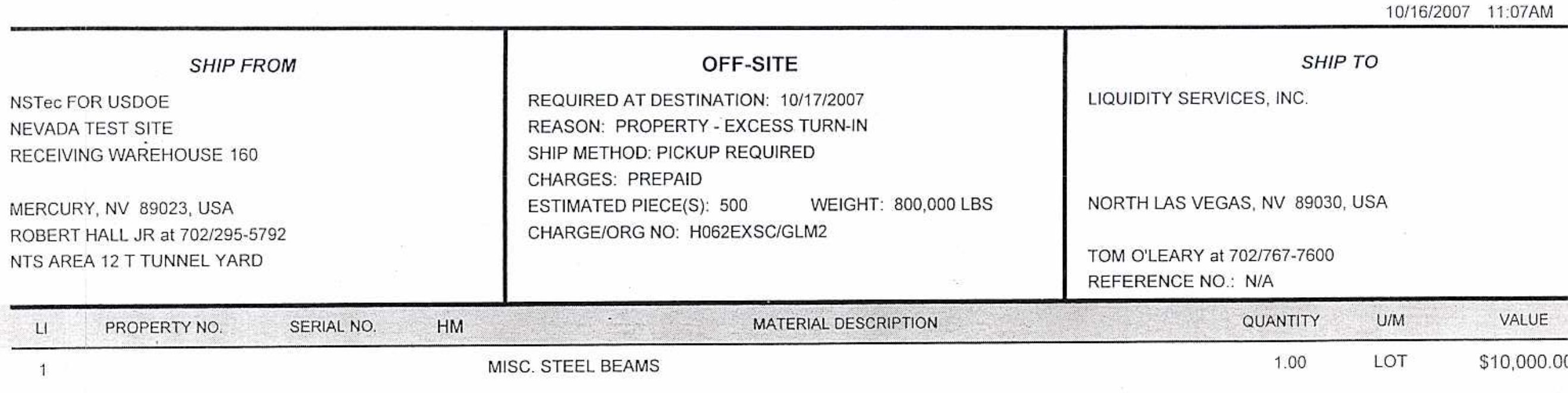

EXCESS CONDITION: PROPERTY WITH NO VALUE EXCEPT BASIC MAT

THESE STEEL BEAMS ARE CONSIDERED SCRAP AND ARE TO BE DISPOSED OF.
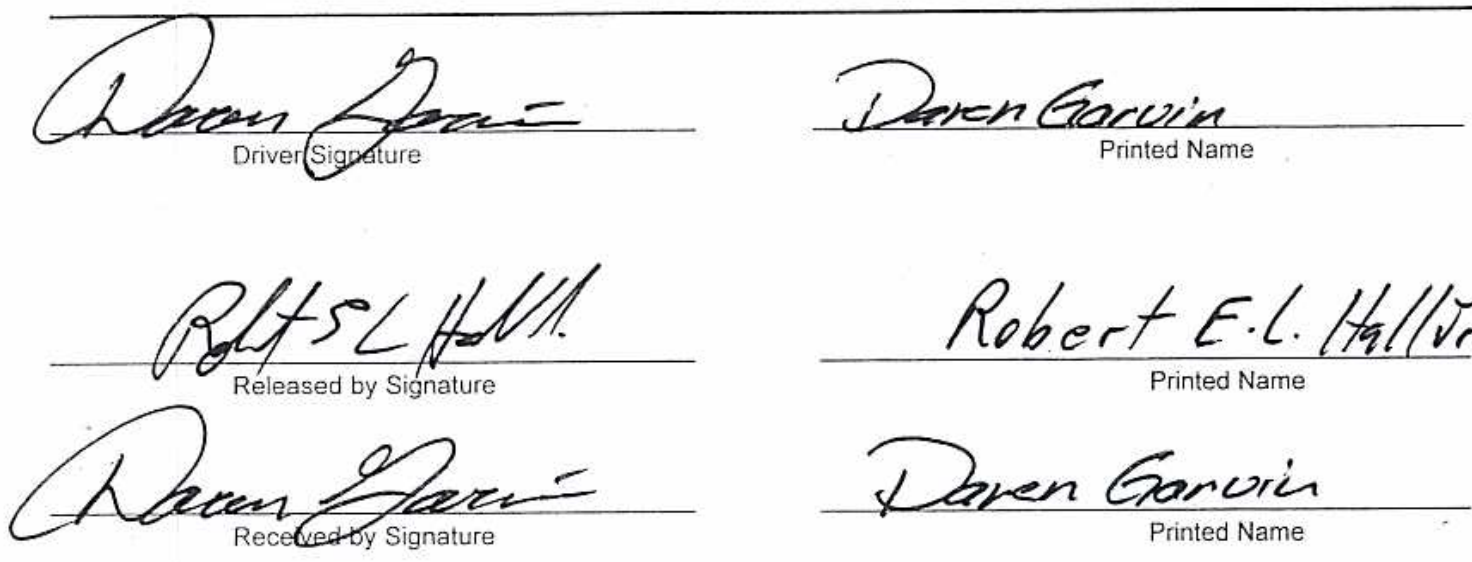

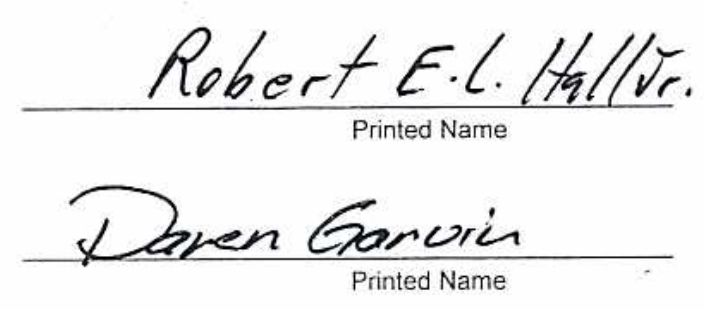

NO. 2075740

10/16/2007 11:07 AM 


\section{BECHTEL NEVADA}

P.O. BOX 98521

DATE $/ 0-24-07$

COMMODITY EXKLSS STEELE DELIVER TO LSi
FROM $/ 1 S \longdiv { E C H }$ AREA $/ 2-\sqrt{-7 \text { rndel }}$
PROPERTY REMOVAL Trhom TRUCK NO. 7 SHIPPER

DRIVER'S SIGNATURE (IN)

DRIVER'S SIGNATURE (OUT)
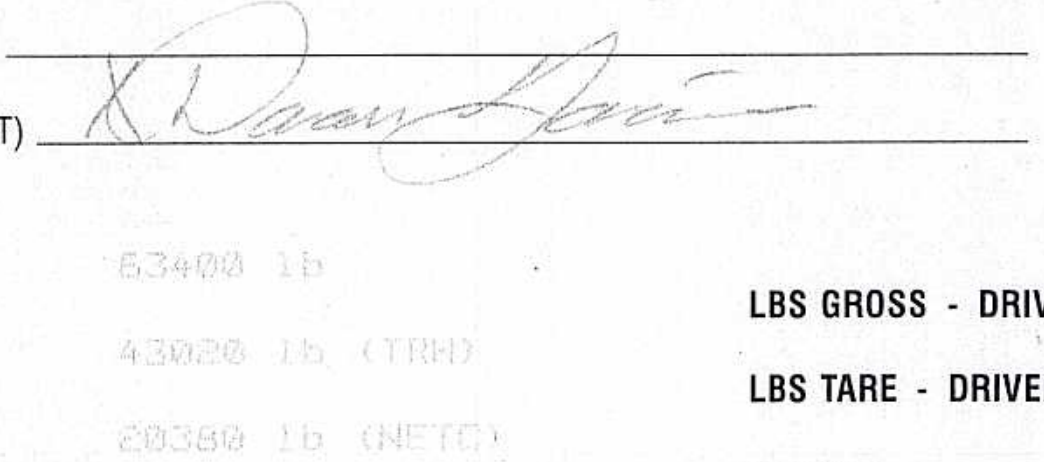

\section{LBS GROSS - DRIVER OFF}

LBS TARE - DRIVER OFF

\section{LBS NET}

WEIGHMASTER'S SIGNATURE (IN)

WEIGHMASTER'S SIGNATURE (OUT)

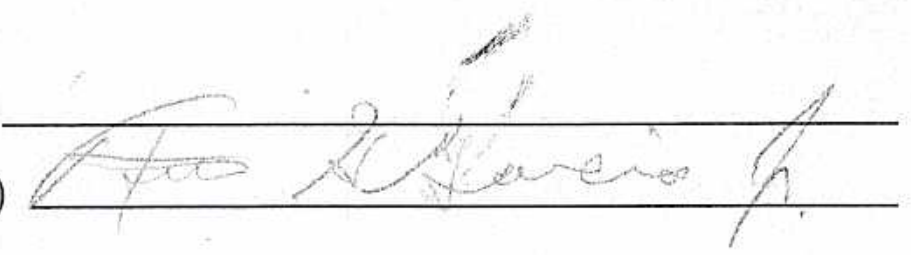




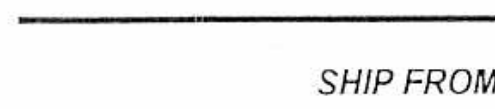

NSTEC FOR USDOE NEVADA TEST SITE RECEIVING WAREHOUSE 160 MERCURY, NV 89023, USA ROBERT HALL JR at 702/295-5792 NTS AREA 12 T TUNNEL YARD

\section{OFF-SITE}

REQUIRED AT DESTINATION: 10/17/2007 REASON: PROPERTY - EXCESS TURN-IN

SHIP METHOD: PICKUP REQUIRED

CHARGES: PREPAID

ESTIMATED PIECE(S): 500 WEIGHT: 800,000 LBS

CHARGEIORG NO: H062EXSC/GLM2

\begin{tabular}{|c|c|c|c|c|c|c|c|}
\hline $\mathrm{LI}$ & PROPERTYNO. & SERIAL NO. & $\mathrm{HM}$ & MATERIAL DESCRIPTION & QUANTITY & U/M & VALUE \\
\hline \multirow[t]{2}{*}{1} & & & & MISC. STEEL BEAMS & 1.00 & LOT & $\$ 10,000.00$ \\
\hline & & & & $\begin{array}{l}\text { EXCESS CONDITION: PROPERTY WITH NO VALUE EXCEPT BASIC MAT } \\
\text { THESE STEEL BEAMS ARE CONSIDERED SCRAP AND ARE TO BE DISPOSED OF. }\end{array}$ & & & \\
\hline
\end{tabular}
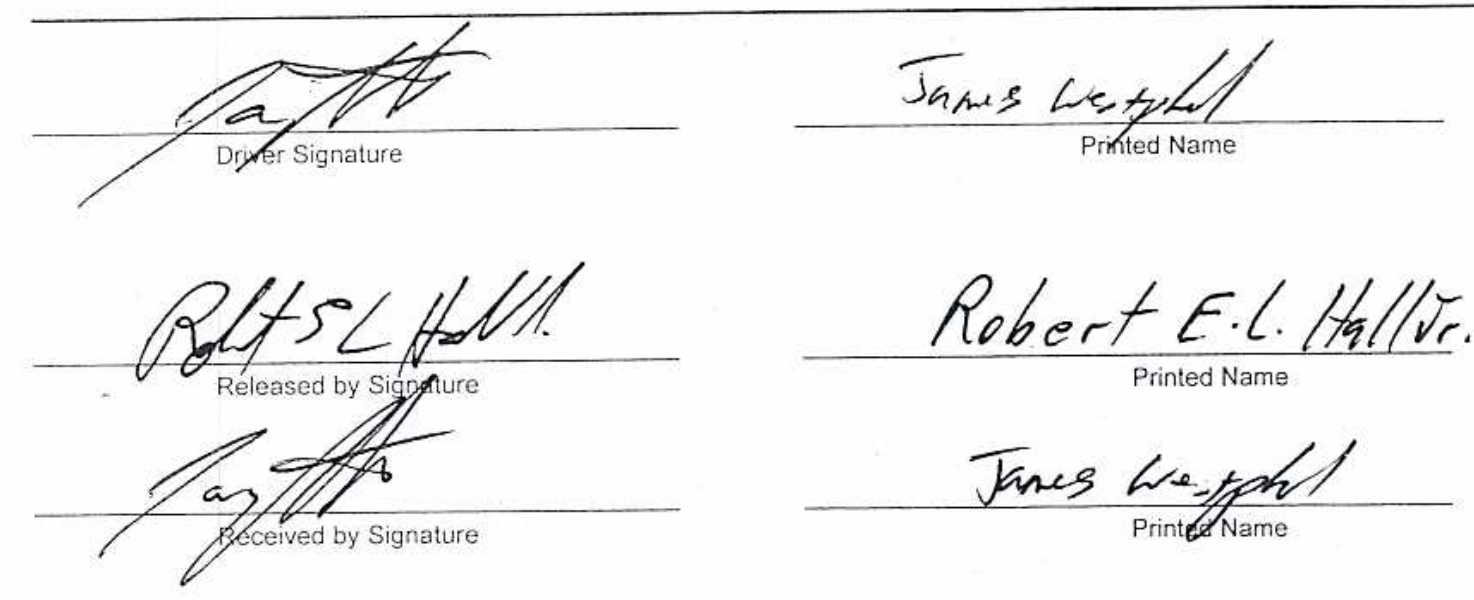

$$
\begin{aligned}
& \frac{p-2 y-u z}{\text { Date }} \\
& \frac{10-24-07}{\text { Date }} \\
& \frac{10-24-07}{\text { Date }} \\
& \text { Trk \#23370-A } \\
& \text { Tw/r\#51285-T } \\
& \text { Time } \\
& \text { Time } \\
& \text { Time }
\end{aligned}
$$

SHIP TO

LIQUIDITY SERVICES, INC.

NORTH LAS VEGAS, NV 89030, USA

TOM O'LEARY at $702 / 767-7600$

REFERENCE NO: N/A

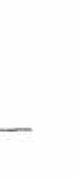




\section{BECHTEL NEVADA}

P.O. BOX 98521

LAS VEGAS, NV 89193-8521

WEIGH TICKET

GATE 100 INSPECTION STATION

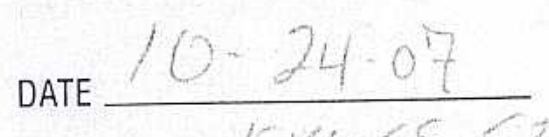

COMMODITY

DELIVER TO 15
- FRON

AREA $/ 27 / N$
PROPERTY REMOVAL

TiR 233704

08202 TRUCK NO.

TRR $51285 T$ SHIPPER

DRIVER'S SIGNATURE (IN)

DRIVER'S SIGNATURE (OUT)

LBS GROSS - DRIVER OFF

LBS TARE - DRIVER OFF

LBS NET

WEIGHMASTER'S SIGNATURE (IN)

WEIGHMASTER'S SIGNATURE (OUT)

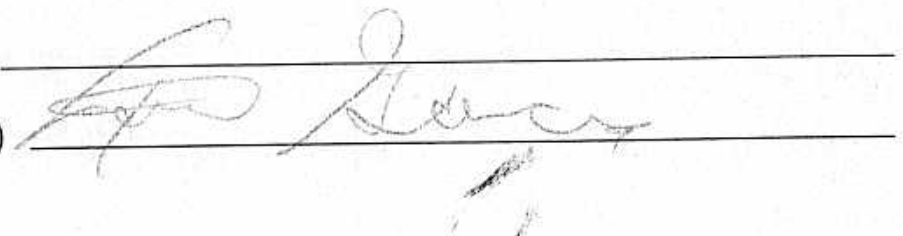




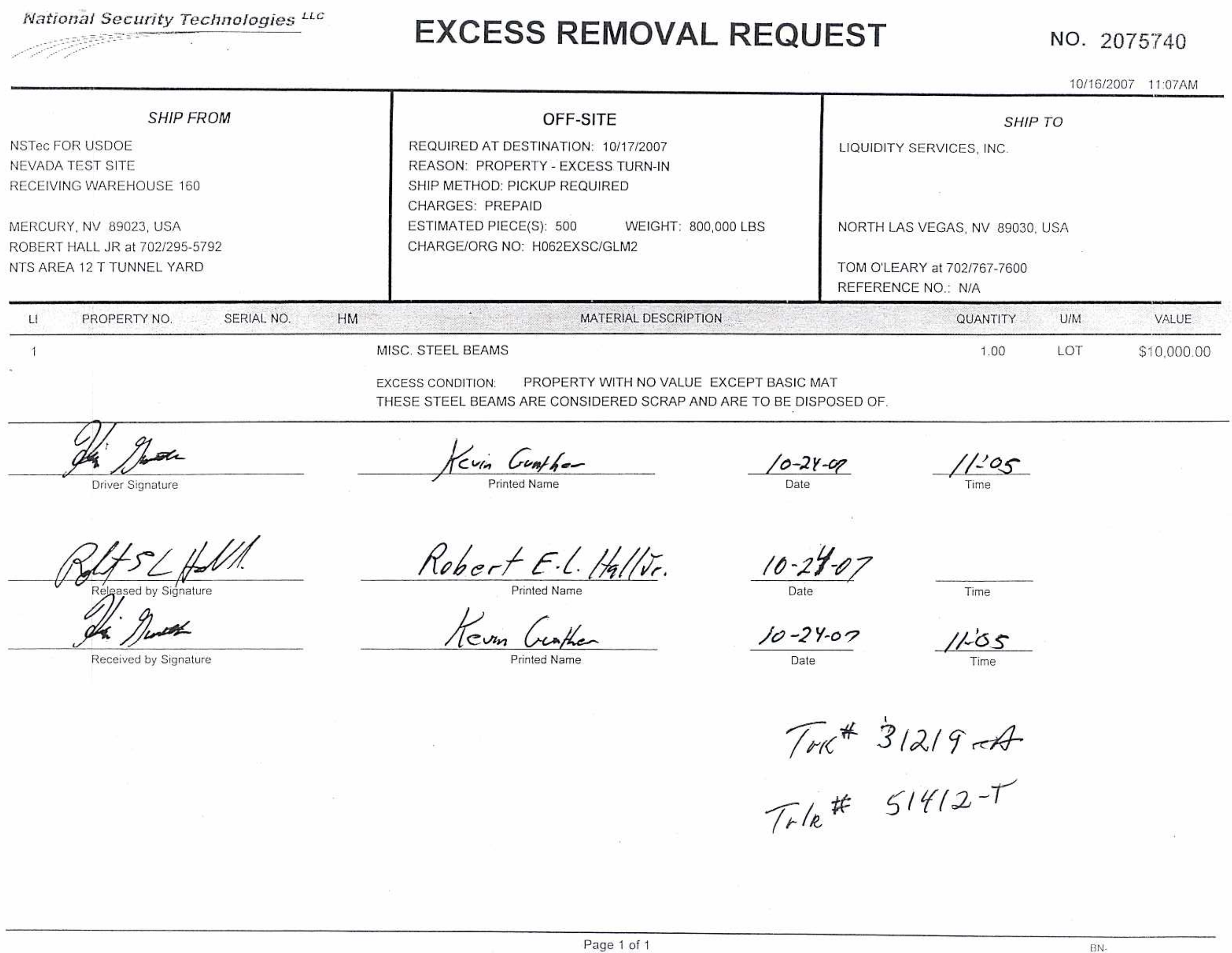




\section{BECHTEL NEVADA}

P.0. BOX 98521

LAS VEGAS, NV 89193-8521

WEIGH TICKET

GATE 100 INSPECTION STATION

DATE $10.24-07$

COMMODITY EXCQSS SOEL

FROM

DELIVER TO\&

AREA $12-7-7 U N N E L$

PROPERTY REMOVAL $\frac{2075 / 4 / 0}{3 / 219 / 4}$ TRUCK NO. RLER $5 / 4 / 2 T$ SHIPPER $2075 \% 40$

DRIVER'S SIGNATURE (IN)

DRIVER'S SIGNATURE (OUT)

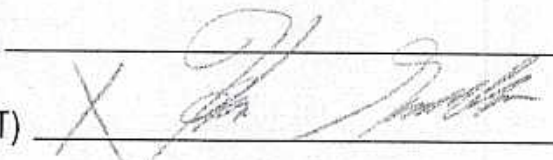

$519=03 \mathrm{~b}$

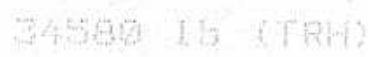

17340 ID (METE)

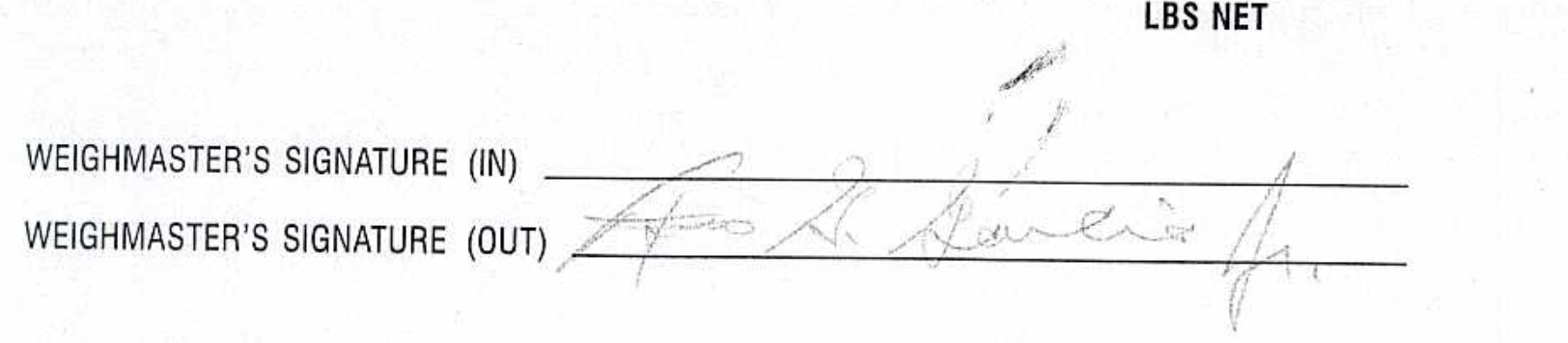

LBS TARE - DRIVER OFF

LBS NET

LBS GROSS - DRIVER OFF 


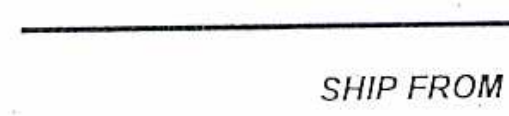

NSTEC FOR USDOE NEVADA TEST SITE

RECEIVING WAREHOUSE 160

MERCURY, NV 89023, USA ROBERT HALL JR at 702/295-5792 NTS AREA 12 T TUNNEL YARD

\section{OFF-SITE}

REQUIRED AT DESTINATION: 10/17/2007

REASON: PROPERTY - EXCESS TURN-IN

SHIP METHOD: PICKUP REQUIRED

CHARGES: PREPAID

ESTIMATED PIECE(S): $500 \quad$ WEIGHT: 800,000 LBS

CHARGE/ORG NO: H062EXSC/GLM2
SHIP TO

LIQUIDITY SERVICES, INC.

NORTH LAS VEGAS, NV 89030, USA

TOM O'LEARY at 702/767-7600

REFERENCE NO:: N/A

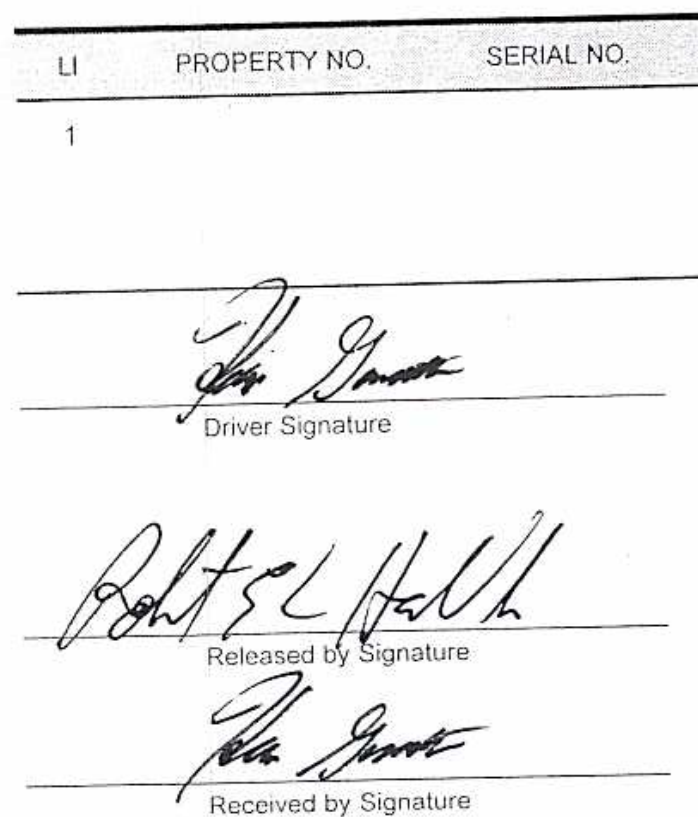

HM

MATERIAL DESCRIPTION

QUANTITY U/M

VALUE

MISC. STEEL BEAMS

EXCESS CONDITION: PROPERTY WITH NO VALUE EXCEPT BASIC MAT

THESE STEEL BEAMS ARE CONSIDERED SCRAP AND ARE TO BE DISPOSED OF

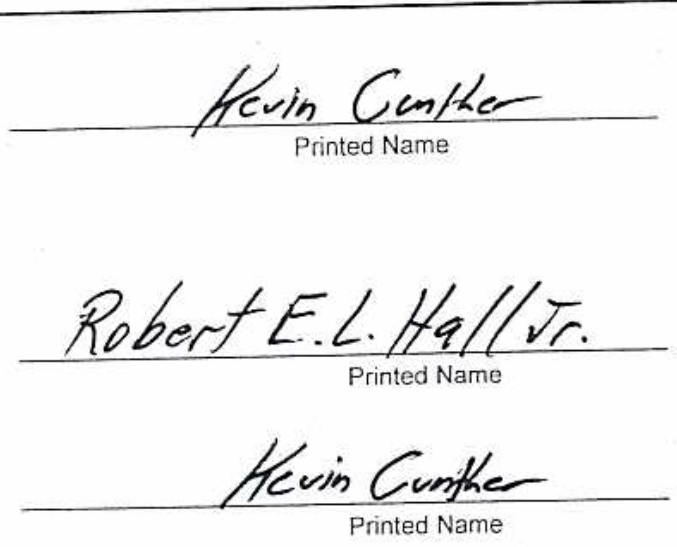

$\frac{10-2500}{\text { Date }}$
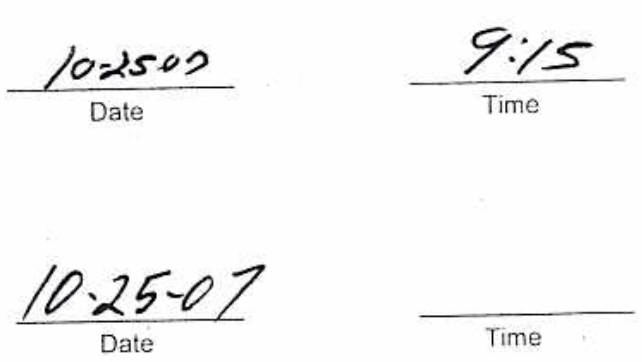

Time

$\operatorname{lar} 25-0 ?$

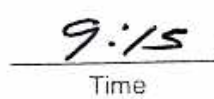

Printed Name

$$
\begin{aligned}
& T \text { TWK }-31219-A 4 \\
& \text { TWK }-51412-T
\end{aligned}
$$


BECHTEL NEVADA

P.O. BOX 98521

LAS VEGAS, NV 89193-8521

DATE $/ 0 / 25 / 07$

COMMODITY TEL 7 CAM

DELIVER TO

$1+15$

-

D

DRIVER'S SIGNATURE (IN)

DRIVER'S SIGNATURE (OUT)
WEIGH TICKET

GATE 100 INSPECTION STATION

PROPERTY REMOVAL

TRUCK NO.

SHIPPER
FROM

AREA

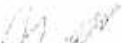

LBS GROSS - DRIVER OFF

LBS TARE - DRIVER OFF

LBS NET

WEIGHMASTER'S SIGNATURE (IN)

WEIGHMASTER'S SIGNATURE (OUT) 
National Security Technologies $^{\text {LC c }} \quad$ EXCESS REMOVAL REQUEST

NO. 2075740

10/16/2007 11:07 AM

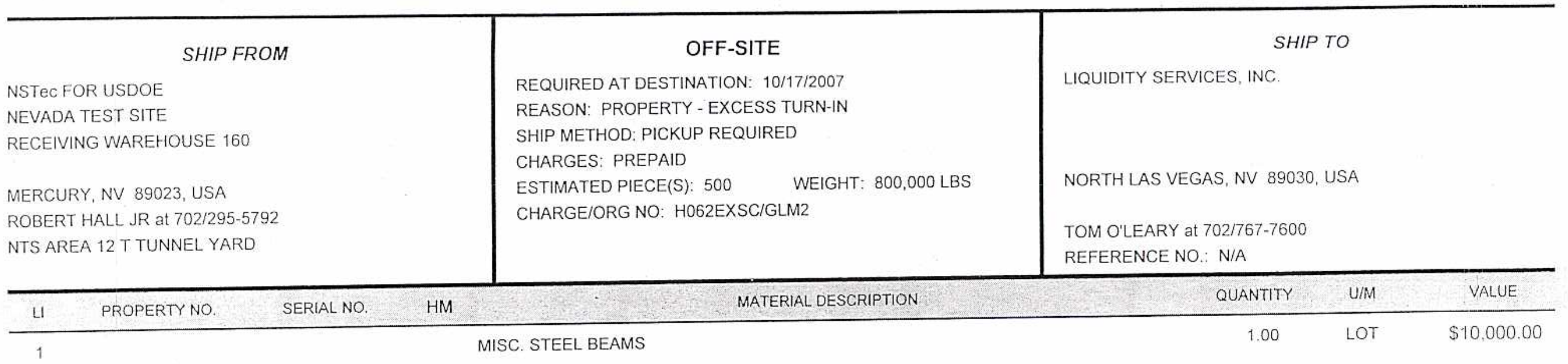

EXCESS CONDITION: PROPERTY WITH NO VALUE EXCEPT BASIC MAT

THESE STEEL BEAMS ARE CONSIDERED SCRAP AND ARE TO BE DISPOSED OF.
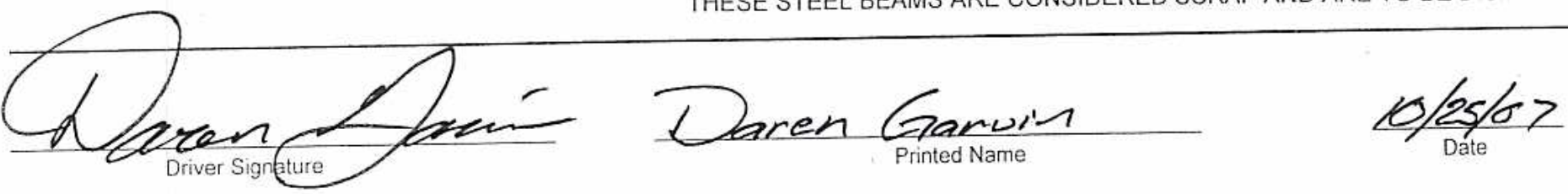

$\frac{10.25-07}{\text { Date }}$

Robert E.L.H.Hal/Vr.
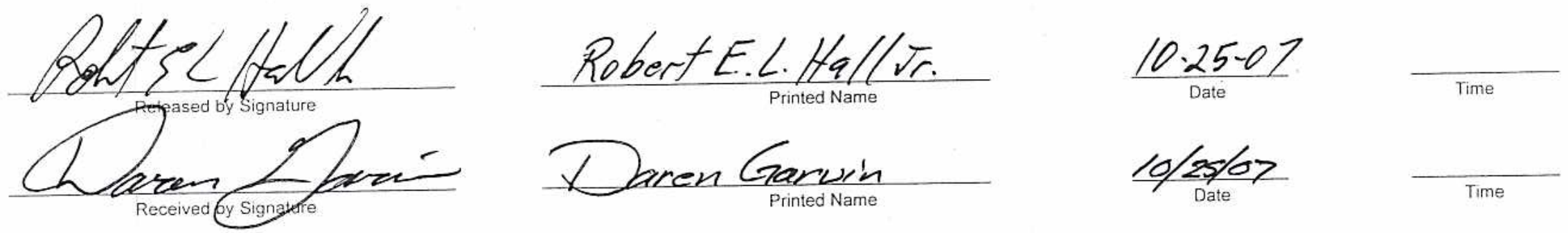

$$
\begin{aligned}
& \text { TAR }-30234.17 \\
& T \text { Th R }-450778 . T
\end{aligned}
$$

Page 1 of 1

$B N$ - 


\section{BECHTEL NEVADA}

P.O. BOX 98521

LAS VEGAS, NV 89193-8521

WEIGH TICKET

GATE 100 INSPECTION STATION

PROPERTY REMOVAL

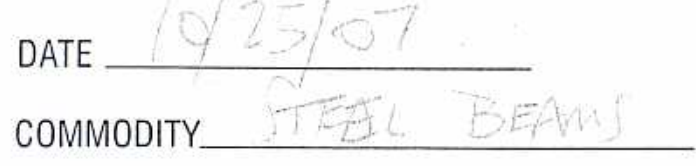

FROM

TRUCK NO.

DELIVER TO

L jow

AREA

SHIPPER

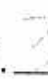

DRIVER'S SIGNATURE (IN)

DRIVER'S SIGNATURE (OUT)

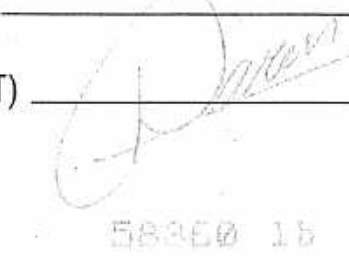

LBS GROSS - DRIVER OFF

46922 ib (PRH)

LBS TARE - DRIVER OFF

LBS NET

WEIGHMASTER'S SIGNATURE (IN)

WEIGHMASTER'S SIGNATURE (OUT)

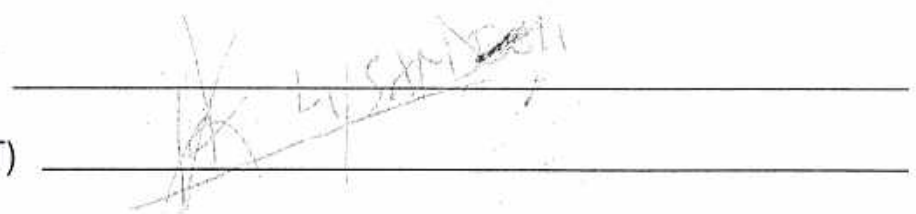




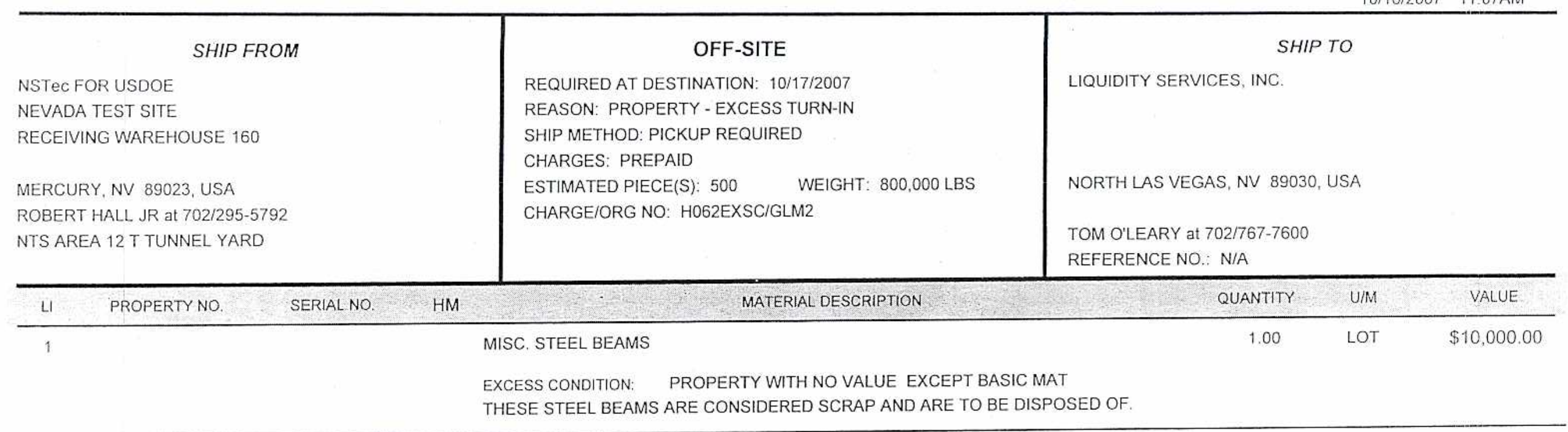
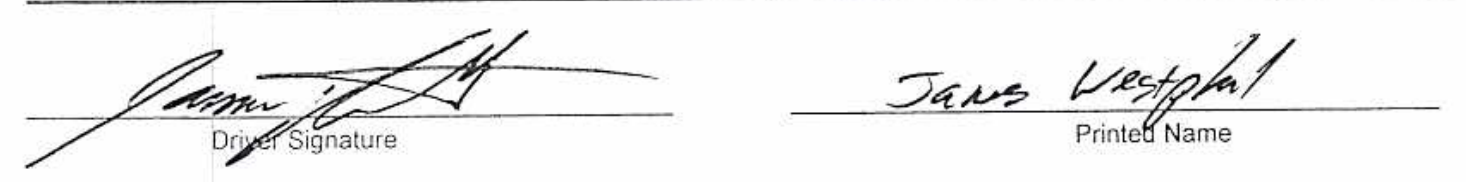

$$
\frac{10-25 \sim 7}{\text { Date }}
$$
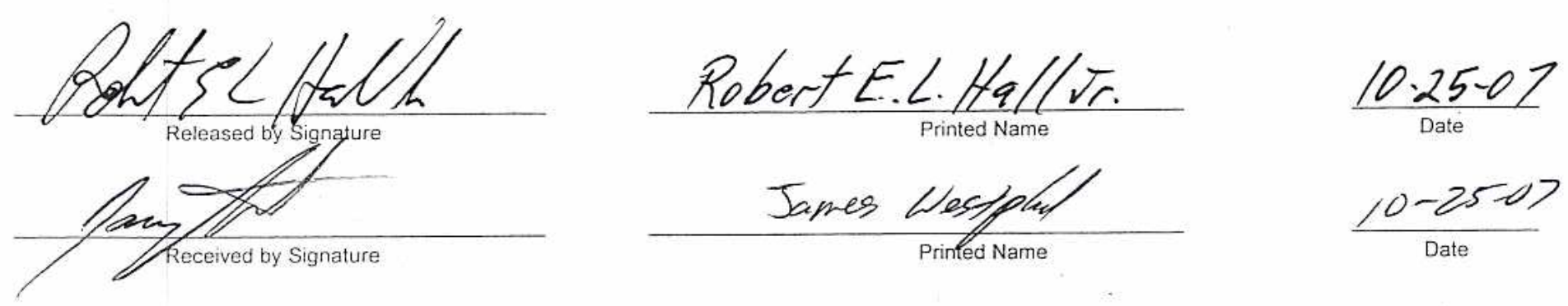

$$
\begin{aligned}
& \text { TrK }-23370-A \\
& \text { Tr/R }-31285-T
\end{aligned}
$$




\section{BECHTEL NEVADA}

P.O. BOX 98521

LAS VEGAS, NV 89193-8521

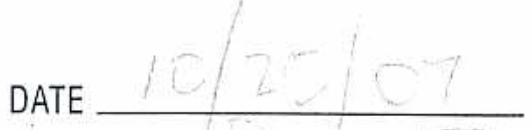

COMMODITY

DELIVER TO

AREA
WEIGH TICKET

GATE 100 INSPECTION STATION

PROPERTY REMOVAL TRUCK NO SHIPPER

DRIVER'S SIGNATURE (IN)

DRIVER'S SIGNATURE (OUT)

LBS GROSS - DRIVER OFF

LBS TARE - DRIVER OFF

LBS NET

WEIGHMASTER'S SIGNATURE (IN) WEIGHMASTER'S SIGNATURE (OUT) 


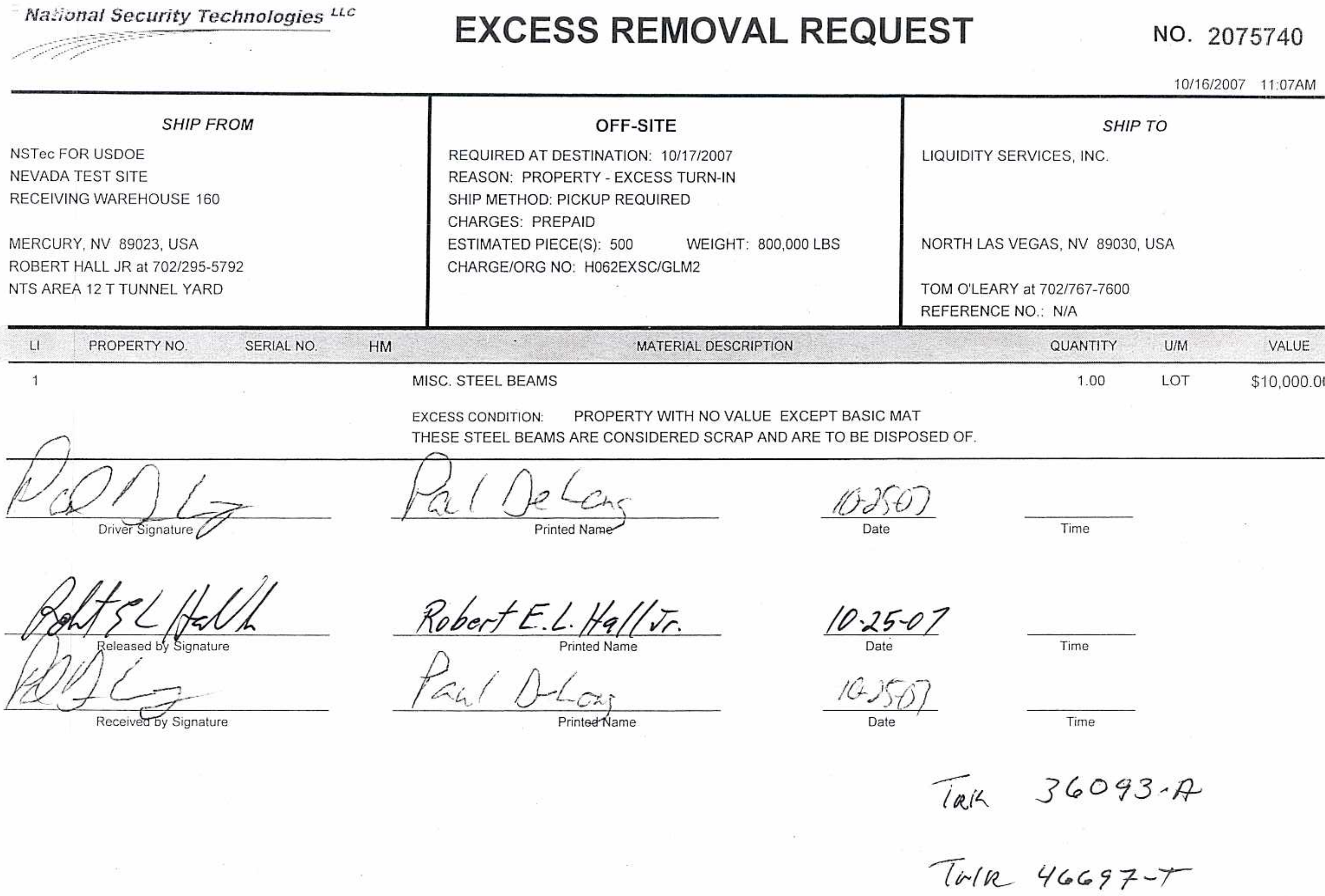




\section{BECHTEL NEVADA}

P.O. BOX 98521

LAS VEGAS, NV 89193-8521

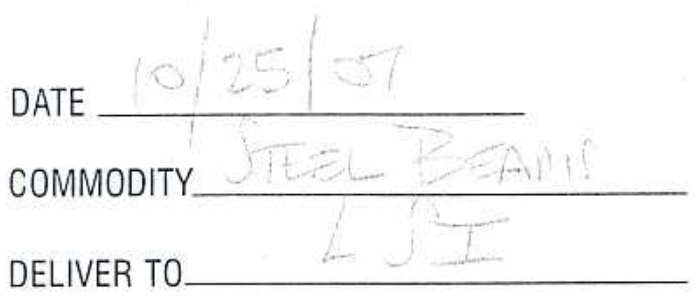

DELIVER TO

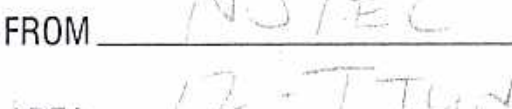
AREA

DRIVER'S SIGNATURE (IN)

DRIVER'S SIGNATURE (OUT)

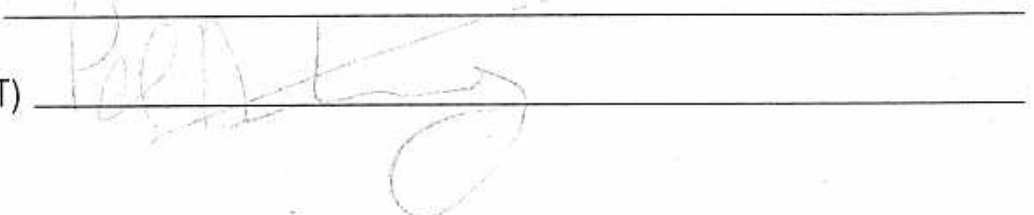

LBS GROSS - DRIVER OFF

LBS TARE - DRIVER OFF

LBS NET

WEIGHMASTER'S SIGNATURE (IN)

WEIGHMASTER'S SIGNATURE (OUT)

PROPERTY REMOVAL

TRUCK NO

SHIPPER

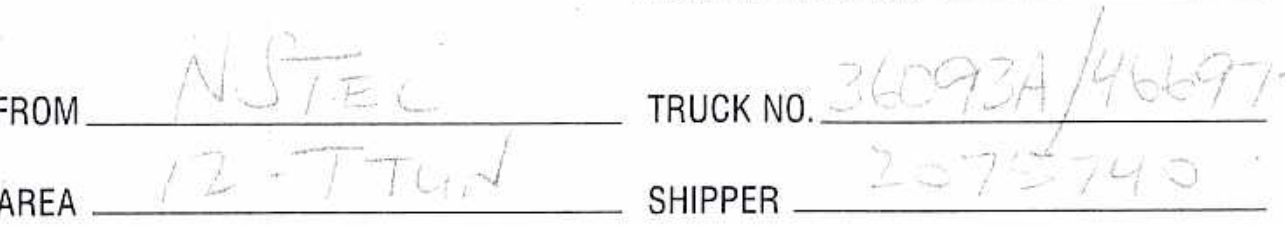

\section{LBS NET}




\section{SHIP FROM}

NSTec FOR USDOE NEVADA TEST SITE RECEIVING WAREHOUSE 160

MERCURY, NV 89023, USA ROBERT HALL JR at 702/295-5792 NTS AREA 12 T TUNNEL YARD

PROPERTYNO SERIALNO.

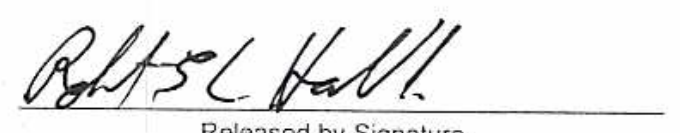

Released by Signature

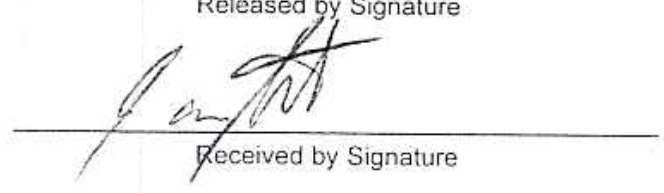

OFF-SITE

REQUIRED AT DESTINATION: 10/17/2007

REASON: PROPERTY - EXCESS TURN-IN

SHIP METHOD: PICKUP REQUIRED

CHARGES: PREPAID

ESTIMATED PIECE(S): $500 \quad$ WEIGHT: 800,000 LBS

CHARGE/ORG NO: H062EXSC/GLM2

\section{SHIP TO}

LIQUIDITY SERVICES, INC.

NORTH LAS VEGAS, NV 89030, USA

TOM O'LEARY at 702/767-7600

REFERENCE NO:: N/A

HM

MATERIAL DESCRIPTION

MISC. STEEL BEAMS

EXCESS CONDITION: PROPERTY WITH NO VALUE EXCEPT BASIC MAT

THESE STEEL BEAMS ARE CONSIDERED SCRAP AND ARE TO BE DISPOSED OF
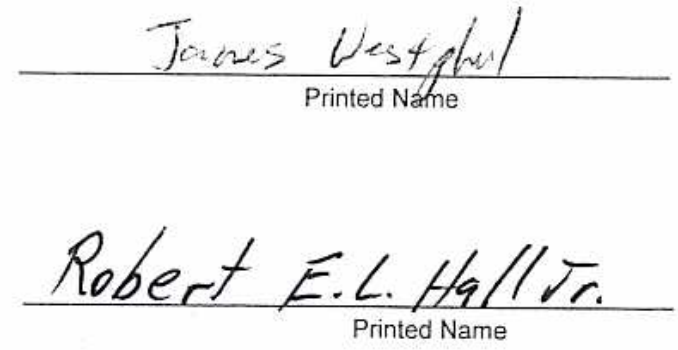

Tance Whtptat $\frac{10-29-67}{\text { Date }}$

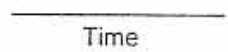

$\frac{10-29-07}{\text { Date }}$

Time

$\frac{10-29-07}{\text { Date }}$

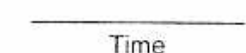




\section{BECHTEI NEVADA}

P.0. BOX 98521

LAS VEGAS, NV 89193-8521

WEIGH TICKET

08217

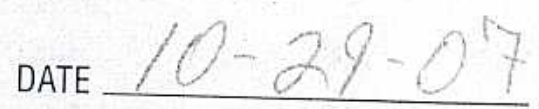

GATE 100 INSPECTION STATION
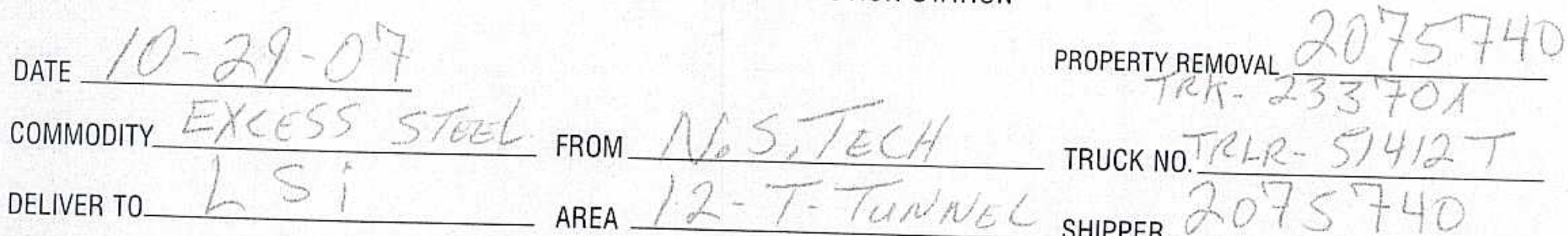
TRUCK NO. $\frac{T / 2 / R-5 / 4 / 27}{20757+40}$
SHIPPER

DRIVER'S SIGNATURE (IN)

DRIVER'S SIGNATURE (OUT)

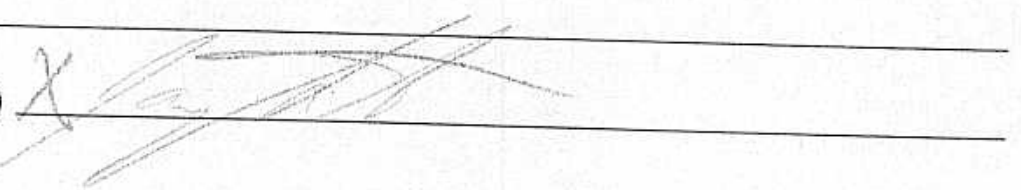

$55820 \times 13$

36090 12 (TRH)

19820 16 (HETC)
LBS GROSS - DRIVER OFF

LBS TARE - DRIVER OFF

LBS NET

WEIGHMASTER'S SIGNATURE (IN) WEIGHMASTER'S SIGNATURE (OUT)

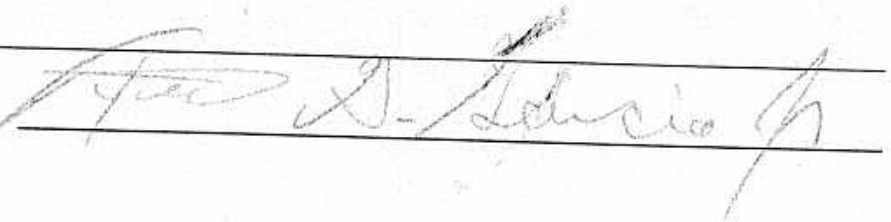




\section{SHIP FROM}

NSTEC FOR USDOE NEVADA TEST SITE

RECEIVING WAREHOUSE 160

MERCURY, NV 89023, USA ROBERT HALL JR at 702/295-5792 NTS AREA 12 T TUNNEL YARD

\section{OFF-SITE}

REQUIRED AT DESTINATION: 10/17/2007

REASON: PROPERTY - EXCESS TURN-IN

SHIP METHOD: PICKUP REQUIRED

CHARGES: PREPAID

ESTIMATED PIECE(S): 500 WEIGHT: 800,000 LBS

CHARGE/ORG NO: H062EXSC/GLM2
SHIP TO

LIQUIDITY SERVICES, INC

NORTH LAS VEGAS, NV 89030 , USA

TOM O'LEARY at 702/767-7600

REFERENCE NO: N/A

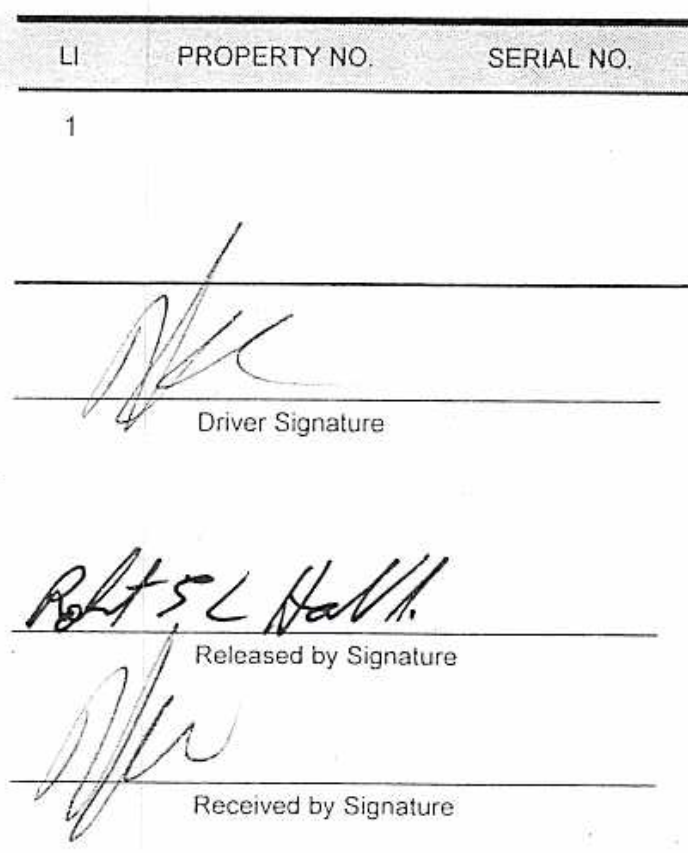

HM

MATERIAL DESCRIPTION

MISC, STEEL BEAMS

EXCESS CONDITION:

THESE STEEL BEAMS ARE CONSIDERED SCRAP AND ARE TO BE DISPOSED OF.

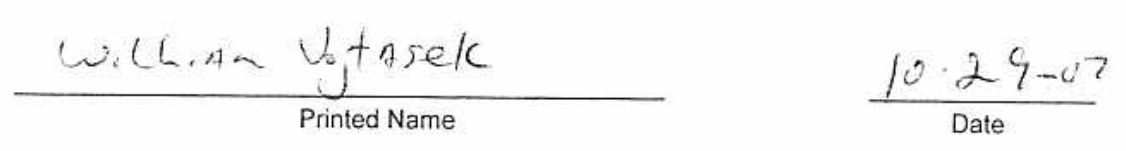
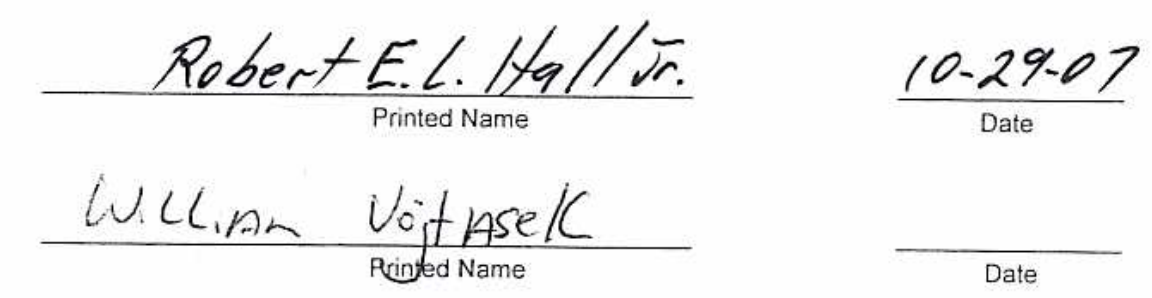

$\frac{\text { LULLinn VojthselC }}{\text { Peined Name }}$

QUANTITY

1.00

U/M

LOT

$10,000.00$

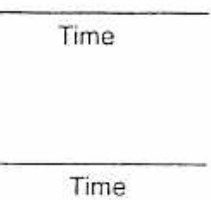

$$
\begin{aligned}
& \text { TrK\# } 32550-A \\
& \text { TrL \# 48995-T }
\end{aligned}
$$




\section{BECHTEL NEVADA}

P.0. BOX 98521

LAS VEGAS, NV 89193-8521

WEIGH TICKET

GATE 100 INSPECTION STATION

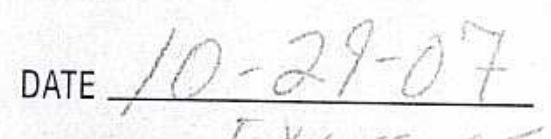

commodity EXCESS STEZL

DELIVER TO

1251

FROM HISTECH

AREA $/ 2-7=7$ TNDLL

PROPERTY REMOVAL

08216

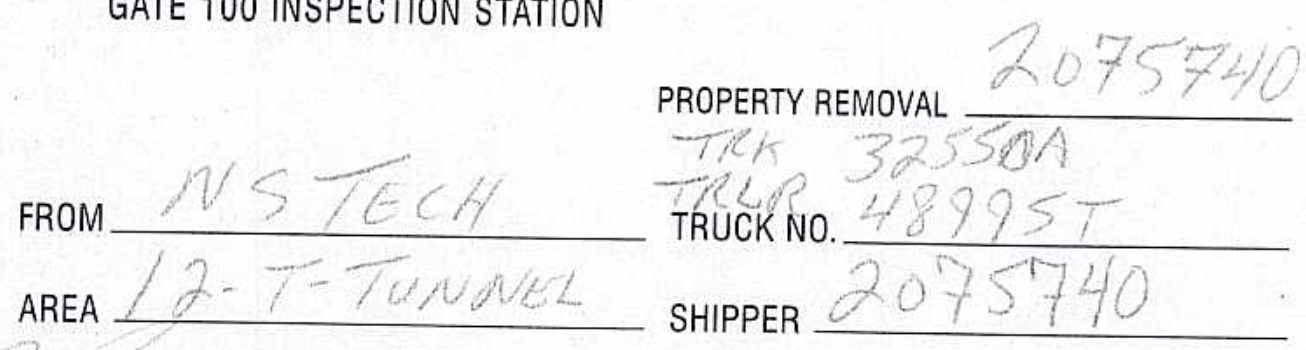

DRIVER'S SIGNATURE (IN)

DRIVER'S SIGNATURE (OUT)

LBS GROSS - DRIVER OFF

A4 458 B ib (TRA)

LBS TARE - DRIVER OFF

$234 A 0$ ib (NETC)

LBS NET

WEIGHMASTER'S SIGNATURE (IN)

WEIGHMASTER'S SIGNATURE (OUT)

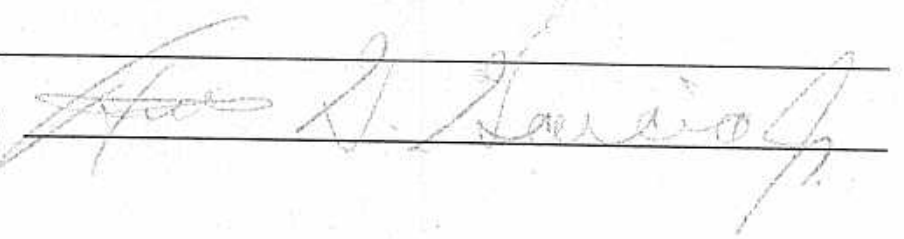




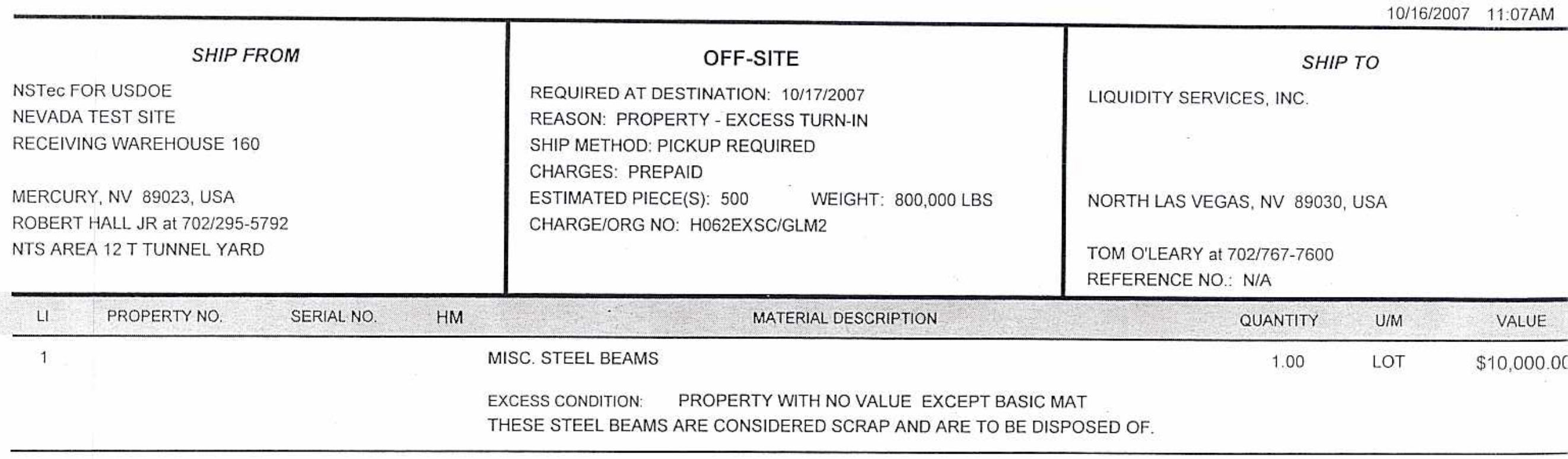
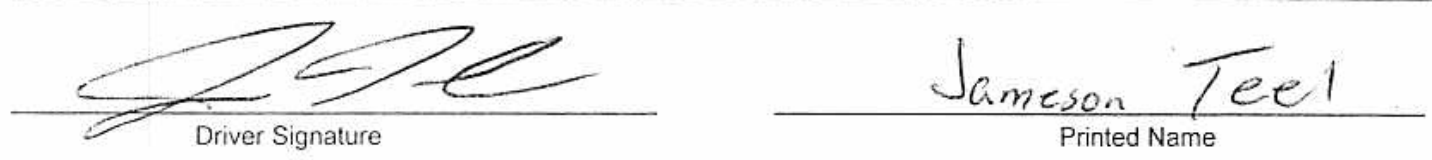

$\frac{10-29}{\text { Date }}$

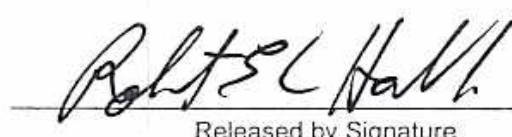

Released by Signature

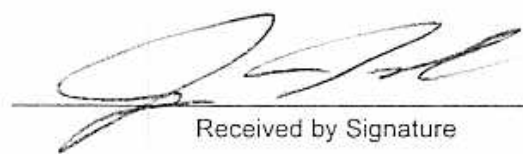

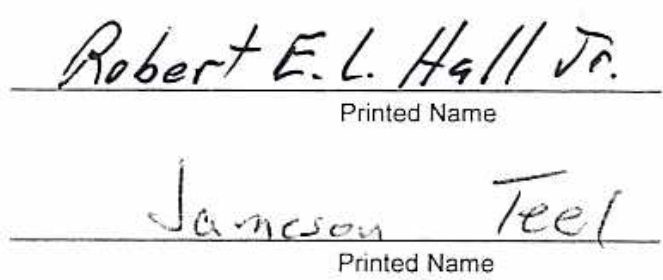

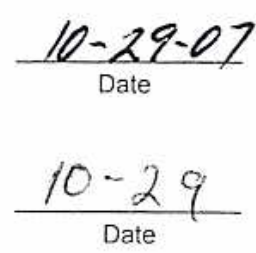

$$
\begin{aligned}
& \text { TrK } 35028-4 \\
& \text { TrL }
\end{aligned}
$$




\section{BECHTEL NEVADA}

P.O. BOX 98521

LAS VEGAS, NV 89193-8521

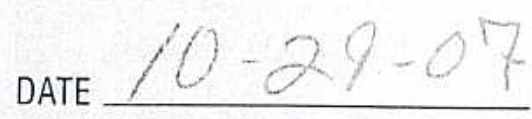

COMMODITY EXCESS STEL DELIVER TO 2.5

\section{WEIGH TICKET}

GATE 100 INSPECTION STATION

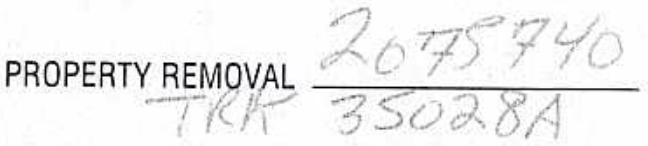

08214 TRUCK NO SHIPPER

DRIVER'S SIGNATURE (IN)

DRIVER'S SIGNATURE (OUT)

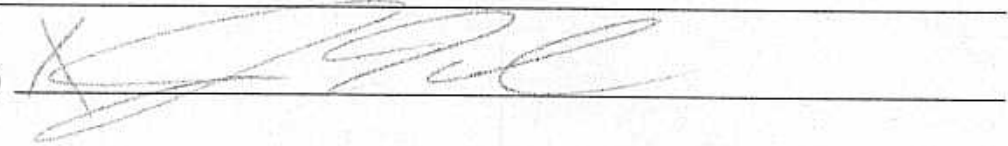

\section{1}

4.3020 16 (TRH)

20060 is (NETC)

WEIGHMASTER'S SIGNATURE (IN) WEIGHMASTER'S SIGNATURE (OUT)
LBS GROSS - DRIVER OFF

LBS TARE - DRIVER OFF

LBS NET
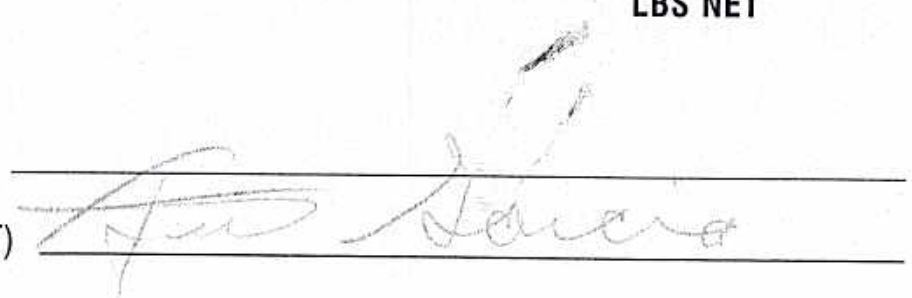


\section{SHIP FROM}

NSTEC FOR USDOE NEVADA TEST SITE

RECEIVING WAREHOUSE 160

MERCURY, NV 89023, USA

ROBERT HALL JR at 702/295-5792

NTS AREA 12 T TUNNEL YARD

\section{OFF-SITE}

REQUIRED AT DESTINATION: 10/17/2007

REASON: PROPERTY - EXCESS TURN-IN

SHIP METHOD: PICKUP REQUIRED

CHARGES: PREPAID

ESTIMATED PIECE(S): $500 \quad$ WEIGHT: 800,000 LBS

CHARGE/ORG NO: H062EXSC/GLM2

\section{SHIP TO}

LIQUIDITY SERVICES, INC

NORTH LAS VEGAS, NV 89030, USA

TOM O'LEARY at 702/767-7600

REFERENCE NO: N/A

\begin{tabular}{lll}
\hline$L$ & PROPERTYNO. & SERIAL NO. \\
\hline 1 & \\
\hline
\end{tabular}
Driver Signature
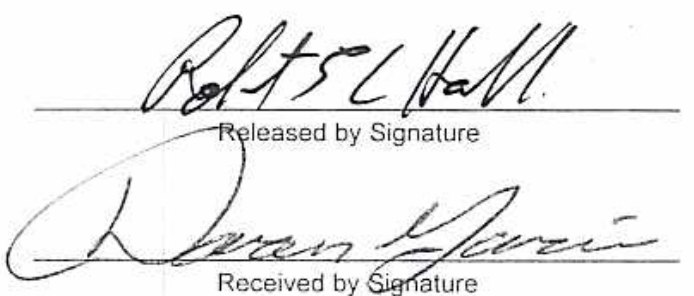
Received by Signature
HM

\section{MISC. STEEL BEAMS}

EXCESS CONDITION

MATERIAL DESCRIPTION

THESE STEEL BEAMS ARE CONSIDERED SCRAP AND ARE TO BE DISPOSED OF

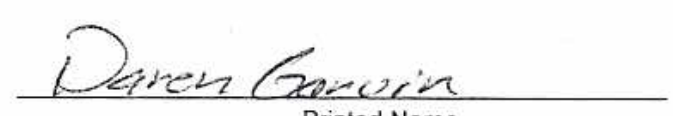

Printed Name

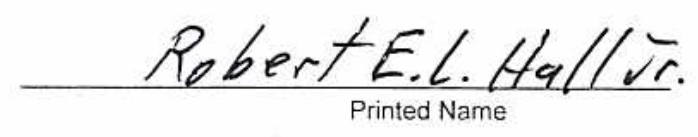

$\frac{\text { Derem Garvilut }}{\text { Printed Name }}$

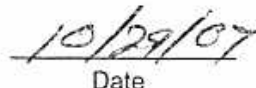

QUANTITY

1.00

U/M

VALUE

.00

LOT

$\$ 10,000.00$
Time

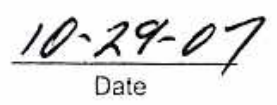

$\frac{10 / 28 / 00}{\text { Date }}$

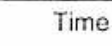

$$
\begin{aligned}
& \text { TrK } \$ 30294-2 \\
& \text { TrL } 45778-T
\end{aligned}
$$




\section{BECHTEL NEVADA}

P.O. BOX 98521

LAS VEGAS, NV 89193-8521

WEIGH TICKET

GATE 100 INSPECTION STATION

DATE $10-29-07$

COMMODITY EXCESS STEEL FROM NSTECH

AREA 12-T-THNINEL

PROPERTY REMOVAL

TRLR

TRUCK KNO

DELIVERTOLLSi

SHIPPER 2075740

DRIVER'S SIGNATURE (IN)

DRIVER'S SIGNATURE (OUT)

T)

LBS GROSS - DRIVER OFF

43620 it (TRH)

LBS TARE - DRIVER OFF

$199201 \mathrm{~b}$ (HeTt)

LBS NET

WEIGHMASTER'S SIGNATURE (IN)

WEIGHMASTER'S SIGNATURE (OUT)

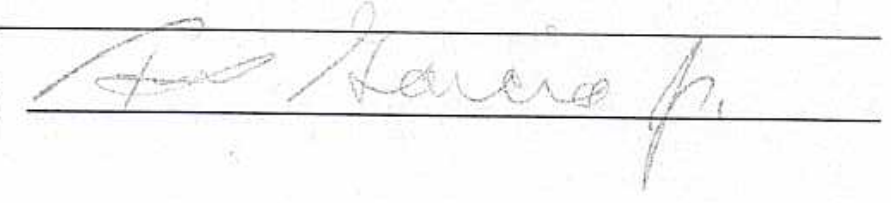




\section{SHIP FROM}

NSTec FOR USDOE NEVADA TEST SITE

RECEIVING WAREHOUSE 160

MERCURY, NV 89023 , USA ROBERT HALL JR at 702/295-5792 NTS AREA 12 T TUNNEL YARD

\section{OFF-SITE}

REQUIRED AT DESTINATION: 10/17/2007 REASON: PROPERTY - EXCESS TURN-IN

SHIP METHOD: PICKUP REQUIRED

CHARGES: PREPAID

ESTIMATED PIECE(S): $500 \quad$ WEIGHT: 800,000 LBS

CHARGE/ORG NO: H062EXSC/GLM2
SHIP TO

LIQUIDITY SERVICES, INC

NORTH LAS VEGAS, NV 89030, USA

TOM O'LEARY at 702/767-7600

REFERENCE NO: N/A

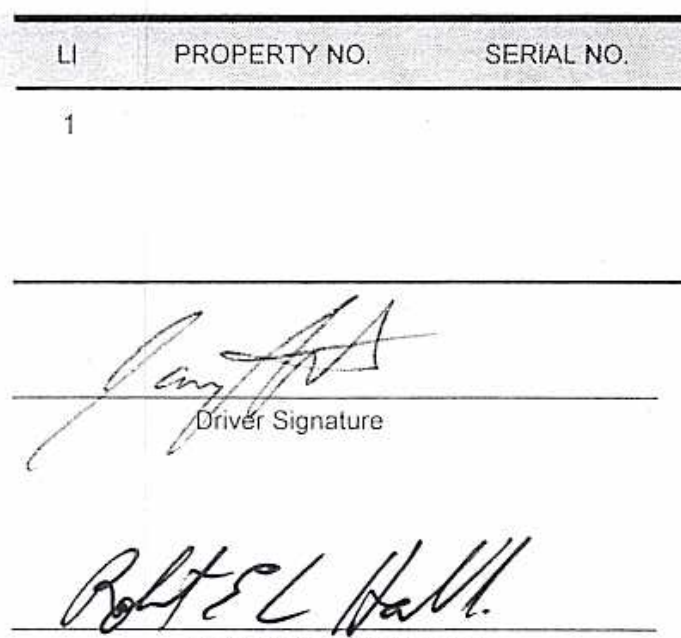

Released by Signature,

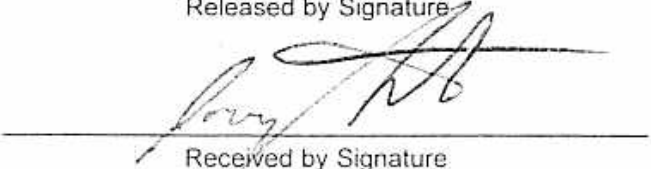

Received by Signature
HM

MISC. STEEL BEAMS

MATERIAL DESCRIPTION
QUANTITY

100

PROPERTY WITH NO VALUE EXCEPT BASIC MAT

EXCESS CONDITION

THESE STEEL BEAMS ARE CONSIDERED SCRAP AND ARE TO BE DISPOSED OF.
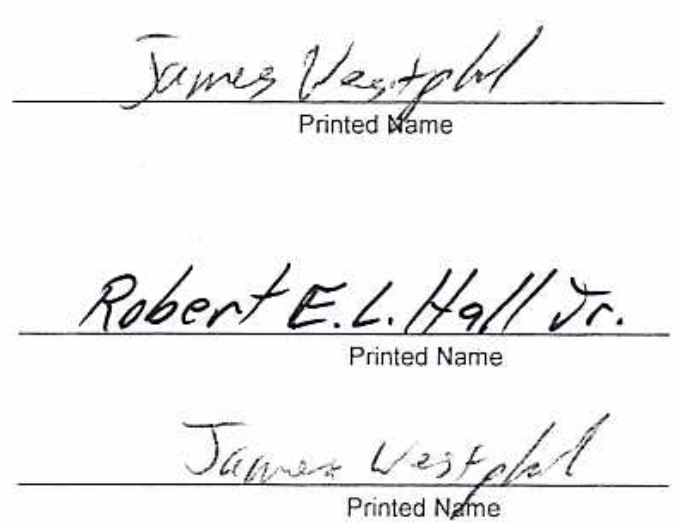

$\frac{10-30-47}{\text { Date }}$

Time

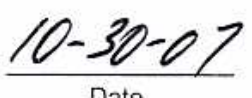

$\frac{10-3.0-0 ?}{\text { Date }}$

Time

Time

$$
\begin{aligned}
& \text { Trk } 23370-2 \\
& \text { TrL } 45778-\pi
\end{aligned}
$$




\section{BECHTEL NEVADA}

P.0. BOX 98521

LAS VEGAS, NV 89193-8521

Date $10=30-07$ commodity EXCESS STEZL DELIVER TO $\angle 5 . i$ FROM

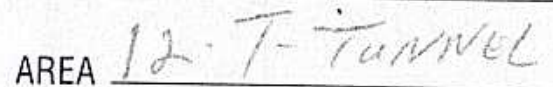

\section{WEIGH TICKET}

GATE 100 INSPECTION STATION

PROPERTY REMOVAL 2075740

$T R L R$ TRUKT? TRUCK NO SHIPPER

DRIVER'S SIGNATURE (IN) DRIVER'S SIGNATURE (OUT)

LBS GROSS - DRIVER OFF

43000 \&. (TRH)

LBS TARE - DRIVER OFF

$2 \pm 726$ ib 4 METC

\section{LBS NET}

WEIGHMASTER'S SIGNATURE (IN) WEIGHMASTER'S SIGNATURE (OUT)

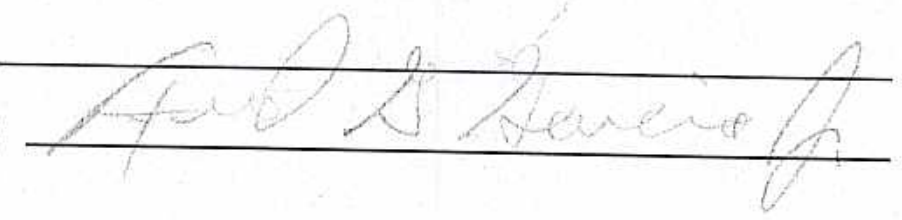




\section{SHIP FROM}

NSTEC FOR USDOE NEVADA TEST SITE

RECEIVING WAREHOUSE 160

MERCURY, NV 89023, USA ROBERT HALL JR at 702/295-5792 NTS AREA 12 T TUNNEL YARD

\section{OFF-SITE}

REQUIRED AT DESTINATION: 10/17/2007

REASON: PROPERTY - EXCESS TURN-IN

SHIP METHOD: PICKUP REQUIRED

CHARGES: PREPAID

ESTIMATED PIECE(S): $500 \quad$ WEIGHT: 800,000 LBS

CHARGE/ORG NO: H062EXSC/GLM2
SHIP TO

LIQUIDITY SERVICES, INC

NORTH LAS VEGAS, NV 89030, USA

TOM O'LEARY at 702/767-7600

REFERENCE NO:: N/A

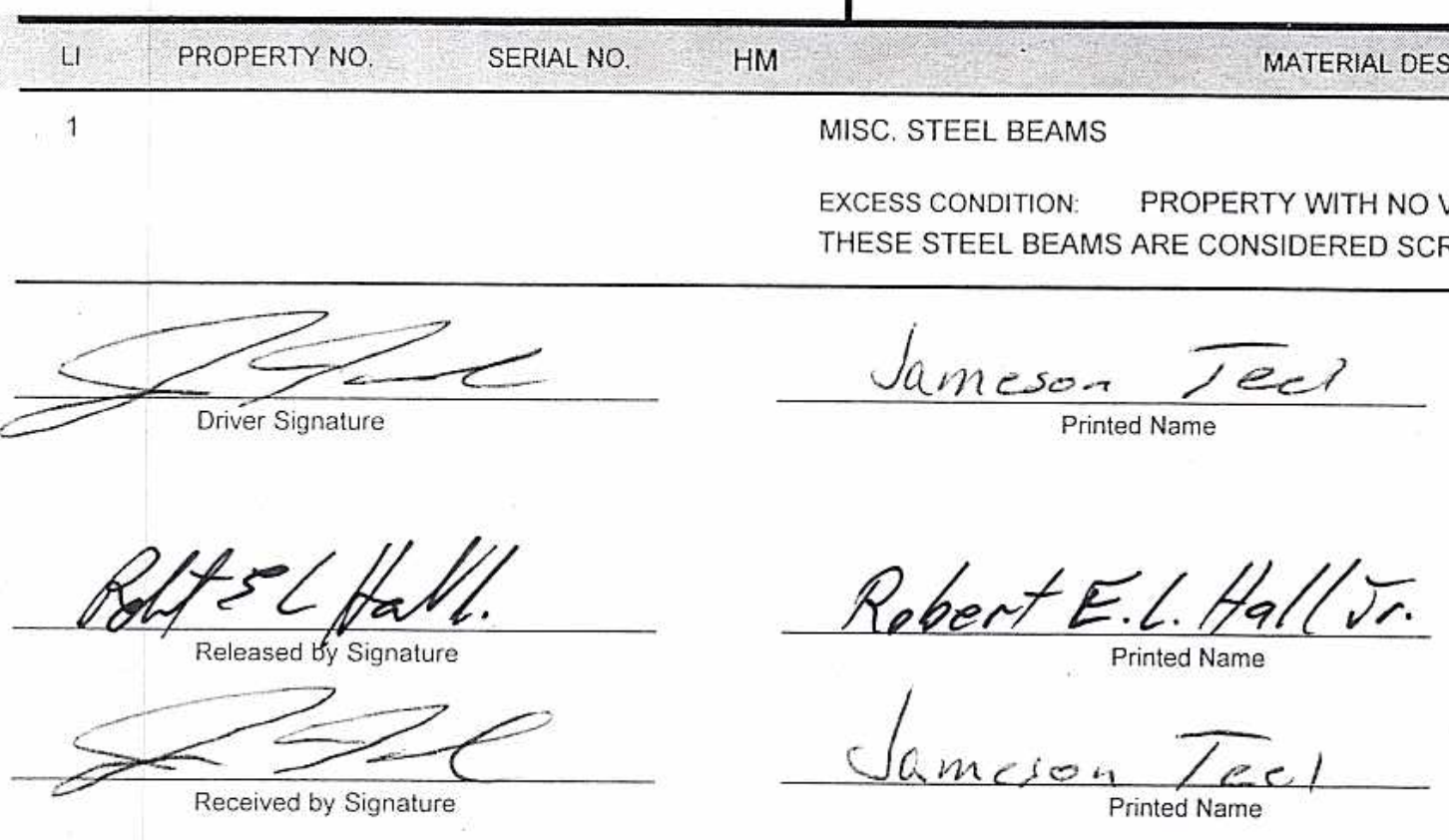

$\frac{10-30.07}{\text { Date }}$

QUANTITY

QUANTITY

U/M

1.00

LOT

$\$ 10,000.00$

EXCESS CONDITION: PROPERTY WITH NO VALUE EXCEPT BASIC MAT

THESE STEEL BEAMS ARE CONSIDERED SCRAP AND ARE TO BE DISPOSED OF.

$$
\begin{aligned}
& \text { TrK \#6 35028-4 } \\
& \text { TrL 45779-T }
\end{aligned}
$$


BECHTEL NEVADA

P.O. BOX 98521

LAS VEGAS, NV 89193-8521

DATE $10.30<0^{17}$

DATE $1 / 36$

COMMODITY

DELIVER TO
WEIGH TICKET

GATE 100 INSPECTION STATION

DRIVER'S SIGNATURE (IN)

DRIVER'S SIGNATURE (OUT)

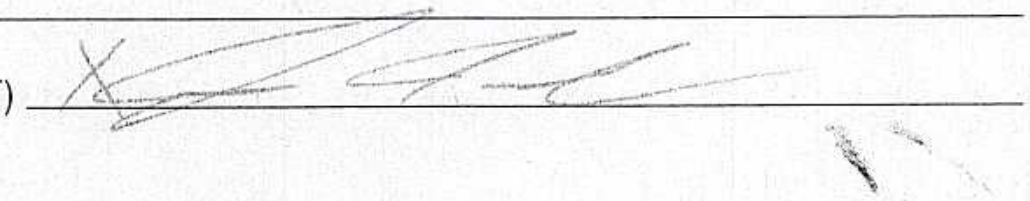

47502 ?

LBS GROSS - DRIVER OFF

41200 ib (TRH)

FABD L

LBS TARE - DRIVER OFF

LBS NET

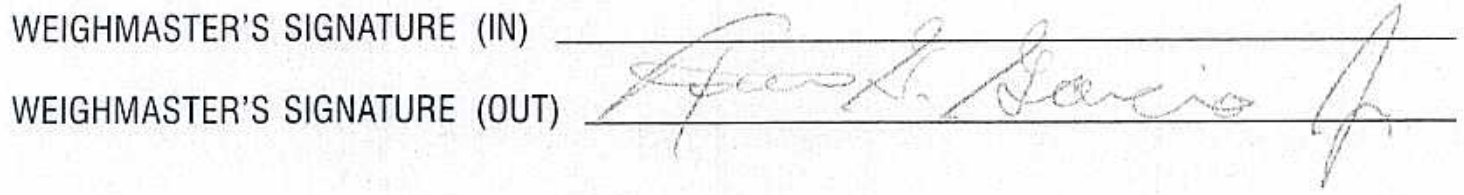




\section{APPENDIX C SECTORED HOUSEKEEPING SITE ClOSURE VERIFICATION FORM}


CAU 481 Closure Report Section: Appendix C

Revision: 0

Date: November 2008

THIS PAGE INTENTIONALLY LEFT BLANK 


\section{Sectored Housekeeping Site Closure Verification Form}

Closure Verification Date: 08/11/2008

CAU Number: 481

CAS Number: $12-42-05$

CAS Description: Housekeeping Waste

Sector Designation: NTS Sector F

Housekeeping Site General Location: Area 12 T-Tunnel Lower Laydown Yard

Northing: 4,118,520 m (UTM, Zone 11) Easting: 574,889 m (UTM, Zone 11)

Latitude: $37.212000000 \quad$ Longitude: -116.156000000

Coordinate/Elevation Data Obtained from: North American Datum, 1927.

Site Access Route: Take Mercury Highway north to Rainier Mesa Road. Continue on Rainier Mesa Road to the 12-01 Road. Turn right (north) on the 12-01 Road and proceed approximately 1.7 miles to North Rainier Mesa Road. Turn left on North Rainier Mesa Road. The site is located 0.4 miles on the left.

\begin{tabular}{|l|l|}
\hline \multicolumn{1}{|c|}{ Waste Item(s) Originally at Site } & \multicolumn{1}{|c|}{ Apparent Waste Type* } \\
\hline $\begin{array}{l}\text { Pipe, valves, clamps, fittings, structural beams (steel } \\
\text { sets) and framework, railroad rail, flat plate, scrap } \\
\text { metal, fiberglass, wire spools, sheetrock, wood, brush, } \\
\text { other debris, tank, chamber, large rectangular vessel, } \\
\text { skids, generators, compressor, hoist and winches, and } \\
\text { equipment fluids. }\end{array}$ & Ordinary, scrap metal, salvageable, radioactive. \\
\hline Ordinary, Scrap Metal, Asbestos, PCB, Salvageable, Hazardous, Radioactive, Mixed, Unknown, Other \\
\hline \multicolumn{2}{|c|}{} \\
\hline
\end{tabular}

Current Site Description/Observations: Petroleum fluids, steel sets, and lead were recycled. Debris not meeting free-release criteria (approximately 50 tons) was disposed of as radioactive waste. All remaining metal, wood, equipment, and debris (approximately 1,464 tons) were removed and transported to the Area 9 U10c Sanitary Landfill for disposal.

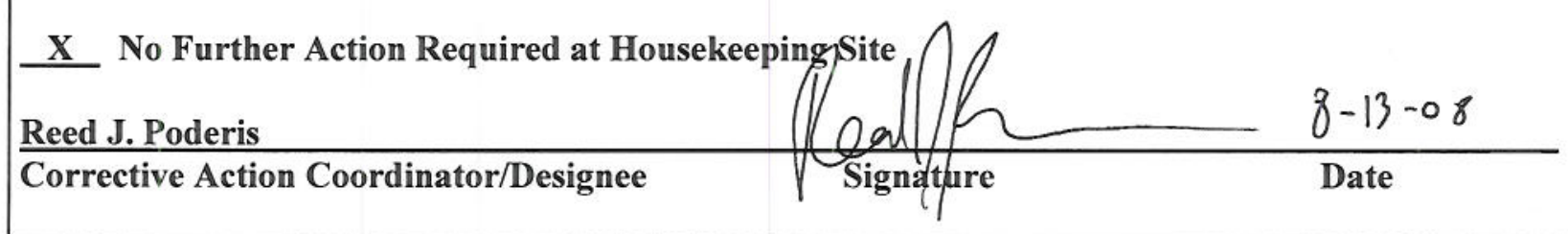


CAU 481 Closure Report

Section: Appendix C

Revision: 0

Date: November 2008

THIS PAGE INTENTIONALLY LEFT BLANK 
CAU 481 Closure Report

Section: Appendix D

Revision: 0

Date: November 2008

\section{APPENDIX D}

SPILL REPORT NUMBER 070813-01 
CAU 481 Closure Report

Section: Appendix D

Revision: 0

Date: November 2008

THIS PAGE INTENTIONALLY LEFT BLANK 


\section{STATE OF NEVADA}

Department of Conservation \& Natural Resources

DIVISION OF ENVIRONMENTAL PROTECTION
Jim Gibbons, Governor Allen Biaggi, Director

Leo M. Drozdoff, P.E., Administrator

protecting the future for generations

149995

November 2, 2007

Kenneth A. Hoar, Director

Environmental, Safety \& Health Division

National Nuclear Security Administration

Nevada Site Office

P.O. Box 98518

Las Vegas, Nevada 89193-8515

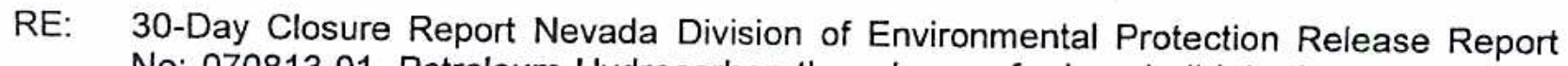
No: 070813-01, Petroleum Hydrocarbon the release of mineral oil into the soil from the two electrical switch boxes in Area 12 of the Nevada Test Site

Dear Mr. Hoar:

The Nevada Division of Environmental Protection, Bureau of Federal Facilities staff (NDEP) has evaluated the National Nuclear Security Administration, Nevada Site Office (NNSANSO) Final Report on NDEP Spill Case No: 070813-01. This report documents a release and subsequent remediation of a petroleum hydrocarbon the release of mineral oil into the soil from the two electrical switch boxes in Area 12 of the Nevada Test Site. NNSA/NSO's report further documents the excavation and completion of the clean-up. Based upon the results of this report, NNSA/NSO requests NDEP approve the closure of this spill site.

NDEP acknowledges this report and reviewed the remedial action at this spill site based upon information and data provided in the final closure report. This action was subject to the qualification of the data and information presented. After a thorough review, NDEP finds no reason to request further information, data, investigation and/or remediation. NDEP therefore approves the closure of this spill site.

Address any questions regarding this matter to either Greg Raab at (702) 486-2850, ext.242, or me at (702) 486-2850, ext. 229.

Sincerely,

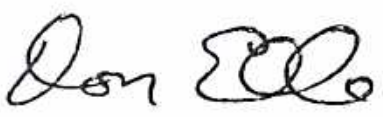

Don Elle, Ph.D.

Supervisor,

Bureau of Federal Facilities

DRE/GR:gr

cc: P.M. Radack, BN, Mercury, NV

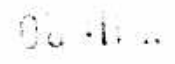




\section{National Security Technologies LLc}

P270-PR-07-0097

August 16, 2007

Donald R. Elle, Ph.D.

Supervisor

Bureau of Federal Facilities

Nevada Division of Environmental Protection

2030 E. Flamingo Road, Suite 230

Las Vegas, NV 89119

\section{Subject: 30 DAY REPORT FOR NEVADA DEPARTMENT OF ENVIRONMENTAL PROTECTION (NDEP) SPILL REPORT NUMBER 070813-01}

On behalf of the National Nuclear Security Administration Nevada Site Office, the enclosed document is submitted in response to a request from NDEP on August 15, 2007, for a written report within 30 days. This document satisfies the request of a written report as stated in the Nevada Administrative Code (NAC) 445A.347 and the Resource Conservation and Recovery Act (Public Law 94-580). Upon completion of the soil remediation process and laboratory results, a final report regarding this matter will be forwarded to your office.

If you have any questions or require additional information, please contact David Rudolph at (702) 295-1224.

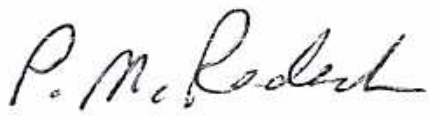

P. M. Radack, Manager

Environmental Services Department

DDR:pdl

Subject Code: ENV 8

Enclosure: as stated

cc w/enc.

Correspondence Control, CF008

T. R. Echelard, NSTec, NST306

K. A. Hoar, NNSA/NSO, 505

A. L. Primrose, NSTec, NLV022

M. G. Skougard, NNSA/NSO, 505

D. S. Tobiason, NSTec, NTS306

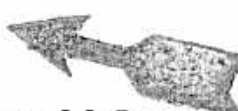

National Security Technologies, LLC

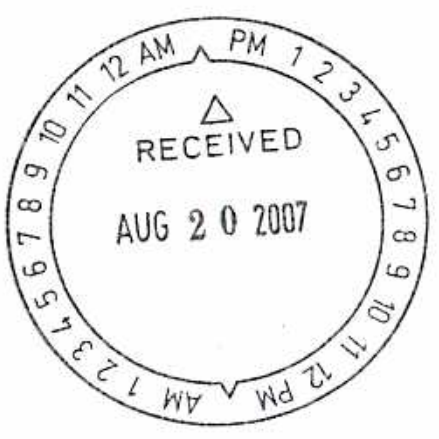

Vision • Service $\cdot$ Partnership 


\section{“T" TUNNEL LOWER LAYDOWN YARD SPILL AREA 12 "T" TUNNEL COMPLEX \\ NDEP Spill Report \# 070813-01 \\ 30 DAY REPORT}

Sometime during the time period of August 6, 2007 to August 9, 2007, a spill of between 40-60 gallons of dielectric mineral oil occurred in the " $T$ " Tunnel Lower Laydown Yard at the Nevada Test Site. Due to the location of the spill, it was not discovered until August 11, 2007. Further investigation revealed that heavy construction equipment used in conjunction with ongoing environmental restoration efforts (Corrective Action Unit 481) at the site caused an electrical breaker box to tip over from its vertical resting position and spill the contents of two switches that contained the oil. After consulting with the facility owner, it was determined that due to the age and era of use of this particular piece of equipment, the dielectric oil was likely to contain polychlorinated biphenyls (PCBs). A sampling plan and remediation process to positively identify the presence of PCBs is currently in place. Laboratory results will be forwarded to NDEP in a final report.

The following information satisfies the requirement for a written report in NDEP's letter sent August 14, 2007.

I. Description of the spill or release including:

A. Type of contaminant/material released into the environment

Dielectric mineral oil

B. Quantity or volume of the material released (metered or estimated)

The estimated quantity released was between 40-60 gallons. This estimate was determined by calculating the total volume of the two breaker boxes (110 gallons) located in the electrical cabinet and assuming that roughly two-thirds of the volume was displaced by wiring and circuit breakers.

C. Date and time of release

The specific date and time is unknown, but the spill was discovered the morning of August 11, 2007.

D. Cause of the release/spill

Accidental upset of electrical equipment containing mineral oil.

E. Distance to and location of the closest well or reservoir used for drinking water purposes

The nearest drinking water supply is Well 8 , which is located approximately 12.8 kilometers ( 8 miles) southeast of the site. The static water level is approximately $330 \mathrm{~m}(1084 \mathrm{ft}) \mathrm{bgs}$.

F. Latitude and longitude of the contaminated site (Nevada coordinates)

$372122 \mathrm{~N} \quad 1161562 \mathrm{~W}$ 
G. A site map, which depicts the general location of the site

Attached

H. Depth to groundwater

Greater than $425 \mathrm{~m}(1400 \mathrm{ft})$ bgs

I. General lithology of the contaminated area

The affected soil was Type 2 fill material that has been compacted.

J. A plot plan that depicts drainage features and structures, underground utilities, roadways and right-of-ways, and spill surface area boundaries

Attached

K. Description/identification and location of any threatened, endangered, or sensitive plant or animal species in the area, which may have been or may be impacted by the release.

None

II. Description of response activities that will be taken or completed

A. Laboratory testing, test methods and results

Sampling and lab results are pending and will be forwarded to NDEP in a final report.

B. Description of completed or proposed abatement, containment and other remediation methods

The soil will be excavated to a maximum depth of 12 inches and staged on-site. After the initial excavation is completed and there are no signs of soil discoloration, the site is believed to be clean. Samples will be collected and the results will be transmitted in a final report. Work packages are being prepared to start the excavation of the affected area. Laboratory analysis will determine the final disposition of the contaminated soil.

C. Soil, ground water and air monitoring methods and results, including confirmation sampling and analysis

See above.

D. Contaminated soil removal

(1) Amount of soil removed: pending

(2) PCB concentration of soil removed: pending

(3) Final disposition of removed soils: pending

(4) Date(s) soil removed: pending 
E. Measures taken to correct and prevent the recurrence of this incident

National Security Technologies, LLC (NSTec) personnel will conduct additional walk-downs of remediation areas and flag electrical equipment for detailed inspections to prevent and dispose of hazardous materials prior to starting site remediation.

F. Consultant(s) employed and scope of duties and responsibilities

All work related to remediating this spill has been and will be performed by NSTec personnel.

G. Contractor(s) employed and scope of duties and responsibilities

All work related to remediating this spill has been and will be performed by NSTec personnel.

H. Final disposition of underground storage tank(s) removed

Not applicable.

I. Description of proposed remediation plans

None required. 


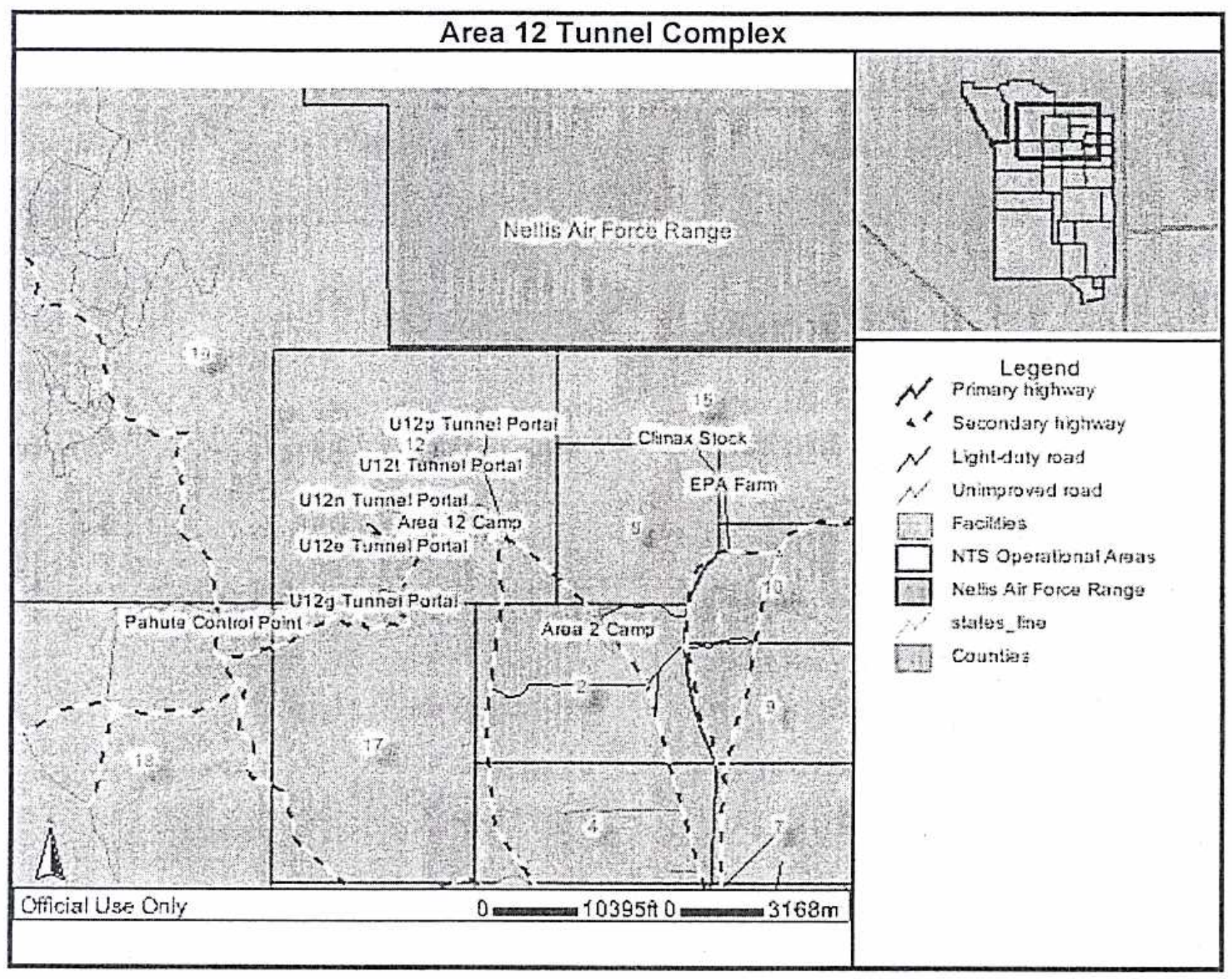




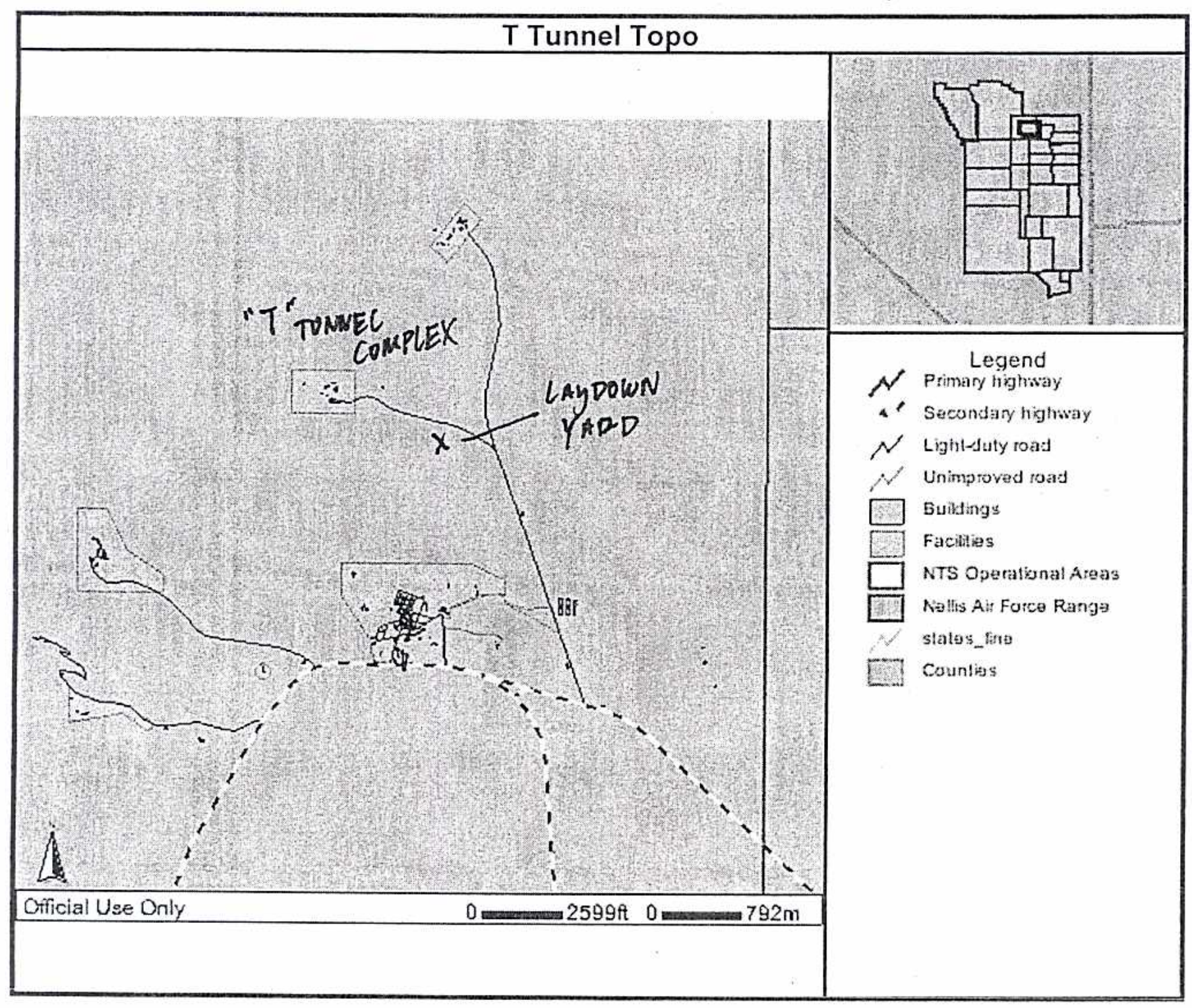




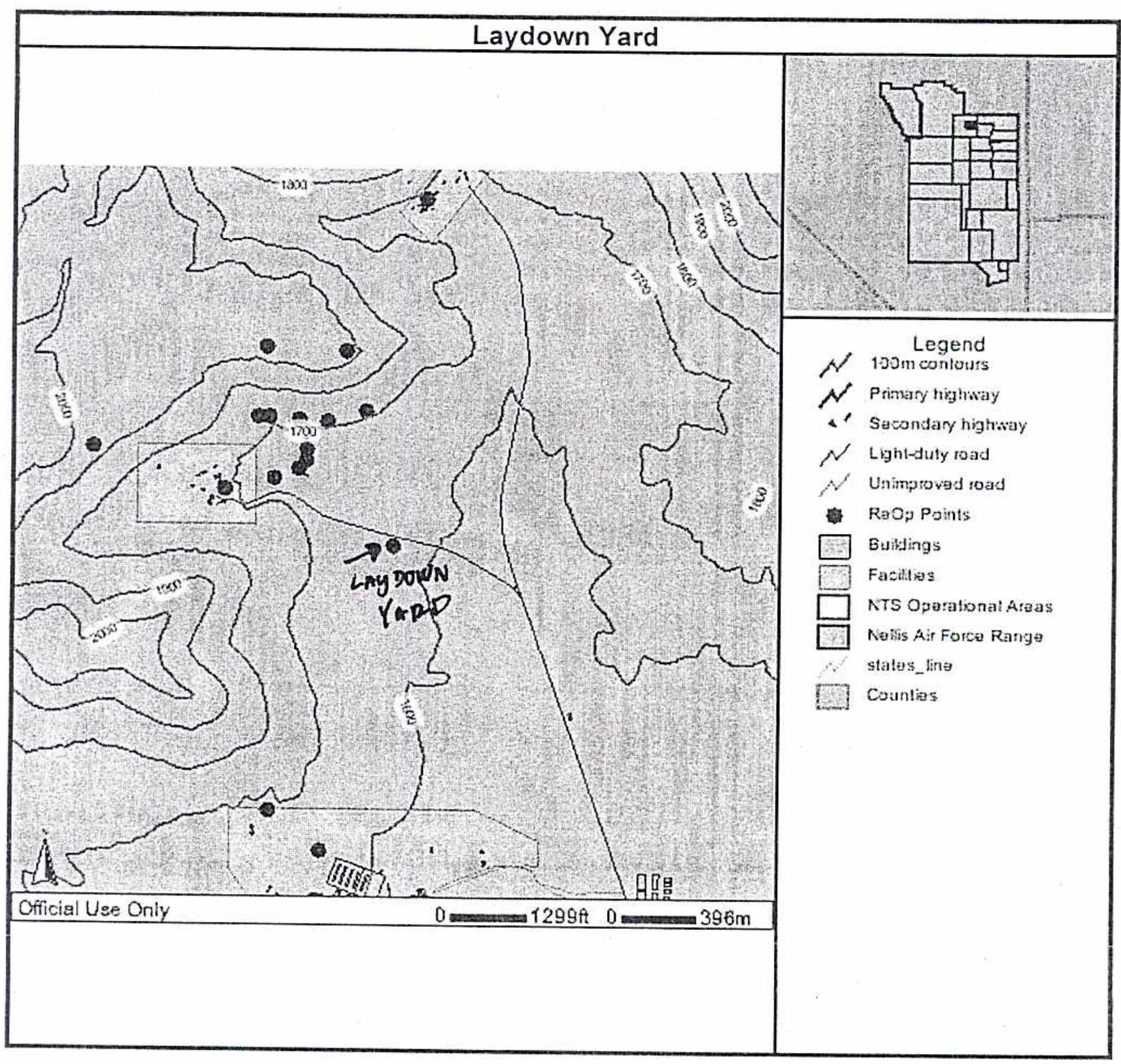


CAU 481 Closure Report

Section: Appendix E

Revision: 0

Date: November 2008

APPENDIX E ANAlytical Results 
CAU 481 Closure Report

Section: Appendix E

Revision: 0

Date: November 2008

THIS PAGE INTENTIONALLY LEFT BLANK 
Lionville Laboratory, Inc. PCBS DY GC

Report Date: 08/24/07 06:43 RFW Batch Number. 0708L796 Client: NSTEC V2969 Work Order. 60052001001 Page: 1.

\begin{tabular}{|c|c|c|c|c|c|c|c|c|c|c|c|}
\hline \multirow{5}{*}{$\begin{array}{l}\text { Sample } \\
\text { Information }\end{array}$} & Cust ID: & \multicolumn{2}{|c|}{ ECO 7000041} & \multicolumn{2}{|c|}{ EC0700004I } & \multicolumn{2}{|c|}{ EC0 7000041} & \multicolumn{2}{|l|}{ PBLKFF } & \multicolumn{2}{|l|}{ PBLKFF BS } \\
\hline & REW\#: & \multicolumn{2}{|c|}{001} & \multicolumn{2}{|c|}{$001 \mathrm{MS}$} & \multicolumn{2}{|c|}{$001 \mathrm{MSD}$} & \multicolumn{2}{|c|}{ 07LE0480-MBI } & \multicolumn{2}{|c|}{ 07LE0480-MB1 } \\
\hline & Matrix: & \multirow{2}{*}{\multicolumn{2}{|c|}{ OIL }} & \multicolumn{2}{|c|}{ OIL } & \multicolumn{2}{|c|}{ OIL } & \multicolumn{2}{|l|}{ SOIL } & \multicolumn{2}{|c|}{ SOIL } \\
\hline & D.F. & \multirow{2}{*}{\multicolumn{2}{|c|}{$\begin{array}{r}1.00 \\
\mathrm{UG} / \mathrm{KG}\end{array}$}} & \multirow{2}{*}{\multicolumn{2}{|c|}{$\begin{array}{r}1.00 \\
\mathrm{UG} / \mathrm{KG}\end{array}$}} & \multirow{2}{*}{\multicolumn{2}{|c|}{$\begin{array}{r}1.00 \\
\mathrm{UG} / \mathrm{KG}\end{array}$}} & \multirow{2}{*}{\multicolumn{2}{|c|}{$\begin{array}{r}1.00 \\
\mathrm{UG} / \mathrm{KG}\end{array}$}} & \multirow{2}{*}{\multicolumn{2}{|c|}{$\begin{array}{r}1.00 \\
\mathrm{UG} / \mathrm{KG}\end{array}$}} \\
\hline & Units: & & & & & & & & & & \\
\hline \multirow[t]{2}{*}{ Surrogate: } & Tetracnloro-m-xylene & 59 & $\%$ & 74 & $\%$ & 72 & $\%$ & 88 & $\%$ & 94 & $\%$ \\
\hline & Decachlorobiphenyl & 90 & $\%$ & 120 & $\%$ & 115 & $\%$ & 96 & $\%$ & 103 & $\%$ \\
\hline \multicolumn{6}{|c|}{ 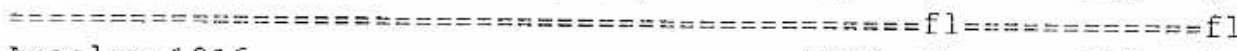 } & $==x=x====0$ & $=f 1$ & $===E=====$ & $=f 1$ & $==========$ & $=\mathrm{fl}======\pi=z===\mathrm{fl}$ \\
\hline Aroclor -1016 & & 4000 & U & 113 & $\%$ & 104 & $\%$ & 400 & $\mathrm{U}$ & 93 & $\div$ \\
\hline Aroclor-1221 & & 4000 & $\mathrm{U}$ & 4000 & $U$ & 4000 & $\mathrm{U}$ & 400 & $\mathrm{U}$ & 400 & $\mathrm{U}$ \\
\hline Aroc Lor -1232 & . & 4000 & $\mathrm{U}$ & 4000 & $\mathrm{U}$ & 4000 & $\mathrm{U}$ & 400 & $\mathrm{U}$ & 400 & $\mathrm{u}$ \\
\hline Aroc lor -1242 & & 4000 & $\mathrm{U}$ & 4000 & $\mathrm{U}$ & 4000 & $\mathrm{U}$ & 400 & $\mathrm{U}$ & 400 & $\mathrm{~J}$ \\
\hline Aroclor -1248 & & 4000 & $\mathrm{U}$ & 4000 & $\mathrm{U}$ & 4000 & $\mathrm{U}$ & 400 & $\mathrm{U}$ & 400 & $\mathrm{U}$ \\
\hline Aroclor -1254 & & 4000 & $\mathrm{U}$ & 4000 & $\mathrm{U}$ & 4000 & $\mathrm{U}$ & 400 & $\mathrm{U}$ & 400 & $\mathrm{U}$ \\
\hline Aroclor -1260 & & 4000 & $\mathrm{U}$ & 116 & $\%$ & 112 & $\%$ & 400 & U & 102 & $\%$ \\
\hline
\end{tabular}

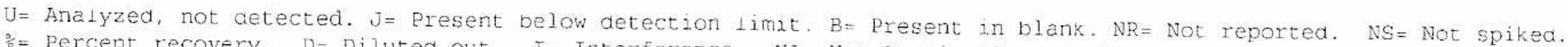

$\because=$ Percent recovery. $D=$ Diluted out. I = Interference. NA= Not Applicable. * $=$ Outside of EPA CLP QC 



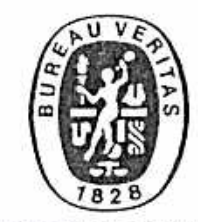

BUREAU

एVERITAS

August 30, 2007

Jon Spezialetti

NATIONAL SECURITY TECHNOLOGIES

Nevada Test Site / MS:NTS327

Building 23-111 No. 139

Mercury, NV 89023-

Bureau Veritas Work Order No. 07081432

Reference: Subcontract No. 53533/SDG 07-0167

Dear Jon Spezialetti:

Bureau Veritas North America, Inc. received 5 samples on 8/29/2007 for the analyses presented in the following report.

Enclosed is a copy of the Chain-of-Custody record, acknowledging receipt of these samples. Please note that any unused portion of the samples will be discarded 30 days after the date of this report, unless you have requested otherwise.

This material is confidential and is intended solely for the person to whom it is addressed. If this is received in error, please contact the number provided below.

We appreciate the opportunity to assist you. If you have any questions concerning this report, please contact a Client Services Representative at (800) 806-5887.

Sincerely,

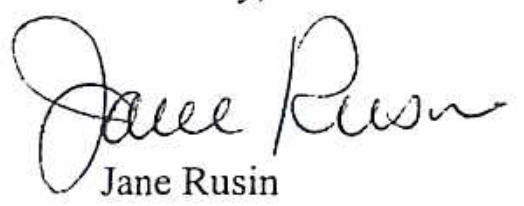

Client Service Representative

cc: 


\section{Client: NATIONAL SECURITY TECHNOLOGIES}

Project: $\quad$ Subcontract No. 53533/SDG 07-0167

Work Order No 07081432

Unless otherwise noted below, all quality control results associated with this sample set were within acceptable limits and/or do not adversely affect the reported results.

Unless otherwise indicated below, the industrial hygiene results have not been blank corrected.

Bulk Asbestos Analysis:

Use of EPA/600/R-93/116 satisfies applicable requirements of the USEPA's "Interim Method for the Determination of Asbestos in Bulk Insulation Sample", EPA-600/M4-82-020, December 1982, published as AppendixE to Subpart E of 40CFR763.

Percentages are visual estimations. The reliable limit of quantitation of the method is $1 \%$, although asbestos may be qualitatively detected at concentrations less than $1 \%$. Samples for which asbestos is detected at $<1 \%$ are reported as trace, " $<1 \%$ ". "None Detected" indicates that no asbestos fibers were observed. 


\section{Client: NATIONAL SECURITY TECHNOLOGIES}

Client Reference: Subcontract No. 53533/SDG 07-0167

Sample Type: Bulk

Method Reference EPA/600/R-93/116

Analyst: AJP

Work Order No.: 07081432

Date Sampled: 08/23/2007

Date Received: 08/29/2007

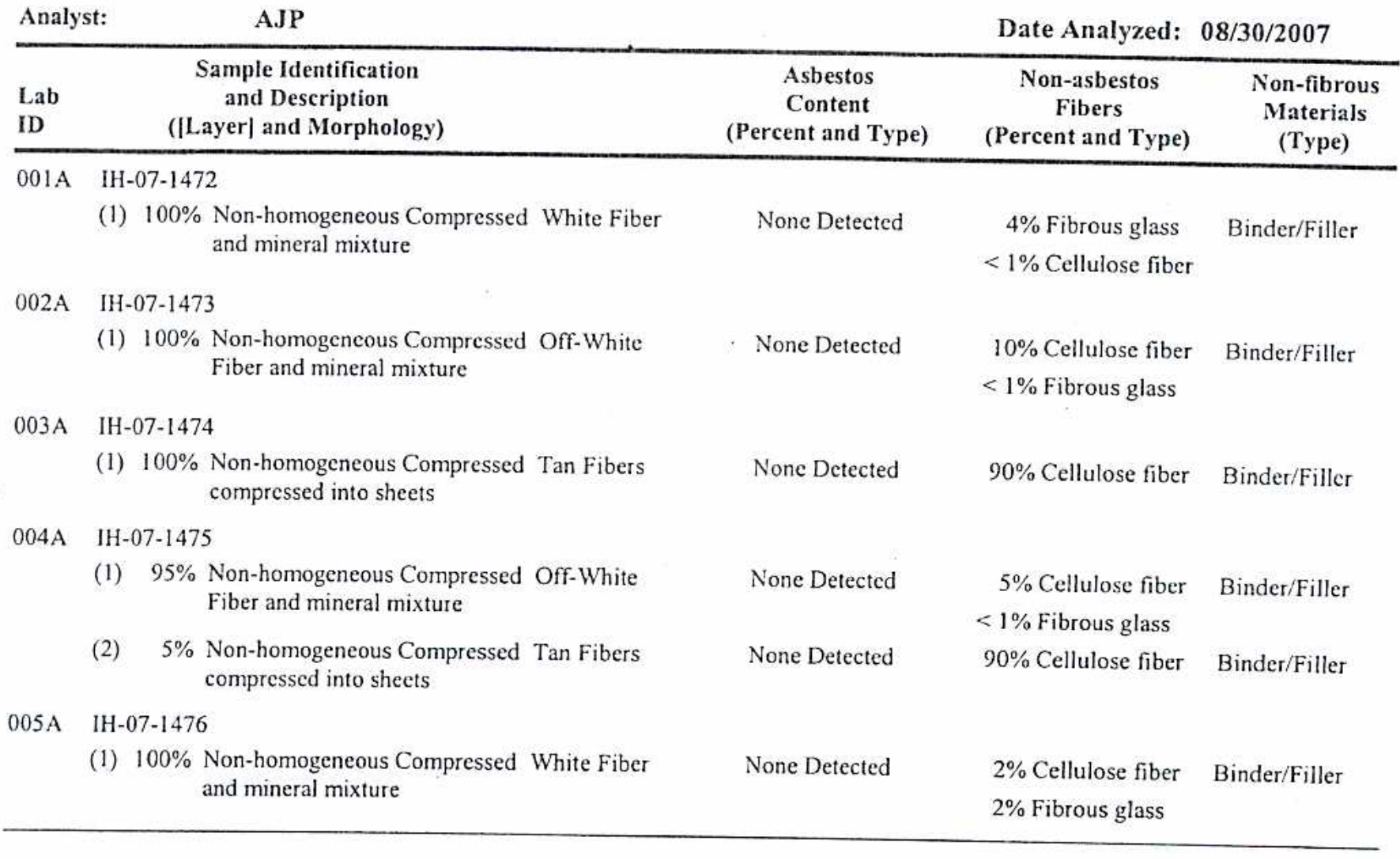




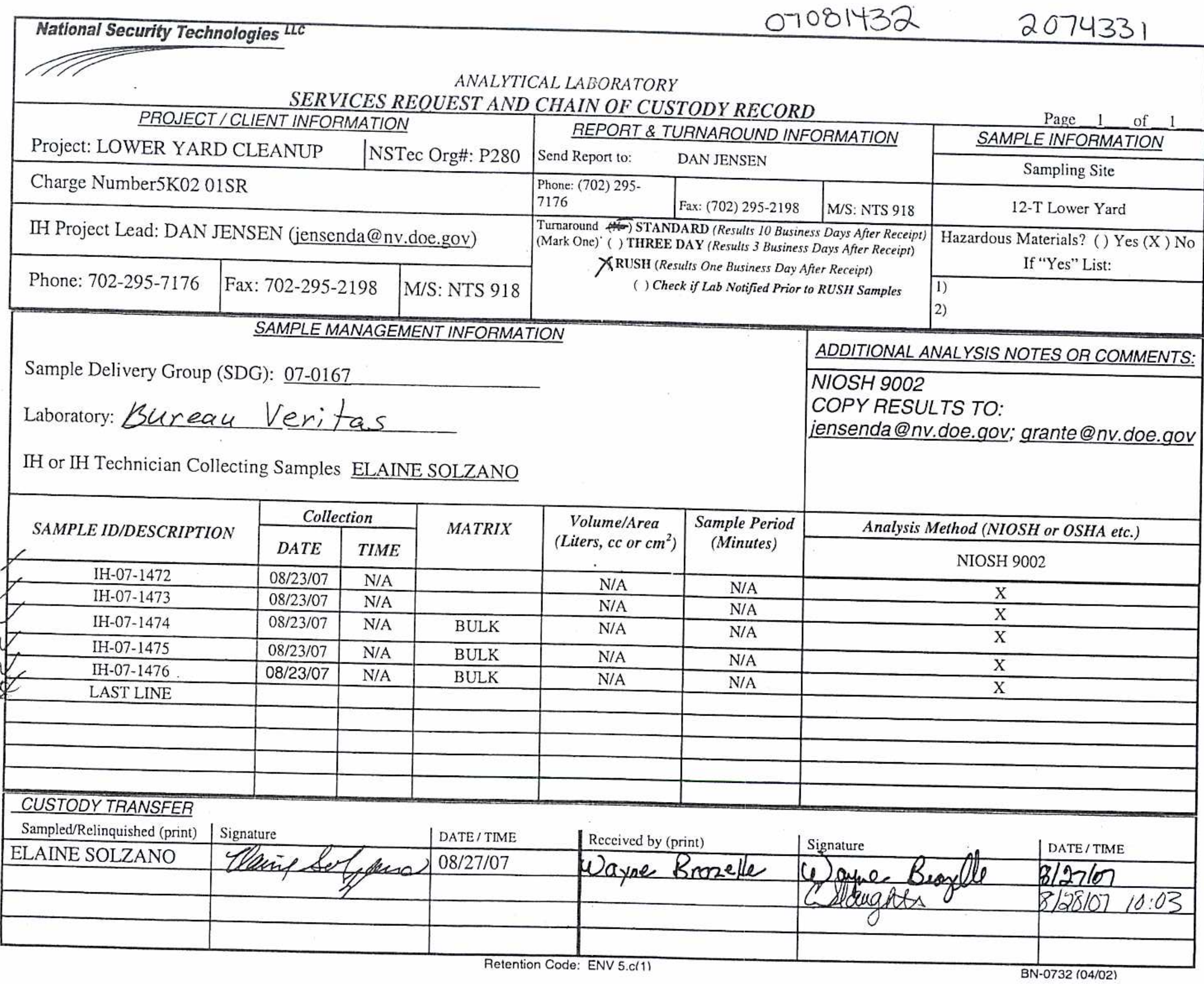




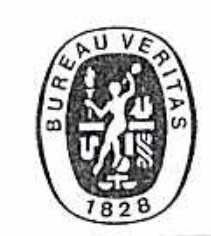

BUREAU

VERITAS:

September 04, 2007

Jon Spezialetti

NATIONAL SECURITY TECHNOLOGIES

Nevada Test Site/MS:NTS327

Building 23-111 No. 139

Mercury, NV 89023-

Bureau Veritas Work Order No. 07081561

Reference: Subcontract No. 53533/SDG

Dear Jon Spezialetti:

Bureau Veritas North America, Inc. received 1 sample on 8/30/2007 for the analyses presented in the following report.

Enclosed is a copy of the Chain-of-Custody record, acknowledging receipt of these samples. Please note that any unused portion of the samples will be discarded 30 days after the date of this report, unless you have requested otherwise.

This material is confidential and is intended solely for the person to whom it is addressed. If this is received in error, please contact the number provided below.

We appreciate the opportunity to assist you. If you have any questions concerning this report, please contact a Client Services Representative at (800) 806-5887.

Sincerely,

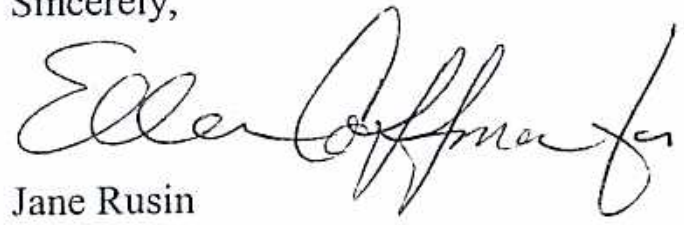

Client Service Representative

cc: 


\begin{tabular}{ll}
\hline Client: & NATIONAL SECURITY TECHNOLOGIES \\
Project: & Subcontract No. 53533/SDG \\
Work Order No & $\mathbf{0 7 0 8 1 5 6 1}$ \\
\hline
\end{tabular}

Unless otherwise noted below, all quality control results associated with this sample set were within acceptable limits and/or do not adversely affect the reported results.

Unless otherwise indicated below, the industrial hygiene results have not been blank corrected.

Bulk Asbestos Analysis:

Use of EPA/600/R-93/116 satisfies applicable requirements of the USEPA's "Interim Method for the Determination of Asbestos in Bulk Insulation Sample", EPA-600/M4-82-020, December 1982, published as AppendixE to Subpart E of 40CFR763.

Percentages are visual estimations. The reliable limit of quantitation of the method is $1 \%$, although asbestos may be qualitatively detected at concentrations less than $1 \%$. Samples for which asbestos is detected at $<1 \%$ are reported as trace, " $<1 \%$ ". "None Detected" indicates that no asbestos fibers were observed. 


\section{Client: NATIONAL SECURITY TECHNOLOGIES}

Client Reference: Subcontract No. 53533/SDG

Sample Type: Bulk

Method Reference EPA/600/R-93/116

Analyst:

AJP

Sample Identification
Lab

ID ([Layer] and Morphology)

001 A IH-07-1498

(1) $50 \%$ Non-homogeneous Non-compressed OffWhite Fibers, Woven

(2) $50 \%$ Non-homogeneous Compressed White Other (specify)

Other refers to a compressed synthetic material.
Work Order No.: 07081561

Date Sampled: 08/28/2007

Date Received: 08/30/2007

Date Analyzed: 09/04/2007

$\begin{array}{ccc}\text { Asbestos } & \text { Non-asbestos } & \text { Non-fibrous } \\ \text { Content } & \text { Fibers } & \text { Materials }\end{array}$

$\begin{array}{lll}\text { (Percent and Type) (Percent and Type) } & \text { (Type) }\end{array}$

$\begin{array}{lll}\text { None Detected } & 60 \% \text { Fibrous glass } & \text { Binder/Filler } \\ & 30 \% \text { Synthetic fiber } & \\ \text { None Detected } & <1 \% \text { Fibrous glass } \quad \text { Binder } / \text { Filler }\end{array}$

None 


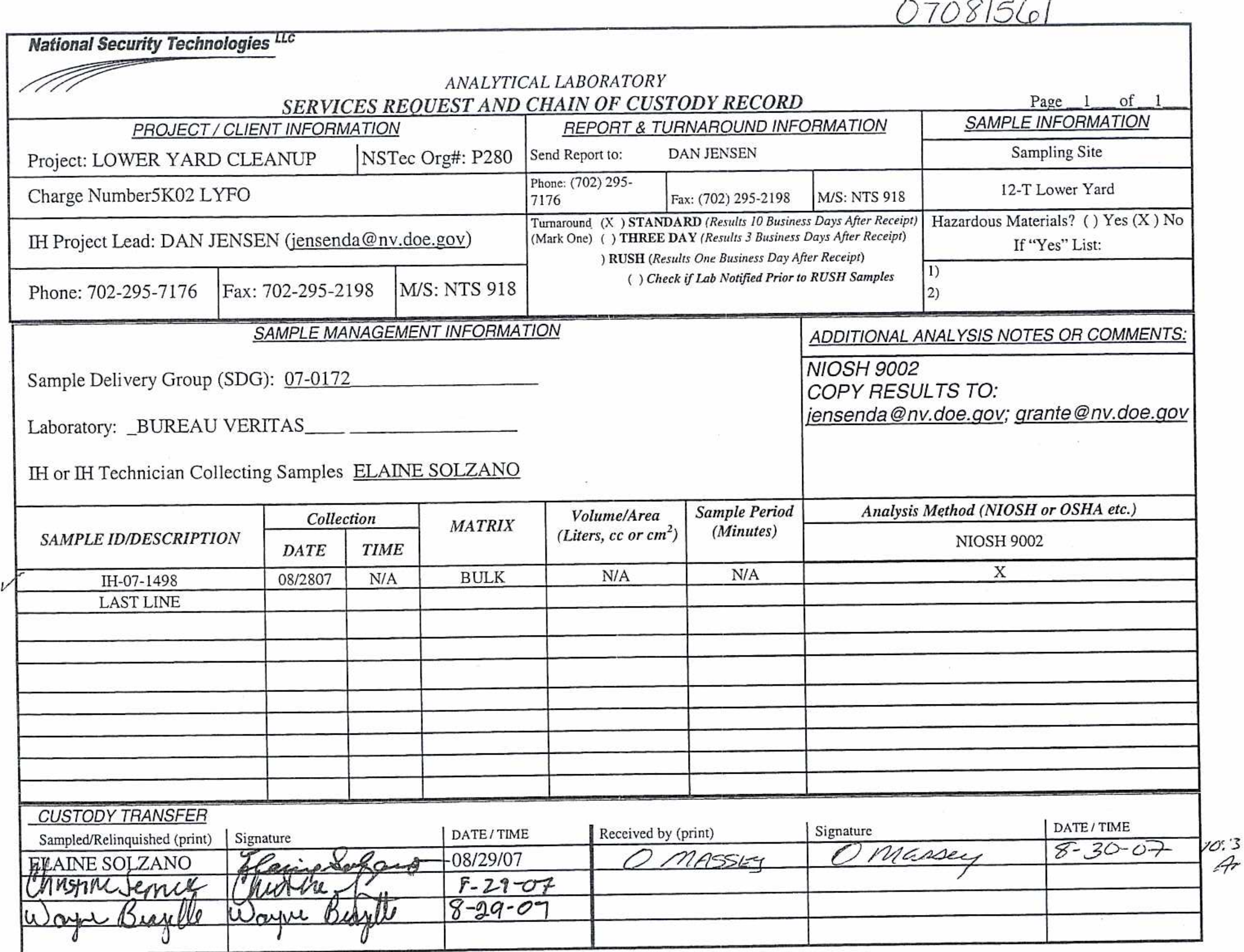




\section{APPENDIX F \\ NeVAda Division of ENVIRonmental Protection COMMENT RESPONSE FORM}


CAU 481 Closure Report

Section: Appendix F

Revision: 0

Date: November 2008

\section{THIS PAGE INTENTIONALLY LEFT BLANK}




\section{NEVADA ENVIRONMENTAL RESTORATION PROJECT}

DOCUMENT REVIEW SHEET

\section{Document Title/Number: CLOSURE REPORT FOR CORRECTIVE ACTION Document Date: September 2008 \\ UNIT 481: AREA 12 T-TUNNEL CONDITIONAL RELEASE}

STORAGE YARD, NEVADA TEST SITE, NEVADA

Author/Organization: NSTec

Revision Number: 0

Date Comments Due: October 23, 2008

Review Criteria: Full

Reviewer / Phone: Dennis Nicodemus / (702) 486-2850 ext. 237

Comment Numbe

Comment

Location

1. General

\begin{tabular}{c|l} 
Type $^{\mathbf{a}}$ & \multicolumn{1}{|c}{ Comment } \\
$\mathbf{M}$ & $\begin{array}{l}\text { Include a summary of the Final Report for Spill \# } \\
070813-01 \text { that occurred on the storage yard. }\end{array}$
\end{tabular}

The Spill Report has been added as Appendix D, and the analytical results have been added as Appendix E. 
CAU 481 Closure Report

Section: Appendix F

Revision: 0

Date: November 2008

\section{THIS PAGE INTENTIONALLY LEFT BLANK}


CAU 481 Closure Report

Section: Library Distribution List

Revision: 0

Date: November 2008

\section{LIBRARY DISTRIBUTION LIST}


CAU 481 Closure Report

Section: Library Distribution List

Revision: 0

Date: November 2008

\section{THIS PAGE INTENTIONALLY LEFT BLANK}




\section{LIBRARY DISTRIBUTION LIST}

U.S. Department of Energy

National Nuclear Security Administration

Nevada Site Office

Technical Library

P.O. Box 98518, M/S 505

Las Vegas, NV 89193-8518

U.S. Department of Energy

Office of Scientific and Technical Information

P.O. Box 62

Oak Ridge, TN 37831-0062

Southern Nevada Public Reading Facility

c/o Nuclear Testing Archive

P.O. Box 98521, M/S 400

Las Vegas, NV 89193-8521

Manager, Northern Nevada FFACO

Public Reading Facility

c/o Nevada State Library \& Archives

Carson City, NV 89701-4285
1 (Uncontrolled, electronic copy)

1 (Uncontrolled, electronic copy)

2 (Uncontrolled, electronic copies)

1 (Uncontrolled, electronic copy) 
CAU 481 Closure Report

Section: Library Distribution List

Revision: 0

Date: November 2008

THIS PAGE INTENTIONALLY LEFT BLANK 